\title{
Influência do Fíler Mineral em Propriedades de Misturas Asfálticas Densas
}

Tese apresentada à Escola de Engenharia de São Carlos, da Universidade de São Paulo, como parte dos requisitos para obtenção do Título de Doutor em Ciências, Programa de Pós-Graduação em Engenharia de Transportes. Área de Concentração: Infraestrutura de Transportes.

Orientador: Professor Associado José Leomar Fernandes Júnior

São Carlos 


\begin{abstract}
AUTORIZO A REPRODUÇÃO E DIVULDAÇÃO TOTAL OU PARCIAL DESTE TRABALHO, POR QUALQUER MEIO CONVENCIONAL OU ELETRÔNICO, PARA FINS DE ESTUDO E PESQUISA, DESDE QUE CITADA A FONTE.
\end{abstract}

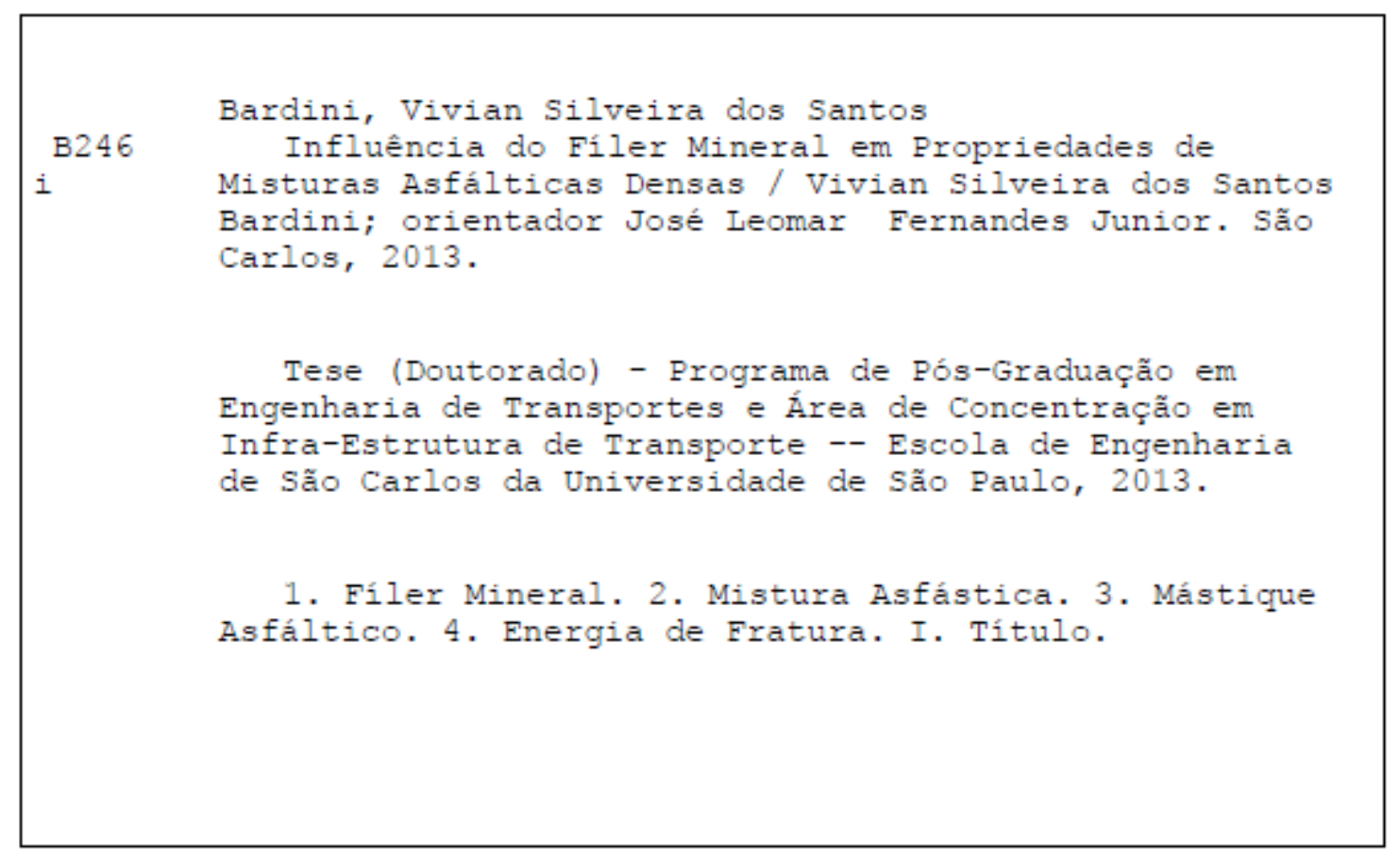




\section{FOLHA DE IULGAMENTO}

\section{Candidata: Engenheira VIVIAN SILVEIRA DOS SANTOS BARDINI.}

Titulo da tese: "Influência do filer mineral em propriedades de misturas asfalticas densas".

Data da defesa: 25/03/2013

\section{Comissiojo Julgadora:}

Prof. Associado José Leomar Fernandes Júnior (Orientador)

(Escola de Engenharia de São Carlos/EESC)

Prof. Dr. Glauco Túlio Pessa Fabbri

(Escola de Engenharia de São Carlos/EESC)

Profe. Dr'. Ana Paula Furlan

(Escola de Engenharia de São Carlos/EESC)

Prof. Dr. Jorge Augusto Pereira Ceratti

(Universidade Federal do Rio Grande do Sul/UFRGS)

Prof. Dr. John Kennedy Guedes Rodrigues

(Universidade Federal de Campina Grande/UFCG)
Resultado:

Aramon Da

APHOUADA

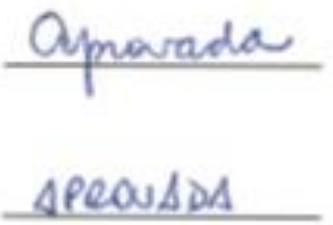

A ceostant

Coordenador do Programa de Pós-Graduação em Engenharia de Transportes: Prof. Associado Antônio Nélson Rodrigues da Silva

Presidente da Comissão de Pós-Graduação:

Prof. Titular Denis Vinicius Coury 



\section{DEDICATÓRIA}

Aos meus pais, Sérgio e Nádia, e ao Luis Miguel, pelo apoio, amor e incentivo em todas as horas 

EPÍGRAFE

"A tarefa não é tanto ver aquilo que ninguém viu, mas pensar o que ninguém ainda pensou sobre aquilo que todo mundo vê" (Arthur Schopenhauer) 

A Deus, por permitir que mais uma etapa da minha vida fosse cumprida em paz e tranquilamente.

Ao professor Dr. José Leomar Fernandes Júnior, pela excelente orientação no desenvolvimento desse trabalho, pela grande amizade, apoio e por ser o maior incentivador do meu caminho para a carreira acadêmica.

Aos professores do Departamento de Transportes, da EESC - USP pelos ensinamentos, especialmente ao Dr. Glauco Túlio Pessa Fabbri, Dr. Adalberto Leandro Faxina e Dra ${ }^{\mathrm{a}}$. Ana Paula Furlan, pelas sugestões e contribuições nesta pesquisa.

Aos professores Dr. Reynaldo Roque, Dr. Mang Tia e George Loop, da Universidade da Flórida, por me acolherem em Gainesville-FL e me darem a oportunidade de ter uma experiência enriquecedora na UF.

Aos técnicos do Laboratório de Estradas, Antônio Carlos Gigante, Paulo Toyama e João Pereira Filho, pelo auxílio nos ensaios, moldagens e à grande amizade.

Aos funcionários do Departamento de Transportes, Magaly Marcondes César, Heloísa Pereira, Elizabeth Ortega, Alexandre Oliveira, Sueli de Lima e Antônio Carlos Mariano.

À Coordenação de Aperfeiçoamento Pessoal de Nível Superior - CAPES, pela bolsa de estudo concedida, inclusive a do Programa de Doutorando no Brasil com Estágio no Exterior (Processo: BEX 0341/11-8).

À pedreira Badeirantes, pedreira São Jerônimo e Betunel, pelos materiais concedidos para a realização da pesquisa.

Aos amigos do Departamento de Transportes, Sérgio Soncim, Jesner Ildefonso, Bruno Vieira, Mateus Araújo, Marcela Navarro, Helen Miranda, Madalena Ribeiro, Monique Gomes, Luciana Spigolon, Fabio Zanchetta, Gustavo Henrique, Heliana Fontenelle, pelo apoio.

Às minhas amigas de infância Samara Tonin, Daniele Cerquiari, Veridiana Rosa e Carol Cardoso, pela amizade e apoio fundamental em todas as horas.

Ao Luis Miguel, por todo amor, carinho, amizade e pelo incentivo e apoio em todos os momentos.

Aos meus pais, Sérgio e Nádia Bardini, por todo incentivo, dedicação e amor, acreditando sempre em meu potencial e pela dedicação de toda a vida para me dar a maior herança de todas: o estudo.

Ao meu irmão, Vinícius, por todo companheirismo, incentivo e ser sempre um exemplo para mim.

À toda minha família que me incentivou todo o tempo, dando todo carinho e atenção. 

BARDINI, V.S.S. Influência do Fíler Mineral nas Propriedades de Misturas Asfálticas Densas. 2013. 337 p. Tese (Doutorado). Escola de Engenharia de São Carlos, Universidade de São Paulo, São Carlos, 2013.

Esta pesquisa tem por objetivo contribuir para o melhor entendimento dos efeitos do fíler mineral sobre o comportamento mecânico de misturas asfálticas densas, particularmente em relação ao tipo e teor de fíler. O comportamento mecânico de misturas asfálticas densas foi avaliado em função do tipo e teor de fíler (diferentes propriedades físicas e geométricas, mineralógica), do tipo de agregado (diferentes origens mineralógicas) e do tipo de ligante asfáltico (diferentes consistências). Para alcançar o objetivo geral, a pesquisa foi dividida em três partes: o estudo da mistura asfáltica completa, através de ensaios mecânicos; o estudo do mástique, resultante da mistura de fíler com ligante asfáltico, através dos ensaios comumente aplicados aos ligantes asfálticos puros; e o estudo do comportamento de trincamento dos mástiques nas temperaturas intermediárias, através das características de energia fratura. A análise de variância dos resultados auxiliou na identificação dos fatores com influência significativa nas propriedades apresentadas pelas misturas e mástiques asfálticos. Quanto aos resultados de vida de fadiga, as misturas asfálticas compostas com cal hidratada apresentaram as maiores vidas de fadiga e quanto maior o teor de fíler, maior a vida de fadiga. Em relação à deformação permanente, as misturas asfálticas contendo o menor teor de fíler apresentam os menores valores de deformação não recuperável, enquanto que as misturas contendo o valor intermediário de fíler apresentam os maiores valores. As propriedades reológicas dos mástiques mostraram que a adição de fíler torna o ligante asfáltico mais rígido e a cal hidratada é o fíler que provoca o maior aumento do valor do $G^{*}$. A elasticidade do mástique aumenta com a adição dos fileres e é mais expressivo para os mástiques compostos pelos fileres de cal hidratada e cimento Portland. Quanto maior o teor de fíler utilizado, maior a temperatura correspondente a $\mathrm{G}^{*} / \operatorname{sen} \delta \geq 1,0 \mathrm{kPa}$ da especificação Superpave, o que pode se refletir em misturas asfálticas com maior resistência à deformação permanente. Nas propriedades à baixa temperatura, a utilização de maiores teores de fíler prejudicam a resposta ao trincamento a baixas temperaturas e diminuem a eficiência na dissipação das tensões formadas durante a contração do ligante asfáltico, quando a temperatura do revestimento cai abruptamente, 
viii

aumentando a formação de trincas e fissuras. Analisando os resultados da energia de fratura, a adição de fíler no mástique diminui a resistência ao trincamento por fadiga nas temperaturas intermediárias, porém a presença de fíler na mistura durante o envelhecimento torna seus efeitos menos prejudiciais.

Palavras-chave: fíler mineral, mástique asfáltico, mistura asfáltica, energia de fratura. 
BARDINI, V.S.S. Mineral Filler Influence on Hot Mix Asphalt Properties. 2013. 337 p. Thesis (Phd). Escola de Engenharia de São Carlos, Universidade de São Paulo, São Carlos, 2013.

The objective of this research is to contribute to the better understanding of mineral filler effects on the mechanical behavior of hot mix asphalt (HMA), particularly related to the filler type and content. The hot mix asphalt mechanical behavior was evaluated according to: the filler type and content (different physical, geometrical and mineralogical properties); the aggregate type (different mineralogical source); and the asphalt binder type (different consistency). To reach the global objective, the research was divided in three parts: the study of the complete HMA, through the mechanical tests; the study of the mastic, resulting from mixture of mineral filler and asphalt binder, through tests commonly applied to pure asphalt binder; and the study of cracking performance behavior at intermediate temperature, through the fracture energy characteristics. The analysis of variance of the results assisted to identify the factors with significant influence in properties of the hot mix and mastic asphalt. Regarding the results of the fatigue life, the HMA composed with the hydrated lime presented the longer fatigue life and the higher the filler content the longer the fatigue life. Related to the permanent deformation, the HMA containing the lowest content of filler presented the lowest non-recoverable strain, while the HMA containing an intermediate value of filler presented the highest values. The mastics rheological properties showed that addition of filler makes the asphalt binder stiffer, and the hydrated lime causes the greatest increase of $\mathrm{G}^{*}$. The mastic elasticity increases with the filler, and it's more notorious when the mastic is composed by the hydrated lime and Portland cement. The higher the filler content, the higher the temperature corresponding to $\mathrm{G}^{*} / \mathrm{sen} \delta \geq 1,0 \mathrm{kPa}$ of the Superpave specification, which may be reflected in HMA with higher permanent deformation resistance. At low temperature properties, the use of higher filler content prejudice the low temperatures cracking response, and decrease the efficiency of stress dissipation formed during contraction of the asphalt binder when the pavement temperature drops abruptly, increasing the formation of cracks and fissures. Analyzing the energy fracture results, adding filler to the mastic decrease the cracking resistance by fatigue at intermediate temperature, but the filler presence in the mixture during aging makes the effect less damaging. 
Key words: mineral filler, asphalt mastic, hot mix asphalt, fracture energy 


\section{LISTA DE FIGURAS}

Figura 2.1 - (a) Granulometria do Agregado Basáltico (b) Granulometria do Agregado Basáltico especificação Superpave ............................................................................................. 33

Figura 2.2 - (a) Granulometria do Agregado Granítico (b) Granulometria do Agregado Granítico especificação Superpave ................................................................................................. 33

Figura 2.3 - Ensaio de Tração Indireta (a) durante o carregamento e (b) na ruptura ..................... 44

Figura 2.4 - Esquema $\Delta \sigma$ no centro da amostra durante o ensaio de compressão indireta ............. 47

Figura 2.5 - Curva Granulométrica com teor de fíler de 2,5\% ................................................... 50

Figura 2.6 - Teor de ligante de projeto para as misturas contendo agregado: (a) basáltico e (b)

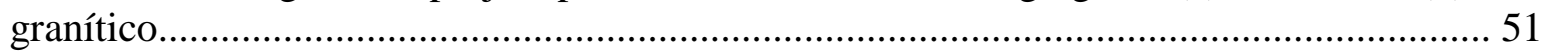

Figura 2.7 - Valores de Absorção de ligante asfáltico para misturas compostas pelo agregado granítico e ligante asfáltico: (a) CAP50/70 e (b) CAP 85/100............................................ 54

Figura 2.8 - Valores de Absorção de ligante asfáltico para misturas compostas pelo agregado basáltico e CAP 50/70 ............................................................................................. 55

Figura 2.9 - Resistência à Tração para Misturas contendo CAP 50/70 e Agregado: (a) basáltico e (b) granítico 66

Figura 2.10 - Resistência à Tração para misturas contendo CAP 85/100 e agregado: (a) basáltico e (b) granítico 66

Figura 2.11 - Módulo de Resiliência para misturas contendo CAP 50/70 e agregado: (a) basáltico e (b) granítico 69

Figura 2.12 - Módulo de Resiliência para misturas contendo CAP 85/100 e agregado: (a) basáltico e (b) granítico.

Figura $2.13-\varepsilon_{\mathrm{r}}$ para misturas contendo CAP 50/70 e o agregado: (a) Basáltico e (b) Granítico .75 Figura $2.14-\varepsilon_{\mathrm{r}}$ para misturas contendo CAP 85/100 e o agregado: (a) basáltico e (b) granítico. 75 Figura 2.15 - Deformação Total para misturas contendo CAP 50/70 e agregado: (a) basáltico e (b) granítico...... 79

Figura 2.16 - Deformação Total para misturas contendo CAP 85/100 e agregado: (a) basáltico e (b) granítico 80

Figura 2.17 - Deformação Recuperável para misturas contendo CAP 50/70 e agregado: (a)

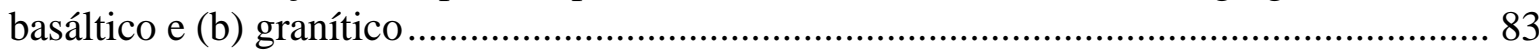

Figura 2.18 - Deformação Recuperável para misturas contendo CAP 85/100 e agregado: (a) basáltico e (b) granítico ................................................................................................. 83

Figura 2.19 - Deformação Não Recuperável para misturas contendo CAP 50/70 e agregado: (a) basáltico e (b) granítico.

Figura 2.20 - Deformação Não Recuperável para misturas contendo CAP 85/100 e agregado: (a) basáltico e (b) granítico.

Figura 2.21 - Recuperação (\%) para misturas contendo CAP 50/70 e agregado: (a) basáltico e (b) granítico.

Figura 2.22 - Recuperação (\%) para misturas contendo CAP 85/100 e agregado: (a) basáltico e (b) granítico

Figura 2.23 - Módulo de Fluência para misturas contendo CAP 50/70 e agregado: (a) basáltico e

(b) granítico

Figura 2.24 - Módulo de Fluência para misturas contendo CAP 85/100 e agregado: (a) basáltico e

(b) granítico 
Figura 2.25 - Módulo de Fluência Após a Recuperação para misturas contendo CAP 50/70 e agregado: (a) basáltico e (b) granítico .......................................................................... 97

Figura 2.26 - Módulo de Fluência Após a Recuperação para misturas contendo CAP 85/100 e agregado: (a) basáltico e (b) granítico

Figura 2.27 - Inclinação para misturas contendo CAP 50/70 e agregado: (a) basáltico e (b) granítico

Figura 2.28 - Inclinação para misturas contendo CAP 85/100 e agregado: (a) basáltico e (b) granítico.....

Figura 3.1 - (a) Curvas mestre transladadas para a temperatura de referência de $-15^{\circ} \mathrm{C}(\mathrm{b})$ Curvas de deslocamento horizontal em função da temperatura (log (a)) [Adaptado de Bahia et.al., $1992]$

Figura 3.2 - Curva mestre de materiais de comportamento molecular [Adaptado de Lima et al., 2008]

Figura 3.3 - Curva mestre do Ensaio BBR e determinação do módulo de relaxação .................. 125

Figura 3.4 - Curva mestre de $\mathrm{G}^{*}$ e $\delta$ em função da frequência, para mástiques compostos com o

CAP 50/70 e com o fíler de cimento Portland, em função da relação f/a

Figura 3.5 - Curva Mestre de $\mathrm{G}^{*} \delta$ em função da frequência, para mástiques compostos com o CAP 50/70 e com o fíler de sílica, em função da relação f/a

Figura 3.6 - Curva Mestre de $\mathrm{G}^{*}$ e $\delta$ em função da frequência, para mástiques compostos com o CAP 50/70 e com o fíler de pó calcário, em função da relação f/a

Figura 3.7 - Curva Mestre de $\mathrm{G}^{*}$ e $\delta$ em função da frequência, para mástiques compostos com o CAP 50/70 e com o fíler de cal hidratada, em função da relação f/a

Figura 3.8 - Curva Mestre de $G^{*}$ e $\delta$ em função da frequência, para mástiques compostos com o CAP 85/100 e com o fíler de cimento Portland, em função da relação f/a 136

Figura 3.9 - Curva Mestre de $G^{*}$ e $\delta$ em função da frequência, para mástiques compostos com o CAP 85/100 e com o fíler de sílica, em função da relação f/a

Figura 3.10 - Curva Mestre de $\mathrm{G}^{*}$ e $\delta$ em função da frequência, para mástiques compostos com o CAP85/100 e com o fíler de pó calcário, em função da relação f/a.

Figura 3.11- Curva Mestre de $\mathrm{G}^{*}$ e $\delta$ em função da frequência, para mástiques compostos com o CAP 85/100 e com o fíler de cal hidratada, em função da relação f/a 138

Figura 3.12- Fatores de Deslocamento Horizontal em função da temperatura para os mástique compostos pela cal hidratada e: (a) CAP 50/70 e (b) CAP 85/100

Figura 3.13 - Fatores de Deslocamento Horizontal em função da temperatura para os mástique compostos pelo cimento Portland e: (a) CAP 50/70 e (b) CAP 85/100

Figura 3.14 - Fatores de Deslocamento Horizontal em função da temperatura para os mástique compostos pela sílica e: (a) CAP 50/70 e (b) CAP 85/100

Figura 3.15 - Fatores de Deslocamento Horizontal em função da temperatura para os mástique compostos pelo pó calcário e: (a) CAP 50/70 e (b) CAP 85/100

Figura 3.16 - Ângulo de fase $(\delta)$ versus temperatura $\left({ }^{\circ} \mathrm{C}\right)$ em função da relação f/a para mástiques compostos com o CAP 50/70, na frequência de $0,1 \mathrm{rad} / \mathrm{s}$, e: (a) cal hidratada, (b) cimento Portland, (c) sílica e (d) pó de calcário

Figura 3.17 - Ângulo de fase $(\delta)$ versus temperatura $\left({ }^{\circ} \mathrm{C}\right)$ em função da relação f/a para mástiques compostos com o CAP 50/70, na frequência de 1,0 rad/s, e: (a) cal hidratada, (b) cimento Portland, (c) sílica e (d) pó de calcário 
Figura 3.18 - Ângulo de fase $(\delta)$ versus temperatura $\left({ }^{\circ} \mathrm{C}\right)$ em função da relação f/a para mástiques compostos com o CAP 50/70, na frequência de 10,0 rad/s, e: (a) cal hidratada, (b) cimento Portland, (c) sílica e (d) pó de calcário

Figura 3.19 - Ângulo de fase $(\delta)$ versus temperatura $\left({ }^{\circ} \mathrm{C}\right)$ em função da relação f/a para mástiques compostos com o CAP 85/100, na frequência de $0,1 \mathrm{rad} / \mathrm{s}$, e: (a) cal hidratada, (b) cimento Portland, (c) sílica e (d) pó de calcário

Figura 3.20 - Ângulo de fase $(\delta)$ versus temperatura $\left({ }^{\circ} \mathrm{C}\right)$ em função da relação f/a para mástiques compostos com o CAP 85/100, na frequência de 1,0 rad/s, e: (a) cal hidratada, (b) cimento Portland, (c) sílica e (d) pó de calcário 145

Figura 3.21 - Ângulo de fase $(\delta)$ versus temperatura $\left({ }^{\circ} \mathrm{C}\right)$ em função da relação f/a para mástiques compostos com o CAP 85/100, na frequência de 10,0 rad/s, e: (a) cal hidratada, (b) cimento Portland, (c) sílica e (d) pó de calcário 146

Figura 3.22 - Módulo Complexo $\left(\mathrm{G}^{*}\right)$ versus temperatura $\left({ }^{\circ} \mathrm{C}\right)$ em função do tipo de fíler para mástiques compostos com o CAP 50/70, na frequência de $0,1 \mathrm{rad} / \mathrm{s}$, e relação f/a: (a) 0,6 (b) 0,9 e (c) 1,2 .

Figura 3.23 - Módulo Complexo $\left(\mathrm{G}^{*}\right)$ versus temperatura $\left({ }^{\circ} \mathrm{C}\right)$ em função do tipo de fíler para mástiques compostos com o CAP 50/70, na frequência de 1,0 rad/s, e relação f/a: (a) 0,6 (b) 0,9 e (c) 1,2 .

Figura 3.24 - Módulo Complexo $\left(\mathrm{G}^{*}\right)$ versus temperatura $\left({ }^{\circ} \mathrm{C}\right)$ em função do tipo de fíler para mástiques compostos com o CAP 50/70, na frequência de 10,0 rad/s, e relação f/a (a) 0,6 (b) 0,9 e (c) 1,2

Figura 3.25 - Módulo Complexo $\left(\mathrm{G}^{*}\right)$ versus temperatura $\left({ }^{\circ} \mathrm{C}\right)$ em função do tipo de fíler para mástiques compostos com o CAP 85/100, na frequência de $0,1 \mathrm{rad} / \mathrm{s}$, e relação f/a: (a) 0,6

(b) 0,9 e (c) 1,2

Figura 3.26 - Módulo Complexo $\left(\mathrm{G}^{*}\right)$ versus temperatura $\left({ }^{\circ} \mathrm{C}\right)$ em função do tipo de fíler para mástiques compostos com o CAP 85/100, na frequência de $1,0 \mathrm{rad} / \mathrm{s}$, e relação f/a: (a) 0,6 (b) 0,9 e (c) 1,2

Figura 3.27 - Módulo Complexo $\left(\mathrm{G}^{*}\right)$ versus temperatura $\left({ }^{\circ} \mathrm{C}\right)$ em função do tipo de fíler para mástiques compostos com o CAP 85/100, na frequência de 10,0 rad/s, e relação f/a: (a) 0,6 (b) 0,9 e (c) 1,2 . 152

Figura 3.28 - Aumento do módulo complexo $\left(\mathrm{G}^{*}\right)$ em função da relação f/a, para mástiques compostos com o CAP 50/70, na frequência de: (a) $0,1 \mathrm{rad} / \mathrm{s}$ (b) 1,0 rad/s e (c) 10,0 rad/s 154

Figura 3.29 - Aumento do módulo complexo $\left(\mathrm{G}^{*}\right)$ em função da relação f/a, para mástiques compostos com o CAP 85/100, na frequência de: (a) 0,1 rad/s (b) 1,0 rad/s e (c) 10,0 rad/s 155

Figura $3.30-\mathrm{G}^{*} / \operatorname{sen} \delta$ versus temperatura $\left({ }^{\circ} \mathrm{C}\right)$ em função da relação f/a, para os mástique compostos pelo CAP 50/70 e fíler de: (a) cal hidratada, (b) cimento Portland, (c) sílica e (d) pó de calcário

Figura 3.31- $\mathrm{G}^{*} / \operatorname{sen} \delta$ versus temperatura $\left({ }^{\circ} \mathrm{C}\right)$ em função da relação f/a, para os mástique compostos pelo CAP 85/100 e fíler de: (a) cal hidratada, (b) cimento Portland, (c) sílica e (d) pó de calcário.

Figura 3.32 - Valores de Rigidez à Fluência na flexão [S(60)] para mástiques submetidos ao PAV convencional: (a) CAP 50/70 e (b) CAP 85/100. 165

Figura 3.33 - Valores de Módulo de relaxação [m(60)] para mástiques submetidos ao PAV convencional: (a) CAP 50/70 e (b) CAP 85/100. 
Figura 3.34 - Valores de Rigidez à Fluência na Flexão para mástiques submetidos ao PAV modificado: (a) CAP 50/70 e (b) CAP 85/100 ....

Figura 3.35 - Valores de Módulo de Relaxação [m(60)] para mástiques submetidos ao PAV modificado: (a) CAP 50/70 e (b) CAP 85/100

Figura 3.36 - Aumento da rigidez na fluência na flexão, para mástiques envelhecidos no PAV convencional e: (a) CAP 50/70 e (b) CAP 85/100

Figura 3.37 - Aumento da rigidez na fluência na flexão, para mástiques envelhecidos no PAV modificado e: (a) CAP 50/70 e (b) CAP 85/100

Figura 3.38 - Ponto de amolecimento em função da relação f/a, para os mástiques compostos com: CAP (a) 50/70 e (b) CAP85/100.

Figura 3.39 - Aumento do Ponto de Amolecimento dos Mástiques Compostos: (a) CAP 50/70 e

(b) CAP $85 / 100$

Figura 4.1 Geometria e estado de tensões nos corpos de prova dos ensaios de Tração Indireta do Superpave (IDT) e de Tração Direta "Dog Bone” (DBDT) [Adaptado de Koh e Roque (2010)]

Figura 4.2 - Comparação dos resultados dos ensaios de IDT e DBDT: (a) resistência a tração, (b) deformação na fratura, (c) energia de fratura [Adaptado de Koh e Roque (2010)] .....

Figura 4.3 - Configuração do Ensaio de Tração em formato de Disco [Adaptado de Braham et al. (2007)]

Figura 4.4 - (a) Tendência da energia de fratura e temperatura de ensaio, e (b) Efeito do tipo de agregado na energia de fratura [Adaptado de Braham et al. (2007)] ............................... 185

Figura 4.5 - (a) Curvas de energia de fratura para misturas asfálticas frágeis (ensaio a $-24{ }^{\circ} \mathrm{C}$ ) e dúcteis (ensaio a $-18^{\circ} \mathrm{C}$ ) e (b) Efeito do teor de ligante asfáltico na energia de fratura.

(J/m3) [Adaptado de Buttlar e Marasteanu (2007)]

Figura 4.6 - Corpo de prova do Ensaio de Tração Direta Superpave (DTT)

Figura 4.7 - Geometria do corpo de prova do Ensaio de Tração Direta "Dog-Bone" [Adaptado de Roque et al. (2012)]

Figura 4.8 - Comparação da curva tensão-deformação para diferentes ligantes asfálticos

[Adaptado de Roque et al. (2012)] . 192

Figura 4.9 - Curva tensão-deformação de ligante asfáltico modificado por polímero e sem modificação [Adaptado de Roque et al. (2012)].

Figura 4.10 - Áreas de aplicação da Mecânica da Fratura [Adaptado de Anderson T.L. (1994)]194

Figura 4.11 - Comportamento típico de propagação de trincas [Adaptado de Romeo (2008)] ... 196

Figura 4.12 - Propagação de trincas em misturas asfálticas de acordo com a Mecânica das

Fraturas [Adaptado de Romeo (2008)]

Figura 4.13 - Aparecimento e propagação de trincas em misturas asfálticas [Adaptado de Romeo (2008)] 201

Figura 4.14 - Determinação dos limites inferior e superior para misturas asfálticas [Adaptado de Romeo (2008)]. 202

Figura 4.15 - (a) Molde para o corpo de prova do ensaio de tração direta "dog bone", (b) Configuração final do molde com o corpo de prova ..... 203

Figura 4.16 - Configuração final do corpo de prova do ensaio de tração direta "dog bone".......204 Figura 4.17 - Ensaio de tração direta "dog bone": (a) Disposição do corpo de prova no dispositivo de aplicação de carga, (b) Configuração final do corpo de prova, após a aplicação da carga 204

Figura 4.18 - Transformação de deslocamento em deformação no centro da seção transversal

[Adaptado de Roque et al. (2012)] 
Figura 4.19 - Transformação de força em tensão no centro da seção transversal [Adaptado de

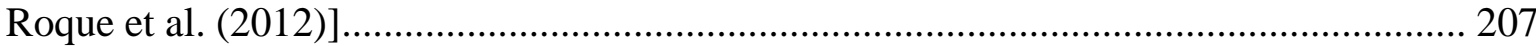

Figura 4.20 - Seção no estreitamento: (a) $3 \mathrm{~mm}$ antes do ensaio; (b) $3 \mathrm{~mm}$ sendo alongado para $\mathrm{L}_{1}$ no primeiro pico de tensão; (c) $\mathrm{L}_{1}$ é alongado e sofre a estricção [Adaptado de Roque et al.

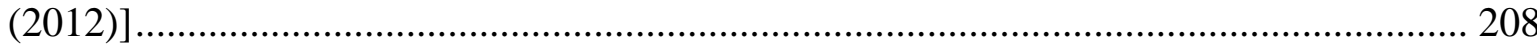

Figura 4.21 - Cálculo do comprimento $\mathrm{L}_{1}$ da parte central de $3 \mathrm{~mm}$ no primeiro pico de tensão [Adaptado de Roque et al. (2012)] .............................................................................. 209

Figura 4.22 - Cálculo da área central da seção transversal $A_{1}$ no primeiro pico de tensão [Adaptado de Roque et al. (2012)]

Figura 4.23 - Deformação da parte central após o primeiro pico de tensão [Adaptado de Roque et al. (2012)]

Figura 4.24 - Curva tensão-deformação pelo método de cálculo proposto por Roque et al. (2012) 211

Figura 4.25 - Exemplo de fratura do corpo de prova no ensaio de tração direta "dog bone": (a) fratura apropriada; (b) fratura prematura

Figura 4.26 - Energia de Fratura para ligantes asfálticos puros, CAP 50/70 e CAP 85/100, para várias taxas de carregamento e temperatura de ensaio de $10^{\circ} \mathrm{C}$

Figura 4.27 - Energia de Fratura para ligantes asfálticos puros, CAP 50/70 e CAP 85/100 envelhecidos no PAV, para várias taxas de carregamento e temperatura de ensaio de $15{ }^{\circ} \mathrm{C}$ 214

Figura 4.28 - Energia de Fratura para ligantes asfálticos puros CAP 50/70 e CAP 85/100 envelhecidos no PAV- $100 \mathrm{~h}-60^{\circ} \mathrm{C}$, para várias taxas de carregamento e temperatura de ensaio de $15{ }^{\circ} \mathrm{C}$

Figura 4.29 - Curva tensão-deformação para o ligante asfáltico CAP 50/70 .

Figura 4.30 - Curva tensão-deformação para o ligante asfáltico CAP 85/100

Figura 4.31 - Energia de Fratura para mástiques compostos com fíler de cimento Portland e CAP 50/70, para várias temperaturas de ensaio e taxas de carregamento

Figura 4.32 - Energia de Fratura para mástiques compostos com fíler de cimento Portland e CAP 85/100, para várias temperaturas de ensaio e taxas de carregamento

Figura 4.33 - Energia de Fratura para mástiques envelhecidos no PAV, compostos com fíler de cimento Portland e CAP 50/70, para várias temperaturas de ensaio e taxas de carregamento 218

Figura 4.34 - Energia de Fratura para mástiques envelhecidos no PAV compostos com fíler de cimento Portland e CAP 85/100, para várias temperaturas de ensaio e taxas de carregamento

Figura 4.35 - Energia de Fratura para mástiques envelhecidos no PAV-100h- $60^{\circ} \mathrm{C}$, compostos com fíler de cimento Portland e CAP 50/70, para várias temperaturas de ensaio e taxas de carregamento

Figura 4.36 - Energia de Fratura para mástiques envelhecidos no PAV-100h- $60^{\circ} \mathrm{C}$, compostos com fíler de cimento Portland e CAP 85/100, para várias temperaturas de ensaio e taxas de carregamento

Figura 4.37 - Curva tensão-deformação para mástiques compostos pelo cimento Portland e o ligante asfáltico CAP 50/70

Figura 4.38 - Curva tensão- deformação para mástiques compostos pelo cimento Portland e o ligante asfáltico CAP 85/100 
Figura 4.39 - Energia de Fratura para mástiques compostos com fíler de pó calcário e CAP 50/70, para várias temperaturas de ensaio e taxas de carregamento.........................................222

Figura 4.40 - Energia de Fratura para mástiques compostos com fíler de pó calcário e CAP 85/100, para várias temperaturas de ensaio e taxas de carregamento ............................. 222

Figura 4.41 - Energia de Fratura para mástiques envelhecidos no PAV, compostos com fíler de pó calcário e CAP 50/70, para várias temperaturas de ensaio e taxas de carregamento .........223

Figura 4.42 - Energia de Fratura para mástiques envelhecidos no PAV, compostos com fíler de pó calcário e CAP 85/100, para várias temperaturas de ensaio e taxas de carregamento. ...... 223

Figura 4.43 - Energia de Fratura para mástiques envelhecidos no PAV-100h- $60^{\circ} \mathrm{C}$, compostos com fíler de pó calcário e CAP 50/70, para várias temperaturas de ensaio e taxas de

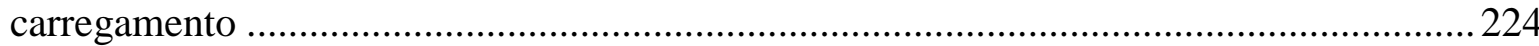

Figura 4.44 - Energia de Fratura para mástiques envelhecidos no PAV-100h- $60^{\circ} \mathrm{C}$ compostos com fíler de pó calcário e CAP 85/100, para várias temperaturas de ensaio e taxa de carregamento

Figura 4.45 - Curva tensão-deformação para mástiques compostos pelo pó calcário e o ligante asfáltico CAP 50/70

Figura 4.46 - Curva tensão- deformação para mástiques compostos pelo pó calcário e o ligante asfáltico CAP 85/100.

Figura 4.47 - Energia de Fratura para mástiques compostos com fíler de cal hidratada e CAP 50/70, para várias temperaturas de ensaio e taxas de carregamento ..............................226

Figura 4.48 - Energia de Fratura para mástiques compostos com fíler de cal hidratada e CAP 85/100, para várias temperaturas de ensaio e taxas de carregamento 226

Figura 4.49 - Energia de Fratura para mástiques envelhecidos no PAV, compostos com fíler de cal hidratada e CAP 50/70, para várias temperaturas de ensaio e taxas de carregamento .227

Figura 4.50 - Energia de Fratura para mástiques envelhecidos no PAV, compostos com fíler de cal hidratada e CAP 85/100, para várias temperaturas de ensaio e taxas de carregamento 227

Figura 4.51 - Energia de Fratura para mástiques envelhecidos no PAV- $100 \mathrm{~h}-60^{\circ} \mathrm{C}$, compostos com fíler de cal hidratada e CAP 50/70, para várias temperaturas de ensaio e taxas de carregamento

Figura 4.52 - Energia de Fratura para mástiques envelhecidos no PAV-100h- $60^{\circ} \mathrm{C}$, compostos com fíler de cal hidratada e CAP 85/100, para várias temperaturas de ensaio e taxas de carregamento

Figura 4.53 - Curva tensão-deformação para mástiques compostos pela cal hidratada e o ligante asfáltico CAP 50/70

Figura 4.54 - Curva tensão- deformação para mástiques compostos pela cal hidratada e o ligante asfáltico CAP 85/100

Figura 4.55 - Resumo das Médias da Energia de Fratura para mástiques compostos pelo CAP

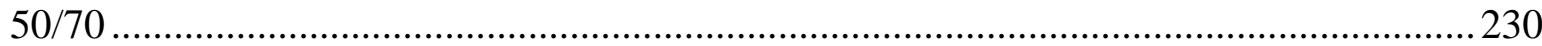

Figura 4.56 - Resumo das Médias da Energia de Fratura para mástiques compostos pelo CAP 50/70 sem envelhecimento e envelhecidos no PAV.

Figura 4.57 - Resumo das Médias da Energia de Fratura para mástiques compostos pelo CAP 50/70 sem envelhecimento, envelhecidos no PAV convencional e no PAV por 100 horas e a $60^{\circ} \mathrm{C}$ 232

Figura 4.58 - Resumo das Médias da Energia de Fratura para mástiques compostos pelo CAP $85 / 100$ 
Figura 4.59 - Resumo das Médias da Energia de Fratura para mástiques compostos pelo CAP 85/100 sem envelhecimento e envelhecidos no PAV

Figura 4.60 - Resumo das Médias da Energia de Fratura para mástique compostos pelo CAP 85/100 sem envelhecimento, envelhecidos no PAV convencional e no PAV por 100 horas e $60^{\circ} \mathrm{C}$ 
xviii 


\section{LISTA DE TABELAS}

Tabela 2.1 - Especificações Superpave: requisitos das propriedades de consenso ..................... 20

Tabela 2.2 - Pontos de controle conforme o Diâmetro Máximo Nominal ................................... 23

Tabela 2.3- Zona de restrição de acordo com o Diâmetro Máximo Nominal .............................. 23

Tabela 2.4 - Requisitos de VAM da Especificação Superpave .............................................. 27

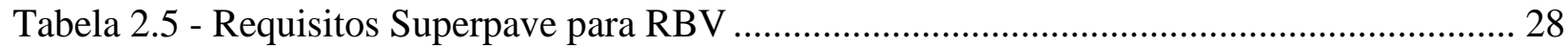

Tabela 2.6 - Características Físicas dos Agregados ........................................................... 32

Tabela 2.7 - Granulometria dos Agregados............................................................................. 32

Tabela 2.8 - Caracterização do Ligante Asfáltico CAP 50/70 …............................................... 33

Tabela 2.9 - Caracterização do Ligante Asfáltico CAP 85/100 ................................................. 34

Tabela 2.10- Massa e Superfície Específica dos Fileres ........................................................ 34

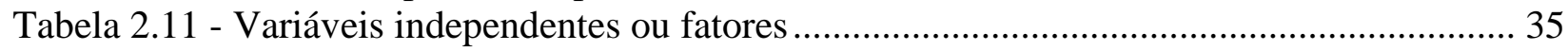

Tabela 2.12 - Condições experimentais avaliadas .............................................................. 36

Tabela 2.13 - Curva granulométrica para misturas com teor de 2,5; 5,0 e 7,5\% de fíler ............ 49

Tabela 2.14 - Dados do experimento para a análise do teor de ligante de projeto nas misturas

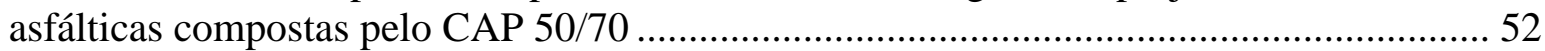

Tabela 2.15 - Resumo da Análise de Variância do teor de ligante de projeto da influência dos fatores e sua interação, nas misturas asfálticas compostas pelo CAP 50/70..................... 52

Tabela 2.16 - Dados do experimento do teor de ligante de projeto nas misturas asfálticas compostas pelo agregado granítico ............................................................................ 53

Tabela 2.17 - Resumo da Análise de Variância do teor de ligante de projeto, da influência dos fatores e sua interação, nas misturas asfálticas compostas pelo agregado granítico............ 54

Tabela 2.18 - Dados do experimento da absorção de ligante asfáltico nas misturas asfálticas

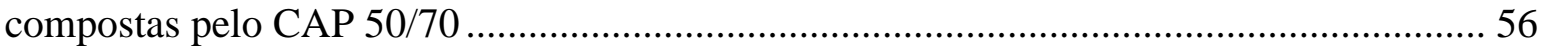

Tabela 2.19 - Resumo da Análise de Variância da absorção, influência dos fatores e sua interação, nas misturas asfálticas compostas pelo CAP 50/70 ....................................... 56

Tabela 2.20 - Dados do experimento da absorção de ligante asfáltico nas misturas asfálticas compostas pelo agregado granítico ............................................................................ 57

Tabela 2.21 - Resumo da Análise de Variância da absorção de ligante asfáltico, influência dos fatores e sua interação, nas misturas asfálticas compostas pelo agregado granítico............ 57

Tabela 2.22 - Condições experimentais testadas nos ensaios mecânicos................................... 58

Tabela 2.23 - Divisão do experimento fatorial fracionado em dois níveis - Parte 1................... 59

Tabela 2.24 - Fatores e níveis do experimento fatorial fracionado em dois níveis - Parte 1 ........ 59

Tabela 2.25 - Divisão do experimento fatorial fracionado em dois níveis - Parte 2.................. 59

Tabela 2.26 - Fatores e níveis do experimento fatorial fracionado em dois níveis - Parte 2 ........ 59

Tabela 2.27 - Divisão do experimento fatorial fracionado em dois níveis - Parte 3.................. 59

Tabela 2.28 - Fatores e níveis do experimento fatorial fracionado em dois níveis - Parte 3 ........ 60

Tabela 2.29 - Divisão do experimento fatorial fracionado em dois níveis - Parte 4................... 60

Tabela 2.30 - Fatores e níveis do experimento fatorial fracionado em dois níveis - Parte 4....... 60

Tabela 2.31 - Divisão do experimento fatorial fracionado em dois níveis - Parte 5................... 60

Tabela 2.32 - Fatores e níveis do experimento fatorial fracionado em dois níveis - Parte 5 ........ 60

Tabela 2.33 - Divisão do experimento fatorial fracionado em dois níveis - Parte 6................... 61

Tabela 2.34 - Fatores e níveis do experimento fatorial fracionado em dois níveis - Parte 6 ........ 61

Tabela 2.35 - Arranjo experimental fatorial fracionado em dois níveis .................................. 61

Tabela 2.36 - Valores médios de Resistência à Tração, em MPa............................................. 62 
Tabela 2.37 - Dados do experimento fatorial fracionado para a análise da Resistência à Tração .63 Tabela 2.38 - Arranjo experimental fatorial fracionado para análise da Resistência à Tração......63 Tabela 2.39 - Arranjo experimental fatorial fracionado da Parte 1 para análise da Resistência à

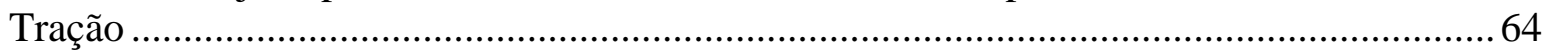

Tabela 2.40 - Valores estimados da Resistência à Tração, em MPa..........................................65

Tabela 2.41 - Resumo da Análise de Variância da resistência à tração, dos valores de $\mathrm{f}_{0}$ e da influência dos fatores e sua interação, das análises (1) e (2) ...........................................67

Tabela 2.42 - Valores médios de Módulo de Resiliência, em MPa ...........................................68

Tabela 2.43 - Dados do experimento fatorial fracionado para a análise do Módulo de Resiliência

68

Tabela 2.44 - Valores estimados do Módulo de Resiliência, em MPa ......................................69

Tabela 2.45 - Resumo da Análise de Variância do módulo de resiliência, dos valores de $\mathrm{f}_{0}$ e da influência dos fatores e sua interação, das análises (1) e (2) ........................................... 71

Tabela 2.46 - Numeração das condições experimentais ensaiadas no ensaio de Vida de Fadiga .72 Tabela 2.47 - Parâmetros k1, k2, k3, k4 do ensaio de Vida de Fadiga .....................................72

Tabela 2.48 - Equações das curvas de fadiga para as diferentes condições experimentais: número de aplicações de carga em função da diferença de tensões e número de aplicações de carga em função da deformação resiliente ............................................................................. 73

Tabela 2.49 - Valores calculados de Deformação Resiliente $\left(\varepsilon_{\mathrm{r}}\right)$............................................ 74

Tabela 2.50 - Dados do experimento fatorial fracionado para a análise da Deformação Resiliente,

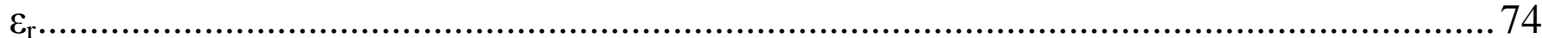

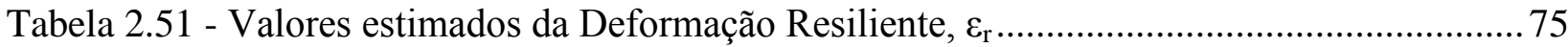

Tabela 2.52 - Resumo da Análise de Variância da deformação resiliente, dos valores de $\mathrm{f}_{0}$ e da influência dos fatores e sua interação, para as análises (1) e (2) ..................................... 77

Tabela 2.53 - Valores médios da Deformação Total .............................................................. 78

Tabela 2.54 - Dados do experimento fatorial fracionado para a análise da Deformação Total ..... 78

Tabela 2.55 - Valores estimados da Deformação Total .......................................................... 79

Tabela 2.56 - Resumo da Análise de Variância da deformação total, dos valores de $\mathrm{f}_{0}$ e da influência dos fatores e sua interação, para as análises (1) e (2) ...................................... 81

Tabela 2.57 - Valores médios da Deformação Recuperável ..................................................82

Tabela 2.58 - Dados do experimento fatorial fracionado para a análise da Deformação

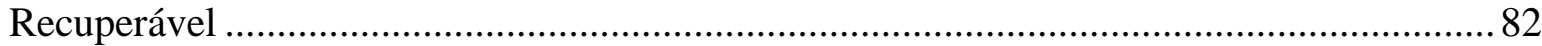

Tabela 2.59 - Valores estimados da Deformação Recuperável ...................................................83

Tabela 2.60 - Resumo da Análise de Variância da deformação recuperável, dos valores de $\mathrm{f}_{0}$ e da influência dos fatores e sua interação, para a análise (1) e (2) ....................................... 85

Tabela 2.61 - Valores médios da Deformação Não Recuperável ............................................. 85

Tabela 2.62 - Dados do experimento fatorial fracionado para a análise da Deformação Não

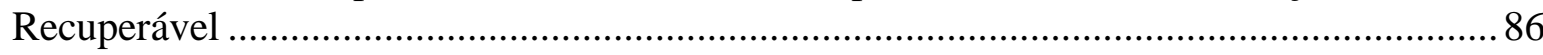

Tabela 2.63 - Valores estimados da Deformação Não Recuperável ...........................................86

Tabela 2.64 - Resumo da Análise de Variância da deformação não recuperável, dos valores de $\mathrm{f}_{0}$ e da influência dos fatores e sua interação, para as análises (1) e (2) ................................ 88

Tabela 2.65 - Valores médios da Recuperação (\%) ...................................................................89

Tabela 2.66 - Dados do experimento fatorial fracionado para a análise da Recuperação .............89

Tabela 2.67 - Valores estimados da Recuperação (\%)............................................................90

Tabela 2.68 - Resumo da Análise de Variância da recuperação, dos valores de $\mathrm{f}_{0}$ e da influência dos fatores e sua interação, para as análises (1) e (2) ..................................................... 92

Tabela 2.69 - Valores médios do Módulo de Fluência, em MPa .................................................92 
Tabela 2.70 - Dados do experimento fatorial fracionado para a análise do Módulo de Fluência . 93

Tabela 2.71 - Valores estimados do Módulo de Fluência, em MPa ......................................... 93

Tabela 2.72 - Resumo da Análise de Variância do módulo de fluência, dos valores de $\mathrm{f}_{0}$ e da

influência dos fatores e sua interação, para as análises (1) e (2) ...................................... 95

Tabela 2.73 - Valores médios do Módulo de Fluência Após a Recuperação, em MPa ............... 96

Tabela 2.74 - Dados do experimento fatorial fracionado para a análise do Módulo de Fluência

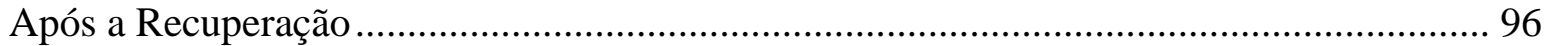

Tabela 2.75 - Valores estimados do Módulo de Fluência Após a Recuperação, em MPa ............ 97

Tabela 2.76 - Resumo da Análise de Variância do Módulo de Fluência após a Recuperação, dos valores de $f_{0}$ e da influência dos fatores e sua interação, para as análises (1) e (2) ............ 99

Tabela 2.77 - Valores médios da Inclinação ....................................................................... 99

Tabela 2.78 - Dados do experimento fatorial fracionado para a análise da Inclinação ............... 100

Tabela 2.79 - Valores estimados da Inclinação .................................................................... 100

Tabela 2.80 - Resumo da Análise de Variância da inclinação, dos valores de $\mathrm{f}_{0}$ e da influência dos fatores e sua interação, para as análises (1) e (2) ........................................................ 102

Tabela 3.1 - Valores do aumento do módulo complexo $\left(\mathrm{G}^{*}\right)$ em função da relação f/a, tipo de

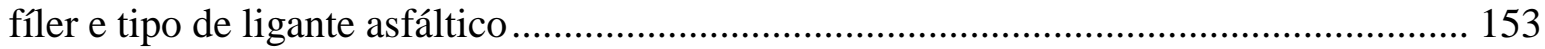

Tabela 3.2 - Dados do experimento do módulo complexo.................................................... 159

Tabela 3.3 - Resumo da Análise de Variância do módulo complexo, dos valores de $\mathrm{f}_{0}$ e da influência dos fatores e suas interações, para as análises (1) e (2) .................................. 160

Tabela 3.4 - Dados do experimento do ângulo de fase......................................................... 161

Tabela 3.5 - Resumo da Análise de Variância do ângulo de fase, dos valores de $\mathrm{f}_{0}$ e da influência dos fatores e suas interações, para as análises (1) e (2) ................................................ 162

Tabela 3.6 - Dados do experimento do parâmetro $G^{*} / \operatorname{sen} \delta$.................................................... 163

Tabela 3.7 - Resumo da Análise de Variância do parâmetro $G^{*} / \operatorname{sen} \delta$, dos valores de $f_{0}$ e da influência dos fatores e sua interação, para as análises (1) e (2)..................................... 164

Tabela 3.8 - Valores de aumento da rigidez à fluência na flexão........................................... 168

Tabela 3.9 - Dados do experimento da rigidez à fluência na flexão $(\mathrm{S}(60))$............................. 170

Tabela 3.10 - Resumo da Análise de Variância da rigidez à fluência na flexão, dos valores de $\mathrm{f}_{0} \mathrm{e}$ da influência dos fatores e sua interação, para as análises (1) e (2) ................................ 171

Tabela 3.11 - Dados do experimento do módulo de relaxação $(\mathrm{m}(60))$.................................... 172

Tabela 3.12 - Resumo da Análise de Variância do módulo de relaxação, dos valores de $\mathrm{f}_{0}$ e da influência dos fatores e sua interação, para as análises (1) e (2) ..................................... 173

Tabela 3.13 - Aumento do Ponto de Amolecimento dos mástiques em função do tipo de ligante

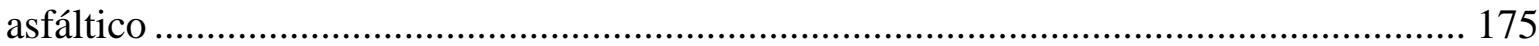

Tabela 3.14 - Dados do experimento da temperatura do ponto de amolecimento ..................... 176

Tabela 3.15 - Resumo da Análise de Variância da temperatura do ponto de amolecimento, dos valores de $\mathrm{f}_{0}$ e da influência dos fatores e sua interação, para as análises (1) e (2) .......... 177

Tabela 4.1 - Combinações de fatores e níveis para a análise de variância da energia de fratura 235

Tabela 4.2 - Dados para as análise de variância da energia de fratura ..................................... 236

Tabela 4.3 - Resumo da Análise de Variância para as análises (1) e (2), valores de $\mathrm{f}_{0}$ e influência dos fatores e suas interações ........................................................................................ 237

Tabela 4.4 - Resumo da Análise de Variância para as análises (3) e (4), valores de $\mathrm{f}_{0}$ e influência dos fatores e suas interações ................................................................................ 238

Tabela 4.5 - Resumo da Análise de Variância para as análises (5) e (6), valores de $\mathrm{f}_{0}$ e influência dos fatores e suas interações ............................................................................... 239 
xxii 


\section{LISTA DE SIGLAS, SÍMBOLOS E ABREVIATURAS}

AAPT - Association of Asphalt Paving Technologists

AASHTO - American Association of State Highway and Transportation Officials

$\delta-\hat{A}$ ngulo de Fase

ANOVA - Análise de Variância

ASTM - American Society for Testing and Materials

BBR - Reômetro de Fluência em Viga à Flexão

CAP - Cimento Asfáltico de Petróleo

$\mathrm{D}_{\mathrm{ap}}$ - Densidade Aparente

DMN - Diâmetro Máximo Nominal

DMT - Densidade Máxima Teórica

DNER - Departamento Nacional de Estradas e Rodagem

DSR - Reômetro de Cisalhamento Dinâmico

DTT - Teste de Tração Direta

ER - Recuperação Elástica por Torção

FD - Retorno Elástico por Ductilidade

G* - Módulo Complexo de Cisalhamento

$\mathrm{G}_{\mathrm{mb}}-$ Bulk Specific Gravity

Gmm - Densidade Máxima

LVDT - Linear Variable Differential Transducer

m - Módulo De Relaxação

MR - Módulo de Resiliência

PG - Grau de Desempenho 
xxiv

PAV - Estufa de Vaso Pressurizado Pressure Aging Vessel

RBV - Relação Betume Vazios

RTFOT - Estufa de Filme Fino Rotativo - Rolling Thin Oven Test

RV - Viscosímetro Rotacional

S - Rigidez Estática

SGC - Compactador Giratório Superpave Superpave Gyratory Compactor

SHRP - Strategic Highway Research Program

SUPERPAVE - Superior Performing Asphalt Pavements

VAM - Vazios Do Agregado Mineral

Vv - Volume de Vazios 
DEDICATÓRIA. i

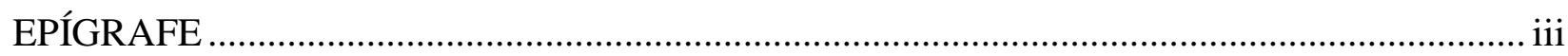

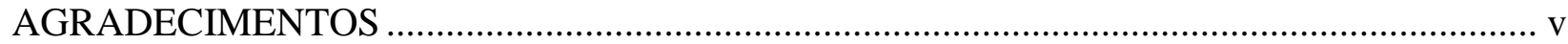

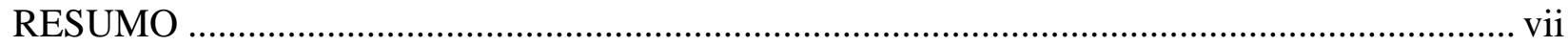

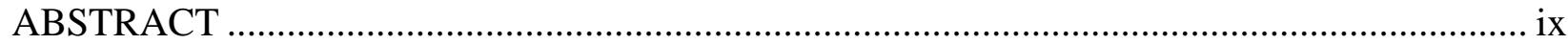

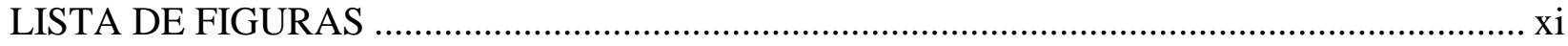

LISTA DE TABELAS …………………………....................................................

LISTA DE SIGLAS, SÍMBOLOS E ABREVIATURAS .......................................................... xxiii

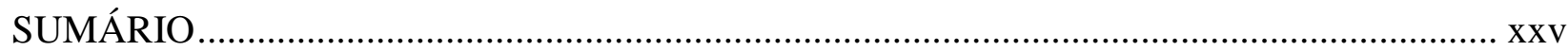

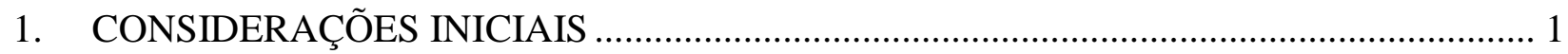

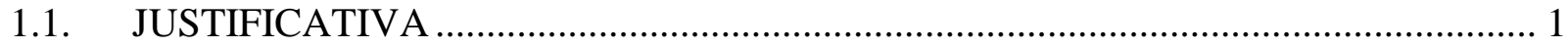

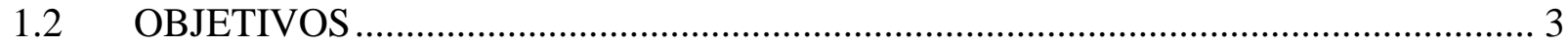

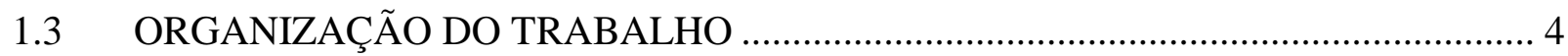

2. INFLUÊNCIA DO FÍLER EM MISTURAS ASFÁLTICAS ................................................. 5

2.1 PAPEL DO FÍLER MINERAL EM MISTURAS ASFÁLTICAS ................................. 6

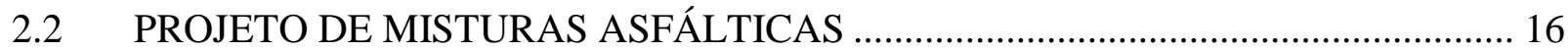

2.2.1 Método Superpave ...................................................................................... 16

2.2.2 Determinação da Densidade Máxima Teórica e Absorção de Misturas Asfálticas 29

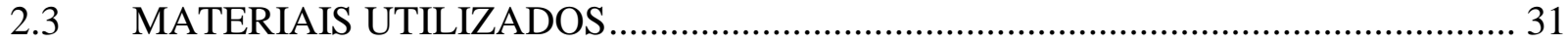

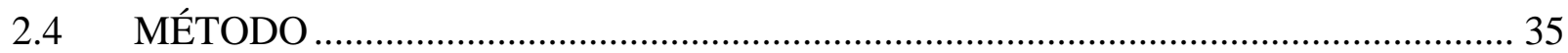

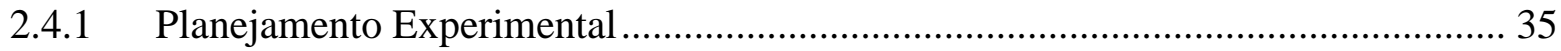

2.4.2 Planejamento e Análise de Experimentos .......................................................... 36

2.4.3 Avaliação de Misturas Asfálticas ......................................................................... 37

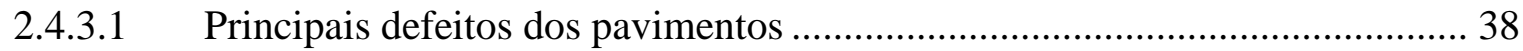

2.4.4 Ensaios para Avaliação de Misturas Asfálticas ........................................................ 42

2.4.4.1 Ensaio de Módulo de Resiliência .................................................................... 42

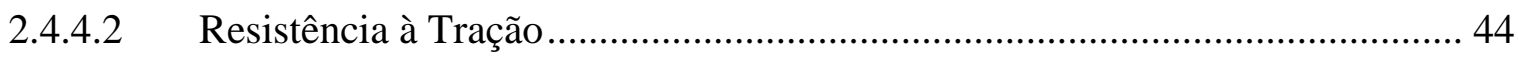

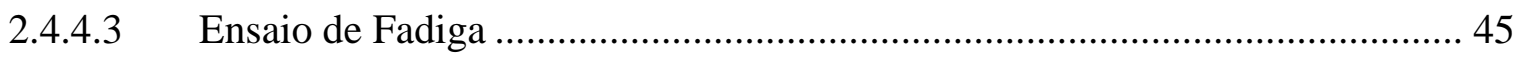

2.4.4.4 Ensaio de Fluência por Compressão Uniaxial Estática....................................... 48 


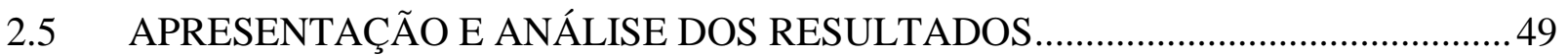

2.5.1 Projeto Volumétrico das Misturas Asfálticas..............................................................49

2.5.2 Absorção de Ligante Asfáltico nas Misturas Asfálticas .............................................54

2.5.3 Montagem do Experimento Fatorial Fracionado para a Caracterização das

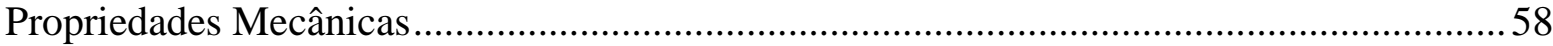

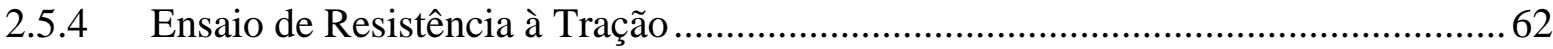

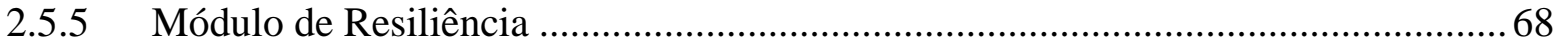

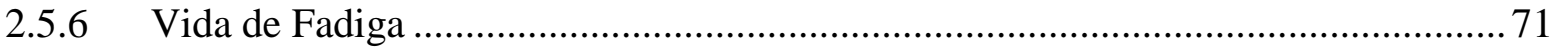

2.5.6 Fluência por Compressão Uniaxial Estática …………………….............................. 77

3. INFLUÊNCIA DO FÍLER NO COMPORTAMENTO DO MÁSTIQUE ASFÁLTICO ... 103

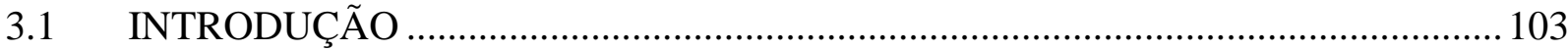

3.1.1 Importância das Propriedades Reológicas dos Mástiques ...................................... 106

3.1.2 Reologia de Ligantes e Mástiques Asfálticos ........................................................... 109

3.2 CARACTERIZAÇÃO DE LIGANTES E MÁSTIQUES ASFÁLTICOS ....................111

3.2.1 Especificação Superpave para Ligantes Asfálticos................................................... 111

3.2.2 Envelhecimento de Ligante e do Mástique Asfáltico ............................................113

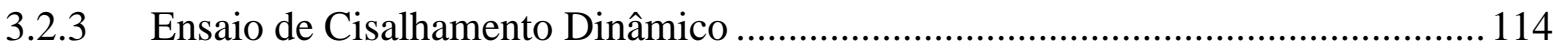

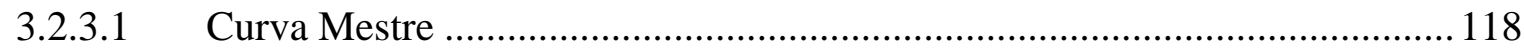

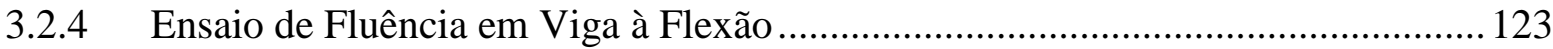

3.2.5 Ensaio de Ponto de Amolecimento pelo Método Anel e Bola.................................126

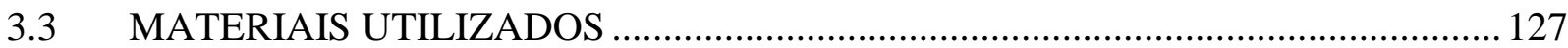

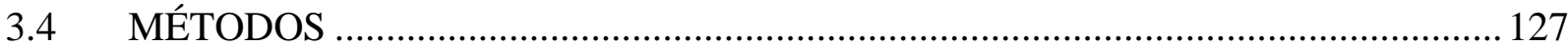

3.4.1 Ensaio de Cisalhamento em Regime Oscilatório .....................................................129

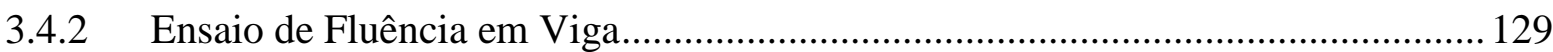

3.4.3 Ensaio de Ponto de Amolecimento pelo Método Anel e Bola..................................130

3.4.4 Envelhecimento de Ligantes e Mástiques Asfálticos................................................ 131

3.5 APRESENTAÇÃO E ANÁLISE DOS RESULTADOS........................................... 133

3.5.1 Ensaio de Cisalhamento em Regime Oscilatório ...................................................133

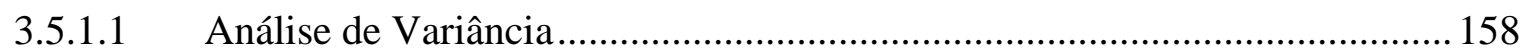

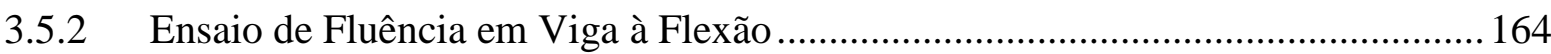

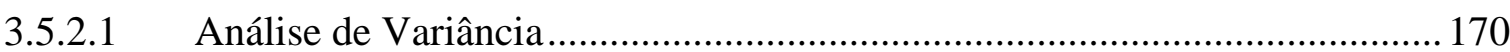

3.5.3 Ensaio de Ponto de Amolecimento pelo Método Anel e Bola................................ 173

3.5.3.1 Análise de Variância................................................................................ 176 
4. INFLUÊNCIA DO FÍLER NA ENERGIA DE FRATURA DE MÁSTIQUES ASFÁLTICOS 179

4.1 ENERGIA DE FRATURA EM MISTURAS ASFÁLTICAS …….............................. 180

4.2 ENERGIA DE FRATURA EM LIGANTES ASFÁSTICOS …................................. 186

4.3 CONCEITOS BÁSICOS DA TEORIA DE MECÂNICA DAS FRATURAS............ 193

4.3.1 Desenvolvimento da Mecânica da Fratura para Misturas Asfálticas a Quente ..... 199

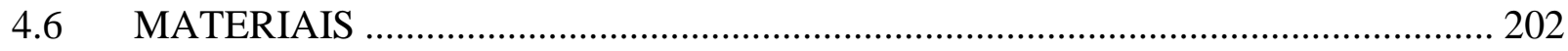

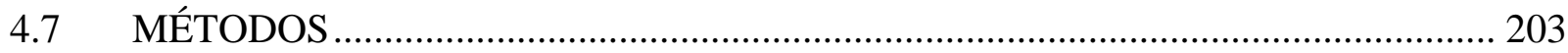

4.7.1 Procedimento de Cálculo da Energia de Fratura ............................................... 205

4.8 APRESENTAÇÃO E ANÁLISE DOS RESULTADOS .......................................... 212

4.8.1 Resultados da Energia de Fratura para os Ligantes Asfálticos Puros..................... 213

4.8.2 Resultados da Energia de Fratura para Mástiques Compostos com Cimento Portland 217

4.8.3 Resultados da Energia de Fratura para Mástiques Compostos com Pó Calcário .. 221

4.8.4 Resultados da Energia de Fratura para Mástiques Compostos com Cal Hidratada225

4.8.5 Resumo e Análise de Variância dos Resultados................................................... 230

4.8.5.1 Resumo dos Valores da Energia de Fratura .............................................. 230

4.8.4.2 Análise de Variância para a Energia de Fratura ............................................ 234

5. CONCLUSÕES E SUGESTÕES PARA TRABALHOS FUTUROS …............................. 241

5.1 PROPRIEDADES DA MISTURA ASFÁLTICA..................................................... 242

5.2 PROPRIEDADES REOLÓGICAS DOS MÁSTIQUES ASFÁLTICOS ..................... 247

5.3 PROPRIEDADES DE ENERGIA DE FRATURA DOS MÁSTIQUES ASFÁLTICOS 251

5.4 SUGESTÕES PARA TRABALHOS FUTUROS …………………......................... 252

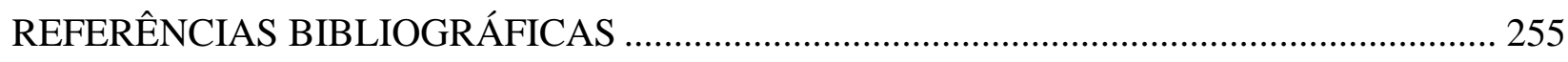

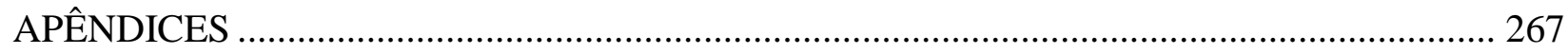

APÊNDICE A - PROPRIEDADES VOLUMÉTRICAS DOS CORPOS DE PROVA

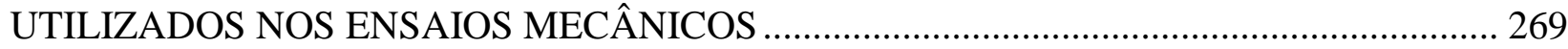

APÊNDICE B - TABELAS DE ANÁLISE DE VARIÂNCIA ……........................................... 277

APÊNDICE C - PROPRIEDADES MECÂNICAS DOS CORPOS DE PROVA ....................... 299 
Xxviii 


\section{CONSIDERAÇÕES INICIAIS}

\subsection{JUSTIFICATIVA}

Os sistemas de transportes são elementos estruturantes da vida econômica e social dos países, proporcionando o deslocamento de cargas e de passageiros. Dentre os elementos que compõem os sistemas de transportes do Brasil, o modo rodoviário e a infraestrutura de estradas têm papel fundamental, pois são responsáveis por $62 \%$ do transporte de cargas e por $96 \%$ do transporte de passageiros (CNT, 2008). Assim, justifica-se o interesse pelo desenvolvimento de materiais de melhor desempenho econômico e técnico para uso em pavimentos rodoviários.

Entre os principais defeitos estruturais dos pavimentos asfálticos pode-se destacar as deformações permanentes, encontradas nas trilhas de roda, e as trincas por fadiga, cada um associado a uma etapa da vida em serviço do pavimento. As deformações permanentes geralmente aparecem nos anos iniciais, antes do enrijecimento que acompanha o processo de envelhecimento dos revestimentos asfálticos, causadas por consolidação ou ruptura plástica por cisalhamento, podendo ser, também, decorrentes das solicitações de cargas elevadas associadas a altas temperaturas. Já as trincas por fadiga manifestam-se normalmente quando o revestimento asfáltico encontra-se mais envelhecido, após ter sido submetido às cargas cíclicas do tráfego, podendo ocorrer, também, quando não se utilizam materiais adequados ou o projeto correto.

Com a finalidade de minimizar os efeitos do tráfego e do clima e o aparecimento dos defeitos no revestimento, muitas pesquisas têm procurado garantir o comportamento adequado dos materiais que compõem as misturas asfálticas, assim como a sua interação, para que as propriedades especificadas sejam alcançadas.

Fíler mineral ou material de enchimento constitui um material mineral inerte em relação aos demais componentes da mistura asfáltica, finamente dividido, passando pelo menos $65 \%$ na peneira de 0,075 mm de abertura de malha quadrada (DNER - EM 367/97). 
Em decorrência do pequeno tamanho das partículas e de suas características de superfície, o fíler age como material ativo, manifestado nas propriedades da interface fíler/ligante asfáltico, não sendo, portanto, apenas um material de enchimento inerte, como é apresentado na definição geral do DNER EM 367/97.

O fíler mineral é um material constituído de partículas minerais provenientes dos agregados graúdos e/ou miúdos empregados na mistura asfáltica, ou de outras fontes como, por exemplo, pó calcário, cal hidratada, cimento Portland etc., que pode melhorar o comportamento reológico, mecânico, e de susceptibilidade térmica e à água das misturas asfálticas. Pode ser utilizado como material de enchimento dos vazios entre agregados graúdos e miúdos, contribuindo para fechamento da mistura, modificando sua trabalhabilidade, resistência à água e resistência ao envelhecimento.

Dois mecanismos descrevem o papel desempenhado pelo fíler em uma mistura asfáltica: o fíler fornece pontos de contato adicionais entre os agregados maiores e pode ser considerado como continuação da fração de agregado da mistura asfáltica, e o fíler aumenta a estabilidade da mistura, aumentando a viscosidade do ligante e mudando suas propriedades. É evidente que todos os fileres apresentam as duas funções na mistura asfáltica; porém, dependendo das características do agregado, do ligante asfáltico e do fíler, uma função predominará, (TUNNICLIFF,1962).

Se o fíler é suficientemente fino e a mistura contém quantidade adequada de ligante, os finos ficam envoltos na película de ligante e, portanto, mudam suas propriedades; porém, se o agregado da mistura é bem graduado, ou se a mistura contém quantidade relativamente pequena de ligante e a película de ligante é relativamente fina, pelo menos uma parte do fíler contribuirá para a produção de pontos de contato entre as partículas do esqueleto pétreo. Esse duplo papel é específico do fíler mineral em misturas asfálticas e separa-se nitidamente dos outros componentes pétreos da mistura (KALLAS e PUZINAUSKAS, 1961).

Já há muito tempo tem sido reconhecido que o fíler tem papel importante no comportamento de misturas asfálticas. O fíler preenche os vazios entre os agregados graúdos nas misturas e altera as propriedades dos ligantes asfálticos, pois age como parte ativa do mástique (combinação de 
ligante asfáltico, fíler e ar). A qualidade do mástique influencia todas as propriedades mecânicas das misturas asfálticas, assim como sua trabalhabilidade. O processo de fadiga, fenômeno afetado pelo desenvolvimento e crescimento de microfissuras no mástique, está fortemente relacionado às características do ligante asfáltico, às propriedades do fíler e à interação físico-química entre os dois, que é afetada, principalmente, pela finura e características de superfície do fíler.

Na dosagem, o mástique influencia na lubrificação das partículas de agregados maiores e afeta os vazios do agregado mineral, as características de compactação e o teor ótimo de ligante asfáltico. A rigidez do mástique afeta a resistência à deformação permanente da mistura asfáltica a altas temperaturas, influencia as tensões desenvolvidas e a resistência à fadiga a temperaturas intermediárias e influencia as tensões desenvolvidas e a resistência ao trincamento a baixas temperaturas.

\subsection{OBJETIVOS}

Esta pesquisa tem por objetivo contribuir para o melhor entendimento dos efeitos do fíler mineral sobre o comportamento mecânico de misturas asfálticas densas, particularmente em relação ao tipo e teor de fíler e tipo de agregado. Existe correlação entre a proporção de finos menores que $75 \mu \mathrm{m}$ na mistura e o comportamento de revestimento asfáltico no pavimento em serviço. Contudo, as propriedades físico-químicas do fíler, que determinam de fato o bom ou mau desempenho no campo, devem ser melhor estudadas, ou seja, ainda há muito para se entender a respeito do mecanismo que governa a contribuição do fíler no desempenho global da mistura.

O objetivo geral desta pesquisa é avaliar o comportamento mecânico de misturas asfálticas densas em função do tipo e teor de fíler (diferentes propriedades físicas, geométricas e mineralógicas) do tipo de agregado (diferentes origens mineralógicas) e do tipo de ligante asfáltico (diferentes consistências).

Para alcançar o objetivo geral, a pesquisa foi dividida em três estudos, que tem os seguintes objetivos específicos: 
- Estudo da mistura asfáltica completa, através dos ensaios de resistência à tração por compressão diametral, fadiga, módulo de resiliência e fluência por compressão uniaxial estática;

- Estudo do mástique, resultante da mistura fíler e ligante asfáltico, com o auxílio dos parâmetros obtidos nos ensaios comumente aplicados aos ligantes asfálticos puros: ensaio de cisalhamento dinâmico, ensaio de fluência de viga à flexão e ponto de amolecimento;

- Estudo do comportamento de trincamento dos mástiques nas temperaturas intermediárias, através características de energia fratura, em conjunto com a Universidade da Flórida. O método de ensaio utilizado nesta pesquisa foi desenvolvido por Roque et al. (2012), que constataram que os métodos de ensaios existentes nas especificações atuais, incluindo o Reômetro de Cisalhamento Dinâmico - DSR (G*senס), Recuperação Elástica por Torção (ER) e Retorno Elástico por Ductilidade (FD) não tem a capacidade de prever o desempenho quanto ao trincamento nas temperaturas intermediárias.

\subsection{ORGANIZAÇÃO DO TRABALHO}

Este trabalho está dividido em cinco capítulos, incluindo esta introdução (Capítulo 1). O Capitulo 2 traz um estudo da influência do fíler mineral nas propriedades volumétricas e mecânicas das misturas asfálticas, desenvolvido com a aplicação da técnica de planejamento e análise de experimentos fatoriais.

No Capitulo 3 foi realizada a caracterização da escala mais fina da mistura asfáltica, o mástique mistura de fíler mineral e ligante asfáltico, com a avaliação da influência do tipo e teor de fíler mineral e do tipo de ligante no comportamento reológico de mástiques asfálticos ao longo de toda a faixa de temperaturas a que um pavimento pode estar sujeito durante a vida em serviço.

O Capitulo 4 foi desenvolvido em conjunto com pesquisadores da Universidade da Flórida, com estudo sobre a fadiga de ligantes e mástiques asfálticos, através da determinação da energia de fratura, que se correlaciona fortemente com o aparecimento de trincas em misturas asfálticas.

No Capitulo 5 estão as principais conclusões do trabalho, assim como sugestões para trabalhos futuros. 


\section{INFLUÊNCIA DO FÍLER EM MISTURAS ASFÁLTICAS}

São muitos os problemas a serem resolvidos em pavimentação asfáltica, com destaque para o aparecimento e propagação das trincas por fadiga, o acúmulo de deformação permanente nas trilhas de roda e o trincamento térmico provocado pela variação térmica do pavimento. A solução passa pela ampliação do conhecimento dos efeitos dos ligantes asfálticos e dos fileres minerais, com desenvolvimento de melhores critérios para o projeto de misturas asfálticas e o controle dos principais fatores durante a execução dos pavimentos.

Há muito tempo é reconhecida a importância do papel do fíler no comportamento de misturas asfálticas. O fíler preenche os vazios entre os agregados graúdos nas misturas e altera as propriedades dos ligantes asfálticos, pois age como parte ativa do mástique (combinação de ligante asfáltico, fíler e ar). Na dosagem, o mástique influencia a lubrificação das partículas de agregados maiores e afeta os vazios do agregado mineral, as características de compactação e o teor ótimo de ligante asfáltico.

A qualidade do mástique influencia todas as respostas mecânicas das misturas asfálticas, assim como a trabalhabilidade. O processo de fadiga, fenômeno afetado pelo desenvolvimento e crescimento de microfissuras no mástique, está fortemente relacionado às características do ligante asfáltico, às propriedades do fíler e à interação físico-química entre os dois, que é afetada, principalmente, pela finura e características de superfície do fíler. A rigidez do mástique influencia as tensões desenvolvidas e a resistência à fadiga a temperaturas intermediárias, bem como afeta a resistência à deformação permanente da mistura asfáltica a altas temperaturas e as tensões desenvolvidas e a resistência ao trincamento a baixas temperaturas.

Craus et al. (1978) considera que o fíler atua de duas maneiras distintas nas misturas asfálticas densas:

- as partículas maiores do fíler são parte do agregado mineral e preencherão os vazios e interstícios dos agregados graúdos, promovendo o contato pontual entre as partículas maiores e dando maior resistência às misturas; 
- as partículas menores do fíler se misturam com o ligante asfáltico, aumentando sua consistência e cimentando as partículas maiores.

Fíler é um material de preenchimento, que reduz o tamanho dos vazios da mistura asfáltica, resultando em uma mistura mais densa, menos permeável e de textura mais fina. Porém o excesso de fíler pode reduzir a flexibilidade e durabilidade da mistura.

A porção do fíler com partículas maiores que a película de ligante contribui para o intertravamento dos agregados, produzindo pontos de contato entre eles; a outra porção do fíler, com partículas menores que a película de ligante, fica suspenso e constitui o ligante efetivo da mistura, mudando suas propriedades. Vários fatores como granulometria dos agregados minerais da mistura asfáltica, grau de compactação, espessura da película de ligante, proporção entre fíler e ligante asfáltico, e outros, podem determinar qual função do fíler irá predominar.

A densificação e a rigidez de uma mistura asfáltica são afetadas pela porcentagem de material passante na peneira $\mathrm{n}^{\circ} 200(0,075 \mathrm{~mm}$ de abertura) e são influenciadas pela forma, natureza e pela granulometria das partículas menores que esse diâmetro (MOTTA e LEITE, 2000). Se a maior parte do material de enchimento que passa na peneira ${ }^{\circ} 200$ é relativamente grossa, vai cumprir a função de preencher os vazios do esqueleto mineral, diminuindo o índice de vazios e alterando o teor ótimo de ligante asfáltico. No entanto, um fíler ultrafino, com porcentagem significativa de material menor que $20 \mu \mathrm{m}$, e até com alguma porção menor que $5 \mu \mathrm{m}$, tende a ser incorporado ao ligante asfáltico, compondo uma película que envolve as partículas de agregados miúdos e graúdos (AASHTO, 1991).

\subsection{PAPEL DO FÍLER MINERAL EM MISTURAS ASFÁLTICAS}

Fíler é a porção do agregado mineral, geralmente passante na peneira de número 200 (0,075 mm de abertura), que ocupa os vazios entre as partículas de agregados graúdos, com o objetivo de reduzir o tamanho desses vazios e aumentar a densidade e estabilidade da mistura asfáltica, e também, como sendo um material mineral que fica em suspensão no ligante asfáltico, aumentando sua consistência (TUNNICLIFF, 1962). 
A distinção entre partículas de fíler e partículas de agregado é que as características principais do fíler são sua área superficial e sua habilidade em permanecer em suspensão, enquanto que as características principais do agregado são seu volume, peso e inércia, que evita a suspensão e deixa a energia superficial em um papel secundário em relação à estabilidade interna (MACK, 1957). As partículas de fíler reagem quimicamente e interagem fisicamente com o ligante asfáltico, enquanto que as partículas de agregado preenchem parcialmente os vazios e apenas secundariamente formam a ligação ligante-fíler (TUNNICLIFF, 1962).

Craus et al. (1978) consideram, dentre os vários aspectos físico-químicos da interação fílerligante asfáltico, a intensidade de adsorção como o fator mais importante de caracterização do fíler. Kavussi e Hicks (1997), complementarmente, destacam os seguintes fatores:

- tipo de fíler: graduação, textura superficial, superfície específica, forma dos grãos etc.;

- natureza do fíler: a composição mineralógica e a atividade físico-química, que afetam a afinidade com o ligante asfáltico;

- concentração do fíler na mistura.

Para Rigden (1947) as características primárias do fíler incluem a densidade dos sólidos, a forma, a textura, a distribuição granulométrica e a área superficial, sendo características secundárias, derivadas das primárias, a massa específica, o diâmetro dos poros e a permeabilidade, destacando que as propriedades geométricas dos fileres são, provavelmente, mais significativas que as diferenças químicas entre os vários fileres.

Traxler (1937) listou o tamanho, a distribuição granulométrica e a forma como propriedades físicas fundamentais dos fileres. Essas propriedades determinam o volume de vazios e o tamanho médio dos vazios, que são importantes, pois a viscosidade do mástique é inversamente proporcional à média do diâmetro dos vazios do fíler contido na mistura.

A atividade superficial do fíler é uma propriedade complexa, usualmente relacionada à adsorção, à sorção seletiva, à absorção e à atividade química. Essa propriedade é afetada principalmente pela composição mineralógica das partículas e a textura superficial. A atividade do fíler, em relação à sua interação com o ligante, pode ser avaliada por métodos de cromatografia ou pela 
medida da intensidade de adsorção, refletida pelo calor liberado durante a interação fíler-ligante (ISHAI et al., 1979).

Dois mecanismos de atração superficial entre as partículas minerais e o ligante asfáltico, absorção e adsorção, são apresentados pela literatura. Por definição, adsorver é um fenômeno superficial, envolvendo forças moleculares na ou entre superfícies, enquanto que absorver é também um fenômeno superficial, mas é uma ação através da superfície. Se a absorção ocorre, deve haver espaço ou volume para o material absorvido ocupar após ir através da superfície. Fileres apresentam uma grande superfície e, assim, uma grande capacidade de adsorção, mas seu volume - e sua capacidade de absorção - é pequena, sendo que a absorção, se ocorrer, provavelmente terá efeito insignificante diante da adsorção (TUNNICLIFF, 1962).

Para Tunnicliff (1962), o enrijecimento é causado pela energia superficial de atração entre a superfície do mineral e o ligante, em que se forma uma película que exibe maior resistência a forças externas de tentativa de punção ou penetração, resultado da adsorção, pois a energia superficial deve ser substituída ou superada antes que a deterioração do revestimento ocorra, sendo que as forças de deterioração aparecem na forma de materiais externos, como água ou poeira, ou em forma de tensão induzida, como expansão e contração térmica.

A porção adsorvida do ligante asfáltico pelo fíler são os asfaltenos, que é a fração mais rígida do ligante, ou seja, mais viscosa, resultando em um material mais fluido entre as partículas que são propensas a escoar, pois o ligante restante, que é menos susceptível à adsorção, é mais fluido e de natureza oleosa.

Quando ocorrem baixas temperaturas, com a adsorção seletiva, o material que é menos afetado pela adsorção e está mais disponível para o trincamento é o mais fluido e, portanto, o menos provável a trincar. Por outro lado, em altas temperaturas, esse mesmo material seria o mais provável a fluir (TUNNICLIFF, 1962).

Para Tunnicliff (1962), a adsorção ocorre nas partículas de fíler mineral suspensas no ligante asfáltico, sendo que a proporção de fíler deve ser suficiente para afetar a máxima quantidade de 
ligante. O estado desejado é o intermediário entre o sistema líquido viscoso, em que o ligante apresenta-se em sua consistência original, e o sistema plástico, em que a resistência à deformação sob tração é máxima. Porém, fíler em excesso pode causar repulsão entre as partículas, quando as partículas de fíler se tocam.

A utilização de fíler em misturas asfálticas melhora a adesão no sistema ligante-agregado, através de mecanismos mecânico e físico-químico: o efeito mecânico do fíler na adesão é promover o aumento da viscosidade do ligante, que aumenta a resistência ao descolamento; o efeito físicoquímico aparece nos fileres que apresentam atividade na interface agregado-mástique, como, por exemplo, a cal hidratada.

A cal hidratada é utilizada, tradicionalmente, como aditivo melhorador de adesividade ("antistripping") em misturas asfálticas, sendo incorporada como parte do fíler (1 a $3 \%$ do peso dos agregados). Por um lado, assume-se que a cal hidratada reage com os ácidos carboxílicos existentes no ligante asfáltico, permitindo que outros grupos funcionais do asfalto (como cetonas) reajam com os agregados, ligando-se à sua superfície e fazendo com que a mistura asfáltica se torne menos susceptível ao descolamento na presença de água.

Ishai e Craus (1977) explicam o mecanismo físico-químico que melhora as propriedades de adesão com a presença de cal hidratada $\left(\mathrm{Ca}(\mathrm{OH})_{2}\right)$ na mistura asfáltica. Durante a penetração de água $\left(\mathrm{H}_{2} \mathrm{O}\right)$ através do mástique com cal hidratada, uma solução saturada de cal hidratada é formada e, inicialmente, um filme multi-molecular de água fica presente na interface $\left((\mathrm{OH})^{-}+\right.$ $\mathrm{H}^{+}$), com isso desenvolve-se uma adsorção química seletiva durante a penetração da solução na interface, formando-se íons de cálcio nos pontos ativos da interface $\left(\mathrm{Ca}^{2+}+(\mathrm{OH})^{-}\right)$, esses íons tem afinidade com os componentes do ligante que causa uma adsorção química entre o radical ácido do ligante e os íons de cálcio, que reveste a superfície do agregado e, devido a esses efeitos, o ligante tende a se espalhar e umedecer a superfície do agregado; o excesso de solução de cal hidratada na interface é incorporado ao mástique, formando uma emulsão asfáltica inversa. Quando se utiliza um fíler não ativo, como o pó calcário, a água que penetra na interface agregado-mástique é adsorvida na superfície do agregado $\left((\mathrm{CO})_{3} \mathrm{Ca}\right)$, formando-se o ácido 
silícico, e os íons de hidrogênio adsorvem e orientam os íons dissociados da água, formando um filme multi-molecular de água na interface $\left((\mathrm{OH})^{-}+\mathrm{H}^{+}\right)$, e o descolamento é iminente.

Whiteoak (1990) sugeriu que, quando existe água na interface entre os agregados e o ligante asfáltico, a cal hidratada adicionada às misturas asfálticas reage com a água da interface, dando origem a cal hidratada. Os íons de cálcio da cal hidratada tornam a superfície dos agregados básicos, e o balanço eletroquímico na interface entre os agregados e o ligante asfáltico afasta a água da superfície dos agregados para uma emulsão dentro do ligante asfáltico. Neste contexto, o ligante asfáltico consegue ligar-se melhor à superfície hidrófoba do agregado.

Richardson (1915) afirmou que para manter a água longe da superfície do ligante asfáltico é necessário ter vazios na mistura, tão pequeno quanto possível em tamanho, mas não necessariamente em volume, para preenchê-los com ligante em uma consistência que permita sua contração e enrijecimento, com um apropriado teor de fíler. Se os espaços intersticiais são pequenos em número, mas grande em tamanho, a quantidade necessária de ligante para ocupá-los se presentará em grandes massas para preencher inteiramente os vazios, produzindo tensões e causando deformações e deslocamentos; se os vazios não forem preenchidos, a água entrará rapidamente, provocando o descolamento. A utilização de fíler em proporção apropriada, o tamanho dos espaços intersticiais é reduzido, assim como o volume de massa de ligante para preenchê-los, e os vazios podem ser completamente preenchidos sem movimentação.

Uma vez que o fíler tem papel principal nas propriedades e comportamento das misturas asfálticas, é importante compreender alguns conceitos básicos e fundamentais, que são caracterizados por: (a) definir as propriedades do fíler em termos de parâmetros físico-químicos; (b) relacionar essas propriedades e as propriedades do ligante asfáltico ao fenômeno de interface e de comportamento do sistema fíler-ligante (mástique); (c) relacionar o comportamento do mástique com o comportamento das misturas asfálticas (ISHAI et al., 1979).

O índice de vazios de Rigden, modificado por Anderson, é um método para analisar o efeito do fíler na mistura asfáltica. É determinado sob condições padronizadas, em que os vazios da mistura fíler-ligante asfáltico resultam em uma máxima densificação do fíler. Com isso é possível 
avaliar o teor de ligante asfáltico que irá preencher os vazios e ainda avaliar o volume de ligante em relação ao teor determinado para a mistura (HARRIS e STUART, 1995).

Motta e Leite (2000) comentam que, teoricamente, quando a quantidade de ligante aumenta além do índice de vazios de Rigden, as partículas perdem o contato entre elas e a quantidade adicional de ligante promove uma lubrificação entre as partículas. Quando a quantidade livre de ligante asfáltico diminui, a rigidez da mistura aumenta. Quanto mais fino for o fíler, menor deve ser a relação fíler/ligante, pois o volume livre de ligante é que aumenta a espessura de recobrimento das partículas dos agregados, em outras palavras, a razão do volume de ligante livre pelo volume total de ligante tem um efeito significativo na rigidez do mástique.

A interação entre o fíler e ligante asfáltico presente na mistura também influencia a trabalhabilidade, rigidez e propriedades mecânicas da mistura. Para obter misturas com trabalhabilidade adequada, um estudo cuidadoso da interação entre o fíler e o ligante é necessário (KAVUSSI e HICKS, 1997).

A graduação do fíler afeta a trabalhabilidade, da mesma forma que a graduação do esqueleto mineral, sendo proporcional à relação entre a parte mais graúda e mais miúda do fíler (menor que $20 \mu \mathrm{m}$ ). Quanto mais pó estiver contido no fíler, maior seu efeito na trabalhabilidade e no comportamento da mistura. Atualmente, com a tendência cada vez maior de se usar como fíler os finos da coleta de filtros instalados nas usinas, aumenta a importância de estudos das propriedades físicas, de estado e mecânica do fíler (AASHTO, 1991).

Quando a porcentagem de material passante na peneira $\mathrm{n}^{\circ} 200$ aumenta, reduzem-se os vazios do esqueleto mineral, melhora-se a graduação e a trabalhabilidade da mistura asfáltica aumenta até certo ponto. Acima de um dado nível, quanto maior a porcentagem passante na peneira $\mathrm{n}^{\circ} 200$, os finos começam a prejudicar a estabilidade do esqueleto mineral, diminuindo os contatos entre as partículas grossas e alterando a capacidade de compactação. Quanto menor o tamanho da partícula de fíler, maior a incorporação do mineral no ligante, aumentando a rigidez da mistura asfáltica (MOTTA e LEITE, 2000). 
Para evitar os danos causados pelo excesso ou pela ausência de fíler, McGennis et al. (1994) estabeleceram, como parte das especificações SUPERPAVE de dosagem de misturas asfálticas, a razão, em peso, entre o fíler mineral e o ligante asfáltico, denominada de “dust proportion", recomendando valores de 0,6 a 1,8 para todo tipo de mistura.

O uso de fíleres é importante para aumentar a uniformidade na consistência e diminuir suscetibilidade térmica, que podem advir de eventuais irregularidades na produção de ligantes asfálticos e na confecção da massa asfáltica (SANTANA, 1995). O fíler, além de preencher os vazios, aumenta a viscosidade - diminuindo a penetração - do ligante asfáltico. O fíler ativa o ligante asfáltico, espessando-o e encorpando-o, fazendo com que o mástique tenha maior viscosidade que o ligante asfáltico puro. Simultaneamente, tem-se o aumento do ponto de amolecimento, diminuição da suscetibilidade térmica, aumento na resistência aos esforços de cisalhamento (estabilidade), no módulo de rigidez e na resistência à tração na flexão.

Pinilla (1965) propôs uma técnica de determinação da concentração crítica de fíler - denominada de Cs - a partir da qual o sistema fíler-ligante asfáltico deixa de ser viscoso, transformando seu escoamento em não-newtoniano ou plástico. Para dosar misturas asfálticas que se deformam sem ruptura, ou seja, sem comprometer a vida de fadiga, a concentração em volume de fíler deve ser igual ou menor que a concentração crítica - Cs. Quanto maior a concentração volumétrica do sistema fíler-ligante - C - mais próxima estarão as partículas dos agregados na mistura asfáltica e menor será o volume de poros e, consequentemente, mais rígida ficará a mistura asfáltica.

Motta e Leite (2000) estudaram o efeito de três tipos de fileres: pó calcário, cimento Portland e pó de pedra. Dos fileres estudados, o pó calcário apresentou o menor tamanho de partícula e o cimento Portland teve o tamanho intermediário. Foi observado que os corpos-de-prova preparados com fíler de pó calcário apresentaram valores módulos de resiliência e de resistência à tração superiores aos obtidos com os demais fileres, que apresentam granulometria mais grossa. Os resultados dos ensaios mecânicos demonstraram o efeito da granulometria do fíler na rigidez da mistura betuminosa, pois quanto menor o tamanho de partícula do fíler, maior a incorporação do mineral no ligante, aumentando a rigidez da mistura. 
Souza et al. (1998) utilizaram resíduo proveniente da serragem de rochas graníticas como fíler em misturas asfálticas e compararam com misturas asfáltica que utilizaram a cal hidratada e o cimento Portland como fíler. Verificaram que as misturas que têm como fíler a cal hidratada apresentaram valores maiores de estabilidade Marshall e que o teor de ligante asfáltico de projeto foi maior para as misturas com cal hidratada (6\%), depois com o resíduo da serragem de rochas graníticas $(5,5 \%)$ e o mais baixo para o cimento Portland $(5 \%)$.

Contrastando com os resultados de Souza et al. (1998), Soares e Cavalcante (2001), que estudaram fileres de areia de campo, pó de pedra, pó calcário, cal hidratada, carbonato de magnésio e cimento Portland, concluíram que o aumento do teor de fíler aumenta a resistência à tração, mas que, em relação ao teor de ligante asfáltico de projeto, só existe mudança quando se altera o teor de fíler - quanto maior o teor de fíler, menor o teor de ligante.

O comportamento em relação à diminuição do teor de ligante de projeto para teores maiores de fíler também foi constatado por Bardini (2008). Em função da maior superfície específica da matriz de agregado mineral com maior teor de fíler, esperava-se que fosse necessário um maior teor de ligante para envolver adequadamente essas partículas, porém, os ensaios laboratoriais não confirmaram esse comportamento.

Farias (2005) estudou a influência da utilização de fíler proveniente da britagem de concreções lateríticas e da cal hidratada e concluiu que a origem da laterita e o tipo de fíler utilizado influenciaram decisivamente nas propriedades mecânicas das misturas. As amostras com fíler laterítico apresentaram comportamento superior ao das misturas com cal hidratada, em relação à resistência à tração e à resistência à fadiga; porém, o tipo de fíler não influenciou a resistência à deformação permanente. O único ensaio para o qual o fíler cal hidratada resultou em melhor comportamento da mistura foi no ensaio de desgaste Cântabro.

Para Kavussi e Hicks (1997), as partículas de fíler mais longas e angulares, como o quartzo, afetam mais os resultados de penetração, quando comparado a partículas mais finas e com características esféricas; o tamanho e a forma das partículas tem efeito pronunciado nos ensaio de ponto de amolecimento, em que os fileres com partículas maiores são menos incorporados ao 
ligante asfáltico, resultando em maiores valores dessa propriedade para os fileres com granulometria mais fina. Os autores também perceberam que a adição de fíler reduz a susceptibilidade térmica, que aumenta rapidamente para os mástiques com partículas mais finas. Os autores observaram que a adição de fíler aumenta a viscosidade do ligante asfáltico, havendo um aumento maior de seu valor para o fíler de caolim quando comparados aos outros fileres, que é devido às caraterísticas de finura e sua alta afinidade com o ligante asfáltico, consequentemente, maior adsorção.

Ishai et al. (1979) verificaram que misturas com fileres convencionais (dolomita, arenito, basalto e pó calcário) são menos sensíveis ao tipo e teor de fíler, quando avalia a estabilidade Marshall e o Módulo de Resiliência, que as misturas com cal hidratada e esferas de vidro.

Estudos realizados pelo Army Corps of Engineers (1948) mostraram que o teor máximo de fíler que poderia ser adicionado ao areia-asfalto era de $20 \%$, enquanto que para misturas densas esse valor é de $12 \%$, teores superiores a esses limites produziram pavimentos que trincam e fissuram em serviço. Os ensaios a altas temperaturas mostraram que os pavimentos com excesso de fíler apresentam mais trincas, enquanto que ensaios a baixa temperatura não mostraram efeitos prejudiciais pelo excesso de fíler.

Diferentes fileres minerais produzem diferentes efeitos enrijecedores quando adicionados a um ligante asfáltico, efeitos que não podem ser justificados somente com base na granulometria do fíler, mas que incluem os efeitos das interações físico-químicas. A função deslocamento tempotemperatura não é afetada pelo mineral ou o tipo do ligante em relação f/a abaixo de 1,0 (DUKATZ e ANDERSON, 1980).

Para Dukatz e Anderson (1980), quanto maior a relação f/a maior o efeito enrijecedor, em que o aumento na rigidez de misturas contendo o fíler de calcário é de aproximadamente 100 vezes, quando comparado ao ligante asfáltico puro. Quando se observam as curvas de compliância de mástiques com fíler de cal hidratada e de negro de carbono, essas são deslocadas para baixo em ordem de magnitude de 4 a 5 vezes e a inclinação das curvas são mais achatadas, quando comparadas às dos ligantes asfálticos puros, o que demonstra o grande efeito enrijecedor, 
especialmente nas temperaturas altas e períodos de carregamento maiores, o que influencia muito o trincamento térmico, já que esse defeito está relacionado com a rigidez do ligante asfáltico.

Os estudos de Kallas e Puzinauskas (1961) sobre o efeito da concentração do fíler nas propriedades de misturas asfálticas indicam que o teor de fíler tem importância igual ao tipo de fíler utilizado. O tipo de fíler mineral influencia muito na quantidade de ligante asfáltico necessária para produzir a máxima densidade e o volume de vazios adequado em misturas asfálticas, sendo que a quantidade de ligante é maior quanto mais fino é a granulometria dos finos. Muitas propriedades dos fileres minerais influenciam os Vazios Do Agregado Mineral (VAM) das misturas asfálticas, como distribuição granulométrica, superfície específica, forma e características de superfície e a viscosidade do mástique correspondente.

O fíler tem influência significativa no potencial de durabilidade da mistura, especialmente para longos períodos de vida em serviço, sendo que a atividade do fíler (calor de adsorção) no comportamento da mistura asfáltica (durabilidade) é um fator muito importante, pois após longos períodos as fortes ligações adquiridas pelos agregados com o ligante asfáltico começam a se deteriorar e o papel físico-químico dos diferentes tipos de fíler é então manifestado. Em uma pesquisa de Craus et al (1978), misturas asfálticas compostas com fileres não ativos (basalto e arenito) se deterioram rapidamente, após 4 ou 7 dias de imersão, enquanto que as misturas com fileres ativos (cal hidratada, dolomita e pó calcário) mantiveram uma boa resistência retida por longos períodos de imersão.

A durabilidade das misturas asfálticas é influenciada pelo teor de ligante asfáltico, pois quando a película de ligante que cobre a interface agregado ligante torna-se mais espessa, aumentando o ligante efetivo e livre, há redução do volume de vazios e, consequentemente, diminuição da infiltração de água dentro da camada.

Craus et al. (1978) afirmam que o aumento da durabilidade devido ao aumento do teor de ligante depende do tipo de fíler envolvido e que misturas compostas por fileres não-ativos são mais sensíveis ao aumento do teor de ligante que aquelas compostas por fileres ativos, sensibilidade 
que é muito mais pronunciada após longos períodos de imersão (7 e 14 dias), e com teores de ligante maiores que o ótimo.

A sensibilidade dos diferentes tipos de fileres aos teores de ligante, em relação à durabilidade das misturas, é bem coordenada com as características de atividade dos fileres, pois nas misturas contendo fileres ativos, as fortes propriedades de adesão e adsorção da interface diminuem a penetração de água, aumentado a durabilidade, principalmente em longos períodos de imersão (maiores que 4 dias); misturas fileres não-ativos, em que a adesão e adsorção na interface são muito fracas, a presença da agua nessas zonas pode causar uma tendência significativa de melhora no potencial de durabilidade apenas em períodos de imersão curtos (de 4 a 7 dias) (CRAUS et al., 1978).

\subsection{PROJETO DE MISTURAS ASFÁLTICAS}

\subsubsection{Método Superpave (SUperior PERforming PAVEments)}

O Método Superpave é resultado das pesquisas feitas pelo programa SHRP (Strategic Highway Research Program) sobre os materiais utilizados em revestimentos asfálticos e foi concebido para auxiliar na seleção de materiais e no projeto de misturas. Contém especificações de materiais, o projeto e análise de misturas asfálticas, incluindo equipamentos de ensaio, métodos e critérios. Foram desenvolvidos métodos de análise de materiais betuminosos e misturas asfálticas baseados em propriedades fundamentais, diretamente relacionadas com o desempenho dos pavimentos em serviço (HUBER et al.,1998).

Inicialmente não foram realizadas pesquisas específicas para os agregados, pois o objetivo era analisá-los através da análise das misturas. Posteriormente, os pesquisadores perceberam que era necessário avaliar os agregados separadamente dos outros componentes da mistura e, para isso, um grupo de especialistas fez uma abordagem consensual, em que foram estabelecidas recomendações para as propriedades necessárias aos agregados em função dos vários níveis de tráfego. 
As misturas Superpave são dosadas volumetricamente, sendo controladas por propriedades dos agregados e pelo equilíbrio dos volumes de vazios, de ligante asfáltico e de agregados. O projeto volumétrico de mistura asfálticas desempenha um papel central no projeto de mistura Superpave, e é composto por quatro etapas principais:

i. Seleção dos materiais (agregados, ligantes, modificadores etc.);

ii. Seleção da granulometria do agregado;

iii. Seleção do teor de ligante asfáltico;

iv. Estimativa da sensibilidade à umidade da mistura.

A seleção dos materiais consiste na determinação dos fatores ambientais e de tráfego para o projeto de pavimento, em que os materiais são selecionados de acordo com a capacidade para atingir ou exceder os critérios estabelecidos. Com essas informações, é selecionado o grau de desempenho (PG) do ligante asfáltico requerido no projeto e os requisitos do agregado são baseados no volume de tráfego e na espessura da camada.

A seleção do projeto estrutural do agregado é um processo de tentativa e erro, que consiste em misturar agregados de diferentes granulometrias em diferentes porcentagens para alcançar uma granulometria que atenda os requisitos da especificação. Três misturas tentativas são normalmente empregadas com esse propósito e uma das três é considerada aceitável se possuir propriedades volumétricas aceitáveis (baseadas no tráfego e nas condições ambientais) nos teores de ligante previstos em projeto. Uma vez selecionado, a granulometria da mistura tentativa tornase o projeto estrutural do agregado (esqueleto mineral).

A seleção do teor de ligante asfáltico consiste em variar a quantidade de ligante asfáltico para o projeto estrutural do agregado até obter propriedades volumétricas e de compactação compatíveis com os critérios de mistura, os quais estão baseados no volume de tráfego e nas condições ambientais. O projeto estrutural do agregado e o teor do ligante estabelecido tornam-se a dosagem de trabalho da mistura. 
A avaliação da sensibilidade à umidade consiste em avaliar a mistura projetada segundo a AASHTO T283 para determinar a suscetibilidade da mistura em relação a problemas de umidade.

\section{i. Seleção dos Materiais}

Nesta fase são definidos o ligante asfáltico e os agregados a serem utilizados no projeto com base nos fatores ambientais e de tráfego definidos para o projeto do pavimento em estudo. Selecionase o grau de desempenho (PG) do ligante asfáltico requerido no projeto pelas condições climáticas e os agregados são selecionados com base no volume de tráfego e espessura de camada.

\section{a) Agregados}

São especificados dois critérios para a escolha dos agregados no sistema Superpave, as propriedades de origem e de consenso. As propriedades de origem são aquelas que as agências usam regularmente para testar a qualidade das fontes dos agregados. O SHRP não especifica valores limites, pois são muito dependentes da fonte, mas recomenda que os organismos locais os definam para cada projeto específico:

- Dureza (AASHTO T 96): definida como o porcentual, em peso, de material perdido durante o ensaio de Abrasão Los Angeles com agregados maiores que 2,36 mm. O ensaio indica a resistência à abrasão que os agregados devem possuir durante a usinagem, compactação e serviço;

- Sanidade (AASHTO T 104): estima a resistência ao intemperismo, é definida como o porcentual, em peso, de material perdido durante tratamento com solução de sulfato de sódio ou de magnésio, sendo realizado para agregados miúdos e graúdos;

- Materiais Deletérios (AASHTO T 112): é definido pelo porcentual, em peso, de contaminantes nos agregados, podendo ser realizado em agregados miúdos e graúdos.

As propriedades de consenso são aquelas consideradas críticas para o desempenho adequado das misturas asfálticas. São ditas de "consenso", pois foi resultado de um amplo entendimento de 
diversos especialistas americanos, através da comparação entre os valores das especificações em uso. Os valores das propriedades de consenso variam de acordo com o nível de tráfego e a posição relativa da camada na estrutura do pavimento. Essas propriedades são:

- Angularidade do agregado graúdo (ASTM D 6821): definida como o porcentual, em peso, de agregado graúdo retido na peneira de abertura $4,75 \mathrm{~mm}$, que possua uma ou mais faces fraturadas. Agregados de forma cúbica e com faces fraturadas apresentam uma maior resistência ao cisalhamento;

- Angularidade do agregado miúdo (ASTM D 6821): definida como o porcentual de vazios não compactados contidos entre as partículas dos agregados, quando são derramadas de uma altura pré-estabelecida. Quanto maior o teor de vazios, maior a quantidade de faces fraturadas no agregado;

- Partículas planas e alongadas (ASTM D 4791): definida como o porcentual, em peso, de agregado graúdo com relação entre a maior e a menor dimensão maior que 5 . Lamelaridade alta indica a grande presença de partículas planas e alongadas, o que aumenta a tendência de quebra de agregados durante a compactação e vida em serviço do pavimento;

- Teor de finos (AASHTO T 176): é definido como o porcentual, em peso, de material silte mais argila, passante na peneira de abertura $0,075 \mathrm{~mm}$, presente no agregado. Um grande teor de argila impregnado nos agregados dificulta a adesão do ligante ao agregado e deixa a mistura mais suscetível à ação da água.

A Tabela 2.1 reproduz os valores especificados na AASHTO MP 2-01 para as propriedades de consenso. 
Tabela 2.1 - Especificações Superpave: requisitos das propriedades de consenso

\begin{tabular}{|c|c|c|c|c|c|c|}
\hline \multirow[t]{2}{*}{$\begin{array}{l}\text { Número } \mathrm{N}^{\mathrm{a}} \\
\left(10^{6}\right)\end{array}$} & \multicolumn{2}{|c|}{$\begin{array}{c}\text { Faces fraturas } \\
\text { Agregado graúdo } \\
(\%) \text { mínima } \\
\end{array}$} & \multicolumn{2}{|c|}{$\begin{array}{c}\text { Vazios não compactados } \\
\text { Agregado fino } \\
(\%) \text { mínima }\end{array}$} & \multirow[t]{2}{*}{$\begin{array}{l}\text { Equivalente } \\
\text { Areia } \\
\text { (\%) mínima }\end{array}$} & \multirow[t]{2}{*}{$\begin{array}{l}\text { Partículas Planas } \\
\text { e Alongadas } \\
\text { (\%) máxima }\end{array}$} \\
\hline & $\leq 100 \mathrm{~mm}^{*}$ & $>100 \mathrm{~mm}^{*}$ & $\leq 100 \mathrm{~mm}^{*}$ & $>100 \mathrm{~mm}^{*}$ & & \\
\hline$<0,3$ & $55 /-$ & $-1-$ & - & - & 40 & - \\
\hline $0,3 a<3$ & $75 /-$ & $50 /-$ & 40 & 40 & 45 & 10 \\
\hline $3 a<10$ & $85 / 80^{\mathrm{b}}$ & $60 /-$ & 45 & 40 & 45 & \\
\hline $10 a<30$ & $95 / 90$ & $80 / 75$ & 45 & 40 & 45 & \\
\hline$\geq 30$ & $100 / 100$ & $100 / 100$ & 45 & 45 & 50 & \\
\hline
\end{tabular}

a) Tráfego de projeto esperado na faixa de projeto para um período de 20 anos

b) $80 / 85$ indica que $85 \%$ do agregado graúdo têm uma face fraturada e $80 \%$ tem duas ou mais faces fraturadas *Profundidade da camada em relação à superfície do pavimento

Fonte: AASHTO MP 2-01

b) Ligantes Asfálticos

A metodologia Superpave desenvolveu critérios para a especificação de ligantes asfálticos (modificados ou não) com um conjunto de novos ensaios. O novo sistema de especificações baseia-se no desempenho do material, com base no clima e temperatura do pavimento onde se pretende usá-lo. Os requisitos quanto às propriedades físicas permanecem os mesmos, mas muda a temperatura que o ligante deve atendê-los (MOTTA et al., 1996).

O grau de desempenho do ligante ("Performance Grade" - PG) é seguido por dois números (por exemplo, PG 64-22). O primeiro número é a temperatura mais alta em que o ligante possui propriedades físicas adequadas e deve ser comparada à temperatura mais elevada do pavimento que se espera no trecho onde se vai usar o ligante. O segundo número é a temperatura mais baixa em que o ligante possui propriedades físicas adequadas, e, da mesma forma deve ser comparada com a mínima temperatura do trecho onde o ligante será utilizado. São feitas considerações adicionais em termos de volume de tráfego (caminhões pesados) e tempo de aplicação de carga (autopistas, corredores de ônibus etc.) para se especificar adequadamente o ligante em cada caso (MARQUES, 2004). 
As propriedades físicas do ligante são avaliadas na condição inicial de produção e também em ligantes após sofrerem envelhecimento em laboratório, de forma a simular o que ocorre no pavimento real. Para isso, são utilizados dois equipamentos para simular o envelhecimento do ligante asfáltico: a Estufa de Filme Fino Rotativo ("Rolling Thin Oven Test” - RTFOT), que simula o envelhecimento durante e compactação da mistura, e o Estufa de Vaso Pressurizado ("Pressure Aging Vessel" - PAV), que simula o endurecimento oxidativo que ocorre no ligante ao longo da vida útil do pavimento.

As propriedades físicas do ligante são avaliadas em quatro equipamentos:

- Reômetro de Cisalhamento Dinâmico (DSR): caracteriza as propriedades viscoelásticas do ligante, avaliando o módulo complexo de cisalhamento $\left(\mathrm{G}^{*}\right)$ e ângulo de fase $(\delta)$. O parâmetro $\mathrm{G}^{*} / \mathrm{sen} \delta$ é utilizado para controlar a rigidez do ligante a temperaturas altas $\left(>46^{\circ} \mathrm{C}\right)$, assegurando que o ligante asfáltico fornece resistência ao cisalhamento global da mistura em termos de elasticidade a altas temperaturas; e $G^{*}$.sen $\delta$, para o ligante a temperaturas intermediárias $\left(7-34^{\circ} \mathrm{C}\right)$, assegurando que o ligante não contribua para o trincamento for fadiga;

- Viscosímetro Rotacional (RV): caracteriza a rigidez do ligante a $135^{\circ} \mathrm{C}$, onde age quase que inteiramente como um fluido viscoso. O ligante deverá apresentar uma viscosidade menor que $3 \mathrm{~Pa} . \mathrm{s}$ a $135^{\circ} \mathrm{C}$, significando que poderá ser bombeado e facilmente usinado;

- $\quad$ Reômetro de Fluência em Viga à Flexão (BBR): caracteriza a rigidez do ligante a baixa temperatura, através da rigidez estática $(\mathrm{S})$ e do logaritmo do módulo de relaxação $(\mathrm{m})$. Espera-se que ligantes com baixa rigidez estática não apresentem trincamento a baixas temperaturas, e ligantes com alto valor de módulo de relaxação sejam mais eficientes na dissipação das tensões formadas durante a contração do ligante quando a temperatura do pavimento cai abruptamente, minimizando a formação de trincas e fissuras;

- $\quad$ Teste de Tração Direta (DTT): ensaio realizado em ligantes que apresentam altos valores para rigidez e que poderão ser utilizados desde que possuam ductilidade suficiente a baixas temperaturas. Este ensaio avalia a ductilidade do ligante asfáltico a baixas temperaturas, assegurando que a resistência a ruptura do ligante, a baixa temperatura, seja maximizada. 


\section{ii. Seleção da granulometria do agregado}

Para especificar a granulometria do agregado, o Superpave utiliza um gráfico onde no eixo das abscissas estão as aberturas das peneiras, em milímetro, elevadas à potência de 0,45 , e a ordenada é a porcentagem passante de agregado. Apresenta-se nesse gráfico a linha de densidade máxima, que corresponde à reta que parte da origem e vai até o ponto do tamanho máximo do agregado.

Para que a graduação dos agregados atenda aos critérios Superpave, a curva granulométrica deve passar entre os pontos de controle e fora da zona de restrição. Os pontos de controle funcionam como limites dentro dos quais a curva granulométrica deve passar para satisfazer os requisitos do Superpave; esses pontos são fixados nas peneiras de tamanho máximo, nominal máximo, uma peneira abaixo do tamanho nominal máximo e nas peneiras de 2,36 $\mathrm{mm}$ e 0,075 $\mathrm{mm}$. A zona de restrição fica sobre a linha de densidade máxima, entre as peneiras intermediárias $(4,75$ ou 2,36 $\mathrm{mm}$ ) e 0,30 mm. Essa zona define uma região por onde a curva granulométrica não deve passar, porém essa restrição serve apenas como recomendação para se evitar misturas com alta proporção de areia fina natural em relação ao total de agregados finos, que geralmente apresentam baixo volume de vazios do agregado mineral (VAM).

Os valores especificados estão reproduzidos na Tabela 2.2 e 2.3, com as várias faixas possíveis de enquadramento dos agregados (AASHTO MP 2-01), sendo que o Diâmetro Máximo Nominal é definido como sendo a peneira com um tamanho maior do que o primeiro tamanho de peneira que retém mais que $10 \%$ de material. 
Tabela 2.2 - Pontos de controle conforme o Diâmetro Máximo Nominal

\begin{tabular}{cccccccccccc}
\hline Abertura & \multicolumn{3}{c}{$37,5 \mathrm{~mm}$} & \multicolumn{2}{c}{$25,0 \mathrm{~mm}$} & \multicolumn{2}{c}{$19,0 \mathrm{~mm}$} & \multicolumn{2}{c}{$12,5 \mathrm{~mm}$} & \multicolumn{2}{c}{$9,5 \mathrm{~mm}$} \\
\cline { 2 - 10 } mm & Mín & Máx & Mín & Máx & Mín & Máx & Mín & Máx & Mín & Máx \\
\hline 50,0 & 100 & - & - & - & - & - & - & - & - & - \\
37,5 & 90 & 100 & 100 & - & - & - & - & - & - & - \\
25,0 & - & 90 & 90 & 100 & 100 & - & - & - & - & - \\
19,0 & - & - & - & 90 & 90 & 100 & 100 & - & - & - \\
12,5 & - & - & - & - & - & 90 & 90 & 100 & 100 & - \\
9,5 & - & - & - & - & - & - & - & 90 & 90 & 100 \\
4,75 & - & - & - & - & - & - & - & - & - & 90 \\
2,36 & 15 & 41 & 19 & 45 & 23 & 49 & 28 & 58 & 32 & 67 \\
0,075 & 0 & 6 & 1 & 7 & 2 & 8 & 2 & 10 & 2 & 10 \\
\hline
\end{tabular}

Fonte: AASHTO MP 2-01

Tabela 2.3- Zona de restrição de acordo com o Diâmetro Máximo Nominal

\begin{tabular}{|c|c|c|c|c|c|c|c|c|c|c|}
\hline \multirow{2}{*}{$\begin{array}{c}\text { Abertura } \\
\mathrm{mm}\end{array}$} & \multicolumn{2}{|c|}{$37,5 \mathrm{~mm}$} & \multicolumn{2}{|c|}{$25,0 \mathrm{~mm}$} & \multicolumn{2}{|c|}{$19,0 \mathrm{~mm}$} & \multicolumn{2}{|c|}{$12,5 \mathrm{~mm}$} & \multicolumn{2}{|c|}{$9,5 \mathrm{~mm}$} \\
\hline & Mín & Máx & Mín & Máx & Mín & Máx & Mín & Máx & Mín & Máx \\
\hline 4,75 & 34,7 & 34,7 & 39,5 & 39 & - & . & - & 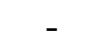 & - & 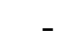 \\
\hline 2,36 & 23,3 & 27,3 & 26,8 & 30,8 & 34,6 & 34,6 & 39,1 & 39 , & 47,2 & 47 \\
\hline 1, & 15,5 & 21,5 & 18,1 & 24 & 22,3 & 28 & 25,6 & 31 & 31,6 & 37 \\
\hline 0,60 & 11,7 & 15 & 13,6 & 17 & 16,7 & 2 & 19,1 & 23 & 23,5 & 27 \\
\hline 0,075 & 10 & 10 & 11,4 & 13,7 & 13,7 & 13,7 & 15,5 & 15,5 & 18,7 & 18,7 \\
\hline
\end{tabular}

Fonte: AASHTO MP 2-01

\section{iii. Seleção do teor de ligante asfáltico}

Na seleção do método de laboratório para compactação, os pesquisadores SHRP desejavam um dispositivo que compactasse a amostra de mistura asfáltica o mais próximo da realidade, ou seja, que as densidades finais fossem aquelas obtidas no pavimento através de condições reais de clima e carregamento, além de fornecer uma medida de compatibilidade, de maneira a identificar problemas de compactação e prever comportamento de misturas potencialmente frágeis (MOTTA et al., 1996). Com esses objetivos, foi desenvolvido um novo compactador, o Compactador Giratório Superpave ("Superpave Gyratory Compactor" - SGC).

O Compactador Giratório Superpave tenta cumprir três objetivos principais: (1) alcançar a densidade sob condições reais de temperatura e tráfego; (2) acomodar sem triturar os agregados 
graúdos dentro da mistura compactada; (3) identificar o comportamento da mistura durante a compactação.

Três níveis de giro são de interesse, que são específicos para cada nível de tráfego (AASHTO PP28 - 2001):

- Número de giros de projeto $\left(\mathrm{N}_{\text {projeto }}\right)$, número de giros correspondente a $96 \%$ da densidade relativa máxima (4\% de volume de vazios);

- Número de giros inicial ( $\mathrm{N}_{\text {inicial }}$ ), número de giros correspondente a $89 \%$ da densidade relativa máxima ( $11 \%$ de volume de vazios);

- Número de giros máximo $\left(\mathrm{N}_{\text {máximo}}\right)$, número de giros correspondente a $98 \%$ da densidade relativa máxima ( $2 \%$ de volume de vazios).

A densidade aparente $\left(\mathrm{D}_{\mathrm{ap}}\right.$ ou $\mathrm{G}_{\mathrm{mb}}$ - Bulk Specific Gravity) dos corpos-de-prova deve ser medida usando a AASHTO T 166. A densidade máxima teórica (DMT) deve ser medida usando a AASHTO T 209. O porcentual de compactação é definido como a razão entre a densidade aparente $\left(\mathrm{D}_{\mathrm{ap}}\right)$ e a densidade máxima teórica (DMT).

$\mathrm{Na}$ especificação Superpave assumiu-se que as misturas asfálticas são projetadas para terem um teor de vazios final entre 3 e 5\%. Uma porcentagem de compactação menor que aquela necessária para produzir vazios da ordem de 3 a $5 \%$ de vazios poderá resultar em desagregação do revestimento, desde que seja permeável. Uma compactação excessiva resultará em um revestimento que não tenha vazios para o ligante se mover, o que pode resultar em escoamento e deformação permanente do pavimento (COMINSKY et al., 1994).

Corpos-de-prova compactados requerem misturas e compactação sob condições de temperatura equivalentes à viscosidade de 1,7P e 2,8 P respectivamente.

Os dados da compactação giratória Superpave devem ser analisados calculando a densidade aparente estimada $\left(D_{\text {ap }}\right)$, a densidade aparente corrigida $\left(D_{\text {ap corr }}\right)$ e a densidade máxima $\left(G_{m m}\right)$, que é a porcentagem em relação à densidade teórica máxima ((DMT) para cada número de giros desejado. 
A medida da altura do corpo-de-prova é uma função importante do SGC. Conhecendo a massa do material colocado no molde, o diâmetro do molde e a altura do corpo-de-prova, pode-se estimar a densidade do corpo-de-prova durante a compactação. A densidade do corpo de prova é calculada dividindo-se a massa pelo volume do corpo-de-prova. A altura é continuadamente medida através da posição da cabeça de carga antes e durante o ensaio. Os valores de $\mathrm{D}_{\text {ap }}$ (estimado) são determinados pelas equações 2.1 e 2.2 :

$$
V o l=\frac{\pi d^{2} h}{4} \times 0,001 \mathrm{~cm}^{3} / \mathrm{mm}^{3}
$$

em que: $\quad$ Vol: volume do corpo-de-prova no molde durante a compactação $\left(\mathrm{cm}^{3}\right)$;

$d$ : diâmetro do molde (mm);

$h$ : altura do corpo-de-prova no molde durante a compactação (mm).

$$
D_{a p}(\text { estimado })=\frac{m / \mathrm{Vol}}{1000 \mathrm{~g} / \mathrm{cm}^{3}}
$$

em que: $\quad D_{a p}($ estimado): densidade aparente estimada do corpo-de-prova no molde durante a compactação;

$m$ : massa do corpo-de-prova (g).

Este cálculo admite que o corpo-de-prova seja um cilindro de laterais sem rugosidade, o que não é verdade. O volume do corpo-de-prova é levemente menor que o volume do cilindro de laterais

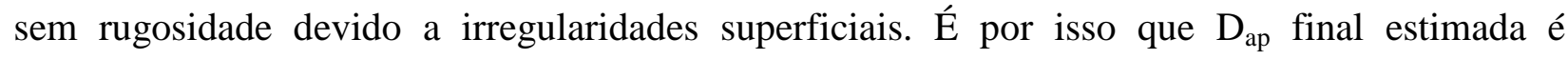
diferente da $\mathrm{D}_{\text {ap }}$ medida. Para corrigir esta diferença a $\mathrm{D}_{\text {ap }}$ estimada a qualquer número de giros é corrigido pela razão da densidade aparente medida pela densidade aparente estimada a $\mathrm{N}_{\text {máx }}$ usando a Equação 2.3.

$$
C=\frac{D_{a p}(\text { medida })}{D_{a p}(\text { estimada })}
$$

em que: $\quad C$ : fator de correção;

$\mathrm{D}_{\text {ap }}$ (medida): densidade específica aparente medida a $\mathrm{N}_{\text {máx }}$; 


$$
\mathrm{D}_{\text {ap }} \text { (estimada): densidade específica aparente estimada a } \mathrm{N}_{\text {máx. }}
$$

A $D_{\text {ap }}$ estimada a todos outros números de giros pode ser corrigida usando o fator de correção da Equação 2.4:

$$
D_{a p}(\text { corrigida })=C \times D_{a p}(\text { estimada })
$$

Em que: $\quad \mathrm{D}_{\mathrm{ap}}$ (corrigida): densidade aparente corrigida do corpo-de-prova a qualquer giro $\mathrm{N}$;

$C$ : fator de correção;

$\mathrm{D}_{\text {ap }}$ (estimada): densidade aparente estimada a qualquer giro $\mathrm{N}$.

O projeto volumétrico engloba a moldagem dos corpos-de-prova utilizando o compactador Giratório Superpave, a seleção do teor de ligante com base no teor de vazios, vazios do agregado mineral (VAM), vazios preenchidos com asfalto (RBV), e razão fíler/asfalto para o teor efetivo de asfalto, como descrito a seguir:

\section{a) Requisitos Volumétricos}

O método Superpave avalia algumas propriedades volumétricas (Vazios do Agregado Mineral VAM, e Relação Betume Vazios - RBV) das misturas asfálticas prontas.

A porcentagem de vazios do agregado mineral (VAM) e a porcentagem de ligante asfáltico interferem diretamente no volume de vazios de uma mistura asfáltica. $\mathrm{O}$ volume de vazios é um fator muito importante para o dimensionamento de misturas asfálticas (CROSS \& BROWN, 1992), pois misturas asfálticas com volume de vazios menor que 2,5\% são propensas à deformação permanente, independentemente das outras propriedades da mistura.

A porcentagem de vazios do agregado mineral (VAM) depende da distribuição granulométrica, da quantidade de fíler mineral ou material passante na peneira 0,075 $\mathrm{mm}$, do grau de compactação, da forma, da textura e da angularidade dos agregados (COMINSKKY et al., 1998). 
Para misturas asfálticas após a compactação pelo tráfego, o método Superpave propõe 4\% de volume de vazios (Vv) e relação betume vazios (RBV), que são os vazios do agregado mineral (VAM) preenchido com ligante asfáltico, entre 75 e 80\%. A especificação de VAM mínimo visa garantir a durabilidade da mistura, através de uma quantidade mínima de asfalto na mesma. Porém, a durabilidade de misturas asfálticas está estreitamente ligada à espessura da película de ligante asfáltico que recobre o agregado. O Superpave estabelece valores mínimos para o VAM de acordo com o diâmetro máximo nominal da mistura, como mostra a Tabela 2.4. Misturas de graduação densa, com o VAM abaixo dos valores especificados, podem apresentar problemas de durabilidade, pois podem não conter vazios suficientes para a adição do ligante asfáltico.

Tabela 2.4 - Requisitos de VAM da Especificação Superpave

\begin{tabular}{cc}
\hline $\begin{array}{c}\text { Diâmetro Máximo Nominal (DMN) } \\
\text { da mistura }(\mathrm{mm})\end{array}$ & $\begin{array}{c}\text { VAM mínimo } \\
(\%)\end{array}$ \\
\hline 9,5 & 15 \\
12,5 & 14 \\
19,0 & 13 \\
25,0 & 12 \\
37,5 & 11 \\
\hline
\end{tabular}

(COMINSKY et al., 1998)

Em misturas de graduação grossa, que passam abaixo da zona de restrição, Kandhal et al. (1998) mostram que o VAM mínimo recomendado é inadequado, penalizando as misturas que apresentam baixos valores de VAM. Misturas de graduação grossa, usadas em rodovias com alto volume de tráfego, e o aumento do esforço de compactação pelo uso do compactador giratório podem resultar em menores valores de VAM, sem comprometer o desempenho.

A relação betume-vazios (RBV), ou os vazios preenchidos com ligante asfáltico, é outro requisito volumétrico de misturas Superpave. O RBV afeta a durabilidade e a flexibilidade do pavimento asfáltico e, portanto, as misturas asfálticas devem se enquadrar numa faixa de RBV para garantir a quantidade suficiente de ligante asfáltico que assegure uma adequada película de asfalto recobrindo as partículas de agregado, de forma a evitar o envelhecimento e endurecimento, mas 
sem excesso, pois muito ligante asfáltico também é prejudicial à mistura, além de aumentar o custo.

Geralmente, o valor ótimo de RBV é atingido quando a mistura se enquadra nos valores de VAM especificados em função do diâmetro máximo nominal e possui $4 \%$ de vazios. Misturas com RBV menor que $65 \%$ podem levar ao endurecimento prematuro ou excessivo de misturas asfálticas projetadas para rodovias com volume de tráfego médio a alto, causando trincas por fadiga e desgaste do revestimento asfáltico. Já misturas com RBV maior que $85 \%$ são propensas à exsudação, corrugação e deformação permanente. Diante disso, Cominsky et al.(1998) indicam $75 \%$ de RBV como ideal.

No Brasil, o RBV indicado para revestimentos fica entre 75 e $82 \%$ e, para camadas de ligação (binder), entre 65 e 72\% (NBR 12891/93). A Tabela 2.5 mostra os valores de RBV para misturas Superpave projetadas com $4 \%$ de volume de vazios, em função do volume de tráfego.

Tabela 2.5 - Requisitos Superpave para RBV

\begin{tabular}{cc}
\hline $\begin{array}{c}\text { Tráfego } \\
(\text { ESALs })\end{array}$ & $\begin{array}{c}\text { RBV de projeto } \\
(\%)\end{array}$ \\
\hline$<3 \times 10^{5}$ & $70-80$ \\
$>3 \times 10^{5}$ & $65-78$ \\
$<1 \times 10^{8}$ & $65-75$ \\
$<1 \times 10^{8}$ & $65-75$ \\
\hline FONTE: COMINSKY et al., (1998)
\end{tabular}

\section{b) Teor de fíler}

O método Superpave propõe como critério de projeto uma determinada quantidade de fíler mineral para misturas asfálticas, expressa em porcentagem do peso total da mistura, calculado como sendo a razão entre a porcentagem em peso do agregado passante na peneira 0,075 $\mathrm{mm}$ e o teor efetivo de asfalto. O teor efetivo de asfalto é a quantidade de asfalto usado na mistura descontando-se o asfalto que é absorvido pelo agregado. É recomendado que a proporção de fíler mineral fique entre 0,6 e 1,8 para qualquer tipo de mistura (MOTTA et al., 1996). 
O teor de pó (“dust proportion”) refere-se à parcela dos agregados com tamanho menor que 0,075 mm (passante na peneira $\mathrm{n}^{\circ} 200$ ). É um importante requisito de mistura definido pelas especificações Superpave e é calculado como a razão entre a porcentagem em peso do agregado passante na peneira $n^{\circ} 200$ e o teor de asfalto efetivo. O teor de asfalto efetivo é o ligante total menos o absorvido. O teor de pó é usado na fase da dosagem da mistura como um critério de projeto. A faixa de aceitação deste parâmetro, segundo o Superpave é de 0,6 a 1,2 para todas as misturas. Quando a curva granulométrica passar abaixo dos limites da zona de restrição a faixa de aceitação pode ser ampliada para 0,8 a 1,6.

\section{iv. Estimativa da sensibilidade à umidade do projeto de mistura}

O ensaio de sensibilidade à umidade é utilizado para estimar o deslocamento de ligante do agregado na mistura asfáltica, especificado pela AASHTO T 283, "Resistência ao Dano pela Umidade Induzida em Misturas Betuminosas Compactadas”. Este ensaio não é um ensaio de desempenho, mas tem duas finalidades: identifica qual combinação e asfalto/agregado é sensível à umidade e avalia a eficiência de agentes melhoradores de adesividade.

Neste ensaio, são produzidos dois subgrupos de corpos-de-prova. Os corpos-de-prova são compactados para atingirem o teor de vazios na faixa de 6 a $8 \%$, sendo $7 \%$ a meta. Estes corposde-prova devem ser dispostos de forma que cada subgrupo tenha o mesmo teor de vazios. Um subgrupo é condicionado pela saturação à vácuo em um grau constante de umidade entre 55 a 80\%. A seguir, aplica-se um ciclo opcional de congelamento e a etapa final é feita em água quente. Após o condicionamento, ambos os subgrupos são ensaiados obtendo-se a resistência à tração indireta. O resultado do ensaio é a razão entre as resistências das amostras condicionadas e das não-condicionadas. Esta razão é chamada de "razão resistência à tração" e o Superpave requer um valor mínimo de $80 \%$.

\subsubsection{Determinação da Densidade Máxima Teórica e Absorção de Misturas Asfálticas}

As amostras para a determinação das densidades máximas teóricas (DMT) através do método Rice são preparadas de acordo com a curva granulométrica e o teor de trabalho de ligante 
asfáltico. A absorção de ligante asfáltico pelo agregado dá-se pela permanência da amostra por duas horas em estufa na temperatura de compactação, conforme a AASHTO PP2.

Após a amostra ser retirada da estufa, é resfriada manualmente, com uma espátula, para evitar a formação de grumos. Depois de resfriada, verifica-se a massa seca da amostra. Em seguida coloca-se a amostra em um kitassato modificado, adiciona-se água destilada até cobrir completamente a massa. Após isso, conecta-se o conjunto kitassato modificado, amostra e água à bomba de vácuo parcial, durante aproximadamente 15 a 20 minutos para que sejam retiradas as bolhas de ar.

Extraídas todas as bolhas, completa-se o kitassato modificado com água destilada, tomando-se o cuidado para não incorporar ar na água, e verifica-se a massa do conjunto. Por fim, mede-se a temperatura da água dentro do kitassato modificado.

O cálculo da Densidade Máxima Teórica (DMT) de cada mistura asfáltica dá-se pela Equação 2.5 .

$$
D M T_{R}=\frac{A}{A+D-E}
$$

onde: $\quad \mathrm{DMT}_{\mathrm{R}}$ : densidade máxima teórica da mistura, determinada pelo Método Rice;
A: massa da amostra seca $(\mathrm{g})$;
D: massa do kitassato modificado preenchido com água, em função da temperatura, de acordo com a curva de calibração $(\mathrm{g})$;
E: massa do conjunto kitassato modificado, água e amostra $(\mathrm{g})$.

Com isso, pode-se determinar a massa específica efetiva do agregado $\left(\rho_{\mathrm{ef}}\right)$, que por definição é a relação entre a massa do agregado e seu volume efetivo, através da Equação 2.6.

$$
\rho_{e f}=\frac{1-C A P}{\frac{1}{\rho_{\text {água }}} \times \frac{1}{D M T_{R}}-\frac{C A P_{P}}{\rho_{C A P}}}
$$


em que: $\quad \rho_{\text {ef: }}$ massa específica efetiva do agregado $\left(\mathrm{g} / \mathrm{cm}^{3}\right)$;

$\rho_{\text {água }}$ : massa específica da água $=1 \mathrm{~g} / \mathrm{cm}^{3}$ (adotada);

$\rho_{\text {CAP: }}$ massa específica do ligante asfáltico $\left(\mathrm{g} / \mathrm{cm}^{3}\right)$;

$\mathrm{DMT}_{\mathrm{R}}$ : densidade máxima teórica da mistura, determinada pelo Método Rice;

$\mathrm{CAP}_{\mathrm{p}}$ : quantidade de ligante asfáltico na mistura $(\%)$.

Também por definição, tem-se que a absorção de ligante asfáltico pelo agregado $\left(\mathrm{A}_{\mathrm{abs}}\right)$ é dada pela relação entre a massa de asfalto absorvida e a massa do agregado da mistura, podendo ser determinada através da Equação 2.7.

$$
A_{a b s}=\left(\frac{\rho_{e f}-\rho_{a p}}{\rho_{e f} \times \rho_{a p}} \times \rho_{C A P}\right) \times 100
$$

Em que: $\quad \mathrm{A}_{\mathrm{abs}}$ : porcentagem de ligante asfáltico absorvido por massa de agregado (\%);

$\rho_{\mathrm{ap}}$ : massa específica aparente do agregado $\left(\mathrm{g} / \mathrm{cm}^{3}\right)$.

\subsection{MATERIAIS UTILIZADOS}

Nesta pesquisa foram utilizados agregados granítico, provenientes da Pedreira São Jerônimo, localizada na cidade de Valinhos/SP, e agregados basáltico, provenientes da Pedreira Bandeirantes, localizada na cidade de São Carlos/SP. As propriedades dos agregados foram determinadas através dos ensaios de massa específica real, aparente e absorção do agregado graúdo e massa específica real, aparente e absorção do agregado fino. Os resultados desses ensaios estão representados na Tabela 2.6. 
Tabela 2.6 - Características Físicas dos Agregados

\begin{tabular}{cccccc}
\hline Ensaio & Pedra 1 & Pedrisco & Pó & Fíler Mineral & \\
\cline { 1 - 5 } Massa específica real $\left(\mathrm{g} / \mathrm{cm}^{3}\right)$ & 2,965 & 2,976 & 3,068 & 2,853 & \\
Massa específica aparente $\left(\mathrm{g} / \mathrm{cm}^{3}\right)$ & 2,828 & 2,810 & 2,844 & - & agregado \\
Absorção $(\%)$ & 1,635 & 1,986 & 2,570 & - & \\
\hline Massa específica real $\left(\mathrm{g} / \mathrm{cm}^{3}\right)$ & 2,635 & 2,622 & 2,661 & & \\
Massa específica aparente $\left(\mathrm{g} / \mathrm{cm}^{3}\right)$ & 2,601 & 2,567 & 2,487 & - & agregado \\
Absorção $(\%)$ & 0,496 & 0,815 & 2,627 & - & \\
\hline
\end{tabular}

A granulometria do agregado utilizado foi determinada utilizando-se as peneiras recomendadas pelo método Superpave, com abertura de malhas de $0,075 \mathrm{~mm} ; 0,15 \mathrm{~mm} ; 0,30 \mathrm{~mm} ; 0,60 \mathrm{~mm}$; $1,18 \mathrm{~mm} ; 2,36 \mathrm{~mm} ; 4,75 \mathrm{~mm} ; 9,5 \mathrm{~mm} ; 12,5 \mathrm{~mm} ; 19,0 \mathrm{~mm}$ e $25,0 \mathrm{~mm}$. O peneiramento dos agregados foi realizado totalmente de maneira manual, para que o erro fosse minimizado e, portanto, pudesse ser produzidos corpos-de-prova com características mais semelhantes possível. Todos os agregados utilizados na composição das misturas asfálticas foram lavados após o peneiramento para eliminação do pó. Os dados de granulometria estão apresentados na Tabela 2.7 e nas Figuras 2.1 e 2.2, para os agregados basáltico e granítico, respectivamente.

Tabela 2.7 - Granulometria dos Agregados

\begin{tabular}{c|ccc|ccc}
\hline $\begin{array}{c}\text { Abertura Peneira } \\
(\mathrm{mm})\end{array}$ & Pedra 1 & $\begin{array}{c}\text { Pedrisco } \\
\text { Basalto }\end{array}$ & Pó & Pedra 1 & $\begin{array}{c}\text { Pedrisco } \\
\text { Granito }\end{array}$ & Pó \\
\hline 25 & 100 & 100 & 100 & 100 & 100 & 100 \\
19 & 84,89 & 100 & 100 & 100 & 100 & 100 \\
12.5 & 9,47 & 100 & 100 & 25,55 & 100 & 100 \\
9.5 & 0,85 & 100 & 100 & 8,49 & 99,2 & 100 \\
4.75 & 0,00 & 28,15 & 96,60 & 0,00 & 32,86 & 98,00 \\
2.36 & 0,00 & 0,00 & 66,16 & 0,00 & 2,24 & 75,00 \\
1.18 & 0,00 & 0,00 & 43,29 & 0,00 & 0,40 & 55,00 \\
0.6 & 0,00 & 0,00 & 30,99 & 0,00 & 0,00 & 40,00 \\
0.3 & 0,00 & 0,00 & 23,81 & 0,00 & 0,00 & 29,00 \\
0.15 & 0,00 & 0,00 & 15,85 & 0,00 & 0,00 & 17,00 \\
0.075 & 0,00 & 0,00 & 10,39 & 0,00 & 0,00 & 9,60 \\
\hline
\end{tabular}




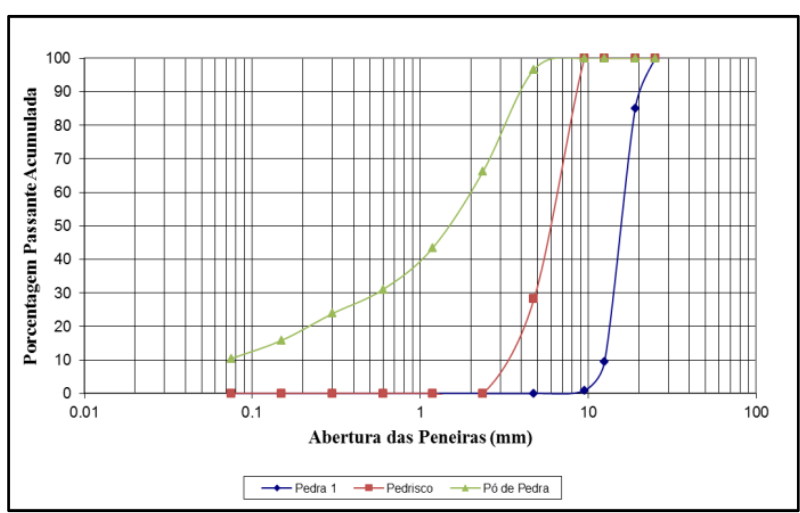

(a)

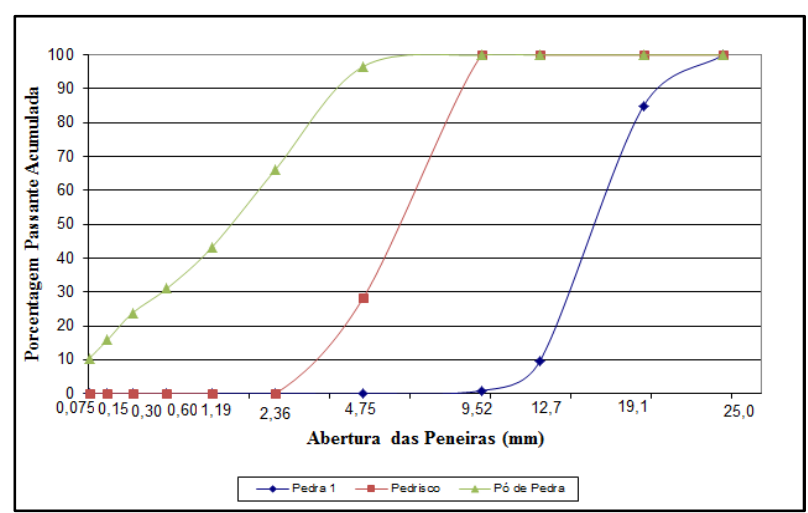

(b)

Figura 2.1 - (a) Granulometria do Agregado Basáltico (b) Granulometria do Agregado Basáltico especificação Superpave

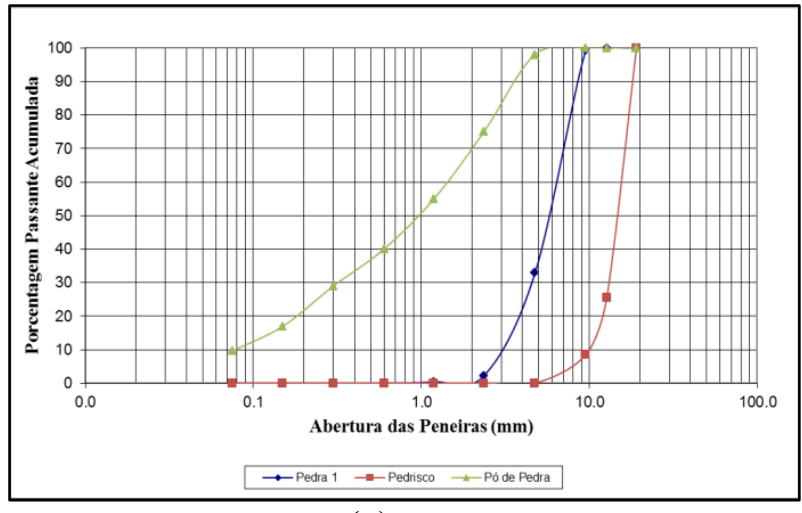

(a)

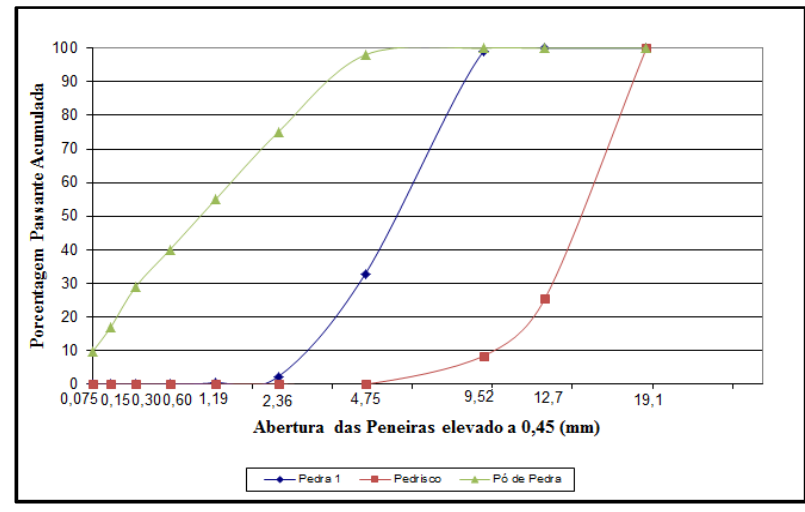

(b)

Figura 2.2 - (a) Granulometria do Agregado Granítico (b) Granulometria do Agregado Granítico especificação Superpave

Os Cimentos Asfálticos de Petróleo (CAP) utilizados foram um CAP 50/70 e 85/100, recebido da empresa BETUNEL, na cidade de Ribeirão Preto, cujas propriedades são apresentadas nas Tabelas 2.8 e 2.9 .

Tabela 2.8 - Caracterização do Ligante Asfáltico CAP 50/70

\begin{tabular}{ccccc}
\hline Característica & Método & Especificação & Resultado & Unidade \\
\hline Penetração & D 5 & 50 a 70 & 50 & $0,1 \mathrm{~mm}$ \\
Ponto de Amolecimento & D 36 & 46 min & 48,6 & ${ }^{\circ} \mathrm{C}$ \\
Viscosidade Brookfield $135^{\circ} \mathrm{C}$ & D 4402 & 274 min & 377 & $\mathrm{cp}$ \\
Viscosidade Brookfield $150^{\circ} \mathrm{C}$ & D 4403 & $112 \mathrm{~min}$ & 187 & $\mathrm{cp}$ \\
Viscosidade Brookfield $177^{\circ} \mathrm{C}$ & D 4404 & 57 a 285 & 69 & $\mathrm{cp}$ \\
\hline
\end{tabular}


Tabela 2.9 - Caracterização do Ligante Asfáltico CAP 85/100

\begin{tabular}{ccccc}
\hline Característica & Método & Especificação & Resultado & Unidade \\
\hline Penetração & D 5 & 85 a 100 & 102 & $0,1 \mathrm{~mm}$ \\
Ponto de Amolecimento & D 36 & 43 mín & 43,5 & ${ }^{\circ} \mathrm{C}$ \\
Viscosidade Brookfield $135^{\circ} \mathrm{C}$ & D 4402 & 214 mín & 252,5 & $\mathrm{cp}$ \\
Viscosidade Brookfield $150^{\circ} \mathrm{C}$ & D 4403 & 97 mín & 130 & $\mathrm{cp}$ \\
Viscosidade Brookfield $177^{\circ} \mathrm{C}$ & D 4404 & 28 a 114 & 52,5 & $\mathrm{cp}$ \\
\hline
\end{tabular}

Os diferentes fileres utilizados foram: pó de sílica, cal hidratada (CHIII), pó calcário e cimento Portland. Os fileres foram escolhidos para que a pesquisa pudesse avaliar fileres considerados ativos (cal hidratada e cimento Portland) e fileres inativos (pó calcário e pó de sílica). O fíler de pó calcário foi obtido na Pedreira da Leão Engenharia S/A, localizada na cidade de Ribeirão Preto; a cal hidratada e o cimento Portland utilizados foram obtidos no mercado.

A massa especifica real dos fileres foi determinada através da norma DNER-ME 085/94, que padroniza o método para a determinação da massa específica real de material de enchimento, e os resultados estão apresentados na Tabela 2.10, assim como os valores médios de superfície específica para diferentes fileres, segundo Pinnila (1965).

Tabela 2.10- Massa e Superfície Específica dos Fileres

\begin{tabular}{ccc}
\hline Material & $\begin{array}{c}\text { Massa Específica } \\
\left(\mathrm{g} / \mathrm{cm}^{3}\right)\end{array}$ & $\begin{array}{c}\text { Superfície Específica } \\
\left(\mathrm{cm}^{2} / \mathrm{g}\right)\end{array}$ \\
\hline Sílica & 2,635 & $2500-3500$ \\
Calcário & 2,749 & $2800-3500$ \\
Cal Cálcica & 2,350 & $5000-15000$ \\
Cimento Portland & 3,030 & $2200-2750$ \\
\hline
\end{tabular}

FONTE: Pinnila (1965) 


\subsection{MÉTODO}

\subsubsection{Planejamento Experimental}

O programa de experimentos desta pesquisa teve como objetivo de abranger os principais fatores (Tabela 2.11) que poderiam influenciar as propriedades das misturas asfálticas em relação ao tipo e teor de fíler.

Tabela 2.11 - Variáveis independentes ou fatores

\begin{tabular}{cc}
\hline Fatores & Níveis dos Fatores \\
\hline Tipo de Agregado & 2 (Basalto e Granito) \\
Tipo de Ligante Asfáltico & $2(50 / 70$ e $85 / 100)$ \\
Tipo de Fíler & 4 (Cimento Portland, Cal, Calcário, Sílica) \\
Teor de Fíler & 3 (Mín, Máx, Méd) \\
\hline
\end{tabular}

Nas misturas asfálticas completas foram realizados os ensaios para avaliação dos danos por fadiga e deformação permanente. Os corpos de prova para realização dos ensaios mecânicos foram compactados segundo a Metodologia Superpave, com a utilização do compactador giratório Superpave. Para a análise do comportamento mecânico das misturas asfálticas foram realizados os ensaios:

- $\quad$ Resistência à Tração Indireta;

- $\quad$ Módulo de Resiliência;

- Vida de Fadiga,

- $\quad$ Fluência por Compressão Uniaxial Estática.

Para a escolha do nível do fator teor de fíler foi considerado o teor mínimo e máximo da metodologia Superpave, que recomenda de 2 e $8 \%$, respectivamente, para o Diâmetro Máximo Nominal da granulometria da mistura. Para que o experimento fatorial fosse simétrico, foram escolhidos os teores de fíler de 2,5; 5,0 e 7,5\%.

Avaliou-se a influência da variação dos fatores no comportamento das misturas asfálticas quanto às propriedades mecânicas através de um programa experimental, utilizando-se a técnica de planejamento e análise de experimentos fatoriais. Dessa forma, foram realizadas variações 
propositais nas variáveis de entrada ou fatores influentes de saída, medidas através dos ensaios laboratoriais. A estimativa da significância do efeito da variação de cada fator e dos efeitos de interação entre os fatores na variação dos parâmetros de ensaio foi realizada através do método de análise de variância (ANOVA).

Para a avaliação das propriedades mecânicas das misturas asfálticas, foram escolhidas 12 condições experimentais para serem ensaiadas, das 36 existentes no planejamento total. Para que o planejamento fatorial fosse simétrico (facilitando assim o fracionamento e a análise dos resultados), o fator Tipo de Fíler, que para a determinação do teor de ligante asfáltico de projeto foi composto por quatro níveis, nas propriedades mecânicas foram avaliados em três níveis, sendo excluído o fíler de sílica. $\mathrm{O}$ fracionamento do planejamento foi necessário para a viabilidade da realização dos ensaios com as misturas asfálticas para os fatores desejados, e as condições experimentais avaliadas estão apresentadas na Tabela 2.12.

Tabela 2.12 - Condições experimentais avaliadas

\begin{tabular}{cc|ccc|ccc}
\hline & Teor de Fíler & \multicolumn{3}{|c|}{ CAP 50/70 } & \multicolumn{3}{c}{ CAP 85/100 } \\
& $\%$ & Calcário & Cimento & Cal & Calcário & Cimento & Cal \\
\hline \multirow{2}{*}{ Agregado } & 2,5 & $\mathrm{x}$ & & & & & $\mathrm{x}$ \\
Basáltico & 5,0 & & & $\mathrm{x}$ & $\mathrm{x}$ & \\
& 7,5 & & $\mathrm{x}$ & & & $\mathrm{x}$ \\
\hline \multirow{2}{*}{ Agregado } & 2,5 & & $\mathrm{x}$ & & & $\mathrm{x}$ \\
Granítico & 5,0 & & & $\mathrm{x}$ & $\mathrm{x}$ & \\
& 7,5 & $\mathrm{x}$ & & & & \\
\hline
\end{tabular}

\subsubsection{Planejamento e Análise de Experimentos}

Um experimento é um teste ou uma série de testes. Experimentos são realizados em toda a engenharia e na ciência e é uma parte importante para aprender como os sistemas e os processos trabalham. A validade das conclusões realizadas a partir de um experimento depende da maneira de como o experimento é conduzido. Assim, o planejamento do experimento tem papel importante na solução de problemas que motivam os experimentos.

Técnicas de projeto experimental baseadas na estatística são úteis para a engenharia, pois ajudam a resolver muitos problemas importantes, como a descoberta de um novo fenômeno e novos produtos, desenvolvimento de novas tecnologias e produtos ou melhoramento nos processos e 
produtos já existentes (MONTGOMERY e RUNGER, 2011). Muitos desses processos podem ser descritos em relação a várias variáveis controláveis, como temperatura, pressão ou taxa de carregamento. Utilizando o planejamento de experimentos é possível determinar qual parte, ou subconjunto, das variáveis do processo, tem maior influencia nas respostas.

O primeiro passo do planejamento de um experimento é a determinação de quais variáveis são mais importantes, já que o objetivo de um experimento é determinar quais níveis resultam no melhor resultado do processo em análise. A sequência de atividades desenvolvidas no planejamento é:

- Hipótese - a idéia inicial que motiva o experimento;

- Experimento - realização de ensaio para investigar a hipótese;

- Análise - a análise estatística dos dados do experimento;

- Conclusão - o que se aprendeu sobre a hipótese inicial do experimento. Talvez seja necessária uma nova hipótese e novo experimento.

Os níveis dos fatores são chamados tratamento, e cada tratamento tem certo número de observações ou réplicas. A aleatoriedade dos dados é extremamente importante no experimento, para que o efeito de qualquer ruído que pode influenciar na resposta seja balanceado.

Um experimento fatorial é uma técnica poderosa quando o experimento inclui dois ou mais fatores, considerados importantes. Geralmente, em um planejamento de experimentos fatoriais, são realizadas todas as combinações dos níveis dos fatores.

\subsubsection{Avaliação de Misturas Asfálticas}

O pavimento é uma estrutura destinada a resistir aos esforços gerados pelo tráfego, garantindo durabilidade à superfície de rolamento e proporcionando conforto e segurança ao usuário; porém esses requisitos ficam comprometidos à medida que surgem defeitos no pavimento, reduzindo seu desempenho ou serventia.

Os pavimentos são estruturas complexas, que envolvem muitas variáveis, tais como: cargas de tráfego, solicitações ambientais, técnicas construtivas, práticas de manutenção e reabilitação, tipo e qualidade dos materiais etc. Representam parcela expressiva da infraestrutura de transporte e, 
portanto, melhoramentos nos seus componentes podem resultar em grandes economias em termos absoluto.

A avaliação do desempenho estrutural de misturas asfálticas deve considerar deformações elásticas ou resilientes, ocasionada pela repetição das cargas, gerando as trincas por fadiga; e deformações plásticas ou permanentes, que podem ser observadas nos afundamentos das trilhas de roda. Por isso, a avaliação de misturas asfálticas em laboratório deve compreender ensaios que avaliem a deformação elástica e que avaliem a deformação permanente.

\subsubsection{Principais defeitos dos pavimentos}

Os principais defeitos nos pavimentos são as deformações permanentes, encontradas nas trilhas de roda, e as trincas por fadiga, cada um associado a uma etapa de vida do pavimento. As deformações permanentes geralmente aparecem nos primeiros anos de vida do pavimento, o que está sujeito à consolidação e as deformações cisalhantes plásticas. Já as trincas por fadiga aparecem normalmente quando o pavimento asfáltico está mais envelhecido e, após ser submetido às cargas cíclicas, já não oferecem boa resposta.

A deformação permanente é causada por deformação plástica e deformação por cisalhamento que pode ocorrer em qualquer camada do pavimento após a compactação de construção, inclusive no próprio subleito, geradas pelo mau dimensionamento; e a deformação permanente na camada asfáltica, que pode ter origem tanto por problemas de execução quanto por falhas em projeto, como por exemplo, alto volume de vazios e baixa resistência ao cisalhamento, o que depende da suscetibilidade térmica do ligante asfáltico e do esqueleto do agregado mineral.

A deformação permanente no revestimento asfáltico ocorre devido a suas características viscoelásticas e sua origem está associada à variação de volume de vazios causado pela ação do tráfego bem como devido ao comportamento plástico do material quando submetido a determinado estado de tensões. 
Souza et al. (1991) citaram que entre os principais fatores que afetam as deformações permanentes estão a magnitude do carregamento aplicado pela pressão dos pneus, o volume de tráfego, o ambiente térmico e as variações das propriedades da mistura, como as características dos agregados e o teor e a rigidez do ligante.

A parcela de deformação permanente causada pela densificação é uma compactação adicional da camada de concreto asfáltico, devido ao tráfego após a construção, caracterizando uma diminuição no volume da camada, sem movimento relativo entre as partículas senão a aproximação entre elas.

A deformação permanente dos pavimentos desenvolve-se gradualmente com o aumento das solicitações das cargas por eixo e geralmente aparecem sob a forma de depressões longitudinais nas faixas de rodagem, acompanhadas ou não de elevações laterais ao longo dessas faixas, sendo o processo de acúmulo destas deformações denominado afundamento de trilhas de rodas. A variação longitudinal da magnitude da deformação permanente causa irregularidade no pavimento, o que diminui a segurança, causa desconforto ao usuário e, principalmente, aumenta os custos de operação dos veículos.

Coelho (1996) cita dois problemas com relação às deformações permanentes: a configuração de um quadro de aquaplanagem, quando a camada superficial do pavimento é impermeável e no canal formado pelas trilhas de roda há uma lâmina de água e; os veículos leves têm uma pior dirigibilidade nos casos de deformações permanentes excessivas, havendo, portanto, redução na segurança, além do comprometimento da estética ou até da estrutura do pavimento.

A deformação permanente causada pela movimentação plástica ocorre geralmente quando o volume de vazios é menor que $4 \%$ e/ou a temperatura ambiente é muito alta, fazendo com que o ligante atue como um lubrificante. A deformação permanente ocorrida por consolidação ocorre quando o volume e vazios da mistura é maior que $8 \%$, ocasionando a compactação da camada asfáltica pelo trafego. 
Segundo Brown et al. (2001) numerosos métodos de ensaio têm sido usados com o intuito de caracterizar as respostas dos materiais de um pavimento à deformação permanente, podendo ser classificados em:

- Ensaios fundamentais: ensaios uniaxial e triaxial (não confinado e confinado, respectivamente), ensaios de cisalhamento e ensaios diametrais (corpos-de-prova cilíndricos);

- Ensaios empíricos: Marshall, Hveen, máquina de ensaios giratórios do "Corps of Engineering" e indicador de pressão lateral;

- Ensaios simulativos: "Asphalt Pavement Analyzer", "Hamburg Wheel-Tracking Device", "French Rutting Tester", "Purdue University Laboratory Wheel Tracking Device", "Model Mobile Load Simulator", "Dry Wheel Tracker" e "Rotary Loaded Wheel Tester".

Outro principal defeito dos pavimentos asfálticos é o trincamento por fadiga, um fenômeno estrutural, progressivo e localizado. Ocorre quando o revestimento é submetido a tensões ou deformações repetidas, inferiores à sua resistência última, em que se desenvolvem alterações em sua estrutura interna, resultando na perda de características estruturais originais. Podem culminar na fissuração ou ruptura completa do material após certo número suficiente de solicitações, dependendo material utilizado, solicitações de carga e climática. O processo de fadiga modifica as propriedades do material a cada ciclo de carga, provocando, geralmente, uma redução na sua capacidade de suporte (FERNANDES Jr. 1994).

O parâmetro estrutural responsável por essa deficiência é a tensão de tração horizontal que se desenvolve na face inferior do revestimento, pois neste ponto o estado de tensões apresenta componentes de tração nas direções transversal e longitudinal e de compressão na direção vertical. O ligante asfáltico que compõe o pavimento suporta deformações plásticas significativas antes que ocorra a ruptura, porém, tais deformações causam microfissuras na estrutura do material. O fenômeno é progressivo e pode causar a fratura do material ao longo do tempo (PINTO, 1991). 
Segundo Motta e Pinto (1994) a trinca por fadiga é decorrente das solicitações repetidas do tráfego, em conjunto com a elevada resiliência das camadas de base e sub-base granulares. A resistência à fadiga de uma mistura asfáltica pode ser definida como a capacidade que esta apresenta de resistir aos esforços repetidos de flexão (esforço cíclico) sem se romper.

O processo de fadiga se acelera com a presença de baixas temperaturas, fazendo com que a mistura asfáltica torne-se mais rígida e não resista à repetição das cargas. Também o envelhecimento do ligante enrijece a mistura e diminui sua resistência à fadiga após certo tempo. Segundo Gondijo (1980) os principais fatores intervenientes são:

- Características do tráfego: carga por roda, pressão de contato, velocidade do veículo, intensidade do tráfego;

- Características próprias do pavimento: espessura e rigidez das camadas, teor de asfalto, volume de vazios, ponto de amolecimento, viscosidade, graduação e textura do agregado;

- Condições climáticas: em particular a temperatura, pois o ligante asfáltico é um material termo sensível, em que temperaturas elevadas aumentam sua flexibilidade, diminuindo a vida de fadiga, e temperaturas mais baixas tornam a camada asfáltica mais rígida e com maior tendência a se tornar quebradiça.

Um aumento na viscosidade do ligante faz com que a rigidez da mistura aumente. Se o pavimento possuir uma camada de concreto asfáltico esbelta e de alta rigidez ele se torna propenso às trincas por fadiga, porém se o pavimento for espesso e projetado para resistir a altos carregamentos, este deve ter uma rigidez elevada (GRECO, 2004).

O volume de vazios assume particular influência no comportamento das misturas asfálticas, sendo que no comportamento à fadiga essa influência pode ser explicada pelos seus efeitos na rigidez e nas suas tensões de tração que se desenvolvem ou no ligante ou na combinação ligantefíler da mistura (SANTOS, 2005).

A caracterização da fadiga em concreto asfáltico pode ter duas abordagens: a fenomenológica e a mecanística (LEE et al., 2000). Os ensaios de fadiga têm o objetivo de verificar o número de 
solicitações que uma determinada carga leva para conduzir uma mistura asfáltica à ruptura. São três os critérios de ruptura utilizados: redução da rigidez inicial da mistura a um determinado valor, surgimento da primeira fissura e ruptura total do corpo-de-prova.

O ensaio pode ser realizado de duas maneiras:

- Tensão controlada: a tensão permanece constante ao longo do ensaio e a deformação aumenta, resultando na vida de fadiga da mistura asfáltica;

- Deformação Controlada: a deformação é mantida constante e a tensão varia ao longo do ensaio, resultando a vida de serviço da mistura asfáltica.

Os revestimentos asfálticos espessos e/ou muito mais rígidos que a estrutura subjacente do pavimento controlam a magnitude das deformações, ao resistirem às cargas aplicadas, estão sujeitos à tensão controlada. Os pavimentos mais esbeltos estão sujeitos a deformação controlada, pois há uma contribuição maior das subcamadas na absorção das tensões (MEDINA, 1997).

Diversos autores recomendam a utilização de um fator campo-laboratório (FCL) visando corrigir a severidade e as condições extremas a que os corpos-de-prova estão sujeitos em laboratório. Medina e Motta (2005) recomendam o uso do FCL de $10^{4}$ para o ensaio com tensão controlada e de $10^{5}$ para o ensaio com deformação controlada, para Pinto (1991) o valor do fator laboratório/campo (FLC) varia entre $10^{3}$ e $10^{4}$, e que também é função do tipo de ensaio realizado em laboratório, quer sejam ensaios de flexão ou de compressão diametral.

\subsubsection{Ensaios para Avaliação de Misturas Asfálticas}

\subsubsection{Ensaio de Módulo de Resiliência}

Segundo o DNER, o módulo de resiliência (MR) de misturas asfálticas é a relação entre a tensão de tração $\left(\sigma_{t}\right)$, aplicada repetidamente no plano vertical de uma amostra cilíndrica de mistura asfáltica, e a deformação específica recuperável $\left(\varepsilon_{t}\right)$, correspondente à tensão aplicada, numa dada temperatura. 
Os materiais que compõe a estrutura de um pavimento, quando sujeitos a carregamentos dinâmicos de curta duração e submetidos a tensões muito abaixo de sua plastificação, exibem comportamento elástico e não necessariamente linear. O módulo de resiliência é o módulo de elasticidade obtido por meio de ensaios laboratoriais, aplicando carregamentos repetidos nos corpos-de-prova, simulando a situação em campo de passadas rápidas e repetidas das rodas dos veículos.

O ensaio de módulo de resiliência visa simular condições encontradas no campo, onde os materiais que constituem o revestimento asfáltico são submetidos a carregamentos de curta duração originados pela ação do tráfego. A deformação específica resiliente, ou recuperável, é medida por um Linear Variable Differential Transducer (LVDT) acoplado a um sistema de aquisição de dados e posicionado no plano perpendicular ao sentido do carregamento; dessa forma, consegue-se avaliar o comportamento da mistura na zona onde ocorrem as deformações de tração, responsáveis pela fadiga da camada.

O modelo de resiliência é obtido através do ensaio de compressão diametral dinâmico, normalizado pelo DNER ME 133.

As alturas dos corpos de prova, determinadas utilizando-se um paquímetro com resolução de centésimo de milímetro, correspondem à média entre três medições efetuadas em cada corpo-deprova. Após serem medidos, os corpos-de-prova permanecem por, no mínimo, 48 horas a $25^{\circ} \mathrm{C}$, em uma sala climatizada, até a realização do ensaio.

O ensaio é realizado a $25^{\circ} \mathrm{C}$, com aplicação de 100 ciclos de carregamento, sendo cada ciclo com duração de 1 segundo, com $0,1 \mathrm{~s}$ de aplicação de carga e $0,9 \mathrm{~s}$ de recuperação. A magnitude da carga aplicada é de 25 a 30\% da resistência à tração do corpo-de-prova, determinada no ensaio de resistência à tração por compressão diametral.

O módulo de resiliência das misturas é calculado através da Equação 2.8:

$$
M R=\frac{F}{\Delta \times H} \times(0,9976 \times \mu+0,2692)
$$


em que: $\quad$ MR: módulo de resiliência (MPa);

F: carga vertical, repetidamente aplicada diametralmente no corpo-de-prova $(\mathrm{N})$;

$\Delta$ : deslocamento total, correspondente à deformação elástica sofrida pelo corpode-prova na direção perpendicular à aplicação de carga (mm);

$\mathrm{H}$ : altura do corpo-de-prova (mm);

$\mu$ : coeficiente de Poisson.

\subsubsection{Resistência à Tração}

O ensaio de resistência à tração por compressão diametral ou tração indireta, conhecido internacionalmente como "ensaio brasileiro", foi desenvolvido pelo professor Fernando Luiz Lobo Carneiro para determinar a resistência à tração de corpos-de-prova de concreto através de carregamento estático.

O ensaio consiste em submeter corpos de prova a uma compressão diametral, recebendo cargas de compressão distribuídas ao longo de duas geratrizes opostas, que vai sendo aumentada progressivamente, até que haja a ruptura do corpo-de-prova (não há esmagamento) ao longo de um plano diametral (Figura 2.3 (a)). Esta forma de carregamento gera uma tensão de tração normal à direção da carga aplicada e ao longo do plano diametral vertical. As tensões de tração na direção perpendicular à direção de aplicação da carga são praticamente constantes ao longo do diâmetro e a ruptura ocorre com um estado de tensões tal que $\sigma_{\mathrm{t}} / \sigma_{\mathrm{c}}=1: 3$ (Figura $2.3(\mathrm{~b})$ ).

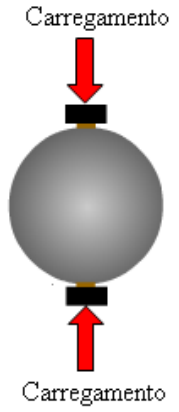

(a)

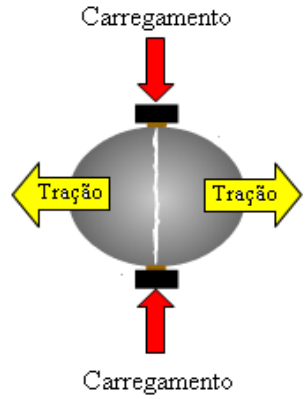

(b)

Figura 2.3 - Ensaio de Tração Indireta (a) durante o carregamento e (b) na ruptura 
Esse método tem sido utilizado para a determinação de propriedades mecânicas de misturas asfálticas (módulo de resiliência, resistência à tração, coeficiente de Poisson). O ensaio é feito segundo a norma DNER-ME 138/96, que estabelece o método para determinar a resistência à tração por compressão diametral de misturas asfálticas, de utilidade para projetos de pavimentos flexíveis.

Determinada através do ensaio normalizado pelo DNER ME 138, é utilizada para definição da carga que deve ser aplicada nos ensaios de módulo de resiliência por compressão diametral e fadiga de misturas asfálticas. $\mathrm{O}$ ensaio é realizado a $25^{\circ} \mathrm{C}$, consiste na aplicação progressiva de carga de compressão diametral estática até a ruptura do corpo de prova.

A Equação 2.9 fornece o valor da resistência à tração de cada corpo-de-prova:

$$
R T=\frac{2 \times F}{\pi \times D \times H}
$$

em que: $\quad$ RT: resistência à tração $(\mathrm{MPa})$;

$\mathrm{F}$ : carga de ruptura $(\mathrm{N})$;

D: diâmetro médio do corpo-de-prova $(\mathrm{mm})$;

$\mathrm{H}$ : altura média do corpo-de-prova $(\mathrm{mm})$.

\subsubsection{Ensaio de Fadiga}

Para a avaliação da suscetibilidade de misturas asfálticas à fadiga, diferentes procedimentos têm sido desenvolvidos, desde os mais complexos que utilizam simuladores de tráfego, até os mais simples como os que se utiliza de ensaios de compressão diametral. Todos procuram, por diferentes maneiras, reproduzir as tensões e deformações que solicitam o revestimento; em laboratório, a vida de fadiga é obtida usando um critério baseado na medida do acúmulo de deformações plásticas em função do numero de ciclos (KHATTAK e BALADI, 2001).

O ensaio de fadiga visa obter o número de solicitações, sob um determinado carregamento, levando o corpo de prova à ruptura. As formas de carregamento utilizadas nos ensaios para 
determinação dos modelos de fadiga podem ser divididas em dois tipos básicos: tensão controlada (TC) e deformação controlada (DC).

Para o caso da deformação controlada (DC), a deformação é mantida constante e a tensão inicial é diminuída até o final do ensaio, e o critério de fadiga não está condicionado à ruptura completa do corpo de prova, pois para que a deformação seja mantida constante ao longo do ensaio, é necessário que haja uma diminuição no carregamento aplicado. A vida de fadiga neste caso será o numero de repetições da carga capaz de reduzir o desempenho ou rigidez inicial da amostra a um nível pré-estabelecido, que é convencionado por alguns autores como a diminuição do módulo de rigidez $\left(\mathrm{S}_{0}\right)$ em $50 \%$ do valor inicial (TAYEBALI et al., 1992).

O ensaio de tensão controlada (TC) é mais comum no Brasil, em que a carga aplicada deve induzir tensões normais horizontais de 10 a $50 \%$ do valor da resistência à tração. Esta carga é aplicada com duração de $0,1 \mathrm{~s}$ e descanso de 0,9 s. Neste ensaio, o critério de fadiga está associado à fratura da amostra. A tensão é mantida constante ao longo do ensaio e as deformações atingem um valor máximo até o estágio de colapso do corpo de prova. A vida de fadiga $(\mathrm{N})$ é definida como o número total de aplicações de uma carga necessária à ruptura completa da amostra.

As tensões encontradas no centro do corpo de prova, a diferença de tensões e a deformação resiliente são determinadas pelas Equações 2.10, 2.11, 2.12 e 2.13, e a Figura 2.4 mostra um esquema da diferença de tensões no centro da amostra.

$$
\begin{gathered}
\sigma_{t}=\frac{2 \times F}{100 \times \pi \times D \times H} \\
\sigma_{c}=\frac{-6 \times F}{100 \times \pi \times D \times H} \\
\Delta \sigma=\frac{8 \times F}{100 \times \pi \times D \times H} \\
\varepsilon_{r}=\frac{\% R T}{M R}
\end{gathered}
$$


em que: $\quad \sigma_{t}$ : tensão de tração $(\mathrm{MPa})$;

$\sigma_{\mathrm{c}}$ : tensão de compressão $(\mathrm{MPa})$;

$\Delta \sigma:$ diferença de tensões no centro do corpo-de-prova (MPa);

$\varepsilon_{\mathrm{r}}$ : deformação resiliente;

RT: resistência à tração (MPa);

MR: módulo de resiliência (MPa).

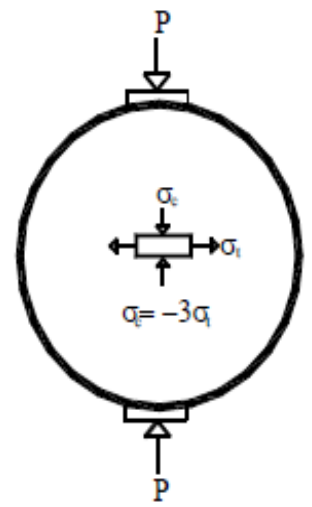

Figura 2.4 - Esquema $\Delta \sigma$ no centro da amostra durante o ensaio de compressão indireta

A representação das curvas de fadiga é feita em um gráfico dilog, com os números de solicitações de carga que levam à ruptura do corpo de prova nas ordenadas e as diferenças de tensões e deformações que levam à ruptura nas abscissas. A curva de fadiga para o material é determinada com as Equações 2.14 e 2.15:

$$
\begin{aligned}
& N_{T}=k_{1} \times\left(\frac{1}{\Delta \sigma}\right)^{k_{2}} \\
& N_{D}=k_{3} \times\left(\frac{1}{\varepsilon_{r}}\right)^{k_{4}}
\end{aligned}
$$

em que: $\quad \mathrm{N}_{\mathrm{T}}$ : número de aplicações de carga até a ruptura do corpo-de-prova, em função da diferença de tensões;

$\mathrm{N}_{\mathrm{D}}$ : número de aplicações de carga até a ruptura do corpo-de-prova, em função da deformação resiliente; 
$\Delta \sigma$ : diferença de tensões no centro do corpo-de-prova (MPa);

$\varepsilon_{\mathrm{r}}$ : deformação resiliente;

$\mathrm{k}_{1}, \mathrm{k}_{2}, \mathrm{k}_{3}, \mathrm{k}_{4}$ : parâmetros determinados por regressão no ensaio de vida de fadiga.

\subsubsection{Ensaio de Fluência por Compressão Uniaxial Estática}

Este ensaio é utilizado para estimar a susceptibilidade das misturas asfálticas à deformação permanente, sob diferentes condições de carregamento e de temperatura. Little et al. (1993) desenvolveram critérios para avaliar o potencial do concreto asfáltico à deformação permanente por meio do ensaio de fluência por compressão uniaxial, que, segundo eles, é suficiente para identificar a sensibilidade das misturas de concreto asfáltico á deformação permanente. O ensaio apresenta sensibilidade as variáveis da mistura, tais como: tipo de asfalto, teor de ligante, tipo de agregado, teor de vazios, temperatura de ensaio e estado de tensões.

O ensaio consiste na aplicação, axialmente, de uma carga estática uniaxial de 0,$1 ; 0,4$ ou $0,7 \mathrm{MPa}$ $\left(4 \mathrm{~kg} / \mathrm{cm}^{2}\right)$ em um corpo de prova cilíndrico, que representa a tensão média no centro de uma camada asfáltica do pavimento em serviço (LITTLE et al., 1993). O ensaio é realizado a $40^{\circ} \mathrm{C}$, com 1 hora de aplicação de carga e 15 minutos de recuperação. As faces dos corpos-de-prova devem ser as mais planas quanto possível para que tensão aplicada seja homogênea em toda a superfície.

É realizada uma fase de pré-condicionamento através da aplicação da carga de ensaio por 5 minutos, seguida de um período de descanso (recuperação) de 5 minutos. São realizadas leituras ao longo do tempo dos deslocamentos axiais e da carga, para obtenção dos seguintes dados: deformação total, deformação recuperável, deformação não recuperável, recuperação, módulo de rigidez à fluência aos 3600 segundos e aos 4500 segundos, inclinação da curva no estágio secundário de deformação e a carga média aplicada. 


\subsection{APRESENTAÇÃO E ANÁLISE DOS RESULTADOS}

\subsubsection{Projeto Volumétrico das Misturas Asfálticas}

Foram compostas curvas granulométricas de acordo com a especificação Superpave, ou seja, respeitando-se os pontos de controle e passando-se acima da zona de restrição. Escolheu-se que a curva granulométrica passasse acima da zona de restrição, pois pesquisa anterior (BARDINI, 2008) mostrou que as misturas contendo os mesmos agregados basálticos, compostas com a curva granulométrica passando abaixo da zona de restrição, não alcançaram o volume de vazios adequado, de $4 \%$.

As misturas foram realizadas para quantidades de fíler, ou seja, conforme considerado neste trabalho, para teores de material totalmente passante na peneira de abertura $0,075 \mathrm{~mm}$ de 2,$5 ; 5,0$ e 7,5\% (Tabela 2.13). A Figura 2.5 apresenta, como um exemplo, a curva granulométrica com teor de fíler de $2,5 \%$.

Tabela 2.13 - Curva granulométrica para misturas com teor de 2,5; 5,0 e 7,5\% de fíler

\begin{tabular}{cccc}
\hline $\begin{array}{c}\text { Abertura Peneiras } \\
(\mathrm{mm})\end{array}$ & \multicolumn{3}{c}{$\begin{array}{c}\text { Porcentagem } \\
\text { passante }\end{array}$} \\
\hline 25 & 100 & 100 & 100 \\
19 & 95 & 95 & 95 \\
12.5 & 85 & 85 & 85 \\
9.5 & 75 & 75 & 75 \\
4.75 & 55 & 55 & 55 \\
2.36 & 40 & 40 & 40 \\
1.18 & 30 & 30 & 30 \\
0.6 & 21 & 21 & 21 \\
0.3 & 16 & 16 & 16 \\
0.15 & 10 & 10 & 10 \\
0.075 & $\mathbf{2 , 5}$ & $\mathbf{5 , 0}$ & $\mathbf{7 , 5}$ \\
\hline
\end{tabular}




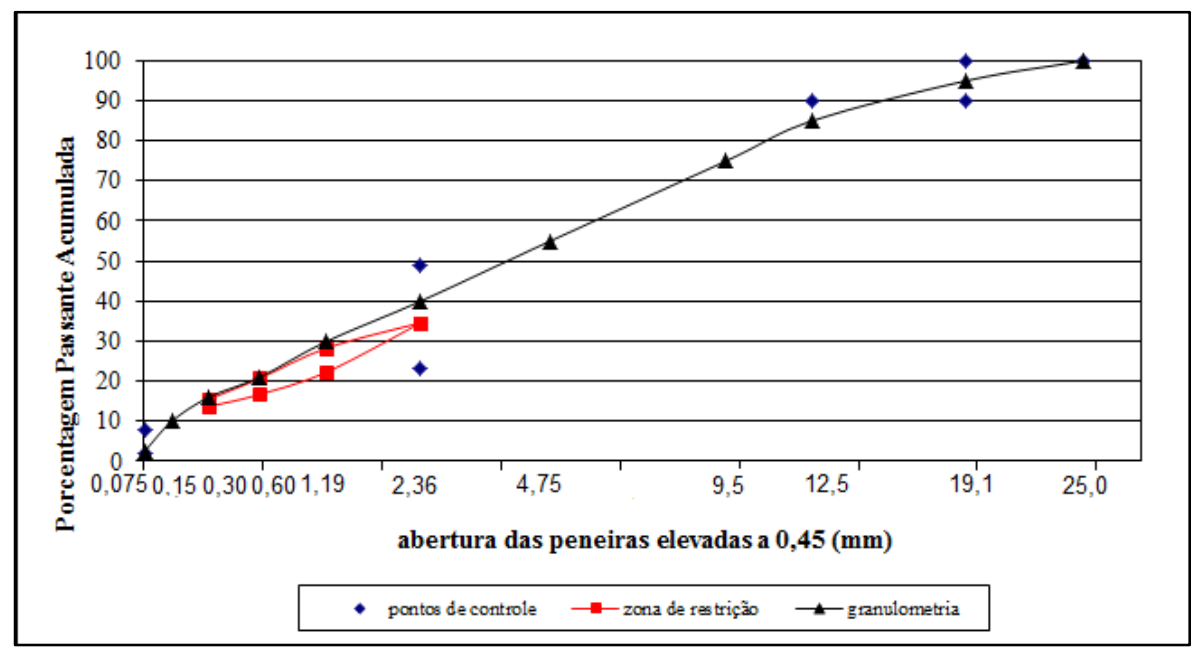

Figura 2.5 - Curva Granulométrica com teor de fíler de 2,5\%

Os corpos de prova compactados requerem mistura e compactação sob condições de temperatura equivalentes a viscosidade de $1,7 \mathrm{P}$ e $2,8 \mathrm{P}$, respectivamente. A mistura é efetuada individualmente na fase de dosagem. Após a mistura as amostras não compactadas são submetidas a duas horas de envelhecimento (curto prazo) numa estufa mantidas na temperatura de compactação. Os moldes de compactação e placas base devem ser também colocados na estufa na temperatura de compactação por pelo menos 30 a 45 minutos antes de serem usados.

As amostras preparadas para a determinação do teor ótimo de projeto foram compactadas no teor ótimo de projeto estimado, no teor de projeto $\pm 0,5$ e $+1,0 \%$. Os corpos de prova foram compactados no molde de $100 \mathrm{~mm}$ de diâmetro, com aproximadamente $1200 \mathrm{~g}$ de material. Após envelhecimento de curto prazo, os corpos de prova não compactados (mistura solta) ficam prontos para compactação no Compactador Giratório Superpave. A pressão vertical é de $600 \mathrm{kPa}$ $( \pm 18 \mathrm{kPa})$ e ângulo de giro de $1,25^{\circ}( \pm 0,02)$. Três níveis de giro são de interesse:

- Número de giros de projeto $\left(\mathrm{N}_{\text {projeto }}\right)$ : 100 ;

- Número de giros inicial $\left(\mathrm{N}_{\text {inicial }}\right)$ : 8;

- Número de giros máximo $\left(\mathrm{N}_{\text {máximo }}\right): 160$.

$\mathrm{Na}$ determinação do teor de ligante asfáltico de projeto, para cada mistura contendo os diferentes tipos e teores de fíler e com os agregados granítico e basáltico, com CAP 50/70 e CAP 85/100, utilizou-se o compactador giratório Superpave. 
Os valores de teor de ligante de projeto para as misturas contendo agregado granítico com os diferentes tipos de ligantes asfáltico, 50/70 e 85/100, foram muito próximos, podendo consideralos como iguais. Por essa razão, para as misturas contendo o agregado basáltico, foram realizadas as dosagens apenas para o ligante asfáltico CAP 50/70, e esses valores foram considerados os mesmos para as misturas asfálticas com o CAP 85/100.

Os resultados dos teores de ligante de projeto estão apresentados na Figura 2.6 para as misturas contendo agregado granítico e CAP 50/70 (a) e para as misturas contendo agregado basáltico e CAP 50/70 (b).

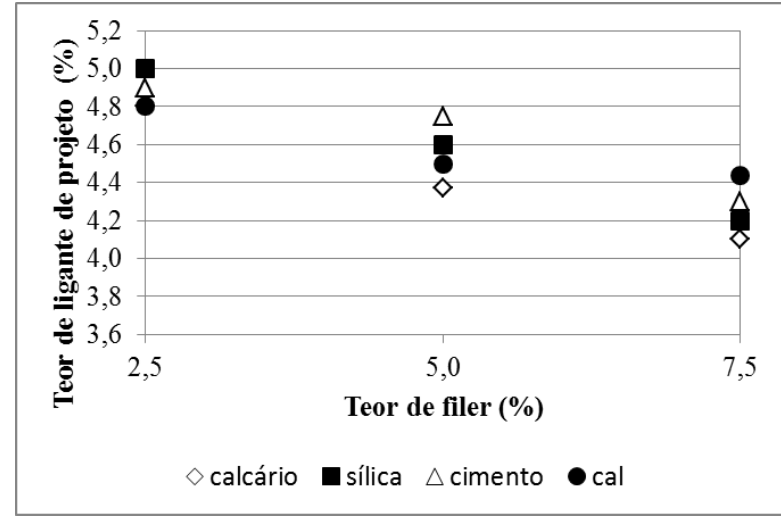

(a)

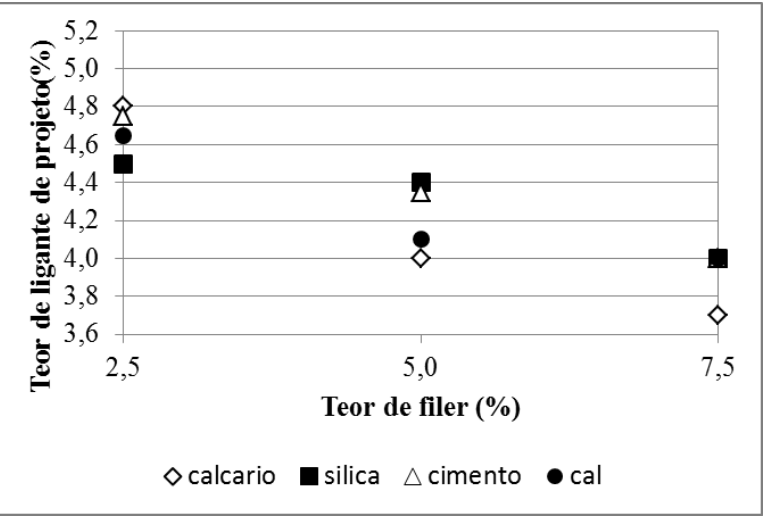

(b)

Figura 2.6 - Teor de ligante de projeto para as misturas contendo agregado: (a) basáltico e (b) granítico

Para testar quais fatores (tipo de fíler, teor de fíler e tipo de agregado) influenciam nos resultados do teor de ligante de projeto, realizou-se a Análise de Variância (ANOVA). Primeiramente, a análise foi realizada considerando o fator tipo de agregado em dois níveis (agregado granítico e basáltico), o fator tipo de fíler em quatro níveis (pó calcário, sílica, cimento Portland e cal hidratada) e o fator teor de fíler em três níveis (relação fíler/asfalto de 2,5; 5,0 e 7,5\%). A Tabela 2.14 mostra os dados do experimento e a Tabela B.1 do Apêndice B apresenta o resumo dos valores da análise de variância. 
Tabela 2.14 - Dados do experimento para a análise do teor de ligante de projeto nas misturas asfálticas compostas pelo CAP 50/70

\begin{tabular}{cccc}
\hline \multirow{2}{*}{ Tipo de Fíler } & Teor de Fíler & \multicolumn{2}{c}{ Tipo de Agregado } \\
\cline { 2 - 4 } & $(\%)$ & Granito & Basalto \\
\hline \multirow{3}{*}{ Calcário } & 2,5 & 4,8 & 4,8 \\
& 5,0 & 4,0 & 4,37 \\
& 7,5 & 3,7 & 4,1 \\
\hline \multirow{3}{*}{ Sílica } & 2,5 & 4,5 & 5,0 \\
& 5,0 & 4,4 & 4,6 \\
Cimento & 7,5 & 4,0 & 4,2 \\
& 2,5 & 4,75 & 4,9 \\
& 5,0 & 4,35 & 4,75 \\
Cal & 7,5 & 4,0 & 4,3 \\
\hline \multirow{3}{*}{ Cany } & 2,5 & 4,65 & 4,8 \\
& 5,0 & 4,1 & 4,5 \\
& 7,5 & 4,0 & 4,44 \\
\hline
\end{tabular}

A Tabela 2.15 apresenta o resumo da análise de variância, considerando nível de significância $(\alpha)$ de 0,05, com a resposta da influência dos fatores considerados. Assim, a seguinte hipótese nula foi testada: $\mathrm{H}_{0}$ : os fatores não influenciam na resposta do valor do teor de ligante de projeto; para valores de $\mathrm{F}_{0}$ maiores que $\mathrm{f}_{0}$, a hipótese nula $\mathrm{H}_{0}$ é rejeitada, ou seja, o fator influencia na resposta. Pode-se perceber que o fator que mais influenciou nos resultados de teor de ligante de projeto é o teor de fíler na mistura asfáltica, seguido pelo tipo de agregado e pelo tipo de fíler.

Tabela 2.15 - Resumo da Análise de Variância do teor de ligante de projeto da influência dos fatores e sua interação, nas misturas asfálticas compostas pelo CAP 50/70

\begin{tabular}{cccc}
\hline Fator & $\mathrm{F}_{0}$ & $\mathrm{f}_{0}$ & Influência \\
\hline Tipo de agregado (Fator A) & 227,12 & 4,26 & $\operatorname{sim}$ \\
Tipo de fíler (Fator B) & 22,58 & 3,01 & $\operatorname{sim}$ \\
Teor de fíler (Fator C) & 424,39 & 3,40 & $\operatorname{sim}$ \\
Interação AB & 0,56 & 3,01 & não \\
Interação AC & 4,07 & 3,40 & $\operatorname{sim}$ \\
Interação BC & 12,43 & 2,51 & $\operatorname{sim}$ \\
Interação ABC & 20,07 & 2,51 & $\operatorname{sim}$ \\
\hline
\end{tabular}

A segunda análise foi realizada considerando-se o fator tipo de ligante asfáltico em dois níveis (CAP 50/70 e CAP 85/100), o fator tipo de fíler em quatro níveis (pó calcário, sílica, cimento 
Portland e cal hidratada) e o fator teor de fíler em três níveis (relação fíler/asfalto de 2,5; 5,0 e 7,5\%), para as misturas compostas com o agregado granítico. A Tabela 2.16 mostra os dados do experimento e a Tabela B.2 do Apêndice B apresenta o resumo dos valores da análise de variância.

A Tabela 2.17 apresenta o resumo da análise de variância, com a resposta da influência dos fatores considerados; para valores de $\mathrm{F}_{0}$ maiores que $\mathrm{f}_{0} \mathrm{o}$ fator influencia na resposta avaliada. Pode-se perceber que o fator que mais influenciou nos resultados de teor de ligante de projeto foi o teor de fíler na mistura asfáltica, seguido pelo e pelo tipo de fíler; como já havíamos constatado o tipo de ligante asfáltico não influencia no teor de ligante asfáltico de projeto.

Tabela 2.16 - Dados do experimento do teor de ligante de projeto nas misturas asfálticas compostas pelo agregado granítico

\begin{tabular}{cccc}
\hline \multirow{2}{*}{ Tipo de Fíler } & $\begin{array}{c}\text { Teor de Fíler } \\
(\%)\end{array}$ & \multicolumn{2}{c}{ Tipo de Ligante } \\
\cline { 3 - 4 } & 2,5 & 4,8 & 4,5 \\
Calcário & 5,0 & 4,0 & 4,2 \\
& 7,5 & 3,7 & 3,75 \\
\hline \multirow{3}{*}{ Silica } & 2,5 & 4,5 & 4,75 \\
& 5,0 & 4,4 & 4,35 \\
& 7,5 & 4,0 & 4,1 \\
\hline \multirow{3}{*}{ Cimento } & 2,5 & 4,75 & 4,7 \\
& 5,0 & 4,35 & 4,5 \\
& 7,5 & 4,0 & 4,15 \\
\hline \multirow{2}{*}{ Cal } & 2,5 & 4,65 & 4,65 \\
& 5,0 & 4,1 & 4,2 \\
& 7,5 & 4,0 & 4,05 \\
\hline
\end{tabular}


Tabela 2.17 - Resumo da Análise de Variância do teor de ligante de projeto, da influência dos fatores e sua interação, nas misturas asfálticas compostas pelo agregado granítico

\begin{tabular}{cccc}
\hline Fator & $\mathrm{F}_{0}$ & $\mathrm{f}_{0}$ & Influência \\
\hline Tipo de ligante (Fator A) & 2,87 & 4,26 & não \\
Tipo de fíler (Fator B) & 14,56 & 3,01 & $\operatorname{sim}$ \\
Teor de fíler (Fator C) & 227,91 & 3,40 & $\operatorname{sim}$ \\
Interação AB & 1,03 & 3,01 & não \\
Interação AC & 1,46 & 3,40 & não \\
Interação BC & 4,28 & 2,51 & sim \\
Interação ABC & 2,97 & 2,51 & sim \\
\hline
\end{tabular}

\subsubsection{Absorção de Ligante Asfáltico nas Misturas Asfálticas}

Para a determinação dos valores de absorção de ligante asfáltico foi realizado o ensaio Rice para determinação da Densidade Máxima Teórica e cálculo da massa específica efetiva do agregado e a absorção correspondente. A Figura 2.7 mostra os valores de absorção de ligante asfáltico para as misturas compostas pelo agregado granítico e CAP 50/70 (a) e CAP 85/100 (b), em função do teor de fíler para o teor de ligante de projeto para cada mistura contendo os diferentes fileres.

Pode-se perceber que as misturas que apresentaram maior absorção de ligante asfáltico foram as contendo o fíler de cimento Portland, para todos os teores de fíler; já as misturas contendo fíler de cal hidratada apresentaram os menores valores de absorção, exceto para o teor de 2,5\% com o CAP 50/70.

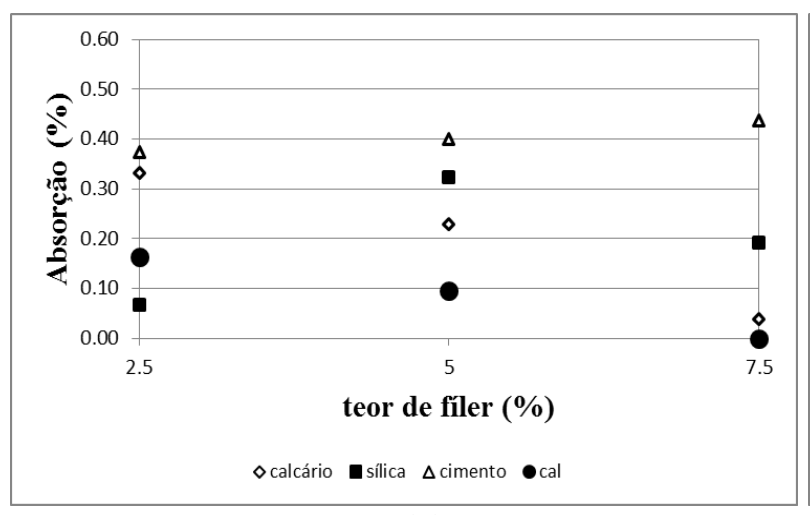

(a)

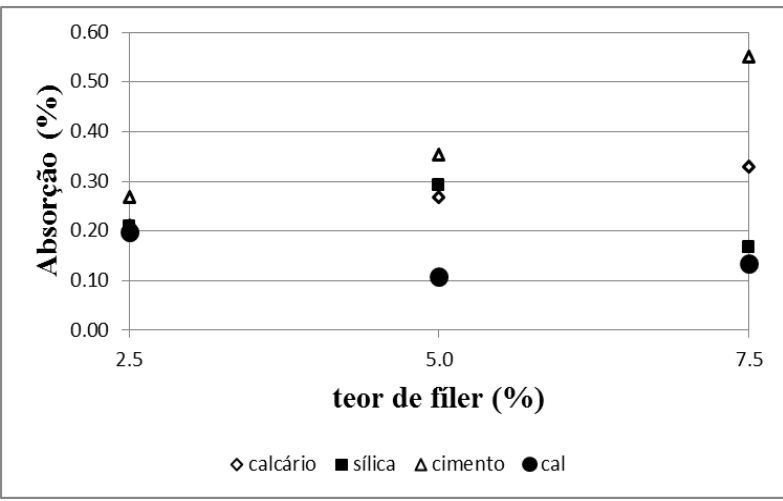

(b)

Figura 2.7 - Valores de Absorção de ligante asfáltico para misturas compostas pelo agregado granítico e ligante asfáltico: (a) CAP50/70 e (b) CAP 85/100 
A Figura 2.8 mostra os valores de absorção de ligante asfáltico para as misturas compostas pelo agregado basáltico e o CAP 50/70 em função do teor de fíler para o teor de ligante de projeto para cada mistura contendo os diferentes fileres.

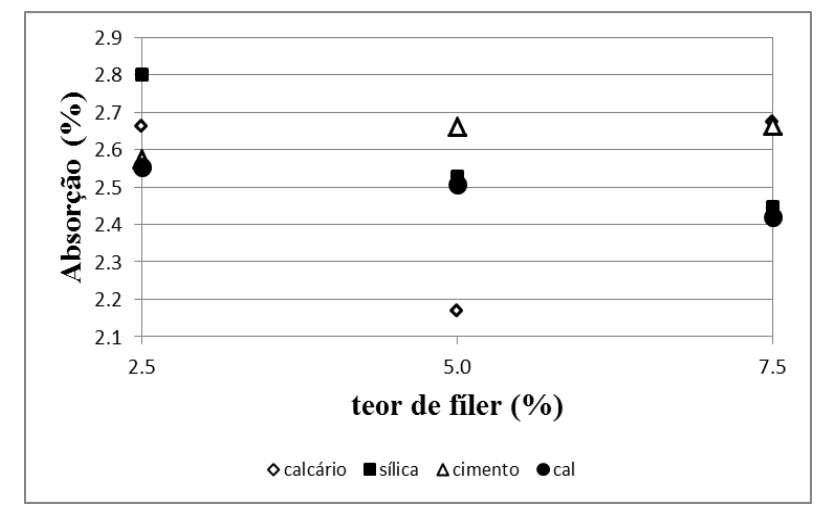

Figura 2.8 - Valores de Absorção de ligante asfáltico para misturas compostas pelo agregado basáltico e CAP 50/70

Para testar quais fatores (tipo de fíler, teor de fíler e tipo de agregado) influenciam nos resultados de absorção de ligante asfáltico nas misturas asfálticas, realizou-se a Análise de Variância (ANOVA). Para isso, a análise foi realizada considerando o fator tipo de agregado em dois níveis (agregado granítico e basáltico), o fator tipo de fíler em quatro níveis (pó calcário, sílica, cimento Portland e cal hidratada) e o fator teor de fíler em três níveis (relação fíler/asfalto de 2,5; 5,0 e 7,5\%), das misturas compostas com o ligante asfáltico 50/70. A Tabela 2.18 mostra os dados do experimento e a Tabela B.3 do Apêndice B apresenta o resumo dos valores da análise de variância.

A Tabela 2.19 apresenta o resumo da análise de variância, considerando nível de significância ( $\alpha$ ) de 0,05, com a resposta da influência dos fatores considerados. Assim, a seguinte hipótese nula foi testada: $\mathrm{H}_{0}$ : os fatores não influenciam na resposta do valor da absorção de ligante asfáltico em misturas asfálticas; para valores de $\mathrm{F}_{0}$ maiores que $\mathrm{f}_{0}$, a hipótese nula $\mathrm{H}_{0}$ é rejeitada, ou seja, o fator influencia na resposta. Pode-se perceber que o fator que mais influenciou nos resultados de absorção de ligante asfáltico foi o tipo de agregado, seguido pelo tipo de fíler e pelo teor de fíler. 
Tabela 2.18 - Dados do experimento da absorção de ligante asfáltico nas misturas asfálticas compostas pelo CAP 50/70

\begin{tabular}{cccc}
\hline \multirow{2}{*}{$\begin{array}{c}\text { Tipo de } \\
\text { Fíler }\end{array}$} & \multirow{2}{*}{ Teor de fíler (\%) } & \multicolumn{2}{c}{ Tipo de Agregado } \\
\cline { 2 - 4 } Calcário & 2,5 & 2,664 & 0,331 \\
& 5,0 & 2,172 & 0,227 \\
& 7,5 & 2,675 & 0,036 \\
\hline \multirow{3}{*}{ Sílica } & 2,5 & 2,799 & 0,067 \\
& 5,0 & 2,529 & 0,324 \\
& 7,5 & 2,445 & 0,192 \\
\hline \multirow{3}{*}{ Cimento } & 2,5 & 2,575 & 0,371 \\
& 5,0 & 2,661 & 0,398 \\
& 7,5 & 2,665 & 0,436 \\
\hline \multirow{3}{*}{ Cal } & 2,5 & 2,555 & 0,163 \\
& 5,0 & 2,508 & 0,097 \\
& 7,5 & 2,421 & 0,000 \\
\hline
\end{tabular}

Tabela 2.19 - Resumo da Análise de Variância da absorção, influência dos fatores e sua interação, nas misturas asfálticas compostas pelo CAP 50/70

\begin{tabular}{cccc}
\hline Fator & $\mathrm{F}_{0}$ & $\mathrm{f}_{0}$ & Influência \\
\hline Tipo de agregado (Fator A) & 5045,082 & 4,26 & sim \\
Tipo de fíler (Fator B) & 8,542 & 3,01 & sim \\
Teor de fíler (Fator C) & 2,572 & 3,40 & não \\
Interação AB & 1,590 & 3,01 & não \\
Interação AC & 3,950 & 3,40 & sim \\
Interação BC & 2,584 & 2,51 & sim \\
\hline
\end{tabular}

A segunda análise foi realizada considerando-se o fator tipo de ligante asfáltico em dois níveis (CAP 50/70 e CAP 85/100), o fator tipo de fíler em quatro níveis (pó calcário, sílica, cimento Portland e cal hidratada) e o fator teor de fíler em três níveis (relação fíler/asfalto de 2,5; 5,0 e 7,5\%), para as misturas compostas com o agregado granítico. A Tabela 2.20 mostra os dados do experimento e a Tabela B.4 do Apêndice B apresenta o resumo dos valores da análise de variância. 
Tabela 2.20 - Dados do experimento da absorção de ligante asfáltico nas misturas asfálticas compostas pelo agregado granítico

\begin{tabular}{cccc}
\hline Tipo de & Teor de & \multicolumn{2}{c}{ Tipo de ligante asfáltico } \\
\cline { 3 - 4 } Fíler & fíler $(\%)$ & CAP 85/100 & CAP 50/70 \\
\hline \multirow{3}{*}{ Calcário } & 2,5 & 0,210 & 0,331 \\
& 5,0 & 0,266 & 0,227 \\
& 7,5 & 0,328 & 0,036 \\
\hline \multirow{3}{*}{ Silica } & 2,5 & 0,209 & 0,067 \\
& 5,0 & 0,292 & 0,324 \\
& 7,5 & 0,167 & 0,192 \\
\hline \multirow{3}{*}{ Cimento } & 5,0 & 0,267 & 0,371 \\
& 7,5 & 0,353 & 0,398 \\
& 2,5 & 0,549 & 0,436 \\
\hline \multirow{2}{*}{ Cal } & 5,0 & 0,199 & 0,163 \\
& 7,5 & 0,107 & 0,097 \\
\hline
\end{tabular}

A Tabela 2.21 apresenta o resumo da análise de variância, com a resposta da influência dos fatores considerados; para valores de $\mathrm{F}_{0}$ maiores que $\mathrm{f}_{0} \mathrm{o}$ fator influencia na resposta avaliada. Pode-se perceber que o fator que mais influenciou nos resultados da absorção é o tipo de fíler, e que o tipo de ligante não influencia na absorção.

Tabela 2.21 - Resumo da Análise de Variância da absorção de ligante asfáltico, influência dos fatores e sua interação, nas misturas asfálticas compostas pelo agregado granítico

\begin{tabular}{cccc}
\hline Fator & $\mathrm{F}_{0}$ & $\mathrm{f}_{0}$ & Influência \\
\hline Tipo de ligante (Fator A) & 1,247 & 4,26 & não \\
Tipo de fíler (Fator B) & 12,449 & 3,01 & sim \\
Teor de fíler (Fator C) & 0,356 & 3,40 & não \\
Interação AB & 0,321 & 3,01 & não \\
Interação AC & 1,968 & 3,40 & não \\
Interação BC & 2,054 & 2,51 & não \\
\hline
\end{tabular}




\subsubsection{Montagem do Experimento Fatorial Fracionado para a Caracterização das Propriedades Mecânicas}

$\mathrm{Na}$ avaliação da influência do fíler nas propriedades mecânicas das misturas asfálticas, os ensaios foram realizados em 12 condições experimentais, das 36 existentes no planejamento total, para a viabilidade da realização dos ensaios com as misturas asfálticas para os fatores desejados. Para que o planejamento fatorial fosse simétrico (facilitando assim o fracionamento e a análise dos resultados), o fator Tipo de Fíler, que inicialmente tinha quatro fatores, foi reduzido para três, sendo que o fíler de sílica não foi incluído nos ensaios de caracterização mecânica.

A Tabela 2.22 apresenta em quais condições experimentais foram realizados em ensaios mecânicos, tanto de resistência à tração, quanto o módulo de resiliência, vida de fadiga e deformação permanente.

Para facilitar a análise dos resultados do experimento fatorial fracionado em diferentes níveis, dividiu-se o experimento para que o experimento fatorial seja da forma $2^{\mathrm{k}}$, que tem a análise mais simplificada.

Tabela 2.22 - Condições experimentais testadas nos ensaios mecânicos

\begin{tabular}{cc|ccc|ccc}
\hline & Teor de Fíler & \multicolumn{3}{|c|}{ CAP 50/70 } & \multicolumn{3}{c}{ CAP 85/100 } \\
& $\%$ & Calcário & Cimento & Cal & Calcário & Cimento & Cal \\
\hline Agregado & 2,5 & $\mathrm{x}$ & & & & & $\mathrm{x}$ \\
Basáltico & 5,0 & & & $\mathrm{x}$ & $\mathrm{x}$ & \\
& 7,5 & & $\mathrm{x}$ & & & $\mathrm{x}$ \\
\hline \multirow{2}{*}{ Agregado } & 2,5 & & $\mathrm{x}$ & & & $\mathrm{x}$ \\
Granítico & 5,0 & & & $\mathrm{x}$ & $\mathrm{x}$ & \\
& 7,5 & $\mathrm{x}$ & & & & \\
\hline
\end{tabular}

A divisão do experimento fatorial fracionado de fatores de três níveis para dois níveis foi realizada da forma mostrada nas Tabelas 2.23, 2.25, 2.27, 2.29, 2.31 e 2.33. Os fatores e níveis dos experimentos fatoriais fracionados em dois níveis correspondentes estão apresentados nas Tabelas 2.24, 2.26, 2.28, 2.30, 2.32 e 2.34, respectivamente. 
Tabela 2.23 - Divisão do experimento fatorial fracionado em dois níveis - Parte 1

\begin{tabular}{cc|cc}
\hline & Teor de Fíler & \multicolumn{2}{c}{ CAP 50/70 } \\
& $(\%)$ & Calcário & Cimento \\
\hline \multirow{2}{*}{ Agregado Basáltico } & 2,5 & $\mathrm{x}$ & \\
& 7,5 & & $\mathrm{x}$ \\
\hline \multirow{2}{*}{ Agregado Granítico } & 2,5 & & $\mathrm{x}$ \\
& 7,5 & $\mathrm{x}$ & \\
\hline
\end{tabular}

Tabela 2.24 - Fatores e níveis do experimento fatorial fracionado em dois níveis - Parte 1

\begin{tabular}{cccc}
\hline & Fator & \multicolumn{2}{c}{ Nível } \\
& & + & - \\
\hline Fator A & Tipo de Agregado & basalto & granito \\
Fator B & Tipo de Fíler & calcário & cimento \\
Fator C & Teor de Fíler & 2,5 & 7,5 \\
\hline
\end{tabular}

Tabela 2.25 - Divisão do experimento fatorial fracionado em dois níveis - Parte 2

\begin{tabular}{cccc}
\hline & Teor de Fíler & \multicolumn{2}{c}{ CAP 85/100 } \\
& $(\%)$ & Cimento & Cal \\
\hline \multirow{2}{*}{ Agregado Basáltico } & 2,5 & & $\mathrm{x}$ \\
& 7,5 & $\mathrm{x}$ & \\
\hline \multirow{2}{*}{ Agregado Granítico } & 2,5 & $\mathrm{x}$ & \\
& 7,5 & & $\mathrm{x}$ \\
\hline
\end{tabular}

Tabela 2.26 - Fatores e níveis do experimento fatorial fracionado em dois níveis - Parte 2

\begin{tabular}{cccc}
\hline & Fator & \multicolumn{2}{c}{ Nível } \\
& & + & - \\
\hline Fator A & Tipo de Agregado & granito & basalto \\
Fator B & Tipo de Fíler & cimento & cal \\
Fator C & Teor de Fíler & 2,5 & 7,5 \\
\hline
\end{tabular}

Tabela 2.27 - Divisão do experimento fatorial fracionado em dois níveis - Parte 3

\begin{tabular}{cc|cc|cc}
\hline & Teor de Fíler & \multicolumn{2}{|c|}{ CAP 50/70 } & \multicolumn{2}{c}{ CAP 85/100 } \\
& $\%$ & Calcário & Cal & Calcário & Cal \\
\hline Agregado & 2,5 & $\mathrm{x}$ & & & $\mathrm{x}$ \\
Basáltico & 5,0 & & $\mathrm{x}$ & $\mathrm{x}$ & \\
\hline
\end{tabular}


Tabela 2.28 - Fatores e níveis do experimento fatorial fracionado em dois níveis - Parte 3

\begin{tabular}{cccc}
\hline & Fator & \multicolumn{2}{c}{ Nível } \\
& & + & - \\
\hline Fator A & Tipo de Ligante Asfaltico & CAP 50/70 & CAP 85/100 \\
Fator B & Tipo de Filer & calcario & cal \\
Fator C & Teor de Filer & 2,5 & 5,0 \\
\hline
\end{tabular}

Tabela 2.29 - Divisão do experimento fatorial fracionado em dois níveis - Parte 4

\begin{tabular}{cccc|cc}
\hline & Teor de Fíler & \multicolumn{2}{c|}{ CAP 50/70 } & \multicolumn{2}{c}{ CAP 85/100 } \\
& $\%$ & Calcário & Cal & Calcário & Cal \\
\hline Agregado & 5,0 & & x & x & \\
Granítico & 7,5 & $\mathrm{x}$ & & & $\mathrm{x}$ \\
\hline
\end{tabular}

Tabela 2.30 - Fatores e níveis do experimento fatorial fracionado em dois níveis - Parte 4

\begin{tabular}{lccc}
\hline & Fator & \multicolumn{2}{c}{ Nível } \\
& & + & - \\
\hline Fator A & Tipo de Ligante Asfáltico & CAP 85/100 & CAP 50/70 \\
Fator B & Tipo de Fíler & calcário & cal \\
Fator C & Teor de Fíler & 5,0 & 7,5 \\
\hline
\end{tabular}

Tabela 2.31 - Divisão do experimento fatorial fracionado em dois níveis - Parte 5

\begin{tabular}{cccc|cc}
\hline & Teor de Fíler & \multicolumn{2}{c|}{ CAP 50/70 } & \multicolumn{2}{c}{ CAP 85/100 } \\
& $\%$ & Cal & Cimento & Calcário & Cimento \\
\hline Agregado & 5,0 & $\mathrm{x}$ & & $\mathrm{x}$ & \\
Basáltico & 7,5 & & $\mathrm{x}$ & & $\mathrm{x}$ \\
\hline
\end{tabular}

Tabela 2.32 - Fatores e níveis do experimento fatorial fracionado em dois níveis - Parte 5

\begin{tabular}{lccc}
\hline & \multirow{2}{*}{ Fator } & + & \multicolumn{2}{c}{ Nível } \\
\hline Fator A & Tipo de Ligante & CAP 50/70 & CAP 85/100 \\
Fator B & Tipo de Fíler & cal & calcario \\
Fator C & Teor de Fíler & 5,0 & 7.5 \\
\hline
\end{tabular}


Tabela 2.33 - Divisão do experimento fatorial fracionado em dois níveis - Parte 6

\begin{tabular}{cccc|cc}
\hline & Teor de Fíler & \multicolumn{2}{c|}{ CAP 50/70 } & \multicolumn{2}{c}{ CAP 85/100 } \\
& $\%$ & Cimento & Cal & Calcário & Cimento \\
\hline Agregado & 2,5 & $\mathrm{x}$ & & & $\mathrm{x}$ \\
Granítico & 5,0 & & $\mathrm{x}$ & $\mathrm{x}$ & \\
\hline
\end{tabular}

Tabela 2.34 - Fatores e níveis do experimento fatorial fracionado em dois níveis - Parte 6

\begin{tabular}{lccc}
\hline & Fator & + & - \\
& & + & Nível \\
\hline Fator A & Tipo de Ligante & CAP 50/70 & CAP 85/100 \\
Fator B & Tipo de Fíler & calcario & cal \\
Fator C & Teor de Fíler & 2,5 & 5,0 \\
\hline
\end{tabular}

Dessa maneira, tem-se um experimento fatorial completo $2^{2}$, com dois fatores, $A$ e $B$, e introduzse um terceiro fator, $C$, coincidindo com os níveis da interação entre os fatores $A$ e $B$, obtendo-se um experimento fatorial fracionado $2^{3-1}$. O arranjo experimental fatorial fracionado está mostrado na Tabela 2.35, que é o mesmo para todas as partes da divisão do experimento.

A relação geradora do experimento fatorial fracionado $2^{3-1}$ é $I=A B C$, e os padrões de acoplamento, obtidos pela multiplicação da relação geradora com cada fator, são: $A=B C, B=$ $A C$ e $C=A B$.

Tabela 2.35 - Arranjo experimental fatorial fracionado em dois níveis

\begin{tabular}{cccc}
\hline $\begin{array}{c}\text { Condição } \\
\text { Experimental }\end{array}$ & A & $\mathrm{B}$ & $\mathrm{AB}=\mathrm{C}$ \\
\hline $\mathrm{a}$ & - & - & + \\
$\mathrm{b}$ & + & - & - \\
$\mathrm{c}$ & - & + & - \\
$(1)$ & + & + & + \\
\hline
\end{tabular}

Com esses dados, podemos determinar os efeitos dos fatores $A, B$ e $C$ e estimar os valores das condições experimentais não obtidos através dos ensaios com a aplicação da Equação 2.16 (MONTGOMERY e RUNGER, 2011).

$$
y=\beta_{0}+\beta_{1} x_{1}+\beta_{2} x_{2}+\beta_{3} x_{3}
$$


em que: $\quad \beta_{0}$ : média dos efeitos dos fatores $A, B$ e $C$;

$\beta_{1}, \beta_{1}$ e $\beta_{3}$ : efeito dos fatores $A, B$ e $C$, respectivamente;

$x_{1}, x_{2}$, e $x_{3}$ : combinação linear das observações dos fatores $A, B$ e $C$, respectivamente.

\subsubsection{Ensaio de Resistência à Tração}

Os resultados do ensaio de resistência à tração por compressão diametral estão apresentados na Tabela 2.36, referentes aos valores médios de três determinações para as diferentes condições experimentais.

Tabela 2.36 - Valores médios de Resistência à Tração, em MPa

\begin{tabular}{cc|ccc|ccc}
\hline & Teor de Fíler & \multicolumn{3}{|c|}{ CAP 50/70 } & \multicolumn{3}{c}{ CAP 85/100 } \\
\cline { 3 - 7 } & $(\%)$ & Calcário & Cimento & Cal & Calcário & Cimento & Cal \\
\hline \multirow{2}{*}{ Agregado } & 2,5 & 1,991 & & & & & 1,154 \\
Basáltico & 5,0 & & & 1,905 & 1,113 & \\
& 7,5 & & 2,074 & & & 1,163 \\
& 2,5 & & 1,965 & & & 1,080 \\
Agregado & 5,0 & & & 1,778 & 1,007 & & \\
Granítico & 7,5 & 1,798 & & & & & 0,988 \\
\hline
\end{tabular}

A Tabela 2.37 mostra os valores dos efeitos dos fatores $A, B$ e $C$, e os valores de $\beta_{0}, \beta_{1}$, $\beta_{2}$ e $\beta_{3}$ para cada parte do experimento fatorial fracionado em dois níveis.

Para exemplificar como foram obtidos os valores da Tabela 2.37, é descrito os cálculos para a Parte 1. O arranjo experimental fatorial fracionado para a análise da resistência a tração está mostrado na Tabela 2.38. 
Tabela 2.37 - Dados do experimento fatorial fracionado para a análise da Resistência à Tração

\begin{tabular}{ccccccc}
\hline & Parte 1 & Parte 2 & Parte 3 & Parte 4 & Parte 5 & Parte 6 \\
\hline Efeito do Fator A & 0,1515 & $-0,1248$ & 0,8147 & $-0,7910$ & 0,8147 & 0,7910 \\
Efeito do Fator B & $-0,1251$ & 0,0505 & 0,0223 & 0,0193 & $-0,0223$ & 0,0193 \\
Efeito do Fator C & 0,0418 & 0,0417 & 0,0638 & $-0,0006$ & $-0,0221$ & 0,0424 \\
\hline$\beta_{0}$ & 1,9576 & 1,0966 & 1,5412 & 1,3929 & 1,5203 & 1,4138 \\
$\beta_{1}$ & 0,0757 & $-0,0624$ & 0,4073 & $-0,3955$ & 0,4073 & 0,3955 \\
$\beta_{2}$ & $-0,0626$ & 0,0252 & 0,0112 & 0,0097 & $-0,0112$ & 0,0097 \\
$\beta_{3}$ & 0,0209 & 0,0209 & 0,0319 & $-0,0003$ & $-0,0111$ & 0,0212 \\
\hline
\end{tabular}

Tabela 2.38 - Arranjo experimental fatorial fracionado para análise da Resistência à Tração

\begin{tabular}{ccccc}
\hline $\begin{array}{c}\text { Condição } \\
\text { Experimental }\end{array}$ & $\mathrm{A}$ & $\mathrm{B}$ & $\mathrm{AB}=\mathrm{C}$ & $\mathrm{RT}(\mathrm{MPa})$ \\
\hline $\mathrm{a}$ & - & - & + & 1,965 \\
$\mathrm{~b}$ & + & - & - & 2,075 \\
$\mathrm{c}$ & - & + & - & 1,798 \\
$(1)$ & + & + & + & 1,992 \\
\hline
\end{tabular}

O cálculo dos efeitos dos fatores está demostrado nas Equações 2.17, 2.18 e 2.19.

$$
\begin{aligned}
& A=1 / 2[-a+b-c+(1)]=1 / 2[-1,965+2,075-1,798+1,992]=0,1515 \\
& B=1 / 2[-a-b+c+(1)]=1 / 2[-1,965-2,075+1,798+1,992]=-0,1251 \\
& C=1 / 2[+a-b-c+(1)]=1 / 2[+1,965-2,075-1,798+1,992]=0,0418
\end{aligned}
$$

A determinação dos parâmetros das Equações 2.17, 2.18 e 2.19 é realizada através das Equações $2.20,2.21,2.22$ e 2.23

$$
\begin{gathered}
\beta_{0}=\frac{[1,965+2,075+1,798+1,992]}{4}=1,9576 \\
\beta_{1}=\frac{0,1515}{2}=0,0757 \\
\beta_{2}=\frac{-0,1251}{2}=-0,0626 \\
\beta_{3}=\frac{0,0418}{2}=0,0209
\end{gathered}
$$


Assim, a Equação 2.24 é a correspondente para estimativa dos valores.

$$
y=1,9576+0,0757 x_{1}-0,0626 x_{2}+0,0209 x_{3}
$$

Substituindo as combinações lineares das observações, estimam-se os valores das condições experimentais executadas, como demostrada nas Equações 2.25, 2.26, 2.27 e 2.28.

Condição Experimental a $\rightarrow y=1,9576+0,0757(-1)-0,0626(-1)+0,0209(+1)=1,965$

Condição Experimental $\mathrm{b} \rightarrow y=1,9576+0,0757(+1)-0,0626(-1)+0,0209(-1)=2,075$

Condição Experimental c $\rightarrow y=1,9576+0,0757(-1)-0,0626(+1)+0,0209(-1)=1,798$

Condição Experimental (1) $\rightarrow y=1,9576+0,0757(+1)-0,0626(+1)+0,0209(+1)=$ 1,992

Da mesma maneira em que os valores das condições experimentais realizadas são obtidas com a Equação 2.24, podem ser estimadas as condições experimentais não realizadas no fatorial fracionado, substituindo as respectivas combinações lineares. Para o experimento fatorial parte 1, temos o esquema das condições experimentais a serem determinados na Tabela 2.39 e nas Equações 2.29, 2.30, 2.31 e 2.32.

Tabela 2.39 - Arranjo experimental fatorial fracionado da Parte 1 para análise da Resistência à Tração

\begin{tabular}{cc|cc}
\hline & Teor de Fíler & \multicolumn{2}{|c}{ CAP 50/70 } \\
\cline { 3 - 4 } & $\%$ & Calcário & Cimento \\
\hline Agregado & 2,5 & 1,9916 & i \\
Basáltico & 7,5 & ii & 2,0749 \\
\hline Agregado & 2,5 & iii & 1,9652 \\
Granítico & 7,5 & 1,7983 & iv \\
\hline
\end{tabular}


Condição Experimental i $\rightarrow y=1,9576+0,0757(+1)-0,0626(-1)+0,0209(+1)=2,117$

Condição Experimental ii $\rightarrow y=1,9576+0,0757(+1)-0,0626(+1)+0,0209(-1)=1,950$

Condição Experimental iii $\rightarrow y=1,9576+0,0757(-1)-0,0626(+1)+0,0209(+1)=1,840$

Condição Experimental iv $\rightarrow y=1,9576+0,0757(-1)-0,0626(-1)+0,0209(-1)=1,924$

Assim, todas as condições experimentais do planejamento fatorial puderam ser estimadas, exceto os valores de resistência a tração para as misturas contendo o fíler de cimento Portland no teor de $5,0 \%$. Os valores estimados para o experimento fatorial completo estão mostrados na Tabela 2.40. As Figuras 2.9 e 2.10 apresentam a comparação dos dados para as misturas contendo o CAP 50/70 e o CAP 85/100, respectivamente, para o agregado basáltico (a) e o agregado granítico (b).

Notou-se que as misturas contendo o ligante asfáltico CAP 50/70 apresentaram maiores valores de resistência à tração, e que as misturas compostas pelo agregado basáltico também apresentaram resistência à tração ligeiramente maior que as compostas com o agregado granítico. Em relação ao tipo de fíler, as misturas contendo fíler de cimento Portland apresentaram os maiores valores de RT, e que menores teores de fíler apresentaram maiores valores de RT.

Tabela 2.40 - Valores estimados da Resistência à Tração, em MPa

\begin{tabular}{ccccc|ccc}
\hline & Teor de Fíler & \multicolumn{3}{c|}{ CAP 50/70 } & \multicolumn{3}{c}{ CAP 85/100 } \\
\cline { 2 - 8 } & $\%$ & Calcário & Cimento & Cal & Calcário & Cimento & Cal \\
\hline \multirow{2}{*}{ Agregado } & 2,5 & 1,991 & 2,117 & 1,969 & 1,177 & 1,205 & 1,154 \\
Basáltico & 5,0 & 1,927 & & 1,905 & 1,113 & & 1,091 \\
& 7,5 & 1,949 & 2,075 & 1,927 & 1,135 & 1,163 & 1,113 \\
\hline \multirow{2}{*}{ Agregado } & 2,5 & 1,840 & 1,965 & 1,821 & 1,049 & 1,080 & 1,030 \\
Granítico & 5,0 & 1,797 & & 1,778 & 1,007 & & 0,987 \\
& 7,5 & 1,798 & 1,924 & 1,779 & 1,007 & 1,039 & 0,988 \\
\hline
\end{tabular}




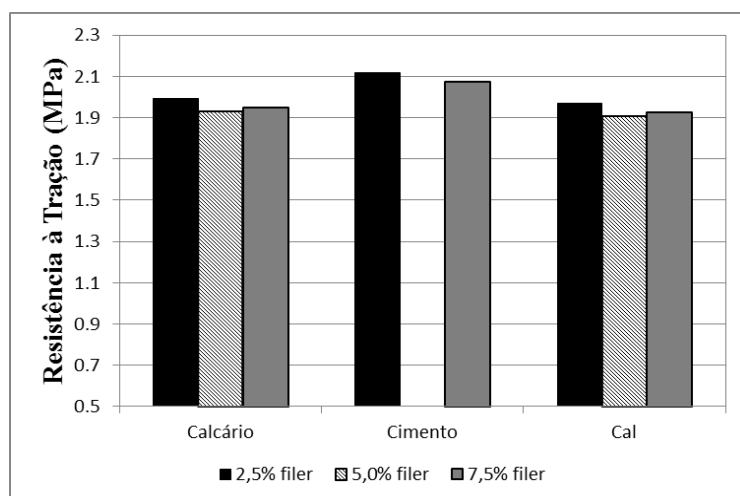

(a)

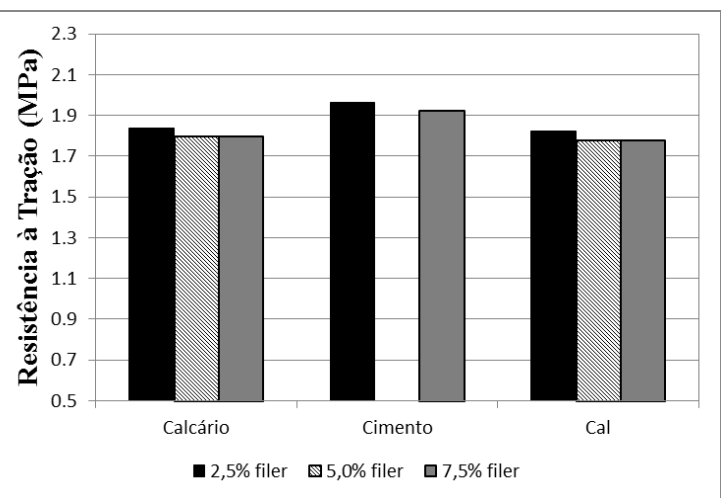

(b)

Figura 2.9 - Resistência à Tração para Misturas contendo CAP 50/70 e Agregado: (a) basáltico e (b) granítico

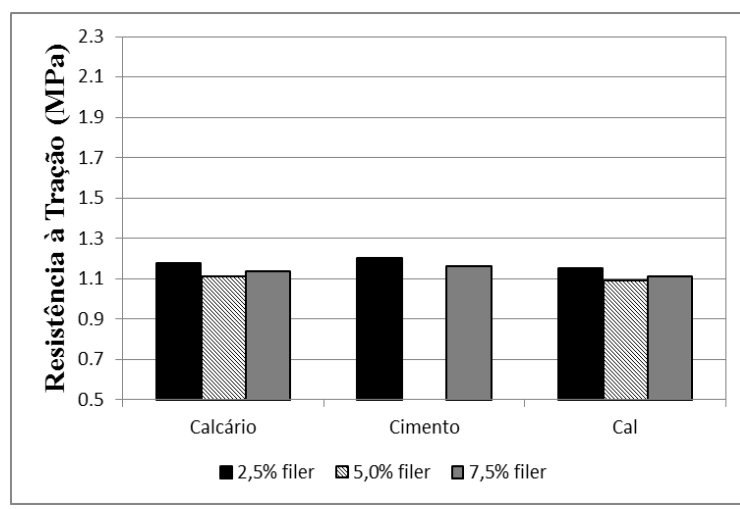

(a)

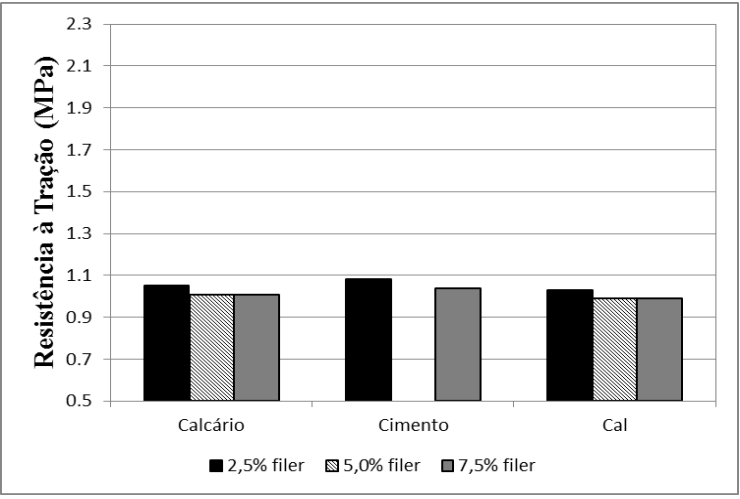

(b)

Figura 2.10 - Resistência à Tração para misturas contendo CAP 85/100 e agregado: (a) basáltico e (b) granítico

Para testar quais fatores (tipo de fíler, teor de fíler, tipo de agregado e tipo de ligante asfáltico) influenciam nos resultados da resistência à tração, realizou-se a Análise de Variância (ANOVA).

Primeiramente, a análise foi realizada considerando o fator tipo de agregado em dois níveis (agregado granítico e basáltico), o fator tipo de ligante asfáltico em dois níveis (CAP 50/70 e CAP 85/100), o fator tipo de fíler em três níveis (pó calcário, cimento Portland e cal hidratada) e o fator teor de fíler em dois níveis $(2,5$ e $7,5 \%)$.

A segunda análise foi realizada considerando o fator tipo de agregado em dois níveis (agregado granítico e basáltico), o fator tipo de ligante asfáltico em dois níveis (CAP 50/70 e CAP 85/100), o fator tipo de fíler em dois níveis (pó calcário e cal hidratada) e o fator teor de fíler em três 
níveis (2,5; 5,0 e 7,5\%). A Tabela B.5 do Apêndice B apresenta o resumo dos valores da análise (1) e da análise (2) para a ANOVA.

A Tabela 2.41 apresenta o resumo da análise de variância, com os valores do teste $\mathrm{f}_{0}$ da análise de variância da resistência à tração, com a resposta da influência dos fatores considerados, para as análises considerando o fator tipo de fíler em 3 níveis e o teor de fíler em 2 níveis (análise (1)) e o tipo de fíler em 2 níveis e o teor de fíler em 3 níveis (análise (2)). Assim, a seguinte hipótese nula foi testada: $\mathrm{H}_{0}$ : os fatores não influenciam na resposta do valor da resistência à tração; para valores de $\mathrm{F}_{0}$ maiores que $\mathrm{f}_{0}$, a hipótese nula $\mathrm{H}_{0}$ é rejeitada, ou seja, o fator influencia na resposta.

Pode-se perceber que o tipo de agregado, o tipo de ligante asfáltico, o tipo e teor de fíler influenciam na resposta da resistência à tração das misturas asfálticas, assim como a interação do tipo de agregado com o tipo de ligante asfáltico e com o tipo de fíler.

Tabela 2.41 - Resumo da Análise de Variância da resistência à tração, dos valores de $\mathrm{f}_{0}$ e da influência dos fatores e sua interação, das análises (1) e (2)

\begin{tabular}{cccccc}
\hline \multirow{2}{*}{ Fator } & \multicolumn{2}{c}{ Análise (1) } & \multicolumn{2}{c}{ Análise (2) } & \multirow{2}{*}{ Influência } \\
\cline { 2 - 5 } & $\mathrm{F}_{0}$ & $\mathrm{f}_{0}$ & $\mathrm{~F}_{0}$ & $\mathrm{f}_{0}$ & \\
\hline Tipo de agregado (Fator A) & $8,05 \mathrm{E}+12$ & 18,51 & $4,78 \mathrm{E}+08$ & 18,51 & sim \\
Tipo de Ligante Asfáltico (Fator B) & $2,94 \mathrm{E}+14$ & 18,51 & $1,80 \mathrm{E}+10$ & 18,51 & sim \\
Tipo de fíler (Fator C) & $1,51 \mathrm{E}+12$ & 19,0 & $1,21 \mathrm{E}+07$ & 18,51 & sim \\
Teor de fíler (Fator D) & $7,35 \mathrm{E}+11$ & 18,51 & $2,90 \mathrm{E}+07$ & 19,0 & sim \\
Interação AB & $6,43 \mathrm{E}+10$ & 18,51 & $3,91 \mathrm{E}+06$ & 18,51 & sim \\
Interação AC & $3,20 \mathrm{E}+08$ & 19,0 & $6,36 \mathrm{E}+04$ & 18,51 & sim \\
Interação AD & 1,50 & 18,51 & $1,43 \mathrm{E}+06$ & 19,0 & não \\
Interação BC & $4,27 \mathrm{E}+11$ & 19,0 & $6,60 \mathrm{E}-05$ & 18,51 & não \\
Interação BD & 12228,00 & 18,51 & 1,50 & 19,0 & não \\
Interação CD & 22730,25 & 19,0 & 1,50 & 19,0 & não \\
Interação ABC & $1,07 \mathrm{E}+08$ & 19,0 & $6,60 \mathrm{E}-05$ & 18,51 & não \\
Interação ABD & 0,00 & 18,51 & 0,50 & 19,0 & não \\
Interação ACD & 0,00 & 19,0 & 0,50 & 19,0 & não \\
Interação BCD & 7576,50 & 19,0 & 0,00 & 19,0 & não \\
\hline
\end{tabular}




\subsubsection{Módulo de Resiliência}

Os resultados do ensaio de módulo de resiliência estão apresentados na Tabela 2.42, referentes aos valores médios de três determinações para as diferentes condições experimentais.

Tabela 2.42 - Valores médios de Módulo de Resiliência, em MPa

\begin{tabular}{lcccc|ccc}
\hline & Teor de Fíler & \multicolumn{3}{c|}{ CAP 50/70 } & \multicolumn{3}{c}{ CAP 85/100 } \\
\cline { 2 - 7 } & $(\%)$ & Calcário & Cimento & Cal & Calcário & Cimento & Cal \\
\hline \multirow{2}{*}{ Agregado } & 2,5 & 6329 & & & & & 4199 \\
Basáltico & 5,0 & & & 6985 & 4594 & & \\
& 7,5 & & 8022 & & & 4598 & \\
\hline \multirow{2}{*}{ Agregado } & 2,5 & & 6845 & & & 4431 \\
Granítico & 5,0 & & & 8469 & 4810 & & \\
& 7,5 & 7765 & & & & & 5525 \\
\hline
\end{tabular}

A Tabela 2.43 mostra os valores dos efeitos dos fatores $A, B$ e $C$, e os valores de $\beta_{0}, \beta_{1}$, $\beta_{2}$ e $\beta_{3}$ para cada parte do experimento fatorial fracionado em dois níveis.

Tabela 2.43 - Dados do experimento fatorial fracionado para a análise do Módulo de Resiliência

\begin{tabular}{ccccccc}
\hline & Parte 1 & Parte 2 & Parte 3 & Parte 4 & Parte 5 & Parte 6 \\
\hline Efeito do Fator A & $-129,272$ & 579,752 & 2260,425 & $-2948,906$ & 2714,331 & 2668,953 \\
Efeito do Fator B & $-386,949$ & $-347,905$ & $-130,571$ & $-709,625$ & $-323,334$ & $-989,578$ \\
Efeito do Fator C & $-1306,665$ & $-746,759$ & $-525,371$ & $-5,402$ & $-327,388$ & $-1021,309$ \\
\hline$\beta_{0}$ & 7240,636 & 4688,641 & 5526,951 & 6642,789 & 5953,331 & 6129,433 \\
$\beta_{1}$ & $-64,636$ & 289,876 & 1130,212 & $-1474,453$ & 1357,165 & 1334,476 \\
$\beta_{2}$ & $-193,474$ & $-173,952$ & $-65,285$ & $-354,812$ & $-161,667$ & $-494,789$ \\
$\beta_{3}$ & $-653,332$ & $-373,379$ & $-262,685$ & $-2,701$ & $-163,694$ & $-510,654$ \\
\hline
\end{tabular}

Os valores estimados para o experimento fatorial completo estão mostrados na Tabela 2.44. As Figuras 2.11 e 2.12 apresentam a comparação dos dados para as misturas contendo o CAP 50/70 e o CAP 85/100, respectivamente, para o agregado basáltico (a) e o agregado granítico (b). 
Tabela 2.44 - Valores estimados do Módulo de Resiliência, em MPa

\begin{tabular}{ccccc|ccc}
\hline & Teor de Fíler & \multicolumn{3}{c|}{ CAP 50/70 } & \multicolumn{3}{c}{ CAP 85/100 } \\
\cline { 2 - 8 } & $\%$ & Calcário & Cimento & Cal & Calcário & Cimento & Cal \\
\hline \multirow{2}{*}{ Agregado } & 2,5 & 6329 & 6716 & 6459 & 4068 & 3851 & 4199 \\
Basáltico & 5,0 & 6854 & & 6985 & 4594 & & 4724 \\
& 7,5 & 7635 & 8022 & 7312 & 4921 & 4598 & 4946 \\
\hline \multirow{2}{*}{ Agregado } & 2,5 & 6458 & 6845 & 7448 & 3789 & 4431 & 4779 \\
Granítico & 5,0 & 7759 & & 8469 & 4810 & & 5520 \\
& 7,5 & 7765 & 8152 & 8474 & 4816 & 5177 & 5525 \\
\hline
\end{tabular}

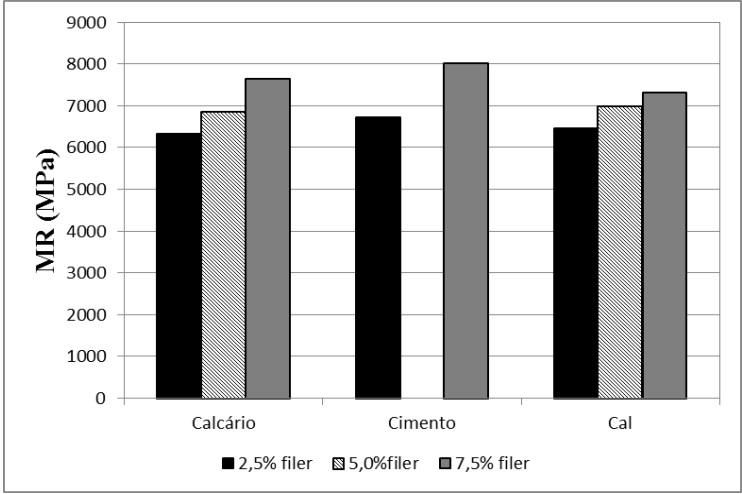

(a)

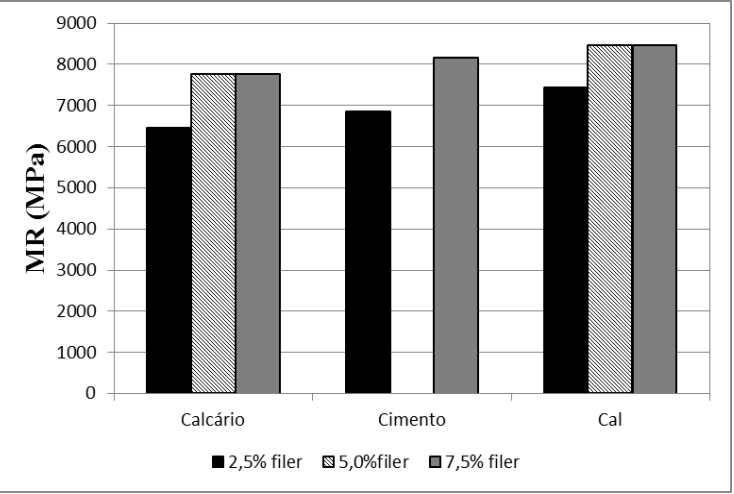

(b)

Figura 2.11 - Módulo de Resiliência para misturas contendo CAP 50/70 e agregado: (a) basáltico e (b) granítico

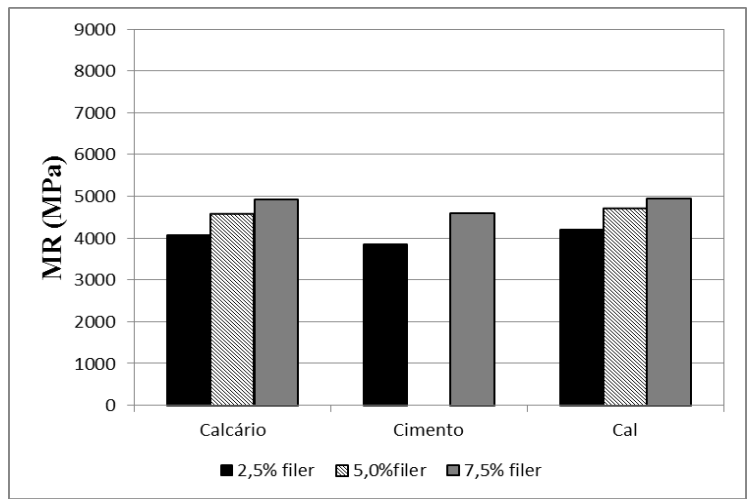

(a)

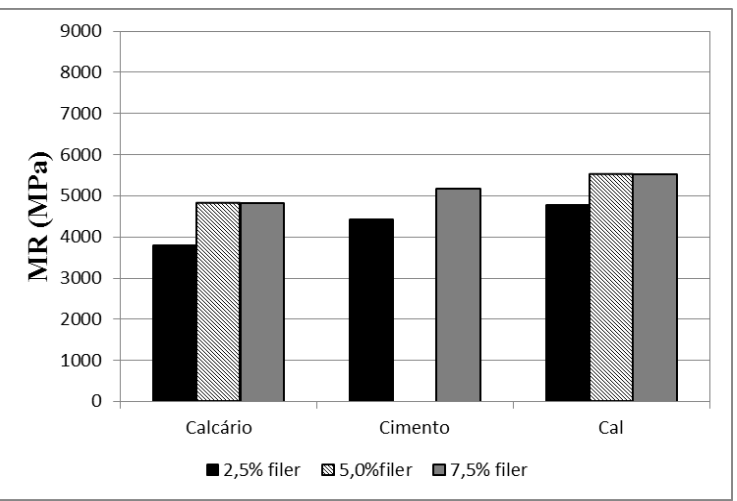

(b)

Figura 2.12 - Módulo de Resiliência para misturas contendo CAP 85/100 e agregado: (a) basáltico e (b) granítico

Nota-se que as misturas contendo o ligante asfáltico CAP 50/70 apresentam maiores valores de módulo de resiliência, e que as misturas compostas pelo agregado granítico também apresentam 
módulo de resiliência ligeiramente maior que as compostas com o agregado basáltico. Em relação ao tipo de fíler, as misturas contendo fíler de pó calcário apresentam os menores valores de MR; e que para as misturas contendo o agregado basáltico, quanto maior o teor de fíler, maior o MR; já para as misturas contendo o agregado granítico, o teor de fíler de 2,5\% apresentam os menores valores de MR, e os teores de 5,0 e 7,5\% não apresentam diferença nos valores de MR

Para testar quais fatores (tipo de fíler, teor de fíler, tipo de agregado e tipo de ligante asfáltico) influenciam nos resultados do módulo de resiliência, realizou-se a Análise de Variância (ANOVA).

Primeiramente, a análise foi realizada considerando o fator tipo de agregado em dois níveis (agregado granítico e basáltico), o fator tipo de ligante asfáltico em dois níveis (CAP 50/70 e CAP 85/100), o fator tipo de fíler em três níveis (pó calcário, cimento Portland e cal hidratada) e o fator teor de fíler em dois níveis $(2,5$ e 7,5\%).

A segunda análise foi realizada considerando o fator tipo de agregado em dois níveis (agregado granítico e basáltico), o fator tipo de ligante asfáltico em dois níveis (CAP 50/70 e CAP 85/100), o fator tipo de fíler em dois níveis (pó calcário e cal hidratada) e o fator teor de fíler em três níveis $(2,5 ; 5,0$ e 7,5\%). A Tabela B.6 do Apêndice B apresenta o resumo dos valores da análise (1) e da análise (2) para a ANOVA.

A Tabela 2.45 apresenta o resumo da análise de variância, com os valores do teste $\mathrm{f}_{0}$ da análise de variância do módulo de resiliência, considerando $\alpha=0,1$, com a resposta da influência dos fatores considerados, para as análises considerando o fator tipo de fíler em 3 níveis e o teor de fíler em 2 níveis (análise (1)) e o tipo de fíler em 2 níveis e o teor de fíler em 3 níveis (análise (2)). Para valores de $\mathrm{F}_{0}$ maiores que $\mathrm{f}_{0} \mathrm{o}$ fator influencia na resposta avaliada.

Pode-se perceber que o tipo de agregado, o tipo de ligante asfáltico e o tipo e teor de fíler influenciam na resposta do módulo de resiliência das misturas asfálticas, assim como a interação entre o tipo de agregado e o tipo de fíler. 
Tabela 2.45 - Resumo da Análise de Variância do módulo de resiliência, dos valores de $\mathrm{f}_{0}$ e da influência dos fatores e sua interação, das análises (1) e (2)

\begin{tabular}{cccccc}
\hline \multirow{2}{*}{ Fator } & \multicolumn{2}{c}{ Análise (1) } & \multicolumn{2}{c}{ Análise (2) } & \multirow{2}{*}{ Influência } \\
\cline { 2 - 5 } & $\mathrm{F}_{0}$ & $\mathrm{f}_{0}$ & $\mathrm{~F}_{0}$ & $\mathrm{f}_{0}$ & \\
\hline Tipo de agregado (Fator A) & 233,30 & 18,51 & 358,34 & 18,51 & sim \\
Tipo de Ligante Asfáltico (Fator B) & 11646,22 & 18,51 & 8071,32 & 18,51 & sim \\
Tipo de fíler (Fator C) & 94,52 & 19,0 & 209,96 & 18,51 & sim \\
Teor de fíler (Fator D) & 1579,05 & 18,51 & 425,34 & 19,0 & sim \\
Interação AB & 5,92 & 18,51 & 74,91 & 18,51 & não \\
Interação AC & 97,88 & 19,0 & 174,38 & 18,51 & sim \\
Interação AD & 1,33 & 18,51 & 27,81 & 19,0 & não \\
Interação BC & 18,46 & 19,0 & 1,00 & 18,51 & não \\
Interação BD & 55,25 & 18,51 & 7,77 & 19,0 & não \\
Interação CD & 10,69 & 19,0 & 7,77 & 19,0 & não \\
Interação ABC & 33,51 & 19,0 & 1,00 & 18,51 & não \\
Interação ABD & 0,00 & 18,51 & 2,59 & 19,0 & não \\
Interação ACD & 0,33 & 19,0 & 2,59 & 19,0 & não \\
Interação BCD & 4,45 & 19,0 & 1,00 & 19,0 & não \\
\hline
\end{tabular}

\subsubsection{Vida de Fadiga}

O ensaio de vida de fadiga foi realizado com tensão controlada, com valores de tensão aplicados de 10, 20, 30 e 40\% da resistência à tração. O critério de parada foi a ruptura completa ou quando o corpo de prova alcançar um deslocamento de $6,0 \mathrm{~mm}$. As curvas de fadiga para as diferentes misturas asfálticas são determinadas com as Equações 2.14 e 2.15.

Para facilitar a visualização dos resultados, as condições experimentais ensaiadas foram numeradas de 1 a 12 , como pode ser verificado na Tabela 2.46 . 
Tabela 2.46 - Numeração das condições experimentais ensaiadas no ensaio de Vida de Fadiga

\begin{tabular}{ccccc|ccc}
\hline & Teor de Fíler & \multicolumn{3}{c|}{ CAP 50/70 } & \multicolumn{3}{c}{ CAP 85/100 } \\
\cline { 2 - 7 } & $(\%)$ & Calcário & Cimento & Cal & Calcário & Cimento & Cal \\
\hline \multirow{2}{*}{ Agregado } & 2,5 & 1 & & & & & 7 \\
Basáltico & 5,0 & & & 2 & 8 & \\
& 7,5 & & 3 & & & 10 \\
\hline \multirow{2}{*}{ Agregado } & 2,5 & & 4 & & & \\
Granítico & 5,0 & & & 5 & 11 & \\
\hline
\end{tabular}

Na Tabela 2.47 estão apresentados os valores dos parâmetros $\mathrm{k}_{1}, \mathrm{k}_{2}, \mathrm{k}_{3}$, $\mathrm{k}_{4}$, determinados pela regressão no ensaio de vida de fadiga, para as diferentes misturas asfálticas.

Tabela 2.47 - Parâmetros k1, k2, k3, k4 do ensaio de Vida de Fadiga

\begin{tabular}{ccccc}
\hline \multirow{2}{*}{$\begin{array}{c}\text { Condição } \\
\text { Experimental }\end{array}$} & \multicolumn{4}{c}{ Parâmetros } \\
\cline { 2 - 5 } & $\mathrm{k}_{1}$ & $\mathrm{k}_{2}$ & $\mathrm{k}_{3}$ & $\mathrm{k}_{4}$ \\
\hline 1 & 13887 & 2,788 & $6,00 \mathrm{E}-10$ & 3,068 \\
2 & 12362 & 2,749 & $1,00 \mathrm{E}-06$ & 2,236 \\
3 & 14861 & 2,843 & $8,00 \mathrm{E}-09$ & 2,730 \\
4 & 5875,5 & 2,362 & $1,00 \mathrm{E}-07$ & 2,435 \\
5 & 7002 & 2,465 & $3,00 \mathrm{E}-06$ & 2,074 \\
6 & 6904 & 2,313 & $2,00 \mathrm{E}-06$ & 2,126 \\
7 & 493,33 & 2,052 & $9,00 \mathrm{E}-06$ & 1,851 \\
8 & 729,95 & 2,266 & $4,00 \mathrm{E}-09$ & 2,688 \\
9 & 970,13 & 2,847 & $2,00 \mathrm{E}-09$ & 2,743 \\
\hline
\end{tabular}

As equações das curvas dos ensaios de fadiga, calibradas com os modelos de fadiga, tanto em função da diferença de tensões como para a deformação resiliente estão apresentadas na Tabela 2.48 para as condições experimentais ensaiadas. 
Tabela 2.48 - Equações das curvas de fadiga para as diferentes condições experimentais: número de aplicações de carga em função da diferença de tensões e número de aplicações de carga em função da deformação resiliente

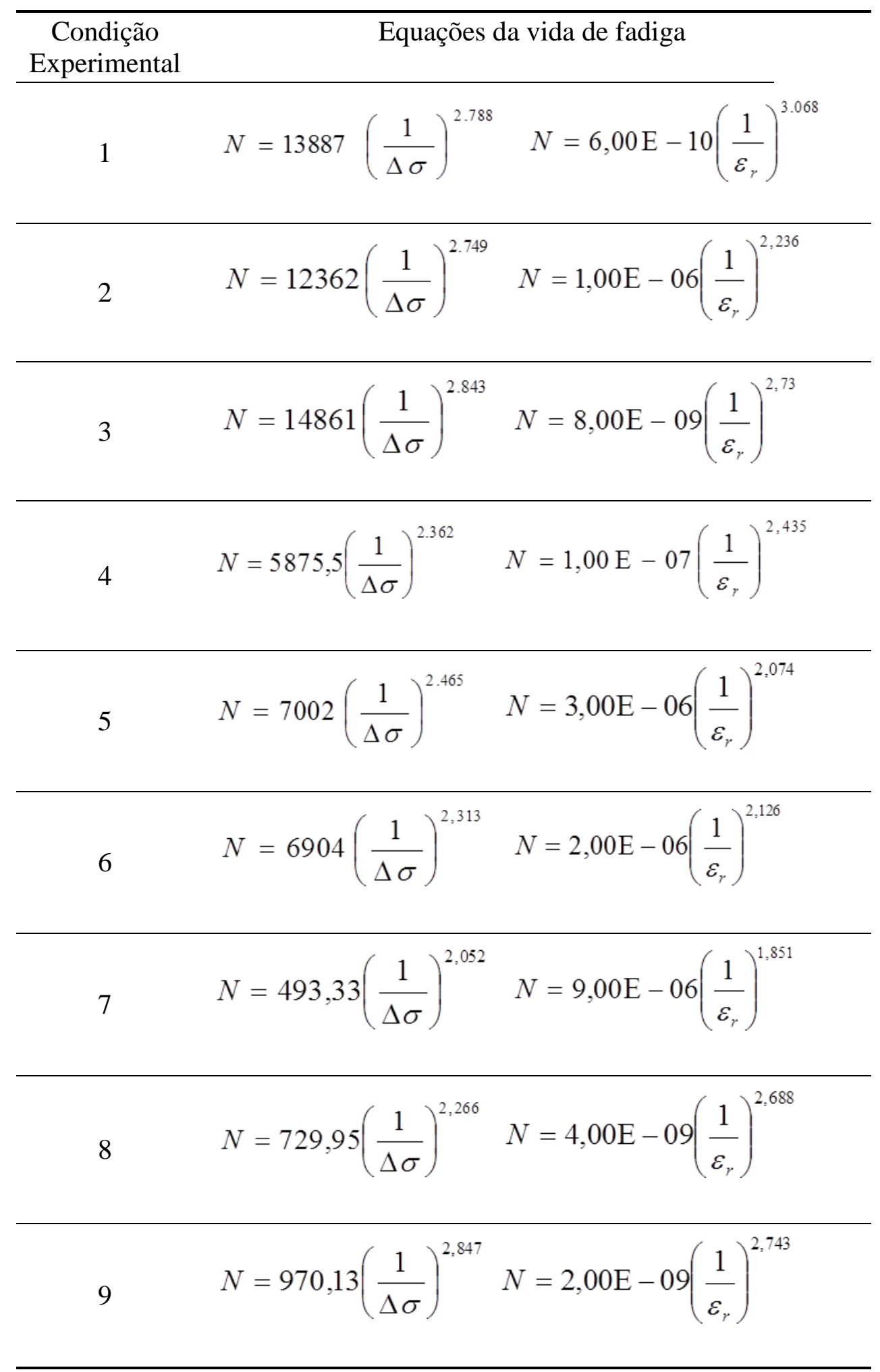


Para a avaliação da vida de fadiga para as diferentes condições experimentais, foi determinada para cada mistura asfáltica a deformação resiliente correspondente a um número de solicitações do eixo padrão de $10^{7}$. Dessa maneira, avaliou-se qual a menor (ou maior) deformação de uma estrutura de pavimento composta pelas misturas asfálticas estudadas, e assim, indiretamente pode-se estimar qual terá a maior (ou menor) vida de fadiga.

Com as equações obtidas através do ensaio de vida de fadiga, foram calculados os valores de deformação resiliente $\left(\varepsilon_{\mathrm{r}}\right)$ para as diferentes condições experimentais, e estão apresentados na Tabela 2.49 .

Tabela 2.49 - Valores calculados de Deformação Resiliente $\left(\varepsilon_{\mathrm{r}}\right)$

\begin{tabular}{ccccc|ccc}
\hline & Teor de Fíler & \multicolumn{3}{c|}{ CAP 50/70 } & \multicolumn{3}{c}{ CAP 85/100 } \\
\cline { 3 - 7 } & $(\%)$ & Calcário & Cimento & Cal & Calcário & Cimento & Cal \\
\hline \multirow{2}{*}{$\begin{array}{c}\text { Agregado } \\
\text { Basáltico }\end{array}$} & 2,5 & $4,92 \mathrm{E}-06$ & & & & & $3,09 \mathrm{E}-07$ \\
& 5,0 & & & $1,53 \mathrm{E}-06$ & $1,86 \mathrm{E}-06$ & & \\
& 7,5 & & $2,93 \mathrm{E}-06$ & & & \multicolumn{3}{|c}{$1,86 \mathrm{E}-06$} & \\
\hline \multirow{2}{*}{$\begin{array}{c}\text { Agregado } \\
\text { Granítico }\end{array}$} & 2,5 & & $1,77 \mathrm{E}-06$ & & & & \\
& 5,0 & & & $9,08 \mathrm{E}-07$ & $8,94 \mathrm{E}-07$ & & \\
& 7,5 & $1,06 \mathrm{E}-06$ & & & & & $2,02 \mathrm{E}-06$ \\
\hline
\end{tabular}

A Tabela 2.50 mostra os valores dos efeitos dos fatores $A, B$ e $C$, e os valores de $\beta_{0}, \beta_{1}, \beta_{2}$ e $\beta_{3}$.para cada parte do experimento fatorial fracionado em dois níveis.

Tabela 2.50 - Dados do experimento fatorial fracionado para a análise da Deformação Resiliente, $\varepsilon_{\mathrm{r}}$

\begin{tabular}{ccccccc}
\hline & Parte 1 & Parte 2 & Parte 3 & Parte 4 & Parte 5 & Parte 6 \\
\hline Efeito do Fator A & $2,51 \mathrm{E}-06$ & $8,53 \mathrm{E}-07$ & $2,14 \mathrm{E}-06$ & $4,73 \mathrm{E}-07$ & $6,92 \mathrm{E}-07$ & $6,31 \mathrm{E}-07$ \\
Efeito do Fator B & $6,40 \mathrm{E}-07$ & $6,96 \mathrm{E}-07$ & $2,47 \mathrm{E}-06$ & $-4,87 \mathrm{E}-07$ & $-1,02 \mathrm{E}-06$ & $6,16 \mathrm{E}-07$ \\
Efeito do Fator C & $1,35 \mathrm{E}-06$ & $-8,56 \mathrm{E}-07$ & $9,20 \mathrm{E}-07$ & $-6,37 \mathrm{E}-07$ & $-1,02 \mathrm{E}-06$ & $8,84 \mathrm{E}-07$ \\
\hline$\beta_{0}$ & $2,67 \mathrm{E}-06$ & $1,51 \mathrm{E}-06$ & $2,16 \mathrm{E}-06$ & $1,22 \mathrm{E}-06$ & $2,21 \mathrm{E}-06$ & $1,34 \mathrm{E}-06$ \\
$\beta_{1}$ & $1,26 \mathrm{E}-06$ & $4,26 \mathrm{E}-07$ & $1,07 \mathrm{E}-06$ & $2,36 \mathrm{E}-07$ & $3,46 \mathrm{E}-07$ & $3,15 \mathrm{E}-07$ \\
$\beta_{2}$ & $3,20 \mathrm{E}-07$ & $3,48 \mathrm{E}-07$ & $1,23 \mathrm{E}-06$ & $-2,44 \mathrm{E}-07$ & $-5,09 \mathrm{E}-07$ & $3,08 \mathrm{E}-07$ \\
$\beta_{3}$ & $6,75 \mathrm{E}-07$ & $-4,28 \mathrm{E}-07$ & $4,60 \mathrm{E}-07$ & $-3,18 \mathrm{E}-07$ & $-5,11 \mathrm{E}-07$ & $4,42 \mathrm{E}-07$ \\
\hline
\end{tabular}


Os valores estimados para o experimento fatorial completo estão mostrados na Tabela 2.51. As Figuras 2.13 e 2.14 apresentam a comparação dos dados para as misturas contendo o CAP 50/70 e o CAP 85/100, respectivamente, e o agregado basáltico (a) e granítico (b).

Tabela 2.51 - Valores estimados da Deformação Resiliente, $\varepsilon_{\mathrm{r}}$

\begin{tabular}{ccccc|ccc}
\hline & Teor de Fíler & \multicolumn{3}{c|}{ CAP 50/70 } & \multicolumn{3}{c}{ CAP 85/100 } \\
\cline { 2 - 8 } & $(\%)$ & Calcário & Cimento & Cal & Calcário & Cimento & Cal \\
\hline \multirow{2}{*}{ Agregado } & 2,5 & $4,92 \mathrm{E}-06$ & $4,28 \mathrm{E}-06$ & $2,45 \mathrm{E}-06$ & $2,78 \mathrm{E}-06$ & $1,01 \mathrm{E}-06$ & $3,09 \mathrm{E}-07$ \\
Basáltico & 5,0 & $2,55 \mathrm{E}-06$ & & $1,53 \mathrm{E}-06$ & $1,86 \mathrm{E}-06$ & & $8,41 \mathrm{E}-07$ \\
& 7,5 & $3,57 \mathrm{E}-06$ & $2,93 \mathrm{E}-06$ & $2,55 \mathrm{E}-06$ & $2,88 \mathrm{E}-06$ & $1,86 \mathrm{E}-06$ & $1,01 \mathrm{E}-06$ \\
\hline \multirow{2}{*}{ Agregado } & 2,5 & $2,41 \mathrm{E}-06$ & $1,77 \mathrm{E}-06$ & $1,79 \mathrm{E}-06$ & $1,78 \mathrm{E}-06$ & $1,86 \mathrm{E}-06$ & $1,16 \mathrm{E}-06$ \\
Granítico & 5,0 & $4,21 \mathrm{E}-07$ & & $9,08 \mathrm{E}-07$ & $8,94 \mathrm{E}-07$ & & $1,38 \mathrm{E}-06$ \\
& 7,5 & $1,06 \mathrm{E}-06$ & $4,18 \mathrm{E}-07$ & $1,55 \mathrm{E}-06$ & $1,53 \mathrm{E}-06$ & $2,71 \mathrm{E}-06$ & $2,02 \mathrm{E}-06$ \\
\hline
\end{tabular}

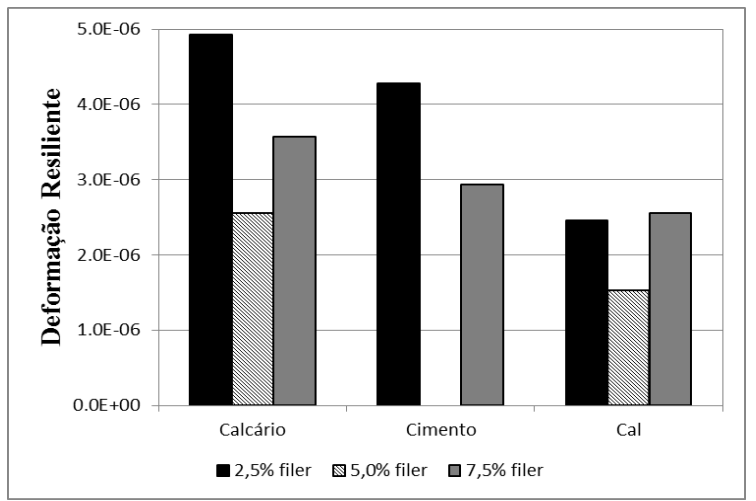

(a)

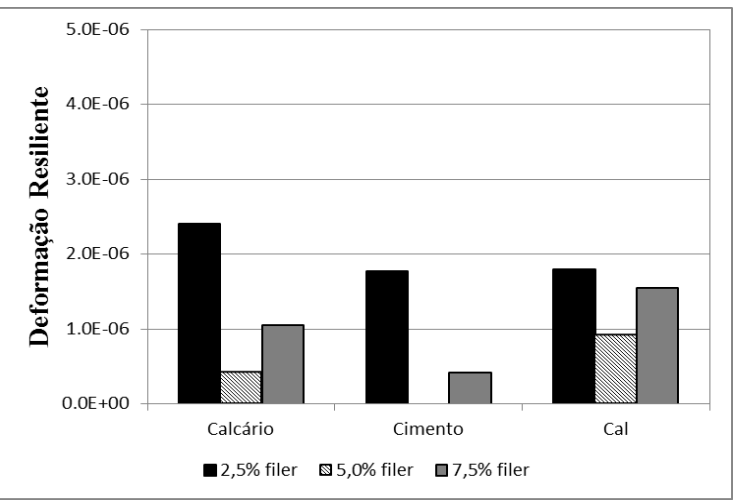

(b)

Figura $2.13-\varepsilon_{\mathrm{r}}$ para misturas contendo CAP 50/70 e o agregado: (a) Basáltico e (b) Granítico

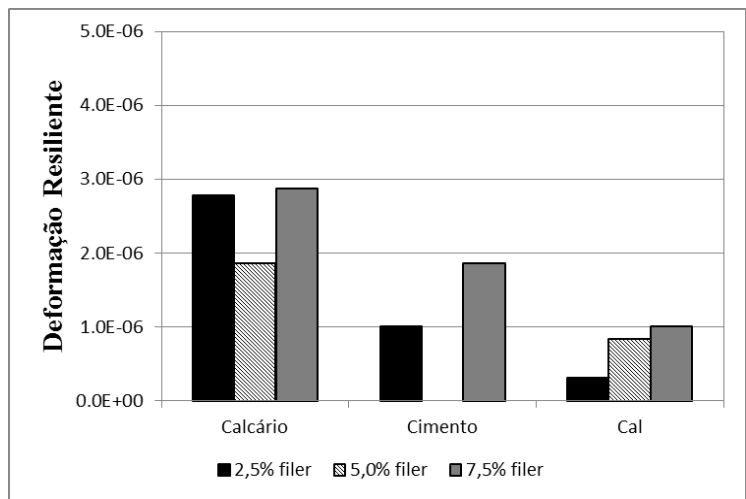

(a)

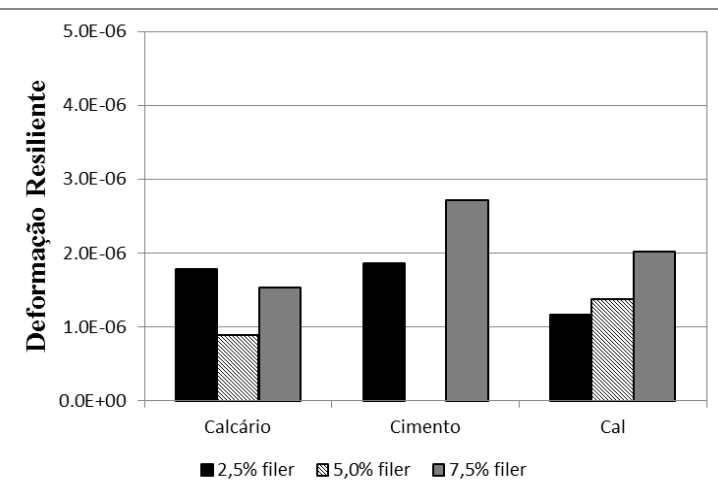

(b)

Figura $2.14-\varepsilon_{\mathrm{r}}$ para misturas contendo CAP 85/100 e o agregado: (a) basáltico e (b) granítico 
Nota-se que as misturas compostas pelo agregado basáltico e o CAP 50/70 apresentam os maiores valores de deformação resiliente. Em relação ao tipo de fíler, as misturas contendo fíler de pó calcário apresentam os maiores valores de deformação resiliente. Para as misturas contendo o CAP 50/70, maiores teores de fíler resultam em menores deformações resiliente, e para teores menores, resultaram em valores maiores; já as misturas contendo o CAP 85/100 não apresentaram tendência de comportamento.

Esse comportamento parece contrário ao esperado, já que as misturas contendo os fileres de cal hidratada e cimento Portland apresentaram valores de resistência à tração e módulo de resiliência que conduziriam a maiores vidas de fadiga. Isso pode ser atribuído ao método utilizado para avaliar a vida de fadiga neste trabalho, através da deformação resiliente; talvez, seria mais adequado realizar uma análise mecanística de um pavimento com uma camada de mistura asfáltica contendo os diferentes tipo e teores de fileres, para a determinação das tensões desenvolvidas e assim, determinar a vida de fadiga.

Para testar quais fatores (tipo de fíler, teor de fíler, tipo de agregado e tipo de ligante asfáltico) influenciam nos resultados de deformação resiliente, realizou-se a Análise de Variância (ANOVA). Primeiramente, a análise foi realizada considerando o fator tipo de agregado em dois níveis (agregado granítico e basáltico), o fator tipo de ligante asfáltico em dois níveis (CAP 50/70 e CAP 85/100), o fator tipo de fíler em três níveis (pó calcário, cimento Portland e cal hidratada) e o fator teor de fíler em dois níveis (2,5 e 7,5\%).

A segunda análise foi realizada considerando o fator tipo de agregado em dois níveis (agregado granítico e basáltico), o fator tipo de ligante asfáltico em dois níveis (CAP 50/70 e CAP 85/100), o fator tipo de fíler em dois níveis (pó calcário e cal hidratada) e o fator teor de fíler em três níveis (2,5; 5,0 e 7,5\%). A Tabela B.7 do Apêndice B apresenta o resumo dos valores da análise (1) e da análise (2) para a ANOVA.

A Tabela 2.52 apresenta o resumo da análise de variância, considerando $\alpha=0,1$, com a resposta da influência dos fatores considerados, para as análises considerando o fator tipo de fíler em 3 níveis 
e o teor de fíler em 2 níveis (análise (1)) e o tipo de fíler em 2 níveis e o teor de fíler em 3 níveis (análise (2)). Para valores de $\mathrm{F}_{0}$ maiores que $\mathrm{f}_{0} \mathrm{o}$ fator influencia na resposta avaliada.

Pode-se perceber que os fatores que influenciam nos resultados da deformação resiliente é o tipo de agregado, tipo de ligante asfáltico e tipo e teor de fíler na mistura asfáltica, assim como as interações do tipo de agregado com tipo de fíler.

Tabela 2.52 - Resumo da Análise de Variância da deformação resiliente, dos valores de $\mathrm{f}_{0}$ e da influência dos fatores e sua interação, para as análises (1) e (2)

\begin{tabular}{|c|c|c|c|c|c|}
\hline \multirow{2}{*}{ Fator } & \multicolumn{2}{|c|}{ Análise (1) } & \multicolumn{2}{|c|}{ Análise (2) } & \multirow{2}{*}{ Influência } \\
\hline & $\mathrm{F}_{0}$ & $\mathrm{f}_{0}$ & $\mathrm{~F}_{0}$ & $f_{0}$ & \\
\hline Tipo de agregado (Fator $\mathrm{A}$ ) & 233,30 & 18,51 & 358,34 & 18,51 & $\operatorname{sim}$ \\
\hline Tipo de Ligante Asfáltico (Fator B) & 11646,22 & 18,51 & 807,32 & 18,51 & $\operatorname{sim}$ \\
\hline Tipo de fíler (Fator C) & 94,52 & 19,0 & 209,96 & 18,51 & $\operatorname{sim}$ \\
\hline Teor de fíler (Fator D) & 1579,05 & 18,51 & 425,34 & 19,0 & $\operatorname{sim}$ \\
\hline Interação AB & 5,92 & 18,51 & 74,91 & 18,51 & não \\
\hline Interação AC & 97,88 & 19,0 & 174,38 & 18,51 & $\operatorname{sim}$ \\
\hline Interação AD & 1,33 & 18,51 & 27,81 & 19,0 & não \\
\hline Interação BC & 18,46 & 19,0 & 1,00 & 18,51 & não \\
\hline Interação BD & 55,25 & 18,51 & 7,77 & 19,0 & não \\
\hline Interação CD & 10,69 & 19,0 & 7,77 & 19,0 & não \\
\hline Interação ABC & 33,51 & 19,0 & 1,00 & 18,51 & não \\
\hline Interação ABD & 0,00 & 18,51 & 2,59 & 19,0 & não \\
\hline Interação ACD & 0,33 & 19,0 & 2,59 & 19,0 & não \\
\hline Interação BCD & 4,45 & 19,0 & 1,00 & 19,0 & não \\
\hline
\end{tabular}

\subsubsection{Fluência por Compressão Uniaxial Estática}

O ensaio de fluência por compressão uniaxial estática foi avaliado através de sete (7) parâmetros: (a) deformação total do corpo de prova no final do ensaio; (b) deformação não-recuperável ou deformação viscoelástica, que permanece após o ensaio de recuperação; (c) deformação recuperável ou deformação elástica, dada pela diferença entre as duas primeiras; (d) recuperação elástica, relação percentual entre a deformação recuperável e a deformação total; (e) módulo de 
fluência após o ensaio de fluência; (f) módulo de fluência após a recuperação; (g) inclinação da curva de fluência.

A seguir, serão apresentados os resultados e as análises para cada parâmetro do ensaio de fluência.

(a) Deformação Total

Os resultados de deformação total estão apresentados na Tabela 2.53, referentes aos valores médios de três determinações para as diferentes condições experimentais.

Tabela 2.53 - Valores médios da Deformação Total

\begin{tabular}{cc|ccc|ccc}
\hline & Teor de Fíler & \multicolumn{3}{|c|}{ CAP 50/70 } & \multicolumn{2}{c}{ CAP 85/100 } \\
& $\%$ & Calcário & Cimento & Cal & Calcário & Cimento & Cal \\
\hline \multirow{2}{*}{ Agregado } & 2,5 & 0,00212 & & & & 0,00245 \\
Basáltico & 5,0 & & & 0,00237 & 0,00249 & \\
& 7,5 & & 0,00249 & & & 0,00271 \\
\hline \multirow{2}{*}{ Agregado } & 2,5 & \multicolumn{3}{|c|}{0,0028} & & & 0,00274 \\
Granítico & 5,0 & & & 0,0026 & 0,00274 & & \\
& 7,5 & 0,0026 & & & & & 0,00274 \\
\hline
\end{tabular}

A Tabela 2.54 mostra os valores dos efeitos dos fatores $A, B$ e $C$, e os valores de $\beta_{0}, \beta_{1}, \beta_{2} e$ $\beta_{3}$.para cada parte do experimento fatorial fracionado em dois níveis.

Tabela 2.54 - Dados do experimento fatorial fracionado para a análise da Deformação Total

\begin{tabular}{ccccccc}
\hline & Parte 1 & Parte 2 & Parte 3 & Parte 4 & Parte 5 & Parte 6 \\
\hline Efeito do Fator A & $-3,94 \mathrm{E}-04$ & $1,60 \mathrm{E}-04$ & $-2,23 \mathrm{E}-04$ & $1,39 \mathrm{E}-04$ & $-3,11 \mathrm{E}-04$ & $-1,17 \mathrm{E}-04$ \\
Efeito do Fator B & $-2,84 \mathrm{E}-04$ & $1,30 \mathrm{E}-04$ & $-1,08 \mathrm{E}-04$ & $-2,50 \mathrm{E}-06$ & $1,96 \mathrm{E}-04$ & $2,00 \mathrm{E}-05$ \\
Efeito do Fator C & $-8,37 \mathrm{E}-05$ & $-1,29 \mathrm{E}-04$ & $-1,40 \mathrm{E}-04$ & $-8,33 \mathrm{E}-07$ & $-3,19 \mathrm{E}-05$ & $-1,05 \mathrm{E}-04$ \\
\hline$\beta_{0}$ & $2,50 \mathrm{E}-03$ & $2,66 \mathrm{E}-03$ & $2,36 \mathrm{E}-03$ & $2,67 \mathrm{E}-03$ & $2,44 \mathrm{E}-03$ & $2,62 \mathrm{E}-03$ \\
$\beta_{1}$ & $-1,97 \mathrm{E}-04$ & $7,98 \mathrm{E}-05$ & $-1,11 \mathrm{E}-04$ & $6,96 \mathrm{E}-05$ & $-1,55 \mathrm{E}-04$ & $-5,83 \mathrm{E}-05$ \\
$\beta_{2}$ & $-1,42 \mathrm{E}-04$ & $6,52 \mathrm{E}-05$ & $-5,40 \mathrm{E}-05$ & $-1,25 \mathrm{E}-06$ & $9,78 \mathrm{E}-05$ & $1,00 \mathrm{E}-05$ \\
$\beta_{3}$ & $-4,19 \mathrm{E}-05$ & $-6,44 \mathrm{E}-05$ & $-6,98 \mathrm{E}-05$ & $-4,17 \mathrm{E}-07$ & $-1,59 \mathrm{E}-05$ & $-5,27 \mathrm{E}-05$ \\
\hline
\end{tabular}


Os valores estimados para o experimento fatorial completo estão mostrados na Tabela 2.55. As Figuras 2.15 e 2.16 apresentam a comparação dos dados para as misturas contendo o CAP 50/70 e o CAP 85/100, respectivamente, para os agregados basáltico (a) e granítico (b).

Nota-se que as misturas compostas pelo CAP 50/70 apresentam os menores valores de deformação total, assim como as misturas contendo o agregado basáltico. Em relação ao tipo de fíler, as misturas compostas pelo fíler de cimento Portland apresentaram os maiores valores de deformação total; e para as misturas contendo o fíler de cal hidratada apresentam os menores valores de deformação total, quando combinados com o agregado basáltico. Quanto ao teor de fíler nas misturas, as contendo os menores teores de fíler apresentam menores valores de deformação total.

Tabela 2.55 - Valores estimados da Deformação Total

\begin{tabular}{ccccc|ccc}
\hline & Teor de Fíler & \multicolumn{3}{c|}{ CAP 50/70 } & \multicolumn{3}{c}{ CAP 85/100 } \\
& $(\%)$ & Calcário & Cimento & Cal & Calcário & Cimento & Cal \\
\hline \multirow{2}{*}{ Agregado } & 2,5 & 0,00212 & 0,00241 & 0,00223 & 0,00235 & 0,00258 & 0,00245 \\
Basáltico & 5,0 & 0,00226 & & 0,00237 & 0,00249 & & 0,00259 \\
& 7,5 & 0,00221 & 0,00249 & 0,00240 & 0,00252 & 0,00271 & 0,00258 \\
\hline \multirow{2}{*}{ Agregado } & 2,5 & 0,00252 & 0,00280 & 0,00250 & 0,00263 & 0,00274 & 0,00261 \\
Granítico & 5,0 & 0,00260 & & 0,00260 & 0,00274 & & 0,00274 \\
& 7,5 & 0,00260 & 0,00288 & 0,00260 & 0,00274 & 0,00287 & 0,00274 \\
\hline
\end{tabular}

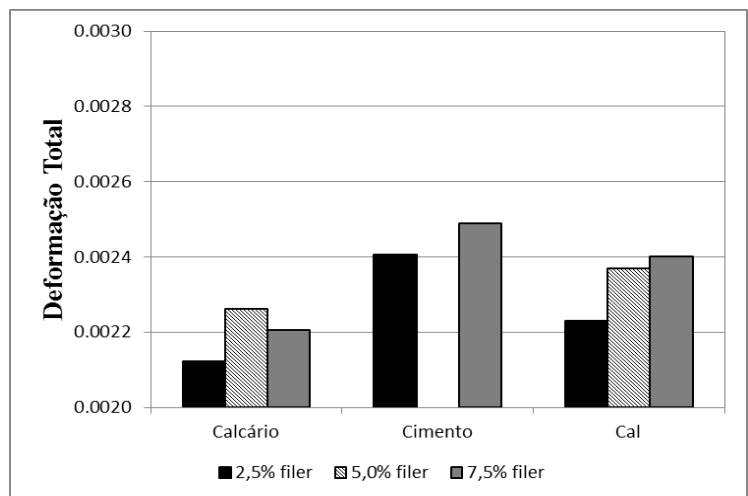

(a)

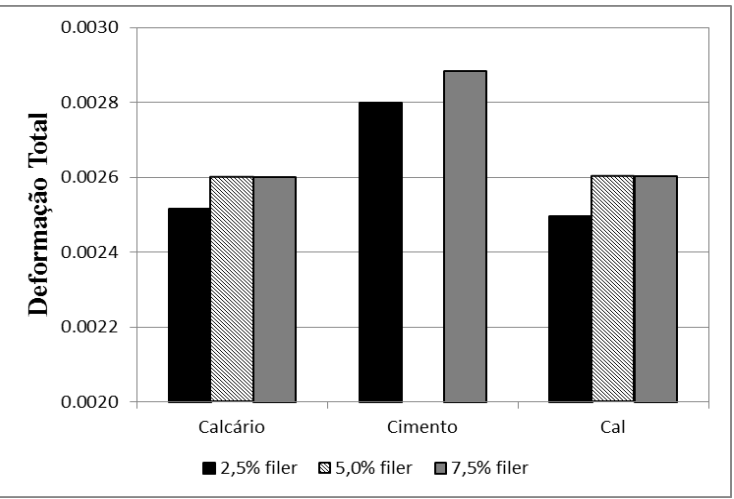

(b)

Figura 2.15 - Deformação Total para misturas contendo CAP 50/70 e agregado: (a) basáltico e (b) granítico 


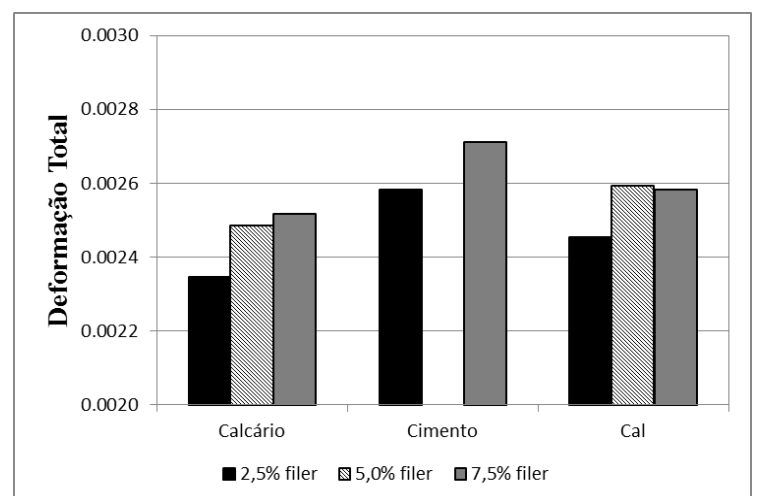

(a)

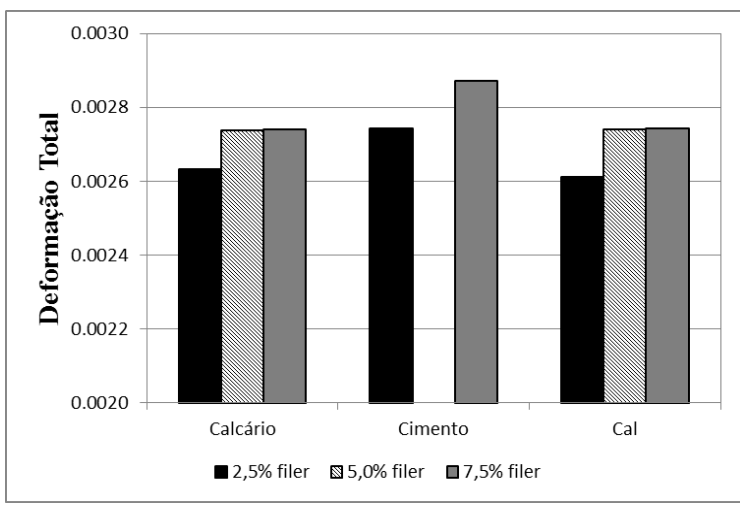

(b)

Figura 2.16 - Deformação Total para misturas contendo CAP 85/100 e agregado: (a) basáltico e (b) granítico

Para testar quais fatores (tipo de fíler, teor de fíler, tipo de agregado e tipo de ligante asfáltico) influenciam nos resultados da deformação total, realizou-se a Análise de Variância (ANOVA).

Primeiramente, a análise foi realizada considerando o fator tipo de agregado em dois níveis (agregado granítico e basáltico), o fator tipo de ligante asfáltico em dois níveis (CAP 50/70 e CAP 85/100), o fator tipo de fíler em três níveis (pó calcário, cimento Portland e cal hidratada) e o fator teor de fíler em dois níveis $(2,5$ e $7,5 \%)$.

A segunda análise foi realizada considerando o fator tipo de agregado em dois níveis (agregado granítico e basáltico), o fator tipo de ligante asfáltico em dois níveis (CAP 50/70 e CAP 85/100), o fator tipo de fíler em dois níveis (pó calcário e cal hidratada) e o fator teor de fíler em três níveis $(2,5 ; 5,0$ e 7,5\%). A Tabela B.8 do Apêndice B apresenta o resumo dos valores da análise (1) e da análise (2) para a ANOVA.

A Tabela 2.56 apresenta o resumo da análise de variância, com os valores do teste $\mathrm{f}_{0}$ da análise de variância das respostas da deformação total, com a resposta da influência dos fatores considerados, para as análises considerando o fator tipo de fíler em 3 níveis e o teor de fíler em 2 níveis (análise (1)) e o tipo de fíler em 2 níveis e o teor de fíler em 3 níveis (análise (2)). 
Pode-se perceber que o tipo de agregado, o tipo de ligante asfáltico, o tipo e teor de fíler influenciam na resposta da deformação total das misturas asfálticas, assim como a interação do tipo de agregado com o tipo de ligante asfáltico.

Tabela 2.56 - Resumo da Análise de Variância da deformação total, dos valores de $\mathrm{f}_{0}$ e da influência dos fatores e sua interação, para as análises (1) e (2)

\begin{tabular}{cccccc}
\hline \multirow{2}{*}{ Fator } & \multicolumn{2}{c}{ Análise (1) } & \multicolumn{2}{c}{ Análise (2) } & \multirow{2}{*}{ Influência } \\
\cline { 2 - 5 } & $\mathrm{F}_{0}$ & $\mathrm{f}_{0}$ & $\mathrm{~F}_{0}$ & $\mathrm{f}_{0}$ & \\
\hline Tipo de agregado (Fator A) & 817,40 & 18,51 & 561,64 & 18,51 & sim \\
Tipo de Ligante Asfáltico (Fator B) & 255,31 & 18,51 & 285,16 & 18,51 & sim \\
Tipo de fíler (Fator C) & 215,35 & 19,0 & 26,61 & 18,51 & sim \\
Teor de fíler (Fator D) & 159,24 & 18,51 & 58,06 & 19,0 & sim \\
Interação AB & 64,43 & 18,51 & 21,30 & 18,51 & sim \\
Interação AC & 16,25 & 19,0 & 31,64 & 18,51 & não \\
Interação AD & 1,40 & 18,51 & 1,09 & 19,0 & não \\
Interação BC & 13,44 & 19,0 & 1,00 & 18,51 & não \\
Interação BD & 2,65 & 18,51 & 0,38 & 19,0 & não \\
Interação CD & 0,86 & 19,0 & 0,38 & 19,0 & não \\
Interação ABC & 6,23 & 19,0 & 1,00 & 18,51 & não \\
Interação ABD & 0,00 & 18,51 & 0,13 & 19,0 & não \\
Interação ACD & 0,35 & 19,0 & 0,13 & 19,0 & não \\
Interação BCD & 1,16 & 19,0 & 1,00 & 19,0 & não \\
\hline
\end{tabular}

(b) Deformação Recuperável

Os resultados de deformação recuperável estão apresentados na Tabela 2.57, referentes aos valores médios de três determinações para as diferentes condições experimentais. 
Tabela 2.57 - Valores médios da Deformação Recuperável

\begin{tabular}{|c|c|c|c|c|c|c|c|}
\hline & \multirow{2}{*}{$\begin{array}{c}\text { Teor de Fíler } \\
(\%)\end{array}$} & \multicolumn{3}{|c|}{ CAP 50/70 } & \multicolumn{3}{|c|}{ CAP 85/100 } \\
\hline & & Calcário & Cimento & Cal & Calcário & Cimento & Cal \\
\hline \multirow{3}{*}{$\begin{array}{l}\text { Agregado } \\
\text { Basáltico }\end{array}$} & 2,5 & 0,001565 & & \multirow{3}{*}{0,00154} & \multirow{3}{*}{0,001587} & & 0,001607 \\
\hline & 5,0 & & & & & & \\
\hline & 7,5 & & 0,001595 & & & 0,001653 & \\
\hline \multirow{3}{*}{$\begin{array}{l}\text { Agregado } \\
\text { Granítico }\end{array}$} & 2,5 & & 0,00182 & \multirow{3}{*}{0,001758} & \multirow{3}{*}{0,001808} & 0,001815 & \\
\hline & 5,0 & & & & & & \\
\hline & 7,5 & 0,001767 & & & & & 0,001853 \\
\hline
\end{tabular}

A Tabela 2.58 mostra os valores dos efeitos dos fatores $A, B$ e $C$, e os valores de $\beta_{0}, \beta_{1}, \beta_{2} e$ $\beta_{3}$.para cada parte do experimento fatorial fracionado em dois níveis.

Tabela 2.58 - Dados do experimento fatorial fracionado para a análise da Deformação Recuperável

\begin{tabular}{ccccccc}
\hline & Parte 1 & Parte 2 & Parte 3 & Parte 4 & Parte 5 & Parte 6 \\
\hline Efeito do Fator A & $-2,13 \mathrm{E}-04$ & $2,05 \mathrm{E}-04$ & $-4,42 \mathrm{E}-05$ & $6,83 \mathrm{E}-05$ & $-7,29 \mathrm{E}-05$ & $-4,15 \mathrm{E}-05$ \\
Efeito do Fator B & $-4,17 \mathrm{E}-05$ & $3,75 \mathrm{E}-06$ & $2,50 \mathrm{E}-06$ & $-1,83 \mathrm{E}-05$ & $2,62 \mathrm{E}-05$ & $8,54 \mathrm{E}-06$ \\
Efeito do Fator C & $1,17 \mathrm{E}-05$ & $-4,21 \mathrm{E}-05$ & $2,25 \mathrm{E}-05$ & $-2,67 \mathrm{E}-05$ & $-3,96 \mathrm{E}-05$ & $1,15 \mathrm{E}-05$ \\
\hline$\beta_{0}$ & $1,69 \mathrm{E}-03$ & $1,73 \mathrm{E}-03$ & $1,57 \mathrm{E}-03$ & $1,80 \mathrm{E}-03$ & $1,58 \mathrm{E}-03$ & $1,79 \mathrm{E}-03$ \\
$\beta_{1}$ & $-1,07 \mathrm{E}-04$ & $1,02 \mathrm{E}-04$ & $-2,21 \mathrm{E}-05$ & $3,42 \mathrm{E}-05$ & $-3,65 \mathrm{E}-05$ & $-2,07 \mathrm{E}-05$ \\
$\beta_{2}$ & $-2,08 \mathrm{E}-05$ & $1,87 \mathrm{E}-06$ & $1,25 \mathrm{E}-06$ & $-9,17 \mathrm{E}-06$ & $1,31 \mathrm{E}-05$ & $4,27 \mathrm{E}-06$ \\
$\beta_{3}$ & $5,83 \mathrm{E}-06$ & $-2,10 \mathrm{E}-05$ & $1,13 \mathrm{E}-05$ & $-1,33 \mathrm{E}-05$ & $-1,98 \mathrm{E}-05$ & $5,73 \mathrm{E}-06$ \\
\hline
\end{tabular}

Os valores estimados para o experimento fatorial completo estão mostrados na Tabela 2.59. As Figuras 2.17 e 2.18 apresentam a comparação dos dados para as misturas contendo o CAP 50/70 e o CAP 85/100, respectivamente, para os agregados basáltico (a) e granítico (b).

Nota-se que as misturas compostas pelo agregado basáltico apresentam os menores valores de deformação recuperável, e que quase não há diferenças entre os valores para as misturas compostas pelo CAP 50/70 e o CAP 85/100. Em relação ao tipo de fíler, para as misturas compostas pelo CAP 50/70, a deformação recuperável de maiores valores foram para as misturas com o cimento Portland, porém para as misturas contendo o CAP 85/100 quase não há diferença entre as misturas com diferentes fileres e em diferentes teores. 
Tabela 2.59 - Valores estimados da Deformação Recuperável

\begin{tabular}{lcccc|ccc}
\hline & Teor de Fíler & \multicolumn{3}{c|}{ CAP 50/70 } & \multicolumn{3}{c}{ CAP 85/100 } \\
& $(\%)$ & Calcário & Cimento & Cal & Calcário & Cimento & Cal \\
\hline \multirow{2}{*}{ Agregado } & 2,5 & 0,001565 & 0,001607 & 0,001563 & 0,001609 & 0,001610 & 0,001607 \\
Basáltico & 5,0 & 0,001543 & & 0,001540 & 0,001587 & & 0,001584 \\
& 7,5 & 0,001553 & 0,001595 & 0,001580 & 0,001626 & 0,001653 & 0,001610 \\
\hline \multirow{3}{*}{ Agregado } & 2,5 & 0,001778 & 0,001820 & 0,001770 & 0,001820 & 0,001815 & 0,001811 \\
Granítico & 5,0 & 0,001740 & & 0,001758 & 0,001808 & & 0,001827 \\
& 7,5 & 0,001767 & 0,001808 & 0,001785 & 0,001835 & 0,001857 & 0,001853 \\
\hline
\end{tabular}

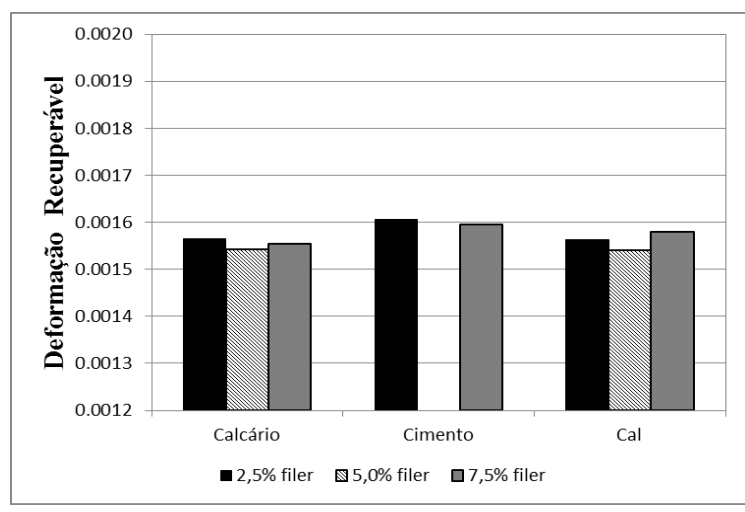

(a)

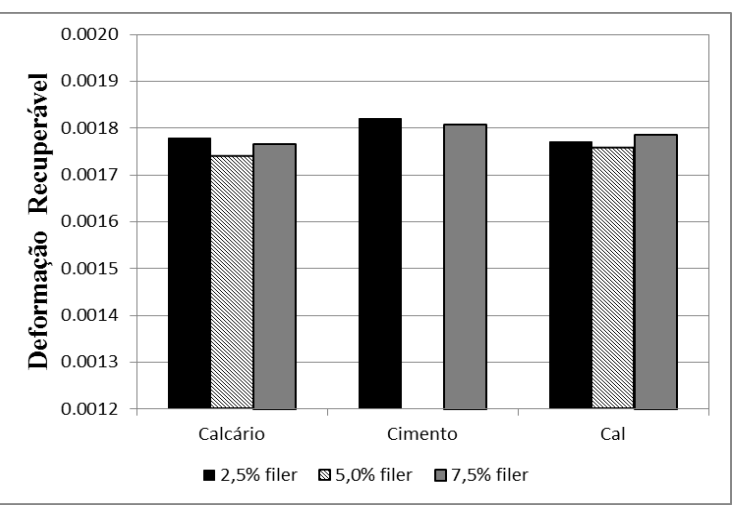

(b)

Figura 2.17 - Deformação Recuperável para misturas contendo CAP 50/70 e agregado: (a) basáltico e (b) granítico

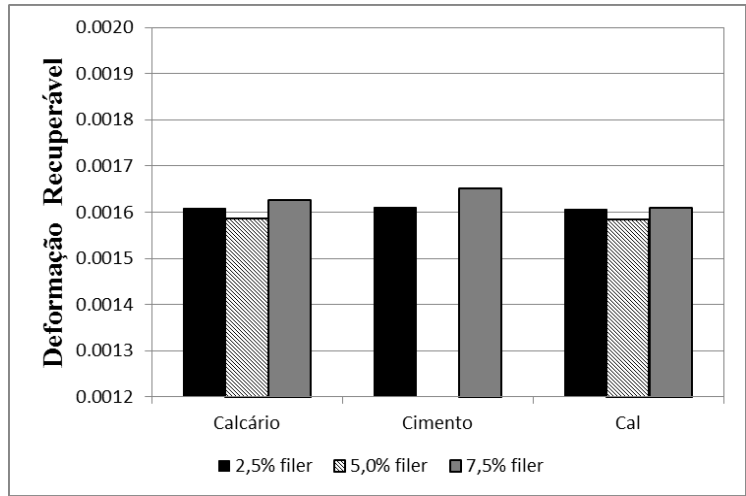

(a)

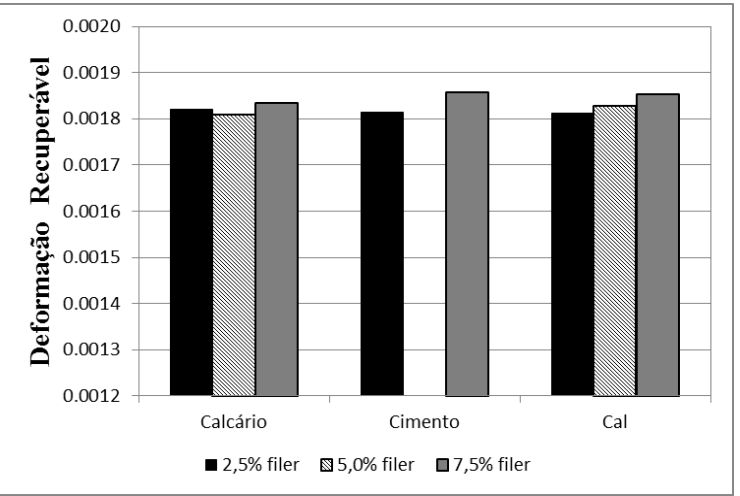

(b)

Figura 2.18 - Deformação Recuperável para misturas contendo CAP 85/100 e agregado: (a) basáltico e (b) granítico 
Para testar quais fatores (tipo de fíler, teor de fíler, tipo de agregado e tipo de ligante asfáltico) influenciam nos resultados da deformação recuperável, realizou-se a Análise de Variância (ANOVA).

Primeiramente, a análise foi realizada considerando o fator tipo de agregado em dois níveis (agregado granítico e basáltico), o fator tipo de ligante asfáltico em dois níveis (CAP 50/70 e CAP 85/100), o fator tipo de fíler em três níveis (pó calcário, cimento Portland e cal hidratada) e o fator teor de fíler em dois níveis $(2,5$ e 7,5\%).

A segunda análise foi realizada considerando o fator tipo de agregado em dois níveis (agregado granítico e basáltico), o fator tipo de ligante asfáltico em dois níveis (CAP 50/70 e CAP 85/100), o fator tipo de fíler em dois níveis (pó calcário e cal hidratada) e o fator teor de fíler em três níveis $(2,5 ; 5,0$ e 7,5\%). A Tabela B.9 do Apêndice B apresenta o resumo dos valores da análise (1) e da análise (2) para a ANOVA.

A Tabela 2.60 apresenta o resumo da análise de variância, com os valores do teste $\mathrm{f}_{0}$ da análise de variância das respostas da deformação recuperável, com a resposta da influência dos fatores considerados, para as análises considerando o fator tipo de fíler em 3 níveis e o teor de fíler em 2 níveis (análise (1)) e o tipo de fíler em 2 níveis e o teor de fíler em 3 níveis (análise (2)).

Pode-se perceber que apenas o tipo de agregado e o tipo de ligante asfáltico influenciam na resposta da deformação recuperável das misturas asfálticas; o tipo de fíler influencia na resposta mecânica apenas quando o fíler de cal hidratada é considerado na análise, o que demostra a grande atividade desse material. 
Tabela 2.60 - Resumo da Análise de Variância da deformação recuperável, dos valores de $\mathrm{f}_{0}$ e da influência dos fatores e sua interação, para a análise (1) e (2)

\begin{tabular}{cccccc}
\hline \multirow{2}{*}{ Fator } & \multicolumn{2}{c}{ Análise (1) } & \multicolumn{2}{c}{ Análise (2) } & \multirow{2}{*}{ Influência } \\
\cline { 2 - 5 } & $\mathrm{F}_{0}$ & $\mathrm{f}_{0}$ & $\mathrm{~F}_{0}$ & $\mathrm{f}_{0}$ & \\
\hline Tipo de agregado (Fator A) & 3811,11 & 18,51 & 3776,77 & 18,51 & sim \\
Tipo de Ligante Asfáltico (Fator B) & 157,43 & 18,51 & 228,88 & 18,51 & sim \\
Tipo de fíler (Fator C) & 23,62 & 19,0 & 1,81 & 18,51 & não \\
Teor de fíler (Fator D) & 12,90 & 18,51 & 21,38 & 19,0 & não \\
Interação AB & 0,06 & 18,51 & 3,25 & 18,51 & não \\
Interação AC & 0,27 & 19,0 & 1,76 & 18,51 & não \\
Interação AD & 0,71 & 18,51 & 0,91 & 19,0 & não \\
Interação BC & 6,78 & 19,0 & 1,00 & 18,51 & não \\
Interação BD & 18,41 & 18,51 & 2,23 & 19,0 & não \\
Interação CD & 2,29 & 19,0 & 2,23 & 19,0 & não \\
Interação ABC & 1,36 & 19,0 & 1,00 & 18,51 & não \\
Interação ABD & 0,87 & 18,51 & 1,30 & 19,0 & não \\
Interação ACD & 0,83 & 19,0 & 1,30 & 19,0 & não \\
Interação BCD & 3,92 & 19,0 & 1,00 & 19,0 & não \\
\hline
\end{tabular}

(c) Deformação Não Recuperável

Os resultados de deformação não recuperável estão apresentados na Tabela 2.61, referentes aos valores médios de três determinações para as diferentes condições experimentais.

Tabela 2.61 - Valores médios da Deformação Não Recuperável

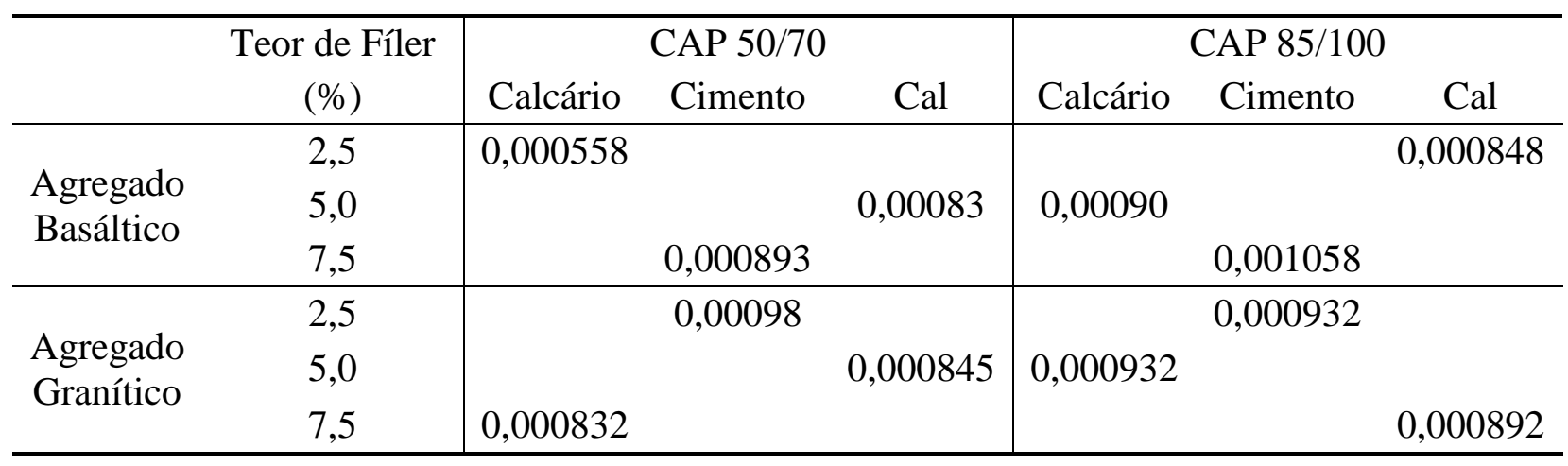


A Tabela 2.62 mostra os valores dos efeitos dos fatores $A, B$ e $C$, e os valores de $\beta_{0}, \beta_{1}, \beta_{2} e$ $\beta_{3}$.para cada parte do experimento fatorial fracionado em dois níveis.

Tabela 2.62 - Dados do experimento fatorial fracionado para a análise da Deformação Não Recuperável

\begin{tabular}{ccccccc}
\hline & Parte 1 & Parte 2 & Parte 3 & Parte 4 & Parte 5 & Parte 6 \\
\hline Efeito do Fator A & $-1,80 \mathrm{E}-04$ & $-4,13 \mathrm{E}-05$ & $-1,80 \mathrm{E}-04$ & $7,33 \mathrm{E}-05$ & $-2,38 \mathrm{E}-04$ & $-7,79 \mathrm{E}-05$ \\
Efeito do Fator B & $-2,42 \mathrm{E}-04$ & $1,25 \mathrm{E}-04$ & $-1,10 \mathrm{E}-04$ & $1,33 \mathrm{E}-05$ & $1,68 \mathrm{E}-04$ & $8,75 \mathrm{E}-06$ \\
Efeito do Fator C & $-9,38 \mathrm{E}-05$ & $-8,46 \mathrm{E}-05$ & $-1,62 \mathrm{E}-04$ & $2,67 \mathrm{E}-05$ & $1,06 \mathrm{E}-05$ & $-1,16 \mathrm{E}-04$ \\
\hline$\beta_{0}$ & $8,16 \mathrm{E}-04$ & $9,32 \mathrm{E}-04$ & $7,84 \mathrm{E}-04$ & $8,75 \mathrm{E}-04$ & $8,60 \mathrm{E}-04$ & $8,30 \mathrm{E}-04$ \\
$\beta_{1}$ & $-9,02 \mathrm{E}-05$ & $-2,06 \mathrm{E}-05$ & $-9,02 \mathrm{E}-05$ & $3,67 \mathrm{E}-05$ & $-1,19 \mathrm{E}-04$ & $-3,90 \mathrm{E}-05$ \\
$\beta_{2}$ & $-1,21 \mathrm{E}-04$ & $6,23 \mathrm{E}-05$ & $-5,52 \mathrm{E}-05$ & $6,67 \mathrm{E}-06$ & $8,41 \mathrm{E}-05$ & $4,38 \mathrm{E}-06$ \\
$\beta_{3}$ & $-4,69 \mathrm{E}-05$ & $-4,23 \mathrm{E}-05$ & $-8,10 \mathrm{E}-05$ & $1,33 \mathrm{E}-05$ & $5,31 \mathrm{E}-06$ & $-5,79 \mathrm{E}-05$ \\
\hline
\end{tabular}

Os valores estimados para o experimento fatorial completo estão mostrados na Tabela 2.63. As Figuras 2.19 e 2.20 apresentam a comparação dos dados para as misturas contendo o CAP 50/70 e o CAP 85/100, respectivamente, para os agregados basáltico (a) e granítico (b).

Tabela 2.63 - Valores estimados da Deformação Não Recuperável

\begin{tabular}{lcccc|ccc}
\hline & $\begin{array}{c}\text { Teor de } \\
\text { Fíler } \\
(\%)\end{array}$ & Calcário & Cimento & Cal & Calcário & Cimento & Cal \\
\hline \multirow{2}{*}{ Agregado } & 2,5 & 0,000558 & 0,000800 & 0,000668 & 0,000738 & 0,000973 & 0,000848 \\
Basáltico & 5,0 & 0,000720 & & 0,000830 & 0,000900 & & 0,001010 \\
& 7,5 & 0,000651 & 0,000893 & 0,000819 & 0,000889 & 0,001058 & 0,000973 \\
\hline \multirow{3}{*}{ Agregado } & 2,5 & 0,000738 & 0,000980 & 0,000729 & 0,000816 & 0,000932 & 0,000807 \\
Granítico & 5,0 & 0,000858 & & 0,000845 & 0,000932 & & 0.000918 \\
& 7,5 & 0,000832 & 0,001074 & 0,000818 & 0,000905 & 0,001016 & 0,000892 \\
\hline
\end{tabular}




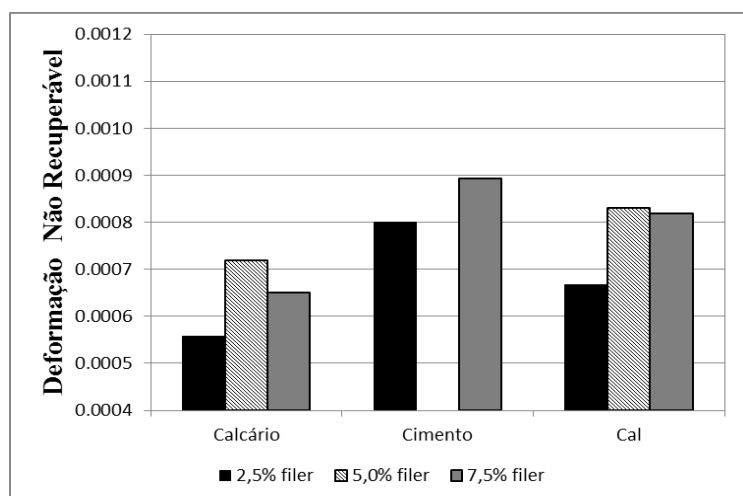

(a)

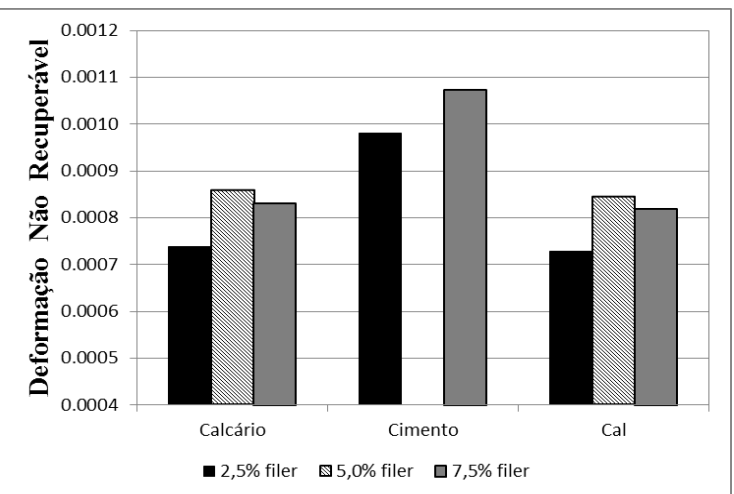

(b)

Figura 2.19 - Deformação Não Recuperável para misturas contendo CAP 50/70 e agregado: (a) basáltico e (b) granítico

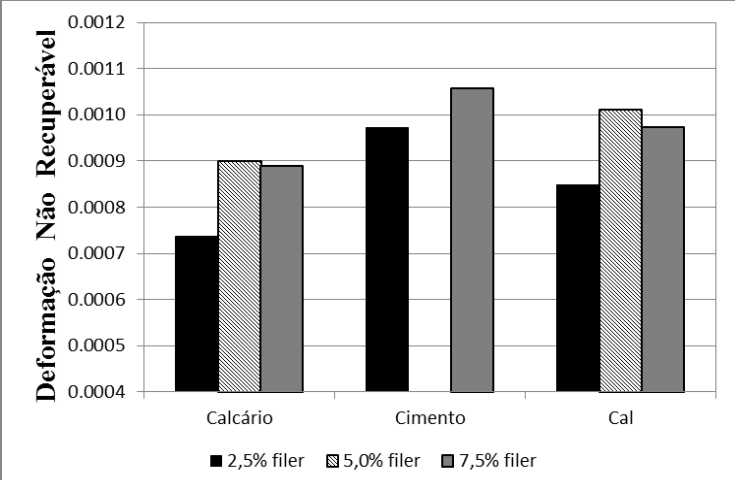

(a)

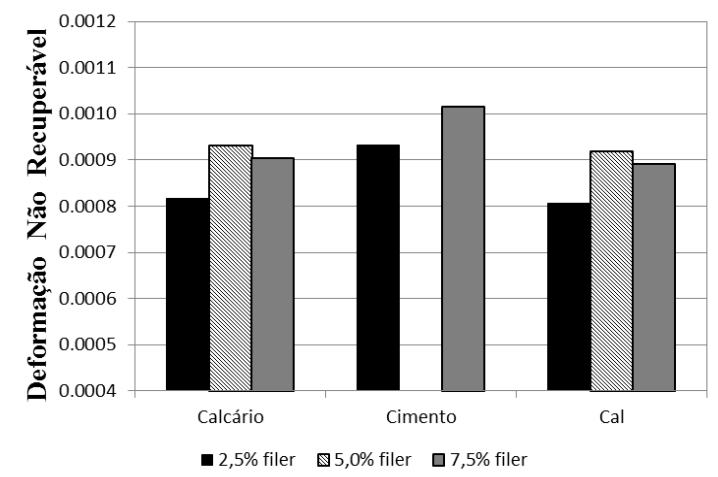

(b)

Figura 2.20 - Deformação Não Recuperável para misturas contendo CAP 85/100 e agregado: (a) basáltico e (b) granítico

Nota-se que as misturas compostas pelo CAP 50/70 e o agregado basáltico apresentam os menores valores de deformação não recuperável. Em relação ao tipo de fíler, as misturas contendo o cimento Portland apresentam os maiores valores de deformação não recuperável, e para todos os fíler, as misturas contendo o menor teor de fíler apresentam os menores valores de deformação não recuperável, enquanto que as misturas contendo o valor intermediário de fíler apresentam os maiores valores.

Para testar quais fatores (tipo de fíler, teor de fíler, tipo de agregado e tipo de ligante asfáltico) influenciam nos resultados da deformação não recuperável, realizou-se a Análise de Variância (ANOVA). 
Primeiramente, a análise foi realizada considerando o fator tipo de agregado em dois níveis (agregado granítico e basáltico), o fator tipo de ligante asfáltico em dois níveis (CAP 50/70 e CAP 85/100), o fator tipo de fíler em três níveis (pó calcário, cimento Portland e cal hidratada) e o fator teor de fíler em dois níveis $(2,5$ e 7,5\%).

A segunda análise foi realizada considerando o fator tipo de agregado em dois níveis (agregado granítico e basáltico), o fator tipo de ligante asfáltico em dois níveis (CAP 50/70 e CAP 85/100), o fator tipo de fíler em dois níveis (pó calcário e cal hidratada) e o fator teor de fíler em três níveis $(2,5 ; 5,0$ e 7,5\%). A Tabela B.10 do Apêndice B apresenta o resumo dos valores da análise (1) e da análise (2) para a ANOVA.

A Tabela 2.64 apresenta o resumo da análise de variância, com os valores do teste $\mathrm{f}_{0}$ da análise de variância das respostas da deformação não recuperável, com a resposta da influência dos fatores considerados, para as análises (1) e (2).

Tabela 2.64 - Resumo da Análise de Variância da deformação não recuperável, dos valores de $\mathrm{f}_{0}$ e da influência dos fatores e sua interação, para as análises (1) e (2)

\begin{tabular}{cccccc}
\hline \multirow{2}{*}{ Fator } & \multicolumn{2}{c}{ Análise $(1)$} & \multicolumn{2}{c}{ Análise (2) } & \multirow{2}{*}{ Influência } \\
\cline { 2 - 5 } & $\mathrm{F}_{0}$ & $\mathrm{f}_{0}$ & $\mathrm{~F}_{0}$ & $\mathrm{f}_{0}$ & \\
\hline Tipo de agregado (Fator A) & 77,95 & 18,51 & 32,94 & 18,51 & sim \\
Tipo de Ligante Asfáltico (Fator B) & 287,13 & 18,51 & 341,25 & 18,51 & sim \\
Tipo de fíler (Fator C) & 356,26 & 19,0 & 54,16 & 18,51 & sim \\
Teor de fíler (Fator D) & 264,35 & 18,51 & 144,05 & 19,0 & sim \\
Interação AB & 138,41 & 18,51 & 61,66 & 18,51 & sim \\
Interação AC & 35,90 & 19,0 & 81,62 & 18,51 & sim \\
Interação AD & 4,70 & 18,51 & 4,31 & 19,0 & não \\
Interação BC & 16,11 & 19,0 & 1,00 & 18,51 & não \\
Interação BD & 0,00 & 18,51 & 0,11 & 19,0 & não \\
Interação CD & 1,24 & 19,0 & 0,11 & 19,0 & não \\
Interação ABC & 9,20 & 19,0 & 1,00 & 18,51 & não \\
Interação ABD & 0,28 & 18,51 & 0,18 & 19,0 & não \\
Interação ACD & 1,38 & 19,0 & 0,18 & 19,0 & não \\
Interação BCD & 1,08 & 19,0 & 1,00 & 19,0 & não \\
\hline
\end{tabular}


Pode-se perceber que o tipo de agregado, o tipo de ligante asfáltico e o tipo e teor de fíler influenciam na resposta da deformação não recuperável das misturas asfálticas, assim como a interação do tipo de agregado com o tipo de ligante asfáltico e com o tipo de fíler.

(d) Recuperação (\%)

Os resultados de recuperação estão apresentados na Tabela 2.65, referentes aos valores médios de três determinações para as diferentes condições experimentais.

Tabela 2.65 - Valores médios da Recuperação (\%)

\begin{tabular}{lc|ccc|ccc}
\hline & Teor de Fíler & \multicolumn{3}{|c|}{ CAP 50/70 } & \multicolumn{3}{c}{ CAP 85/100 } \\
& $(\%)$ & Calcário & Cimento & Cal & Calcário & Cimento & Cal \\
\hline \multirow{2}{*}{ Agregado } & 2,5 & 73,500 & & & & & 65,937 \\
Basáltico & 5,0 & & & 64,980 & 64,118 & & \\
& 7,5 & & 64,442 & & & 61,228 & \\
\hline \multirow{2}{*}{ Agregado } & 2,5 & & 65,063 & & & 66,067 & \\
Granítico & 5,0 & & & 67,698 & 66,202 & & \\
& 7,5 & 68,380 & & & & & 67,937 \\
\hline
\end{tabular}

A Tabela 2.66 mostra os valores dos efeitos dos fatores $A, B$ e $C$, e os valores de $\beta_{0}, \beta_{1}, \beta_{2} e$ $\beta_{3}$.para cada parte do experimento fatorial fracionado em dois níveis.

Tabela 2.66 - Dados do experimento fatorial fracionado para a análise da Recuperação

\begin{tabular}{ccccccc}
\hline & Parte 1 & Parte 2 & Parte 3 & Parte 4 & Parte 5 & Parte 6 \\
\hline Efeito do Fator A & 2,2492 & 3.4196 & 4,2125 & $-0,9700$ & 5,1317 & 1,6956 \\
Efeito do Fator B & 6,1875 & $-3,2896$ & 3,3508 & $-0,5267$ & $-4,2700$ & 0,1990 \\
Efeito do Fator C & 2,8708 & 1,4196 & 5,1692 & $-1,2083$ & $-1,3792$ & 3,3535 \\
\hline$\beta_{0}$ & 67.8463 & 65,2919 & 67,1338 & 67,5542 & 65,2388 & 68,6268 \\
$\beta_{1}$ & 1.1246 & 1,7098 & 2,1063 & $-0,4850$ & 2,5658 & 0,8478 \\
$\beta_{2}$ & 3.0938 & $-1,6448$ & 1,6754 & $-0,2633$ & $-2,1350$ & 0,0995 \\
$\beta_{3}$ & 1.4354 & 0,7098 & 2,5846 & $-0,6042$ & $-0,6896$ & 1,6768 \\
\hline
\end{tabular}


Os valores estimados para o experimento fatorial completo estão mostrados na Tabela 2.67. As Figuras 2.21 e 2.22 apresentam a comparação dos dados para as misturas contendo o CAP 50/70 e o CAP 85/100, respectivamente, para os agregados basáltico (a) e granítico (b).

Tabela 2.67 - Valores estimados da Recuperação (\%)

\begin{tabular}{lcccc|ccc}
\hline & Teor de Fíler & \multicolumn{3}{c|}{ CAP 50/70 } & \multicolumn{3}{c}{ CAP 85/100 } \\
& $(\%)$ & Calcário & Cimento & Cal & Calcário & Cimento & Cal \\
\hline \multirow{2}{*}{ Agregado } & 2,5 & 73,5000 & 67,3125 & 70,1492 & 69,2875 & 62,6471 & 65,9367 \\
Basáltico & 5,0 & 68,3308 & & 64,9800 & 64,1183 & & 60,7675 \\
& 7,5 & 70,6292 & 64,4417 & 66,3592 & 65,4975 & 61,2275 & 62,6471 \\
\hline \multirow{2}{*}{ Agregado } & 2,5 & 71,2508 & 65,0633 & 71,0519 & 69,5552 & 66,0667 & 69,3563 \\
Granítico & 5,0 & 67,1717 & & 67,6983 & 66,2017 & & 66,7283 \\
& 7,5 & 68,3800 & 62,1925 & 68,9067 & 67,4100 & 64,6471 & 67,9367 \\
\hline
\end{tabular}

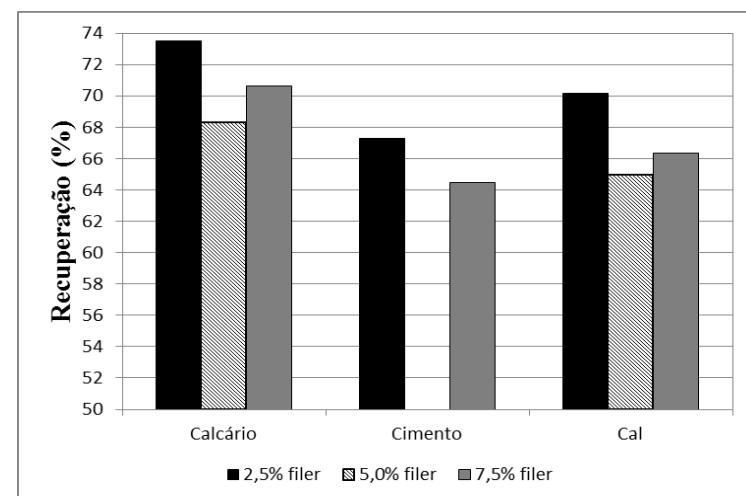

(a)

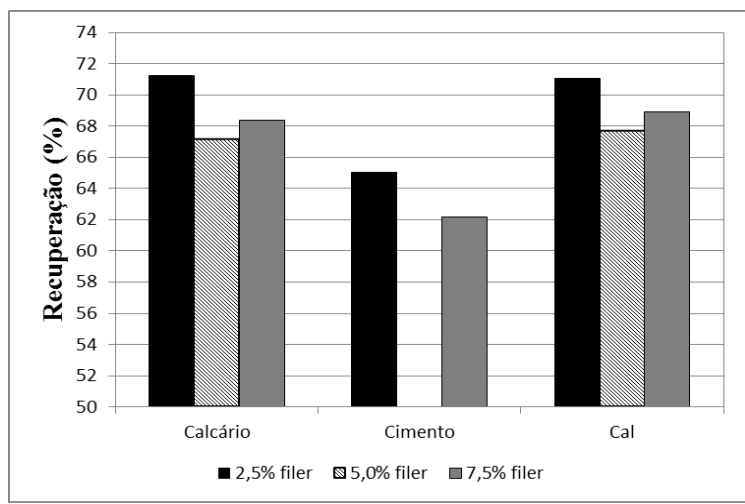

(b)

Figura 2.21 - Recuperação (\%) para misturas contendo CAP 50/70 e agregado: (a) basáltico e (b) granítico

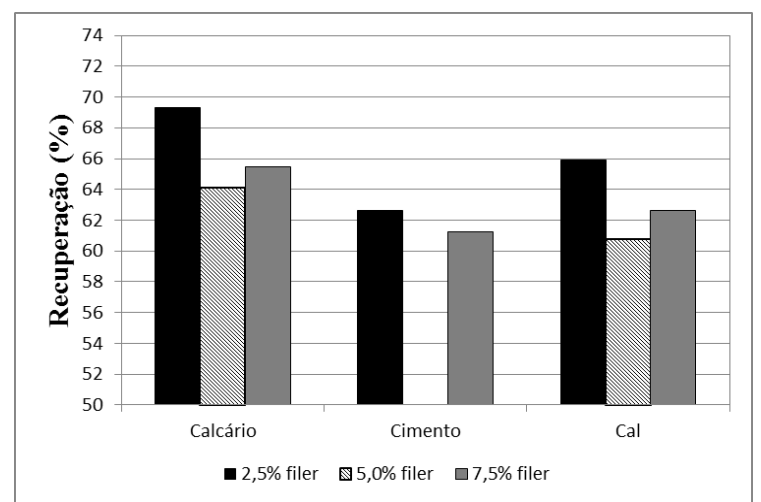

(a)

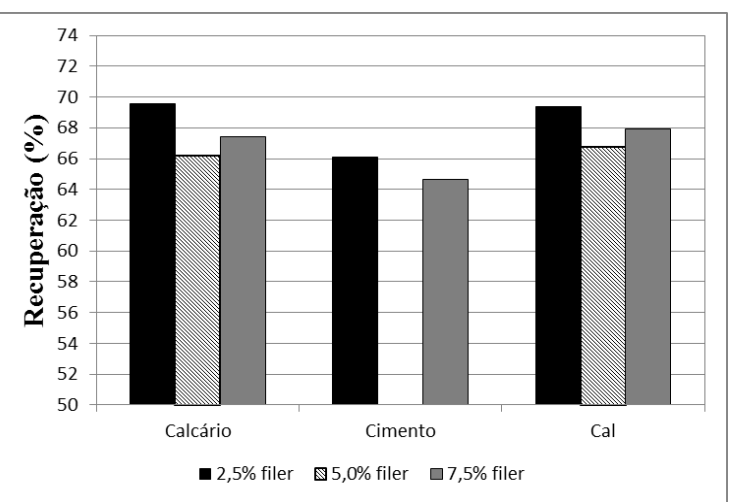

(b)

Figura 2.22 - Recuperação (\%) para misturas contendo CAP 85/100 e agregado: (a) basáltico e (b) granítico 
Nota-se que as misturas contendo o CAP 50/70 apresentam os maiores valores de recuperação quando comparado às contendo o CAP 85/100. Em relação ao tipo de fíler, as misturas compostas com o pó calcário apresentaram os maiores valores de recuperação, enquanto que as com o fíler de cimento Portland apresentaram os menores valores. Quanto ao teor de fíler, as misturas com os menores teores de fíler apresentaram os maiores valores de recuperação, enquanto que os teores intermediários $(5,0 \%)$ apresentaram os menores valores.

Para testar quais fatores (tipo de fíler, teor de fíler, tipo de agregado e tipo de ligante asfáltico) influenciam nos resultados da recuperação, realizou-se a Análise de Variância (ANOVA).

Primeiramente, a análise foi realizada considerando o fator tipo de agregado em dois níveis (agregado granítico e basáltico), o fator tipo de ligante asfáltico em dois níveis (CAP 50/70 e CAP 85/100), o fator tipo de fíler em três níveis (pó calcário, cimento Portland e cal hidratada) e o fator teor de fíler em dois níveis $(2,5$ e 7,5\%).

A segunda análise foi realizada considerando o fator tipo de agregado em dois níveis (agregado granítico e basáltico), o fator tipo de ligante asfáltico em dois níveis (CAP 50/70 e CAP 85/100), o fator tipo de fíler em dois níveis (pó calcário e cal hidratada) e o fator teor de fíler em três níveis (2,5; 5,0 e 7,5\%). A Tabela B.11 do Apêndice B apresenta o resumo dos valores da análise (1) e da análise (2) para a ANOVA.

A Tabela 2.68 apresenta o resumo da análise de variância, com os valores do teste $\mathrm{f}_{0}$ da análise de variância das respostas da recuperação, com a resposta da influência dos fatores considerados, para as análises considerando o fator tipo de fíler em 3 níveis e o teor de fíler em 2 níveis (análise (1)) e o tipo de fíler em 2 níveis e o teor de fíler em 3 níveis (análise (2)).

Pode-se perceber que o tipo de ligante asfáltico e o teor de fíler influenciam na resposta da recuperação das misturas asfálticas, assim como a interação do tipo de agregado com o tipo de ligante asfáltico e com o tipo de fíler. O tipo de fíler influencia na resposta mecânica apenas quando se considera na análise o fíler de cal hidratada. 
Tabela 2.68 - Resumo da Análise de Variância da recuperação, dos valores de $\mathrm{f}_{0}$ e da influência dos fatores e sua interação, para as análises (1) e (2)

\begin{tabular}{cccccc}
\hline \multirow{2}{*}{ Fator } & \multicolumn{2}{c}{ Análise $(1)$} & \multicolumn{2}{c}{ Análise $(2)$} & \multirow{2}{*}{ Influência } \\
\cline { 2 - 5 } & $\mathrm{F}_{0}$ & $\mathrm{f}_{0}$ & $\mathrm{~F}_{0}$ & $\mathrm{f}_{0}$ & \\
\hline Tipo de agregado (Fator A) & 62,21 & 18,51 & 15,75 & 18,51 & não \\
Tipo de Ligante Asfáltico (Fator B) & 306,07 & 18,51 & 45,28 & 18,51 & sim \\
Tipo de fíler (Fator C) & 577,68 & 19,0 & 14,75 & 18,51 & não \\
Teor de fíler (Fator D) & 400,29 & 18,51 & 37,48 & 19,0 & sim \\
Interação AB & 227,08 & 18,51 & 14,14 & 18,51 & não \\
Interação AC & 68,68 & 19,0 & 20,60 & 18,51 & sim \\
Interação AD & 11,16 & 18,51 & 1,75 & 19,0 & não \\
Interação BC & 20,47 & 19,0 & 0,08 & 18,51 & não \\
Interação BD & 6,49 & 18,51 & 0,07 & 19,0 & não \\
Interação CD & 3,12 & 19,0 & 0,07 & 19,0 & não \\
Interação ABC & 12,72 & 19,0 & 0,08 & 18,51 & não \\
Interação ABD & 1,47 & 18,51 & 0,12 & 19,0 & não \\
Interação ACD & 3,89 & 19,0 & 0,12 & 19,0 & não \\
Interação BCD & 3,02 & 19,0 & 0,08 & 19,0 & não \\
\hline
\end{tabular}

(e) Módulo de Fluência

Os resultados de módulo de fluência estão apresentados na Tabela 2.69, referentes aos valores médios de três determinações para as diferentes condições experimentais.

Tabela 2.69 - Valores médios do Módulo de Fluência, em MPa

\begin{tabular}{cc|ccc|ccc}
\hline & $\begin{array}{c}\text { Teor de Fíler } \\
(\%)\end{array}$ & \multicolumn{3}{|c|}{ CAP 50/70 } & \multicolumn{3}{c}{ CAP 85/100 } \\
& Calcário & Cimento & Cal & Calcário & Cimento & Cal \\
\hline \multirow{2}{*}{ Agregado } & 2,5 & 175,8350 & & & & \\
Basáltico & 5,0 & & & 159,6917 \\
& 7,5 & & 155,3617 & & & \\
& 2,5 & & 141,3800 & & \multicolumn{2}{|c}{148,3075} \\
Agregado & 5,0 & & & 149,2017 & 144,0683 & \\
Granítico & 7,5 & 150,3517 & & & & & 145,0233 \\
\hline
\end{tabular}


A Tabela 2.70 mostra os valores dos efeitos dos fatores $A, B$ e $C$, e os valores de $\beta_{0}, \beta_{1}, \beta_{2} e$ $\beta_{3}$.para cada parte do experimento fatorial fracionado em dois níveis.

Tabela 2.70 - Dados do experimento fatorial fracionado para a análise do Módulo de Fluência

\begin{tabular}{ccccccc}
\hline & Parte 1 & Parte 2 & Parte 3 & Parte 4 & Parte 5 & Parte 6 \\
\hline Efeito do Fator A & 19,7325 & $-10,6871$ & 11,4442 & $-5,2308$ & 14,2608 & 6,1156 \\
Efeito do Fator B & 14,7225 & $-7,4029$ & 4,6992 & 0,0975 & $-7,5158$ & 0,9823 \\
Efeito do Fator C & 5,7508 & 3,9813 & 9,2608 & $-1,0525$ & $-0,6933$ & 5,9185 \\
\hline$\beta_{0}$ & 155,7321 & 148,6560 & 163,1329 & 147,1613 & 158,8492 & 149,5943 \\
$\beta_{1}$ & 9,8662 & $-5,3435$ & 5,7221 & $-2,6154$ & 7,1304 & 3,0578 \\
$\beta_{2}$ & 7,3612 & $-3,7015$ & 2,3496 & 0,0487 & $-3,7579$ & 0,4911 \\
$\beta_{3}$ & 2,8754 & 1,9906 & 4,6304 & $-0,5263$ & $-0,3467$ & 2,9593 \\
\hline
\end{tabular}

Os valores estimados para o experimento fatorial completo estão mostrados na Tabela 2.71. As Figuras 2.23 e 2.24 apresentam a comparação dos dados para as misturas contendo o CAP 50/70 e o CAP 85/100, respectivamente, para os agregados basáltico (a) e granítico (b).

Tabela 2.71 - Valores estimados do Módulo de Fluência, em MPa

\begin{tabular}{lcccc|ccc}
\hline & Teor de Fíler & \multicolumn{3}{c|}{ CAP 50/70 } & \multicolumn{3}{c}{ CAP 85/100 } \\
& $(\%)$ & Calcário & Cimento & Cal & Calcário & Cimento & Cal \\
\hline \multirow{2}{*}{ Agregado } & 2,5 & 175,8350 & 161,1125 & 171,1358 & 164,3908 & 152,2888 & 159,6917 \\
Basáltico & 5,0 & 166,5742 & & 161,8750 & 155,1300 & & 150,4308 \\
& 7,5 & 170,0842 & 155,3617 & 162,5683 & 155,8233 & 148,3075 & 152,2888 \\
\hline \multirow{3}{*}{ Agregado } & 2,5 & 156,1025 & 141,3800 & 155,1202 & 149,9869 & 141,6017 & 149,0046 \\
Granítico & 5,0 & 149,2992 & & 149,2017 & 144,0683 & & 143,9708 \\
& 7,5 & 150,3517 & 135,6292 & 150,2542 & 145,1208 & 137,6204 & 145,0233 \\
\hline
\end{tabular}

Nota-se que as misturas compostas pelo agregado basáltico apresentam os maiores valores de módulo de fluência, quando comparado às compostas pelo agregado granítico; e as misturas compostas pelo CAP 50/70 apresentam valores maiores de módulo de fluência, quando comparado às compostas pelo CAP 85/100. Em relação ao tipo de fíler, as misturas compostas pelo cimento Portland apresentam os menores valores de módulo de fluência, enquanto que as compostas pelo pó calcário apresentam os maiores valores. Quanto ao teor de fíler, as misturas 
contendo menores quantidades de fíler apresentam valores maiores de módulo de fluência, e para os teores de 5,0 e 7,5\% apresentam valores quase iguais.

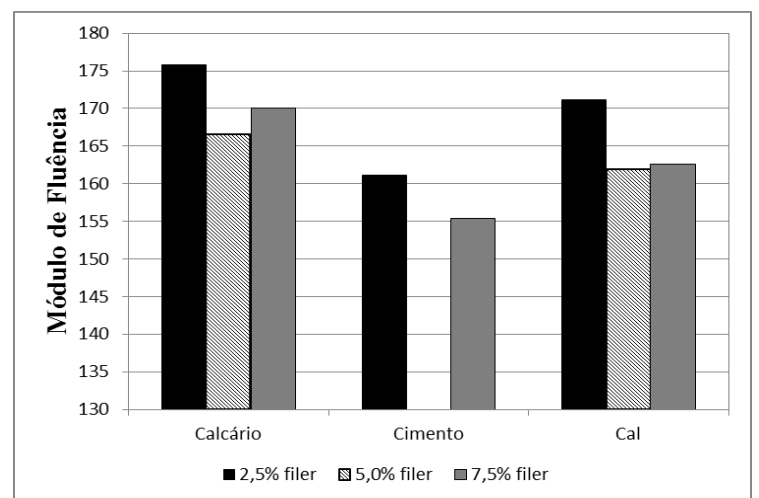

(a)

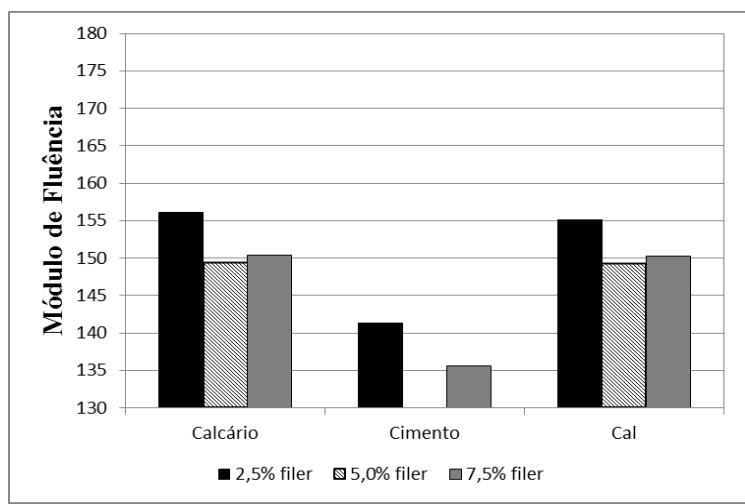

(b)

Figura 2.23 - Módulo de Fluência para misturas contendo CAP 50/70 e agregado: (a) basáltico e (b) granítico

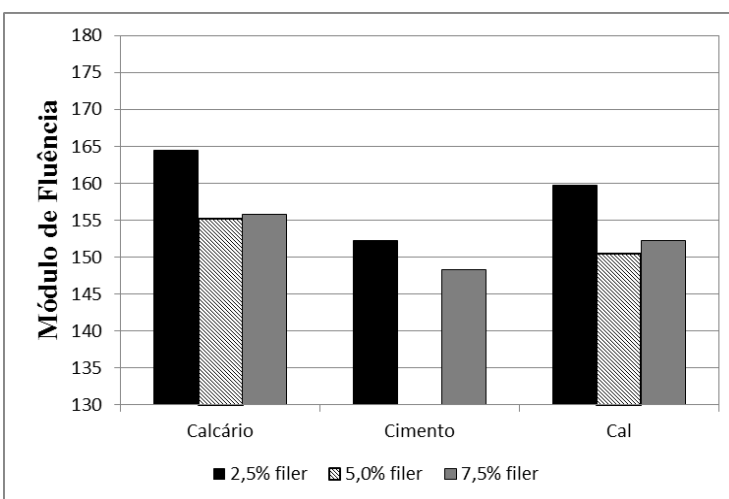

(a)

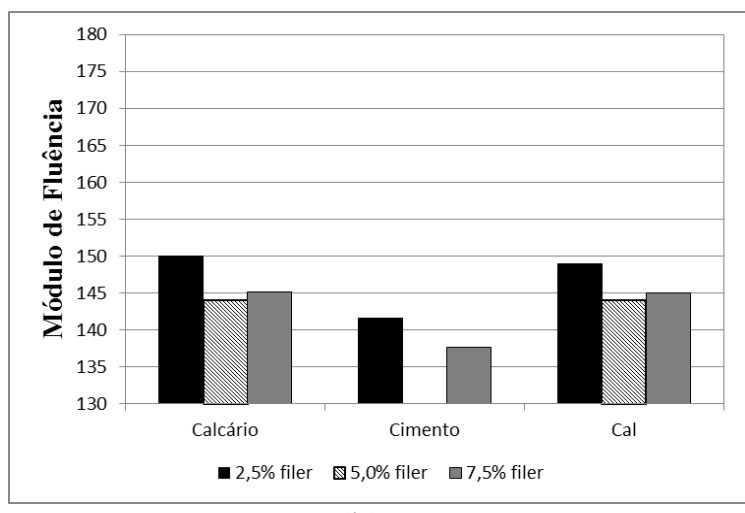

(b)

Figura 2.24 - Módulo de Fluência para misturas contendo CAP 85/100 e agregado: (a) basáltico e (b) granítico

Para testar quais fatores (tipo de fíler, teor de fíler, tipo de agregado e tipo de ligante asfáltico) influenciam nos resultados do módulo de fluência, realizou-se a Análise de Variância (ANOVA).

Primeiramente, a análise foi realizada considerando o fator tipo de agregado em dois níveis (agregado granítico e basáltico), o fator tipo de ligante asfáltico em dois níveis (CAP 50/70 e CAP 85/100), o fator tipo de fíler em três níveis (pó calcário, cimento Portland e cal hidratada) e o fator teor de fíler em dois níveis $(2,5$ e $7,5 \%)$. 
A segunda análise foi realizada considerando o fator tipo de agregado em dois níveis (agregado granítico e basáltico), o fator tipo de ligante asfáltico em dois níveis (CAP 50/70 e CAP 85/100), o fator tipo de fíler em dois níveis (pó calcário e cal hidratada) e o fator teor de fíler em três níveis (2,5; 5,0 e 7,5\%). A Tabela B.12 do Apêndice B apresenta o resumo dos valores da análise (1) e da análise (2) para a ANOVA.

A Tabela 2.72 apresenta o resumo da análise de variância, com os valores do teste $\mathrm{f}_{0}$ da análise de variância das respostas do módulo de fluência, com a resposta da influência dos fatores considerados, para as análises considerando o fator tipo de fíler em 3 níveis e o teor de fíler em 2 níveis (análise (1)) e o tipo de fíler em 2 níveis e o teor de fíler em 3 níveis (análise (2)).

Tabela 2.72 - Resumo da Análise de Variância do módulo de fluência, dos valores de $\mathrm{f}_{0}$ e da influência dos fatores e sua interação, para as análises (1) e (2)

\begin{tabular}{cccccc}
\hline \multirow{2}{*}{ Fator } & \multicolumn{2}{c}{ análise $(1)$} & \multicolumn{2}{c}{ análise $(2)$} & \multirow{2}{*}{ Influência } \\
\cline { 2 - 5 } & $\mathrm{F}_{0}$ & $\mathrm{f}_{0}$ & $\mathrm{~F}_{0}$ & $\mathrm{f}_{0}$ & \\
\hline Tipo de agregado (Fator A) & 1989,81 & 18,51 & 1581,44 & 18,51 & sim \\
Tipo de Ligante Asfáltico (Fator B) & 473,87 & 18,51 & 675,47 & 18,51 & sim \\
Tipo de fíler (Fator C) & 491,89 & 19,0 & 65,42 & 18,51 & sim \\
Teor de fíler (Fator D) & 323,40 & 18,51 & 198,17 & 19,0 & sim \\
Interação AB & 123,80 & 18,51 & 87,13 & 18,51 & sim \\
Interação AC & 18,91 & 19,0 & 47,69 & 18,51 & não \\
Interação AD & 7,91 & 18,51 & 9,54 & 19,0 & não \\
Interação BC & 31,70 & 19,0 & 1,00 & 18,51 & não \\
Interação BD & 0,90 & 18,51 & 0,19 & 19,0 & não \\
Interação CD & 1,98 & 19,0 & 0,19 & 19,0 & não \\
Interação ABC & 3,01 & 19,0 & 1,00 & 18,51 & não \\
Interação ABD & 0,79 & 18,51 & 0,55 & 19,0 & não \\
Interação ACD & 2,57 & 19,0 & 0,55 & 19,0 & não \\
Interação BCD & 1,62 & 19,0 & 1,00 & 19,0 & não \\
\hline
\end{tabular}

Pode-se perceber que o tipo de agregado, o tipo de ligante asfáltico e o tipo e teor de fíler influenciam na resposta da recuperação das misturas asfálticas, assim como a interação entre o tipo de agregado e o tipo de ligante asfáltico. 
(f) Módulo de Fluência Após a Recuperação

Os resultados de módulo de fluência após a recuperação estão apresentados na Tabela 2.73, referentes aos valores médios de três determinações para as diferentes condições experimentais.

Tabela 2.73 - Valores médios do Módulo de Fluência Após a Recuperação, em MPa

\begin{tabular}{|c|c|c|c|c|c|c|c|}
\hline & \multirow{2}{*}{$\begin{array}{c}\text { Teor de Fíler } \\
(\%)\end{array}$} & \multicolumn{3}{|c|}{ CAP 50/70 } & \multicolumn{3}{|c|}{ CAP 85/100 } \\
\hline & & Calcário & Cimento & Cal & Calcário & Cimento & Cal \\
\hline \multirow{3}{*}{$\begin{array}{c}\text { Agregado } \\
\text { Basáltico }\end{array}$} & 2,5 & 683,7625 & & \multirow{3}{*}{473,8800} & \multirow{3}{*}{453,5933} & & 493,8717 \\
\hline & 5,0 & & & & & & \\
\hline & 7,5 & & 448,0483 & & & 388,4075 & \\
\hline \multirow{3}{*}{$\begin{array}{l}\text { Agregado } \\
\text { Granítico }\end{array}$} & 2,5 & & 408,3750 & \multirow{3}{*}{479,6933} & \multirow{3}{*}{431,5600} & 420,0567 & \\
\hline & 5,0 & & & & & & \\
\hline & 7,5 & 483,6117 & & & & & 466,5817 \\
\hline
\end{tabular}

A Tabela 2.74 mostra os valores dos efeitos dos fatores $A, B$ e $C$, e os valores de $\beta_{0}, \beta_{1}, \beta_{2} e$ $\beta_{3}$.para cada parte do experimento fatorial fracionado em dois níveis.

Tabela 2.74 - Dados do experimento fatorial fracionado para a análise do Módulo de Fluência Após a Recuperação

\begin{tabular}{ccccccc}
\hline & Parte 1 & Parte 2 & Parte 3 & Parte 4 & Parte 5 & Parte 6 \\
\hline Efeito do Fator A & 119,9121 & 2,1796 & 105,0888 & $-32,5817$ & 117,7015 & 57,9663 \\
Efeito do Fator B & 155,4754 & $-75,9946$ & 84,8021 & $-15,5517$ & $-97,4148$ & 9,8329 \\
Efeito do Fator C & 80,2388 & 29,4696 & 125,0804 & $-19,4700$ & $-32,2290$ & 74,3242 \\
\hline$\beta_{0}$ & 505,9494 & 442,2294 & 526,2769 & 465,3617 & 479,8511 & 492,7888 \\
$\beta_{1}$ & 59,9560 & 1,0898 & 52,5444 & $-16,2908$ & 58,8507 & 28,9831 \\
$\beta_{2}$ & 77,7377 & $-37,9973$ & 42,4010 & $-7,7758$ & $-48,7074$ & 4,9165 \\
$\beta_{3}$ & 40,1194 & 14,7348 & 62,5402 & $-9,7350$ & $-16,1145$ & 37,1621 \\
\hline
\end{tabular}

Os valores estimados para o experimento fatorial completo estão mostrados na Tabela 2.75. As Figuras 2.25 e 2.26 apresentam a comparação dos dados para as misturas contendo o CAP 50/70 e o CAP 85/100, respectivamente, para os agregados basáltico (a) e granítico (b). 
Tabela 2.75 - Valores estimados do Módulo de Fluência Após a Recuperação, em MPa

\begin{tabular}{lcccc|ccc}
\hline & Teor de Fíler & \multicolumn{3}{c|}{ CAP 50/70 } & \multicolumn{3}{c}{ CAP 85/100 } \\
& $(\%)$ & Calcário & Cimento & Cal & Calcário & Cimento & Cal \\
\hline \multirow{2}{*}{ Agregado } & 2,5 & 683,7625 & 528,2871 & 598,9604 & 578,6738 & 417,8771 & 493,8717 \\
Basáltico & 5,0 & 558,6821 & & 473,8800 & 453,5933 & & 368,7913 \\
& 7,5 & 603,5238 & 448,0483 & 506,1090 & 485,8223 & 388,4075 & 417,8771 \\
\hline \multirow{2}{*}{ Agregado } & 2,5 & 563,8504 & 408,3750 & 554,0175 & 505,8842 & 420,0567 & 496,0513 \\
Granítico & 5,0 & 464,1417 & & 479,6933 & 431,5600 & & 447,1117 \\
& 7,5 & 483,6117 & 328,1363 & 499,1633 & 451,0300 & 390,5871 & 466,5817 \\
\hline
\end{tabular}

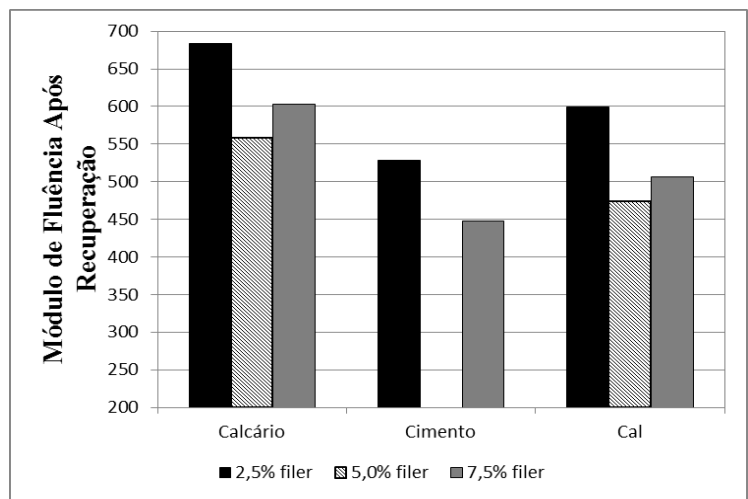

(a)

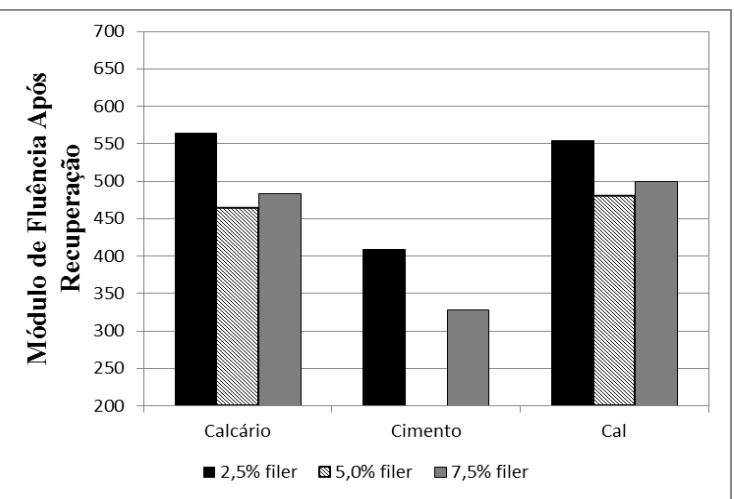

(b)

Figura 2.25 - Módulo de Fluência Após a Recuperação para misturas contendo CAP 50/70 e agregado: (a) basáltico e (b) granítico

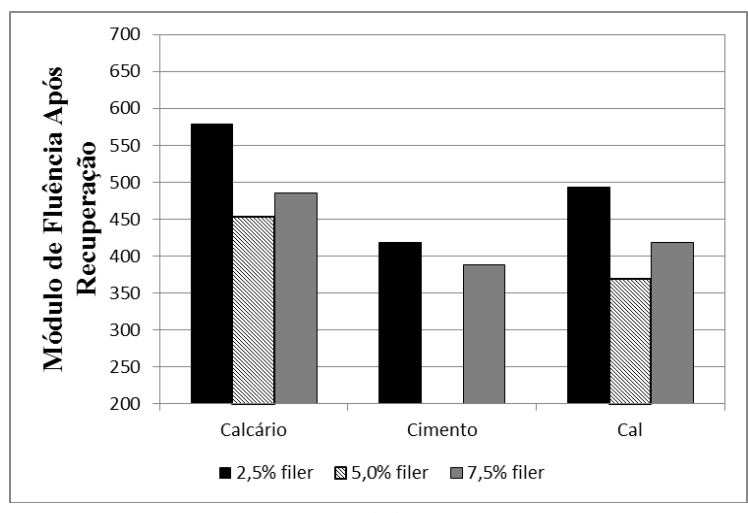

(a)

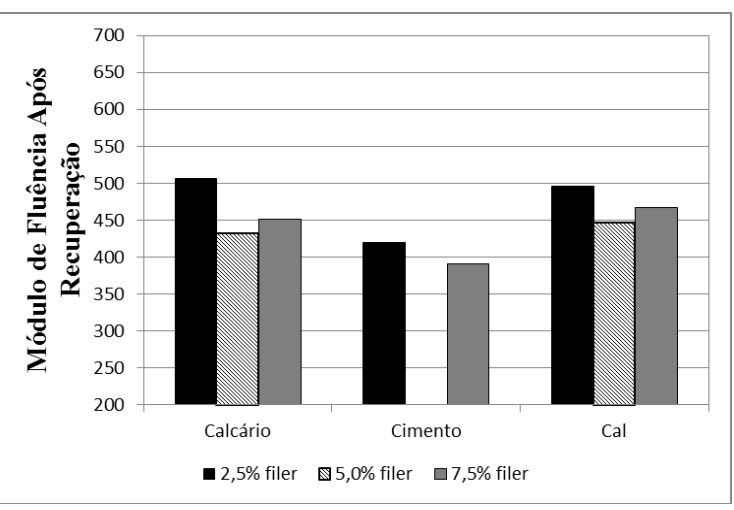

(b)

Figura 2.26 - Módulo de Fluência Após a Recuperação para misturas contendo CAP 85/100 e agregado: (a) basáltico e (b) granítico 
Nota-se que as misturas compostas com o agregado basáltico e o CAP 50/70 apresentam os maiores valores de módulo de fluência após a recuperação. Em relação ao tipo de fíler, as misturas contendo o pó calcário apresentaram os maiores valores da propriedade, enquanto que as contendo o fíler de cimento Portland apresentam os menores valores. Quanto ao teor de fíler, as misturas contendo menores quantidades de fíler apresentam os maiores valores da propriedade, enquanto que as contendo teor intermediário $(5,0 \%)$ de fíler apresentam os menores valores da propriedade.

Para testar quais fatores (tipo de fíler, teor de fíler, tipo de agregado e tipo de ligante asfáltico) influenciam nos resultados do módulo de fluência após a recuperação, realizou-se a Análise de Variância (ANOVA).

Primeiramente, a análise foi realizada considerando o fator tipo de agregado em dois níveis (agregado granítico e basáltico), o fator tipo de ligante asfáltico em dois níveis (CAP 50/70 e CAP 85/100), o fator tipo de fíler em três níveis (pó calcário, cimento Portland e cal hidratada) e o fator teor de fíler em dois níveis $(2,5$ e $7,5 \%)$.

A segunda análise foi realizada considerando o fator tipo de agregado em dois níveis (agregado granítico e basáltico), o fator tipo de ligante asfáltico em dois níveis (CAP 50/70 e CAP 85/100), o fator tipo de fíler em dois níveis (pó calcário e cal hidratada) e o fator teor de fíler em três níveis (2,5; 5,0 e 7,5\%). A Tabela B.13 do Apêndice B apresenta o resumo dos valores da análise (1) e da análise (2) para a ANOVA.

A Tabela 2.76 apresenta o resumo da análise de variância, com os valores do teste $\mathrm{f}_{0}$ da análise de variância das respostas do módulo de fluência após a recuperação, com a resposta da influência dos fatores considerados, para as análises considerando o fator tipo de fíler em 3 níveis e o teor de fíler em 2 níveis (análise (1)) e o tipo de fíler em 2 níveis e o teor de fíler em 3 níveis (análise (2)).

Pode-se perceber que o tipo de agregado, o tipo de ligante asfáltico e o tipo e teor de fíler influenciam na resposta da recuperação das misturas asfálticas, assim como a interação entre o tipo de agregado com o tipo de ligante asfáltico e com o tipo de fíler. 
Tabela 2.76 - Resumo da Análise de Variância do Módulo de Fluência após a Recuperação, dos valores de $\mathrm{f}_{0}$ e da influência dos fatores e sua interação, para as análises (1) e (2)

\begin{tabular}{cccccc}
\hline \multirow{2}{*}{ Fator } & \multicolumn{2}{c}{ análise $(1)$} & \multicolumn{2}{c}{ análise $(2)$} & \multirow{2}{*}{ Influência } \\
\cline { 2 - 5 } & $\mathrm{F}_{0}$ & $\mathrm{f}_{0}$ & $\mathrm{~F}_{0}$ & $\mathrm{f}_{0}$ & \\
\hline Tipo de agregado (Fator A) & 285,88 & 18,51 & 167,02 & 18,51 & sim \\
Tipo de Ligante Asfáltico (Fator B) & 402,87 & 18,51 & 876,66 & 18,51 & sim \\
Tipo de fíler (Fator C) & 692,73 & 19,0 & 245,80 & 18,51 & sim \\
Teor de fíler (Fator D) & 511,20 & 18,51 & 579,84 & 19,0 & sim \\
Interação AB & 192,56 & 18,51 & 166,30 & 18,51 & sim \\
Interação AC & 78,62 & 19,0 & 344,67 & 18,51 & sim \\
Interação AD & 12,59 & 18,51 & 36,11 & 19,0 & não \\
Interação BC & 35,00 & 19,0 & 1,00 & 18,51 & não \\
Interação BD & 20,55 & 18,51 & 3,24 & 19,0 & não \\
Interação CD & 5,05 & 19,0 & 3,24 & 19,0 & não \\
Interação ABC & 14,00 & 19,0 & 1,00 & 18,51 & não \\
Interação ABD & 1,82 & 18,51 & 2,74 & 19,0 & não \\
Interação ACD & 4,51 & 19,0 & 2,74 & 19,0 & não \\
Interação BCD & 5,14 & 19,0 & 1,00 & 19,0 & não \\
\hline
\end{tabular}

(g) Inclinação

Os resultados da inclinação estão apresentados na Tabela 2.77, referentes aos valores médios de três determinações para as diferentes condições experimentais.

Tabela 2.77 - Valores médios da Inclinação

\begin{tabular}{cc|ccc|ccc}
\hline & Teor de Fíler & \multicolumn{3}{|c|}{ CAP 50/70 } & \multicolumn{3}{c}{ CAP 85/100 } \\
& $(\%)$ & Calcário & Cimento & Cal & Calcário & Cimento & Cal \\
\hline \multirow{2}{*}{ Agregado } & 2,5 & 0,04561 & & & & & 0,03975 \\
Basáltico & 5,0 & & & 0,05714 & 0,03987 & \\
& 7,5 & & 0,05646 & & & 0,03545 \\
\hline \multirow{2}{*}{ Agregado } & 2,5 & \multicolumn{2}{|c|}{0,06160} & & \multicolumn{3}{|c}{0,03595} \\
Granítico & 5,0 & & & 0,06307 & 0,03683 & & \\
& 7,5 & 0,06420 & & & & & 0,04428 \\
\hline
\end{tabular}


A Tabela 2.78 mostra os valores dos efeitos dos fatores $A, B$ e $C$, e os valores de $\beta_{0}, \beta_{1}, \beta_{2} e$ $\beta_{3}$.para cada parte do experimento fatorial fracionado em dois níveis.

Tabela 2.78 - Dados do experimento fatorial fracionado para a análise da Inclinação

\begin{tabular}{ccccccc}
\hline & Parte 1 & Parte 2 & Parte 3 & Parte 4 & Parte 5 & Parte 6 \\
\hline Efeito do Fator A & $-0,01187$ & 0,00251 & 0,01156 & $-0,02309$ & 0,01708 & 0,02073 \\
Efeito do Fator B & $-0,00413$ & $-0,00631$ & $-0,00571$ & $-0,00316$ & 0,00019 & $-0,00552$ \\
Efeito do Fator C & $-0,00673$ & $-0,00201$ & $-0,00582$ & $-0,00429$ & 0,00461 & $-0,00008$ \\
\hline$\beta_{0}$ & 0,05697 & 0,03886 & 0,04559 & 0,05210 & 0,04620 & 0,04991 \\
$\beta_{1}$ & $-0,00594$ & 0,00126 & 0,00578 & $-0,01154$ & 0,00854 & 0,01036 \\
$\beta_{2}$ & $-0,00206$ & $-0,00316$ & $-0,00285$ & $-0,00158$ & 0,00010 & $-0,00276$ \\
$\beta_{3}$ & $-0,00336$ & $-0,00101$ & $-0,00291$ & $-0,00214$ & 0,00231 & $-0,00004$ \\
\hline
\end{tabular}

Os valores estimados para o experimento fatorial completo estão mostrados na Tabela 2.79. As Figuras 2.27 e 2.28 apresentam a comparação dos dados para as misturas contendo o CAP 50/70 e o CAP 85/100, respectivamente, para os agregados basáltico (a) e granítico (b).

Tabela 2.79 - Valores estimados da Inclinação

\begin{tabular}{ccccc|ccc}
\hline & Teor de Fíler & \multicolumn{3}{c|}{ CAP 50/70 } & \multicolumn{3}{c}{ CAP 85/100 } \\
& $(\%)$ & Calcário & Cimento & Cal & Calcário & Cimento & Cal \\
\hline \multirow{2}{*}{ Agregado } & 2,5 & 0,0456 & 0,0497 & 0,0513 & 0,0340 & 0,0334 & 0,0398 \\
Basáltico & 5,0 & 0,0514 & & 0,0571 & 0,0399 & & 0,0456 \\
& 7,5 & 0,0523 & 0,0565 & 0,0525 & 0,0353 & 0,0354 & 0,0334 \\
\hline \multirow{3}{*}{ Agregado } & 2,5 & 0,0575 & 0,0616 & 0,0630 & 0,0367 & 0,0360 & 0,0423 \\
Granítico & 5,0 & 0,0599 & & 0,0631 & 0,0368 & & 0,0400 \\
& 7,5 & 0,0642 & 0,0683 & 0,0674 & 0,0411 & 0,0380 & 0,0443 \\
\hline
\end{tabular}

Nota-se que as misturas compostas com o CAP 50/70 apresentaram os maiores valores de inclinação; quanto ao tipo de agregado, quando combinado com o CAP 50/70 as misturas contendo granito apresentaram os maiores valores de inclinação, já para o CAP 85/100, as misturas contendo os diferentes agregados não apresentaram diferença significativa nos valores de inclinação. Em relação ao tipo de fíler, as misturas contendo o pó calcário apresentaram os menores valores de inclinação, quando combinados com o CAP 50/70, já as misturas contendo o CAP 85/100, as contendo o fíler de cimento Portland apresentaram os menores valores de 
inclinação. Quanto ao teor de fíler, as misturas contendo menores quantidades de fíler apresentam os menores valores de inclinação.

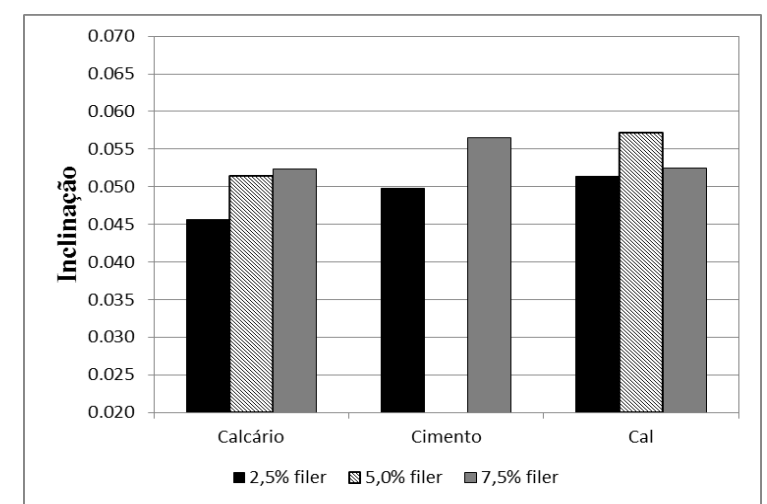

(a)

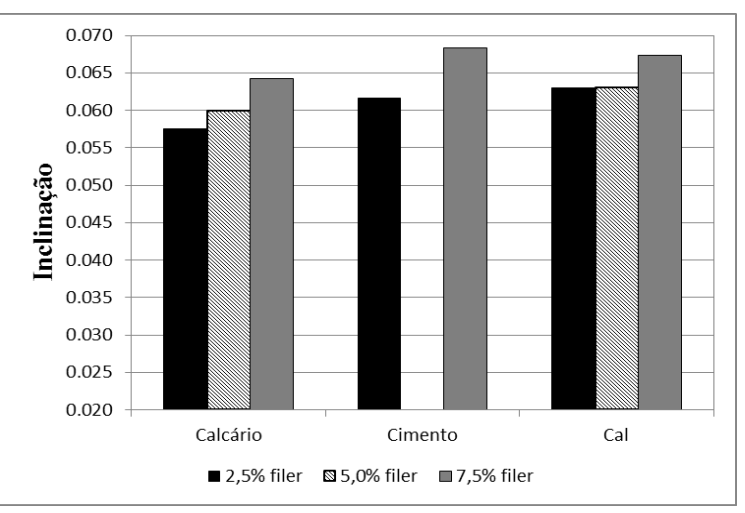

(b)

Figura 2.27 - Inclinação para misturas contendo CAP 50/70 e agregado: (a) basáltico e (b) granítico

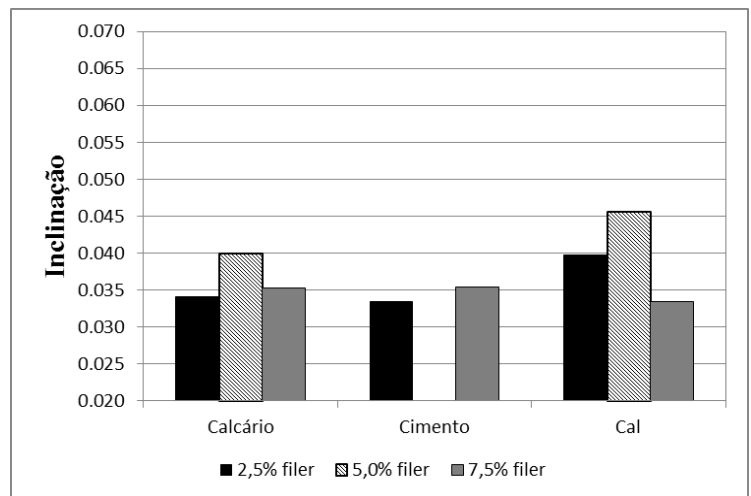

(a)

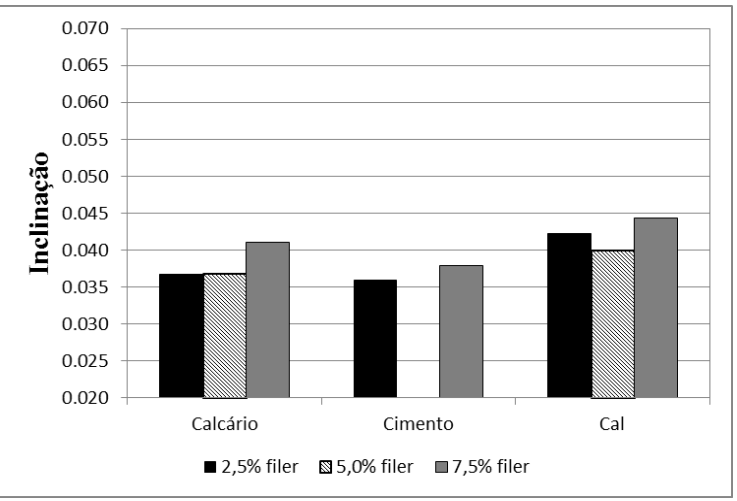

(b)

Figura 2.28 - Inclinação para misturas contendo CAP 85/100 e agregado: (a) basáltico e (b) granítico

Para testar quais fatores (tipo de fíler, teor de fíler, tipo de agregado e tipo de ligante asfáltico) influenciam nos resultados na inclinação, realizou-se a Análise de Variância (ANOVA).

Primeiramente, a análise foi realizada considerando o fator tipo de agregado em dois níveis (agregado granítico e basáltico), o fator tipo de ligante asfáltico em dois níveis (CAP 50/70 e CAP 85/100), o fator tipo de fíler em três níveis (pó calcário, cimento Portland e cal hidratada) e o fator teor de fíler em dois níveis $(2,5$ e 7,5\%). 
A segunda análise foi realizada considerando o fator tipo de agregado em dois níveis (agregado granítico e basáltico), o fator tipo de ligante asfáltico em dois níveis (CAP 50/70 e CAP 85/100), o fator tipo de fíler em dois níveis (pó calcário e cal hidratada) e o fator teor de fíler em três níveis $(2,5 ; 5,0$ e 7,5\%). A Tabela B.14 do Apêndice B apresenta o resumo dos valores da análise (1) e da análise (2) para a ANOVA.

A Tabela 2.80 apresenta o resumo da análise de variância, com os valores do teste $\mathrm{f}_{0}$ da análise de variância das respostas da inclinação, com a resposta da influência dos fatores considerados, para as análises (1) análise (2).

Pode-se perceber que o tipo de agregado, o tipo de ligante asfáltico e o tipo e teor de fíler influenciam na resposta da inclinação das misturas asfálticas, assim como a interação entre o tipo de agregado com o tipo de ligante asfáltico e o tipo de ligante asfáltico com o teor de fíler.

Tabela 2.80 - Resumo da Análise de Variância da inclinação, dos valores de $\mathrm{f}_{0}$ e da influência dos fatores e sua interação, para as análises (1) e (2)

\begin{tabular}{cccccc}
\hline \multirow{2}{*}{ Fator } & \multicolumn{2}{c}{ Análise $(1)$} & \multicolumn{2}{c}{ Análise $(2)$} & Influência \\
\cline { 2 - 5 } & $\mathrm{F}_{0}$ & $\mathrm{f}_{0}$ & $\mathrm{~F}_{0}$ & $\mathrm{f}_{0}$ & \\
\hline Tipo de agregado (Fator A) & 500,24 & 18,51 & 1501,23 & 18,51 & sim \\
Tipo de Ligante Asfáltico (Fator B) & 2832,76 & 18,51 & 11543,16 & 18,51 & sim \\
Tipo de fíler (Fator C) & 27,26 & 19,0 & 497,89 & 18,51 & sim \\
Teor de fíler (Fator D) & 70,07 & 18,51 & 121,10 & 19,0 & sim \\
Interação AB & 108,66 & 18,51 & 652,00 & 18,51 & sim \\
Interação AC & 4,74 & 19,0 & 1,52 & 18,51 & não \\
Interação AD & 10,52 & 18,51 & 266,43 & 19,0 & não \\
Interação BC & 19,51 & 19,0 & 1,00 & 18,51 & não \\
Interação BD & 36,26 & 18,51 & 62,65 & 19,0 & sim \\
Interação CD & 14,23 & 19,0 & 62,65 & 19,0 & não \\
Interação ABC & 1,16 & 19,0 & 1,00 & 18,51 & não \\
Interação ABD & 3,40 & 18,51 & 32,30 & 19,0 & não \\
Interação ACD & 5,18 & 19,0 & 32,30 & 19,0 & não \\
Interação BCD & 0,16 & 19,0 & 1,00 & 19,0 & não \\
\hline
\end{tabular}




\section{INFLUÊNCIA DO FÍLER NO COMPORTAMENTO DO MÁSTIQUE} ASFÁLTICO

\subsection{INTRODUÇÃO}

O mástique asfáltico, que é a mistura de fíler mineral e de ligante asfáltico, tem influência significativa no comportamento das misturas asfálticas. A função do fíler mineral é mais que apenas finos inertes no ligante asfáltico, pois as interações físico-químicas entre o ligante asfáltico e o fíler afetam o desempenho do revestimento, ou seja, apenas a relação fíler/asfalto da Especificação Superpave não é suficiente para avaliar as interações e toda a influência do fíler nas propriedades da mistura.

O mástique envolve e aglutina os agregados graúdos das misturas asfálticas, além de preencher os vazios existentes no esqueleto mineral, garantindo compacidade, impermeabilidade e trabalhabilidade às misturas asfálticas. Habitualmente, nos estudos do mástique caracteriza-se o fíler, a relação fíler/ligante asfáltico e o tipo de ligação entre o fíler e o ligante asfáltico, para avaliar a sua influência no comportamento do mástique e das misturas asfálticas. As conclusões de vários estudos (CRAUS e ISHAI, 1977; ISHAI e CRAUS, 1977; CRAUS et al., 1978b; ISHAI e CRAUS, 1978; CRAUS et al., 1979) indicam que o mástique, assim como os seus componentes (especialmente o fíler), tem uma influência significativa no comportamento das misturas asfálticas.

Neste contexto, a definição de mástique pode ser encontrada nos trabalhos de Harm e Hughes (1989), Mohamed e Nofal (1998), Sadd e Daí (2001), Buttlar e You (2001), Sadd et al. (2002) e You e Buttlar (2005). Estes autores consideram a mistura asfáltica como material heterogêneo, sendo constituída por dois materiais distintos: o mástique e os agregados mais grossos. O mástique, constituído pelos elementos mais finos da mistura asfáltica (ligante asfáltico e fíler), forma uma matriz com um comportamento viscoplástico que envolve e mantêm ligados os agregados mais grossos, considerados elementos elásticos embebidos no mástique. 
O aglutinante das misturas asfálticas é constituído por ligante asfáltico e fíler, ou seja, o mástique. As propriedades do mástique são determinadas pelo tipo e pela quantidade dos seus componentes, pelas propriedades reológicas do ligante asfáltico e pela forma e estrutura dos grãos de fíler. O mástique tem grande influência na estrutura da mistura asfáltica em um nível micro-estrutural.

De acordo com Craus et al. (1978a), o aspecto físico-químico está relacionado com a intensidade de adsorção da interface fíler-ligante asfáltico e é influenciado pela finura e as características de superfície do fíler. Assim, maior atividade de superfície contribui significativamente para ligações mais fortes na interface físico-química, influenciando as características mecânicas da mistura asfáltica, como a ruptura por fadiga.

A viscosidade da mistura fíler/ligante asfáltico está diretamente relacionada com o diâmetro da partícula do fíler: quanto menor o diâmetro do fíler, maior o aumento da viscosidade do mástique. Assim, a adição de fíler aumenta a viscosidade do mástique (KAVUSSI e HICKS, 1997).

A afinidade superficial dos fileres afeta a viscosidade da mistura fíler-asfalto, pois fileres com maior adsorção refletem em maior viscosidade do mástique asfáltico, assim, partículas mais finas incorporam-se mais ao ligante asfáltico, resultando em misturas mais rígidas (KALLAS e PUZINAUSKAS, 1961).

Para Chen e Peng (1998), a utilização do fíler em misturas asfálticas é baseada nos seguintes conceitos: (a) redução dos custos iniciais, pois a demanda por ligante asfáltico na mistura asfáltica é reduzida pela utilização de fíler; (b) obtenção de misturas asfálticas mais rígidas, resultantes da adição de fíler mineral, observada tanto em laboratório quanto em campo e; (c) melhorar o desempenho do revestimento, pois a adição fíler mineral em misturas asfálticas aumenta a resistência à deformação permanente a altas temperaturas. Porém, o fíler mineral pode produzir mástiques que exibem comportamento excessivamente rígido, produzindo misturas asfálticas quebradiças, que afetam negativamente o desempenho do revestimento submetido a baixas temperaturas, resultam em trincas térmicas. 
O conceito de asfalto livre é um fator importante que afeta as propriedades do mástique. Quando o fíler mineral e o ligante asfáltico são misturados, a quantidade de asfalto adicionado deve ser primeiramente suficiente para preencher os vazios entre as partículas do fíler. O volume de asfalto requerido para preencher esses vazios é chamado asfalto fixo. Qualquer quantidade de asfalto adicionado à mistura fíler-ligante a mais que o asfalto fixo é chamada asfalto livre, disponível para lubrificar a mistura fíler-ligante, que em volume deve ser maior que 30\%, para que o fíler mineral flutue no ligante asfáltico e o contato partícula-partícula de fíler mineral não existe (ANDERSON, 1987; CHEN e PENG, 1998).

O dano por fadiga das misturas asfálticas está fortemente relacionado com as características do ligante asfáltico, as propriedades do fíler e a interação entre o ligante asfáltico e o fíler, sendo um fenômeno afetado pelo desenvolvimento e crescimento de fissuras no mástique, que se propagam para a mistura asfáltica (KIM et al., 2003).

Smith e Hesp (2000) estudaram os efeitos das dimensões das partículas de fíler na recuperação mecânica (“healing”) do mástique e da mistura asfáltica a baixas temperaturas. A recuperação mecânica foi avaliada pela medição da recuperação da rigidez de cada corpo de prova após um período de duas horas de repouso, em ensaio de fadiga em um reômetro de cisalhamento dinâmico. Os autores concluíram que os mástique com fileres mais grossos têm uma recuperação mecânica maior do que os mástiques com um fíler mais fino.

Pilat et al. (2000), ao investigarem a possibilidade de aumento da resistência à deformação permanente das misturas asfálticas, mediante às propriedades viscoelásticas do mástique. Concluíram que a adição de cal hidratada, substituindo parte do fíler mineral, melhora a resistência das misturas asfálticas à deformação permanente.

Algumas considerações podem ser feitas a partir de microscopia de finas seções de misturas asfálticas (ANDERSON et al., 1992):

- Em termos de interação físico-química entre o ligante asfáltico e a superfície do mineral, as propriedades da fração fina dominam, pois os finos estão embutidos no ligante asfáltico, e, portanto, têm mais proximidade; 
- A maior parte da superfície específica dos agregados vem dos finos. A superfície específica da fração menor que a peneira $\mathrm{n}^{\circ} 200$ pode ser maior que $1 \mathrm{~m}^{2} / \mathrm{g}$. Portanto, os finos são os maiores contribuidores para qualquer interação físico-química entre a superfície do agregado mineral e o ligante asfáltico;

- Em termos de envelhecimento acelerado, o ensaio de envelhecimento em filme fino (TFOT) não é representativo para misturas asfálticas, pois a distância média de uma molécula de asfalto para o ambiente (oxigênio) é da ordem de vários milhares de $\mu \mathrm{m}$ e não de 10 a $20 \mu \mathrm{m}$, valores muitas vezes assumido por pesquisadores;

- As hipóteses anteriores não implicam que os agregados graúdos não têm importância determinante nas propriedades mecânicas e de envelhecimento das misturas asfálticas, pois a fração de agregados graúdos é dominante nas características de absorção dos agregados, o que tem grande importância no envelhecimento das misturas asfálticas.

\subsubsection{Importância das Propriedades Reológicas dos Mástiques}

Os fileres, quando combinados com o ligante asfáltico, provocam alterações nas propriedades físicas e químicas dos ligantes, as quais dependem do tipo, natureza e concentração do fíler na mistura (KAVUSSI e HICKS, 1997).

A adição de fíler em ligantes asfálticos provoca modificações em seu comportamento reológico, com aumento do módulo complexo e a redução do ângulo de fase, em razão da natureza rígida do fíler mineral. Deve-se destacar que alguns modificadores, como os polímeros e a borracha moída apresentam módulo menor que o dos ligantes asfálticos, sob temperaturas baixas ou intermediárias (BAHIA, 1995).

Os efeitos da incorporação do fíler ao ligante asfáltico são mais significativos e favoráveis nas altas temperaturas, aumentando a rigidez do ligante. Porém, a baixas temperaturas, o fíler aumenta ainda mais a rigidez do ligante asfáltico, acarretando redução da capacidade de relaxar tensões (BAHIA, 1995).

As propriedades reológicas do mástique são resultado da combinação das características elásticas, viscoelásticas ou viscosas do ligante asfáltico e da natureza elástica do fíler mineral, o que afeta 
as propriedades mecânicas da mistura asfáltica composta por esses materiais. Com isso, o estudo das propriedades reológicas do mástique permite uma avaliação de como esse componente pode afetar as propriedades da mistura asfáltica (BECHARA et al., 2008).

Com o surgimento dos ensaios que têm como princípio a avaliação das propriedades fundamentais dos materiais, como é o caso da Especificação Superpave, a simulação das solicitações do tráfego e do intemperismo estão mais próximos das condições a que os ligantes asfálticos, e consequentemente os mástiques, são submetidos em campo (ANDERSON et al., 1994). Um dos ensaios mais utilizados é o de cisalhamento em regime dinâmico (DSR), que pode gerar a curva-mestre, uma representação do comportamento reológico do material em função da frequência (e/ou tempo) de carregamento.

O estudo do comportamento reológico do mástique pode ter três objetivos fundamentais: (1) avaliar o efeito que a quantidade de finos minerais selecionada no projeto da composição granulométrica poderá ter sobre as propriedades mecânicas da mistura asfáltica; (2) monitorar os efeitos que diferentes tipos de finos minerais, para uma mistura asfáltica com a mesma composição granulométrica, poderão ter sobre as propriedades mecânicas da mistura asfáltica e (3) estimar o aumento de rigidez e de elasticidade do ligante asfáltico proporcionada pela adição de finos minerais em diferentes relações fíler/asfalto. Nas duas primeiras situações, os finos minerais são abordados como frações do esqueleto pétreo que compõe a mistura asfáltica e, na terceira, são abordados como modificadores do ligante asfáltico de base (BECHARA et al., 2008)

A curva-mestre tem sido muito utilizada para avaliar o ângulo de fase ou o módulo complexo, em para uma temperatura de referência e para um espectro de frequências, e/ou tempo, de carregamento.

Segundo Bahia (1995), a adição de fíler mineral ao ligante asfáltico provoca um aumento do parâmetro $\mathrm{G}^{*} / \operatorname{sen} \delta$ da especificação Supepave, o que é favorável por aumentar a resistência do ligante à deformação permanente, mas também provoca um aumento do parâmetro $G *$ sen $\delta$, o que é desfavorável em relação ao dano por fadiga, quando o fenômeno ocorre por deformação controlada. Portanto, os efeitos do fíler adicionado ao ligante asfáltico são desfavoráveis a 
temperaturas baixas e intermediarias, pois a rigidez do fíler mineral é muitas vezes maior que a do ligante, proporcionando mástiques mais rígidos.

Bechara et al. (2008) analisaram diferentes relações fíler/ligante asfáltico, e para todas elas o módulo complexo $\left(\mathrm{G}^{*}\right)$ e o parâmetro de deformação permanente do Superpave $\left(\mathrm{G}^{*} / \operatorname{sen} \delta\right)$ aumentaram, ou seja, a adição de fíler pode refletir em um aumento na resistência à deformação permanente das misturas asfálticas. Também ocorreu a redução do ângulo de fase $(\delta)$ com a adição de fíler, o que tornou o mástique mais elástico.

Anderson et al. (1992) analisaram as propriedades reológicas dos mástiques através de um conjunto de curvas-mestre para o módulo complexo e para o ângulo de fase. Observando que nas temperaturas de intermediárias a baixas, o efeito da adição do fíler é praticamente inexpressivo, já nas temperaturas mais altas o efeito mais expressivo no aumento da rigidez do ligante asfáltico provoca um deslocamento vertical na escala de rigidez, praticamente uniforme ao longo da escala de frequência; a elasticidade também aumenta com a adição de fíler, o que é indicado pela redução dos valores de ângulo de fase. Comparando as curvas-mestre da taxa de aumento de $G^{*}$ e G”, em que a taxa utilizada é a relação entre o módulo complexo do material com fíler pelo do material sem fíler, há uma redução gradativa do componente dissipativo do módulo complexo com a redução da temperatura, indicando aumento da elasticidade. No entanto, a adição de quartzo impõe um aumento mais expressivo que a calcita sobre o componente dissipativo do módulo nas temperaturas altas. A calcita torna o ligante asfáltico menos sensível ao efeito da temperatura ou da frequência de carregamento que o quartzo.

Para Anderson et al. (1992), os fatores de deslocamento são pouco sensíveis à adição de finos, o que indica que a dependência da temperatura do mástique e do ligante asfáltico é essencialmente a mesma. Os autores avaliaram as curvas-mestre do aumento relativo do módulo complexo de dois ligantes asfálticos misturados com dois fileres antes a após envelhecimento a longo prazo no PAV, e perceberam que o efeito do tipo de ligante asfáltico é mais expressivo que o efeito do tipo de fíler e que nas temperaturas de intermediárias a altas os ligantes asfálticos são mais sensíveis ao efeito do envelhecimento, enquanto que nas temperaturas de intermediárias a baixas, o efeito 
do tipo de fíler não é expressivo sobre o efeito do envelhecimento a longo prazo, indicando que o tipo de fíler não afeta a sensibilidade do ligante asfáltico ao envelhecimento.

Para Anderson et al. (1992), embora o módulo dos mástiques seja alto sob temperaturas baixas, a resistência à tração também mostrou aumento significativo. Para os vários ligantes asfálticos avaliados, a adição de fíler foi favorável e reduziu significativamente o acúmulo de deformação permanente, no entanto, a adição de fileres minerais pode comprometer a trabalhabilidade da mistura asfáltica e tornar a mistura compactada excessivamente rígida. Além disso, segundo a experiência dos autores, os procedimentos para envelhecimento a curto prazo, tanto no ensaio TFOT quanto no RTFOT, não são indicados para mástiques, em virtude da tendência de separação dos componentes e indicam o envelhecimento a longo prazo, no PAV, como método satisfatório para simular o envelhecimento.

Neste trabalho, o estudo da influência do fíler no mástique asfáltico foi realizado com a caracterização de suas propriedades reológicas, de ensaios de cisalhamento em regime oscilatório de viga em flexão e também, com o ensaio de ponto de amolecimento.

\subsubsection{Reologia de Ligantes e Mástiques Asfálticos}

A reologia de ligantes asfálticos envolve propriedades de fluxo tanto a altas quanto a baixas temperaturas, pois, entre os muitos parâmetros que afetam as propriedades reológicas dos ligantes asfálticos, a temperatura é um dos fatores que tem maior efeito sob seu comportamento reológico (WEGAN e BRULE, 1999).

Os ligantes asfálticos podem apresentar comportamento elástico, viscoso e viscoelástico, dependendo de fatores como temperatura, nível de tensão e tempo de carregamento, sendo tradicionalmente classificados como materiais viscoelásticos.

Um material viscoelástico apresenta tanto o comportamento elástico, em que o material deformase elasticamente e recupera a energia de deformação após a remoção das cargas aplicadas, quanto o comportamento viscoso, no qual o material se deforma permanentemente sob carregamento e 
dissipa a energia necessária para a deformação em forma de calor, que não é recuperada quando removido o carregamento aplicado.

O ligante asfáltico apresenta comportamentos diferentes dependendo da temperatura e do tempo de carregamento: em temperaturas altas (acima de $80^{\circ} \mathrm{C}$ ) ou tempo de carga maiores, se comporta como um líquido viscoso; em temperaturas muito baixas (abaixo de $0^{\circ} \mathrm{C}$ ) ou tempos de carga pequeno, se comporta como um sólido elástico; em temperaturas intermediárias (entre 0 e $80^{\circ} \mathrm{C}$ ), apresenta tanto características viscosas quanto elásticas.

A caracterização das propriedades reológicas do ligante asfáltico deve ser realizada ao longo de toda a faixa de temperaturas ou de tempos de carregamento à qual o pavimento pode ser submetido ao longo da sua vida em serviço: a altas temperaturas, quando atua como lubrificante e permite que seja misturado ao agregado; a temperaturas intermediárias, quando atua como aglutinante para unir os agregados; a baixas temperaturas, que podem estar sujeitos em serviço (YILDIRIM et al., 2000).

Faxina (2006) enfatiza a importância do estudo da reologia dos ligantes asfálticos por determinar a seleção das temperaturas para as operações de usinagem, mistura e compactação na construção do revestimento asfáltico e permitir relacionar os defeitos da camada asfáltica como as propriedades reológicas.

Na reologia dos sólidos, a viscosidade é o parâmetro mais importante, e na reologia de líquidos o mais importante é a elasticidade. Como o ligante asfáltico está sujeito a uma grande variação de temperatura ao longo da sua vida de serviço, é essencial a caracterização dos efeitos da temperatura na viscosidade (WEGAN e BRULE, 1999). Algumas propriedades importantes para o estudo da reologia dos ligantes asfálticos são: viscosidade, rigidez, elasticidade, deformação ao longo do tempo (fluência) e taxa de relaxação (ANDERSON et al., 1991).

A viscosidade pode ser definida como uma propriedade física de um fluido ao resistir ao fluxo induzido pelo cisalhamento, sendo a medida da fricção interna desse fluido quando uma camada 
de fluido move-se em relação a outra camada. Quanto maior a fricção, maior é a força de cisalhamento necessária para causar esse movimento (HOIBERG 1964).

O fluido pode apresentar dois tipos de comportamento (YILDIRIM et al., 2000):

- Fluido Newtoniano, em que a relação entre a tensão de cisalhamento e a taxa de cisalhamento é diretamente proporcional, e a viscosidade do fluido mantem-se constante quando há variação da taxa de cisalhamento. Isso significa que, a uma dada temperatura, a viscosidade de um fluido Newtoniano se manterá constante independentemente de qual modelo de viscosímetro ou taxa de deformação é utilizada para a medida;

- Fluido não-Newtoniano, em que a relação entre a tensão de cisalhamento e a taxa de cisalhamento não é constante, ou seja, quando a variação da taxa de cisalhamento, a tensão de cisalhamento não varia na mesma proporção, e a viscosidade do fluido irá variar com diferentes taxas de cisalhamento. Dependendo da resposta da viscosidade do fluido em relação à variação da taxa de cisalhamento, os fluidos não-Newtonianos podem ser classificados como pseudoplásticos, dilatantes ou plástico.

Devido à sua importância, a taxa de cisalhamento é um fator a ser considerado na avaliação do comportamento reológico de ligantes asfálticos, pois estão sujeitos a uma variação de taxas de cisalhamento durante a construção e, se não são conhecidas, uma estimativa deve ser feita (YILDIRIM et al., 2000).

\subsection{CARACTERIZAÇÃO DE LIGANTES E MÁSTIQUES ASFÁLTICOS}

\subsubsection{Especificação Superpave para Ligantes Asfálticos}

O Método Superpave é resultado das pesquisas feitas pelo programa SHRP (Strategic Highway Reserch Program), entre 1987 e 1993, sobre os materiais utilizados em revestimentos asfálticos (SHRP, 1993). Foram desenvolvidos métodos de análise de materiais betuminosos e misturas asfálticas baseados em propriedades fundamentais, diretamente relacionadas com o desempenho dos pavimentos em serviço (HUBER et al.,1998). 
O programa SHRP visou, principalmente, a avaliação de ligantes asfálticos, o projeto de misturas e sua análise. A especificação de ligantes asfálticos baseada no desempenho é o principal produto do programa de pesquisa de ligantes do SHRP, em que o objetivo principal era identificar e validar as propriedades de engenharia que poderiam estar diretamente relacionadas com a resposta ao carregamento do tráfego e das solicitações ambientais (SHRP-A-410).

A especificação Superpave controla a qualidade do ligante asfáltico em relação aos defeitos no pavimento, como deformação permanente, trincamento térmico e trincamento por fadiga, avaliando algumas propriedades físicas em quatro equipamentos: Reômetro de Viga à Flexão (BBR), Reômetro de Cisalhamento Dinâmico (DSR), Viscosímetro Rotacional e Ensaio de Tração Direta.

A especificação de ligantes asfálticos é baseada na temperatura do pavimento e no desempenho e propriedades de engenharia, ou seja, ao invés de mudar os requisitos das propriedades de engenharia para diferentes temperaturas, a especificação solicita as mesmas propriedades para todas as temperaturas, com a classificação indicando em quais temperaturas as propriedades são satisfeitas (SHRP-A-410). Por exemplo, a altas temperaturas, a rigidez de um ligante não envelhecido $\left(\mathrm{G}^{*} / \mathrm{sen} \delta\right)$ deve ser de no mínimo $1,0 \mathrm{kPa}$, requisito que também deve ser obtido a temperaturas mais elevadas, se o ligante for usado em um clima mais quente.

As propriedades físicas também são avaliadas em ligantes submetidos ao envelhecimento em laboratório, simulando o que ocorre no pavimento em campo. A avaliação de algumas propriedades físicas são realizadas no ligante não envelhecido, outras são realizadas em ligantes que sofreram envelhecimento em estufa de filme fino rotativo (RTFOT) e na estufa de vaso pressurizado (PAV), sendo que há também ensaios em amostras sem e com envelhecimento.

Os requisitos relacionados com o desempenho são listados a seguir (SHRP-A-410):

- Rigidez mínima (1,0 kPa), especificada para ligante não envelhecido, para garantir a estabilidade da mistura; 
- Rigidez mínima (2,0kPa), especificada para ligante envelhecido a curto prazo, para garantir uma adequada resistência à deformação permanente imediatamente após a construção;

- Rigidez máxima (5.000kPa), especificada para ligante envelhecido a longo prazo, para evitar o trincamento por fadiga causado por rigidez excessiva do ligante asfáltico;

- Rigidez máxima (300 MPa) e mínima inclinação $(0,30)$ da deformação à fluência na flexão são especificadas para evitar rigidez excessiva a baixas temperaturas e garantir uma adequada taxa de relaxação de tensões térmicas;

- Rigidez acima de $300 \mathrm{MPa}$ é permitida pela especificação se uma deformação de ruptura mínima (1\%) for alcançada (antecipa-se que isso será aplicado principalmente para ligantes modificados, que apresentam alta rigidez a baixa temperatura, mas apresentam alta deformação de ruptura).

\subsubsection{Envelhecimento de Ligante e do Mástique Asfáltico}

As propriedades físicas do ligante são avaliadas na condição inicial de produção e também em ligantes após sofrerem envelhecimento em laboratório, simulando o que ocorre no pavimento real. Para isso, são utilizados dois equipamentos para simular o envelhecimento do ligante asfáltico: a Estufa de Filme Fino Rotativo (Rolling Thin Film Oven Test - RTFOT), que simula o envelhecimento durante a usinagem e compactação da mistura, e o Vaso Pressurizado (Pressure Aging Vessel - PAV), que simula o enrijecimento oxidativo que ocorre no ligante ao longo da vida útil do pavimento.

A simulação do envelhecimento do ligante asfáltico efetuada pela Estufa de Filme Fino Rotativo (RTFOT) é realizada conforme norma ASTM D2872-97 ("Standard Test Method for Effect of Heat and Air on a Moving Film Asphalt - Rolling Thin-Film Oven Test”). Este procedimento produz um material com características do ligante asfáltico quando submetido a atividades convencionais de usinagem, sob temperatura média de $150^{\circ} \mathrm{C}$, e quando da construção do pavimento asfáltico. Os efeitos do calor e do ar são avaliados através de ensaios de caracterização das propriedades física do ligante asfáltico antes e depois do envelhecimento, assim como na determinação da variação de massa. 
A simulação do envelhecimento que ocorre no campo durante os primeiros 5 a 10 anos é realizada pelo envelhecimento adicional do ligante utilizando-se o Vaso Pressurizado (PAV) descrito na norma ASTM 6521-03A ("Standard Practice for Accelerated Aging of Asphalt Binder Using a Pressurized Aging Vessel - PAV'). Este procedimento utiliza o material obtido do envelhecimento no RTFOT, produzindo material a ser utilizado para a caracterização das propriedades físicas ou químicas dos ligantes asfálticos. É importante, portanto, para avaliação da resistência de diferentes ligantes asfálticos ao envelhecimento por oxidação, sob temperaturas e pressões elevadas, mas não considera variáveis da mistura, como suas proporções volumétricas e de permeabilidade, propriedades dos agregados, ou a resistência ao envelhecimento em condições de campo.

\subsubsection{Ensaio de Cisalhamento Dinâmico}

O reômetro de cisalhamento dinâmico (Dynamic Shear Rheometer - DSR) é utilizado para a caracterização das propriedades viscoelásticas do ligante asfáltico com ou sem envelhecimento a curto e longo prazo. O DSR avalia a rigidez do ligante asfáltico (módulo complexo - G* e ângulo de fase - $\delta$ ), sob carregamento de cisalhamento oscilatório, de forma senoidal, sob várias condições de temperaturas e a taxas de carregamento (frequência) compatíveis com o tráfego rodoviário.

A aplicação de carregamento no reômetro de cisalhamento dinâmico pode ser realizada na forma de tensão ou de deformação controlada: sob tensão controlada, o sistema de aplicação de carga aplica um torque à amostra, de forma que ela esteja submetida à tensão selecionada para a realização do ensaio; sob deformação controlada, o sistema aplica uma deflexão angular à amostra, de forma que ela esteja submetida à deformação desejada para a realização do ensaio (LIMA et al., 2008).

O G* é definido como a razão da taxa de cisalhamento máximo com a deformação máxima e fornece a medida da resistência total à deformação quando o ligante asfáltico está sujeito a um carregamento. $\mathrm{O}$ ângulo de fase $(\delta)$ fornece informações sobre a razão entre as respostas elástica e viscosa durante o processo de cisalhamento (MOTTA et al., 1996). Um alto módulo de 
cisalhamento complexo representa maior rigidez enquanto que um menor ângulo de fase representa uma maior resposta elástica.

No ensaio de cisalhamento dinâmico, o ângulo de rotação $(\theta)$ e o torque aplicado $(\tau)$ são medidos, sendo o $\mathrm{G}^{*}$ calculado em função da tensão e da deformação máxima (Equação 3.1).

$$
G^{*}=\frac{\tau_{\max }}{\gamma_{\max }}
$$

em que: $\quad G^{*}$ : módulo de rigidez ao cisalhamento complexo, $\mathrm{kPa}$;

$\tau_{\text {max }}$ : tensão de cisalhamento máxima, $\mathrm{kPa}$;

$\gamma_{\text {max }}$ : deformação de cisalhamento máxima.

A tensão de cisalhamento $(\tau)$ é calculada utilizando a Equação 3.2.

$$
\tau=\frac{2 T}{\pi r^{3}}
$$

em que: $\quad T$ : torque aplicado;

$r$ : raio da amostra.

A deformação de cisalhamento $(\gamma)$ é calculada utilizando a Equação 3.3.

$$
\gamma=\frac{\theta r}{h}
$$

em que: $\quad \theta$ : deflexão ou ângulo de rotação

O $\delta$ é a medida do balanço viscoelástico do comportamento do material. Para materiais completamente elásticos, não existe atraso entre a tensão cisalhante aplicada e a deformação cisalhante obtida, sendo $\delta$ igual a $0^{\circ}$. Para materiais totalmente viscosos, a deformação obtida está completamente defasada e vale $90^{\circ}$. Materiais viscoelástico, tais como os ligantes asfálticos, possuem ângulo de fase variando entre $0^{\circ}$ e $90^{\circ}$, dependendo da temperatura, sendo este uma 
combinação das respostas viscosas e elásticas. A altas temperaturas o $\delta$ tende a $90^{\circ}$, e a baixas temperaturas o $\delta$ tende a $0^{\circ}$.

O ângulo de fase $(\delta)$ é determinado conhecendo-se o intervalo de tempo entre a aplicação da tensão de cisalhamento (torque) e a deformação de cisalhamento resultante (rotação angular), no ensaio sob de tensão controlada, ou entre a deformação de cisalhamento induzida e a tensão de cisalhamento requerida, no ensaio sob deformação controlada. A Equação 3.4 é utilizada para a determinação do ângulo de fase.

$$
\begin{gathered}
\delta=360 \frac{\Delta t}{t}, \text { graus } \\
\delta=2 \pi \frac{\Delta t}{t}, \text { radianos }
\end{gathered}
$$

em que: $\quad \Delta t$ : intervalo no tempo;

$t$ : tempo de ciclo.

$\mathrm{O} \mathrm{G}^{*}$ é formado por parcelas elásticas e viscosas que são designadas por módulo de armazenamento (G') e módulo de perda (G’'), respectivamente. O módulo de armazenamento (G') representa o componente em fase do módulo complexo $\left(G^{*}\right)$, já o módulo de perda (G”) representa o componente defasado do módulo complexo.

O módulo de armazenamento (G') pode ser definido como a razão da tensão elástica com a deformação, correspondendo à relação entre a tensão - quando a tensão e a deformação estão em fase, ou seja $\delta=0^{\circ}$ - e o pico de deformação. O G' indica a parcela equivalente de energia proveniente da tensão aplicada que é temporariamente armazenada durante o ensaio, mas que pode ser recuperada posteriormente (LIMA et al., 2008).

O módulo de perda (G") é, matematicamente, igual à tensão, quando $\delta=90^{\circ}$, dividida pela deformação. O módulo de perda indica a parcela de energia utilizada para iniciar o escoamento e é transferida irreversivelmente sob forma de calor (LIMA et al., 2008). 
Quando uma substância é puramente viscosa, seu ângulo de fase é $90^{\circ} \mathrm{e}$, consequentemente, seu módulo de armazenamento é zero $\left(\mathrm{G}^{\prime}=0\right)$ e o módulo complexo é igual ao módulo de perda, $\mathrm{G}^{*}$ $=\mathrm{G}^{\prime \prime}$. Por outro lado, se a substância é puramente elástica, seu ângulo de fase é $0^{\circ}$, o seu módulo de perda é zero $\left(\mathrm{G}^{\prime \prime}=0\right)$ e, consequentemente, o módulo complexo é igual ao módulo de armazenamento $\left(\mathrm{G}^{*}=\mathrm{G}^{\prime}\right)$. O ligante asfáltico tende a ser elástico $(\delta=0)$ em temperaturas baixas e viscoso $\left(\delta=90^{\circ}\right)$ em temperaturas muito altas.

O método para o ensaio de cisalhamento dinâmico é o ASTM D D715-05 ("Standard Test Method for Determining the Rheological Properties of Asphalt Binder Using a Dynamic Shear Rheometer"). Esta norma contém o procedimento utilizado para determinar o módulo de cisalhamento complexo $\left(\mathrm{G}^{*}\right)$ e ângulo de fase $(\delta)$ de ligantes asfálticos, com a utilização do reômetro de cisalhamento dinâmico e geometria de placas paralelas. O ensaio é adequado para uso quando o módulo de cisalhamento dinâmico varia entre $100 \mathrm{~Pa}$ e $10 \mathrm{MPa}$, valores que são obtidos geralmente entre 4 e $88^{\circ} \mathrm{C}$. Os corpos-de-prova para o ensaio tem $25 \mathrm{~mm}$ de diâmetro e 1 $\mathrm{mm}$ de espessura ou $8 \mathrm{~mm}$ de diâmetro e $2 \mathrm{~mm}$ de espessura.

O módulo complexo e ângulo de fase podem depender da magnitude da deformação de cisalhamento. Há uma tendência de que o módulo complexo e ângulo de fase, tanto para ligantes asfálticos modificados quanto não-modificados, diminuam com o aumento da tensão ou deformação de cisalhamento. A região de viscoelasticidade linear é caracterizada por pequenas deformações, nas quais o modulo é independente da tensão ou deformação aplicada. A região de viscoelasticidade linear é definida como a faixa de tensões ou deformações na qual $\mathrm{G}^{*}$ é superior a $90 \%$ do $\mathrm{G}^{*}$ inicial.

As propriedades reológicas podem ser representadas tanto pela variação do módulo complexo $\left(G^{*}\right)$ quanto do ângulo de fase $(\delta)$ em função da frequência, sob temperatura constante, denominadas como curva mestre, ou pela variação de $\mathrm{G}^{*}$ e $\delta$ em função a temperatura.

Os pesquisadores do projeto SHRP (1994) determinaram um parâmetro para controlar a deformação permanente, considerando o fenômeno de cargas cíclicas, em que a cada ciclo de carga está sendo realizado um trabalho para deformar a camada asfáltica. Assim, parte desse 
trabalho é recuperada (deformação elástica) e parte dissipada - deformação permanente e calor. Então, para minimizar as deformações permanentes, é necessário reduzir a quantidade de trabalho dissipado a cada ciclo, que matematicamente, é dado pela Equação 3.5. O parâmetro selecionado pela Especificação Superpave para ligantes asfálticos, para limitar a deformação permanente, é inversamente proporcional ao trabalho dissipado, sendo então $G^{*} / \operatorname{sen} \delta$.

$$
W_{c}=\pi \tau_{0}^{2}\left[\frac{1}{\left(\frac{G^{*}}{\operatorname{sen} \delta}\right)}\right]
$$

em que: $\quad \tau_{0}$ : a tensão aplicada durante o ciclo de carregamento; $\mathrm{W}_{\mathrm{c}}$ : trabalho dissipado por ciclo de carregamento

\subsubsection{Curva Mestre}

A curva-mestre é uma representação do comportamento reológico do material em função da frequência (ou tempo) de carregamento, utilizando alguma função reológica, como ângulo de fase ( $\delta)$ ou módulo complexo $\left(\mathrm{G}^{*}\right)$, descrevendo a dependência do tempo. Com isso, a curva-mestre caracteriza um ligante asfáltico ao longo de toda a faixa de temperaturas, ou de tempos de carregamento, que o pavimento pode estar sujeito ao longo da vida de serviço.

As curvas-mestre são utilizadas para avaliar uma propriedade reológica, como ângulo de fase $(\delta)$ ou módulo complexo $\left(\mathrm{G}^{*}\right)$, em função da frequência (ou do tempo) de aplicação do carregamento, descrevendo o comportamento reológico do material para uma única temperatura, denominada temperatura de referência, em uma faixa de frequências ou tempos de carregamento.

Com a curva mestre é possível a determinação das propriedades reológicas não apenas em condições pontuais, pois medidas de tensão e deformação em uma ampla faixa de temperatura ou frequência pode levar muito tempo e inviabilizar o ensaio. A obtenção da curva mestre permite uma extrapolação que torna possível obter propriedades de um material em um ensaio de curta duração, permitindo a previsão do comportamento reológico do material para outras condições. 
Os ligantes asfálticos, de maneira geral, são materiais termorreologicamente simples (ANDERSON et al., 1991), o que permite assumir que o princípio de superposição tempotemperatura é válido (ZANZOTTO et al., 1996; STASTNA et al., 1994). O princípio de superposição tempo-temperatura usa a equivalência entre frequência e temperatura, para o comportamento viscoelástico linear de ligantes asfálticos, sobre a propriedade reológica, ou seja, pode-se afirmar que o efeito na redução da frequência nas propriedades mecânicas do material é equivalente ao aumento da temperatura.

A separação dos efeitos do tempo e da temperatura para materiais cujo comportamento é denominado termorreologicamente simples permite sua caracterização através da construção da curva-mestre, empregando-se apenas fatores de deslocamento horizontal, sem a necessidade de fatores de deslocamento vertical.

A separação dos efeitos da temperatura e da frequência de carregamento é feita por meio de curvas de deslocamento horizontal da temperatura (log a[T]), que indica a dependência da temperatura, e de curvas-mestre, que indica a dependência do tempo de carregamento. Com essas duas curvas a dependência do tempo e da temperatura sobre a resposta tensão-deformação do ligante asfáltico podem ser separadas e caracterizadas por parâmetros distintos, normalmente confundidos, em especial pelas propriedades reológicas empíricas, e em conjunto caracteriza a resposta linear tensão-deformação-tempo-temperatura desse ligante asfáltico.

O método da superposição tempo-temperatura permite que sejam obtidas as curvas mestres das funções viscoelásticas linear, em que os parâmetros reológicos $G^{*}, G^{\prime}, G^{\prime}$ e $\delta$ podem ser dispostos graficamente em uma escala logarítmica, em função da temperatura.

Para a construção da curva-mestre, empregando-se o princípio de superposição tempotemperatura, é realizada uma varredura de dados da função reológica, obtidos em ensaios dinâmicos, em função de faixas curtas de frequência, a diferentes temperaturas. Uma temperatura de referência deve ser selecionada e os dados de ensaios realizados em todas as outras temperaturas são deslocados horizontalmente em relação ao tempo até que as curvas se fundam, compondo uma função suavizada do comportamento reológico do material ao longo de uma faixa 
extensa de frequências de carregamento. A quantidade de deslocamento em cada temperatura, necessária para formar a curva mestre, descreve a dependência da temperatura do material (WITCZAK, 2004).

Com base nos fatores de deslocamento obtidos na geração das curvas mestre, é possível transladar horizontalmente a curva gerada na temperatura de referência e obter uma nova curva, capaz de descrever o comportamento reológico do material ao longo do mesmo espectro de frequências ou tempos de carregamento, na temperatura desejada.

A translação dos dados da varredura pode ser feita com base em qualquer uma das funções viscoelásticas, pois se assume que o princípio da superposição tempo-temperatura é válido, formado funções contínuas para todas as outras funções viscoelásticas após essa translação.

Para a análise da curva-mestre é importante enfatizar que o efeito da frequência alta é equivalente ao da temperatura baixa e o efeito da frequência baixa é equivalente ao da temperatura alta, pois o comportamento reológico é representado em função da frequência de carregamento e não da temperatura.

Para a interpretação da curva de deslocamento horizontal dois conceitos são muito importantes: a susceptibilidade térmica e a dependência da temperatura. A susceptibilidade térmica indica quantas vezes a função reológica analisada aumentou (ou diminuiu) em função da variação da temperatura, enquanto que a dependência da temperatura indica quantas décadas, em escala logarítmica, é necessário para deslocar a curva-mestre horizontalmente para a estimativa do valor da função reológica analisada (BECHARA et al., 2008).

Geralmente, a curva mestre do módulo complexo pode ser modelada matematicamente por uma função senoidal, conforme a Equação 3.6 (WITCAZK e BARI, 2004).

$$
\log \left|E^{*}\right|=\delta+\frac{\alpha}{1+e^{\beta+\gamma\left(\log _{r}\right)}}
$$

em que: $\quad t_{\mathrm{r}}$ : redução do tempo de carregamento na temperatura de referência 
$\delta$ : valor mínimo de $\mathrm{E}^{*}$

$\delta+\alpha$ : valor máximo de $\mathrm{E}^{*}$

$\beta, \gamma$ : parâmetro que descrevem a forma da função senoidal.

O fator de deslocamento pode ser apresentado pela Equação 3.7.

$$
a(T)=\frac{t}{t_{r}}
$$

em que: $\quad a(T)$ : fator de deslocamento em função da temperatura;

t: tempo de carregamento na temperatura desejada

$\mathrm{t}_{\mathrm{r}}$ : redução do tempo de carregamento na temperatura de referência

T: temperatura desejada.

Como exemplo ilustrativo, pode-se considerar os ensaios de fluência (medida da deformação, sob carregamento constante) considerando-se diferentes temperaturas $\left(T_{1}, T_{2}, T_{3} \ldots, T_{n}\right)$. Os dados da rigidez são plotados em função da frequência nas várias temperaturas trabalhadas. Uma temperatura de referência é então escolhida, por exemplo $-15^{\circ} \mathrm{C}$, e todas as outras curvas, para outras temperaturas, são deslocadas horizontalmente em relação à curva $\mathrm{a}-15^{\circ} \mathrm{C}$, até que estas se ajustem na curva de referência, conforme indica a Figura 3.1 (a) (BAHIA et al., 1992).

Para todas as curvas de fluência, nas temperaturas ensaiadas, tem-se associado um fator de deslocamento, que são plotados em função da temperatura (superposição tempo-temperatura), obtendo-se a função de deslocamento da temperatura, de acordo com a Figura 3.1 (b). Essa função mostra uma relação linear simples com a temperatura dentro da faixa de temperatura de ensaio (BAHIA et al., 1992) 


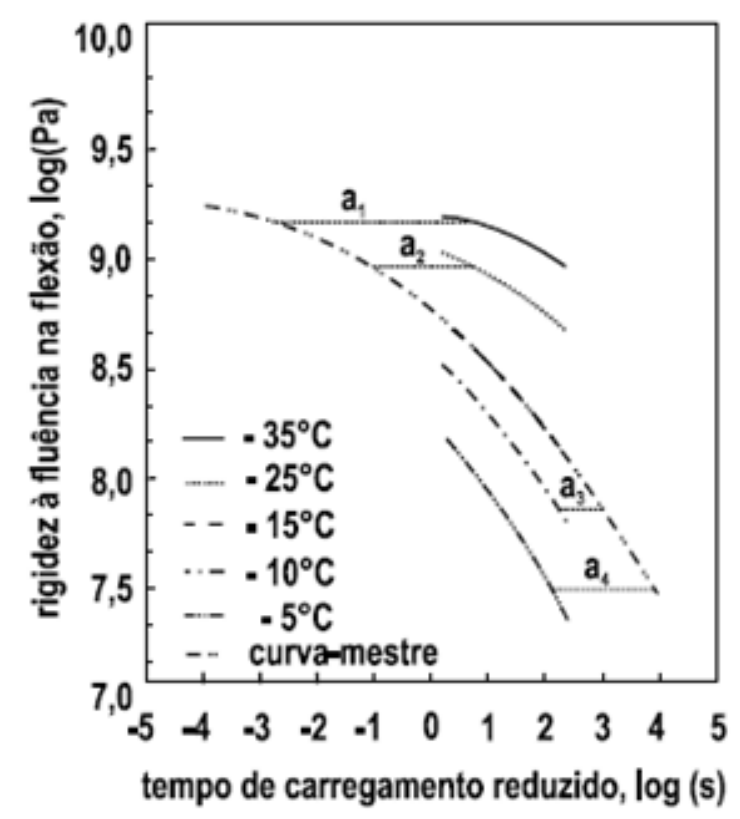

(a)

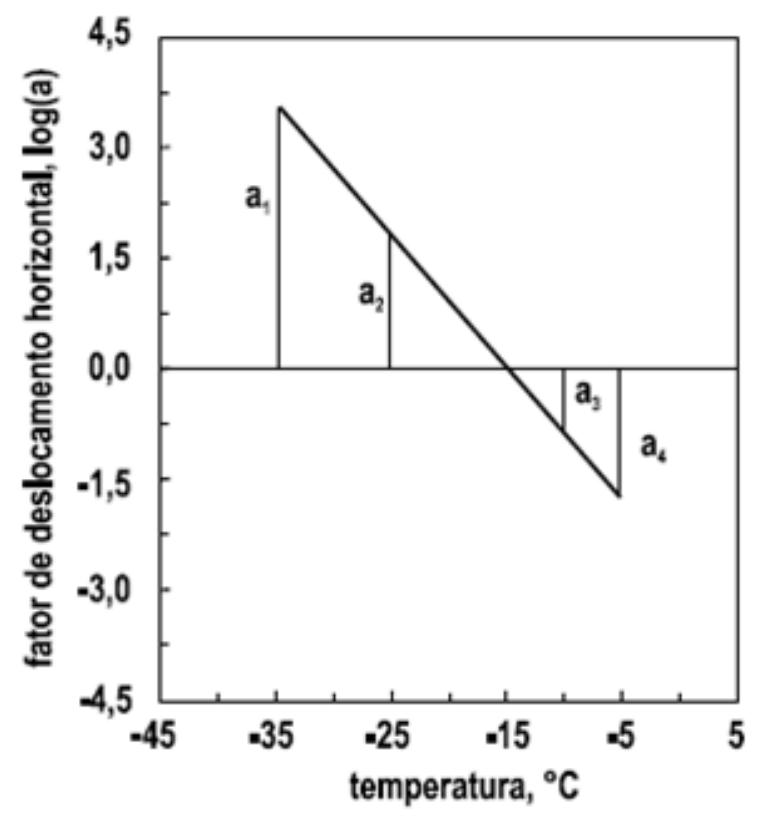

(b)

Figura 3.1 - (a) Curvas mestre transladadas para a temperatura de referência de $-15^{\circ} \mathrm{C}(\mathrm{b})$ Curvas de deslocamento horizontal em função da temperatura (log (a)) [Adaptado de Bahia et.al., 1992]

Segundo Lima et al. (2008), para materiais com comportamento molecular, como um polímero amorfo, uma curva mestre apresenta 5 regiões bem distintas, ou zonas de comportamento reológico que explicam mudanças no comportamento molecular desses materiais, que têm tendência elástica. Como se pode observar na Figura 3.2, na região da Zona de Fluxo (1) ocorrem os primeiros movimentos moleculares e, com o aumento da frequência, esse movimento tende a diminuir, entrando na Zona de Fluxo Elástico (2). Na região do Platô (3) a resposta do material independe da frequência, o que corresponde ao comportamento elástico, e para frequências intermediárias até altas o material entra na região de Transição Vítrea (4), em que o movimento molecular se reduz e os valores de modulo complexo aumentam rapidamente. Finalmente, na Zona Vítrea (5) os valores de módulo complexo permanecem quase constantes.

Os ligantes asfálticos apresentaram apenas as regiões de zona de fluxo elástico e a região de transição vítrea, pois o ligante asfáltico apresenta comportamento viscoelástico. A primeira região ocorre porque para os ligantes asfálticos a viscosidade é controlada pelas altas temperaturas (ou baixas frequências) e na região de transição vítrea o módulo aumenta com a frequência de carregamento, de maneira aproximadamente linear, das frequências mais baixas até 
intermediárias (LIMA et al., 2008). Segundo Bechara et al. (2008) o ligante asfáltico também apresenta a zona vítrea, em que há uma tendência assintótica para o valor de módulo de $10^{9} \mathrm{~Pa}$, denominado módulo vítreo, e que corresponde à rigidez de todos os materiais no zero absoluto de temperatura

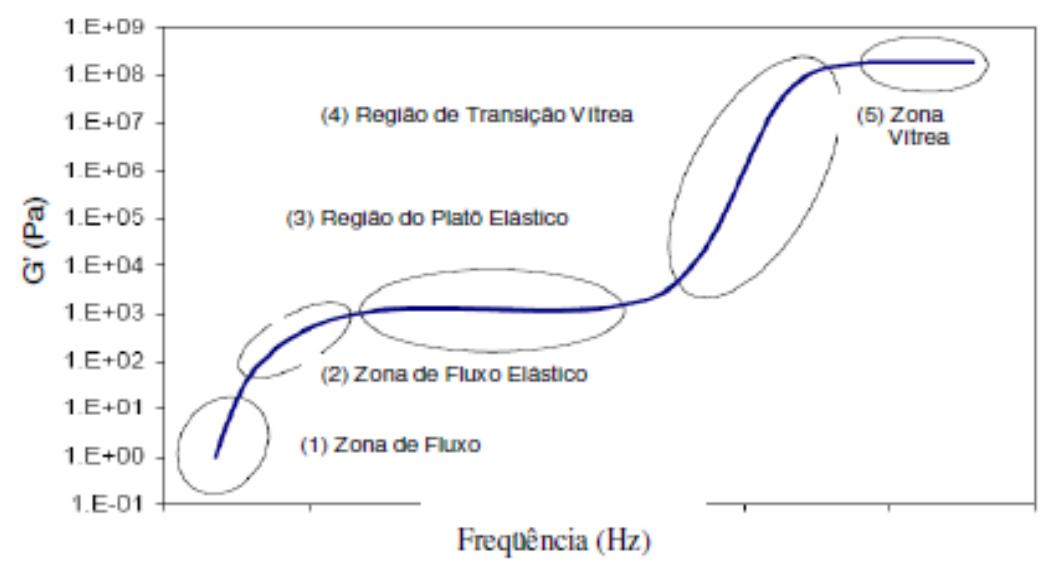

Figura 3.2 - Curva mestre de materiais de comportamento molecular [Adaptado de Lima et al., 2008]

\subsubsection{Ensaio de Fluência em Viga à Flexão}

Os ligantes asfálticos apresentam alta rigidez em baixas temperaturas (10 a $100 \mathrm{MPa}$ ), consequentemente, as deformações são muito pequenas, portanto, as técnicas de ensaio para a determinação das propriedades a temperaturas intermediárias e altas não são adequadas. Por isso, o reômetro de fluência em viga (BBR) foi desenvolvido para caracterizar a rigidez do ligante asfáltico em temperaturas baixas, em que os valores são tipicamente superiores a $10 \mathrm{MPa}$.

No BBR a rigidez é a propriedade avaliada na faixa de viscoelasticidade linear, estimando-se a função de deslocamento da temperatura ("temperature shift function"). Com essa função, pode-se calcular a rigidez a qualquer tempo de carregamento e temperatura, dentro da faixa de temperatura do ensaio (ANDERSON et al., 1992).

As temperaturas utilizadas nesse ensaio estão relacionadas com a temperatura do pavimento nos meses de inverno na área geográfica em que o ligante asfáltico será utilizado, pois a rigidez à 
fluência em flexão e o módulo de relaxação descrevem a resposta tensão-deformação no tempo sob baixa temperatura.

As trincas de origem térmica estão relacionadas à função reológica de rigidez em tempos de carregamento longos e temperaturas baixas, portanto, a temperatura em que o material alcança valores críticos de rigidez, para um dado tempo de carregamento - chamada temperatura de máxima rigidez - influencia a resistência do ligante asfáltico a esse defeito do pavimento asfáltico.

Bahia et al. (1992) relataram que o fenômeno de endurecimento físico, caracterizado pelo aumento da rigidez do ligante asfáltico, é um fator importante a ser considerado na caracterização reológica dos ligantes asfálticos em baixas temperaturas, pois ocorre apenas sob baixas temperaturas e não é previsto pelas medidas realizadas a temperaturas altas. $\mathrm{O}$ endurecimento físico, ou envelhecimento físico, ocorre comumente em ligantes asfálticos em temperaturas próximas ou inferiores à temperatura de transição vítrea, causado por retrações volumétricas retardadas, provocando a diminuição das taxas de fluência.

A dependência do tempo de carregamento no comportamento à fluência dos ligantes asfálticos em temperaturas baixas é uma propriedades que reflete as diferenças entre ligantes asfálticos e sua contribuição no comportamento da mistura asfáltica. Segundo Bahia et al. (1992), a dependência do tempo de carregamento é significativamente afetada pelo envelhecimento, destacando a importância da caracterização dos ligantes asfálticos em relação à dependência do tempo e da temperatura.

O método para o ensaio de fluência em viga é o ASTM D6648-01 ("Standard Test Method for Determining the Flexural Creep Stiffenes of Asphalt Binder Using the Bending Beam Rheometer - $B B R$ ”). Esta norma contém o procedimento utilizado para determinar a rigidez à flexão em fluência (S) e o logaritmo do módulo de relaxação (m), através da medição da deflexão no meio do vão de uma viga prismática simplesmente apoiada, com carregamento estático $(980 \pm 50 \mathrm{mN})$ aplicado no meio do vão por 240 segundos, submetido a baixas temperaturas. O ensaio é realizado em materiais que apresentam valores de rigidez à flexão entre $20 \mathrm{MPa}$ a $1 \mathrm{GPa}$, com ou sem envelhecimento. 
O programa SHRP reconheceu a importância da dependência do tempo da rigidez na determinação de tensões de retração térmica e incluiu o valor absoluto da inclinação da curva mestre de rigidez, m, mostrado na Figura 3.3, e definido pela Equação 3.8. Esse parâmetro pode ser utilizado para controlar a forma da curva mestre de rigidez.

$$
m=\left|\frac{d \log S(t)}{\operatorname{dlog}(t)}\right|
$$

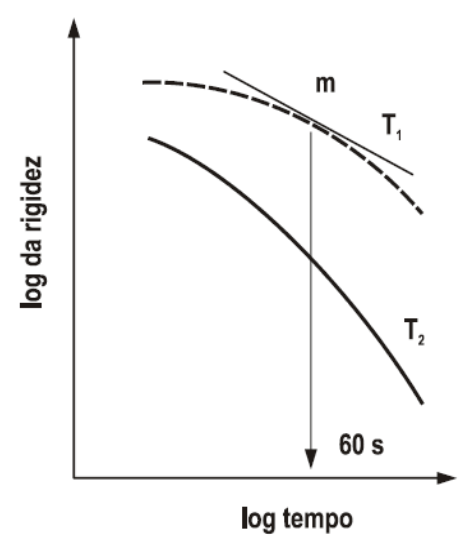

Figura 3.3 - Curva mestre do Ensaio BBR e determinação do módulo de relaxação

Conhecendo-se a carga aplicada sobre a viga e medindo-se a deflexão ao longo do ensaio, a rigidez estática pode ser determinada, usando-se os fundamentos da mecânica. A deflexão, segundo a teoria elementar de vigas, no centro do vão, é dada pela Equação 3.9.

$$
\xi=\frac{P L^{3}}{48 E I}
$$

em que: $\quad \xi$ : deflexão da viga no meio do vão;

$\mathrm{P}$ : carga aplicada $(\mathrm{N})$;

L: vão (mm);

E: módulo de elasticidade $(\mathrm{Pa})$;

I: momento de inércia da seção transversal $\left(\mathrm{mm}^{4}\right)$. 
Pode-se assumir que a distribuição de tensões é igual em uma viga viscoelástica sujeita a carregamentos aplicados no tempo zero e mantidos constantes, e em uma viga elástica submetida ao mesmo carregamento. As deformações e deslocamentos da viga viscoelástica dependem do tempo, sendo derivados das deformações e deslocamentos obtidos na viga elástica.

Então, substituindo E por 1/D(t), e como 1/D(t) é equivalente a $S(t)$, obtém-se a Equação 3.10.

$$
S(t)=\frac{P L^{3}}{4 b h^{3} \xi(t)}
$$

em que: $\quad S(t)$ : rigidez à flexão em fluência, no tempo t(MPa);

$\xi(t)$ : deflexão da viga, no meio do vão, no tempo t;

b: base da viga $(\mathrm{mm})$;

h: altura da viga $(\mathrm{mm})$.

A especificação de ligantes asfáltico estabelece limites para os valores de $S(t)$ e $m$ em função da temperatura máxima do local onde o ligante asfáltico será usado, pois ligantes asfálticos que possuam baixa rigidez estática geralmente apresentam uma melhor resposta ao trincamento a baixas temperaturas. Por outro lado, ligantes que possuam altos valores de $m$ são mais eficientes na dissipação das tensões formadas durante a contração do ligante asfáltico, quando a temperatura do pavimento cai abruptamente, minimizando a formação de trincas e fissuras. (MOTTA et al., 1996).

\subsubsection{Ensaio de Ponto de Amolecimento pelo Método Anel e Bola}

Ligantes asfálticos são materiais viscoelástico sem definição clara do ponto de fusão, que se tornam gradativamente mais moles e menos viscosos com o aumento da temperatura. Por isso, o ponto de amolecimento é útil para a classificação de ligantes asfálticos, indicando a tendência do material de fluir em temperaturas elevadas encontradas em serviço. $O$ ensaio de ponto de amolecimento pode ser realizado em amostras com ou sem envelhecimento a curto e longo prazo. 
O ponto de amolecimento é uma propriedade empírica, obtida no ensaio de anel e bola, que corresponde ao valor da temperatura na qual a consistência do ligante asfáltico passa do estado plástico ou semi-sólido para o estado líquido.

O procedimento de ensaio é descrito na norma ASTM D36-95 ("Standard Test Method for Softening Point of Bitumen: Ring-and-ball Apparatus"). O ensaio utiliza corpos de prova de ligante asfáltico em formato de discos horizontais, suportados dentro de anéis e aquecidos a uma taxa constante em um banho liquido, enquanto cada um suporta esferas de aço. O ponto de amolecimento é relatado como a temperatura na qual os dois discos de ligante asfáltico amolecem o suficiente para permitir que cada esfera, envolvida pelo ligante, caiam uma distância de $25 \mathrm{~mm}$.

\subsection{MATERIAIS UTILIZADOS}

Neste trabalho, para a produção dos mástiques foram utilizados dois tipos de ligantes asfáltico, um Cimento Asfáltico de Petróleo (CAP) 50/70 e um CAP 85/100, ambos fornecidos pela empresa Betunel, da cidade de Riberão Preto, SP. As características dos ligantes asfálticos estão indicadas na Tabela 2.8 e 2.9 do Capítulo 2.

Foram avaliados quatro diferentes fileres: cal hidratada, cimento Portland, sílica e pó de calcário. A massa especifica real dos fíleres foi determinada através da norma DNER-ME 085/94, que padroniza o método para a determinação da massa específica real de material de enchimento, e os resultados estão apresentados na Tabela 2.10 (Capítulo 2), assim como os valores médios de superfície específica para diferentes fileres, segundo Pinnila (1965).

\subsection{MÉTODOS}

A preparação dos mástiques (fíler e ligante asfáltico) foi realizada a partir do seguinte procedimento:

i. Determinação da massa específica do ligante asfáltico e do fíler mineral;

ii. Calcular a massa de ligante asfáltico necessária para a relação fíler-asfalto (f/a) desejada, para uma dada massa de fíler;

iii. A amostra de fíler deve ser seca em estufa até a constância de massa a $100 \pm 5^{\circ} \mathrm{C}$; 
iv. Aquecer a amostra de ligante asfáltico na temperatura correspondente à temperatura para mistura asfáltica, até sua uniformização. Para o CAP 50/70 essa temperatura é de 150 a $154{ }^{\circ} \mathrm{C}$, e para o CAP $85 / 100$ é de 142 a $147^{\circ} \mathrm{C}$;

v. Separar a quantidade de fíler calculada no passo ii, aquecendo-a em um recipiente em estufa, na temperatura correspondente à temperatura dos agregados para misturas asfálticas, até sua uniformização Para os mástique compostos pelo CAP 50/70 essa temperatura é de 165 a $169^{\circ} \mathrm{C}$, e para o CAP 85/100 é de 157 a $162{ }^{\circ} \mathrm{C}$;

vi. Utilizando-se uma balança de precisão de 0,01g, colocar a quantidade de ligante asfáltico calculado no item ii em um recipiente previamente aquecido e, logo em seguida, adicionar a quantidade de fíler já separada;

vii. Misturar os componentes com uma espátula, tomando-se o cuidado para que não haja perda de material, até que a mistura fique homogênea;

viii. $\quad$ mástique pode ser utilizado para ensaio imediatamente ou estocado.

Os ensaios de cisalhamento em regime oscilatório e ponto de amolecimento foram realizados em amostras de mástiques compostos pelos fileres de cimento Portland, sílica e pó de calcário nas relações f/a de 0,6; 0,9 e 1,2, enquanto que para os mástiques compostos pela cal hidratada foram realizados ensaios apenas nas relações f/a de 0,6 e 0,9, pois a mistura do ligante asfáltico com a cal hidratada na relação f/a de 1,2 foi impraticável, devido à baixa massa especifica do fíler, e consequentemente, o grande volume a ser incorporado nessa relação.

Já o ensaio de fluência em viga foi realizado em amostras de mástique envelhecidos no PAV e, devido à falta de informações e pesquisas sobre qual o método mais adequado para o envelhecimento de mástiques, o envelhecimento foi realizado de duas formas: (1) convencional, em que se aplica $100{ }^{\circ} \mathrm{C}$ por 20 horas; (2) modificado, em que se aplica $60^{\circ} \mathrm{C}$ por 100 horas, realizado-se a agitação por mistura da amostra a cada 20 horas. As amostras submetidas a esse envelhecimento e ao ensaio de fluência em viga foram compostas para os fileres de cimento Portland e pó calcário nas relações f/a de 0,6 e 1,2, enquanto que para as compostas de fíler de cal hidratada, nas relações f/a de 0,3 e 0,6 . 


\subsubsection{Ensaio de Cisalhamento em Regime Oscilatório}

O reômetro utilizado nessa pesquisa foi o TA Instruments, modelo AR-2000. O procedimento de ensaio foi realizado da seguinte forma:

i. Empregando-se a geometria de $25 \mathrm{~mm}$ e distância entre placas (gap) de $1 \mathrm{~mm}$, foi realizada uma varredura de tensão, nas temperaturas de $52,64,76$ e $88^{\circ} \mathrm{C}$, em uma faixa de frequência entre 0,1 e $100 \mathrm{rad} / \mathrm{s}$, para determinar a tensão que o material é solicitado, de acordo com a temperatura e a rigidez do material;

ii. Empregando-se a geometria de $8 \mathrm{~mm}$ e distância entre placas de $2 \mathrm{~mm}$, foi realizada uma varredura de tensão nas temperaturas de $40,28,16$ e $4^{\circ} \mathrm{C}$, em uma faixa de frequência entre $0,1 \mathrm{e}$ $100 \mathrm{rad} / \mathrm{s}$, para determinar a tensão que o material é solicitado, de acordo com a temperatura e a rigidez do material;

iii. Utilizando-se o software TA Instruments V5.20 foi composta a curva mestre de G* e a curva de fatores de deslocamento horizontal em função da temperatura, baseando-se no deslocamento horizontal das curvas das varreduras das propriedades reológicas com a frequência.

\subsubsection{Ensaio de Fluência em Viga}

O equipamento do ensaio de fluência em viga a flexão é composto por uma estrutura para aplicação de carga, que, juntamente com a deflexão, são monitoradas ao longo do tempo, com suporte para o corpo de prova, um banho de álcool com temperatura controlada que mantem a amostra na temperatura de ensaio e proporciona um empuxo para contrabalançar o peso próprio da viga, um circulador para o fluido do banho e um sistema computadorizado de aquisição de dados.

O conjunto de aplicação de carga consiste em um equipamento capaz de aplicar o carregamento no meio do vão da viga, que deve ser capaz de aplicar uma carga de contato de $35 \pm 10 \mathrm{mN}$ ao corpo de prova e manter a carga de ensaio de $980 \pm 50 \mathrm{mN}$ com variação de $\pm 10 \mathrm{mN}$.

Antes da realização do ensaio, a temperatura deve ser selecionada e o banho deve ser ajustado na temperatura escolhida, permitindo que a temperatura do banho equilibre-se com a temperatura de ensaio, o que leva geralmente de 60 a 90 minutos. 
Para a preparação da amostra, primeiramente, deve-se preparar os moldes de metal, de dimensões internas de $6,35 \pm 0,05 \mathrm{~mm} \times 12,70 \pm 0,05 \mathrm{~mm} \times 127 \pm 5 \mathrm{~mm}$, que consistem em colocar tiras de plástico, apropriados para o ensaio, sob a superfície dos moldes já lubrificada.

Deve-se aquecer o ligante asfáltico até estar suficientemente fluido e despejar a amostra até encher completamente um extremo do molde e, então, preencher o molde até o outro extremo, com excesso de material. O corpo de prova é deixado por, no mínimo, 45 a 60 minutos para resfriar, após esse período, deve-se aparar a face exposta do corpo de prova no nível do molde com uma espátula aquecida. Em seguida, colocar o conjunto em um banho a baixa temperatura

por 5 minutos, até que esteja suficientemente rígido para a desmoldagem. Imediatamente após a desmoldagem, imergir o corpo de prova no banho na temperatura do ensaio durante $60 \pm 5$ min.

Para a realização do ensaio, verifica-se inicialmente a carga de contato $(35 \pm 10 \mathrm{mN})$ e a carga de ensaio $(980 \pm 50 \mathrm{mN})$. Em seguida, o corpo de prova é posicionado e inicia-se o ensaio, com aplicação do pré-carregamento, de $980 \pm 50 \mathrm{mN}$, por $1 \pm 0,1 \mathrm{~s}$ e imediatamente em seguida, reduz-se a carga para $35 \pm 10 \mathrm{mN}$ por $20 \pm 0,1 \mathrm{~s}$, para finalmente, aplicar a carga de ensaio por $240 \mathrm{~s}$.

Os dados gerados no ensaio são a carga aplicada e a deflexão medida, em função do tempo de carregamento, em intervalos de 0,5 segundos. Com os dados, pode-se determinar a rigidez do corpo de prova nos tempos de carregamento de 8,0;15,0;30,0;60,0;120,0 e 240 s, através da Equação 3.10.

\subsubsection{Ensaio de Ponto de Amolecimento pelo Método Anel e Bola}

O ensaio utiliza duas pastilhas de ligante asfáltico, moldadas em anéis de latão, que sustentam uma esfera de aço e que ficam imersas em um banho e aquecidas com taxa de aquecimento controlada. Para a moldagem dos corpos de prova, as amostras são aquecidas até que o ligante asfáltico esteja líquido o suficiente para fluir adequadamente nos moldes. Os anéis devem ser aquecidos aproximadamente na mesma temperatura do ligante asfáltico e devem ser colocados em uma base para moldagem preparada com material antiaderente. A amostra é colocada com 
excesso nos anéis, em seguida é deixado para resfriar por, no mínimo, 30 minutos, aparando-se a amostra com uma espátula aquecida.

Para a realização do ensaio deve-se utilizar água destilada como fluido do banho, para pontos de amolecimento entre 30 e $80^{\circ} \mathrm{C}$, com temperatura inicial de $5 \pm 1^{\circ} \mathrm{C}$. Para tanto, o béquer com a água destilada, a guia, as esferas e as amostras devem ser resfriados durante 15 minutos ou até que atinjam a temperatura de início do ensaio. Em seguida, deve-se posicionar as esferas sobre as amostra e levar para aquecimento, na taxa de $5^{\circ} \mathrm{C} / \mathrm{min}$, até o instante em que cada amostra com a esfera atingir o fundo do béquer, anotando-se as temperaturas correspondentes.

O ponto de amolecimento é a média das temperaturas nas quais as duas pastilhas amolecem o suficiente para que as esferas rompam a pastilha de ligante asfáltica e percorram verticalmente a distância de $25 \mathrm{~mm}$.

\subsubsection{Envelhecimento de Ligantes e Mástiques Asfálticos}

A simulação do envelhecimento que ocorre no campo pode ser realizada através de dois ensaios, segundo a metodologia do SUPERPAVE, a estufa de filme rotativo (RTFOT), que simula o envelhecimento no curto prazo, e a estufa de vaso pressurizado (PAV), que simula o envelhecimento no longo prazo. Porém, para a simulação do envelhecimento de mástiques asfáltico ainda não há um consenso entre os pesquisadores, devido a fatores como sedimentação do fíler nos equipamento do ensaio, distribuição uniforme do fíler nas amostras, separação do fíler e o ligante asfáltico.

Para Anderson et al. (1992) os ensaios convencionais de envelhecimento (TFOT e RTFOT) não podem ser utilizados no sistema com fíler, pois os fileres se separam do ligante asfáltico em temperaturas altas, como a utilizada nesses ensaio, de $163^{\circ} \mathrm{C}$. Para os pesquisadores, o procedimento do PAV pode ser realizado em sistemas com fíler devido à utilização de temperaturas de ensaio mais baixas, que não reduzem a viscosidade do ligante asfáltico o suficiente para ocorrer a sedimentação do fíler. No PAV, o ligante ou o mástique asfáltico é submetido a condições que simulam o envelhecimento que ocorre tipicamente no campo, em climas moderados, após 5 a 10 anos de serviço. 
Molenaar et al. (2010) utilizaram dois procedimentos para o envelhecimento de mástiques asfálticos: (1) envelhecimento a curto prazo através da realização do RTFOT convencional $\left(163^{\circ} \mathrm{C}\right.$ por 75 minutos), seguido do ensaio de envelhecimento em cilindro rotativo (RCAT), por 235 minutos a $163^{\circ} \mathrm{C}$; (2) envelhecimento a longo prazo, realizado no RCAT, em períodos maiores (185 horas) e temperaturas menores $\left(90^{\circ} \mathrm{C}\right)$, após a amostra ser submetida ao envelhecimento a curto prazo). Os pesquisadores concluíram, comparando os dados obtidos em laboratório com amostras retiradas do campo, que os procedimentos de envelhecimento de laboratório não foram capazes de simular adequadamente o envelhecimento no longo prazo (7 anos) que ocorre no campo, apenas os resultados de envelhecimento no curto prazo (de ate 2 anos) puderam ser adequadamente simulados.

Gluber et al. (1999) realizaram uma pesquisa sobre os mástiques asfálticos através das suas medidas reológicas e para a simulação do envelhecimento, foi realizado, primeiramente, o RTFOT apenas nas amostras de ligante asfáltico e só depois misturaram seu resíduo com o fíler, sendo o mástique submetido ao PAV. Os pesquisadores realizaram o ensaio do RTFOT com mástique, porém eram muito rígidos para cobrir os recipientes do RTFOT rapidamente quando colocados na estufa, sendo que a cobertura foi de apenas $80 \%$, após sete rotações do equipamento, e mesmo após mais 10 rotações alguns recipientes ainda apresentavam-se sem cobertura total. Além da distribuição do material no recipiente e seu contato com o ar ser muito diferente do que ocorre com os ligantes asfálticos e, devido à dificuldade de se controlar o processo, os resultados não seria confiáveis.

Cooley et al. (1998) caracterizaram mástiques asfálticos através da realização dos ensaio da metodologia Superpave e, para a simulação do envelhecimento, foram executados o ensaio de TFOT (curto prazo) e PAV (longo prazo). Os autores afirmam que durante os ensaios preliminares no RTFOT houve uma tendência do mástique de vazar dos recipientes, por isso foi escolhido para simulação do envelhecimento no curto prazo o TFOT.

Huang e Zeng (2007) realizaram uma pesquisa sobre o efeito do envelhecimento em mástique asfálticos compostos por pó calcário e granito, submetendo amostras ao envelhecimento oxidativo no PAV a $60{ }^{\circ} \mathrm{C}$, temperatura escolhida por simular realisticamente o efeito da 
exposição ao meio ambiente a longo prazo, sendo que em temperaturas maiores - como $100{ }^{\circ} \mathrm{C}$, utilizada convencionalmente no ensaio de PAV - as moléculas polares reativas são mobilizadas por dissociação da microestrutura, tornando-as mais disponíveis para oxidação. Os tempos de ensaio utilizados foram de 100, 400, 800 e 2000 horas. Huang et al. (2002) também investigaram os efeitos da cal hidratada no envelhecimento de longo prazo e, para isso, realizaram o PAV a $60^{\circ} \mathrm{C}$ em tempos de até 800 horas.

Foram utilizados na pesquisa dois procedimentos para a simulação do envelhecimento dos mástiques asfálticos:

i. Ensaio de Vaso Pressurizado (PAV) Convencional: a amostra de mástique foi submetida ao PAV por 20 horas a $100^{\circ} \mathrm{C}$ em um vaso pressurizado, a 2,10 MPa. Nesse procedimento, 50 $\pm 0,5 \mathrm{~g}$ de material foi colocado nos recipientes (pratos), formando uma película de aproximadamente $3,2 \mathrm{~mm}$. A amostra foi colocada no equipamento (vaso) e, após a estabilização da temperatura $\left(100 \pm 0,5{ }^{\circ} \mathrm{C}\right)$, a pressão foi colocada $(2,10 \pm 0,1 \mathrm{Mpa})$, durante $20 \mathrm{~h} \pm 10 \mathrm{~min}$. No final do tempo de ensaio, a pressão interna do PAV foi liberada lentamente (10 minutos) e as amostras foram removidas do equipamento e colocadas em estufa a $163{ }^{\circ} \mathrm{C}$ durante $15 \pm 1 \mathrm{~min}$, em seguida foram retiradas dos pratos e colocadas em recipientes apropriados e levadas para a estufa de vácuo a $170 \pm 5^{\circ} \mathrm{C}$ por $30 \pm 1 \mathrm{~min}$, para a retirada de bolhas;

ii. Ensaio de Vaso Pressurizado (PAV) Modificado: a amostra de mástique foi submetida ao PAV por 100 horas a $60^{\circ} \mathrm{C}$, sendo que a cada 20 horas a pressão foi retirada e os mástiques foram misturados novamente, no próprio recipiente de ensaio, para que a dispersão do mástique na amostra se mantivesse uniforme.

\subsection{APRESENTAÇÃO E ANÁLISE DOS RESULTADOS}

\subsubsection{Ensaio de Cisalhamento em Regime Oscilatório}

As Figuras 3.4, 3.5, 3.6 e 3.7 trazem as curvas mestre de $\mathrm{G}^{*}$ e $\delta$ para os mástiques compostos pelo CAP 50/70, em função da relação fíler/asfalto, para os fileres de cimento Portland, sílica, pó 
de calcário e cal hidratada, respectivamente. As Figuras 3.8, 3.9, 3.10 e 3.11 mostram os comparativos das curvas mestre dos mástiques compostos pelo CAP 85/100, em função da relação fíler/asfalto, para os fileres de cimento Portland, sílica, pó de calcário e cal hidratada, respectivamente.

A adição de fíler aumentou os valores de $G^{*}$ e reduziu os valores de $\delta$, tornando o ligante asfáltico mais rígido e mais elástico. $\mathrm{O}$ aumento da rigidez foi observado para qualquer frequência de carregamento ou temperatura. A adição de fíler provocou um deslocamento vertical na escala de rigidez, praticamente uniforme ao longo da escala de frequência. A elasticidade também aumentou com a adição dos fileres, o que se observou pela redução dos valores de ângulo de fase.

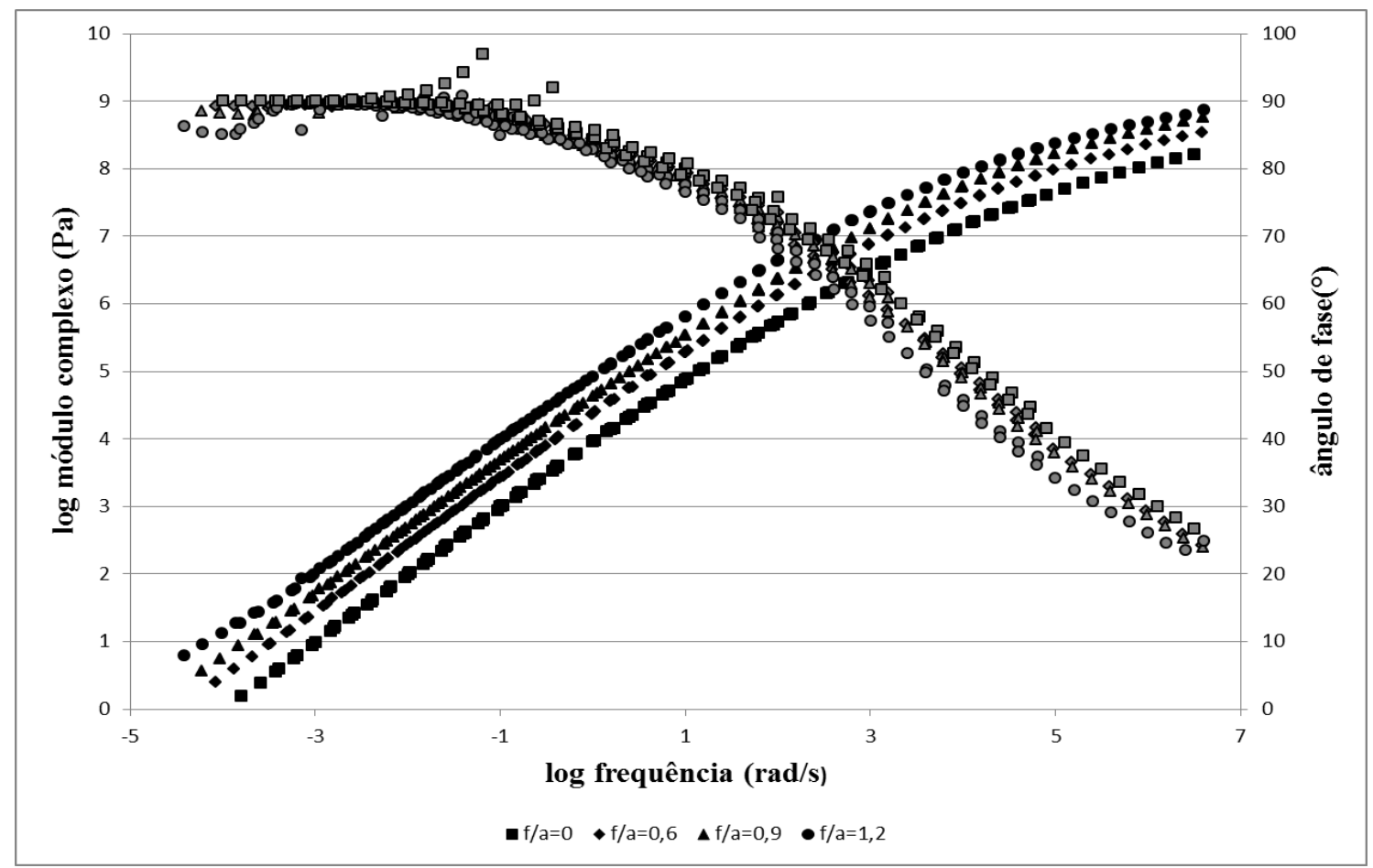

Figura 3.4 - Curva mestre de $\mathrm{G}^{*} \mathrm{e} \delta$ em função da frequência, para mástiques compostos com o CAP 50/70 e com o fíler de cimento Portland, em função da relação f/a 


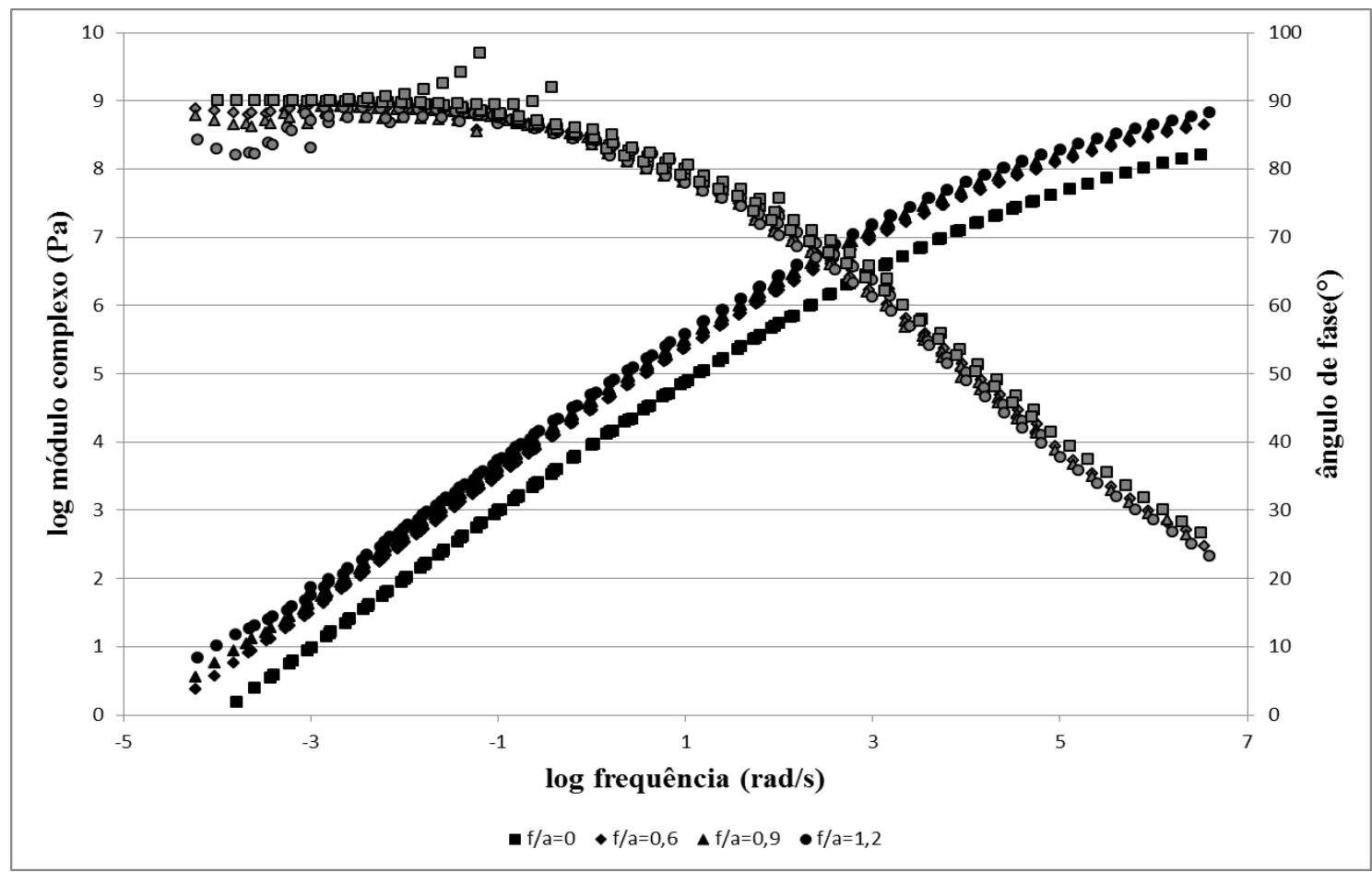

Figura 3.5 - Curva Mestre de $\mathrm{G}^{*} \delta$ em função da frequência, para mástiques compostos com o CAP 50/70 e com o fíler de sílica, em função da relação f/a

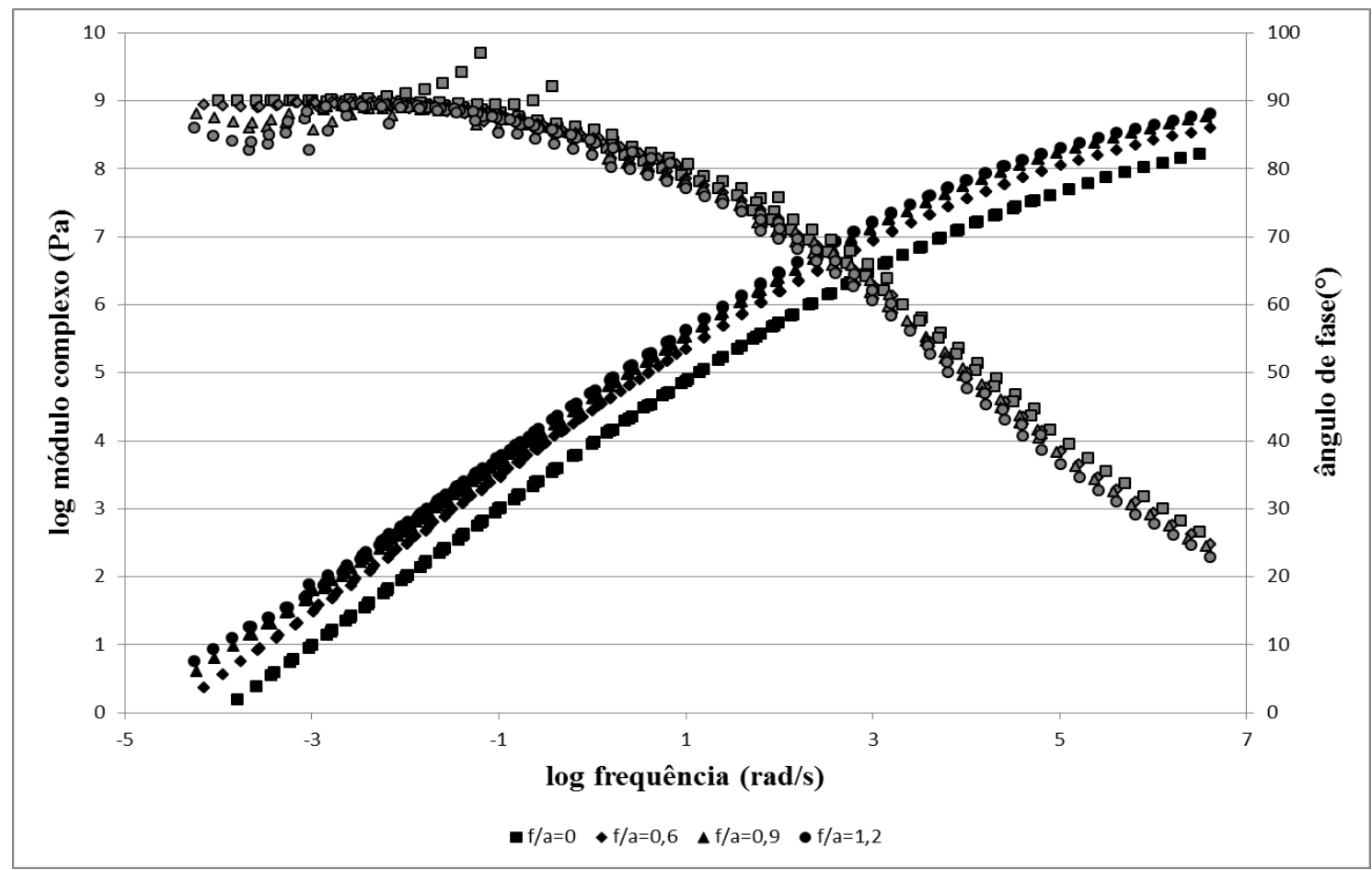

Figura 3.6 - Curva Mestre de $\mathrm{G}^{*}$ e $\delta$ em função da frequência, para mástiques compostos com o CAP 50/70 e com o fíler de pó calcário, em função da relação f/a 


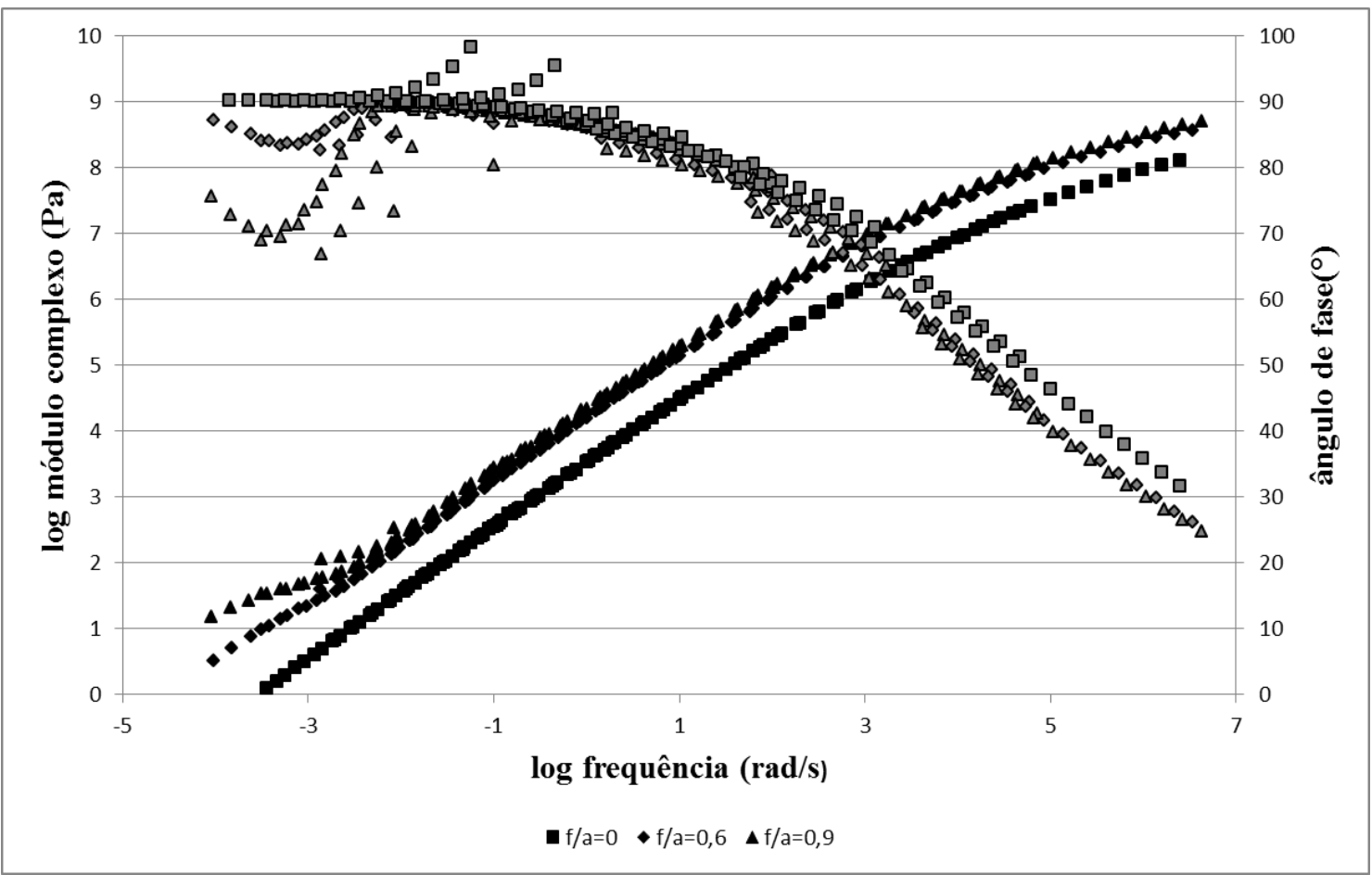

Figura 3.7 - Curva Mestre de $\mathrm{G}^{*}$ e $\delta$ em função da frequência, para mástiques compostos com o CAP 50/70 e com o fíler de cal hidratada, em função da relação f/a

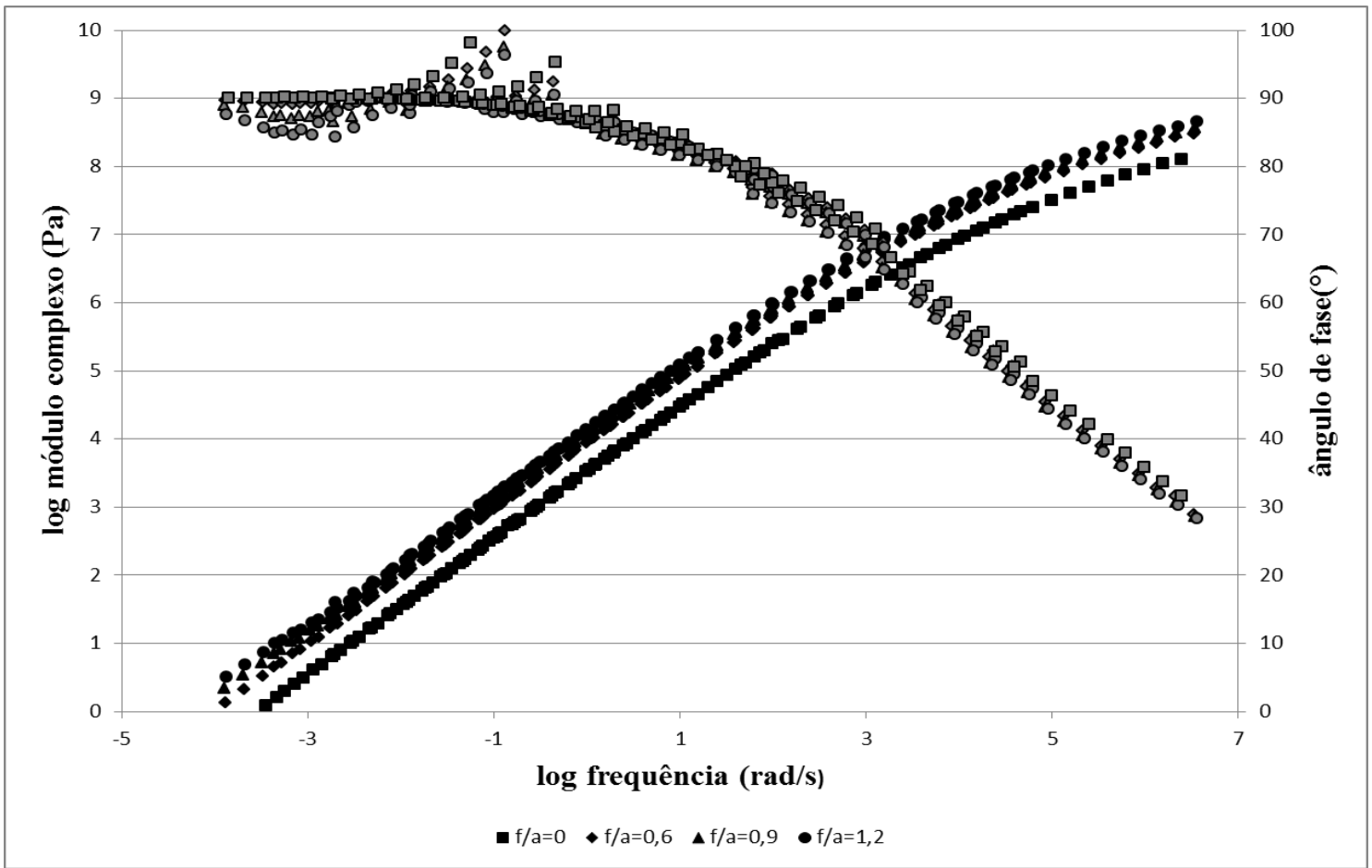

Figura 3.8 - Curva Mestre de $\mathrm{G}^{*}$ e $\delta$ em função da frequência, para mástiques compostos com o CAP 85/100 e com o fíler de cimento Portland, em função da relação f/a 


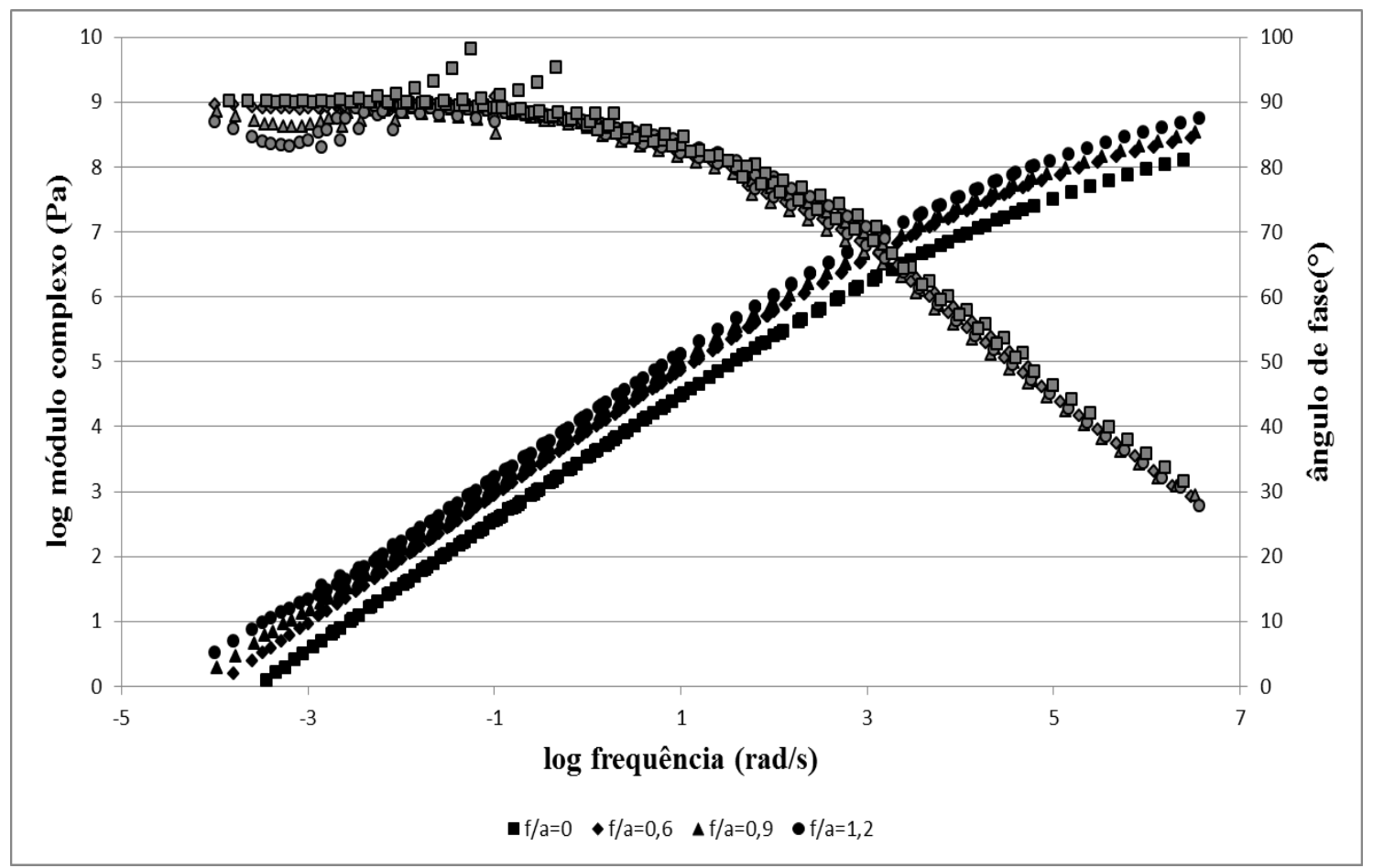

Figura 3.9 - Curva Mestre de $\mathrm{G}^{*}$ e $\delta$ em função da frequência, para mástiques compostos com o CAP 85/100 e com o fíler de sílica, em função da relação f/a

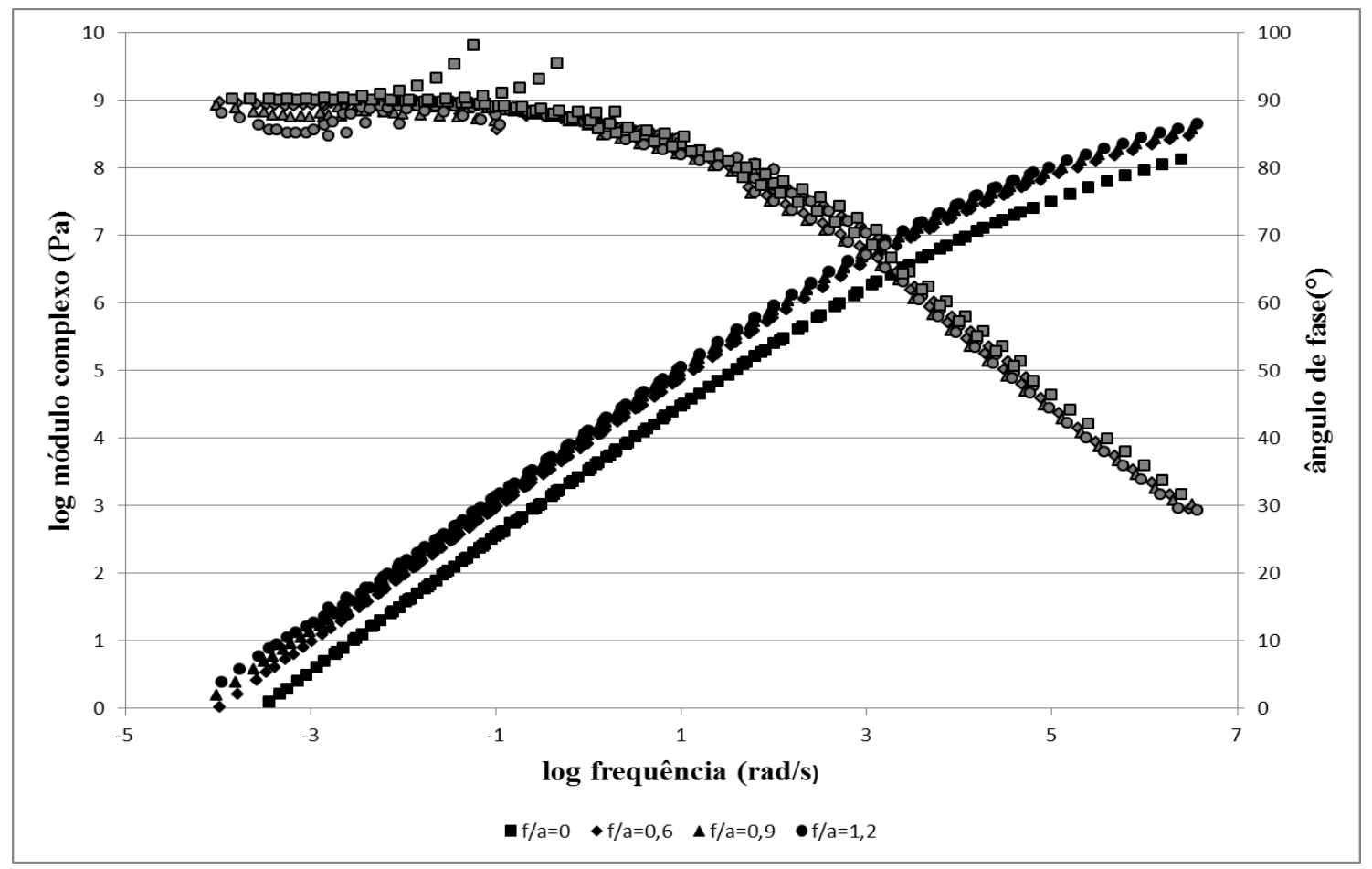

Figura 3.10 - Curva Mestre de $\mathrm{G}^{*}$ e $\delta$ em função da frequência, para mástiques compostos com o CAP85/100 e com o fíler de pó calcário, em função da relação f/a. 


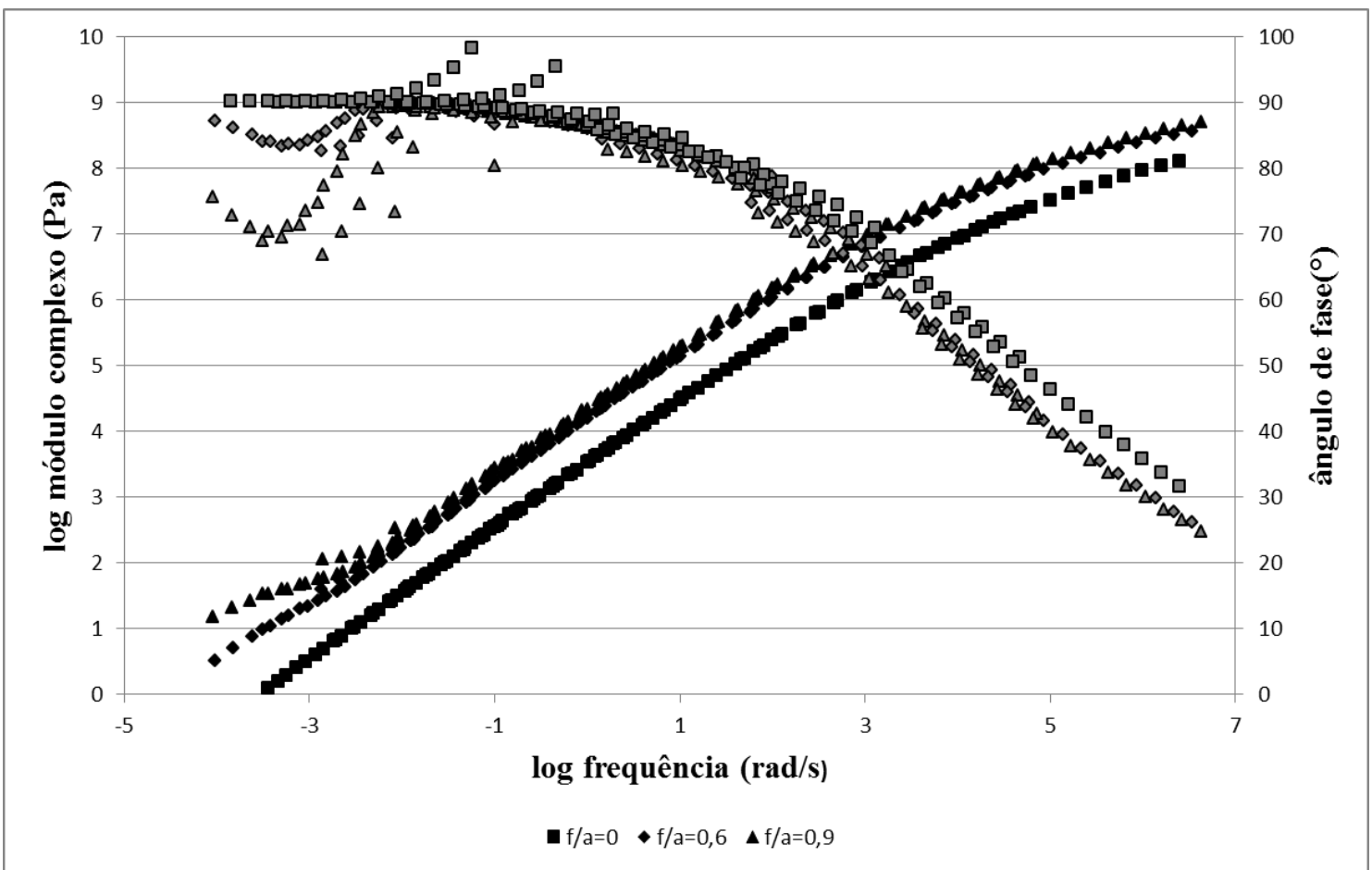

Figura 3.11- Curva Mestre de $\mathrm{G}^{*}$ e $\delta$ em função da frequência, para mástiques compostos com o CAP 85/100 e com o fíler de cal hidratada, em função da relação f/a

Pode-se perceber que no desenvolvimento da curva mestre de $G^{*}$ com a frequência, observado da Figura 3.4 a 3.11, o material apresentou valor de módulo complexo próximo ao do módulo vítreo em temperaturas baixas (frequência alta) e teve sua rigidez reduzida à medida que a temperatura aumentou (frequência diminui). A forma da curva mestre é de ligantes asfálticos, em que o módulo aumenta linearmente com a frequência de carregamento, das frequências mais baixas até intermediárias, e tende assintoticamente para o módulo de $10^{9} \mathrm{~Pa}$ (módulo vítreo).

As Figuras 3.12, 3.13, 3.14 e 3.15 mostram as curvas de log a[T] versus temperatura, para os mástique compostos pelo CAP 50/70 (a) e 85/100 (b), em função das relações fíler/asfalto, para os fileres de cal hidratada, cimento Portland, sílica e pó de calcário, respectivamente.

Observando-se as Figuras 3.12 a 3.15, percebe-se que a incorporação do fíler mineral não interferiu na dependência da temperatura, quando comparado ao ligante asfáltico puro. Também não houve mudança da dependência da temperatura com os diferentes tipos e teores de fíler utilizados, com isso conclui-se que o potencial enrijecedor do fíler é o mesmo para diferentes temperaturas. 


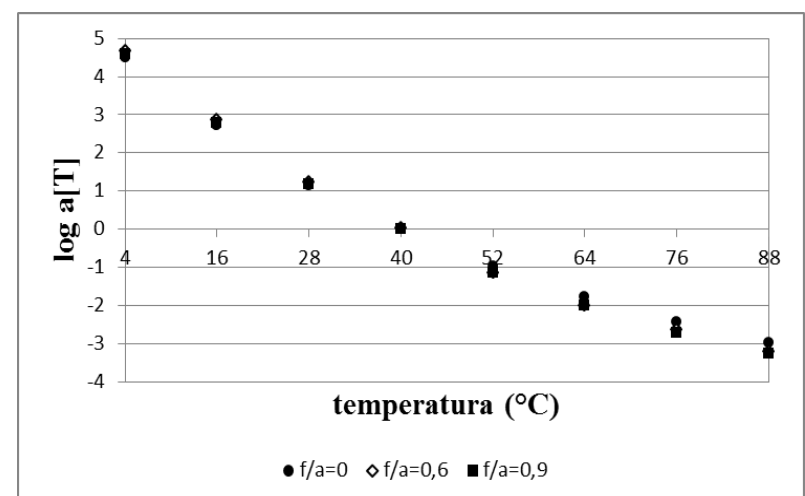

(a)

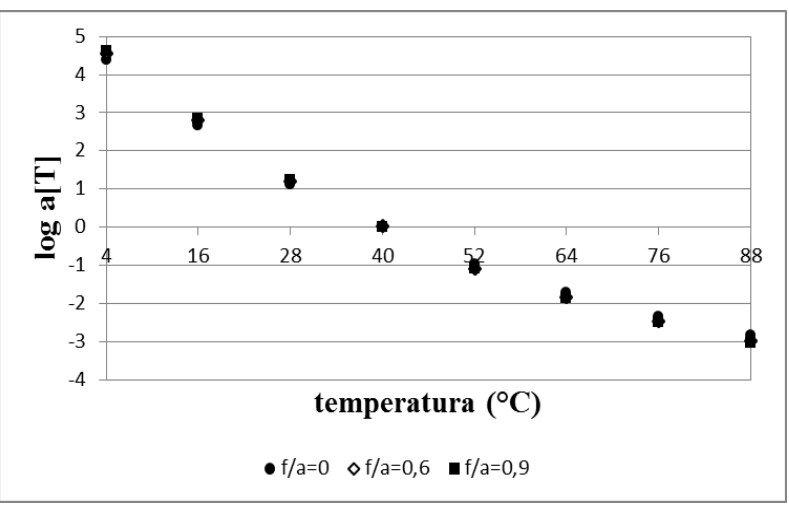

(b)

Figura 3.12- Fatores de Deslocamento Horizontal em função da temperatura para os mástique compostos pela cal hidratada e: (a) CAP 50/70 e (b) CAP 85/100

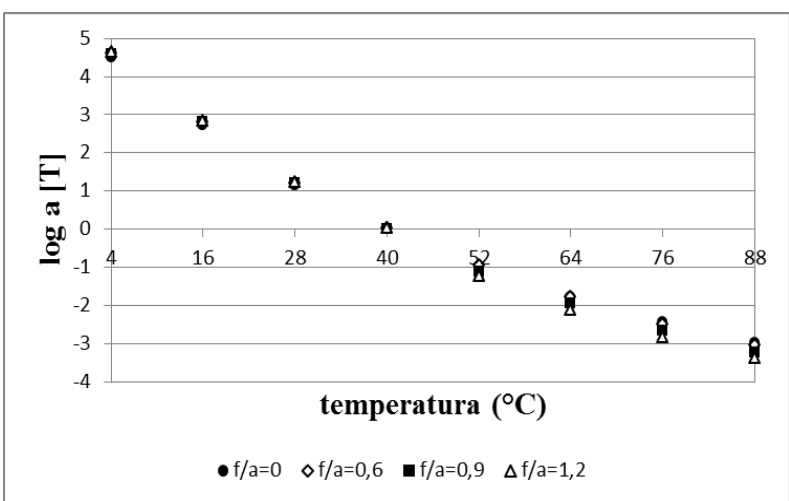

(a)

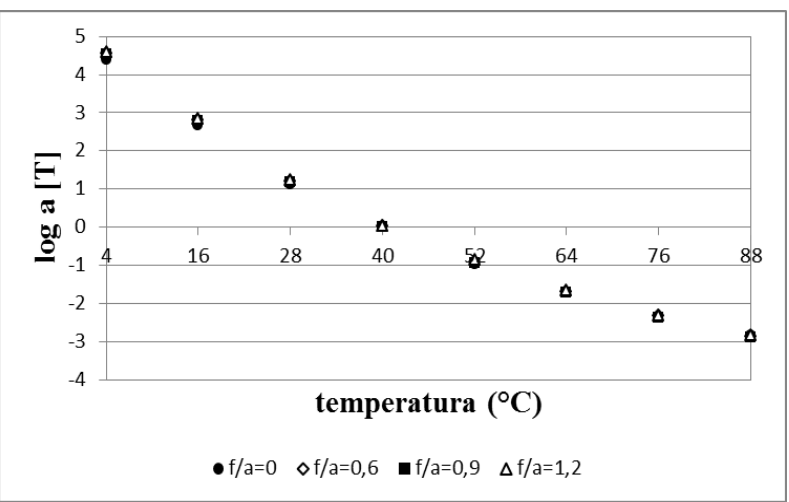

(b)

Figura 3.13 - Fatores de Deslocamento Horizontal em função da temperatura para os mástique compostos pelo cimento Portland e: (a) CAP 50/70 e (b) CAP 85/100

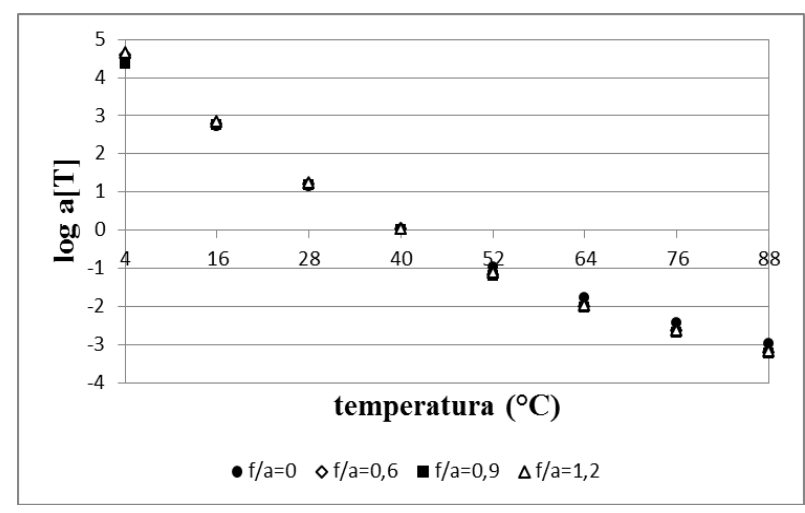

(a)

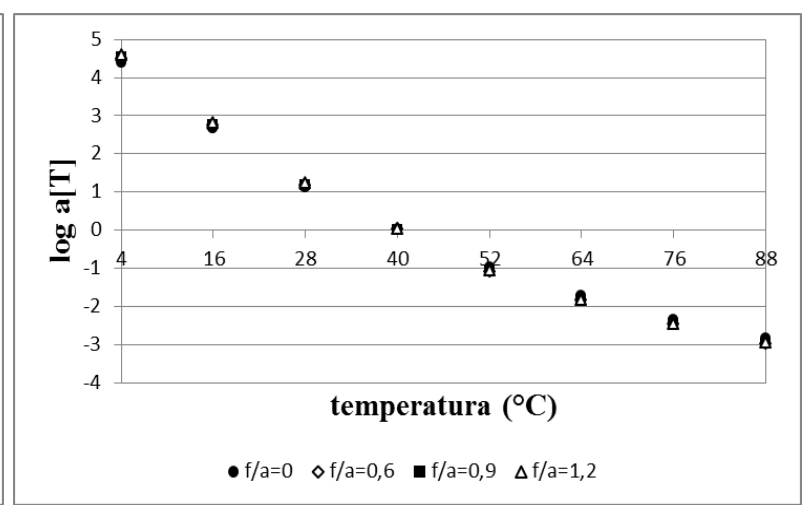

(b)

Figura 3.14 - Fatores de Deslocamento Horizontal em função da temperatura para os mástique compostos pela sílica e: (a) CAP 50/70 e (b) CAP 85/100 


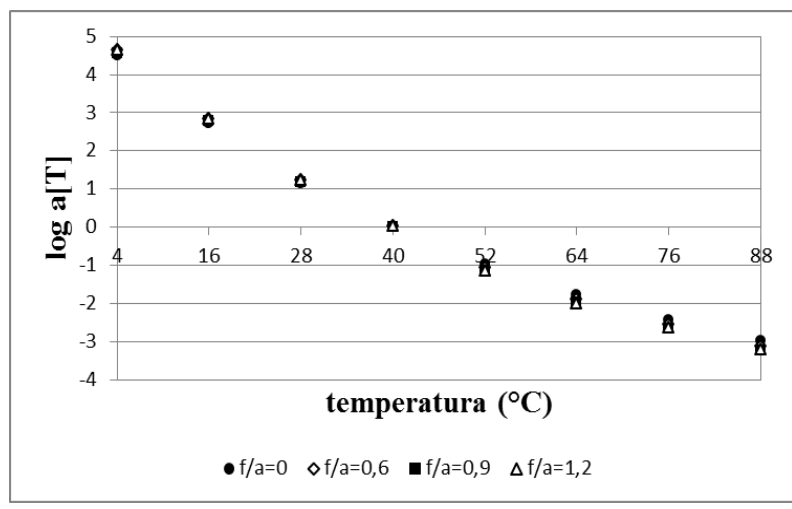

(a)

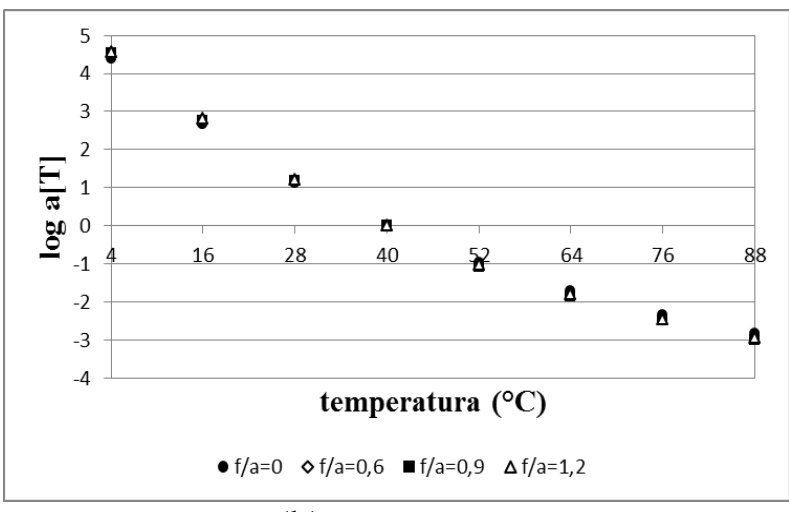

(b)

Figura 3.15 - Fatores de Deslocamento Horizontal em função da temperatura para os mástique compostos pelo pó calcário e: (a) CAP 50/70 e (b) CAP 85/100

As Figuras 3.16, 3.17 e 3.18 comparam os valores de $\delta$ em função da temperatura, para os mástiques compostos pelos fileres de cal hidratada (a), cimento Portland (b), sílica (c) e pó de calcário (d), nas temperaturas de 4 a $88^{\circ} \mathrm{C}$, para o ligante asfáltico CAP 50/70, em função das relações fíler/asfalto, para as frequências de carregamento de 0,1; 1,0 e $10 \mathrm{rad} / \mathrm{s}$, respectivamente. 


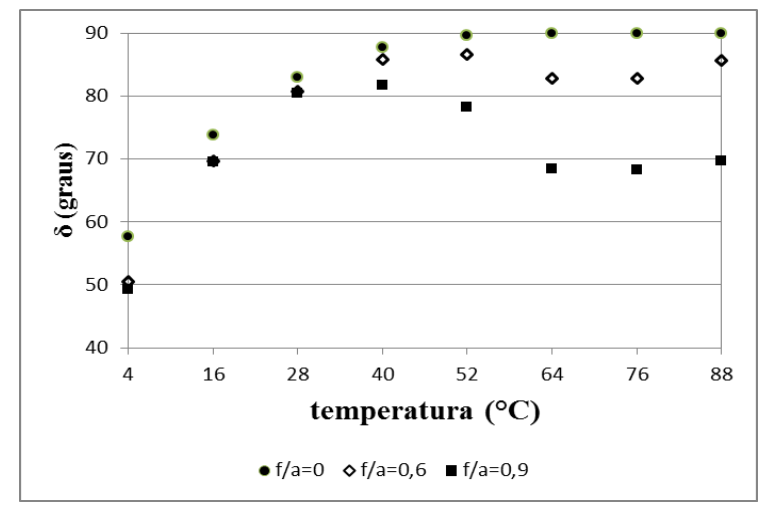

(a)

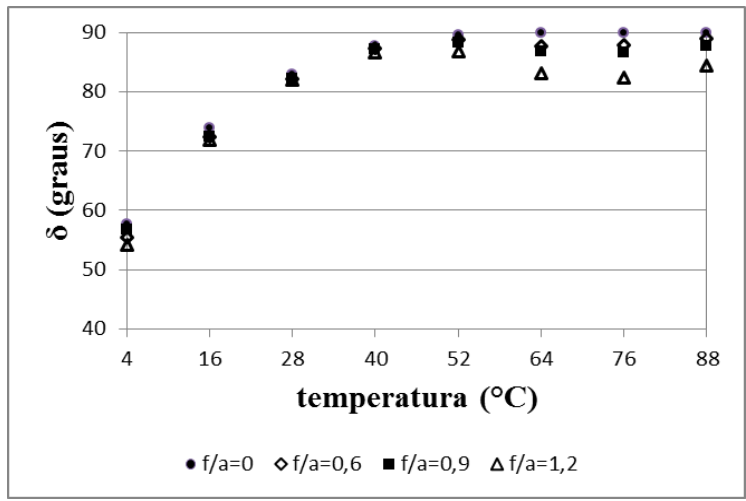

(c)

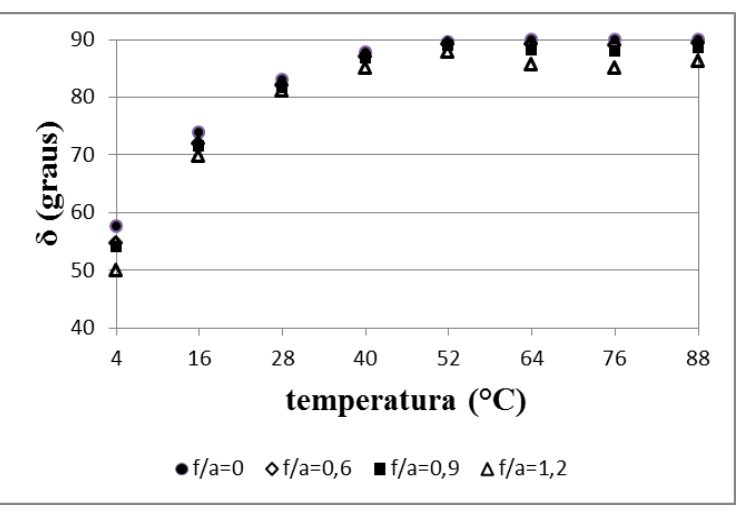

(b)

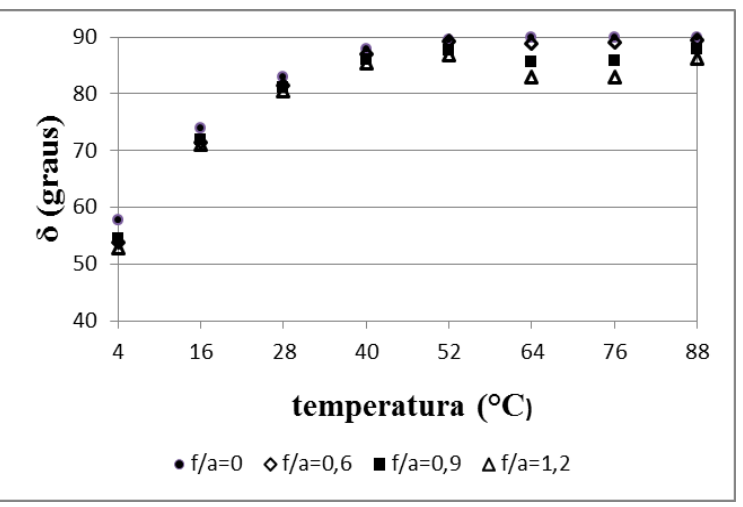

(d)

Figura 3.16 - Ângulo de fase $(\delta)$ versus temperatura $\left({ }^{\circ} \mathrm{C}\right)$ em função da relação f/a para mástiques compostos com o CAP 50/70, na frequência de $0,1 \mathrm{rad} / \mathrm{s}$, e: (a) cal hidratada, (b) cimento Portland, (c) sílica e (d) pó de calcário 


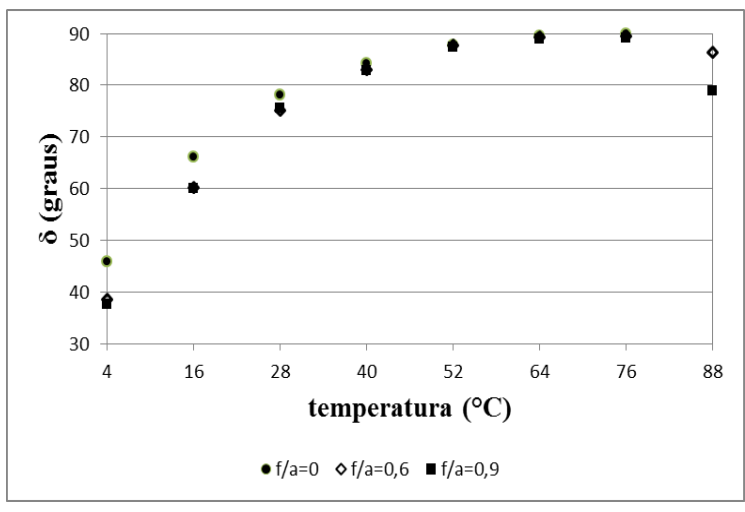

(a)

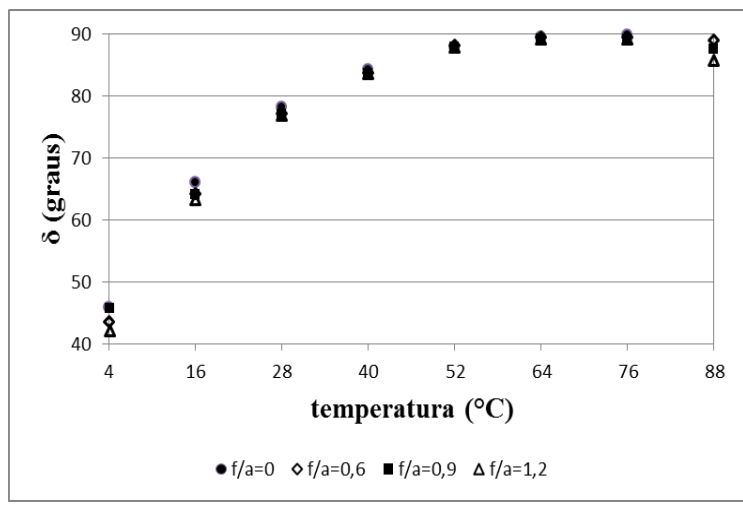

(c)

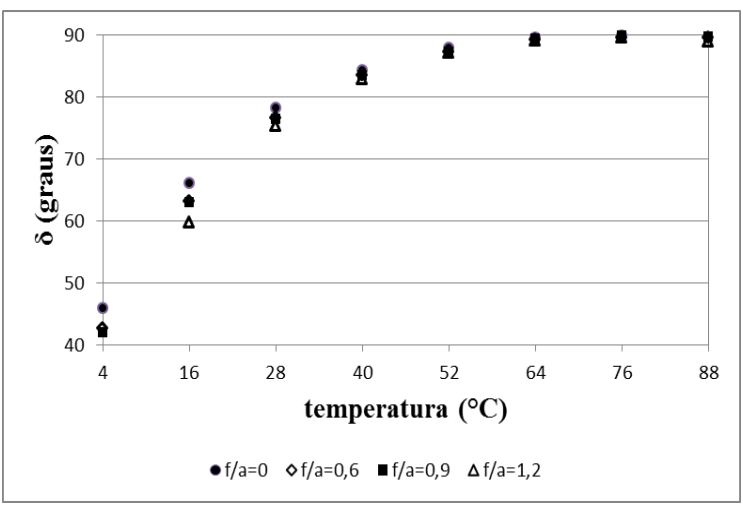

(b)

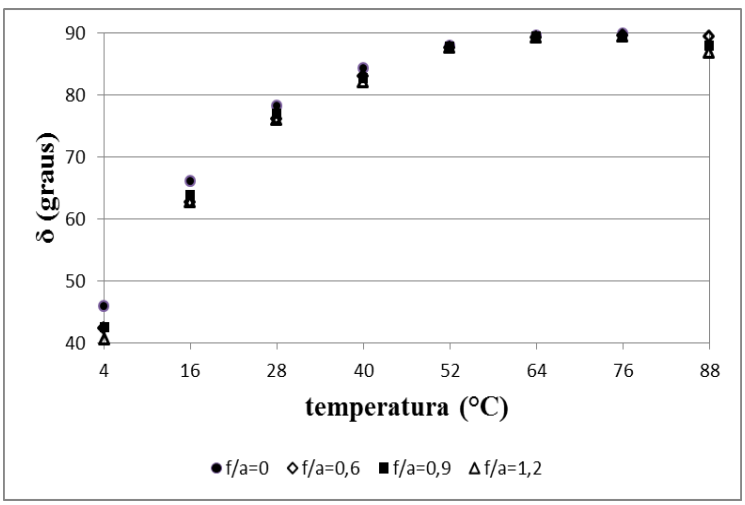

(d)

Figura 3.17 - Ângulo de fase $(\delta)$ versus temperatura $\left({ }^{\circ} \mathrm{C}\right)$ em função da relação f/a para mástiques compostos com o CAP 50/70, na frequência de 1,0 rad/s, e: (a) cal hidratada, (b) cimento Portland, (c) sílica e (d) pó de calcário 


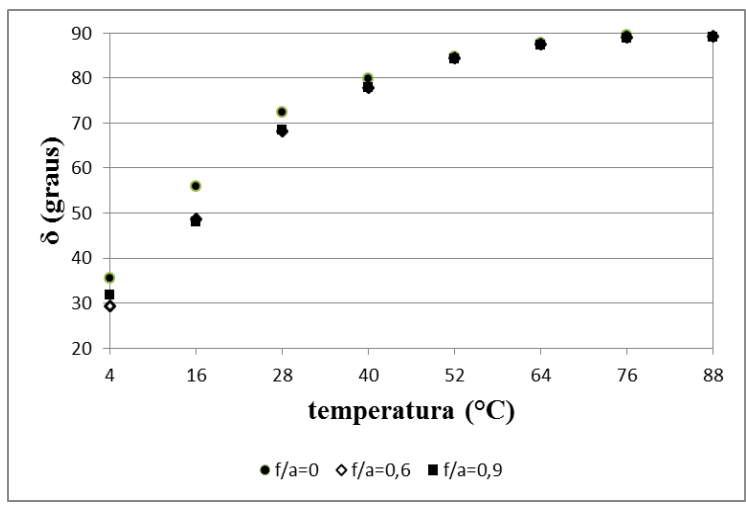

(a)

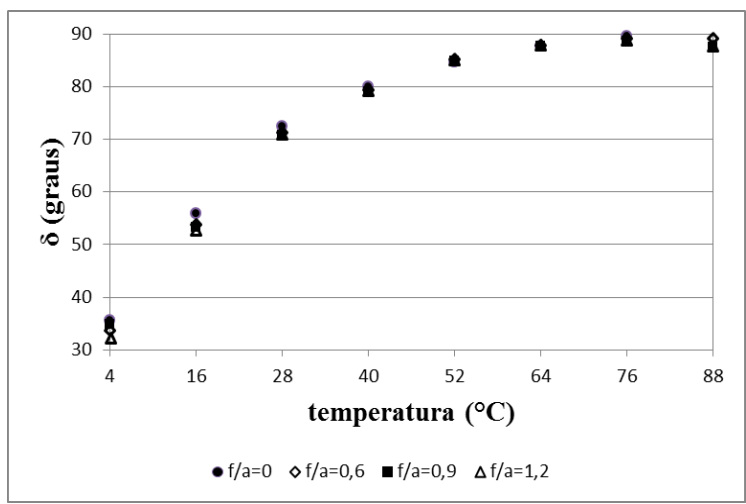

(c)

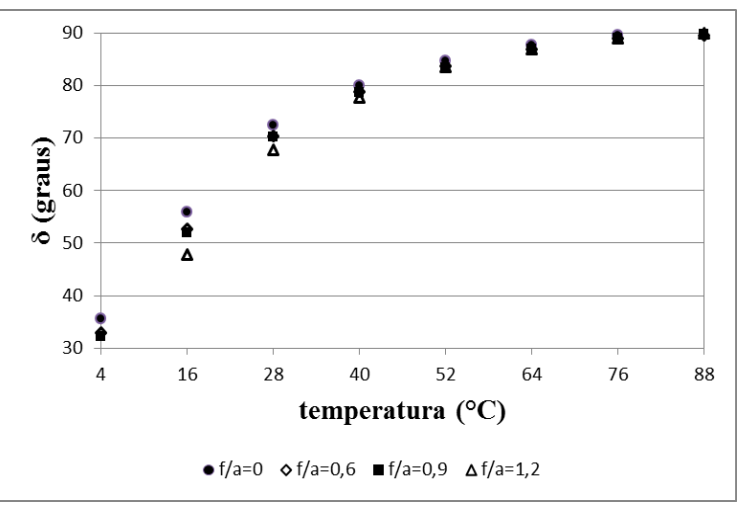

(b)

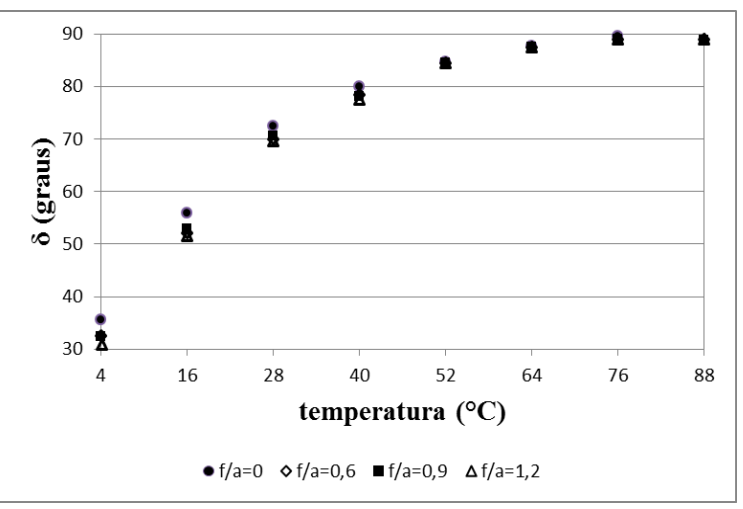

(d)

Figura 3.18 - Ângulo de fase $(\delta)$ versus temperatura $\left({ }^{\circ} \mathrm{C}\right)$ em função da relação f/a para mástiques compostos com o CAP 50/70, na frequência de 10,0 rad/s, e: (a) cal hidratada, (b) cimento Portland, (c) sílica e (d) pó de calcário

Analisando-se as Figuras 3.16 a 3.18, pode-se perceber que nos mástiques asfálticos compostos pelo CAP 50/70, o ângulo de fase aumentou com a temperatura, uma tendência de variação do ângulo de fase com a temperatura semelhante à dos ligantes asfálticos. A adição de fíler provocou redução do ângulo de fase, o que significa que o mástique se torna mais elástico. O efeito da relação f/a é sutilmente diferente para cada frequência de carregamento: para a frequência de 0,1 $\mathrm{rad} / \mathrm{s}$ pode-se perceber que o efeito da adição de fíler foi mais expressivo, principalmente nas altas temperaturas; nas frequências de 1,0 e 10,0 rad/s a diminuição do ângulo de fase foi maior nas temperaturas mais baixas e foi mais expressiva para os mástiques compostos pelo fíler de cal hidratada e cimento Portland, mostrando o efeito da atividade do mineral. 
As Figuras 3.19, 3.20 e 3.21 comparam os valores de $\delta$ em função da temperatura, para os mástiques compostos pelos fileres de cal hidratada (a), cimento Portland (b), sílica (c) e pó de calcário (d), nas temperaturas de 4 a $88^{\circ} \mathrm{C}$, para o ligante asfáltico CAP $85 / 100$, em função das relações fíler/asfalto, para as frequências de carregamento de 0,$1 ; 1,0$ e $10 \mathrm{rad} / \mathrm{s}$, respectivamente.

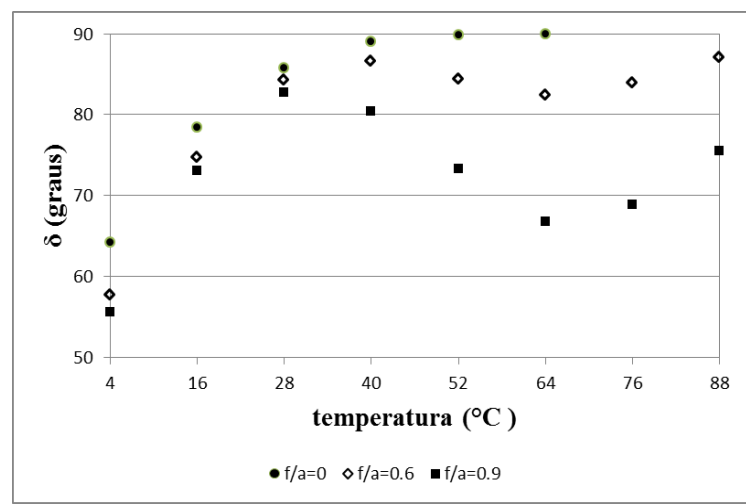

(a)

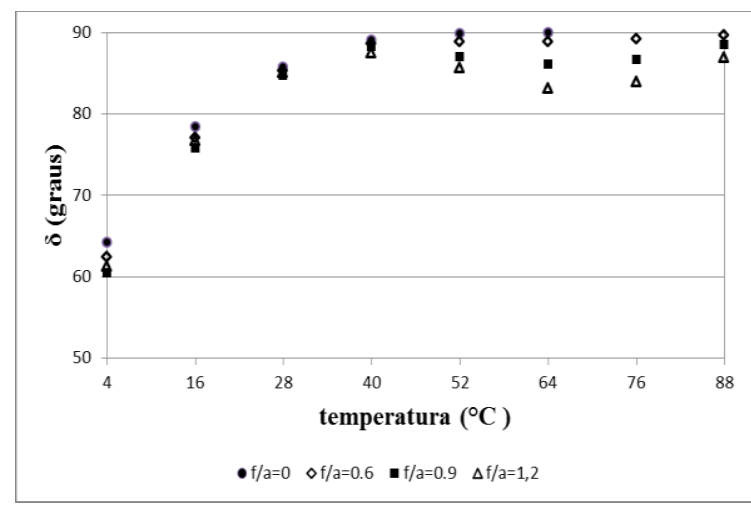

(c)

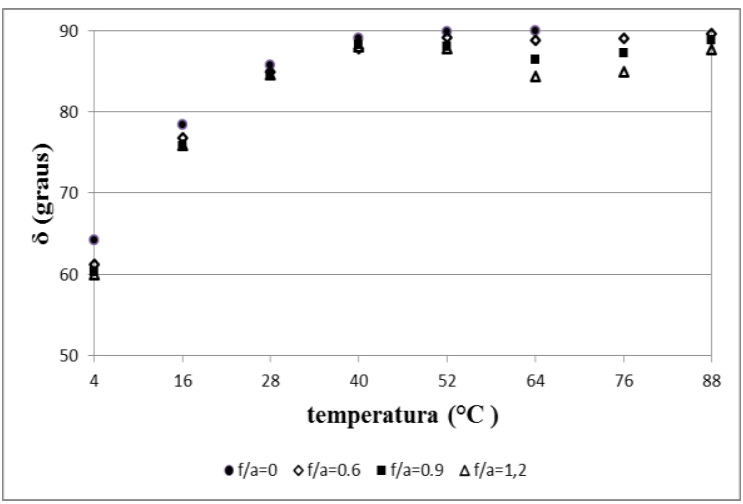

(b)

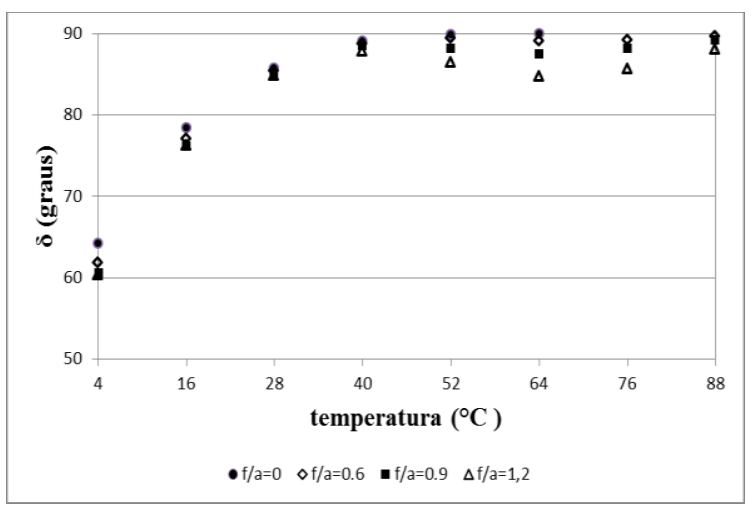

(d)

Figura 3.19 - Ângulo de fase $(\delta)$ versus temperatura $\left({ }^{\circ} \mathrm{C}\right)$ em função da relação f/a para mástiques compostos com o CAP 85/100, na frequência de $0,1 \mathrm{rad} / \mathrm{s}$, e: (a) cal hidratada, (b) cimento

Portland, (c) sílica e (d) pó de calcário 


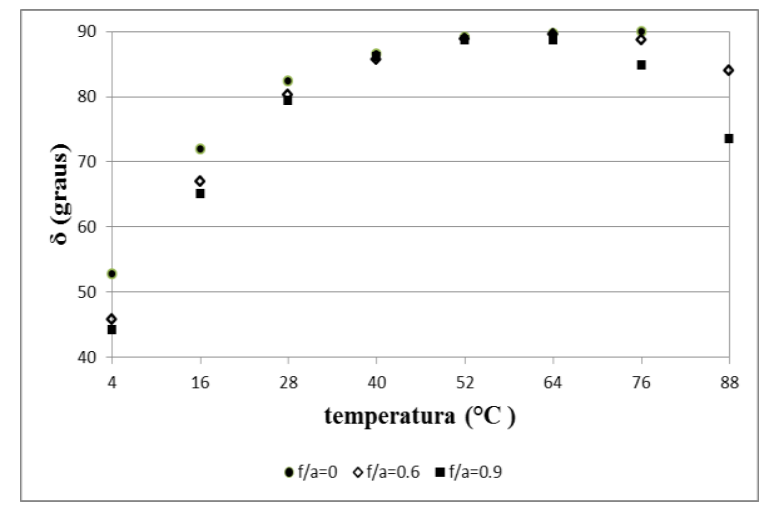

(a)

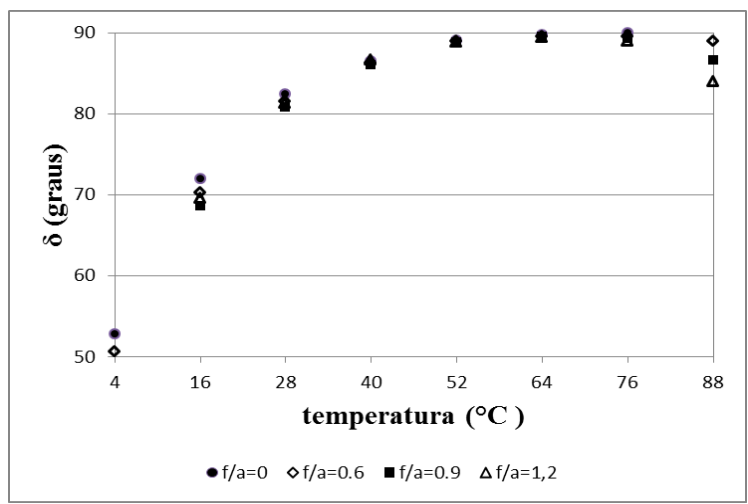

(c)

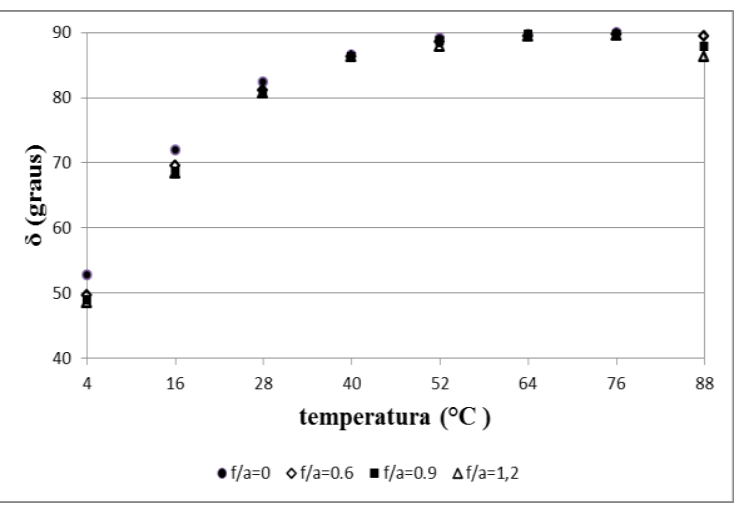

(b)

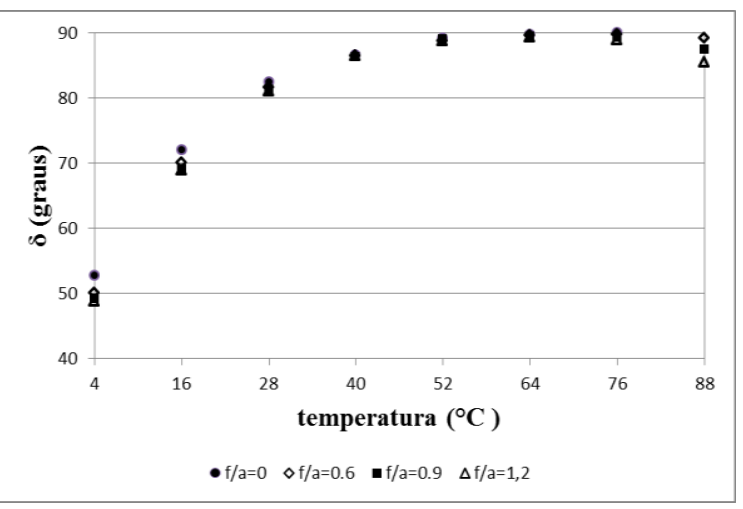

(d)

Figura 3.20 - Ângulo de fase $(\delta)$ versus temperatura $\left({ }^{\circ} \mathrm{C}\right)$ em função da relação f/a para mástiques compostos com o CAP 85/100, na frequência de 1,0 rad/s, e: (a) cal hidratada, (b) cimento Portland, (c) sílica e (d) pó de calcário 


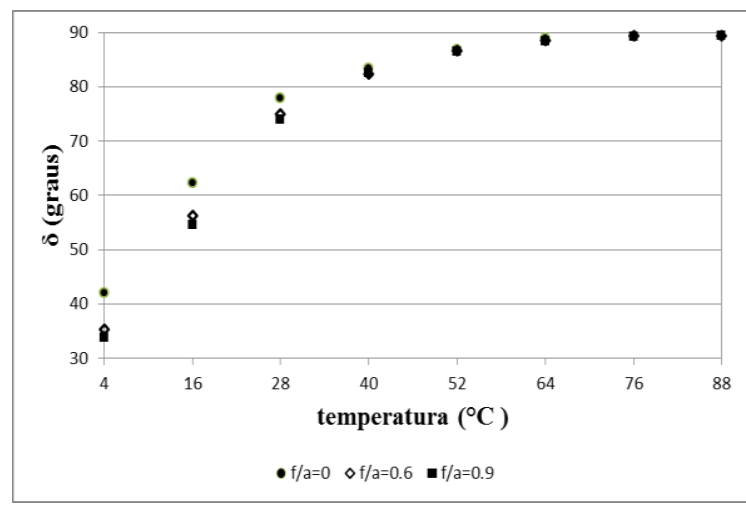

(a)

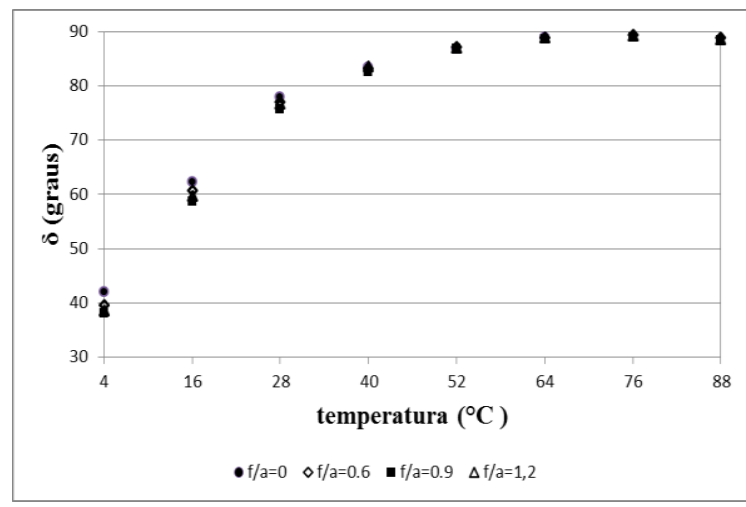

(c)

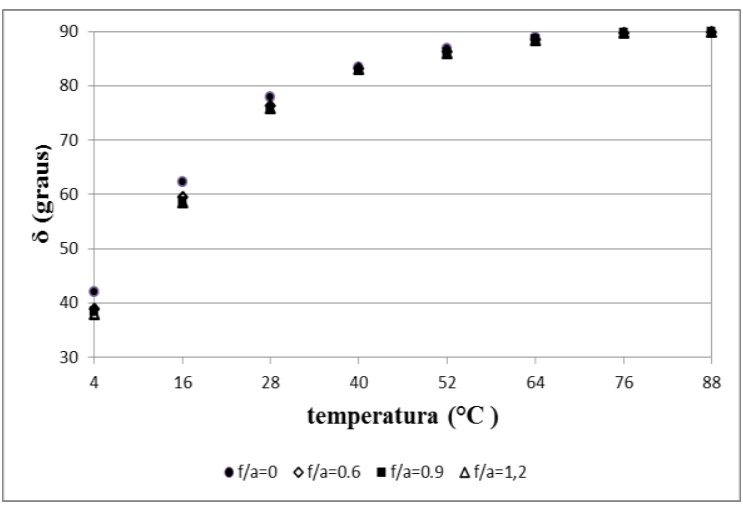

(b)

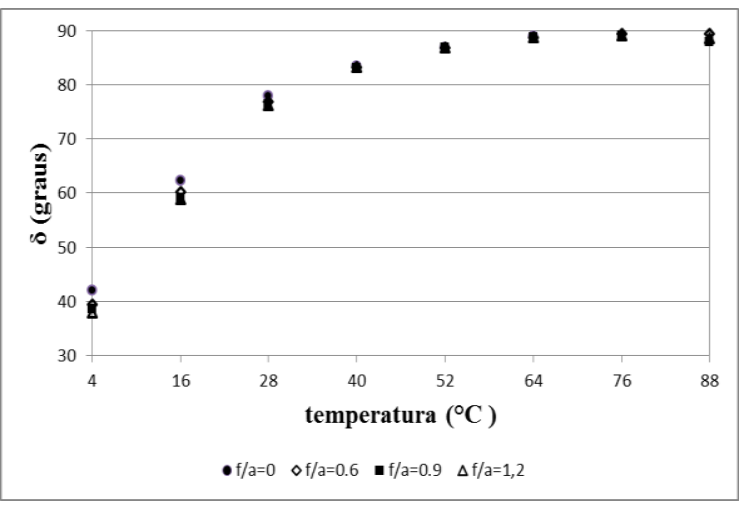

(d)

Figura 3.21 - Ângulo de fase $(\delta)$ versus temperatura $\left({ }^{\circ} \mathrm{C}\right)$ em função da relação f/a para mástiques compostos com o CAP 85/100, na frequência de 10,0 rad/s, e: (a) cal hidratada, (b) cimento

Portland, (c) sílica e (d) pó de calcário

Pelas Figuras 3.19 a 3.21, pode-se perceber que nos mástiques asfálticos, compostos pelo CAP 85/100, o ângulo de fase aumentou com a temperatura, uma tendência semelhante à do ligante asfáltico CAP 50/70, e que a adição de fíler também provocou redução do ângulo de fase, tornando o mástique mais elástico. Similarmente ao efeito da relação f/a dos mástique compostos pelo CAP 50/70, nos com o CAP 85/100, na frequência de $0,1 \mathrm{rad} / \mathrm{s}$, a adição de fíler foi mais expressiva, principalmente nas altas temperaturas, e para os mástiques compostos pelo fíler de cal hidratada e cimento Portland. Nas frequências de 1,0 e 10,0 rad/s a diminuição do ângulo de fase foi maior nas temperaturas mais baixas, porém, para os mástiques compostos pelo fíler de cal hidratada e cimento Portland, esse efeito não foi tão expressivo nos mástiques compostos pelo 85/100. 
As Figuras 3.22, 3.23 e 3.24 apresentam os valores comparativos do módulo complexo - G* - em função da temperatura para os mástiques compostos pelos fileres de cal hidratada, cimento Portland, sílica e pó de calcário, para o ligante asfáltico CAP 50/70, nas temperaturas de 52 a $88^{\circ} \mathrm{C}$, nas relações f/a de 0,6 (a); 0,9 (b) e 1,2 (c), nas frequências de carregamento de 0,$1 ; 1,0$ e $10,0 \mathrm{rad} / \mathrm{s}$, respectivamente. Escolheu-se apresentar os resultados do módulo complexo nas temperaturas altas (acima de $52^{\circ} \mathrm{C}$ ), pois são nessas temperaturas que o efeito da adição do fíler é mais expressivo.

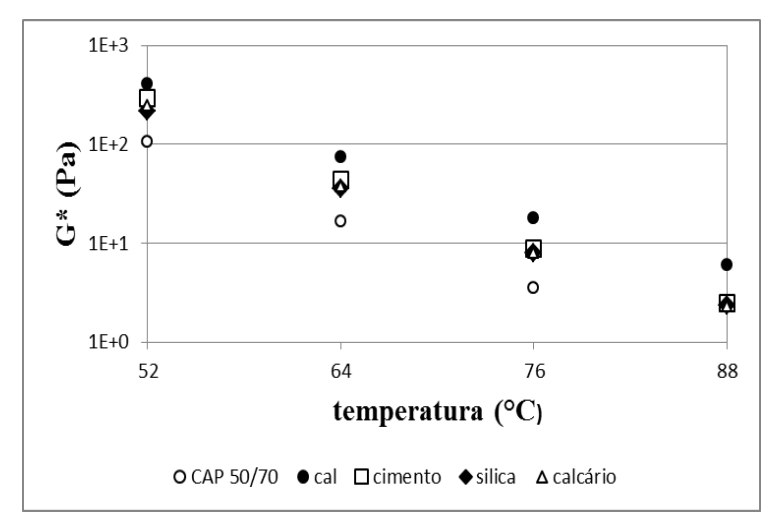

(a)

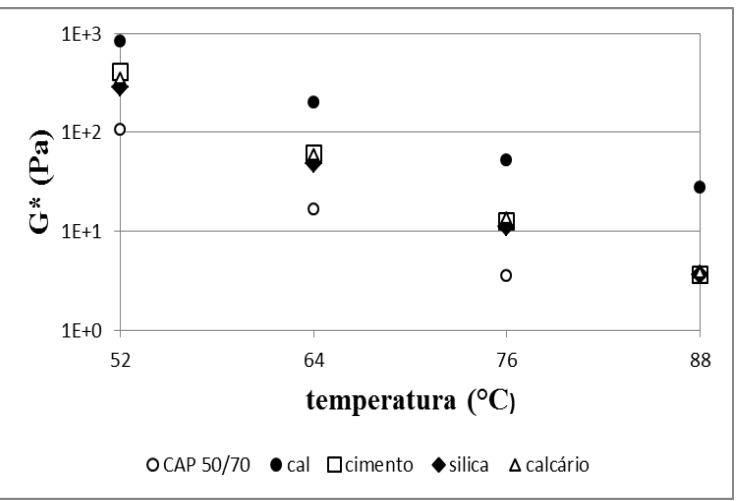

(b)

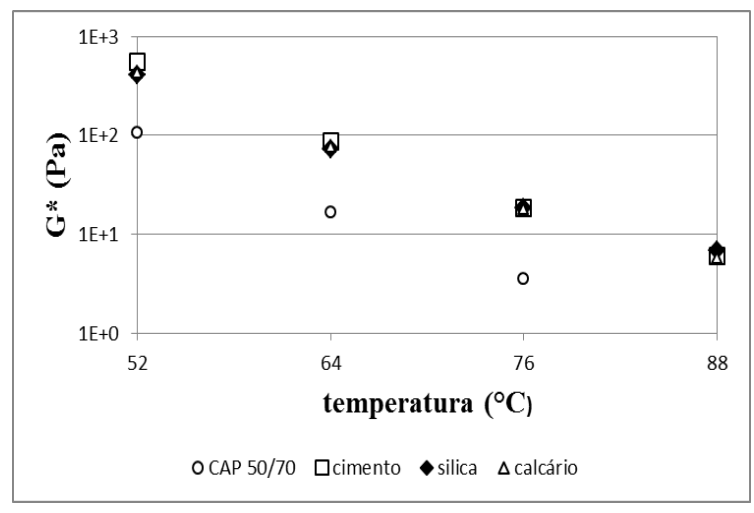

(c)

Figura 3.22 - Módulo Complexo $\left(\mathrm{G}^{*}\right)$ versus temperatura $\left({ }^{\circ} \mathrm{C}\right)$ em função do tipo de fíler para mástiques compostos com o CAP 50/70, na frequência de $0,1 \mathrm{rad} / \mathrm{s}$, e relação f/a: (a) 0,6 (b) 0,9 e (c) 1,2 


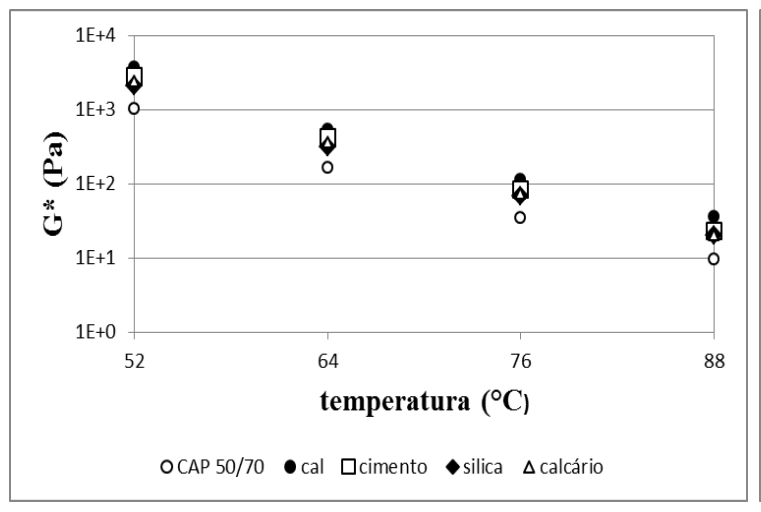

(a)

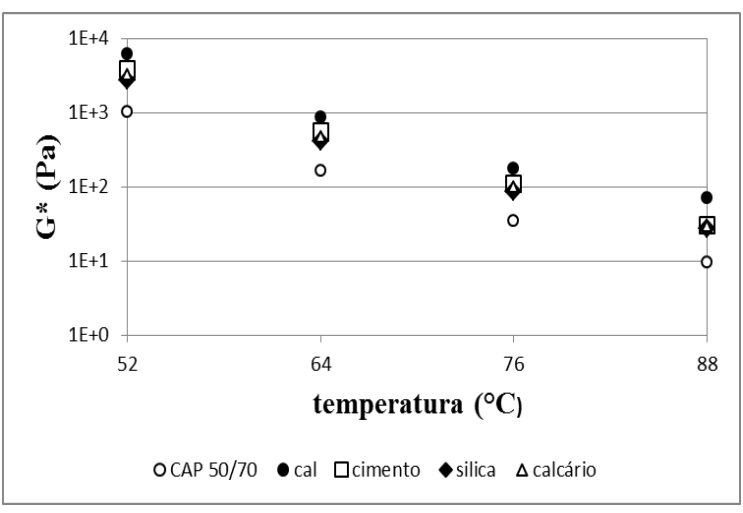

(b)

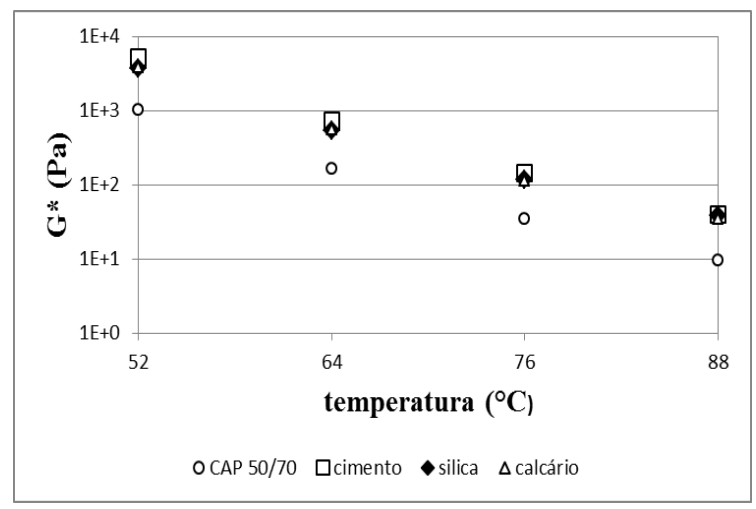

(c)

Figura 3.23 - Módulo Complexo $\left(\mathrm{G}^{*}\right)$ versus temperatura $\left({ }^{\circ} \mathrm{C}\right)$ em função do tipo de fíler para mástiques compostos com o CAP 50/70, na frequência de 1,0 rad/s, e relação f/a: (a) 0,6 (b) 0,9 e (c) 1,2 


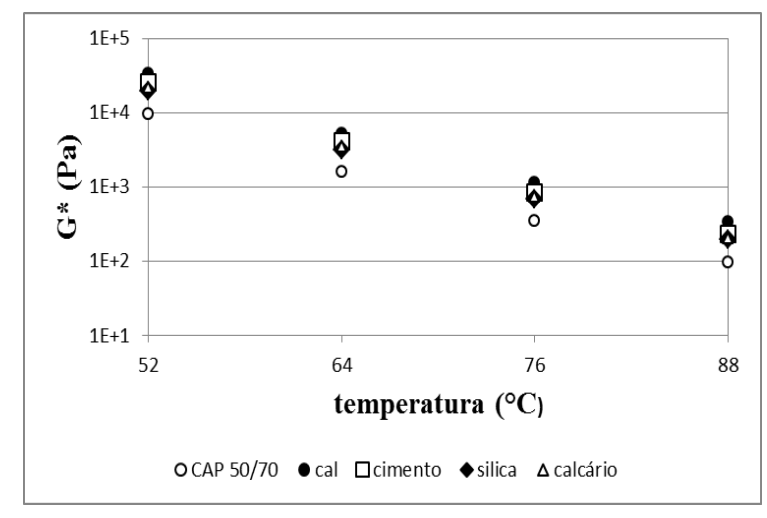

(a)

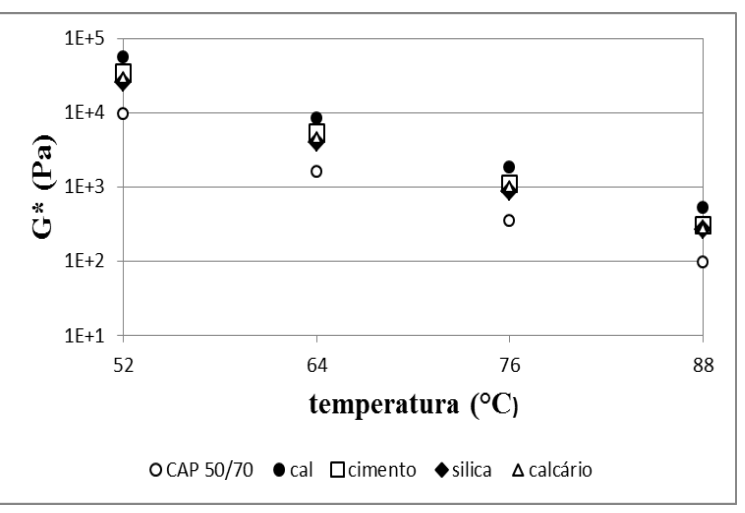

(b)

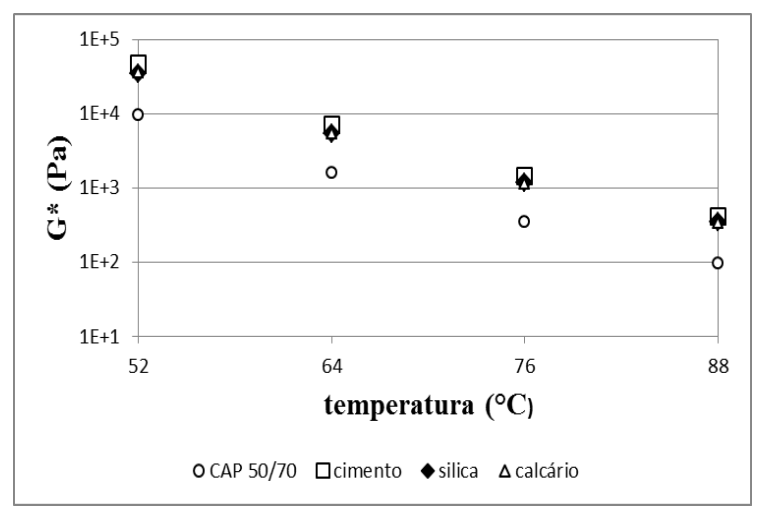

(c)

Figura 3.24 - Módulo Complexo $\left(\mathrm{G}^{*}\right)$ versus temperatura $\left({ }^{\circ} \mathrm{C}\right)$ em função do tipo de fíler para mástiques compostos com o CAP 50/70, na frequência de 10,0 rad/s, e relação f/a (a) 0,6 (b) 0,9 e (c) 1,2

Os mástiques asfálticos apresentaram uma tendência de variação da rigidez com a temperatura semelhante à dos ligantes asfálticos. A rigidez diminuiu com a temperatura, de forma aproximadamente linear, quando a escala de $\mathrm{G}^{*}$ é logarítmica. A utilização do fíler mineral aumentou o valor de $\mathrm{G}^{*}$ para todas as temperaturas avaliadas, o que pode ser comparado a um deslocamento vertical da curva isócrona do ligante asfáltico puro. Pode-se perceber que para todas as frequências de carregamento estudadas, os mástiques compostos pelo fíler de cal hidratada tiveram maior valor de rigidez, seguido pelos compostos pelo cimento Portland.

As Figuras 3.25, 3.26 e 3.27 apresentam os valores comparativos do módulo complexo - G* - em função da temperatura para os mástiques compostos pelos fileres de cal hidratada, cimento Portland, sílica e pó de calcário, para o ligante asfáltico CAP 85/100, nas temperaturas de 52 a 
$88^{\circ} \mathrm{C}$, nas relações f/a de 0,6 (a); 0,9 (b) e 1,2 (c) e nas frequências de carregamento de 0,$1 ; 1,0$ e $10,0 \mathrm{rad} / \mathrm{s}$, respectivamente.

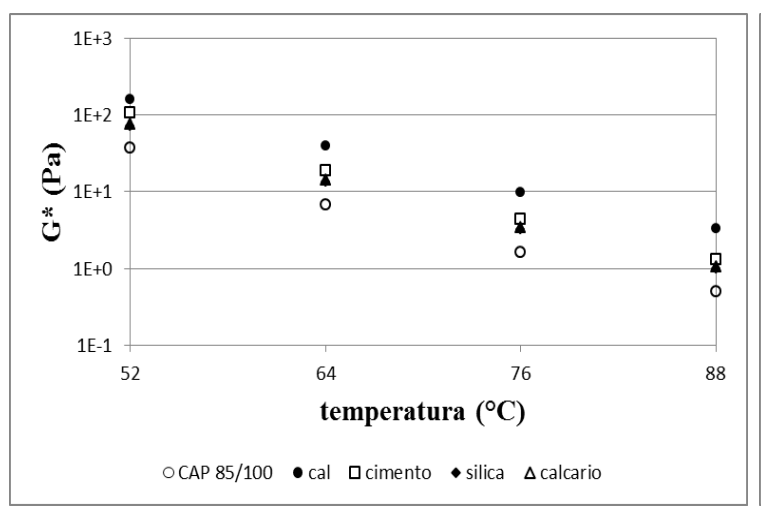

(a)

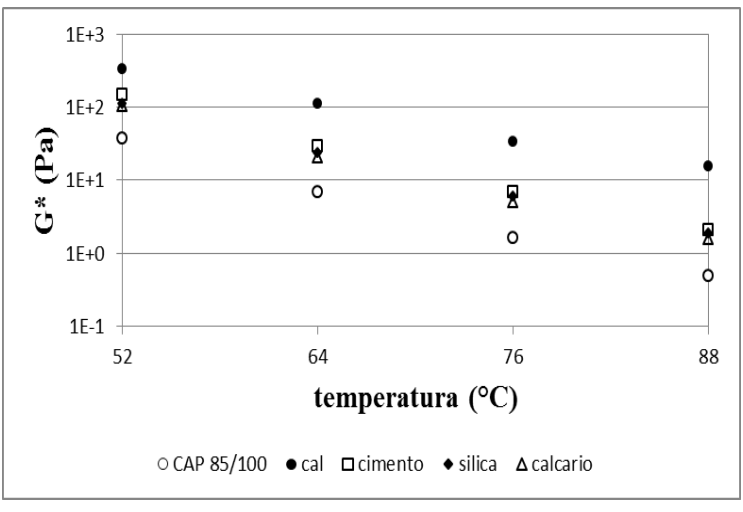

(b)

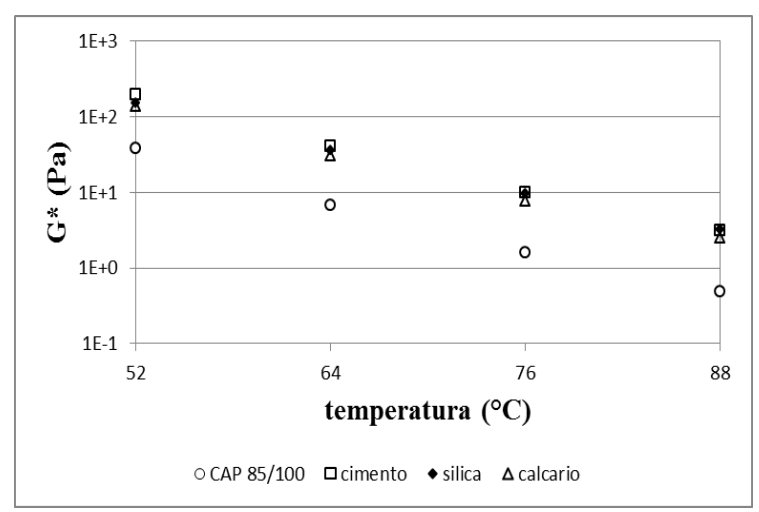

(c)

Figura 3.25 - Módulo Complexo $\left(\mathrm{G}^{*}\right)$ versus temperatura $\left({ }^{\circ} \mathrm{C}\right)$ em função do tipo de fíler para mástiques compostos com o CAP 85/100, na frequência de $0,1 \mathrm{rad} / \mathrm{s}$, e relação f/a: (a) 0,6 (b) 0,9 e (c) 1,2 


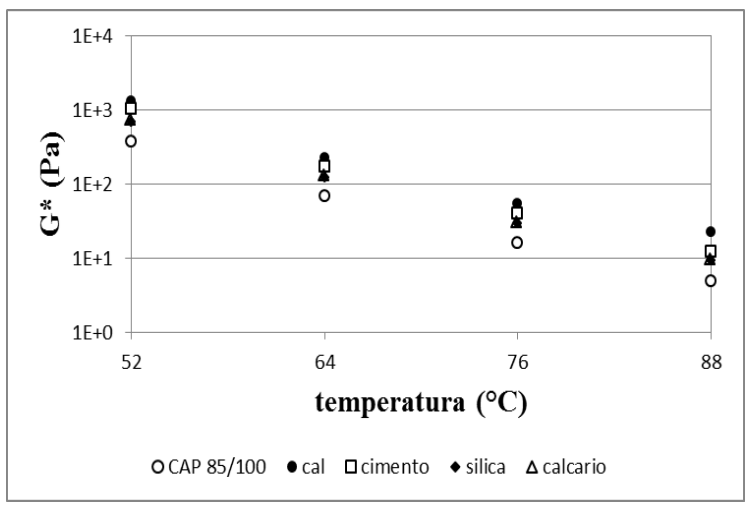

(a)

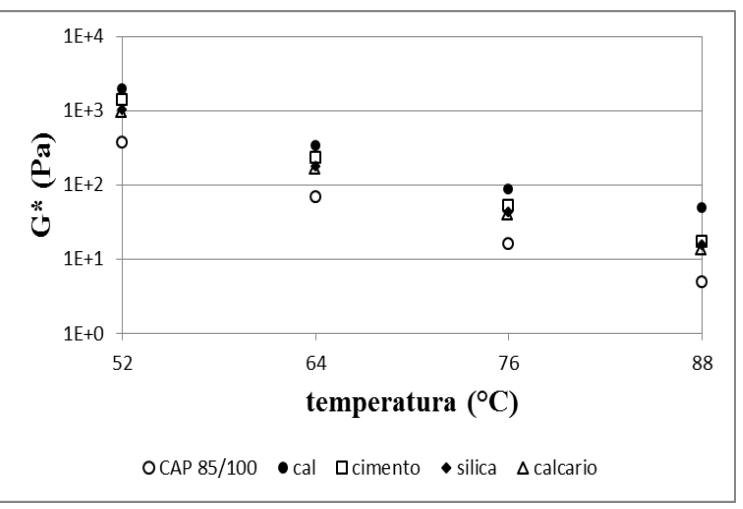

(b)

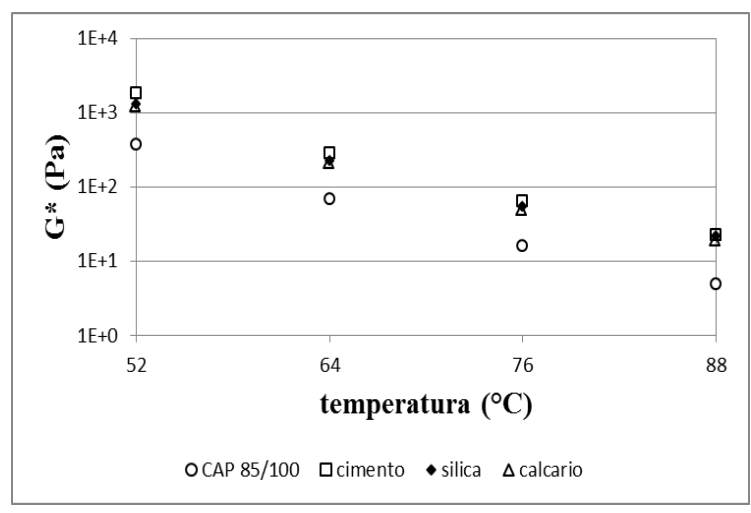

(c)

Figura 3.26 - Módulo Complexo $\left(\mathrm{G}^{*}\right)$ versus temperatura $\left({ }^{\circ} \mathrm{C}\right)$ em função do tipo de fíler para mástiques compostos com o CAP 85/100, na frequência de 1,0 rad/s, e relação f/a: (a) 0,6 (b) 0,9 e (c) 1,2 


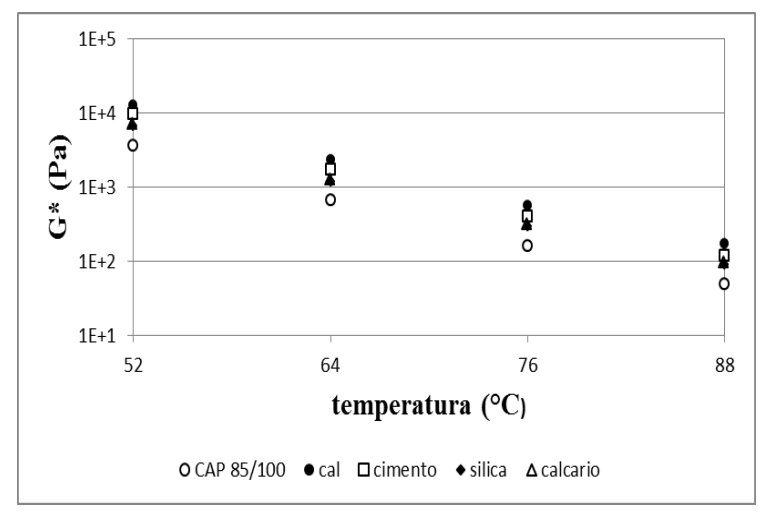

(a)

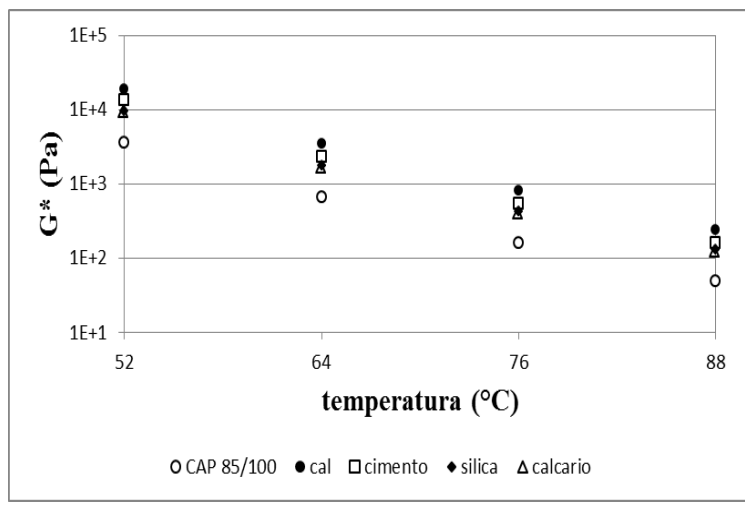

(b)

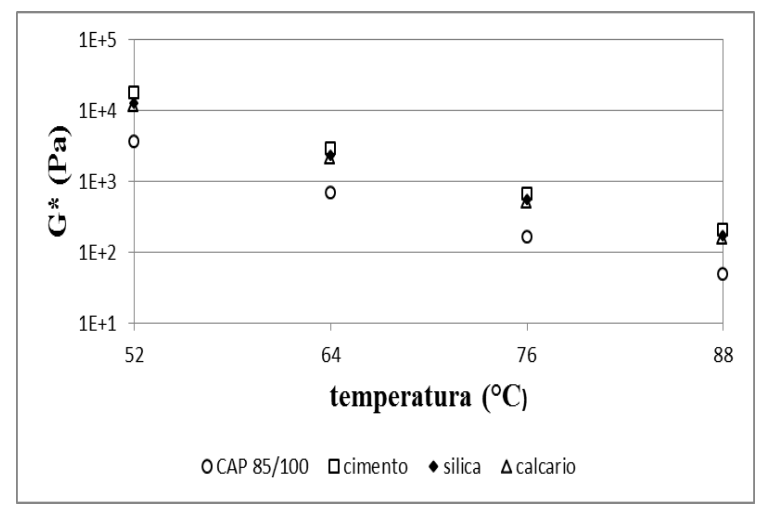

(c)

Figura 3.27 - Módulo Complexo $\left(\mathrm{G}^{*}\right)$ versus temperatura $\left({ }^{\circ} \mathrm{C}\right)$ em função do tipo de fíler para mástiques compostos com o CAP 85/100, na frequência de 10,0 rad/s, e relação f/a: (a) 0,6 (b) 0,9 e (c) 1,2

Da mesma maneira que para os mástique compostos pelo CAP 50/70, nos mástiques compostos pelo CAP 85/100 a utilização do fíler mineral aumentou o valor de $\mathrm{G}^{*}$ para todas as temperaturas avaliadas. Também, para todas as frequências de carregamento estudadas, os mástiques compostos pelo fíler de cal hidratada tiveram maior valor de rigidez, sendo inclusive mais acentuado o aumento em relação aos mástiques compostos pelo CAP 50/70, seguido pelo mástique com cimento Portland.

Para avaliar o aumento de rigidez, que pode ser um indicador do potencial enrijecedor do fíler, através da comparação dos valores com o ligante asfáltico puro, com isso, indica-se quantas vezes a rigidez dos mástiques aumentou em relação à do ligante asfáltico puro $(\mathrm{f} / \mathrm{a}=0,0)$. A Tabela 3.1 mostra o aumento da rigidez dos mástique compostos com os fileres de sílica, cimento 
Portland, pó de calcário, e cal hidratada, em função das relações fíler/asfalto, para os ligantes asfálticos CAP 50/70 e CAP 85/100. Os números entre parênteses na linha correspondente a f/a de 0,0 são os valores do módulo complexo $\left(G^{*}\right)$ do ligante asfáltico puro e os valores nas linhas correspondentes às relações f/a indicam quantas vezes a rigidez aumentou em relação ao valor do ligante asfáltico puro. As Figuras 3.28 e 3.29 mostram o aumento do módulo complexo $\left(G^{*}\right)$ em função da relação f/a, para mástiques compostos com o CAP 50/70 e 85/100, respectivamente, na frequência de (a) $0,1 \mathrm{rad} / \mathrm{s}$ (b) $1,0 \mathrm{rad} / \mathrm{s}$ e (c) $10,0 \mathrm{rad} / \mathrm{s}$.

Tabela 3.1 - Valores do aumento do módulo complexo (G*) em função da relação f/a, tipo de fíler e tipo de ligante asfáltico

\begin{tabular}{c|c|ccc|ccc}
\hline \multicolumn{2}{l|}{} & \multicolumn{5}{c|}{ CAP 50/70 } & \multicolumn{3}{c}{ CAP 85/100 } \\
\hline f/a & filer & $0,1 \mathrm{rad} / \mathrm{s}$ & $1 \mathrm{rad} / \mathrm{s}$ & $10 \mathrm{rad} / \mathrm{s}$ & $0,1 \mathrm{rad} / \mathrm{s}$ & $1 \mathrm{rad} / \mathrm{s}$ & $10 \mathrm{rad} / \mathrm{s}$ \\
\hline 0 & & 1,0 & 1,0 & 1,0 & 1,0 & 1,0 & 1,0 \\
& & $(4,55 \mathrm{E}+04)$ & $(2,34 \mathrm{E}+05)$ & $(1,45 \mathrm{E}+06)$ & $(1,91 \mathrm{E}+04)$ & $(1,14 \mathrm{E}+05)$ & $(7,50 \mathrm{E}+05)$ \\
\hline 0,6 & & 3,4 & 3,3 & 2,9 & 2,2 & 2,6 & 1,8 \\
0,9 & silica & 3,8 & 4,0 & 2,9 & 3,0 & 3,7 & 3,8 \\
1,2 & & 4,0 & 4,2 & 4,8 & 4,6 & 3,8 & 5,3 \\
\hline 0,6 & \multirow{2}{*}{ cimento } & 2,0 & 2,9 & 2,2 & 2,4 & 2,9 & 2,0 \\
0,9 & Portland & 3,5 & 4,3 & 4,0 & 3,1 & 3,9 & 4,1 \\
1,2 & & 6,7 & 7,8 & 6,5 & 4,3 & 4,9 & 4,0 \\
\hline 0,6 & & 3,5 & 3,1 & 3,0 & 2,2 & 2,6 & 1,8 \\
0,9 & pó & 3,7 & 4,2 & 3,9 & 3,2 & 3,5 & 3,6 \\
1,2 & calcario & 5,7 & 4,1 & 4,8 & 3,5 & 4,5 & 3,6 \\
\hline 0,6 & cal & 3,9 & 4,3 & 4,0 & 4,3 & 4,8 & 3,8 \\
0,9 & hidratada & 8,3 & 9,5 & 5,4 & 7,5 & 7,0 & 5,7 \\
\hline
\end{tabular}




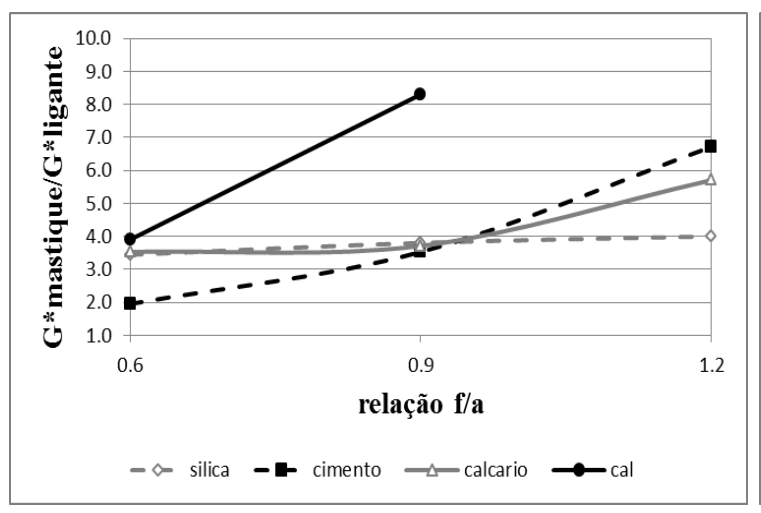

(a)

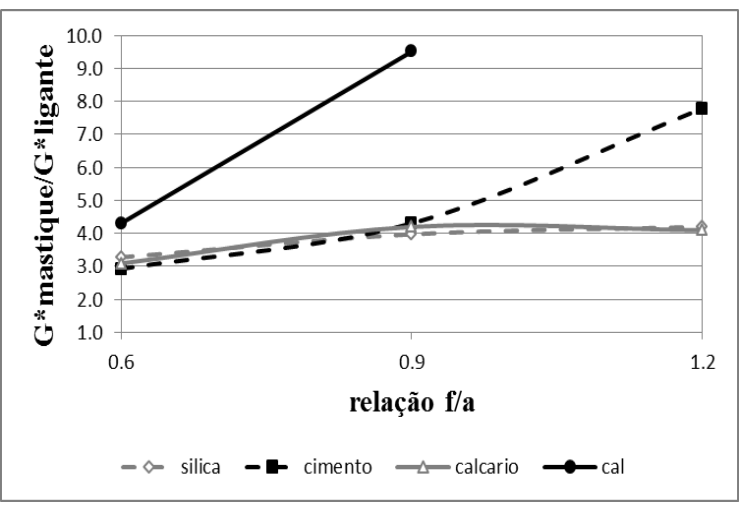

(b)

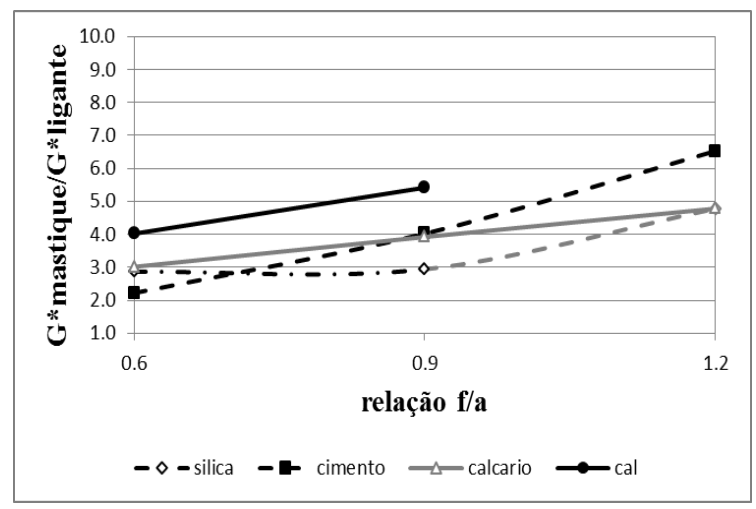

(c)

Figura 3.28 - Aumento do módulo complexo $\left(\mathrm{G}^{*}\right)$ em função da relação f/a, para mástiques compostos com o CAP 50/70, na frequência de: (a) $0,1 \mathrm{rad} / \mathrm{s} \mathrm{(b)} \mathrm{1,0} \mathrm{rad/s} \mathrm{e} \mathrm{(c)} \mathrm{10,0} \mathrm{rad/s}$ 


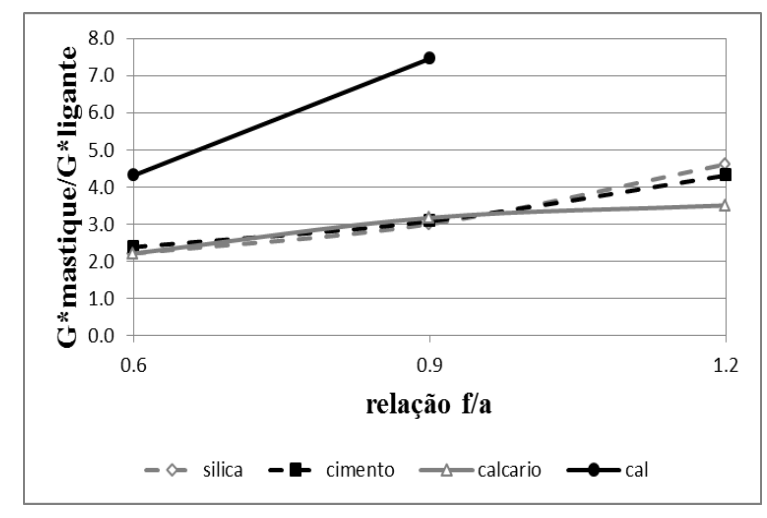

(a)

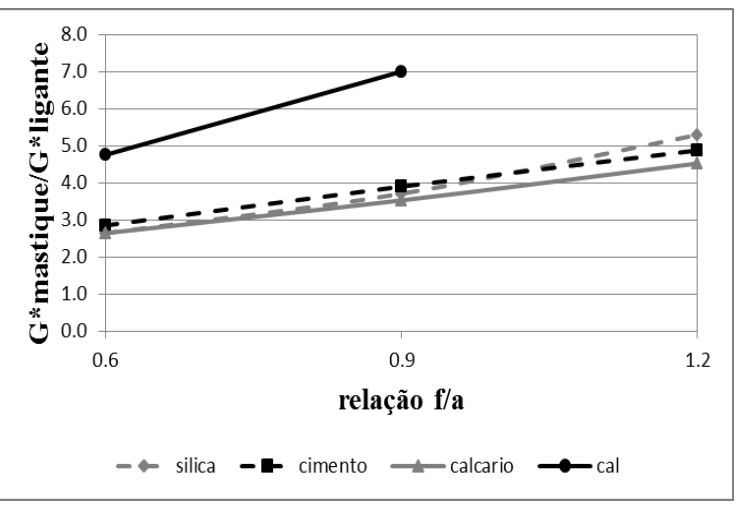

(b)

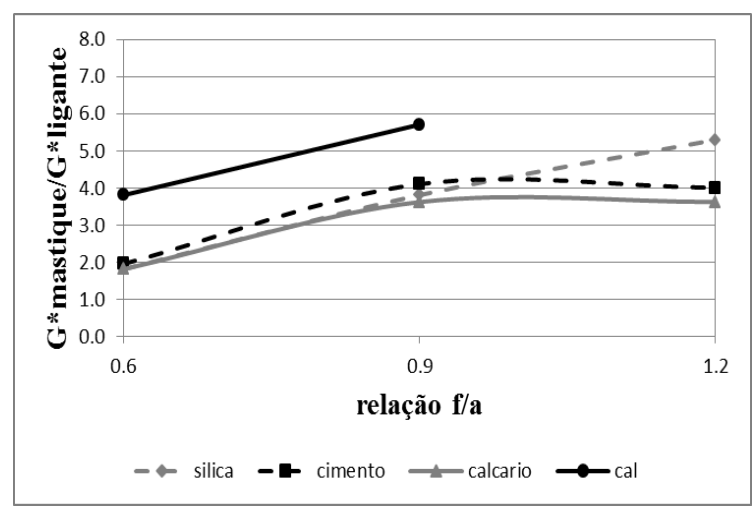

(c)

Figura 3.29 - Aumento do módulo complexo $\left(\mathrm{G}^{*}\right)$ em função da relação f/a, para mástiques compostos com o CAP 85/100, na frequência de: (a) $0,1 \mathrm{rad} / \mathrm{s}$ (b) 1,0 rad/s e (c) 10,0 rad/s

Pode-se perceber que, para todas as frequências e para os dois ligantes asfálticos, o enrijecimento causado pela cal hidratada foi maior, embora para os mástiques compostos pelo CAP 85/100 esse efeito foi mais pronunciado, indicando a maior atividade superficial desse mineral e sua maior afinidade com o ligante asfáltico menos rígido. O potencial físico-químico da cal hidratada foi muito grande, além da forma das partículas e a textura superficial contribuírem significativamente para o efeito enrijecedor.

O efeito causado pelo cimento Portland é bem interessante, pois para os mástiques compostos pelo CAP 50/70 o enrijecimento foi maior que os causados pelos fileres de sílica e calcário para a relação f/a de 1,2, mostrando que o efeito enrijecedor do cimento é mais pronunciado para teores maiores de fíler; ainda que quando utilizado com o CAP 85/100, não se observa esse efeito, provavelmente devido à diferença na afinidade entre o cimento Portland e os dois tipos de 
ligantes asfálticos. O enrijecimento causado pelos fileres de pó calcário e sílica têm efeitos quase iguais, independente do tipo de ligante asfáltico e da frequência.

As Figuras 3.30 e 3.31 apresentam os valores comparativos do parâmetro de deformação permanente da especificação Superpave - $G^{*} / \operatorname{sen} \delta$ - em função da temperatura, nas relações f/a de 0,$6 ; 0,9$ e 1,2, para os mástiques compostos pelos fileres de cal hidratada (a), cimento Portland (b), sílica (c) e pó de calcário (d), para o ligante asfáltico 50/70, nas temperaturas de 28 a $88^{\circ} \mathrm{C}$, na frequência de carregamento de $10 \mathrm{rad} / \mathrm{s}$.

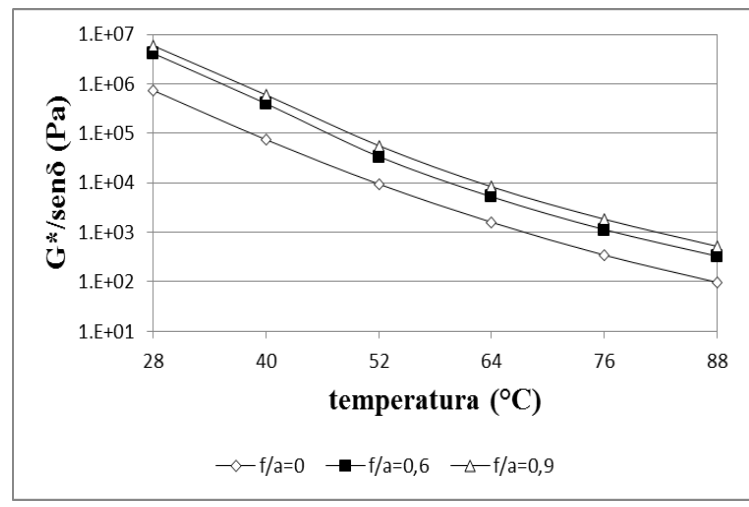

(a)

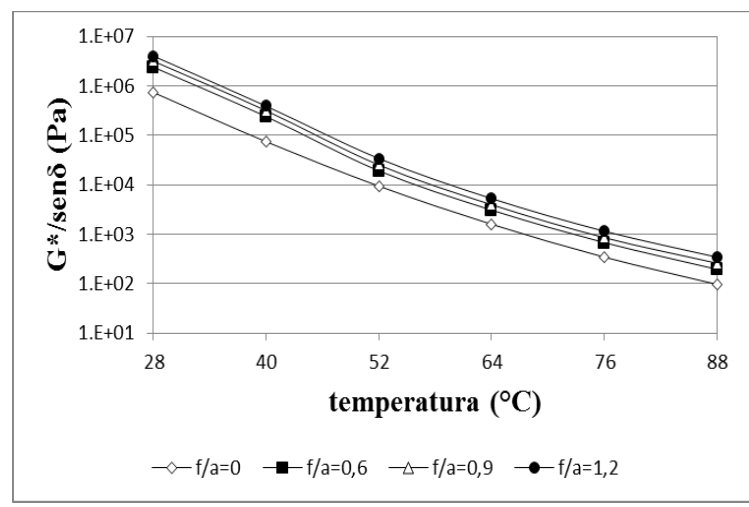

(c)

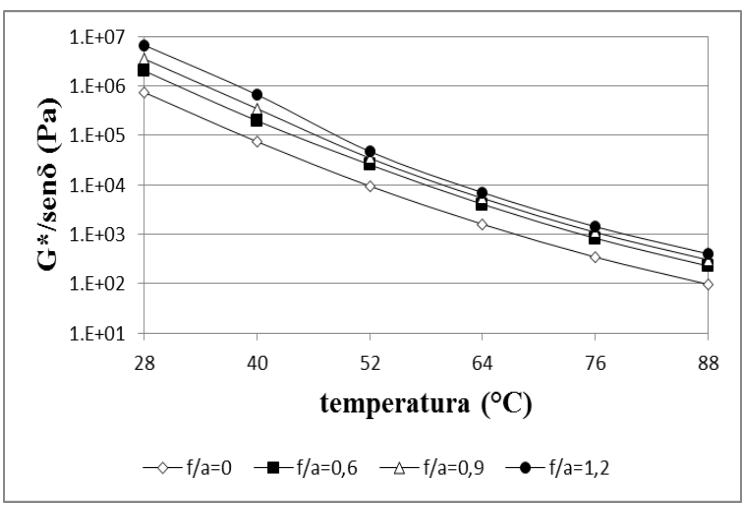

(b)

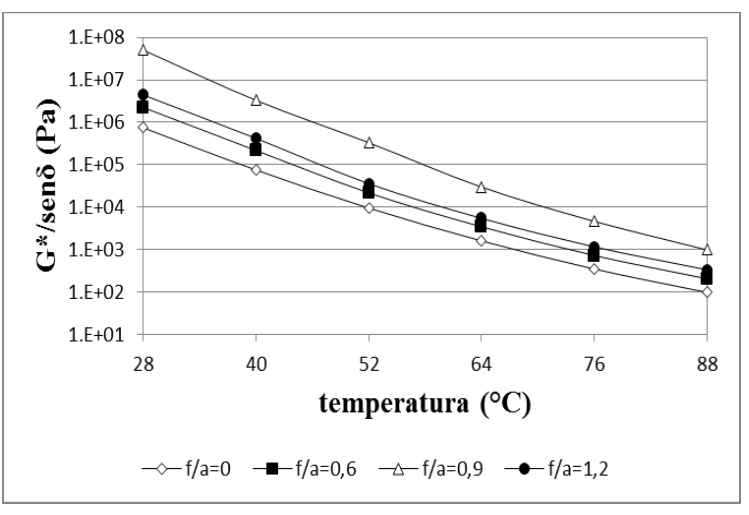

(d)

Figura 3.30 - $\mathrm{G}^{*} / \operatorname{sen} \delta$ versus temperatura $\left({ }^{\circ} \mathrm{C}\right)$ em função da relação f/a, para os mástique compostos pelo CAP 50/70 e fíler de: (a) cal hidratada, (b) cimento Portland, (c) sílica e (d) pó de calcário 


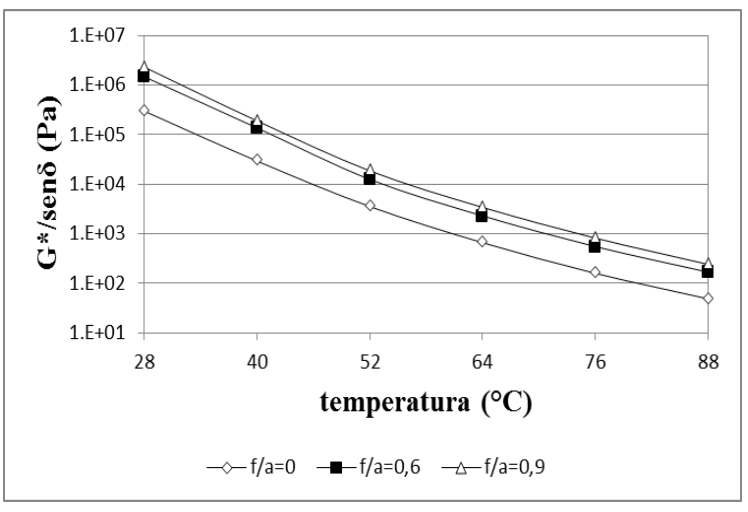

(a)

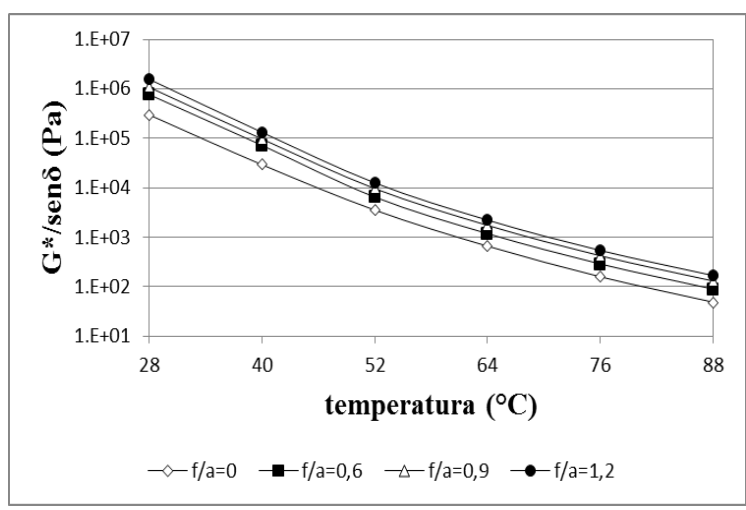

(c)

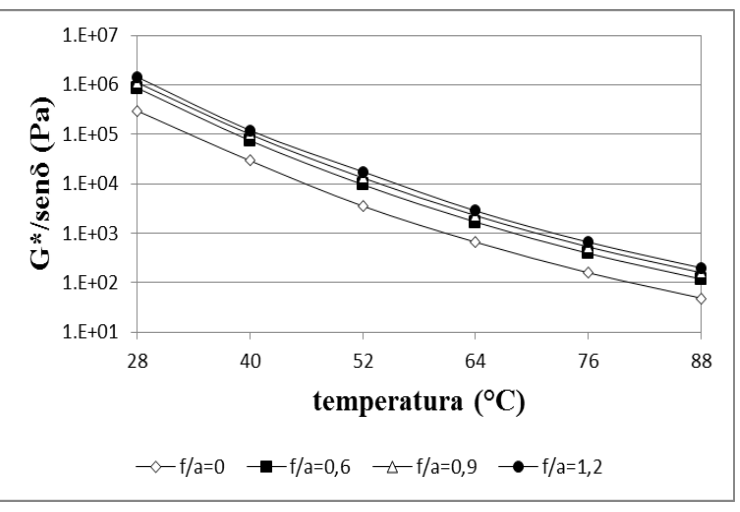

(b)

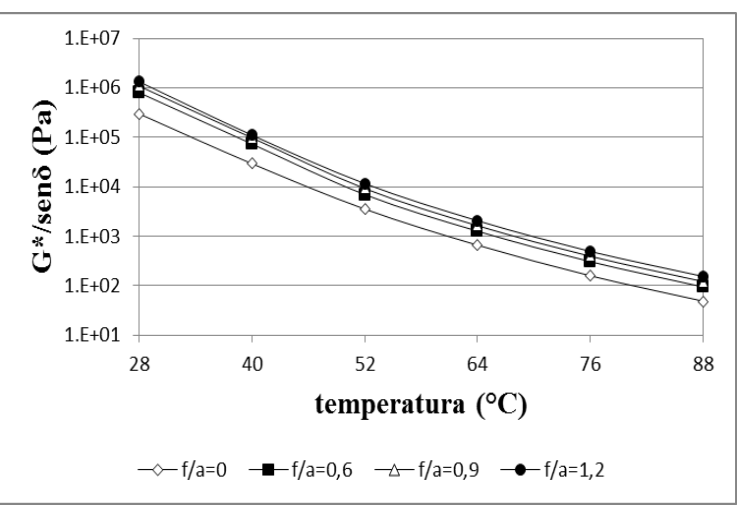

(d)

Figura 3.31- $\mathrm{G}^{*} / \mathrm{sen} \delta$ versus temperatura $\left({ }^{\circ} \mathrm{C}\right)$ em função da relação f/a, para os mástique compostos pelo CAP 85/100 e fíler de: (a) cal hidratada, (b) cimento Portland, (c) sílica e (d) pó de calcário

As Figuras 3.30 e 3.31 mostram que o efeito da relação f/a sobre o parâmetro de deformação permanente da especificação Superpave é semelhante ao efeito observado para a rigidez. Os valores do parâmetro $G^{*} / \operatorname{sen} \delta$ diminuem com a temperatura quando a escala de $G^{*} / \operatorname{sen} \delta$ é logarítmica, para ambos os tipos de CAP. Por apresentar consistência maior que a do CAP85/100, o CAP 50/70 proporciona mástiques com valores de $\mathrm{G}^{*} / \mathrm{sen} \delta$ superiores, o que pode se refletir em misturas asfálticas com maior resistência à deformação permanente.

A utilização do fíler mineral aumenta a temperatura correspondente ao valor de $G^{*} / \operatorname{sen} \delta \geq$ $1,00 \mathrm{kPa}$, que é a especificação do Superpave e, consequentemente, aumenta o valor do grau de desempenho (PG) do ligante asfáltico com fíler mineral. Como consequência, quanto maior o teor de fíler utilizado, maior a temperatura correspondente a $\mathrm{G}^{*} / \mathrm{sen} \delta \geq 1,00 \mathrm{kPa}$, o que pode se refletir em misturas asfálticas com maior resistência à deformação permanente. 


\subsubsection{Análise de Variância}

Para avaliar a influência dos diferentes fatores - tipo e teor de fíler, tipo de agregado e de ligante asfáltico - nas propriedades reológicas do mástique foi realizada a análise de variância para os valores de módulo complexo $\left(G^{*}\right)$, ângulo de fase $(\delta)$ e o parâmetro da especificação Superpave para a deformação permanente $\left(\mathrm{G}^{*} / \operatorname{sen} \delta\right)$.

Assim, a seguinte hipótese nula foi testada: $\mathrm{H}_{0}$ : os fatores não influenciam na resposta do valor propriedades reológicas do mástique asfáltico; para valores de $\mathrm{F}_{0}$ maiores que $\mathrm{f}_{0}$, a hipótese nula $\mathrm{H}_{0}$ é rejeitada, ou seja, o fator influencia na resposta.

\section{a) Módulo Complexo}

Primeiramente, consideraram-se os fatores tipo de fíler em quatro níveis (sílica, cimento Portland, pó calcário e cal hidratada), teor de fíler em três níveis (f/a=0,0;0,6 e 0,9), tipo de ligante asfáltico (CAP 50/70 e CAP 85/100) e frequência de carregamento (0,1; 1,0 e $10 \mathrm{rad} / \mathrm{s})$.

A segunda análise foi realizada considerando-se os fatores tipo de fíler em três níveis (sílica, cimento Portland e pó calcário), teor de fíler em quatro níveis (f/a=0;0,6;0,9 e 1,2), tipo de ligante asfáltico (CAP 50/70 e CAP 85/100) e frequência de carregamento (0,1; 1,0 e $10 \mathrm{rad} / \mathrm{s})$.

Os dados do experimento para a Análise de Variância (ANOVA) do módulo complexo estão na Tabela 3.2, enquanto que a Tabela B.15 do Apêndice B apresenta o resumo dos valores da análise (1) e da análise (2). 
Tabela 3.2 - Dados do experimento do módulo complexo

\begin{tabular}{ccccc|ccc}
\hline \multirow{2}{*}{$\begin{array}{c}\text { Teor de } \\
\text { fíler }\end{array}$} & \multirow{2}{*}{$\begin{array}{c}\text { Tipo de } \\
(\%)\end{array}$} & \multicolumn{4}{c}{ CAP 85/100 } & \multicolumn{4}{c}{ CAP 50/70 } \\
\cline { 3 - 8 } & & \multicolumn{4}{c}{ Frequência de carregamento } \\
\hline 0 & & $1,91 \mathrm{rad}+04$ & $1,14 \mathrm{rad}+05$ & $10 \mathrm{rad} / \mathrm{s}$ & $0,1 \mathrm{rad} / \mathrm{s}$ & $1 \mathrm{rad} / \mathrm{s}$ & $10 \mathrm{rad} / \mathrm{s}$ \\
0,6 & silica & $4,22 \mathrm{E}+04$ & $3,02 \mathrm{E}+05$ & $1,36 \mathrm{E}+06$ & $1,57 \mathrm{E}+05$ & $7,65 \mathrm{E}+05$ & $4,17 \mathrm{E}+06$ \\
0,9 & & $5,74 \mathrm{E}+04$ & $4,23 \mathrm{E}+05$ & $2,85 \mathrm{E}+06$ & $1,73 \mathrm{E}+05$ & $9,28 \mathrm{E}+05$ & $4,28 \mathrm{E}+06$ \\
1,2 & & $8,82 \mathrm{E}+04$ & $6,03 \mathrm{E}+05$ & $3,97 \mathrm{E}+06$ & $1,82 \mathrm{E}+05$ & $9,80 \mathrm{E}+05$ & $6,96 \mathrm{E}+06$ \\
\hline 0 & & $1,91 \mathrm{E}+04$ & $1,14 \mathrm{E}+05$ & $7,50 \mathrm{E}+05$ & $4,55 \mathrm{E}+04$ & $2,34 \mathrm{E}+05$ & $1,45 \mathrm{E}+06$ \\
0,6 & & $4,55 \mathrm{E}+04$ & $3,25 \mathrm{E}+05$ & $1,46 \mathrm{E}+06$ & $8,87 \mathrm{E}+04$ & $6,83 \mathrm{E}+05$ & $3,23 \mathrm{E}+06$ \\
0,9 & cimento & $5,88 \mathrm{E}+04$ & $4,44 \mathrm{E}+05$ & $3,08 \mathrm{E}+06$ & $1,61 \mathrm{E}+05$ & $1,01 \mathrm{E}+06$ & $5,85 \mathrm{E}+06$ \\
1,2 & & $8,25 \mathrm{E}+04$ & $5,55 \mathrm{E}+05$ & $3,00 \mathrm{E}+06$ & $3,05 \mathrm{E}+05$ & $1,82 \mathrm{E}+06$ & $9,50 \mathrm{E}+06$ \\
\hline 0 & & $1,91 \mathrm{E}+04$ & $1,14 \mathrm{E}+05$ & $7,50 \mathrm{E}+05$ & $4,55 \mathrm{E}+04$ & $2,34 \mathrm{E}+05$ & $1,45 \mathrm{E}+06$ \\
0,6 & & $4,22 \mathrm{E}+04$ & $3,02 \mathrm{E}+05$ & $1,36 \mathrm{E}+06$ & $1,61 \mathrm{E}+05$ & $7,21 \mathrm{E}+05$ & $4,39 \mathrm{E}+06$ \\
0,9 & calcario & $6,06 \mathrm{E}+04$ & $4,02 \mathrm{E}+05$ & $2,71 \mathrm{E}+06$ & $1,69 \mathrm{E}+05$ & $9,80 \mathrm{E}+05$ & $5,71 \mathrm{E}+06$ \\
1,2 & & $6,69 \mathrm{E}+04$ & $5,15 \mathrm{E}+05$ & $2,71 \mathrm{E}+06$ & $2,60 \mathrm{E}+05$ & $9,56 \mathrm{E}+05$ & $6,96 \mathrm{E}+06$ \\
\hline 0 & & $1,91 \mathrm{E}+04$ & $1,14 \mathrm{E}+05$ & $7,50 \mathrm{E}+05$ & $4,55 \mathrm{E}+04$ & $2,34 \mathrm{E}+05$ & $1,45 \mathrm{E}+06$ \\
0,6 & cal & 82450,39 & 541735,7 & $2,85 \mathrm{E}+06$ & $1,77 \mathrm{E}+05$ & $1,01 \mathrm{E}+06$ & $5,85 \mathrm{E}+06$ \\
0,9 & & 142642,3 & 797315,5 & $4,28 \mathrm{E}+06$ & $3,78 \mathrm{E}+05$ & $2,22 \mathrm{E}+06$ & $7,88 \mathrm{E}+06$ \\
\hline
\end{tabular}

$\mathrm{Na}$ Tabela 3.3 está apresentado o resumo dos valores do teste $\mathrm{f}_{0}$ da análise de variância do módulo complexo, com a identificação da influência dos fatores e interações considerados; para valores de $\mathrm{F}_{0}$ maiores que $\mathrm{f}_{0}$ o fator influencia o módulo complexo.

Pode-se perceber que os fatores que mais influenciaram o módulo complexo foram a frequência de carregamento e o tipo de ligante, como já havia sido concluído através das curvas mestre. O teor de fíler teve influência significativa no módulo complexo, enquanto que o tipo de fíler apresentou influência apenas quando se considera na análise o fíler de cal hidratada, mostrando a grande atividade desse mineral. 
Tabela 3.3 - Resumo da Análise de Variância do módulo complexo, dos valores de $\mathrm{f}_{0} \mathrm{e}$ da influência dos fatores e suas interações, para as análises (1) e (2)

\begin{tabular}{|c|c|c|c|c|c|c|}
\hline \multirow{2}{*}{ Fator } & \multicolumn{3}{|c|}{ Análise (1) } & \multicolumn{3}{|c|}{ Análise (2) } \\
\hline & $\mathrm{F}_{0}$ & $\mathrm{f}_{0}$ & Influência & $\mathrm{F}_{0}$ & $\mathrm{f}_{0}$ & Influência \\
\hline $\begin{array}{c}\text { A } \\
\text { (tipo de fíler) }\end{array}$ & 24,92 & 3,49 & $\operatorname{sim}$ & 1,04 & 3,89 & não \\
\hline $\begin{array}{c}\text { B } \\
\text { (teor de fíler) }\end{array}$ & 226,05 & 3,89 & $\operatorname{sim}$ & 68,94 & 3,49 & $\operatorname{sim}$ \\
\hline (tipo de ligante ) & 233,43 & 4,75 & $\operatorname{sim}$ & 130,10 & 4,75 & $\operatorname{sim}$ \\
\hline $\begin{array}{c}\text { D } \\
\text { (frequência de carregamento) }\end{array}$ & 997,97 & 3,89 & $\operatorname{sim}$ & 498,37 & 3,89 & $\operatorname{sim}$ \\
\hline $\mathrm{AB}$ & 7,97 & 3,00 & $\operatorname{sim}$ & 1,54 & 3,00 & não \\
\hline $\mathrm{AC}$ & 2,52 & 3,49 & não & 1,63 & 3,89 & não \\
\hline $\mathrm{AD}$ & 31,13 & 3,89 & $\operatorname{sim}$ & 0,42 & 4,75 & não \\
\hline $\mathrm{BC}$ & 26,41 & 3,89 & $\operatorname{sim}$ & 11,91 & 3,89 & $\operatorname{sim}$ \\
\hline $\mathrm{BD}$ & 116,42 & 4,75 & $\operatorname{sim}$ & 40,41 & 3,00 & $\operatorname{sim}$ \\
\hline $\mathrm{CD}$ & 114,77 & 3,89 & $\operatorname{sim}$ & 71,88 & 3,89 & $\operatorname{sim}$ \\
\hline $\mathrm{ABC}$ & 2,03 & 3,00 & não & 1,99 & 3,00 & não \\
\hline $\mathrm{ABD}$ & 3,52 & 2,69 & $\operatorname{sim}$ & 0,85 & 2,69 & não \\
\hline $\mathrm{ACD}$ & 1,02 & 3,00 & não & 1,00 & 4,75 & não \\
\hline $\mathrm{BCD}$ & 12,13 & 4,75 & $\operatorname{sim}$ & 7,13 & 3,00 & $\operatorname{sim}$ \\
\hline
\end{tabular}

b) Ângulo de Fase

Para a análise da influência dos diferentes fatores no ângulo de fase, primeiramente consideraram-se os fatores tipo de fíler em quatro níveis (sílica, cimento Portland, calcário e cal hidratada), teor de fíler em três níveis (f/a=0,0; 0,6 e 0,9), tipo de ligante asfáltico em dois níveis (CAP 50/70 e CAP 85/100) e frequência de carregamento em três níveis (0,1; 1,0 e $10 \mathrm{rad} / \mathrm{s}$ ).

Na segunda análise foram considerados os fatores tipo de fíler em três níveis (sílica, cimento Portland e pó calcário), teor de fíler em quatro níveis (f/a=0;0,6;0,9 e 1,2), tipo de ligante asfáltico (CAP 50/70 e CAP 85/100) e frequência de carregamento (0,1; 1,0 e $10 \mathrm{rad} / \mathrm{s})$. 
Os dados do experimento para a análise do ângulo de fase estão mostrados na Tabela 3.4 enquanto que na Tabela B.16 do Apêndice B apresentam-se o resumo dos valores da ANOVA para as análises (1) e (2).

Tabela 3.4 - Dados do experimento do ângulo de fase

\begin{tabular}{ccccc|ccc}
\hline \multirow{2}{*}{$\begin{array}{c}\text { Teor de } \\
\text { fíler } \\
(\%)\end{array}$} & \multirow{2}{*}{$\begin{array}{c}\text { Tipo de } \\
\text { fíler }\end{array}$} & & \multicolumn{5}{c}{ CAP 50/70 } \\
\cline { 3 - 8 } 0 & & $0,1 \mathrm{rad} / \mathrm{s}$ & $1 \mathrm{rad} / \mathrm{s}$ & $10 \mathrm{rad} / \mathrm{s}$ & $0,1 \mathrm{rad} / \mathrm{s}$ & $1 \mathrm{rad} / \mathrm{s}$ & $10 \mathrm{rad} / \mathrm{s}$ \\
\hline 0,6 & & 80,53 & 74,57 & 67,45 & 83,62 & 80,36 & 74,12 \\
0,9 & silica & 81,05 & 73,60 & 66,43 & 84,21 & 79,49 & 73,26 \\
1,2 & & 81,11 & 73,80 & 66,19 & 83,01 & 77,15 & 70,60 \\
\hline 0 & & 80,22 & 73,19 & 65,79 & 82,96 & 77,98 & 72,82 \\
0,6 & & 80,53 & 74,57 & 67,45 & 83,62 & 80,36 & 74,12 \\
0,9 & cimento & 79,12 & 72,84 & 65,48 & 83,72 & 72,84 & 72,49 \\
1,2 & & 80,33 & 72,48 & 65,04 & 83,13 & 72,48 & 71,93 \\
\hline 0 & & 78,59 & 70,86 & 62,80 & 82,96 & 77,41 & 71,95 \\
\hline 0,6 & & 80,53 & 74,57 & 67,45 & 83,62 & 80,36 & 74,12 \\
0,9 & calcario & 78,61 & 72,56 & 65,29 & 84,24 & 79,42 & 73,10 \\
1,2 & & 79,90 & 72,88 & 65,55 & 83,38 & 77,41 & 71,09 \\
\hline 0 & & 78,79 & 72,12 & 64,56 & 82,88 & 77,53 & 72,45 \\
\hline 0,6 & \multirow{2}{*nnyyyyy}{ cal } & 80,53 & 74,57 & 67,45 & 83,62 & 80,36 & 74,12 \\
0,9 & & 79,54 & 71,33 & 63,27 & 83,00 & 76,40 & 70,82 \\
\hline & & 79,61 & 70,99 & 63,14 & 80,31 & 75,54 & 68,32 \\
\hline
\end{tabular}

Na Tabela 3.5 está apresentado o resumo dos valores do teste $\mathrm{f}_{0}$ da análise de variância do ângulo de fase, com a influência dos fatores considerados, para as análises considerando o fator tipo de fíler em 4 e o teor de fíler em 3 níveis (análise (1)) e o tipo de fíler em 3 níveis e o teor de fíler em 4 níveis (análise (2)); para valores de $\mathrm{F}_{0}$ maiores que $\mathrm{f}_{0} \mathrm{o}$ fator influencia o ângulo de fase.

Pode-se perceber que os fatores que mais influenciaram o ângulo de fase foram a frequência de carregamento e o tipo de ligante, como já havia sido concluído através das curvas mestre. O teor de fíler teve influência maior que o tipo de fíler, sendo que os dois fatores influenciaram significativamente a resposta do ângulo de fase do mástique. 
Tabela 3.5 - Resumo da Análise de Variância do ângulo de fase, dos valores de $\mathrm{f}_{0}$ e da influência dos fatores e suas interações, para as análises (1) e (2)

\begin{tabular}{|c|c|c|c|c|c|c|}
\hline \multirow{2}{*}{ Fator } & \multicolumn{3}{|c|}{ Análise (1) } & \multicolumn{3}{|c|}{ Análise (2) } \\
\hline & $\mathrm{F}_{0}$ & $\mathrm{f}_{0}$ & Influência & $\mathrm{F}_{0}$ & $\mathrm{f}_{0}$ & Influência \\
\hline $\begin{array}{c}\text { A } \\
\text { (tipo de fíler) }\end{array}$ & 14,70 & 3,49 & $\operatorname{sim}$ & 10,78 & 3,89 & $\operatorname{sim}$ \\
\hline $\begin{array}{c}\text { B } \\
\text { (teor de fíler) }\end{array}$ & 60,15 & 3,89 & $\operatorname{sim}$ & 22,68 & 3,49 & $\operatorname{sim}$ \\
\hline $\begin{array}{c}\mathrm{C} \\
\text { (tipo de ligante ) }\end{array}$ & 666,60 & 4,75 & $\operatorname{sim}$ & 657,89 & 4,75 & $\operatorname{sim}$ \\
\hline $\begin{array}{c}\text { D } \\
\text { (frequência de carregamento) }\end{array}$ & 1567,40 & 3,89 & $\operatorname{sim}$ & 1373,24 & 3,89 & $\operatorname{sim}$ \\
\hline $\mathrm{AB}$ & 4,05 & 3,00 & $\operatorname{sim}$ & 1,52 & 3,00 & não \\
\hline $\mathrm{AC}$ & 2,50 & 3,49 & não & 2,27 & 3,89 & não \\
\hline $\mathrm{AD}$ & 9,64 & 3,89 & $\operatorname{sim}$ & 2,81 & 4,75 & não \\
\hline $\mathrm{BC}$ & 9,51 & 3,89 & $\operatorname{sim}$ & 5,63 & 3,89 & $\operatorname{sim}$ \\
\hline $\mathrm{BD}$ & 7,63 & 4,75 & $\operatorname{sim}$ & 3,50 & 3,00 & $\operatorname{sim}$ \\
\hline $\mathrm{CD}$ & 26,57 & 3,89 & $\operatorname{sim}$ & 26,36 & 3,89 & $\operatorname{sim}$ \\
\hline $\mathrm{ABC}$ & 1,00 & 3,00 & não & 1,82 & 3,00 & não \\
\hline $\mathrm{ABD}$ & 0,86 & 2,69 & não & 0,97 & 2,69 & não \\
\hline $\mathrm{ACD}$ & 3,07 & 3,00 & $\operatorname{sim}$ & 2,70 & 4,75 & não \\
\hline BCD & 1,71 & 4,75 & não & 1,31 & 3,00 & não \\
\hline
\end{tabular}

c) Parâmetro de Deformação Permanente $\left(\mathrm{G}^{*} / \operatorname{sen} \delta\right)$

Para a análise do parâmetro de deformação permanente $\left(\mathrm{G}^{*} / \mathrm{sen} \delta\right)$, determinou-se qual a temperatura em que $\mathrm{G}^{*} / \operatorname{sen} \delta \geq 1 \mathrm{kPa}$, para cada mástique sem envelhecimento, que é o valor determinado pela especificação Superpave.

Analisou-se a influência, primeiramente, dos fatores tipo de fíler em quatro níveis (sílica, cimento Portland, calcário e cal hidratada), teor de fíler em três níveis (f/a=0,0; 0,6 e 0,9) e tipo de ligante asfáltico (CAP 50/70 e CAP 85/100). 
$\mathrm{Na}$ segunda análise, foram analisados os fatores tipo de fíler em três níveis (sílica, cimento Portland e pó calcário), teor de fíler em quatro níveis ( $\mathrm{f} / \mathrm{a}=0 ; 0,6 ; 0,9$ e 1,2) e tipo de ligante asfáltico (CAP 50/70 e CAP 85/100).

Os dados do experimento para a análise das temperaturas em que $\mathrm{G}^{*} / \mathrm{sen} \delta \geq 1 \mathrm{kPa}$ estão mostrados na Tabela 3.6 enquanto que na Tabela B.17 do Apêndice B apresentam-se o resumo dos valores da ANOVA para as análises (1) e (2).

Tabela 3.6 - Dados do experimento do parâmetro G*/sen $\delta$

\begin{tabular}{cccc}
\hline \multirow{2}{*}{$\begin{array}{c}\text { Teor de fíler } \\
(\%)\end{array}$} & Tipo de fíler & \multicolumn{2}{c}{ Tipo de ligante asfáltico } \\
\cline { 3 - 4 } & & CAP 50/70 & CAP 85/100 \\
\hline 0 & & 65,0 & 60,0 \\
0,6 & \multirow{2}{*}{ silica } & 73,5 & 65,0 \\
0,9 & & 76,0 & 69,0 \\
1,2 & & 78,5 & 71,0 \\
\hline 0 & & 65,0 & 60,0 \\
0,6 & cimento & 74,5 & 66,5 \\
0,9 & & 77,5 & 72,0 \\
1,2 & & 81,0 & 74,0 \\
\hline 0 & & 65,0 & 60,0 \\
0,6 & calcario & 75,0 & 60,0 \\
0,9 & & 77,5 & 67,5 \\
1,2 & & 90,5 & 69,5 \\
\hline 0 & & 65,0 & 60,0 \\
0,6 & cal & 77,5 & 70,5 \\
0,9 & & 82,5 & 71,5 \\
\hline
\end{tabular}

Na Tabela 3.7 está apresentado o resumo dos valores do teste $\mathrm{f}_{0}$ da análise de variância do parâmetro $\mathrm{G}^{*} / \mathrm{sen} \delta$, com a resposta da influência dos fatores considerados, para as análises considerando-se o fator tipo de fíler em 4 e o teor de fíler em 3 níveis (análise (1)) e o tipo de fíler em 3 níveis e o teor de fíler em 4 níveis (análise (2)); para valores de $\mathrm{F}_{0}$ maiores que $\mathrm{f}_{0} \mathrm{o}$ fator influencia o parâmetro $\mathrm{G}^{*} / \mathrm{sen} \delta$. 
Pode-se perceber que o fator que mais influenciou no parâmetro de deformação permanente foi o tipo de ligante, como já concluído através das curvas mestre. O fator teor de fíler também foi significativo para a resposta do mástique, porém, o fator tipo de fíler apenas foi significativo quando considerado na análise o fíler de cal hidratada, da mesma forma que para o módulo complexo, o que reforça o comportamento de grande atividade desse mineral.

Tabela 3.7 - Resumo da Análise de Variância do parâmetro G*/sen $\delta$, dos valores de $\mathrm{f}_{0}$ e da influência dos fatores e sua interação, para as análises (1) e (2)

\begin{tabular}{|c|c|c|c|c|c|c|}
\hline \multirow{2}{*}{ Fator } & \multicolumn{3}{|c|}{ análise (1) } & \multicolumn{3}{|c|}{ análise (2) } \\
\hline & $\mathrm{F}_{0}$ & $\mathrm{f}_{0}$ & Influência & $\mathrm{F}_{0}$ & $\mathrm{f}_{0}$ & Influência \\
\hline $\begin{array}{c}\mathrm{A} \\
\text { (tipo de fíler) }\end{array}$ & 5,51 & 4,76 & $\operatorname{sim}$ & 0,86 & 5,14 & não \\
\hline $\begin{array}{c}\text { B } \\
\text { (teor de fíler) }\end{array}$ & 99,46 & 5,14 & $\operatorname{sim}$ & 42,61 & 4,76 & $\operatorname{sim}$ \\
\hline $\begin{array}{c}\text { C } \\
\text { (tipo de ligante asfáltico) }\end{array}$ & 123,71 & 5,99 & $\operatorname{sim}$ & 79,86 & 5,99 & $\operatorname{sim}$ \\
\hline $\mathrm{AB}$ & 1,53 & 4,28 & não & 0,98 & 4,28 & não \\
\hline $\mathrm{AC}$ & 1,47 & 4,76 & não & 4,33 & 5,14 & não \\
\hline $\mathrm{BC}$ & 4,02 & 5,14 & não & 2,47 & 4,76 & não \\
\hline
\end{tabular}

\subsubsection{Ensaio de Fluência em Viga à Flexão}

A Figura 3.32 (a) e (b) ilustra os resultados da rigidez à fluência na flexão [S(60)], para os mástiques compostos pelo CAP 50/70 e 85/100, respectivamente, e com os fileres de pó calcário, cimento Portland e cal hidratada, em função do teor de fíler, para o envelhecimento no PAV convencional $\left(20\right.$ horas a $\left.100^{\circ} \mathrm{C}\right)$. 


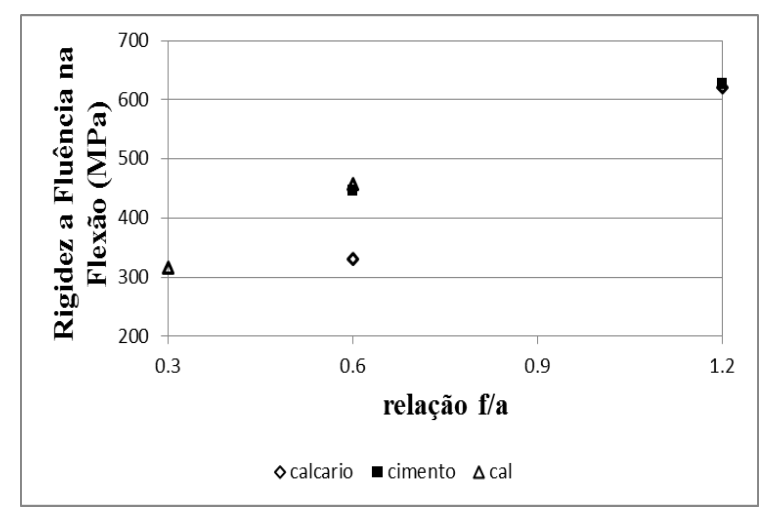

(a)

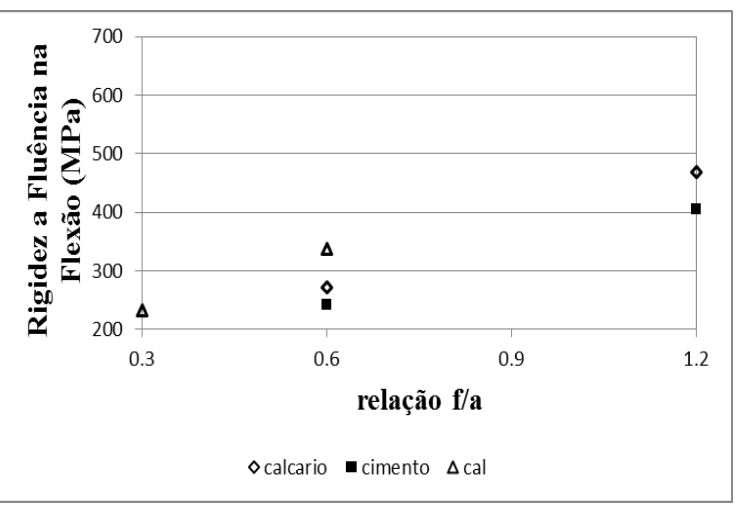

(b)

Figura 3.32 - Valores de Rigidez à Fluência na flexão [S(60)] para mástiques submetidos ao PAV convencional: (a) CAP 50/70 e (b) CAP 85/100

Pode-se observar que houve um aumento da rigidez com o aumento do teor de fíler e que o fíler de cal hidratada apresentou maior rigidez, para ambos os ligantes asfáltico (CAP 50/70 e CAP 85/100), com evidências de que a utilização de maiores teores de fíler prejudicam a resposta ao trincamento a baixas temperaturas.

Para o CAP 85/100, o mástique composto pelo fíler de pó calcário apresentou valor de rigidez maior que o com cimento Portland, para todos os teores ensaiados. Já para o CAP 50/70, o mástique composto pelo cimento Portland apresentou valores semelhantes ao da cal hidratada, na relação f/a de 0,6 , sendo que para a relação f/a de 1,2 o mástique composto pelo cimento Portland apresentou o mesmo valor que o com fíler de pó calcário. Isso indica que o comportamento de diferentes fileres depende não somente do tipo de fíler ou do tipo de ligante asfáltico, mas sim da interação fíler-ligante asfáltico, da afinidade entre a superfície e composição do fíler e as propriedades do ligante asfáltico.

A Figura 3.33 (a) e (b) ilustra os resultados do módulo de relaxação [m(60)] para os mástiques compostos pelo CAP 50/70 e 85/100, respectivamente, com os fileres de pó calcário, cimento Portland e cal hidratada, em função do teor de fíler, para o envelhecimento no PAV convencional (20 horas a $\left.100^{\circ} \mathrm{C}\right)$. 


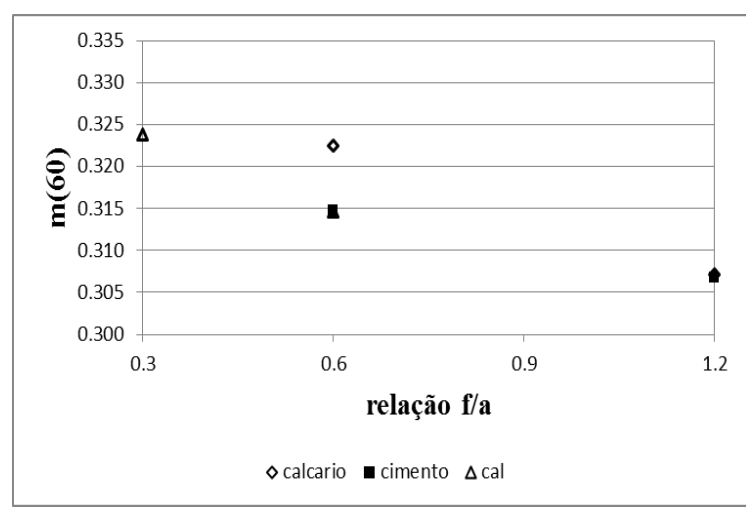

(a)

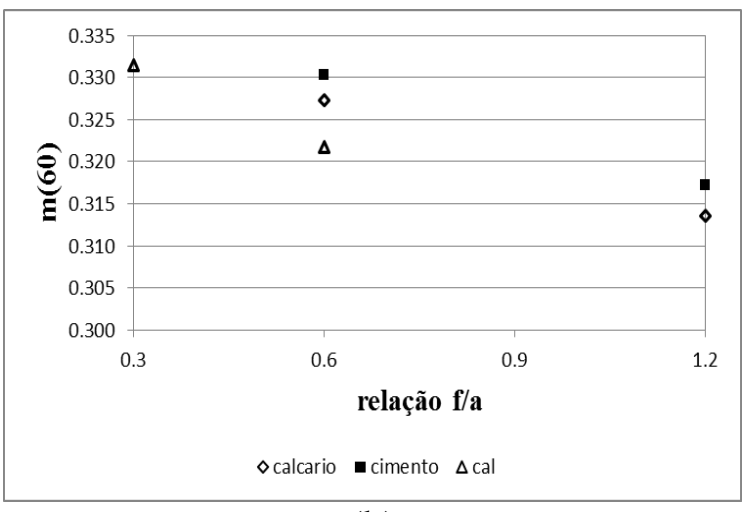

(b)

Figura 3.33 - Valores de Módulo de relaxação [m(60)] para mástiques submetidos ao PAV convencional: (a) CAP 50/70 e (b) CAP 85/100

Pode-se perceber que o aumento do teor de fíler diminui o módulo de relaxação. Com isso, maiores teores de fíler diminuem a eficiência na dissipação das tensões formadas durante a contração do ligante asfáltico, quando a temperatura do pavimento cai abruptamente, aumentando a formação de trincas.

Em relação ao tipo de fíler, os mástiques compostos pela cal hidratada apresentaram os menores valores do módulo de relaxação, para ambos os ligantes asfálticos. O comportamento dos mástiques compostos pelo fíler de cimento Portland depende do tipo de ligante utilizado, pois para o CAP 50/70 apresentaram valores de módulo de relaxação próximos ao da cal hidratada para a relação f/a de 0,6 e próximos ao do pó calcário para a relação f/a de 1,2, enquanto que para o CAP 85/100, os mástique compostos pelo fíler de cimento Portland apresentaram os maiores valores de módulo de relaxação.

A Figura 3.34 (a) e (b) ilustra os resultados da rigidez à fluência na flexão [S(60)] para os mástiques compostos pelo CAP 50/70 e 85/100, respectivamente, com os fileres de pó calcário, cimento Portland e cal hidratada, em função do teor de fíler, para o envelhecimento no PAV modificado (100 horas a $\left.60^{\circ} \mathrm{C}\right)$. 


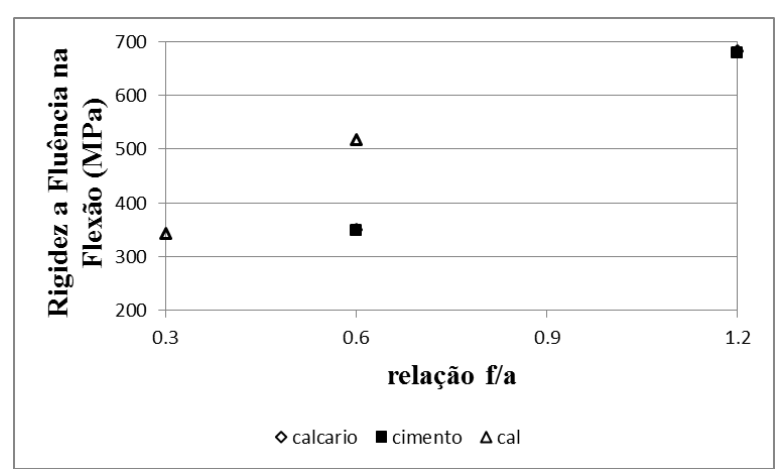

(a)

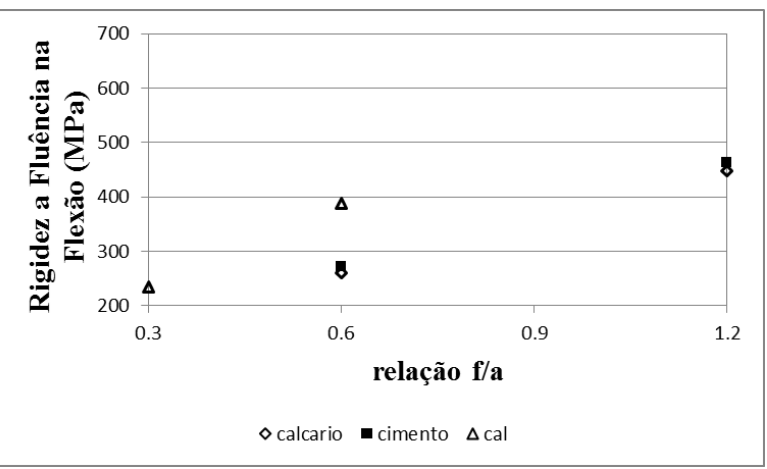

(b)

Figura 3.34 - Valores de Rigidez à Fluência na Flexão para mástiques submetidos ao PAV modificado: (a) CAP 50/70 e (b) CAP 85/100

O comportamento da rigidez dos mástiques não sofreu influência significativa dos procedimentos de envelhecimento no PAV, pois os valores com o ligante asfáltico modificado foram ligeiramente superiores, porém a tendência foi a mesma, o que leva à conclusão que o tipo de envelhecimento não interfere na rigidez à fluência.

A Figura 3.35 (a) e (b) ilustra os resultados do módulo de relaxação [m(60)] para os mástiques compostos pelo CAP 50/70 e 85/100, respectivamente, e com os fileres de pó calcário, cimento Portland e cal hidratada em função do teor de fíler, para o envelhecimento no PAV modificado $\left(100\right.$ horas a $\left.60^{\circ} \mathrm{C}\right)$.

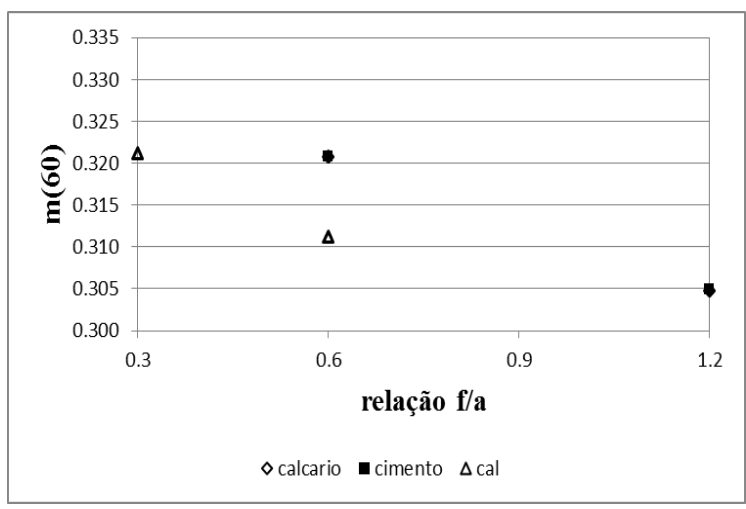

(a)

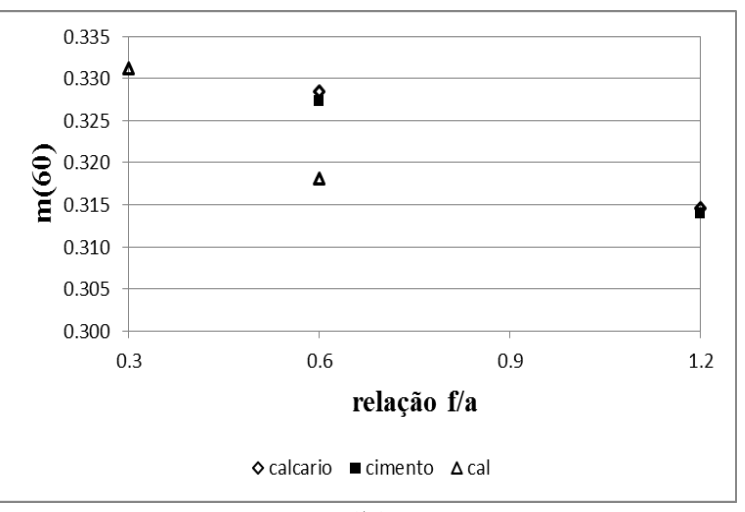

(b)

Figura 3.35 - Valores de Módulo de Relaxação [m(60)] para mástiques submetidos ao PAV modificado: (a) CAP 50/70 e (b) CAP 85/100 
O comportamento do módulo de relaxação dos mástiques também não sofreu influência do procedimento de envelhecimento no PAV, assim como ocorreu para a rigidez.

Para avaliar o aumento de rigidez na fluência na flexão, que pode ser um indicador do potencial enrijecedor do fíler, fez-se a comparação dos valores obtidos com os mástiques com o valor do ligante asfáltico puro, indicando-se quantas vezes a rigidez dos mástiques aumentou em relação à do ligante asfáltico puro $(\mathrm{f} / \mathrm{a}=0,0)$. A Tabela 3.8 mostra os valores do aumento da rigidez na fluência na flexão dos mástique compostos com os fileres de pó de calcário, cimento Portland e cal hidratada, em função das relações fíler/asfalto, para os ligantes asfálticos CAP 50/70 e o CAP 85/100, para os envelhecimentos em PAV convencional (20 horas e $\left.100{ }^{\circ} \mathrm{C}\right)$ e modificado $(100$ horas e $60{ }^{\circ} \mathrm{C}$ ). Os números entre parênteses são os valores da rigidez na fluência na flexão do ligante asfáltico puro.

Tabela 3.8 - Valores de aumento da rigidez à fluência na flexão

\begin{tabular}{c|c|cc|cc}
\hline \multirow{2}{*}{$\begin{array}{c}\text { Relação } \\
\text { fíler/asfalto }\end{array}$} & \multirow{2}{*}{ Fíler } & \multicolumn{2}{|c|}{ PAV Convencional } & \multicolumn{2}{c}{ PAV Modificado } \\
\cline { 3 - 6 } & & CAP 50/70 & CAP 85/100 & CAP 50/70 & CAP 85/100 \\
\hline \multirow{2}{*}{0} & - & 1,00 & 1,0 & 1,0 & 1,00 \\
& & $(186,91 \mathrm{MPa})$ & $(123,02 \mathrm{MPa})$ & $(204,95 \mathrm{MPa})$ & $(136,33 \mathrm{MPa})$ \\
\hline 0.6 & pó & 1,8 & 2,2 & 1,70 & 1,91 \\
1.2 & calcário & 3,3 & 3,8 & 3,30 & 3,3 \\
\hline 0.6 & cimento & 2,4 & 2,0 & 1,71 & 1,98 \\
1.2 & Portland & 3,3 & 3,3 & 3,3 & 3,4 \\
\hline 0.3 & cal & 1,7 & 1,9 & 1,67 & 1,71 \\
0.6 & hidratada & 2,4 & 2,7 & 2,5 & 2,8 \\
\hline
\end{tabular}

As Figuras 3.36 e 3.347 mostram o aumento da rigidez na fluência na flexão em função da relação f/a, compostos com o CAP 50/70 (a) e 85/100 (b), para mástiques envelhecidos no PAV convencional e no PAV modificado, respectivamente. 


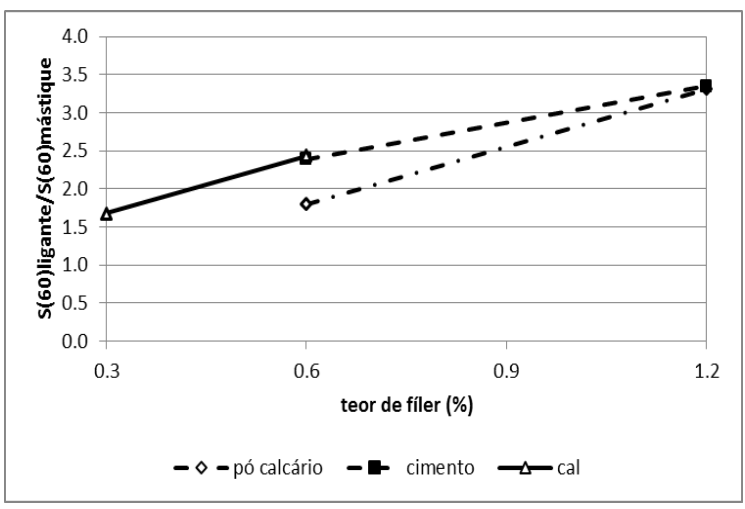

(a)

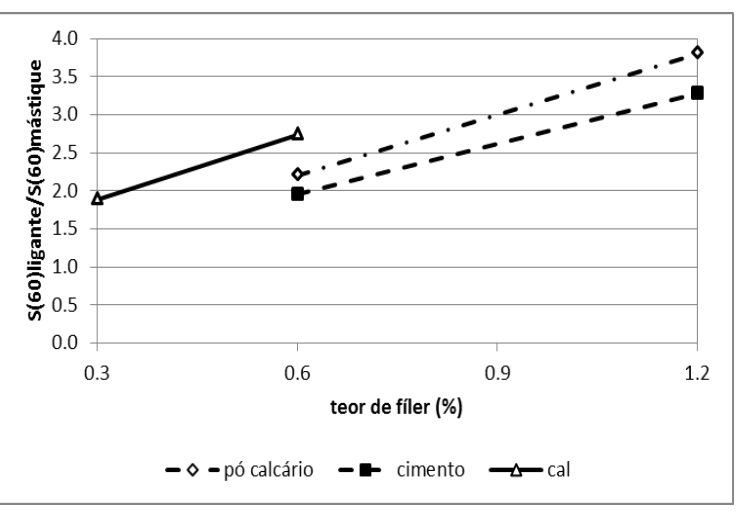

(b)

Figura 3.36 - Aumento da rigidez na fluência na flexão, para mástiques envelhecidos no PAV convencional e: (a) CAP 50/70 e (b) CAP 85/100

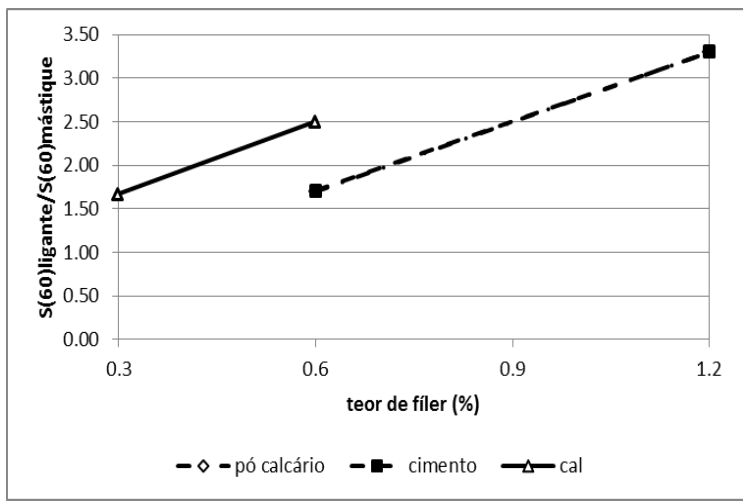

(a)

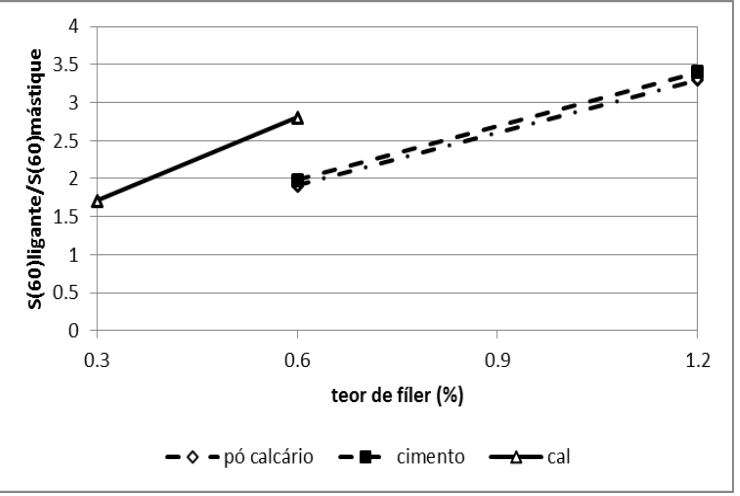

(b)

Figura 3.37 - Aumento da rigidez na fluência na flexão, para mástiques envelhecidos no PAV modificado e: (a) CAP 50/70 e (b) CAP 85/100

Pode-se observar que quanto maior o teor de fíler no mástique asfáltico, maior foi o aumento da rigidez, e que o fíler de cal hidratada provocou os maiores aumentos da propriedade. No envelhecimento no PAV modificado $\left(100\right.$ horas a $60^{\circ} \mathrm{C}$ ), os mástiques compostos pelos fileres de cimento Portland e pó calcário tiveram efeitos similares, para ambos os tipos de ligante asfáltico. Já no envelhecimento no PAV convencional, o aumento de rigidez foi afetado pelo tipo de ligante asfáltico: no CAP 85/100 os mástiques compostos pelo pó calcário provocaram um maior aumento de rigidez que o de cimento Portland; para o CAP 50/70, o cimento Portland teve efeito similar ao da cal hidratada, na relação f/a de 0,6, e similar ao do pó calcário, na relação f/a de 1,2. 


\subsubsection{Análise de Variância}

Para a análise da influência dos diferentes fatores sobre a rigidez à fluência na flexão $(S(60))$, primeiramente consideraram-se os fatores tipo de fíler em três níveis (pó calcário, cimento Portland e cal hidratada), teor de fíler em dois níveis ( $\mathrm{f} / \mathrm{a}=0,0$ e 0,6$)$, tipo de ligante asfáltico (CAP 50/70 e CAP 85/100) e tipo de envelhecimento (PAV convencional -20 horas a $100{ }^{\circ} \mathrm{C}-\mathrm{e}$ PAV modificado - 100 horas a $60^{\circ} \mathrm{C}$ ).

$\mathrm{Na}$ segunda análise, foram considerados os fatores tipo de fíler em dois níveis (pó calcário e cimento Portland), teor de fíler em três níveis (f/a=0,0; 0,6 e 1,2), tipo de ligante asfáltico (CAP 50/70 e CAP 85/100) e tipo de envelhecimento (PAV convencional - 20 horas a $100{ }^{\circ} \mathrm{C}$ - e PAV modificado - 100 horas a $60^{\circ} \mathrm{C}$ ). Os dados do experimento para a análise da rigidez à fluência na flexão estão mostrados na Tabela 3.9 e na Tabela B.18 do Apêndice B apresentam-se o resumo dos valores da análise de variância das análises (1) e (2).

Tabela 3.9 - Dados do experimento da rigidez à fluência na flexão $(\mathrm{S}(60))$

\begin{tabular}{|c|c|c|c|c|c|c|}
\hline \multirow{2}{*}{ Tipo de ligante } & \multirow{2}{*}{ Tipo de filer } & \multirow{2}{*}{$\begin{array}{c}\text { Teor de fíler } \\
(\%)\end{array}$} & \multicolumn{4}{|c|}{ Tipo de Envelhecimento } \\
\hline & & & \multicolumn{2}{|c|}{ Convencional } & \multicolumn{2}{|c|}{ Modificado } \\
\hline \multirow{8}{*}{ CAP 50/70 } & \multirow{3}{*}{ Calcário } & 0,0 & 190,00 & 188,00 & 206,26 & 203,63 \\
\hline & & 0,6 & 318,96 & 337,68 & 323,51 & 376,40 \\
\hline & & 1,2 & 643,07 & 595,93 & 680,57 & 685,70 \\
\hline & \multirow{3}{*}{ Cimento } & 0,0 & 190,00 & 188,00 & 206,26 & 203,63 \\
\hline & & 0,6 & 445,04 & 448,90 & 323,50 & 375,75 \\
\hline & & 1,2 & 605,65 & 646,35 & 676,90 & 679,30 \\
\hline & \multirow{2}{*}{ Cal } & 0,0 & 190,00 & 188,00 & 206,26 & 203,63 \\
\hline & & 0,6 & 406,46 & 503,05 & 516,24 & 520,14 \\
\hline \multirow{8}{*}{ CAP 85/100 } & \multirow{3}{*}{ Calcário } & 0,0 & 125,00 & 121,00 & 133,00 & 139,00 \\
\hline & & 0,6 & 287,21 & 255,81 & 238,96 & 281,63 \\
\hline & & 1,2 & 464,09 & 471,85 & 451,89 & 444,81 \\
\hline & \multirow{3}{*}{ Cimento } & 0,0 & 125,00 & 121,00 & 133,00 & 139,00 \\
\hline & & 0,6 & 238,06 & 244,60 & 269,22 & 273,09 \\
\hline & & 1,2 & 400,33 & 408,09 & 429,74 & 496,88 \\
\hline & \multirow{2}{*}{$\mathrm{Cal}$} & 0,0 & 125,00 & 121,00 & 133,00 & 139,00 \\
\hline & & 0,6 & 336,59 & 215,67 & 386,66 & 390,41 \\
\hline
\end{tabular}


Na Tabela 3.10 está apresentado o resumo dos valores do teste $\mathrm{f}_{0}$ da análise de variância da rigidez à fluência na flexão, com a influência dos fatores considerados, para as análises considerando-se o fator tipo de fíler em 3 níveis e o teor de fíler em 2 níveis (análise (1)) e o fator tipo de fíler em 2 níveis e o teor de fíler em 3 níveis (análise (2)); para valores de $\mathrm{F}_{0}$ maiores que $\mathrm{f}_{0} \mathrm{o}$ fator influencia a rigidez à fluência na flexão

Os fatores que mais influenciaram na rigidez na fluência na flexão foram o teor de fíler e o tipo de ligante asfáltico. O tipo de fíler foi significativo apenas quando se considerou a cal hidratada na análise, o que confirma o caráter ativo desse fíler.

Tabela 3.10 - Resumo da Análise de Variância da rigidez à fluência na flexão, dos valores de $\mathrm{f}_{0} \mathrm{e}$ da influência dos fatores e sua interação, para as análises (1) e (2)

\begin{tabular}{c|ccc|ccc}
\hline \multirow{2}{*}{ Fator } & \multicolumn{3}{|c|}{ Análise (1) } & \multicolumn{3}{c}{ Análise (2) } \\
& $\mathrm{F}_{0}$ & $\mathrm{f}_{0}$ & Influência & $\mathrm{F}_{0}$ & $\mathrm{f}_{0}$ & Influência \\
\hline A & 10,85 & 3,4 & $\operatorname{sim}$ & 0,50 & 4.26 & não \\
(tipo de fíler) & & & & & & \\
B & 348,72 & 4,26 & $\operatorname{sim}$ & 1344,76 & 3.4 & sim \\
(teor de fíler) & & & & & & \\
C & 94,42 & 4,26 & sim & 430,76 & 4.26 & sim \\
(tipo de ligante) & & & & & & \\
D & 3,05 & 4,26 & não & 4,52 & 4.26 & sim \\
(tipo de envelhecimento) & 10,85 & 4,26 & sim & 3,11 & 3.4 & não \\
AB & 1,65 & 3,4 & não & 6,55 & 4.26 & não \\
AC & 3,34 & 3,4 & não & 0,02 & 4.26 & não \\
AD & 8,05 & 4,26 & sim & 45,06 & 3.4 & sim \\
BC & 0,07 & 4,26 & não & 6,29 & 3.4 & sim \\
BD & 1,30 & 4,26 & não & 0,03 & 4.26 & não \\
CD & 1,65 & 3,4 & não & 2,70 & 3.4 & não \\
ABC & 3,34 & 3,4 & não & 2,94 & 3.4 & não \\
ABD & 1,39 & 3,4 & não & 11,63 & 4.26 & sim \\
ACD & 1,67 & 4,26 & não & 4,09 & 3.4 & sim \\
BCD & 1,39 & 3,4 & não & 3,58 & 3.4 & sim \\
ABCD & & & & & & \\
\hline
\end{tabular}

Para a análise da influência dos diferentes fatores sobre módulo de relaxação (m(60)), primeiramente consideraram-se os fatores tipo de fíler em três níveis (pó calcário, cimento Portland e cal hidratada), teor de fíler em dois níveis (f/a=0,0 e 0,6), tipo de ligante asfáltico 
(CAP 50/70 e CAP 85/100) e tipo de envelhecimento (PAV convencional -20 horas a $100{ }^{\circ} \mathrm{C}-\mathrm{e}$ PAV modificado - 100 horas a $60{ }^{\circ} \mathrm{C}$ ).

$\mathrm{Na}$ segunda análise, foram considerados os fatores tipo de fíler em dois níveis (pó calcário e cimento Portland), teor de fíler em três níveis (f/a=0,0; 0,6 e 1,2), tipo de ligante asfáltico (CAP 50/70 e CAP 85/100) e tipo de envelhecimento (PAV convencional - 20 horas a $100{ }^{\circ} \mathrm{C}$ - e PAV modificado - 100 horas a $60^{\circ} \mathrm{C}$ ).

Os dados do experimento para a análise do módulo de relaxação estão mostrados na Tabela 3.11, enquanto que na Tabela B.19 do Apêndice B apresentam-se o resumo dos valores da análise de variância das análises (1) e (2).

Tabela 3.11 - Dados do experimento do módulo de relaxação (m(60))

\begin{tabular}{|c|c|c|c|c|c|c|}
\hline \multirow{3}{*}{ Tipo de ligante } & \multirow{2}{*}{ Tipo de filer } & \multirow{2}{*}{$\begin{array}{c}\text { Teor de fíler } \\
(\%)\end{array}$} & \multicolumn{4}{|c|}{ Tipo de Envelhecimento } \\
\hline & & & \multicolumn{2}{|c|}{ Convencional } & \multicolumn{2}{|c|}{ Modificado } \\
\hline & \multirow{3}{*}{ Calcário } & 0,0 & 0,336 & 0,338 & 0,334 & 0,336 \\
\hline \multirow{7}{*}{ CAP 50/70 } & & 0,6 & 0,323 & 0,322 & 0,323 & 0,319 \\
\hline & & 1,2 & 0,306 & 0,308 & 0,305 & 0,305 \\
\hline & \multirow{3}{*}{ Cimento } & 0,0 & 0,336 & 0,338 & 0,334 & 0,336 \\
\hline & & 0,6 & 0,315 & 0,315 & 0,319 & 0,323 \\
\hline & & 1,2 & 0,308 & 0,306 & 0,301 & 0,308 \\
\hline & \multirow{2}{*}{$\mathrm{Cal}$} & 0,0 & 0,336 & 0,338 & 0,334 & 0,336 \\
\hline & & 0,6 & 0,317 & 0,312 & 0,311 & 0,311 \\
\hline \multirow{8}{*}{ CAP 85/100 } & \multirow{3}{*}{ Calcário } & 0,0 & 0,349 & 0,349 & 0,345 & 0,347 \\
\hline & & 0,6 & 0,326 & 0,329 & 0,331 & 0,326 \\
\hline & & 1,2 & 0,314 & 0,313 & 0,314 & 0,315 \\
\hline & \multirow{3}{*}{ Cimento } & 0,0 & 0,349 & 0,349 & 0,345 & 0,347 \\
\hline & & 0,6 & 0,331 & 0,330 & 0,327 & 0,327 \\
\hline & & 1,2 & 0,317 & 0,317 & 0,316 & 0,312 \\
\hline & \multirow[b]{2}{*}{ Cal } & 0,0 & 0,349 & 0,349 & 0,345 & 0,347 \\
\hline & & 0,6 & 0,322 & 0,333 & 0,318 & 0,318 \\
\hline
\end{tabular}

$\mathrm{Na}$ Tabela 3.12 está apresentado o resumo do teste $\mathrm{f}_{0}$ da análise de variância do módulo de relaxação, com a resposta da influência dos fatores considerados, para as análises considerandose o fator tipo de fíler em 3 e o teor de fíler em 2 níveis (análise (1)) e o fator tipo de fíler em 2 e 
o teor de fíler em 3 níveis (análise (2)); para valores de $F_{0}$ maiores que $f_{0}$ o fator influencia no módulo de relaxação

Os fatores que mais influenciaram na resposta do módulo de relaxação foram o teor de fíler e o tipo de ligante asfáltico. O tipo de fíler foi significativo apenas quando se considerou a cal hidratada na análise, da mesma maneira que na análise da rigidez na fluência na flexão.

Tabela 3.12 - Resumo da Análise de Variância do módulo de relaxação, dos valores de $\mathrm{f}_{0}$ e da influência dos fatores e sua interação, para as análises (1) e (2)

\begin{tabular}{c|ccc|ccc}
\hline \multirow{2}{*}{ Fator } & \multicolumn{3}{|c|}{ análise (1) } & \multicolumn{4}{|c}{ análise (2) } \\
& $\mathrm{F}_{0}$ & $\mathrm{f}_{0}$ & Influência & $\mathrm{F}_{0}$ & $\mathrm{f}_{0}$ & Influência \\
\hline $\begin{array}{c}\text { A } \\
\text { (tipo de fíler) }\end{array}$ & 5,86 & 3,4 & $\operatorname{sim}$ & 0,23 & 4,26 & não \\
B & & & & & & \\
(teor de fíler) & 518,50 & 4,26 & $\operatorname{sim}$ & 1027,54 & 3,4 & sim \\
C & & & & & & \\
(tipo de ligante) & 140,93 & 4,26 & $\operatorname{sim}$ & 294,07 & 4,26 & sim \\
D & & & & & & \\
(tipo de & 5,89 & 4,26 & sim & 4,35 & 4,26 & sim \\
envelhecimento) & & & & & & \\
AB & 5,86 & 4,26 & sim & 1,06 & 3,4 & não \\
AC & 0,67 & 3,4 & não & 3,47 & 4,26 & não \\
AD & 1,91 & 3,4 & não & 0,01 & 4,26 & não \\
BC & 2,05 & 4,26 & não & 2,64 & 3,4 & não \\
BD & 0,29 & 4,26 & não & 2,99 & 3,4 & não \\
CD & 2,44 & 4,26 & não & 0,97 & 4,26 & não \\
ABC & 0,67 & 3,4 & não & 1,45 & 3,4 & não \\
ABD & 1,91 & 3,4 & não & 1,01 & 3,4 & não \\
ACD & 1,07 & 3,4 & não & 5,73 & 4,26 & sim \\
BCD & 0,79 & 4,26 & não & 1,30 & 3,4 & não \\
ABCD & 1,07 & 3,4 & não & 2,41 & 3,4 & não \\
\hline
\end{tabular}

\subsubsection{Ensaio de Ponto de Amolecimento pelo Método Anel e Bola}

A Figura 3.38 mostra os resultados do ponto de amolecimento para os mástiques compostos os fileres de cal hidratada, cimento Portland, sílica e pó de calcário para as relações fíler/asfalto de 0,3; 0,6 e 1,2 para o CAP 50/70 (a) e para o CAP 85/100 (b). 


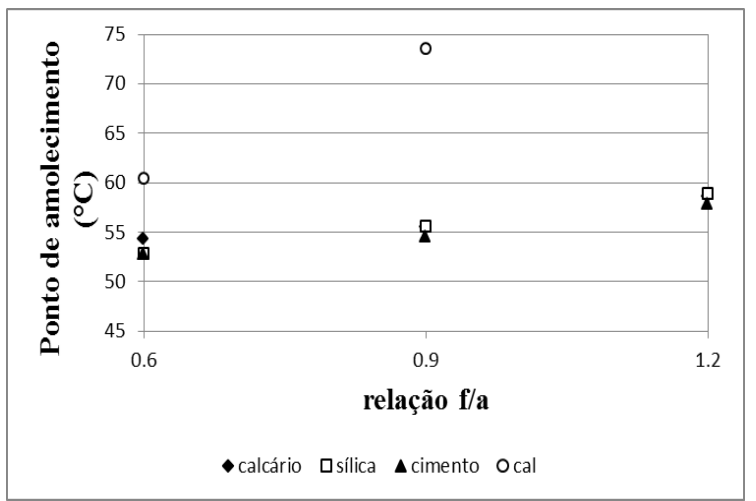

(a)

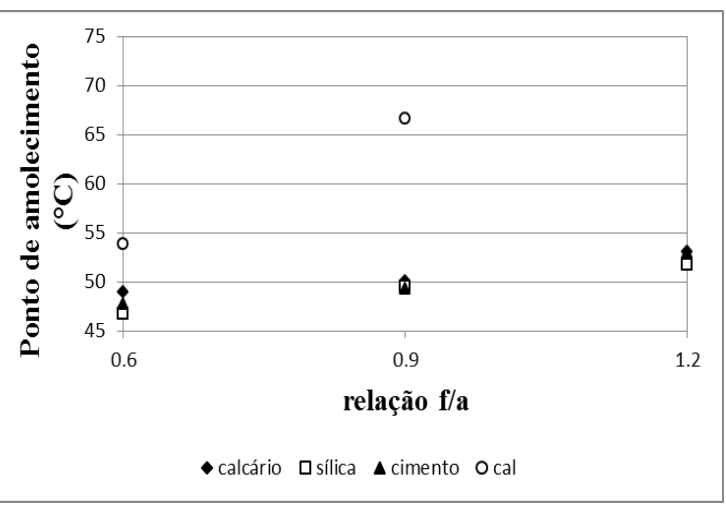

(b)

Figura 3.38 - Ponto de amolecimento em função da relação f/a, para os mástiques compostos com: CAP (a) 50/70 e (b) CAP85/100

Pode-se observar que com o aumento do teor de fíler, a temperatura do ponto de amolecimento do mástique também aumentou. Em relação ao tipo de fíler, a cal hidratada proporcionou mástiques com maiores valores de ponto de amolecimento. Para o CAP 50/70, os mástiques compostos pelo fíler de sílica apresentaram o segundo maior valor da propriedade (depois da cal hidratada), para as relações f/a de 0,9 e 1,2; e para o CAP 85/100 os mástique compostos pelo pó calcário apresentaram o segundo maior valor, para todas as relações f/a. Em relação ao tipo de ligante, o CAP 50/70 produz mástiques com maior temperatura de ponto de amolecimento, quando comparado ao CAP 85/100.

Para avaliar o aumento do ponto de amolecimento, que pode ser um indicador do potencial enrijecedor do fíler, foram determinados o aumento das temperaturas, em função das relações f/a (de 0 a 1,2), através da comparação com os valores do ligante asfáltico puro, indicando-se quantas vezes a temperatura do ponto de amolecimento dos mástiques aumentou em relação a do ligante asfáltico puro $(\mathrm{f} / \mathrm{a}=0,0)$.

A Tabela 3.13 mostra os valores do aumento do ponto de amolecimento dos mástiques compostos com os fileres de cal hidratada, cimento Portland, sílica e pó de calcário, para as relações fíler/asfalto de 0,3; 0,6 e 1,2, para os ligantes asfálticos CAP 50/70 e o CAP 85/100. Os números entre parênteses são os valores da temperatura do ponto de amolecimento do ligante asfáltico puro. 
Tabela 3.13 - Aumento do Ponto de Amolecimento dos mástiques em função do tipo de ligante asfáltico

\begin{tabular}{c|c|c|c}
\hline f/a & fíler & CAP 50/70 & CAP 85/100 \\
\hline 0,0 & - & $1,00\left(48,6^{\circ} \mathrm{C}\right)$ & $1,00\left(43,5^{\circ} \mathrm{C}\right)$ \\
\hline 0,6 & & 1,12 & 1,13 \\
0,9 & \multirow{2}{*}{ calcário } & 1,14 & 1,15 \\
1,2 & & 1,21 & 1,22 \\
\hline 0,6 & & 1,09 & 1,07 \\
0,9 & \multirow{2}{*}{ silica } & 1,14 & 1,14 \\
1,2 & & 1,21 & 1,19 \\
\hline 0,6 & & 1,09 & 1,10 \\
0,9 & \multirow{2}{*}{ cimento } & 1,12 & 1,13 \\
1,2 & & 1,19 & 1,22 \\
\hline 0,6 & \multirow{2}{*}{ cal } & 1,24 & 1,24 \\
0,9 & & 1,51 & 1,53 \\
\hline
\end{tabular}

A Figura 3.39 mostra o aumento do ponto de amolecimento em função da relação f/a, para mástiques compostos com o CAP 50/70 (a) e 85/100 (b).

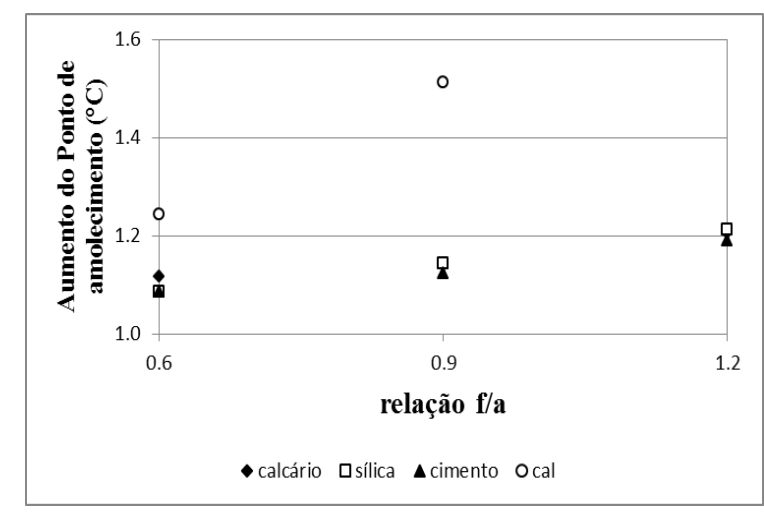

(a)

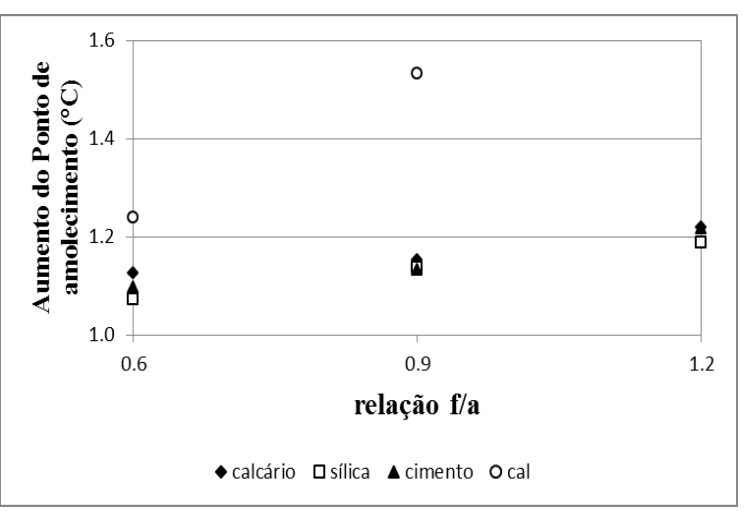

(b)

Figura 3.39 - Aumento do Ponto de Amolecimento dos Mástiques Compostos: (a) CAP 50/70 e (b) CAP 85/100

Pode-se observar que o aumento da temperatura do ponto de amolecimento foi praticamente o mesmo para os dois tipos de ligante, assim como ocorreu em função do teor de fíler na mistura. Os mástiques compostos pela cal hidratada proporcionaram os maiores aumentos da propriedade. 


\subsubsection{Análise de Variância}

Foram realizadas as análises de variância para os valores das temperaturas do ponto de amolecimento, considerando-se o tipo de fíler (pó calcário, cimento Portland, sílica e cal hidratada) e teor de fíler (f/a=0,6; 0,9 e 1,2).

Como os mástiques compostos com o fíler de cal hidratada não foram realizados na relação f/a=1,2; dividiu-se a análise em duas: (1) considerando-se tipo de fíler em quatro níveis (pó calcário, cimento Portland, sílica e cal hidratada), o teor de fíler em três níveis (f/a=0,0; 0,6 e 0,9) e o tipo de ligante (CAP5070 e CAP 85100); (2) considerando-se tipo de fíler em três níveis (pó calcário, cimento Portland e sílica), o teor de fíler em quatro níveis (f/a=0,0;0,6;0,9 e 1,2).

Os dados do experimento para a análise dos valores das temperaturas do ponto de amolecimento estão mostrados na Tabela 3.14. Na Tabela B.20 do Apêndice B apresenta-se o resumo dos valores da análise de variância das análises (1) e (2).

Tabela 3.14 - Dados do experimento da temperatura do ponto de amolecimento

\begin{tabular}{c|c|cc|cc}
\hline \multirow{2}{*}{ Tipo de fíler } & \multirow{2}{*}{ Teor de fíler (\%) } & \multicolumn{4}{|c}{ Tipo de ligante } \\
\cline { 3 - 6 } & 0 & 49,0 & 48,2 & 43,1 & 43,9 \\
& 0,6 & 54,1 & 54,5 & 48,6 & 49,3 \\
\multirow{3}{*}{ calcário } & 0,9 & 55,4 & 55,7 & 49,9 & 50,3 \\
& 1,2 & 58,3 & 58,8 & 53,1 & 53,0 \\
\hline \multirow{3}{*}{ sílica } & 0 & 49,0 & 48,2 & 43,1 & 43,9 \\
& 0,6 & 52,5 & 53,0 & 46,5 & 46,7 \\
& 0,9 & 55,3 & 55,8 & 49,8 & 49,2 \\
& 1,2 & 58,8 & 59,0 & 51,9 & 51,5 \\
\hline \multirow{3}{*}{ cimento } & 0 & 49,0 & 48,2 & 43,1 & 43,9 \\
& 0,6 & 52,5 & 53,1 & 47,6 & 47,8 \\
& 0,9 & 54,3 & 54,8 & 49,2 & 49,4 \\
& 1,2 & 57,7 & 58,1 & 53,0 & 52,9 \\
\hline \multirow{3}{*}{ cal } & 0 & 49,0 & 48,2 & 43,1 & 43,9 \\
& 0,6 & 60,3 & 60,6 & 54,1 & 53,7 \\
& 0,9 & 73,2 & 73,9 & 66,5 & 66,8 \\
\hline
\end{tabular}


$\mathrm{Na}$ Tabela 3.15 está apresentado o resumo dos valores do teste $\mathrm{f}_{0}$ da análise de variância da temperatura do ponto de amolecimento, com a influência dos fatores considerados, para as análises (1) e (2); para valores de $\mathrm{F}_{0}$ maiores que $\mathrm{f}_{0}$ o fator influencia na temperatura do ponto de amolecimento.

Os fatores que mais influenciaram a temperatura do ponto de amolecimento foram o tipo de ligante asfáltico e o teor de fíler. O tipo de fíler foi muito significativo também, porém a influência foi maior na análise que considerou o fíler de cal hidratada.

Tabela 3.15 - Resumo da Análise de Variância da temperatura do ponto de amolecimento, dos valores de $f_{0}$ e da influência dos fatores e sua interação, para as análises (1) e (2)

\begin{tabular}{c|ccc|ccc}
\hline \multirow{2}{*}{ Fator } & \multicolumn{3}{|c|}{ Análise (1) } & \multicolumn{3}{c}{ Análise (2) } \\
& $\mathrm{F}_{0}$ & $\mathrm{f}_{0}$ & Influência & $\mathrm{F}_{0}$ & $\mathrm{f}_{0}$ & Influência \\
\hline $\mathrm{A}$ & 1131,11 & 3,01 & $\operatorname{sim}$ & 16,78 & 3,40 & $\operatorname{sim}$ \\
$\mathrm{B}$ & 2666,71 & 3,40 & $\operatorname{sim}$ & 1297,36 & 3,01 & $\operatorname{sim}$ \\
$\mathrm{C}$ & 2140,21 & 4,26 & $\operatorname{sim}$ & 2526,26 & 4,26 & $\operatorname{sim}$ \\
$\mathrm{AB}$ & 458,07 & 2,51 & $\operatorname{sim}$ & 6,19 & 2,51 & $\operatorname{sim}$ \\
$\mathrm{AC}$ & 3,76 & 3,01 & $\operatorname{sim}$ & 7,88 & 3,40 & $\operatorname{sim}$ \\
$\mathrm{BC}$ & 4,35 & 3,40 & $\operatorname{sim}$ & 2,16 & 3,01 & não \\
$\mathrm{ABC}$ & 0,99 & 2,51 & não & 1,63 & 2,51 & não \\
\hline
\end{tabular}




\section{INFLUÊNCIA DO FÍLER NA ENERGIA DE FRATURA DE MÁSTIQUES ASFÁLTICOS}

O desempenho das misturas e pavimentos asfálticos quanto à fadiga está fortemente influenciado pela resistência à fadiga do ligante asfáltico. Porém, um estudo de Roque et al. (2009) mostrou que os métodos de ensaios existentes nas especificações atuais, incluindo o Reômetro de

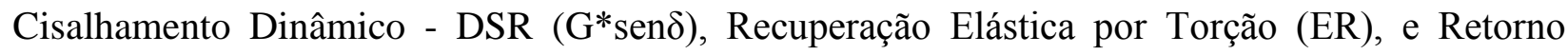
Elástico por Ductilidade (FD) não têm a capacidade de prever com precisão o desenvolvimento de trincas nas temperaturas intermediárias. Os autores acreditam que a energia de fratura do ligante asfáltico se correlaciona fortemente com a resistência a fratura da mistura asfáltica.

A determinação da energia de fratura a partir das propriedades de seus constituintes (ou seja, das propriedades dos agregados e do ligante asfáltico) pode ser utilizada em projeto estrutural de pavimentos e, com base na energia de fratura do ligante asfáltico, poderia ser prevista a resistência à fratura da mistura asfáltica.

A energia de fratura é definida como a quantidade de energia necessária para criar uma unidade de área de uma trinca e é uma propriedade importante relacionada com a resistência à fadiga de ligantes asfálticos (ROMEO, 2008). A determinação da energia acumulada até a ruptura em ensaios realizados em ligantes asfálticos melhora a habilidade de previsão do desenvolvimento de trincas nas temperaturas intermediárias. Assim, um ensaio que determine a energia de fratura de ligantes asfálticos pode fornecer parâmetros efetivamente relacionados com a resistência à fadiga de misturas asfálticas. Além disso, a energia de fratura é uma propriedade fundamental, independente do estado de tensões ou condições de carregamento (KOH e ROQUE, 2010).

A definição do conceito e o procedimento ideal de ensaio para determinação desse parâmetro é um tópico importante, recentemente estudado por vários comitês da "American Society for Testing and Materiails (ASTM)" e cuidadosamente discutido por muitos pesquisadores (ROMEO, 2008). 


\subsection{ENERGIA DE FRATURA EM MISTURAS ASFÁLTICAS}

O trincamento por fadiga em pavimentos flexíveis, devido ao carregamento repetido do tráfego, é um dos defeitos mais comuns que afetam a vida útil do pavimento flexível, reduzindo sua capacidade estrutural e, por isso, deve ser considerado nos projetos de pavimentos novos e de reabilitação. As trincas podem começar como microfissuras, que se conectam para formar as macrofissuras, propagando-se devido às tensões de tração ou de cisalhamento, ou a combinação de ambas. Segundo Koh e Roque (2010), para avaliar e prever o desempenho do pavimento asfáltico e desenvolver modelos apropriados em relação à resistência ao trincamento é necessário determinar os limites de fratura na tração, deformação de fratura e energia de fratura.

Portanto, é necessário adquirir maior conhecimento em relação ao comportamento das trincas das misturas asfálticas, com o objetivo de entender melhor o mecanismo de trincamento em pavimentos asfálticos e também para se ter um sistema prático e confiável na determinação da resistência ao aparecimento e propagação das trincas na mistura. $\mathrm{O}$ uso da mecânica das fraturas é necessário para explicar fundamentalmente e com precisão os diferentes fatores que afetam o comportamento das trincas em misturas asfálticas (ZHANG et al., 2001).

Melhoramentos na resistência ao trincamento de misturas asfálticas exigem um entendimento de como a trinca se inicia, se propaga e se aglutina em faixas de trincas maiores, até atingir a ruptura completa (BIRGISSON et al., 2006). Assim, o uso da energia de fratura como critério de ruptura para o aparecimento e propagação de trincas pode explicar tanto a taxa de crescimento de trincas medidas em laboratório quanto o seu desempenho ao trincamento em campo (ZHANG et al., 2001).

Em vista da importância da resistência de fratura no mecanismo de trincamento em pavimentos asfálticos tem sido estudado desde o início da década de 1970, quando muitas pesquisas começaram a aplicar a mecânica das fraturas para analisar o comportamento de fadiga de materiais asfálticos (MAJIDZADEH et al., 1971; SCHAPERY, 1973). Infelizmente, a complexidade da propagação de trincas em misturas asfálticas tem sido um obstáculo para a incorporação da abordagem da mecânica das fraturas na área de pavimentação asfáltica (ROMEO, 2008). 
A abordagem convencional para fadiga, baseada na deformação, não considera os efeitos das trincas (macro e micro fissuras) em misturas asfálticas, ou seja, não é considerada a redistribuição da tensão induzida pelas mudanças na geometria (Zhang et al., 2001). Os resultados do trabalho de Birgisson et al. (2006) mostram que a fratura de misturas pode ser modelada efetivamente com a abordagem micromecânica, que considera a propagação das trincas tanto pela superfície dos agregados quanto através deles.

O modelo que descreve a fratura deve incorporar: (a) deformação de fratura, (b) energia de fratura e (c) resistência à tração. Com esses parâmetros, o modelo permite a determinação do limiar para a falha local ou global da mistura (ZHANG et al., 2001). Por outro lado, Jacobs et al. (1996) indicaram que a taxa de propagação das trincas é função: (a) resistência a tração, (b) elasticidade, (c) energia de fratura e (d) módulo de resiliência.

Recentemente, verificou-se que o mecanismo de trincamento de misturas asfálticas pode ser simulado utilizando-se um modelo de trincamento com base na Mecânica das Fraturas de Misturas Asfálticas, desenvolvido na Universidade da Flórida por Zhang et al. (2001) e Roque et al. (2002), em que as trincas propagam-se de forma gradual e não contínua. O mais importante desse modelo é o conceito de limite fundamental da propagação da trinca, elemento que define o mecanismo de trincamento e a resistência à fratura de misturas asfálticas. Esse conceito baseia-se em informações de que as microfissuras parecem ser completamente curáveis, enquanto as macrofissuras parecem não serem curáveis.

Pesquisas conduzidas por Wen e Kim (2002) confirmam que a energia de fratura é um excelente indicador da resistência de misturas asfálticas ao trincamento por fadiga, através da realização do ensaio de tração indireta. No modelo de mecânica das fraturas desenvolvido na Universidade da Flórida, a energia de fratura é uma das propriedades chave que governam a resistência da mistura asfáltica à fadiga (ZHANG, 2000).

O ensaio de tração direta "dog-bone" (Dog Bone Direct Tension - DBDT) foi desenvolvido na Universidade da Flórida por Koh e Roque (2010) para determinação da resistência à tração e energia de fratura. Esse ensaio foi comparado com o ensaio de tração indireta do Superpave 
(Indirect Tension Test - IDT), que apresenta diferente estado de tensão e deformação (Figura 4.1). Os autores observaram que, apesar do parâmetro resistência à tração e o parâmetro deformação na ruptura apresentarem valores diferentes (Figura 4.2 (a) e (b)), o valor de energia de fratura é muito próxima em ambos ensaios, para materiais similares (Figura 4.2 (c)). Isso indica que a energia de fratura é uma propriedade fundamental, sendo independente do estado de tensões, condição de carregamento e geometria do corpo de prova.
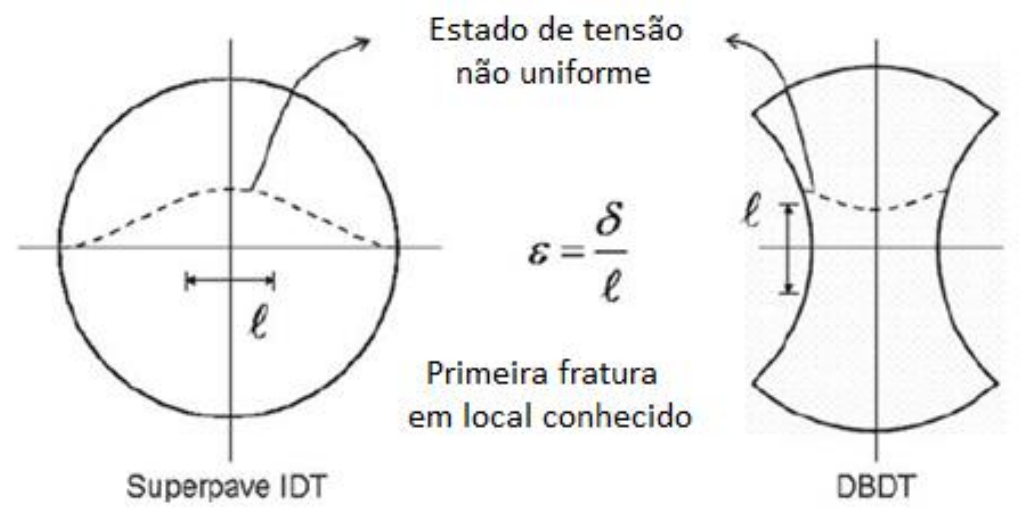

Figura 4.1 Geometria e estado de tensões nos corpos de prova dos ensaios de Tração Indireta do Superpave (IDT) e de Tração Direta "Dog Bone" (DBDT) [Adaptado de Koh e Roque (2010)] 

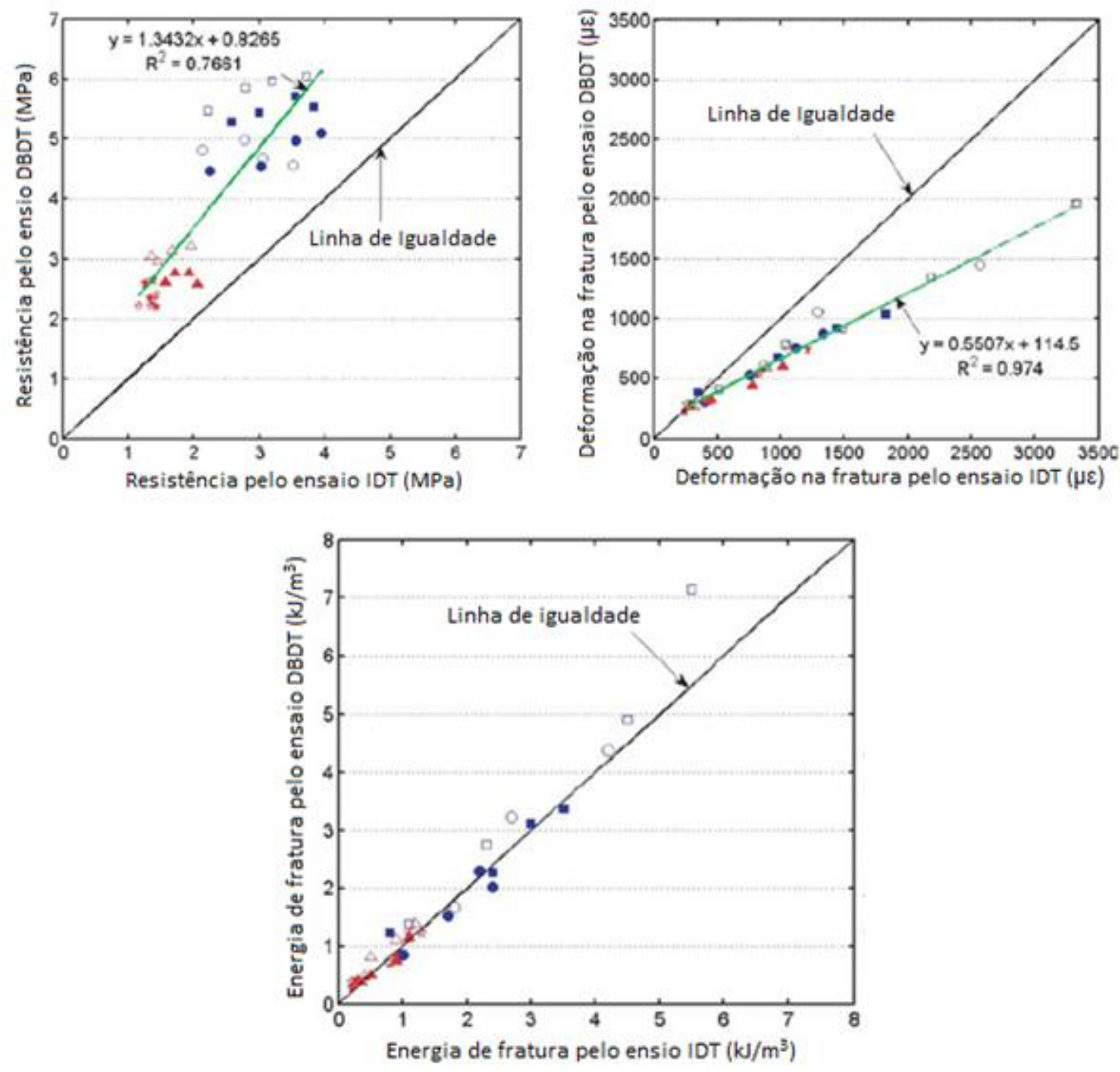

Figura 4.2 - Comparação dos resultados dos ensaios de IDT e DBDT: (a) resistência a tração, (b) deformação na fratura, (c) energia de fratura [Adaptado de Koh e Roque (2010)]

Braham et al. (2007) investigaram a energia de fratura de misturas asfálticas, determinada através do ensaio de tração em formato de disco ("disk-shaped compact tension test" - DC(T)), como mostrado na Figura 4.3, através de quatro parâmetros: temperatura de ensaio, tipo de agregado, teor de ligante e volume de vazios. 


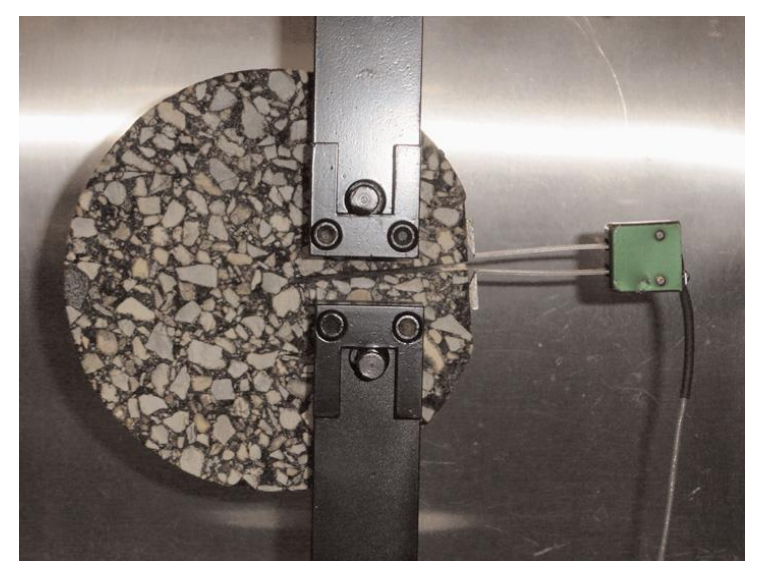

Figura 4.3 - Configuração do Ensaio de Tração em formato de Disco [Adaptado de Braham et al. (2007)]

Para o efeito do tipo de ligante asfáltico, não foi identificada nenhuma tendência na energia de fratura, porém a Figura 4.4 (a) indica que a especificação Superpave, quanto aos requisitos à temperatura mínima do ligante asfáltico, tem alguma relação com a energia de fratura, pois todas as misturas tiveram valores de energia de fratura em torno de 300 a $800 \mathrm{~J} / \mathrm{m}^{2}$ quando ensaiadas a $2^{\circ} \mathrm{C}$ abaixo da temperatura de especificação, independentemente do tipo de ligante asfáltico. Uma diferença significativa nos níveis da energia de fratura e da sequência de classificação aparece para os resultados de ensaios realizados em temperaturas altas, sendo que essa diferença na energia de fratura é muito maior e mais aparente quando comparada aos resultados nas temperaturas alta e média.

O tipo de agregado mostrou um comportamento particular na energia de fratura, como nota-se na Figura 4.4 (b). As misturas com granito apresentaram maiores valores de energia de fratura para baixas temperaturas (Região A), mas em temperaturas elevadas nota-se um efeito contrário (Região B), em que os dados se encontram logo acima da linha de igualdade, mostrando que as misturas com calcário apresentaram valores maiores de energia de fratura. Segundo Braham et. al. (2007), nas temperaturas maiores, em que a resistência à fratura e tração das misturas é governada pelas características dos agregados, a maior reatividade físico-química do agregado calcário resulta em maior resistência à fratura das misturas que contém esse mineral. 

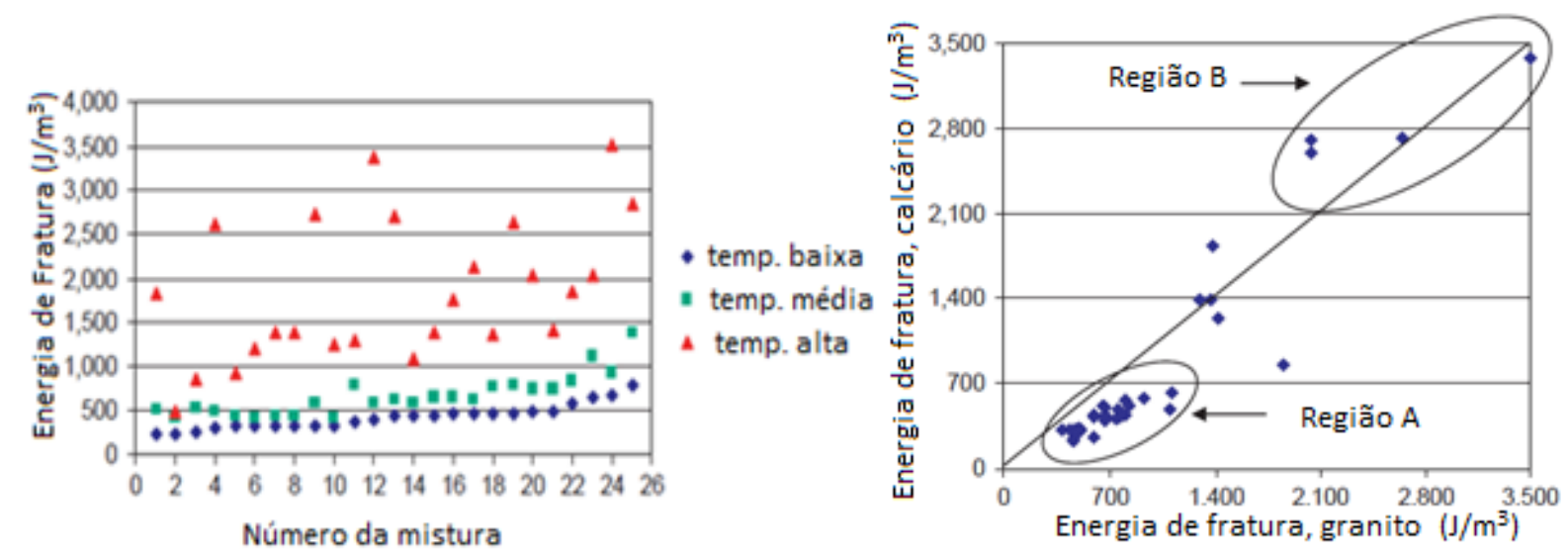

Figura 4.4 - (a) Tendência da energia de fratura e temperatura de ensaio, e (b) Efeito do tipo de agregado na energia de fratura [Adaptado de Braham et al. (2007)]

O terceiro parâmetro investigado foi o efeito da temperatura na energia de fratura. Nas temperaturas baixa e média, o material apresenta um comportamento frágil, enquanto que em alta temperatura o material apresenta um comportamento mais dúctil. A Figura 4.5 (a) mostra as curvas de energia de fratura para ambas as misturas, as altamente frágeis e altamente dúcteis. Portanto, a energia de fratura, ou a área sob a curva de carregamento versus o aumento da abertura da trinca ("Crack Mouth Opening Displacement” - CMOD), é menor para misturas frágeis e maior para misturas dúcteis. Essas tendências podem ser causadas pelo fato de que a temperaturas baixas, a energia de fratura do ligante asfáltico tem valor próximo à energia de fratura do agregado, enquanto que em temperaturas maiores, a tolerância de deformação do ligante asfáltico é dominante. Em outras palavras, devido a que o ligante asfáltico se torna menos frágil com o aumento da temperatura, a energia de fratura das misturas aumenta (BRAHAM et al, 2007).

O quarto parâmetro investigado é o efeito do teor de ligante asfáltico na energia de fratura. A Figura 4.5 (b) mostra o gráfico da energia de fratura de misturas com teor de ligante asfáltico de projeto Superpave em comparação com o teor de ligante asfáltico de projeto mais $0,5 \%$. Nas temperaturas de ensaio baixa e média, a adição de ligante asfáltico parece não influir. Porém, nas temperaturas altas, a adição de 0,5\% de ligante asfáltico aumentou a energia de fratura. Isso indica que teores maiores de ligante asfáltico não necessariamente aumenta a energia de fratura em temperaturas baixas, mas aumenta a energia de fratura nas temperaturas maiores. Isso é 
racional, pois o ligante asfáltico dissipa grandes quantidades de energia nas temperaturas altas e intermediárias, mas por outro lado, produz uma matriz frágil a temperaturas muito baixas (BRAHAM et al, 2007).
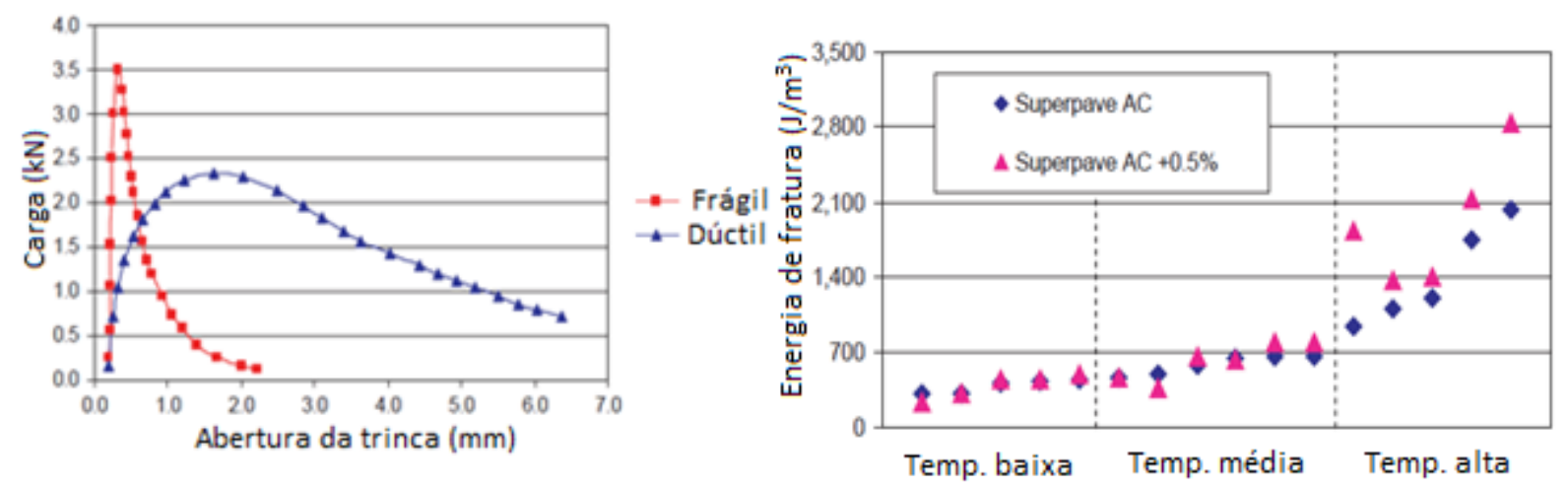

Figura 4.5 - (a) Curvas de energia de fratura para misturas asfálticas frágeis (ensaio a $-24{ }^{\circ} \mathrm{C}$ ) e dúcteis (ensaio a $-18^{\circ} \mathrm{C}$ ) e (b) Efeito do teor de ligante asfáltico na energia de fratura. $(\mathrm{J} / \mathrm{m} 3)$ [Adaptado de Buttlar e Marasteanu (2007)]

\subsection{ENERGIA DE FRATURA EM LIGANTES ASFÁSTICOS}

A mecânica das fraturas tem sido utilizada para descrever a propagação e crescimento de trincas, em uma ampla variedade de materiais frágeis, assim como para materiais dúcteis, viscoelásticos e viscoplásticos. A teoria da mecânica da fratura é muito utilizada em misturas asfálticas, porém não é muito aplicada a ligantes asfálticos, embora em razão de estudos sobre a fratura de compósitos é de se esperar que as propriedades de fratura do concreto asfáltico sejam significativamente influenciadas pela propriedade de fratura do ligante asfáltico. Consequentemente, as propriedades de fratura devem ser uma consideração importante na especificação de ligantes asfálticos (ANDERSON e DONGRE, 1995).

Para a avaliação das propriedades de fratura de ligantes asfálticos, a maior parte das pesquisas utiliza métodos tradicionais de ensaio, como o Reômetro de Cisalhamento Dinâmico (DSR), o Reômetro de Viga à Flexão (BBR), o Retorno Elástico, a Ductilidade, com utilização de parâmetros tradicionais, como o módulo complexo $\left(\mathrm{G}^{*}\right)$, o ângulo de fase $(\delta)$ ou parâmetros derivados desses ensaios, como a energia e deformação produzidas na tensão máxima (BAHIA et al., 2008). Vale notar que a maioria dos ensaios de energia de fratura para ligantes asfálticos são desenvolvidos para utilização em baixas temperaturas. 
Durante o desenvolvimento do projeto de misturas asfálticas a quente do programa SHRP, o trincamento térmico a baixas temperaturas foi considerado um fator importante, por ser um dos modos principais de desenvolvimento de defeito no pavimento. Assim, baseado em considerações práticas, dois ensaios foram adotados nas especificações do SHRP para ligantes asfálticos visando caracterizar as propriedades a baixas temperaturas, o Reômetro de Viga à Flexão (BBR), para medir as propriedades reológicas, e o Ensaio de Tração Direta, para caracterizar as propriedades de fratura. Os dois ensaios são complementares, um determina a rigidez e o outro as propriedades de fratura do ligante asfáltico (ANDERSON e DONGRE, 1995).

O mecanismo de trincamento a baixas temperaturas é bastante complicado e envolve muitas considerações, como a recuperação de trincas ("healing”), o envelhecimento oxidativo e o enrijecimento físico. Essas considerações requerem sustentação nos complexos conceitos e formulações da mecânica das fraturas, tanto em termos de medidas como de aplicação, por isso, até o desenvolvimento do programa SHRP, não existiam procedimentos de ensaio para obtenção das propriedades de fratura, em temperatura baixa a alta (ANDERSON e DONGRE, 1995).

Os métodos de ensaio da mecânica das fraturas e a teoria e análise associada eram muito complexas para a aplicação em especificações de rotina quando foram desenvolvidas as pesquisas do SHRP. Porém, para propósitos de engenharia, era aceitável especificar o critério de falha em termos de valores críticos de tensão ou deformação em que ocorre a fratura, devido a ruptura ou alongamento excessivo. Esse valor de tensão ou deformação representa uma combinação da fase inicial e de propagação das trincas (ANDERSON e DONGRE, 1995).

Conceitualmente, o ensaio de Tração Direta (“Direct Tension Test” - DTT), que a configuração do corpo de prova está mostrada na Figura 4.6, é uma abordagem apropriada para determinar a energia de fratura do ligante asfáltico. Porém, devido à configuração do corpo de prova, o DTT tradicional resulta em uma variabilidade muito grande e não representa apropriadamente a condição de fratura de ligantes asfálticos entre os agregados na mistura, o que impossibilita a determinação da energia de fratura. A tensão de tração é bastante uniforme na extensa seção central, por isso o corpo de prova pode romper em qualquer ponto nesta seção, o que torna impossível a medida precisa da tensão de fratura no plano de fratura, o que é necessário para a 
determinação da energia de fratura. Portanto, a geometria do corpo de prova dificulta a aplicação uma taxa de deformação alta o suficiente para reduzir a ductilidade do corpo de prova, o que torna o cálculo da energia de fratura muito dependente de qualquer imprecisão durante o ensaio. Para alguns ligantes asfálticos muito dúcteis e com alta energia de fratura, o ensaio pode exceder a capacidade de taxa de carregamento do equipamento de ensaio, sem ocorrer a ruptura.

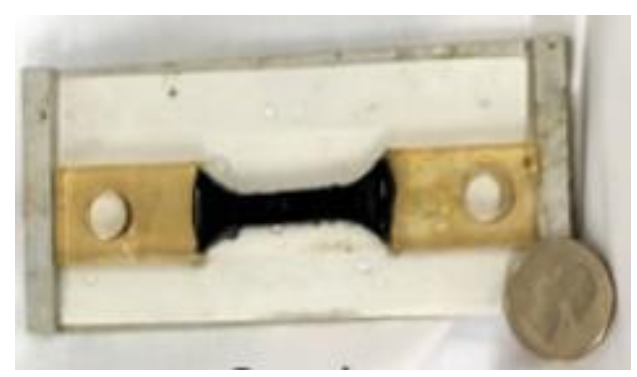

Figura 4.6 - Corpo de prova do Ensaio de Tração Direta Superpave (DTT)

Em temperaturas baixas, ou a taxa de alongamento alta, o ligante asfáltico se comporta de maneira frágil, com a curva tensão-deformação linear, refletindo uma resposta elástica, com deformação na ruptura tipicamente inferior a 1 ou $2 \%$. Com o aumento da temperatura, ou com a diminuição da taxa de alongamento, o ligante entra em transição entre o comportamento frágil e o dúctil, região chamada de região frágil-dúctil, ou simplesmente região dúctil, na qual a falha do ligante asfáltico ainda ocorre pela fratura, ou seja, com uma completa ruptura do corpo de prova, porém, sem o estreitamento da seção transversal, sendo que a deformação na ruptura nessa região tem valores típicos entre 2 e 10\%, porém, para alguns ligantes essa região pode alcançar deformações de 20 a $30 \%$.

O método de ensaio deveria limitar-se a deformações de até $10 \%$ para evitar a necessidade de correção pela redução da seção transversal. Com o aumento da temperatura e redução da taxa de alongamento, a fratura do ligante ocorre com grandes deformações e é causada pelo escoamento do corpo de prova, não pela ruptura (ANDERSON e DONGRE, 1995).

Ponniah et al. (1996) propôs uma especificação de energia de fratura para ligantes asfáltico modificados, em que utilizaram o método de flexão em viga de três pontos para determinar a tenacidade de fratura e com isso calcularam a energia de fratura baseada na tenacidade (energia 
total que o material pode absorver até a ruptura, por unidade de volume). Anderson et al. (2001) realizaram o ensaio $\mathrm{BBR}$ de três pontos para vários ligantes asfálticos e descobriram que a tenacidade na fratura fornece uma classificação muito mais exigente da resistência ao trincamento térmico que o critério Superpave. Hoare et al. (2000) analisaram os resultados do ensaio de viga a flexão de três pontos e contataram que a tenacidade de fratura e a energia de fratura são dependentes da morfologia do ligante asfáltico, do teor de polímero, e da rigidez. Porém, esse método é adequado apenas para amostras de ligante frágeis, ou seja, a baixas temperaturas, quando se aplica a Mecânica da Fratura Elástica-Linear (Linear Elastic Fracture Mechanics - LEFM), mas não é aplicável a ligantes asfálticos dúcteis, ou seja, em temperaturas intermediárias.

O ensaio de energia de fratura em temperaturas intermediárias é dificultado pela complexidade da modelagem constitutiva da tensão-deformação para materiais viscoelásticos ou plásticos nãolineares, que podem ser altamente dúcteis e sofrem grandes deformações até atingir a fratura. A modelagem constitutiva da tensão e deformação pode basear-se na simulação e análises de Elementos Finitos em ensaios de laboratório. Geralmente há um nível máximo de deformação que essa análise simula precisamente, porém, o Método de Elementos Finitos Estendido, pela utilização de funções de descontinuidade para deslocamentos da abertura de trincas, pode ser utilizado, pois a malha não necessita ser atualizada ao longo da trinca.

Pesquisadores da Universidade da Flórida (ROQUE et al., 2012) desenvolveram um ensaio para determinar a energia acumulada até a ruptura, que é capaz de prever o desempenho de ligantes asfálticos ao trincamento em temperaturas intermediárias. O estudo desenvolveu um Ensaio de Tração Direta para ligantes asfálticos e um método de interpretação de dados que permite a determinação precisa da energia de fratura em temperaturas intermediárias.

O Ensaio de Tração Direta para determinação de energia de fratura de ligantes asfálticos (ROQUE et al., 2012) baseia-se na Análise de Elementos Finitos tridimensional para identificar e otimizar a geometria apropriada, que assegura uma determinação acurada da tensão e da deformação no plano da fratura, assegurando, também, a determinação da energia de fratura. A viabilidade e validade de diferentes geometrias foram avaliadas realizando-se ensaios com 
protótipos, utilizando um equipamento de carga servo-hidráulica em uma câmara de temperatura controlada ("Universal Test Machine”- UTM).

Um conjunto de diagramas foi proposto, baseado nos resultados da Análise de Elementos Finitos, para a realização do procedimento de cálculo. Em avaliações preliminares, o novo ensaio de energia de fratura e o sistema de interpretação de dados forneceu valores de energia de fratura consistentes com os valores de ligantes asfálticos em temperaturas intermediárias.

Roque et al. (2012) testaram o novo procedimento em vários tipos de ligantes asfálticos, incluindo ligantes não modificados, ligantes modificados com polímero, ligantes modificados com SBS e ligantes modificados com borracha. Para cada ligante, os ensaios foram realizados em várias taxas de carregamento e temperatura.

A geometria do corpo de prova é em formato de "osso de cachorro" ("dog-bone”), como apresentado na Figura 4.7. Essa geometria resulta em uma concentração de tensão maior do que cinco (relativamente à tensão na aplicação do carregamento), o que é considerado suficiente para resultados consistentes da fratura na seção transversal central (ROQUE et al.,2012).

Segundo Roque et al. (2012), a análise estatística dos resultados mostrou que o ensaio distingue significativamente diferentes ligantes asfálticos através de valores de energia de fratura e que, para um dado ligante asfáltico, a energia de fratura é independente da taxa de carregamento e da temperatura de ensaio. Assim, a energia de fratura parece ser uma propriedade fundamental do ligante asfáltico, não dependente das condições de ensaio, e pode ser determinada por ensaios realizados em uma única temperatura e taxa de carregamento. Porém, resultados errôneos podem ocorrer se utilizada taxas de carregamento excessivamente alta ou baixa. 

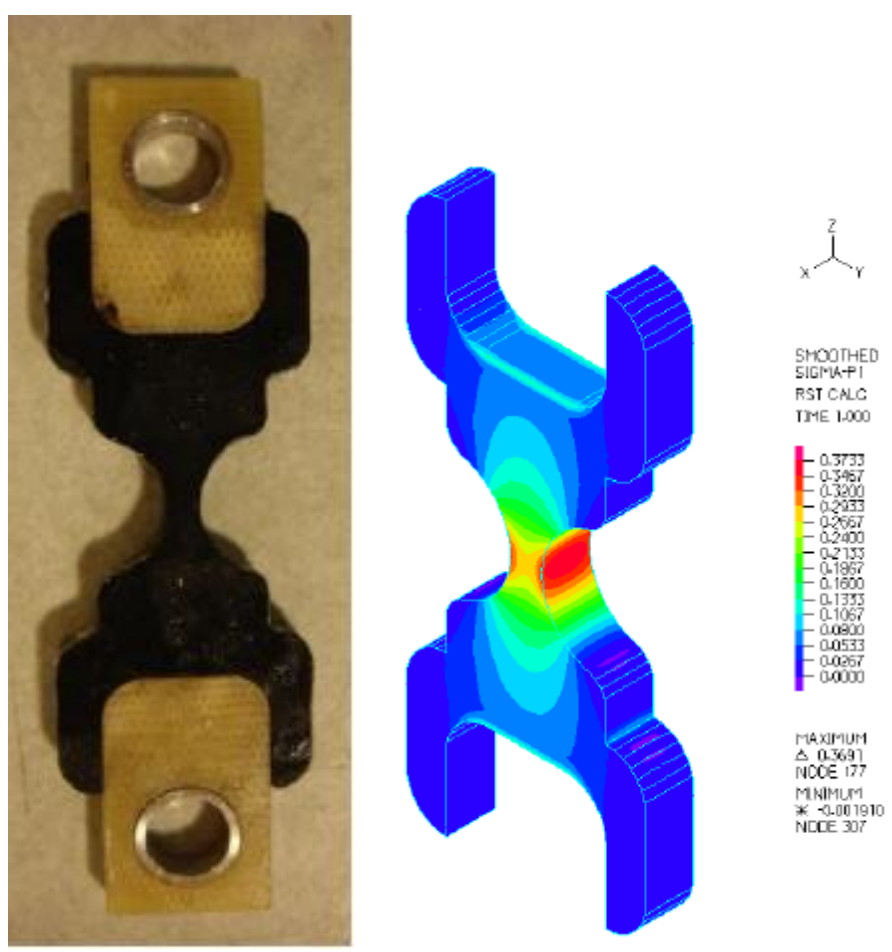

Figura 4.7 - Geometria do corpo de prova do Ensaio de Tração Direta "Dog-Bone" [Adaptado de Roque et al. (2012)]

Outra descoberta importante na pesquisa de Roque et al. (2012) é que as características da curva tensão-deformação de ligantes asfálticos estão estreitamente relacionados com o tipo e teor de modificador, incluindo a presença de modificadores e borracha e que cada tipo de ligante asfáltico tem sua própria curva tensão-deformação característica. Assim, a curva tensãodeformação pode ser utilizada para identificar o tipo de ligante, o tipo e o teor do modificador.

Alguns princípios podem ser importantes para identificar o tipo e teor de modificador no ligante asfáltico, como a presença de dois picos de tensão na curva tensão-deformação para ligantes com SBS, enquanto os ligantes asfálticos puros, sem modificadores, apresentam apenas um pico de tensão. A curva típica para ligantes asfálticos com polímero exibem maiores deformações na ruptura quando comparada às dos ligantes sem modificadores e com borracha (Figura 4.8). Parece existir uma faixa de valores típica de energia de fratura associada com cada tipo de ligante asfáltico, que pode ajudar a diferenciar os ligantes asfálticos. A existência de dois picos de tensão e alta energia de fratura identificam ligantes asfálticos com polímero, ligantes asfálticos com borracha exibem apenas uma inflexão após o primeiro pico de tensão, ao invés de um segundo 
pico e a energia de fratura para os ligantes modificados com borracha é usualmente menor que dos com polímero.

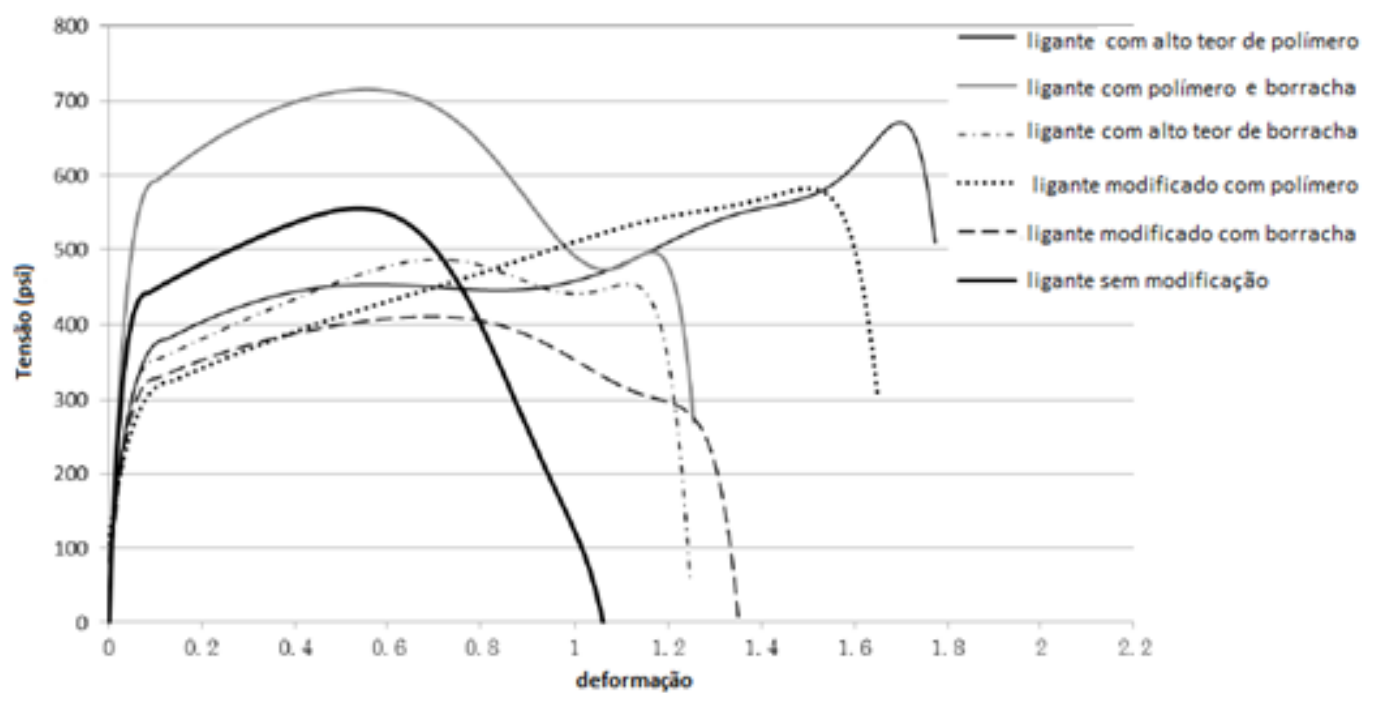

Figura 4.8 - Comparação da curva tensão-deformação para diferentes ligantes asfálticos [Adaptado de Roque et al. (2012)]

A Figura 4.9 mostra uma forma típica da curva tensão-deformação de ligante asfáltico puro e de ligante asfáltico com polímero. Assumindo-se que as áreas abaixo de cada curva sejam exatamente iguais, as energias de fratura não seriam as mesmas, pois para o ligante asfáltico puro a maior parte da energia de fratura corresponde à área após o pico de tensão, que está associada ao aparecimento da trinca e a fratura já teria se iniciado, assim, além desse pico, as tensões e deformações, não podem ser determinada com precisão e estão associadas com a propagação das trincas. Por isso, o cálculo da energia de fratura utilizando-se toda a área sob a curva tensãodeformação significaria superestimar a energia de fratura de ligantes asfálticos não modificados. Para ligantes modificados por polímero, a energia de fratura corresponde à área até o segundo pico de tensão, antes do início da fratura. 


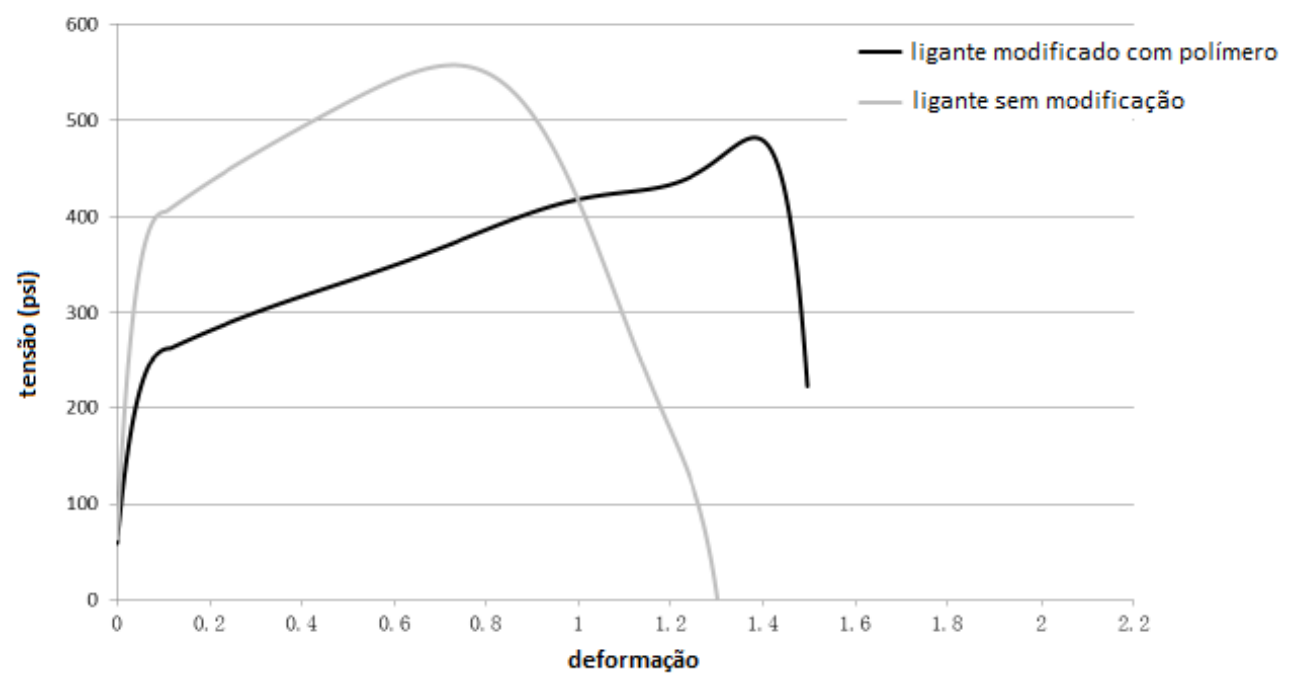

Figura 4.9 - Curva tensão-deformação de ligante asfáltico modificado por polímero e sem modificação [Adaptado de Roque et al. (2012)]

Assim, Roque et al. (2012) concluíram que: o ligante asfáltico modificado por polímero apresenta o maior valor de energia de fratura; todos os ligantes asfálticos híbridos (com alto teor de borracha, alto teor de polímero e com polímero e borracha) têm energia de fratura maior do que a dos ligantes não-modificados e valores maiores ou iguais ao do ligante asfáltico modificado por SBS; o ligante asfáltico modificado por borracha tem energia de fratura ligeiramente maior que os ligantes não-modificados, porém menores que a dos outros ligantes modificados.

\subsection{CONCEITOS BÁSICOS DA TEORIA DE MECÂNICA DAS FRATURAS}

Os conceitos da mecânica das fraturas têm sido adotados por muitos pesquisadores para quantificar a resistência à fratura de misturas asfálticas, resultando no desenvolvimento de modelos para prever o desenvolvimento de trincas em concreto asfáltico (ROMEO, 2008).

A Figura 4.10 mostra de uma maneira simplificada as áreas de aplicação da Mecânica das Fraturas, dependendo do comportamento à fratura de cada material. 


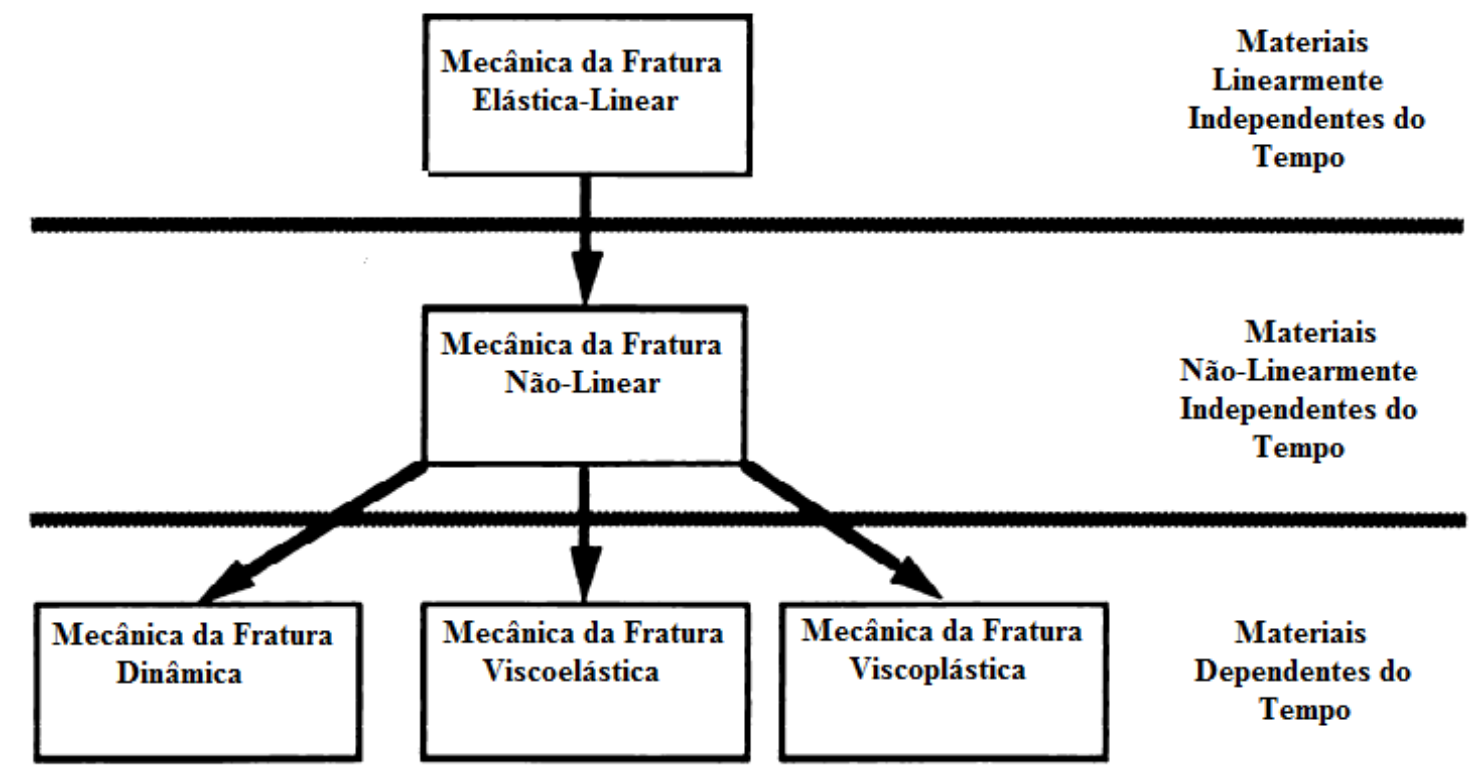

Figura 4.10 - Áreas de aplicação da Mecânica da Fratura [Adaptado de Anderson T.L. (1994)]

A Mecânica da Fratura Elástica-Linear (MFEL) supõe que existem fissuras intrínsecas nos materiais, das quais as trincas se propagam quando algum carregamento é aplicado. De acordo com a teoria da MFEL, a energia dissipada ocorre apenas na extremidade da trinca, assim, a energia de fratura está diretamente relacionada com a energia de separação necessária para a criação de uma nova superfície por um corte no material.

Existem dois parâmetros que descrevem o comportamento da propagação de trincas: (a) taxa de liberação de energia $G$ e (b) fator de intensidade de tensão $K$. O primeiro fator quantifica a mudança no potencial de energia que acompanha o incremento da extensão da trinca, enquanto o segundo caracteriza as tensões, deformações e deslocamentos na extremidade da trinca. Os dois parâmetros podem ser utilizados como medidas globais do processo de fratura, no caso de mecânica da fratura elástico-linear, como mostrado na Equação 4.1.

$$
G=\frac{K_{I}^{2}}{E}(4.1)
$$

em que: $\quad$ E: módulo de Young ou módulo de elasticidade

$\mathrm{K}_{\mathrm{I}}$ : fator de intensidade de tensão $=\sigma \sqrt{\pi a}$ 


$$
\begin{aligned}
& \sigma: \text { tensão aplicada } \\
& a \text { : dimensão da trinca. }
\end{aligned}
$$

No momento da fratura (ou ruptura), $G=G_{F}$, que é a taxa de liberação de energia crítica, corresponde à resistência à fratura do material. Uma das hipóteses da mecânica da fratura é que $G_{F}$ é independente do tamanho e da geometria do material.

Na MFEL, a taxa de propagação de trincas é descrita utilizando a lei de Paris (Paris e Erdogan, 1963), dada pela Equação 4.2.

$$
\frac{d a}{d N}=A(\Delta K)^{n}
$$

em que: $\quad a$ : dimensão da trinca;

n: número de carregamentos repetidos;

$\Delta K$ : variação do fator de intensidade de tensão;

$A$ e $n$ : parâmetros do material, determinados por ajuste de dados do ensaio de propagação de trincas.

Como mostrado na Figura 4.11, $\mathrm{K}_{\text {lim }}$ representa um valor limite, abaixo do qual se assume que não ocorrem trincas. A resistência à fratura, $K_{c}$, representa a resistência do material à ruptura por fratura e é considerada intrínseca ao material. A curva sinusoidal apresenta três regiões distintas: na região I, $d a / d N$ se aproxima de zero no valor limite $\Delta \mathrm{K}_{\text {lim }}$; na região II a taxa de propagação de trinca aumenta linearmente com o aumento de $\Delta K$, mas se afasta da tendência linear em níveis maiores e menores que $\Delta \mathrm{K}$; na região III a taxa de propagação de trinca aumenta rapidamente quando $\Delta K$ se aproxima do $K_{c}$, que é a resistência à fratura do material (ROMEO, 2008). 


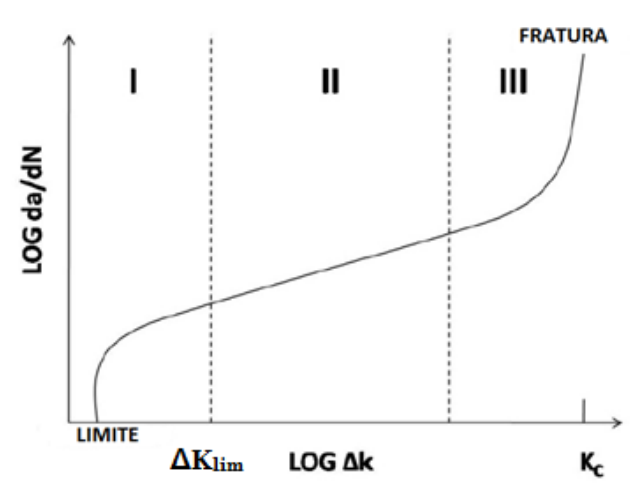

Figura 4.11 - Comportamento típico de propagação de trincas [Adaptado de Romeo (2008)]

A teoria da Mecânica da Fratura Não-Linear (MFNL) estende a mecânica das fraturas para além dos limites válidos para a MFEL. O parâmetro mais comum utilizado para caracterizar os materiais de comportamento não-linear é a integral- $J$, introduzida primeiramente por Rice (1968). A integral-J, dada pela Equação 4.3, tem significado físico para os comportamentos elástico nãolinear e elastoplástico, podendo ser utilizada como um parâmetro de energia e também como parâmetro de intensidade de tensão (ANDERSON, 1995).

$$
J=\int_{\Gamma}\left(W d y-\sigma_{i j} n_{j} \frac{d u_{i}}{d x} d s\right)
$$

em que: $\quad W$ : densidade de energia de deformação;

$\Gamma$ : contorno ao redor da fissura;

$d s$ : incremento da dimensão ao longo do contorno;

$d y$ : incremento da dimensão ao logo da direção y;

$d x$ : incremento da dimensão ao logo da direção $\mathrm{x}$

$d u$ : incremento da deformação.

Para avaliar a propagação das trincas de fadiga em materiais viscoelástico lineares homogêneos utiliza-se a teoria da Mecânica da Fratura Viscoelástica (MFV), desenvolvida por Schapery (1973). Essa abordagem estima os parâmetros $A$ e $n$ a partir das características mecânicas, químicas e termodinâmicas, como compliância na fluência e resistência à tração. 
Já que o concreto asfáltico é um material viscoelástico, a integral- $J$ parece ser mais adequada para caracterizar as condições na extremidade da trinca. Além disso, o uso da integral- $J$ torna mais fácil o emprego do principio da correspondência viscoelástica na lei de propagação de trincas de fadiga (KUAI et al., 2009).

Kuai et al. (2009) concluíram que a integral- $J$ considera tanto o nível de carregamento quanto a dependência da frequência da velocidade da trinca, porém, não foi possível eliminar a dependência da temperatura em relação à velocidade da trinca completamente. A integral- $J$ considera a dependência do tempo e da temperatura do material através do uso da compliância (“creep compliance"), que é uma propriedade da viscoelasticidade linear do material.

Desde que a abordagem da mecânica da fratura foi aceita para a análise da propagação de trinca em materiais, muitos pesquisadores adotaram os conceitos e os aplicaram no estudo de materiais de pavimentação.

O Modelo de Trincamento Coesivo ("Cohesive Crack Model" - CCM) tem sido extensivamente aplicado em concreto de cimento Portland e apenas recentemente tem sido pesquisado para misturas asfálticas. O CCM é um modelo simples utilizado para descrever o processo de fratura não-linear ao redor de um trinca pré-existente. De acordo com esse modelo, o material pode ser caracterizado por várias leis constitutivas: relação tensão-deformação, válida para materiais não danificados, e a relação tensão versus abertura da trinca, a chamada lei da coesão. Essa lei descreve como a tensão diminui do seu valor máximo a zero quando a distancia entre as faces da trinca aumentam de zero ao valor critico, $w_{c}$. A área abaixo da curva tensão versus abertura da trinca representa a energia dispendida para criar uma unidade de trinca superficial (Energia de Fratura, $\mathrm{G}_{\mathrm{F}}$ ). Se as duas porções em que o corpo de prova se separa sob descarregamento elástico, o trabalho realizado para separar o corpo de prova pode ser considerado exatamente igual ao produto de $\mathrm{G}_{\mathrm{F}}$ vezes a área trincada. A energia de fratura pode ser obtida pela Equação 4.5.

$$
G_{F}=\int_{0}^{\infty} \sigma d w=\int_{0}^{\infty} f(w) d w
$$


Os trabalhos conduzidos por Carpinteri e Ferro $(1994,1998)$ e Mier e Van Vliet (1999) provaram que os parâmetros de caracterização física da lei de coesão são dependentes da escala, mostrando os limites do modelo de Hillerborg. Assim, aumentando as dimensões dos corpos de prova, a tensão limite diminui, enquanto que a energia de fratura aumenta.

Por outro lado, a abordagem pelo Dano Contínuo analisa as microfissuras em misturas asfálticas sob condições realísticas de carregamento e efeito de recuperação (“healing”). Pesquisas realizadas por Kim et al. (1990) mostraram que ciclos contínuos de carregamentos com deformação ou tensão controlados, geralmente utilizados em ensaios laboratoriais, não representam as condições reais de carregamento em campo. A maior diferença é atribuída aos períodos de recuperação entre as aplicações do carregamento, que no campo ocorre de maneira aleatória. Kim et al. (1990) observaram que em um pavimento parcialmente trincado ocorrem dois mecanismos diferentes durante o período de recuperação: a relaxações das tensões no sistema devido à natureza viscoelástica do ligante asfáltico, e a cicatrização química através das faces das micro e macro fissuras.

Uma abordagem mecânica para a caracterização da fadiga de misturas asfálticas utilizando a teoria do dano contínuo e viscoelasticidade, foi introduzido por Kim et al. (1997). Eles modelaram a acumulação do dano (assumindo-se a propagação contínua sob carregamento cíclico de tração uniaxial) e a cicatrização das microfissuras durante os períodos de recuperação utilizando o princípio da correspondência viscoelástico desenvolvido por Schapery (1984).

Baseado nos dados experimentais de concretos asfálticos submetidos a carregamentos de tração contínuo e uniaxial, Lee e Kim (1998a) propuseram um modelo constitutivo que descreve o comportamento mecânico do material sob essas condições, dado pela Equação 4.6.

$$
\sigma=I\left(\varepsilon_{e}^{R}\right)(F+G)
$$

em que: $\quad$ I: pseudo rigidez inicial;

$\varepsilon$ : pseudo deformação efetiva considera a pseudo deformação acumulada no modo tensão controlada; 

F: função dano;
G: função histerese.

\subsubsection{Desenvolvimento da Mecânica da Fratura para Misturas Asfálticas a Quente}

Trabalhos prévios de Zhang et al. (2001) e Roque et al. (2002) mostraram que as propriedades de fratura de misturas podem ser descritas dentro da mecânica da fratura viscoelástica, baseada no que eles chamaram de Mecânica da Fratura para Misturas Asfálticas a Quente, que foi recentemente desenvolvida por pesquisadores na Universidade da Flórida. Eles observaram que as trincas em misturas asfálticas se propagam gradualmente e não de maneira contínua, como mostrado na Figura 4.12. As consequências deste trabalho é que talvez não seja suficiente monitorar as mudanças de um único parâmetro, como resistência ou rigidez para avaliar os efeitos de micro e macro fissura em misturas. Ao invés disso, mudanças na rigidez e na resistência são tipicamente fornecidas por mudanças nas propriedades viscoelásticas da mistura, assim como resistência e rigidez.

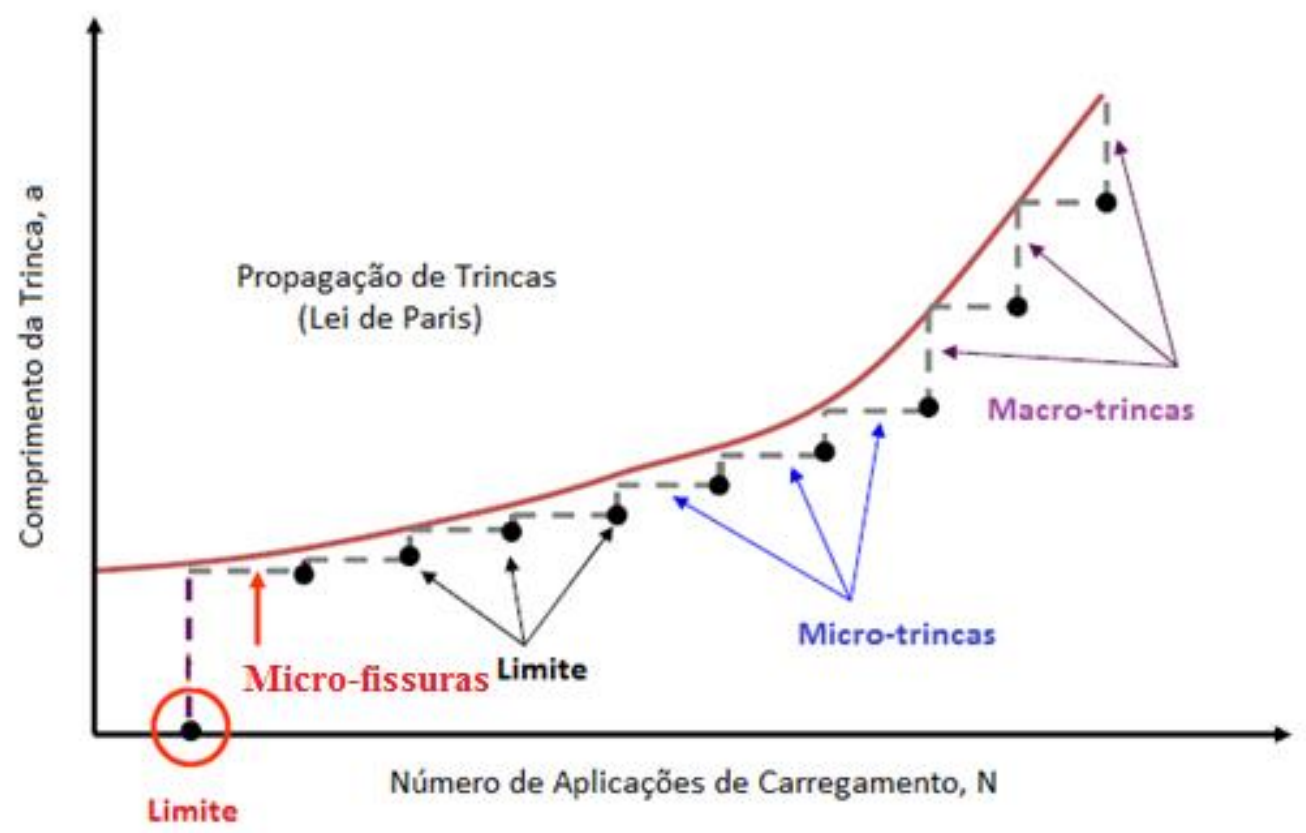

Figura 4.12 - Propagação de trincas em misturas asfálticas de acordo com a Mecânica das Fraturas [Adaptado de Romeo (2008)] 
Segundo o estudo de Zhang et al. (2001) existe um limite fundamental na propagação de trincas. $\mathrm{O}$ conceito introduzido por esses autores é baseado em observações de que as microfissuras (ou seja, dano não associado com aparecimento e propagação das trincas) parecem ser completamente curáveis, enquanto macrofissuras (ou seja, dano associado ao aparecimento e propagação de trincas) parecem não ser curáveis. Isso indica que existe um limite de dano abaixo do qual esse dano é completamente curável. Portanto, esse limite define o desenvolvimento de macrofissuras, a qualquer momento tanto durante o aparecimento quanto a propagação das trincas, em qualquer ponto da mistura. Se as condições de carregamento e recuperação são tais que a energia induzida não excede ao valor limite da mistura, então a mistura nunca será danificada, independente do numero de aplicações aplicada.

Discutido por Roque et al. (2002), a fratura (aparecimento e propagação de trincas) pode desenvolver-se em misturas asfálticas de duas formas diferentes, definido por dois limites distintos (Figura 4.13). O limite inferior está associado com o carregamento repetitivo, quando ocorrem ciclos de tensão significativamente abaixo da resistência a tração, em que eventualmente irá ocorrer o trincamento se a taxa de dano acumulado exceder a taxa de recuperação durante o período de recuperação. O limite superior de energia corresponde ao limite necessário para romper a mistura com uma única aplicação de carregamento, em que a fratura pode ocorrer se qualquer carregamento aplicado durante o ciclo de carregamento exceder o limite necessário para levar a mistura à fratura com um único carregamento. Basicamente, a fratura pode não ocorrer com uma única aplicação de carregamento a menos que o limite superior seja excedido. 


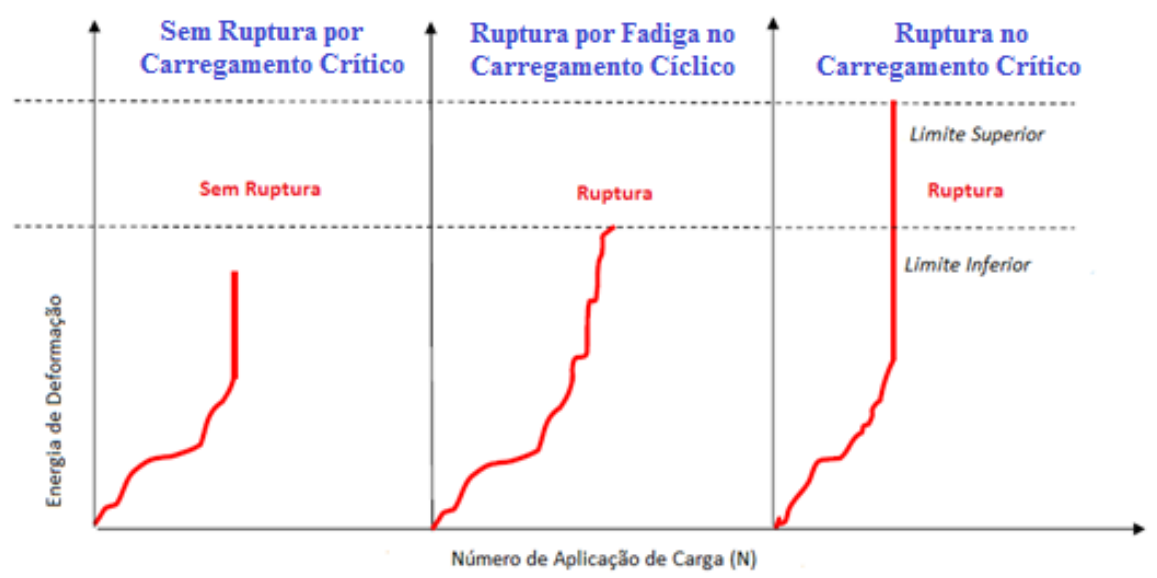

Figura 4.13 - Aparecimento e propagação de trincas em misturas asfálticas [Adaptado de Romeo (2008)]

Foi determinado que o limite de energia dissipada na fluência (DCSE) e o limite de energia de fratura (FE) de misturas asfálticas definem de maneira adequada esses valores limites inferior e superior. Esses parâmetros podem ser facilmente determinados da resposta tensão-deformação do Ensaio de Tração Indireta (IDT), como mostrado na Figura 4.14 e discutido por Roque et al. (2002). O limite de energia de fratura é determinado como a área abaixo da curva tensãodeformação na primeira trinca, enquanto que o limite de energia dissipada na fluência é a energia de fratura menos a energia elástica. A primeira trinca dos corpos de prova do ensaio de tração indireta é determinada como o ponto em que a diferença entra as deformações verticais e horizontais atingem o máximo valor. 


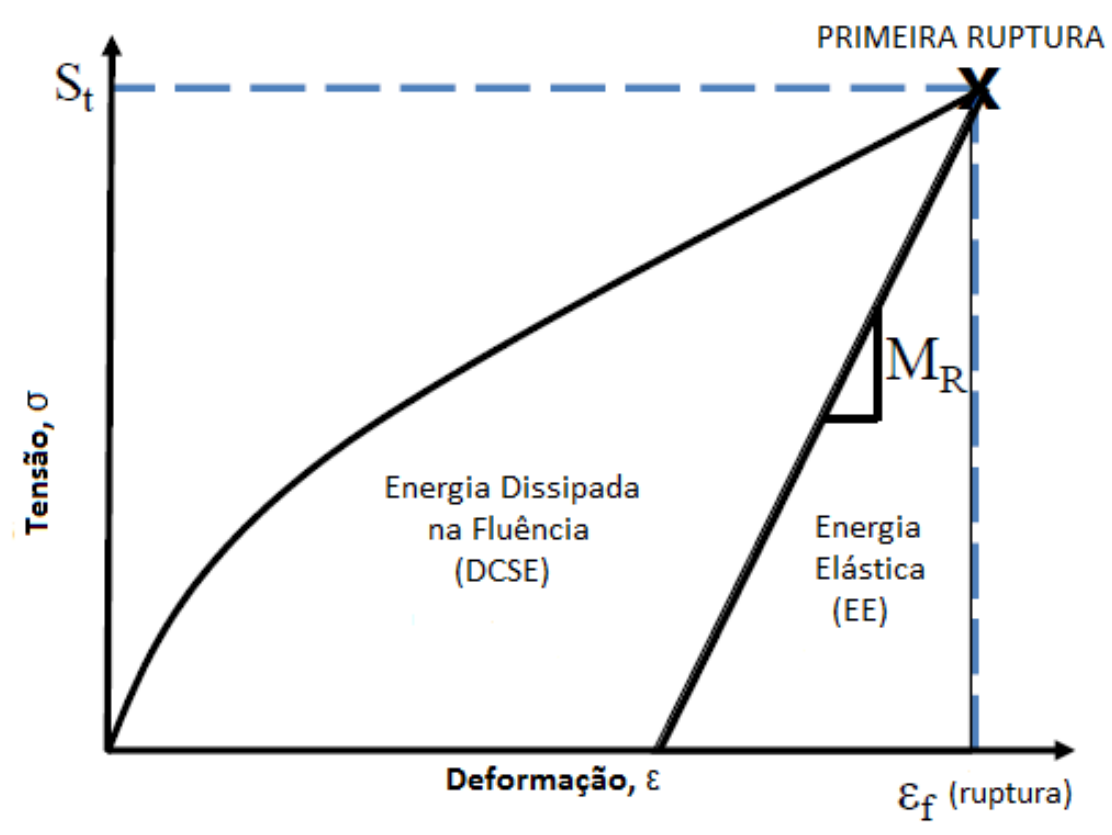

Figura 4.14 - Determinação dos limites inferior e superior para misturas asfálticas [Adaptado de Romeo (2008)]

\subsection{MATERIAIS}

Para a produção dos mástiques, foram utilizados dois tipos de ligantes asfálticos, um Cimento Asfáltico de Petróleo (CAP) 50/70 e um CAP 85/100, ambos fornecidos pela empresa Betunel, da cidade de Riberão Preto, SP. As características dos ligantes asfálticos estão indicadas nas Tabelas 2.8 e 2.9 do Capítulo 2.

Foram avaliados três diferentes fileres: cal hidratada, cimento Portland e pó de calcário. A determinação da energia de fratura foi realizada em amostras de mástique sem envelhecimento e envelhecidos no PAV. Devido à falta de informações e pesquisas sobre qual o método mais adequado para o envelhecimento de mástiques, o envelhecimento foi realizado de duas formas: (1) convencional, em que se aplica $100{ }^{\circ} \mathrm{C}$ por 20 horas; (2) modificado, em que se aplica $60^{\circ} \mathrm{C}$ por 100 horas, com a agitação por mistura da amostra a cada 20 horas.

As amostras submetidas ao ensaio de tração direta "dog-bone", com e sem envelhecimento foram compostas pelos fileres de cimento Portland e pó calcário, nas relações f/a de 0,6 e 1,2, enquanto 
que as compostas de fíler de cal hidratada apresentaram relações f/a de 0,3 e 0,6. Para maiores detalhes sobre a preparação do mástique, consultar o Capítulo 3.

\subsection{MÉTODOS}

A preparação da amostra consiste em aquecer o ligante ou o mástique asfáltico até que esteja liquido o suficiente para fluir adequadamente. Os moldes devem ser aquecidos aproximadamente na mesma temperatura do ligante asfáltico (Figura 4.15 (a)), por aproximadamente 3 minutos. Os moldes devem ser colocados em uma base para moldagem preparada com material antiaderente sendo que as paredes internas do molde também recebem o produto antiaderente, como glicerina, para que o desmolde seja realizado sem deformação do corpo de prova. A amostra deve ser colocada com excesso nos moldes, sendo deixada resfriar por, no mínimo 30 minutos. Ao final, apara-se a amostra com uma espátula aquecida, sendo que a configuração final deve ser de acordo com a Figura 4.15 (b).
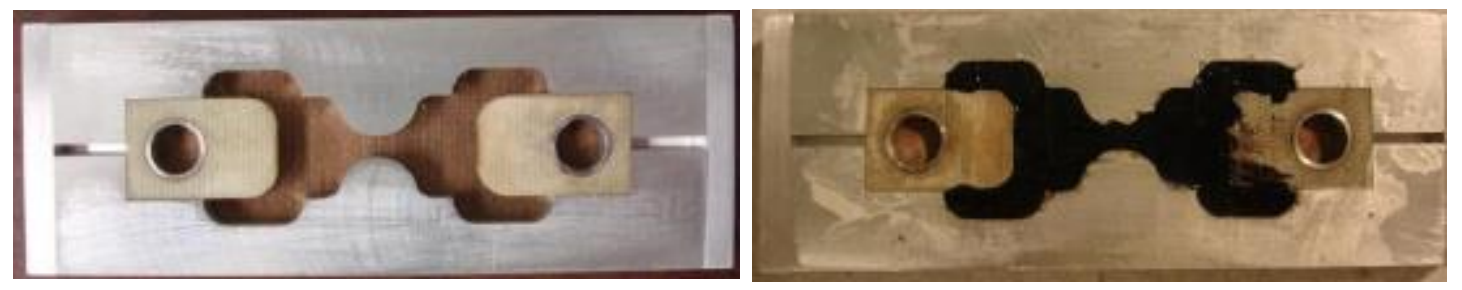

Figura 4.15 - (a) Molde para o corpo de prova do ensaio de tração direta "dog bone", (b) Configuração final do molde com o corpo de prova

Em seguida, os corpos de prova, ainda nos moldes, devem ser colocados na estufa de temperatura controlada, dentro da prensa universal. Esse conjunto deve permanecer na temperatura de ensaio durante, no mínimo, 4 horas, para estabilização da temperatura.

As medidas do carregamento do equipamento servo-hidráulico são muito sensíveis, devido aos baixos carregamentos necessários para romper o corpo de prova de ligante asfáltico, sendo necessária uma célula de carga pequena.

Deve-se retirar os corpos de prova dos moldes com cuidado, pois se o ligante asfáltico se deformar, mesmo que seja pouco, ou se a desmoldagem não for realizada de forma suave devido 
à falta de produto antiaderente em algum lugar no molde, a amostra deve ser descartada. A geometria e configuração final do corpo de prova estão mostrados na Figura 4.16.

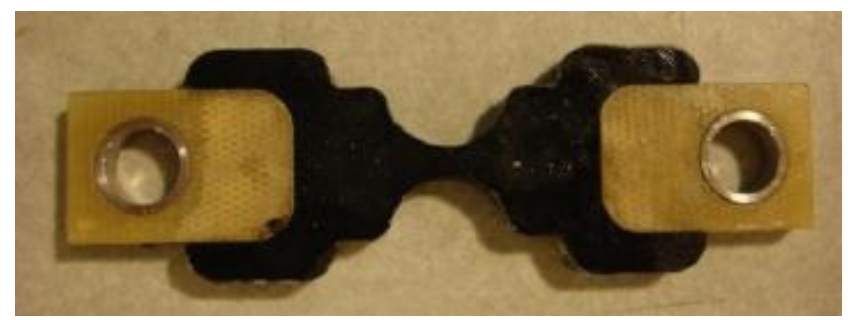

Figura 4.16 - Configuração final do corpo de prova do ensaio de tração direta "dog bone"

O corpo de prova deve ser colocado verticalmente e ficar livremente suspendido na prensa, pois qualquer pequeno desvio deformará o corpo de prova e o tornará inadequado para o ensaio. Colocar a abertura da parte superior do corpo de prova na prensa e inserir uma pequena barra de aço através dos orifícios. O dispositivo de aplicação da carga deve ser abaixado lentamente, colocando-se o orifício do corpo de prova suavemente na abertura do dispositivo do equipamento, inserindo-se, em seguida, uma barra de aço através dos orifícios das cabeças de carregamento, como mostrado na Figura 4.17 (a).
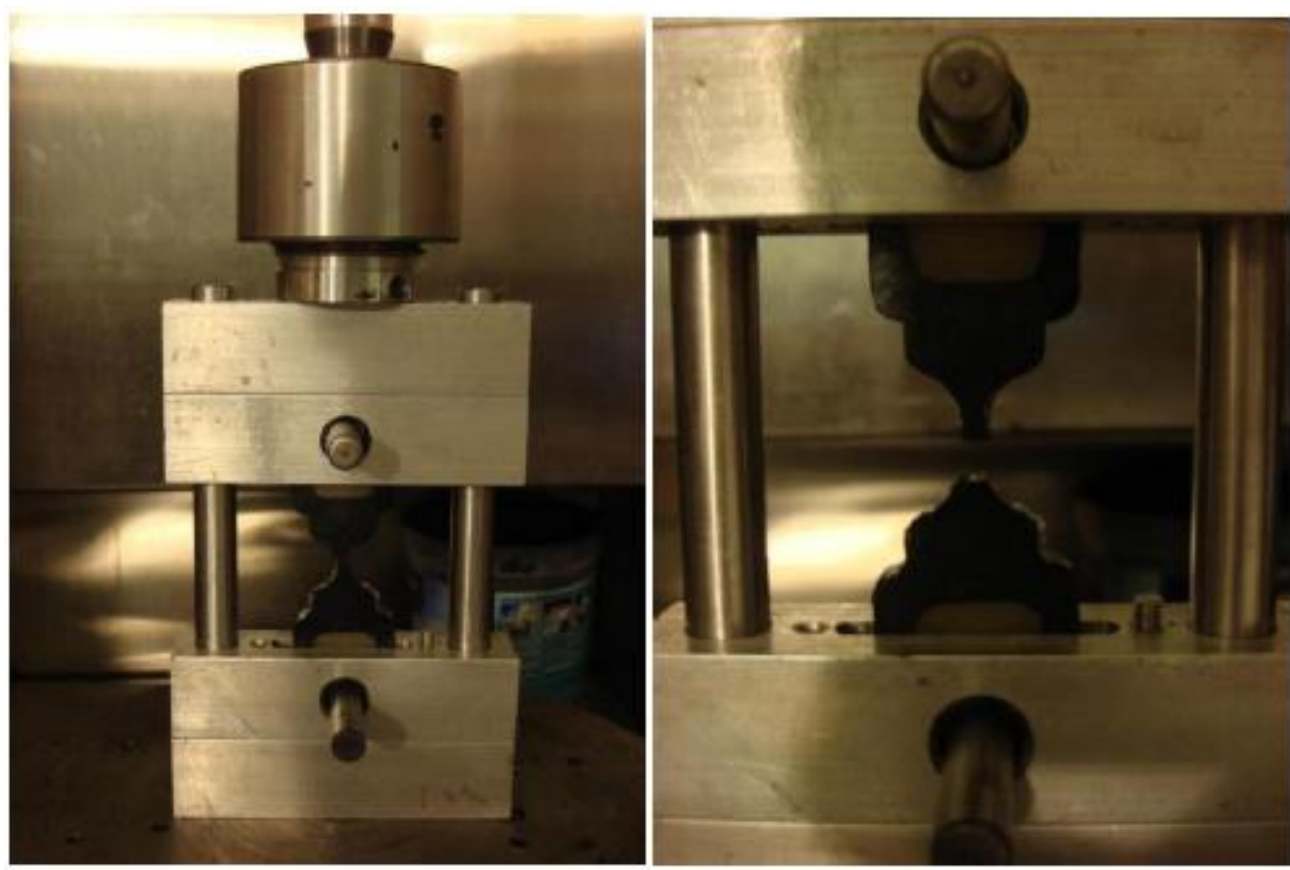

Figura 4.17 - Ensaio de tração direta "dog bone": (a) Disposição do corpo de prova no dispositivo de aplicação de carga, (b) Configuração final do corpo de prova, após a aplicação da carga 
Após o corpo de prova alcançar a temperatura desejada para o ensaio, escolher a taxa de carregamento, que depende muito do material a ser ensaiado. Foram realizados ensaios em ligantes asfálticos puros e modificados por polímero e SBS, com taxa de carregamento inicial para o ensaio de $500 \mathrm{~mm} / \mathrm{min}$. Para mástiques, a taxa de carregamento inicial mais adequada foi de $100 \mathrm{~mm} / \mathrm{min}$. A configuração final do corpo de prova após o ensaio de fadiga está mostrada na Figura 4.17 (b).

Se o ensaio resultar em uma curva tensão-deformação completa, então os resultados são aceitáveis e o ensaio deve ser repetido utilizando o mesmo procedimento para diferentes corpos de prova, em taxas de carregamento acima da já utilizada. Para cada taxa de carregamento, o ensaio deve ser realizado com duas réplicas, com diferença da densidade de energia de fratura entre duas réplicas devendo ser de, no máximo, 15\%. O valor médio deve ser tomado como a densidade de energia de fratura.

Quando a fratura prematura ocorre (ou seja, curva tensão-deformação incompleta), o ensaio deve ser realizado a taxas de carregamento menores, até que a fratura não seja prematura. Se a fratura prematura ainda ocorrer, a temperatura de ensaio deve ser mudada. Roque et al. (2012) indicam as características da curva tensão-deformação para cada tipo de ligante asfáltico ensaiado.

\subsubsection{Procedimento de Cálculo da Energia de Fratura}

Para o cálculo preciso da energia de fratura do ligante asfáltico, a força medida deve ser transformada em tensão média e o deslocamento medido deve ser transformado em deformação média na área da seção transversal central do corpo de prova, onde a fratura se inicia e se propaga. A Análise de Elementos Finitos Não-Linear pode ser utilizada para realizar esse procedimento de cálculo até certo nível de deformação, pois a fratura dúctil exibe um estreitamento devido à grande deformação até a ruptura, por isso, a Análise de Elementos Finitos não é adequada para simular esse tipo de ruptura precisamente, mesmo com a formulação para grandes deformações (ROQUE et al., 2012). 
Um novo procedimento de análise dos dados de ensaio foi desenvolvido por Roque et al. (2012) para ajustar a menor deformação da solução por elementos finitos, considerando a estricção que ocorre em grandes deformações. Os seguintes passos estão envolvidos na análise dos dados:

1. Transformação da força medida versus deslocamento para tensão média versus deformação média na área central da seção transversal do corpo de prova, utilizando Análise de Elementos Finitos não-linear e formulação para grandes deformações, (Figuras 4.18 e 4.19);

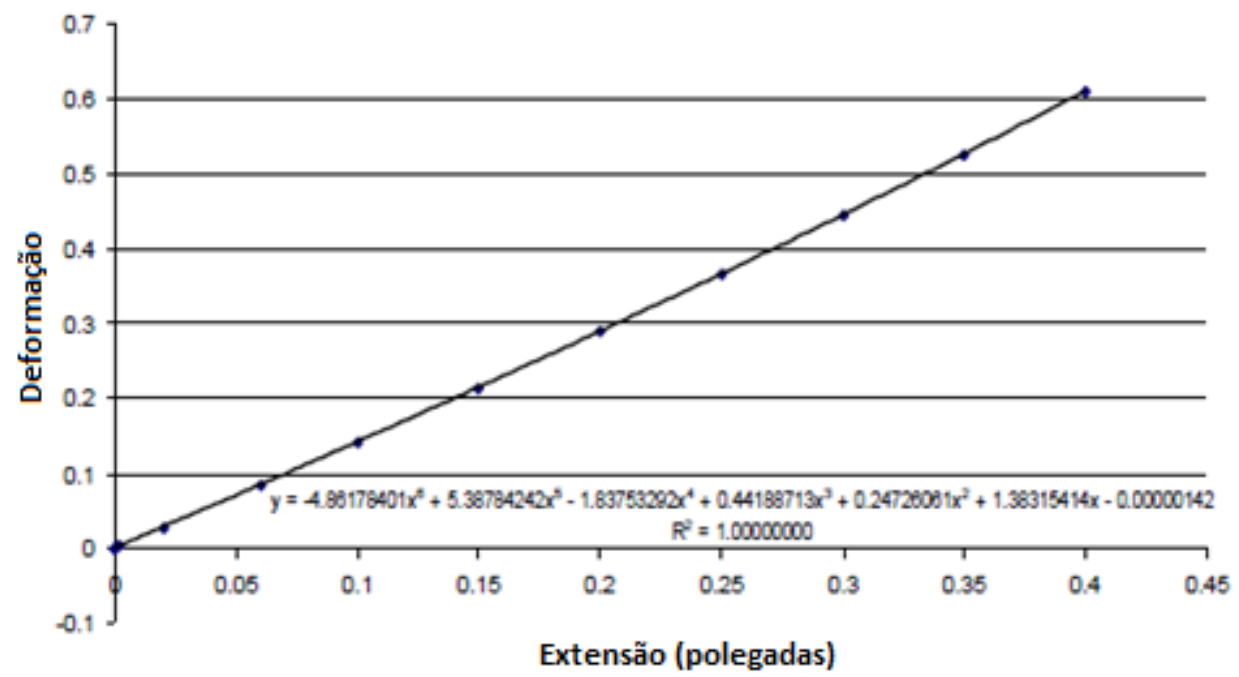

Figura 4.18 - Transformação de deslocamento em deformação no centro da seção transversal [Adaptado de Roque et al. (2012)] 


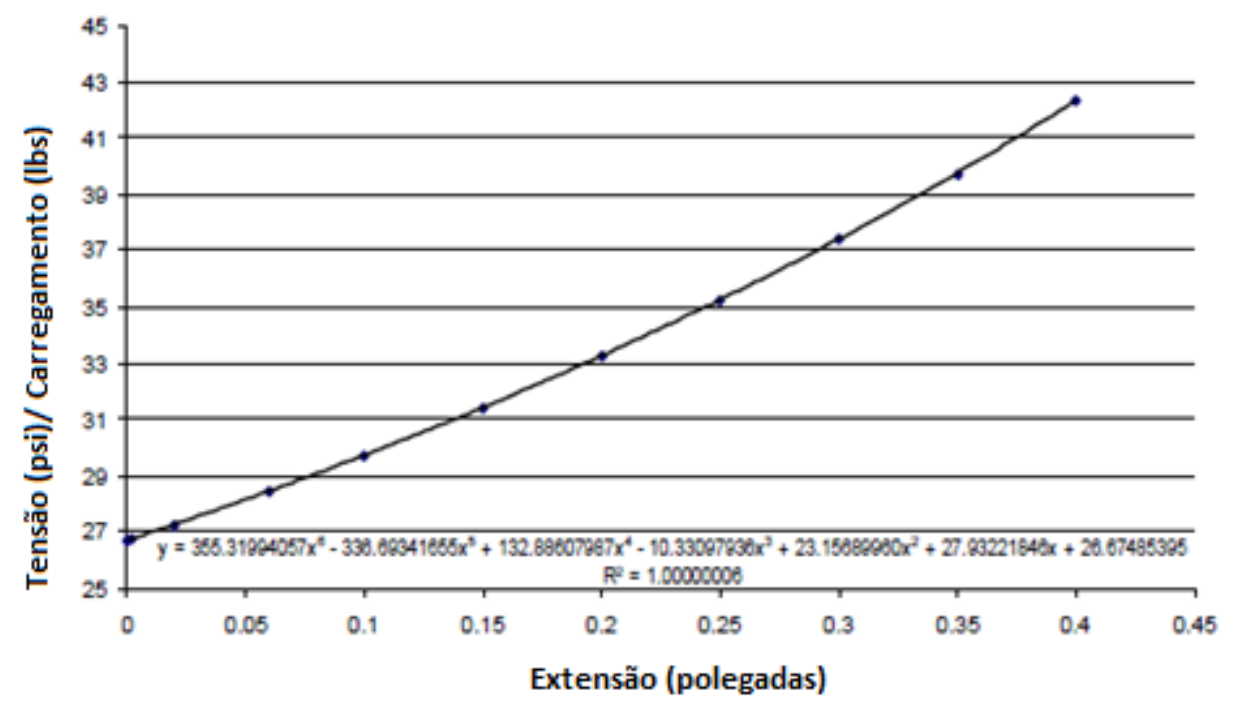

Figura 4.19 - Transformação de força em tensão no centro da seção transversal [Adaptado de Roque et al. (2012)]

2. Construção da curva tensão-deformação transformada pela Análise de Elementos Finitos do passo 1;

3. Até o primeiro pico de tensão, os resultados de tensão-deformação calculados pela análise de elementos finitos são precisos e utilizados como respostas de tensão e deformação;

4. Após o primeiro pico de tensão, na seção central do corpo de prova, o estreitamento se desenvolve, assim, a extensão da parte central do estreitamento é igual ao deslocamento medido. Então, após o primeiro pico de tensão, necessita-se apenas excluir a parte central do estreitamento para calcular a deformação. Baseado nas dimensões do corpo de prova e observações durante o ensaio, o comprimento inicial da seção sob o estreitamento é aproximadamente $3 \mathrm{~mm}$ (Figura 4.20 (a)), que se alonga para $\mathrm{L}_{1}$ no primeiro pico de tensão (Figura 4.20 (b)) e em seguida sofre a estreitamento (Figura 4.20 (c)). 


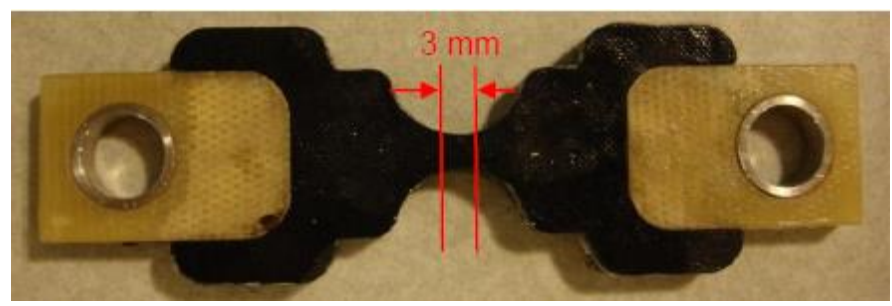

(a)

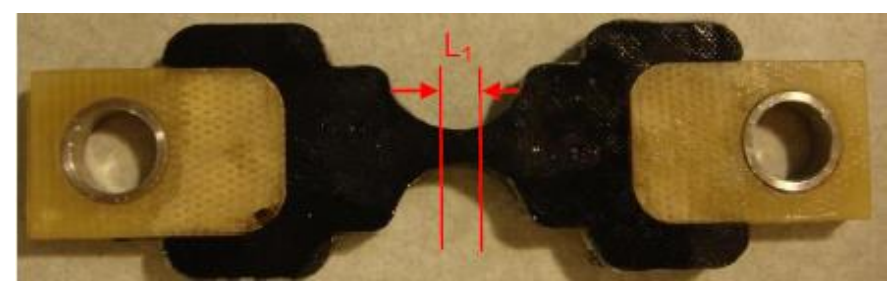

(b)

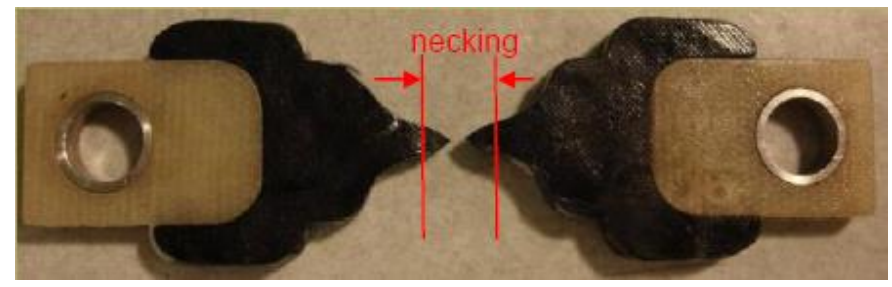

(c)

Figura 4.20 - Seção no estreitamento: (a) $3 \mathrm{~mm}$ antes do ensaio; (b) $3 \mathrm{~mm}$ sendo alongado para $L_{1}$ no primeiro pico de tensão; (c) $\mathrm{L}_{1}$ é alongado e sofre a estriç̧ão [Adaptado de Roque et al. (2012)]

No primeiro pico de tensão, a área da seção transversal $A_{1}$ e comprimento $L_{1}$ dos $3 \mathrm{~mm}$ iniciais da parte central pode ser obtido utilizando-se a Análise de Elementos Finitos nãolinear, com a formulação de grandes deformações (Figuras 4.21 e 4.22); 


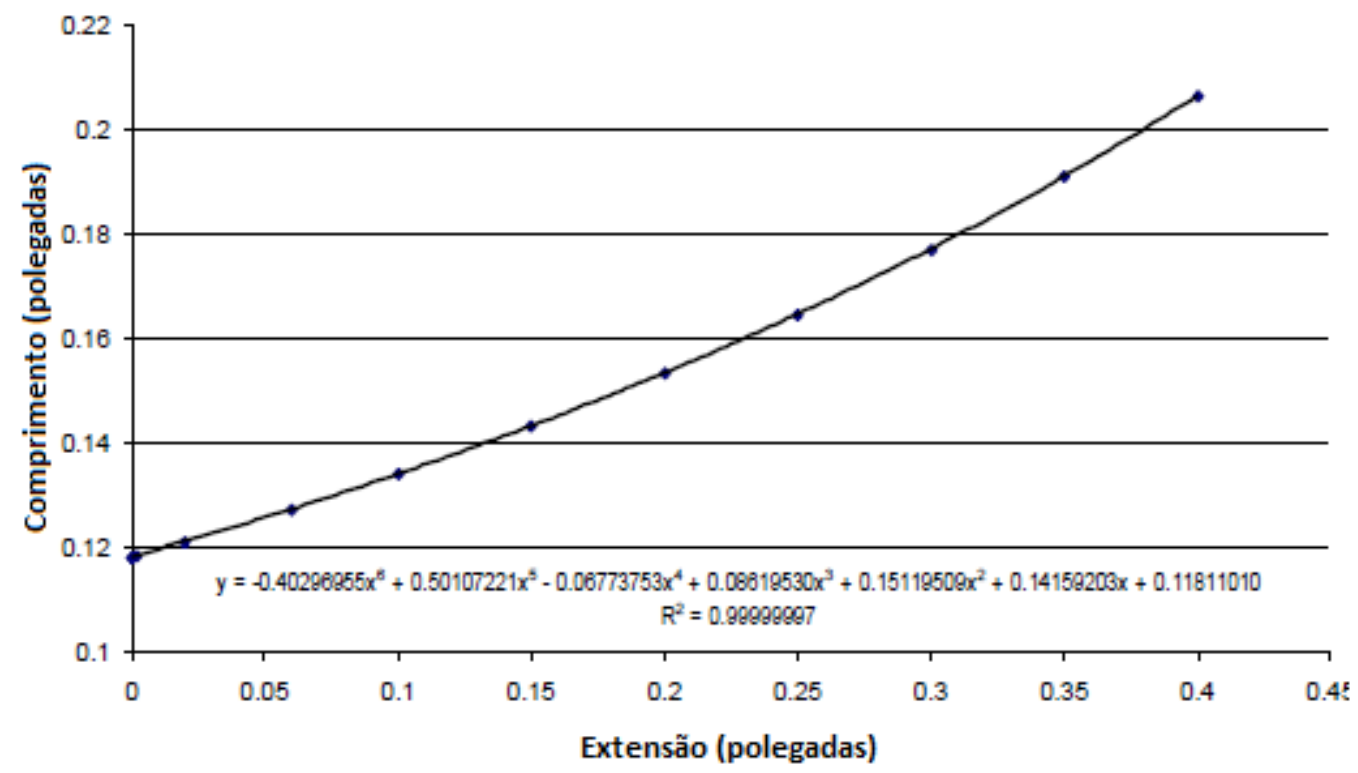

Figura 4.21 - Cálculo do comprimento $\mathrm{L}_{1}$ da parte central de $3 \mathrm{~mm}$ no primeiro pico de tensão [Adaptado de Roque et al. (2012)]

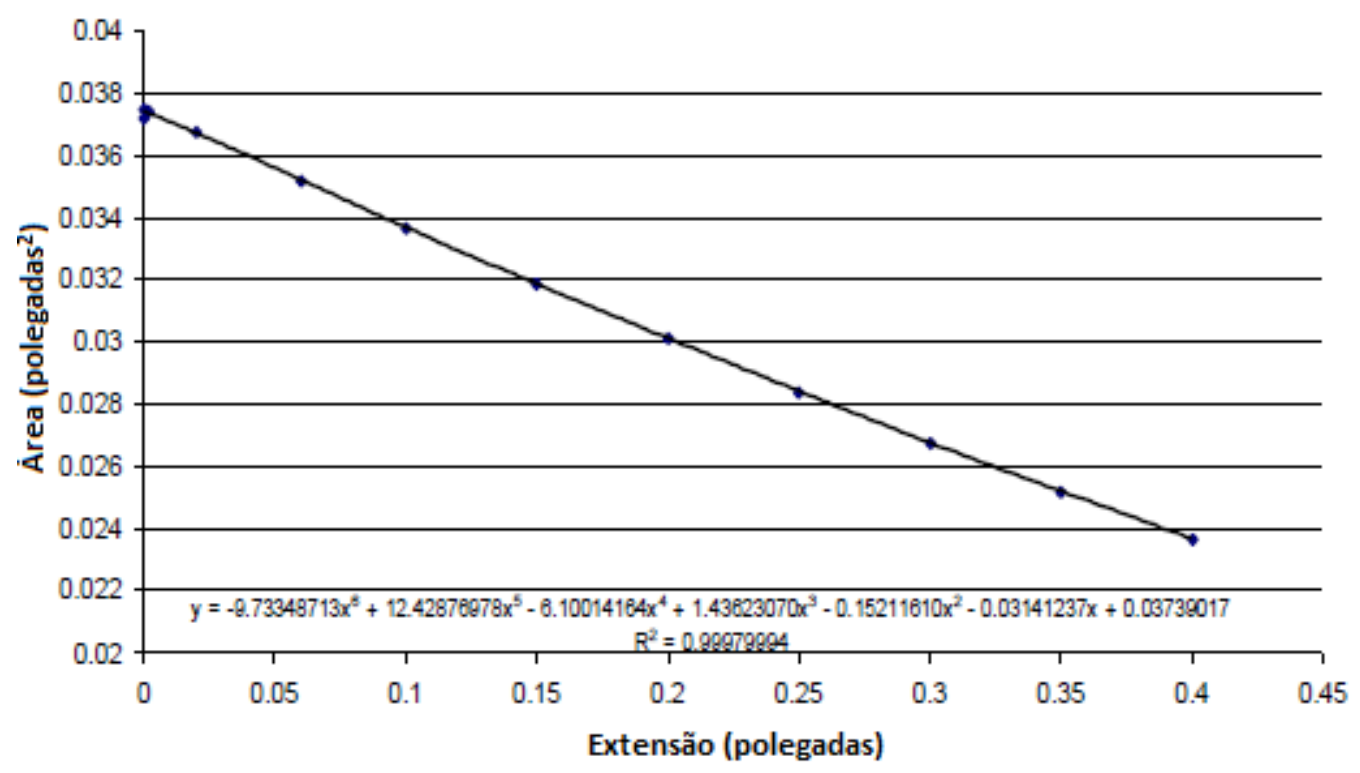

Figura 4.22 - Cálculo da área central da seção transversal $A_{1}$ no primeiro pico de tensão [Adaptado de Roque et al. (2012)]

Após, é retirada a parte central e calcula-se sua deformação após o primeiro pico de tensão (Figura 4.23). 


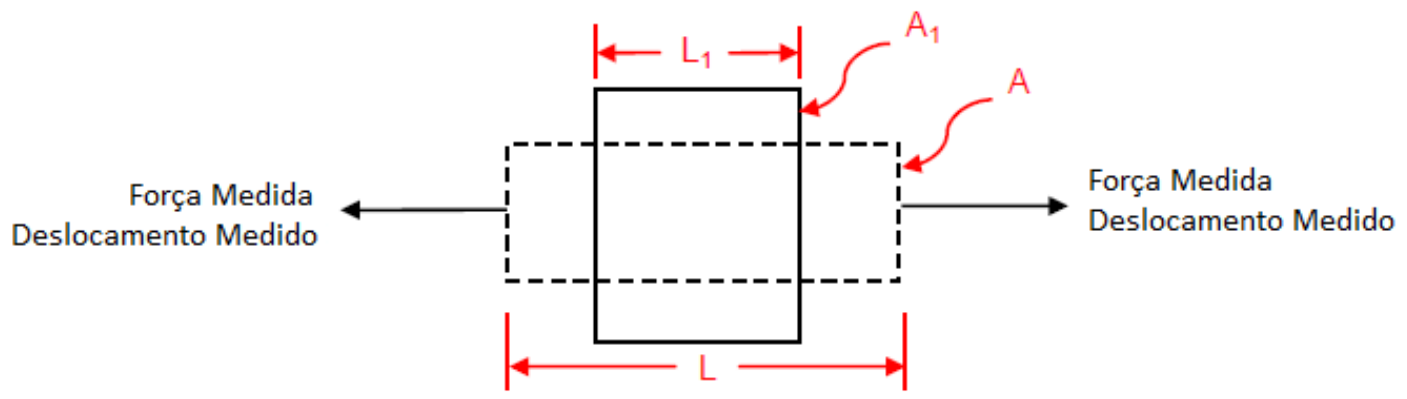

Figura 4.23 - Deformação da parte central após o primeiro pico de tensão [Adaptado de Roque et al. (2012)]

Como o coeficiente de Poisson do ligante asfáltico é geralmente muito alto, podemos assumir que o volume da parte central é constante durante a extensão. Então, obtém-se a Equação 4.12 em que se calcula a área da seção transversal a após o primeiro pico de tensão.

$$
A \cdot L=A_{1} \cdot L_{1} \Rightarrow A=A_{1} \cdot \frac{L_{1}}{L}
$$

em que: $\quad A_{1}$ : área da seção transversal central no primeiro pico de tensão;

A: área da seção transversal central após o primeiro pico de tensão;

$\mathrm{L}_{1}$ : comprimento inicial de $3 \mathrm{~mm}$ da parte central no primeiro pico de tensão;

L: comprimento inicial dos $3 \mathrm{~mm}$ da parte central após o primeiro pico de tensão.

Agora, pode-se calcular a tensão após o primeiro pico de tensão (Equação 4.13).

$$
\sigma=\frac{F}{A}=\frac{F}{A_{1} \cdot \frac{L_{1}}{L}}
$$

em que: $\quad \sigma$ : tensão média na área da seção transversal central após o primeiro pico de tensão;

F: força medida. 
Com a formulação de grandes deformações (Equação 4.14), calcula-se a deformação após o primeiro pico de tensão.

$$
\varepsilon=\ln \frac{L}{L_{1}}
$$

em que: $\quad \varepsilon$ : deformação após o primeiro pico de tensão.

Como mostrado na Figura 4.24, após a aplicação desse método de cálculo o ponto inicial de trincamento fica bem claro. A energia após o ponto de fratura inicial não deve ser considerada no cálculo da energia de fratura, pois é a energia necessária para separar o corpo de prova ao meio, e não a energia necessária para iniciar o trincamento no ligante asfáltico. A energia de fratura deve ser calculada desde o começo da curva tensão-deformação até o último pico, que é o ponto de fratura.
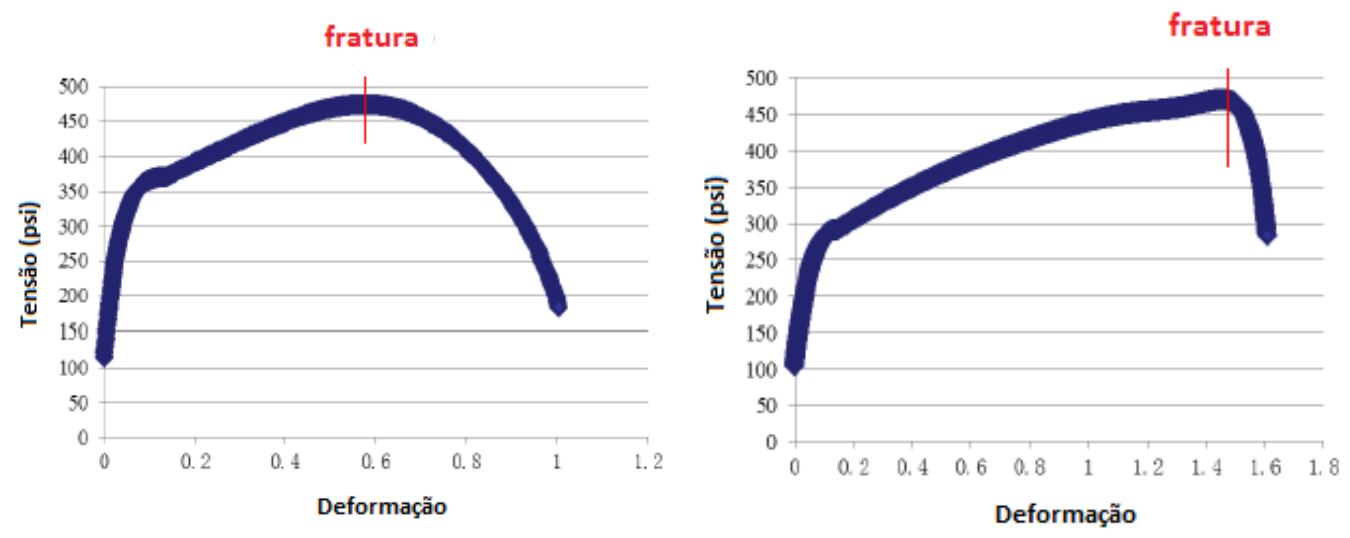

Figura 4.24 - Curva tensão-deformação pelo método de cálculo proposto por Roque et al. (2012)

Alguns pesquisadores calculam a energia de fratura com base na área total sob a curva tensãodeformação, do começo ao fim. Teoricamente, pode estar correto, porém, no ensaio desenvolvido na Universidade da Flórida, isso pode não ser adequado. Durante a extensão até a ruptura, fraturas localizadas ocorrem primeiro no centro da seção transversal, antes da ruptura completa do corpo de prova ou sua divisão em dois pedaços. Assim, a energia além do ponto de fratura, que geralmente ocorre no pico de tensão no corpo de prova de tração direta, é a energia associada à quebra da área transversal restante do corpo de prova, após a fratura já ter ocorrido. Assim, não 
tem sentido incluir a energia além da fratura como parte da energia necessária para induzir a fratura (ou seja, a energia de fratura).

\subsection{APRESENTAÇÃO E ANÁLISE DOS RESULTADOS}

Para que o resultado de um ensaio seja aceitável, há uma combinação ótima de uma faixa de temperatura e taxa de carregamento para se obter a energia de fratura consistentemente, ou seja, existem condições para que o tipo de ruptura seja satisfatório, ou seja, para cada tipo de ligante asfáltico há uma taxa de carregamento apropriada para diferentes temperaturas.

Quando ocorre a ruptura prematura, a energia de fratura correspondente é muito pequena (perto de zero). Adicionalmente à observação visual, a ruptura prematura pode ser identificada pela ocorrência de uma curva tensão-deformação incompleta (ROQUE et al., 2012). Também pode ocorrer a ruptura após uma deformação muito elevada do corpo de prova, condição não adequada para o ensaio, pois a análise de elementos finitos não-linear pode ser utilizada até certo nível de deformação. Fraturas dúcteis exibem o estreitamento no centro do corpo de prova, devido à grande deformação na ruptura, e a análise de elementos finitos não é adequada para simular esse tipo de ruptura, mesmo com a utilização da formulação de grandes deformações (ROQUE et al., 2012).

A Figura 4.25 (a) e (b) mostram exemplo de fratura apropriada e fratura prematura do ensaio de energia de fratura, em que esse tipo de ruptura não é adequado para o cálculo da propriedade. 


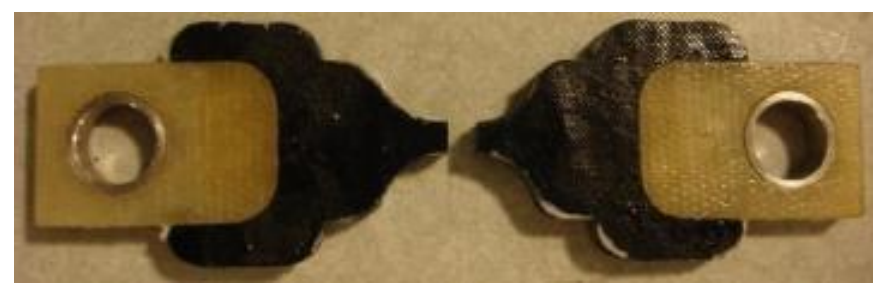

(a)

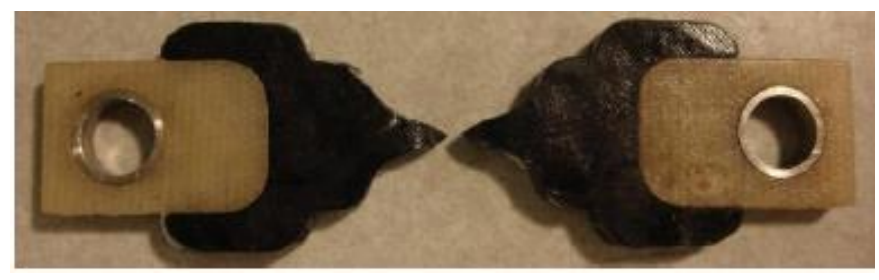

(b)

Figura 4.25 - Exemplo de fratura do corpo de prova no ensaio de tração direta "dog bone": (a) fratura apropriada; (b) fratura prematura

\subsubsection{Resultados da Energia de Fratura para os Ligantes Asfálticos Puros}

Primeiramente, o ensaio para determinação da energia de fratura foi realizado para os ligantes asfálticos puros, o CAP 50/70 e o CAP 85/100. Como já foi apresentado por Roque et al. (2012), a energia de fratura é independente da taxa de carregamento e da temperatura, e recomendando-se uma temperatura inicial de ensaio de $15{ }^{\circ} \mathrm{C}$. Com o ligante asfáltico utilizado nesta pesquisa apresentou ruptura dúctil, ou seja, um alongamento muito grande na seção transversal central, o que leva à determinação incorreta da energia de fratura. Os ensaios foram realizados a $10{ }^{\circ} \mathrm{C}$. A Figura 4.26 apresenta os valores de energia de fratura para várias taxas de carregamento e temperatura de ensaio de $10^{\circ} \mathrm{C}$. 


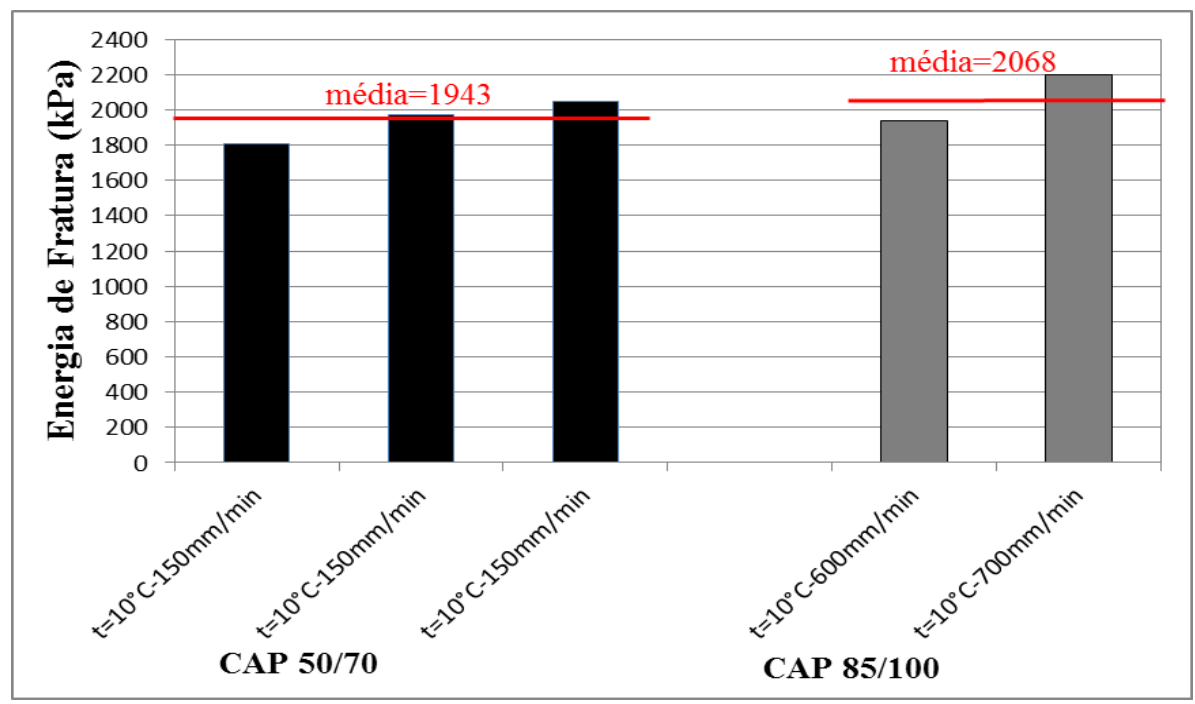

Figura 4.26 - Energia de Fratura para ligantes asfálticos puros, CAP 50/70 e CAP 85/100, para várias taxas de carregamento e temperatura de ensaio de $10{ }^{\circ} \mathrm{C}$

Em seguida, foi realizado o ensaio em amostras de ligantes asfálticos puros submetidos ao envelhecimento no PAV, com o procedimento usual, ou seja, na temperatura de $100{ }^{\circ} \mathrm{C}$ por 20 horas. Os resultados do ensaio, realizado em várias taxas de carregamento e para a temperatura de ensaio de $15^{\circ} \mathrm{C}$, estão apresentados na Figura 4.27 .

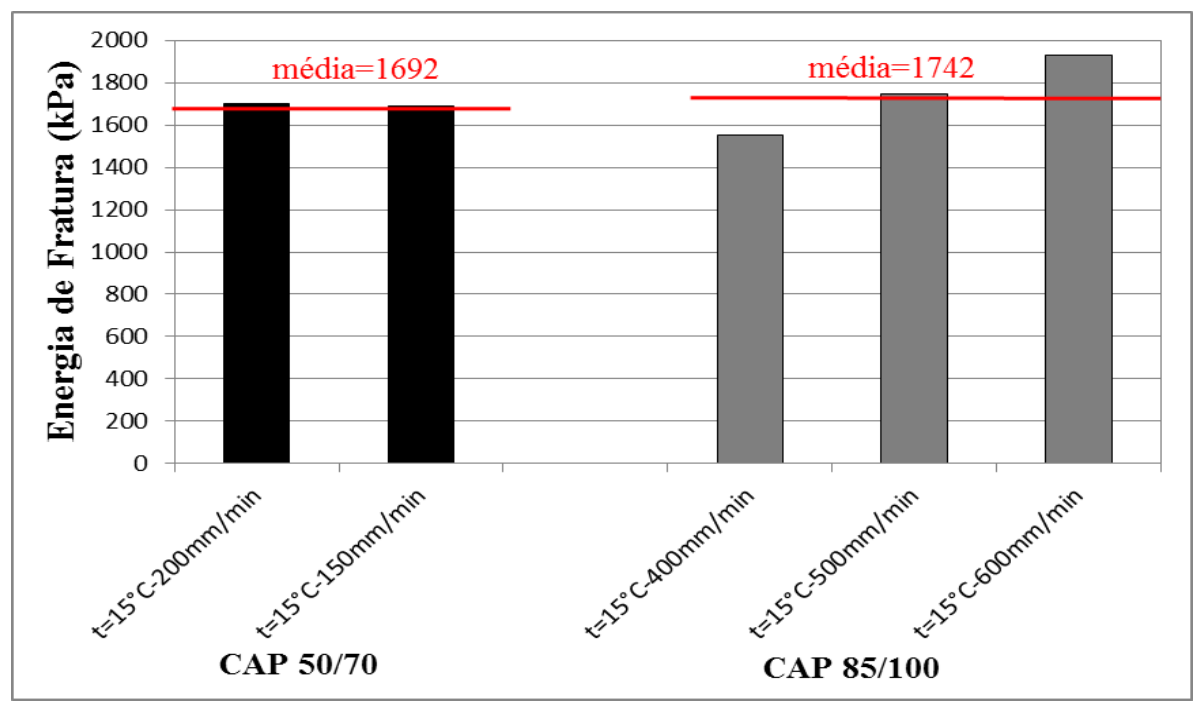

Figura 4.27 - Energia de Fratura para ligantes asfálticos puros, CAP 50/70 e CAP 85/100 envelhecidos no PAV, para várias taxas de carregamento e temperatura de ensaio de $15^{\circ} \mathrm{C}$ 
Finalmente, as amostras dos ligantes asfálticos puros, envelhecidos no PAV modificado $\left(60{ }^{\circ} \mathrm{C}\right.$ por 100 horas) foram submetidas ao ensaio, realizado em várias taxas de carregamento e para a temperatura de ensaio de $15{ }^{\circ} \mathrm{C}$ (Figura 4.28).

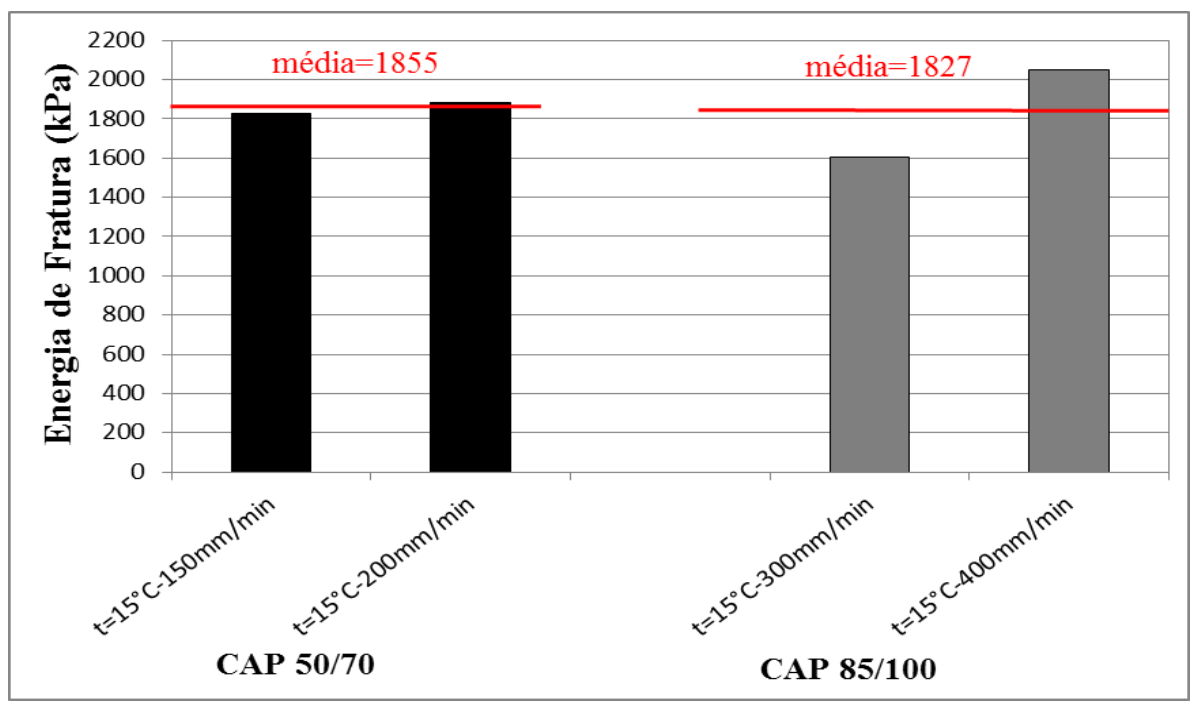

Figura 4.28 - Energia de Fratura para ligantes asfálticos puros CAP 50/70 e CAP 85/100 envelhecidos no PAV- $100 \mathrm{~h}-60^{\circ} \mathrm{C}$, para várias taxas de carregamento e temperatura de ensaio de $15^{\circ} \mathrm{C}$

As Figuras 4.29 e 4.30 mostram a curva tensão-deformação para os ligantes asfálticos CAP 50/70 e CAP 85/100, respectivamente. Essas curvas tem o mesmo formato que as curvas de ligantes asfálticos não-modificados, segundo Roque et al. (2012), pois exibem apenas um pico de tensão, seguido de uma queda acentuada na curva tensão-deformação. 


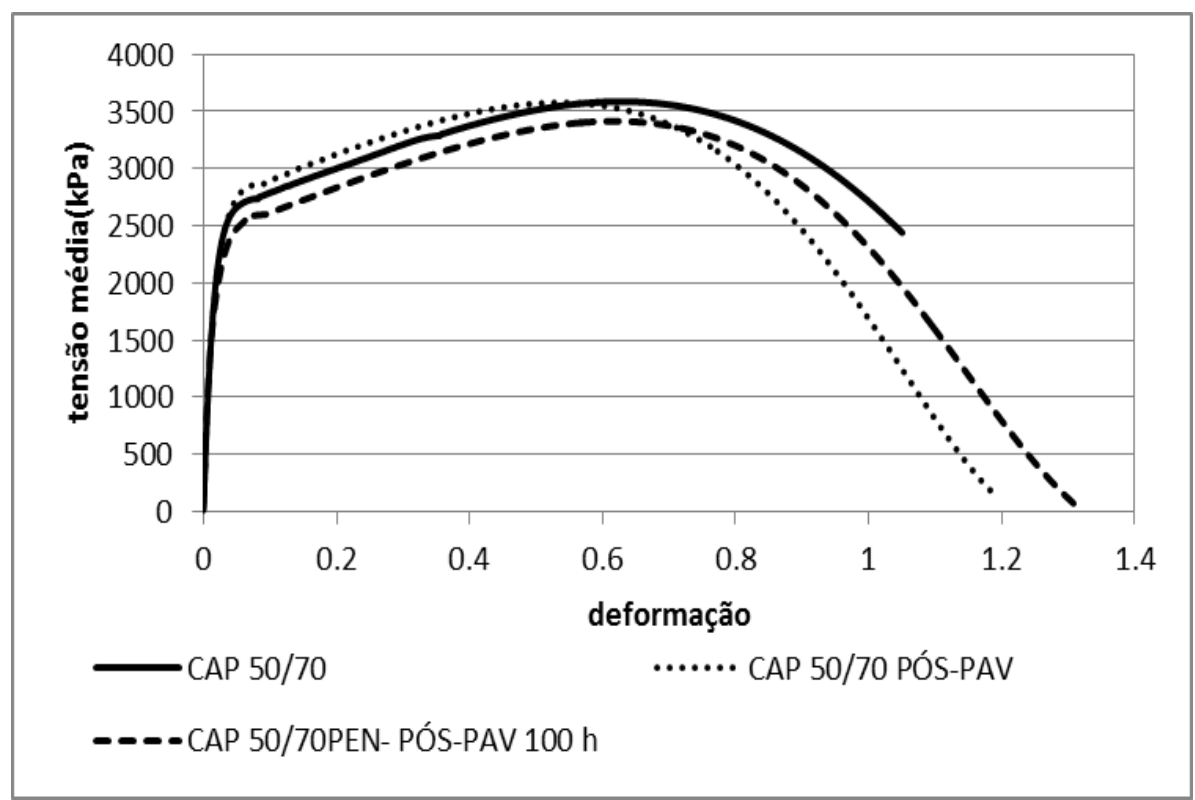

Figura 4.29 - Curva tensão-deformação para o ligante asfáltico CAP 50/70

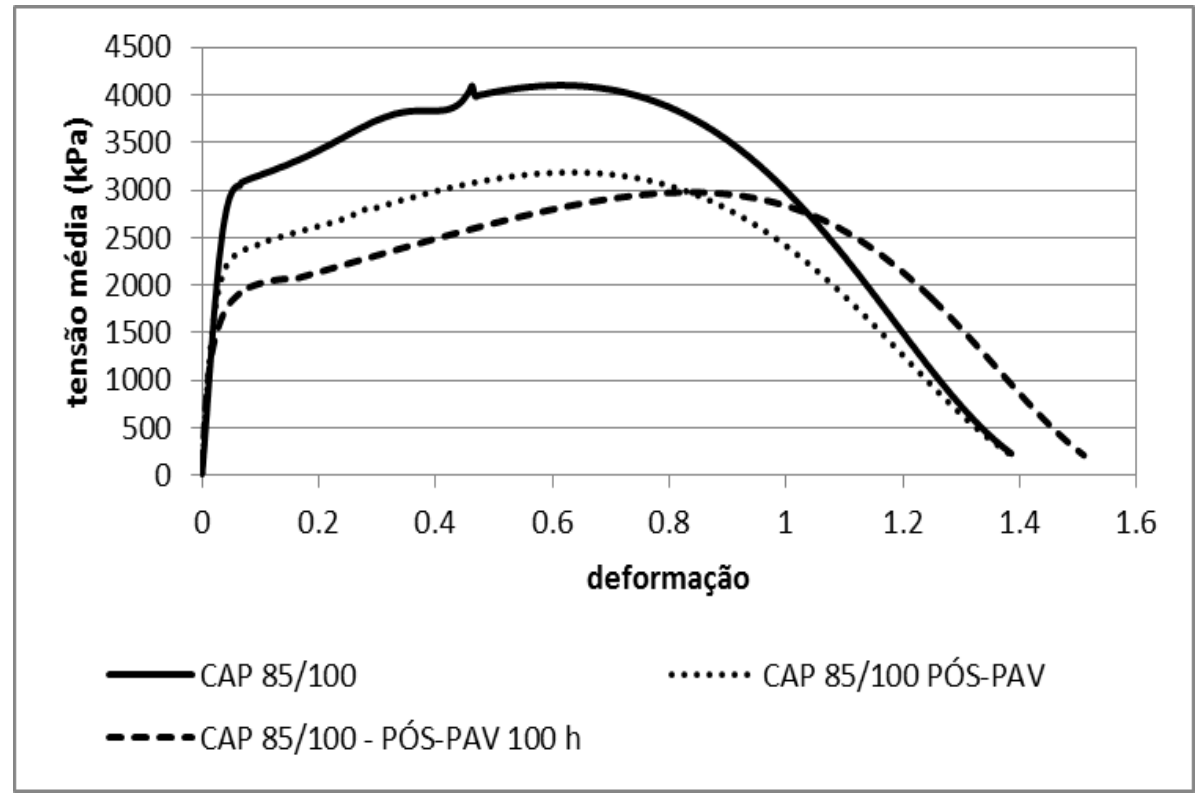

Figura 4.30 - Curva tensão-deformação para o ligante asfáltico CAP 85/100 


\subsubsection{Resultados da Energia de Fratura para Mástiques Compostos com Cimento}

\section{Portland}

Os resultados de Roque et al. (2012) são referentes apenas a ligantes asfálticos puros e modificados, porém, para mástiques asfálticos, foi necessário validar se a energia de fratura é independente da temperatura e da taxa de carregamento.

Primeiramente, foi realizado o ensaio para os mástique compostos com o cimento Portland $(\mathrm{f} / \mathrm{a}=0,6$ e 1,2$)$. Foram utilizadas duas temperaturas $\left(15\right.$ e $\left.20^{\circ} \mathrm{C}\right)$ e várias taxas de carregamento. Para os mástique compostos pelo CAP 50/70, os resultados estão apresentados na Figura 4.31, e para os mástiques com o CAP 85/100, na Figura 4.32.

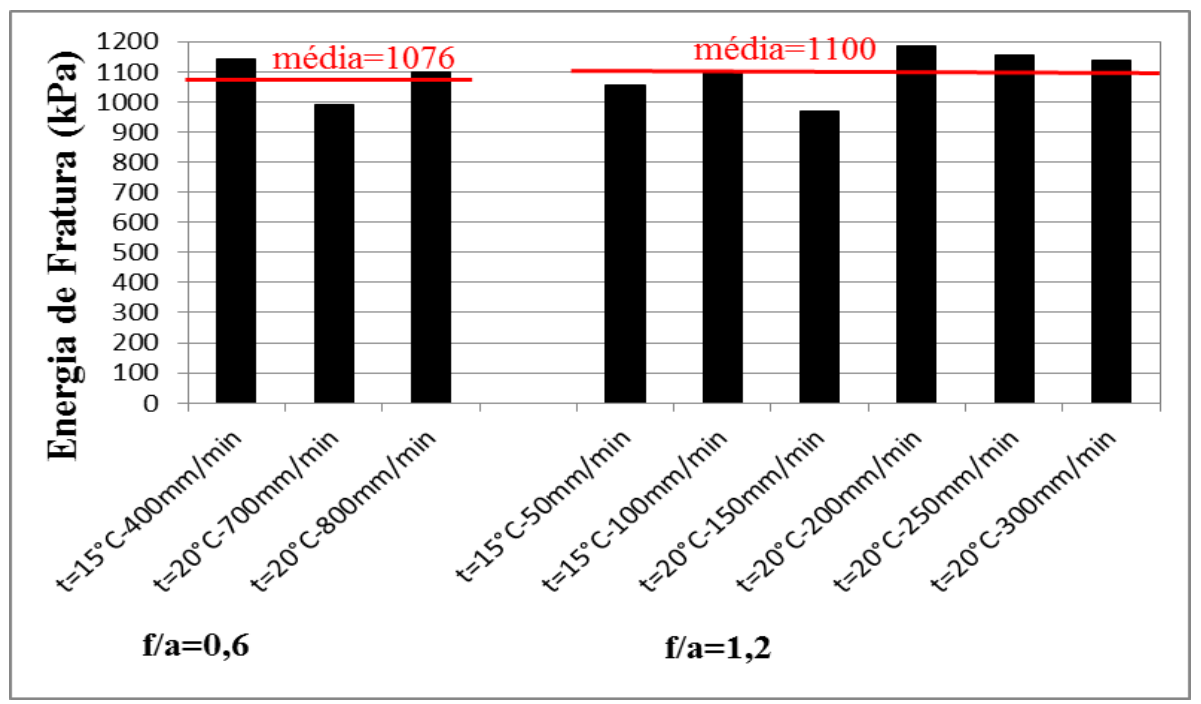

Figura 4.31 - Energia de Fratura para mástiques compostos com fíler de cimento Portland e CAP 50/70, para várias temperaturas de ensaio e taxas de carregamento 


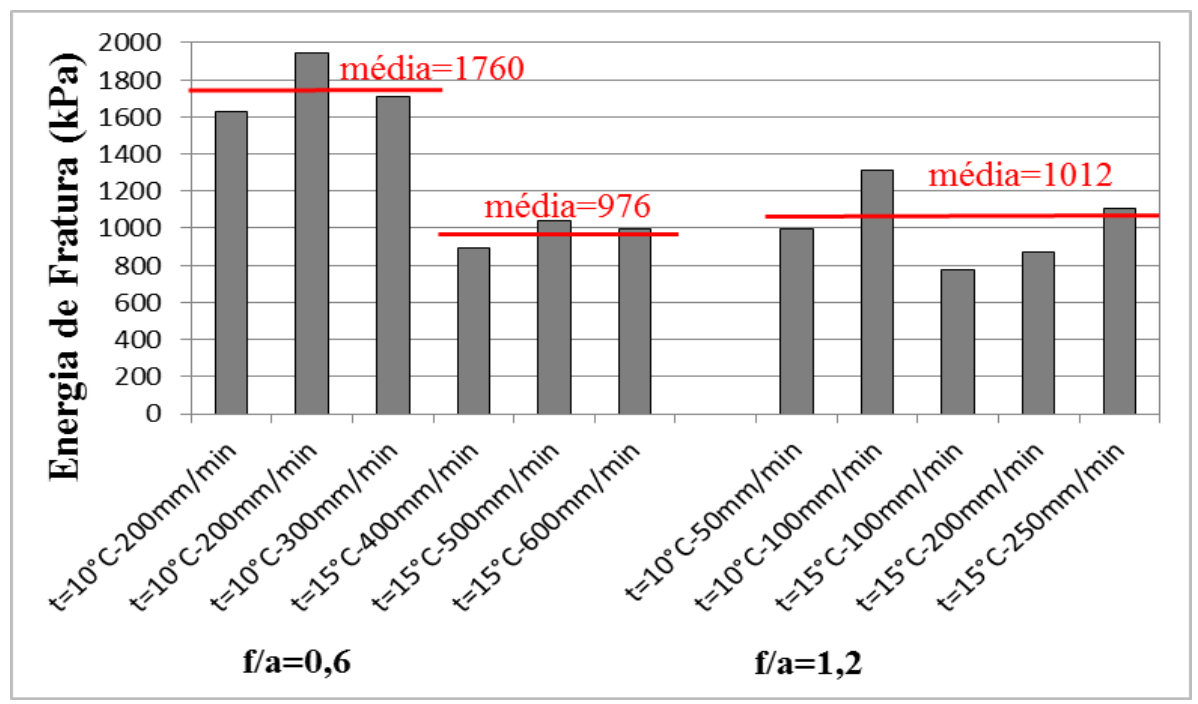

Figura 4.32 - Energia de Fratura para mástiques compostos com fíler de cimento Portland e CAP $85 / 100$, para várias temperaturas de ensaio e taxas de carregamento

Em seguida, o ensaio foi realizado em amostras de mástiques, compostos pelo fíler de cimento Portland, submetidos ao envelhecimento na Estufa de Vaso Pressurizado (PAV). Os resultados de energia de fratura para os mástique compostos pelo CAP 50/70 estão apresentados na Figura 4.33 e para os compostos pelo CAP 85/100 na Figura 4.34.

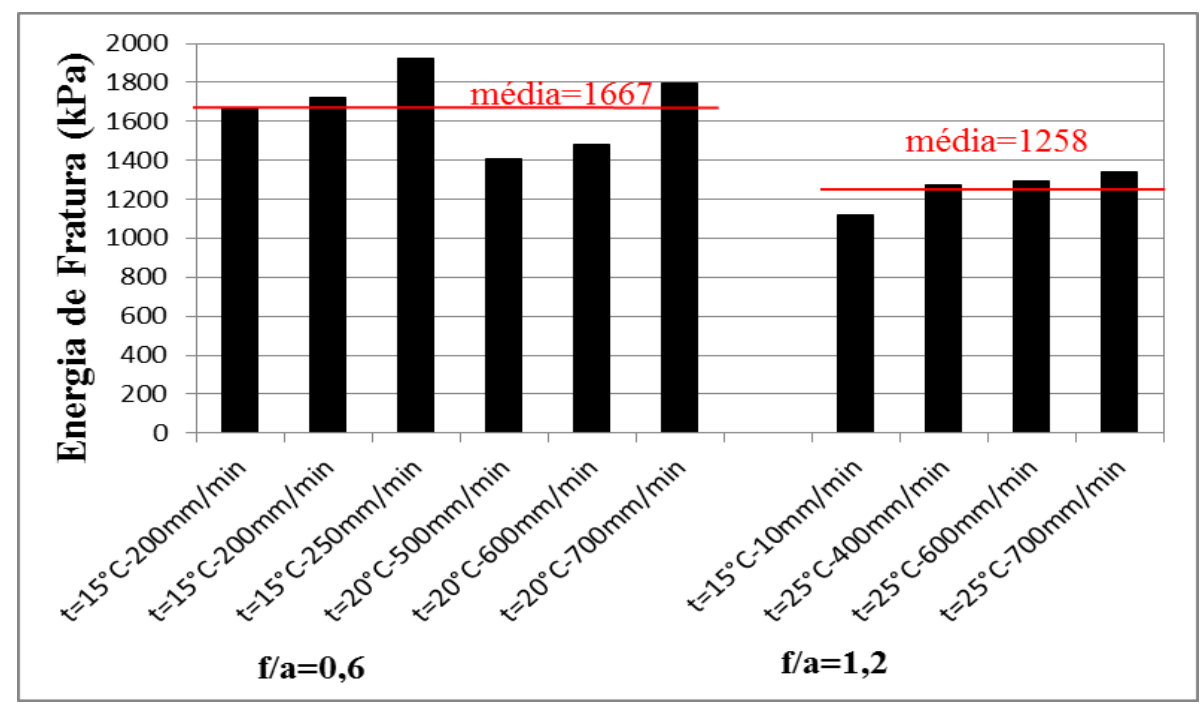

Figura 4.33 - Energia de Fratura para mástiques envelhecidos no PAV, compostos com fíler de cimento Portland e CAP 50/70, para várias temperaturas de ensaio e taxas de carregamento 


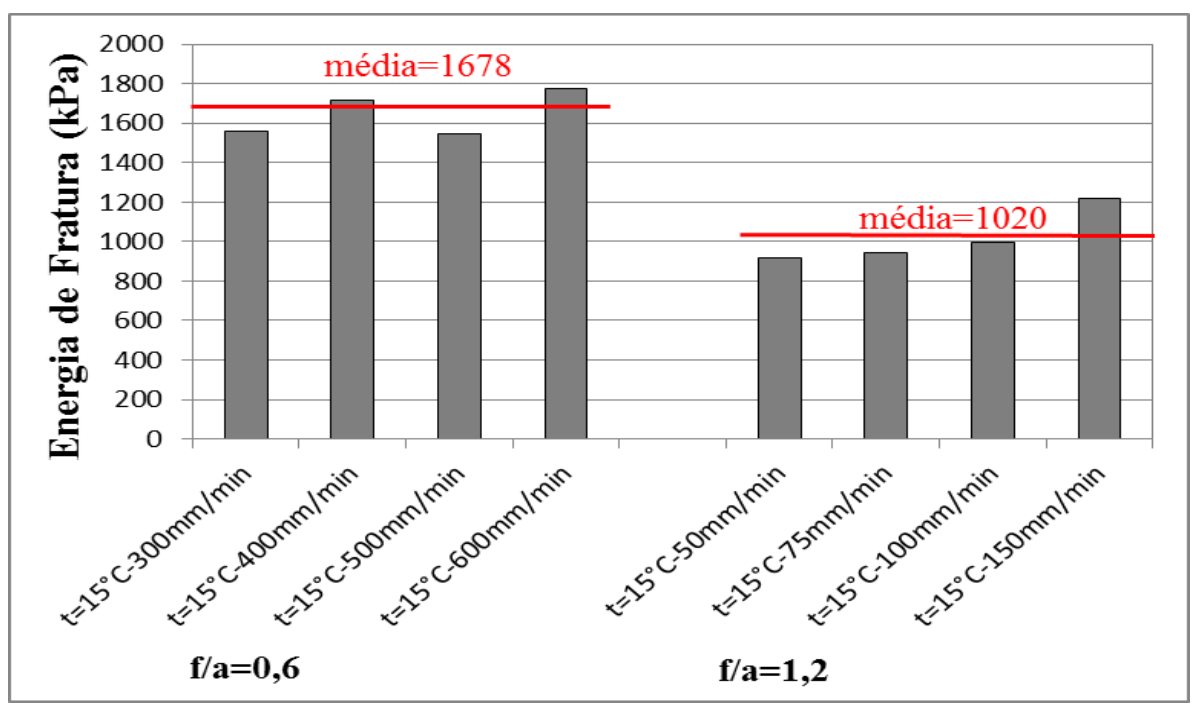

Figura 4.34 - Energia de Fratura para mástiques envelhecidos no PAV compostos com fíler de cimento Portland e CAP 85/100, para várias temperaturas de ensaio e taxas de carregamento

Também foram realizados ensaios de energia de fratura em mástiques compostos pelo fíler de cimento Portland, envelhecidos no PAV por 100 horas, na temperatura de $60{ }^{\circ} \mathrm{C}$. Para os mástique compostos pelo CAP 50/70, os resultados estão apresentados na Figura 4.35, e para os mástiques com o CAP 85/100, na Figura 4.36.

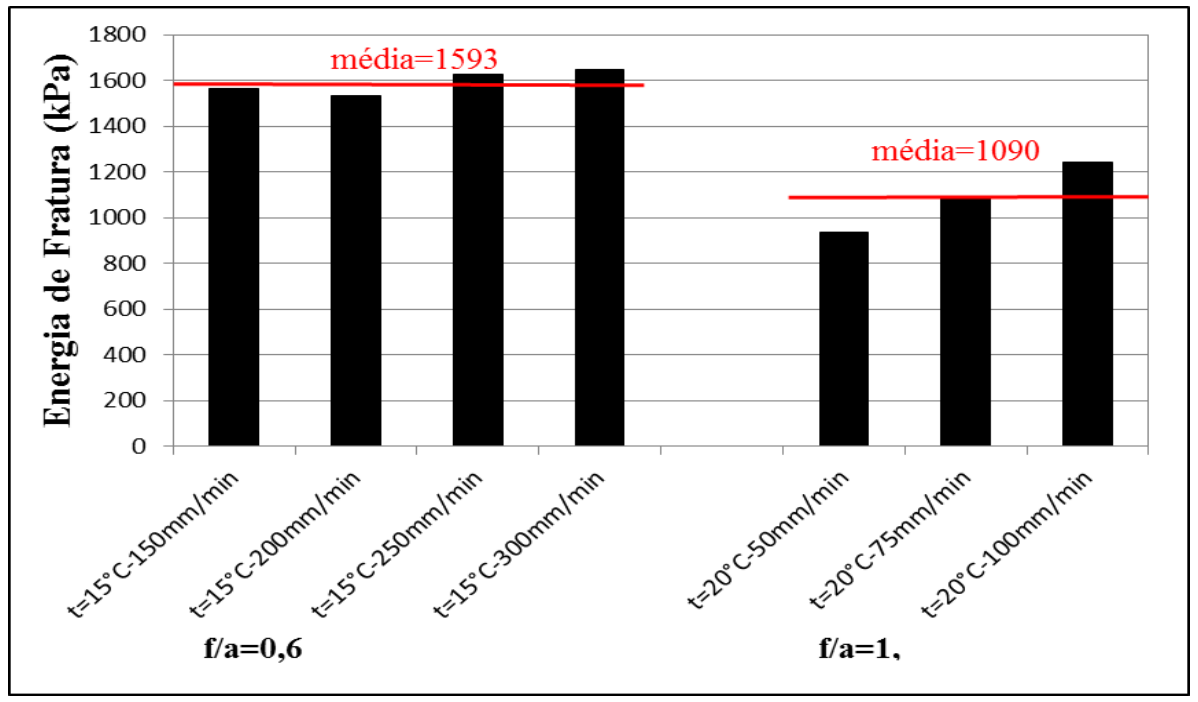

Figura 4.35 - Energia de Fratura para mástiques envelhecidos no PAV-100h- $60^{\circ} \mathrm{C}$, compostos com fíler de cimento Portland e CAP 50/70, para várias temperaturas de ensaio e taxas de carregamento 


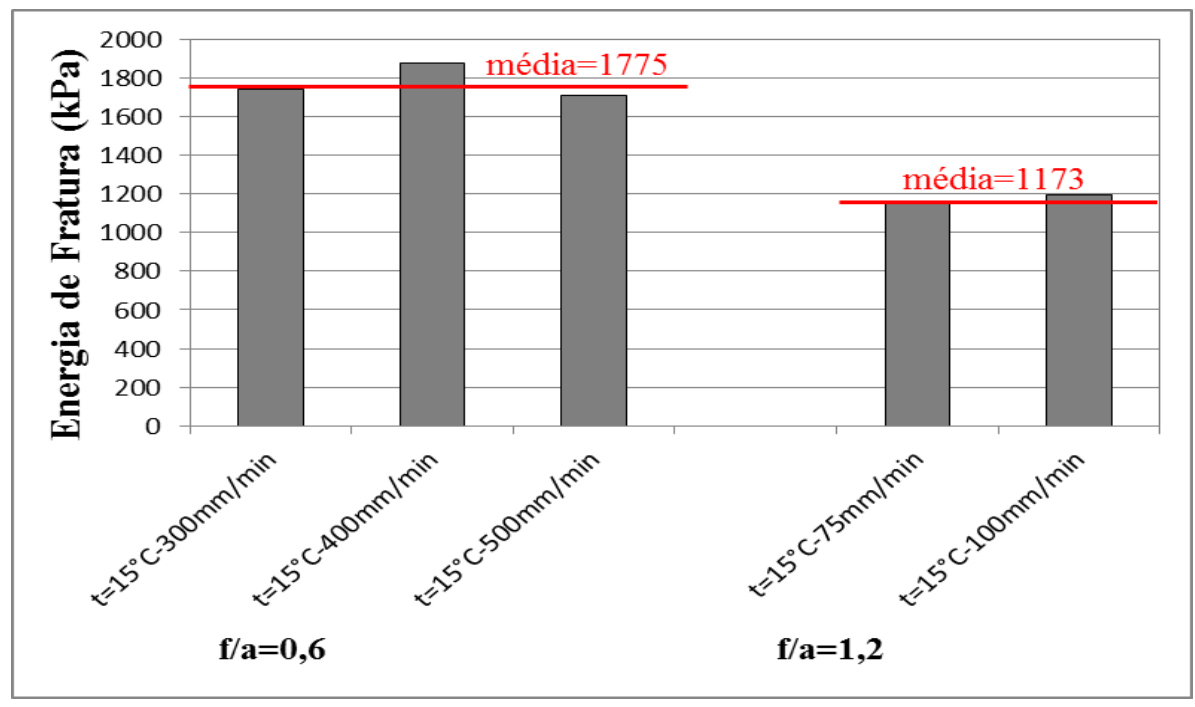

Figura 4.36 - Energia de Fratura para mástiques envelhecidos no PAV-100h-60 $\mathrm{C}$, compostos com fíler de cimento Portland e CAP 85/100, para várias temperaturas de ensaio e taxas de carregamento

As Figuras 4.37 e 4.38 mostram a curva tensão-deformação para os mástiques compostos pelo cimento Portland e os ligantes asfálticos CAP 50/70 e CAP 85/100. Essas curvas tem o mesmo formato que as curvas de ligantes asfálticos puros não-modificados e sem envelhecimento, com apenas um pico de tensão seguido de um queda relativamente acentuada da curva tensãodeformação.

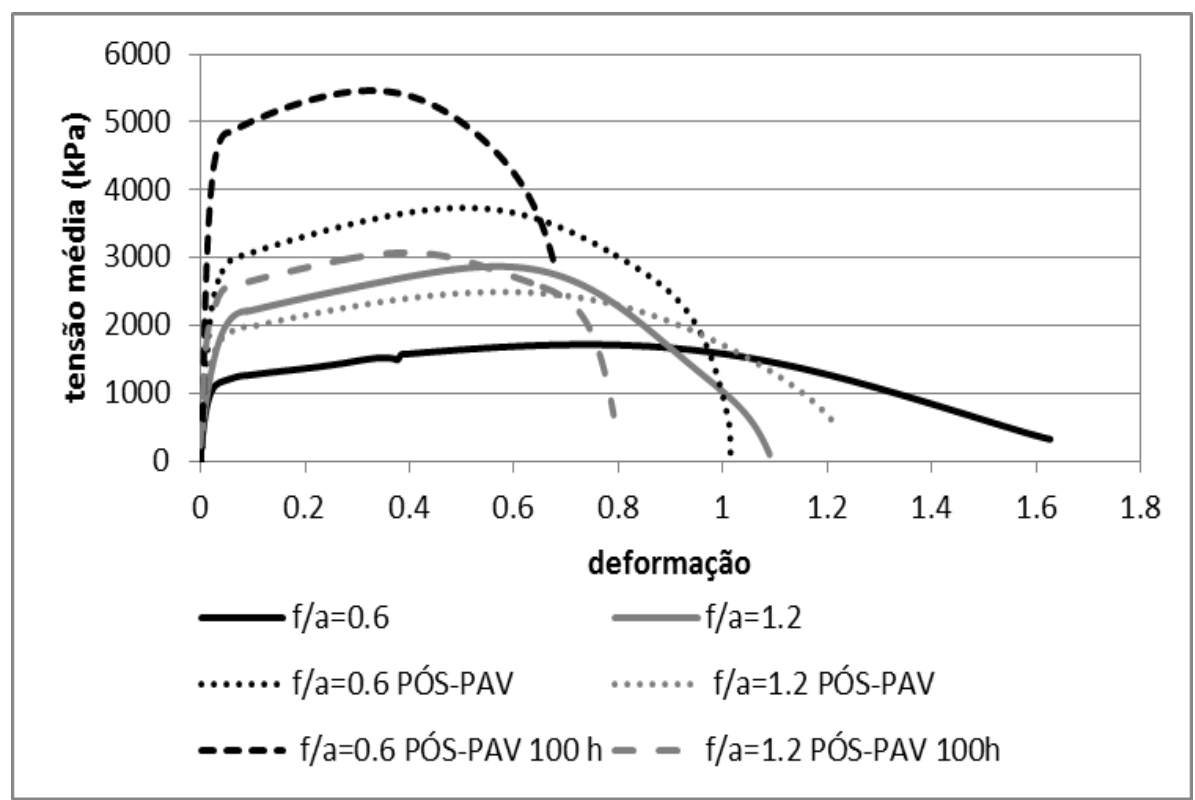

Figura 4.37 - Curva tensão-deformação para mástiques compostos pelo cimento Portland e o ligante asfáltico CAP 50/70 


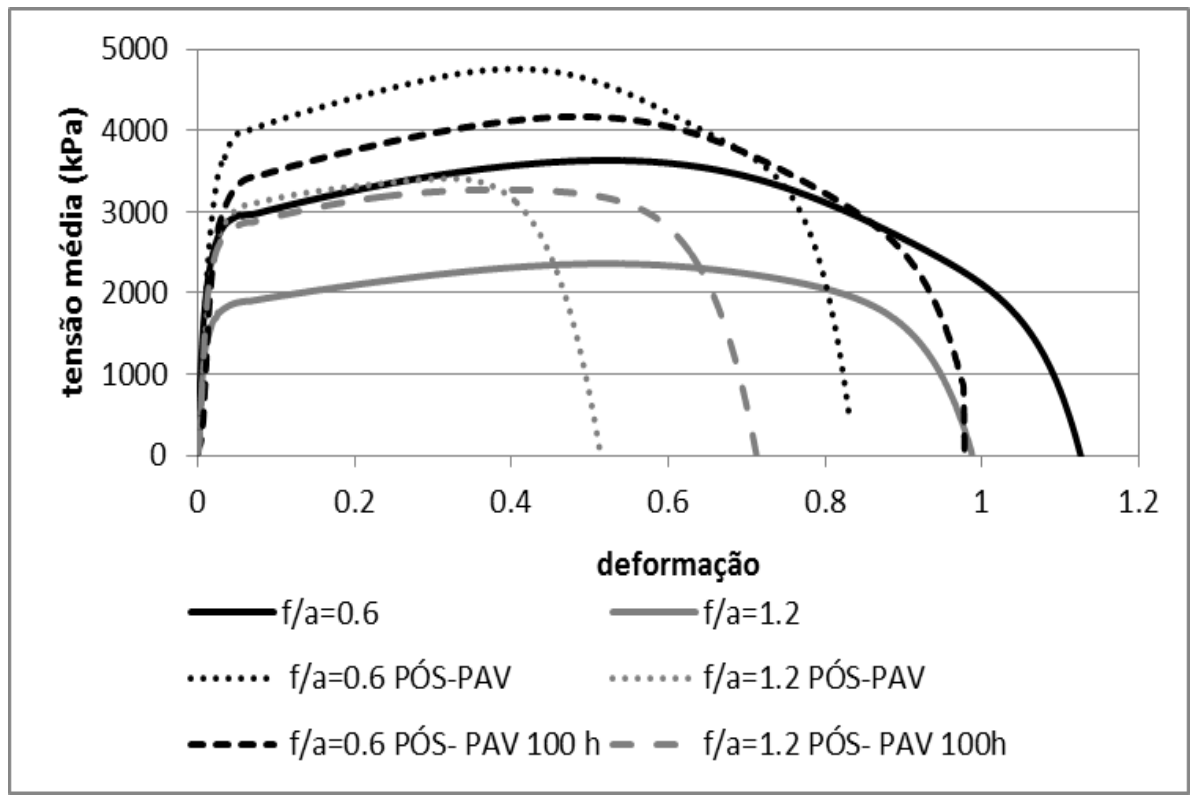

Figura 4.38 - Curva tensão- deformação para mástiques compostos pelo cimento Portland e o ligante asfáltico CAP 85/100

\subsubsection{Resultados da Energia de Fratura para Mástiques Compostos com Pó Calcário}

O ensaio de energia de fratura foi realizado para mástiques compostos com pó calcário (f/a=0,6 e 1,2). Foram utilizadas duas temperaturas $\left(15\right.$ e $\left.20{ }^{\circ} \mathrm{C}\right)$, e várias taxas de carregamento. Para os mástique compostos pelo CAP 50/70, os resultados estão apresentados na Figura 4.39, e para os mástiques com o CAP 85/100, na Figura 4.40. 


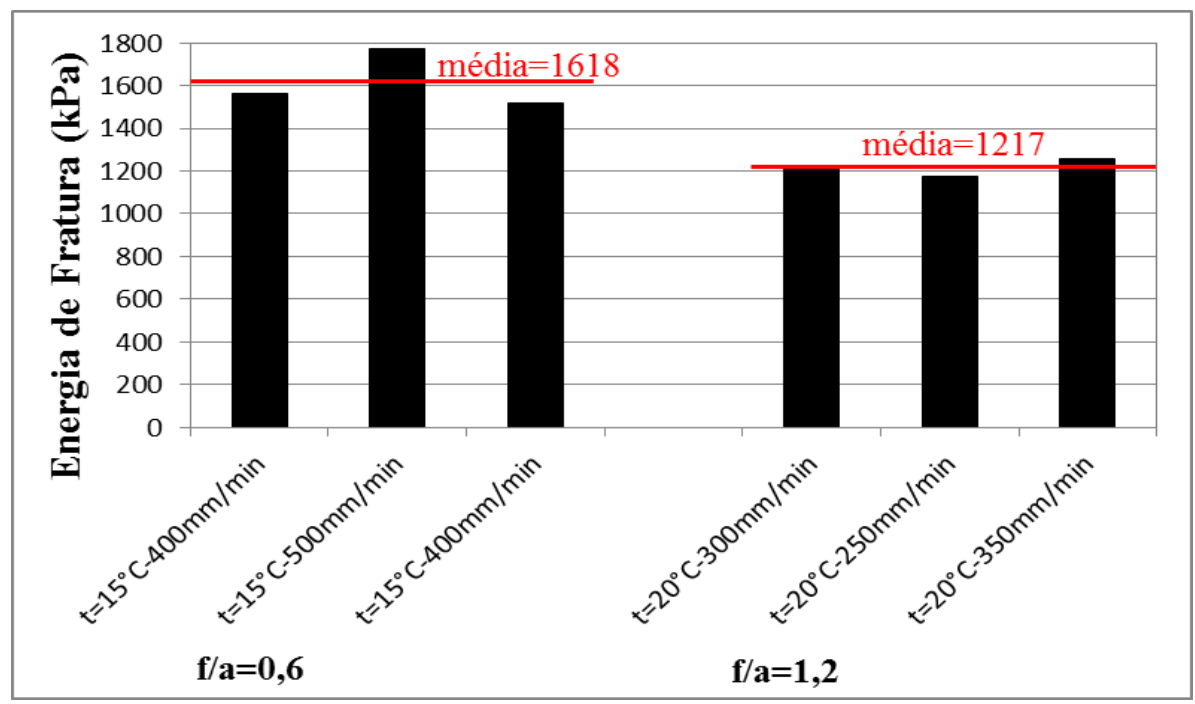

Figura 4.39 - Energia de Fratura para mástiques compostos com fíler de pó calcário e CAP 50/70, para várias temperaturas de ensaio e taxas de carregamento

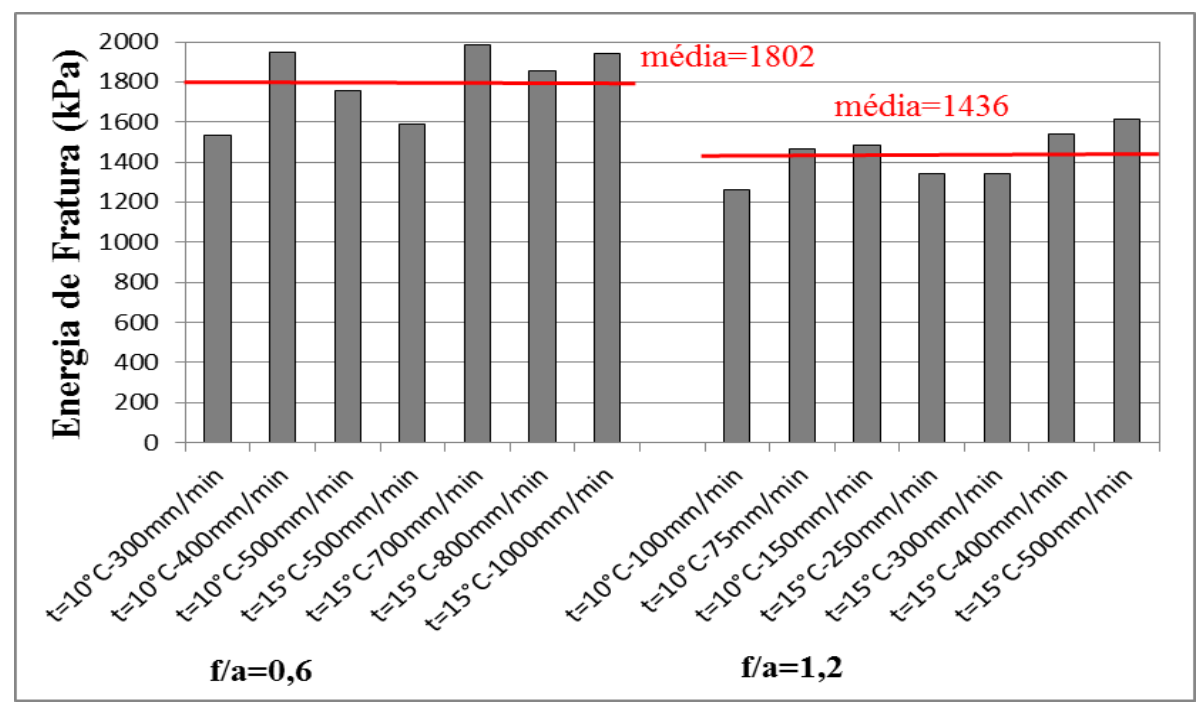

Figura 4.40 - Energia de Fratura para mástiques compostos com fíler de pó calcário e CAP 85/100, para várias temperaturas de ensaio e taxas de carregamento

Em seguida, o ensaio foi realizado em amostras de mástiques compostos pelo fíler de pó calcário submetidas ao envelhecimento no PAV. Os resultados de energia de fratura para os mástique compostos pelo CAP 50/70 estão apresentados na Figura 4.41 e para os compostos pelo CAP 85/100 na Figura 4.42. 


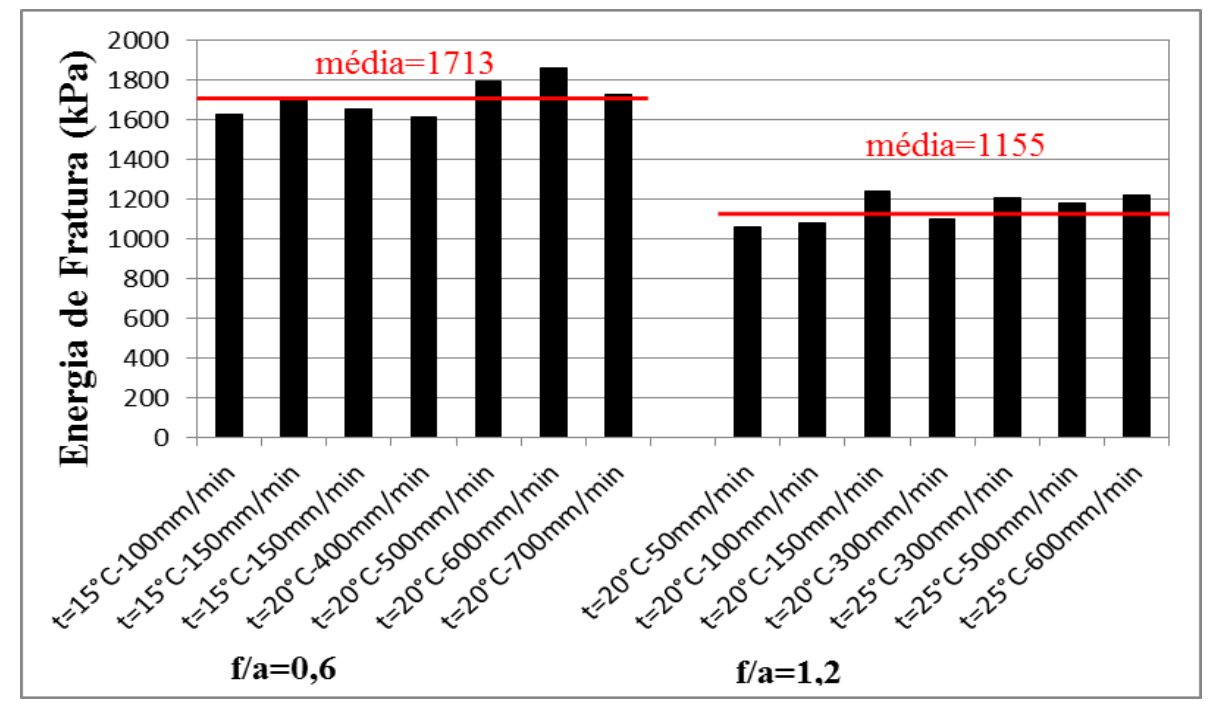

Figura 4.41 - Energia de Fratura para mástiques envelhecidos no PAV, compostos com fíler de pó calcário e CAP 50/70, para várias temperaturas de ensaio e taxas de carregamento

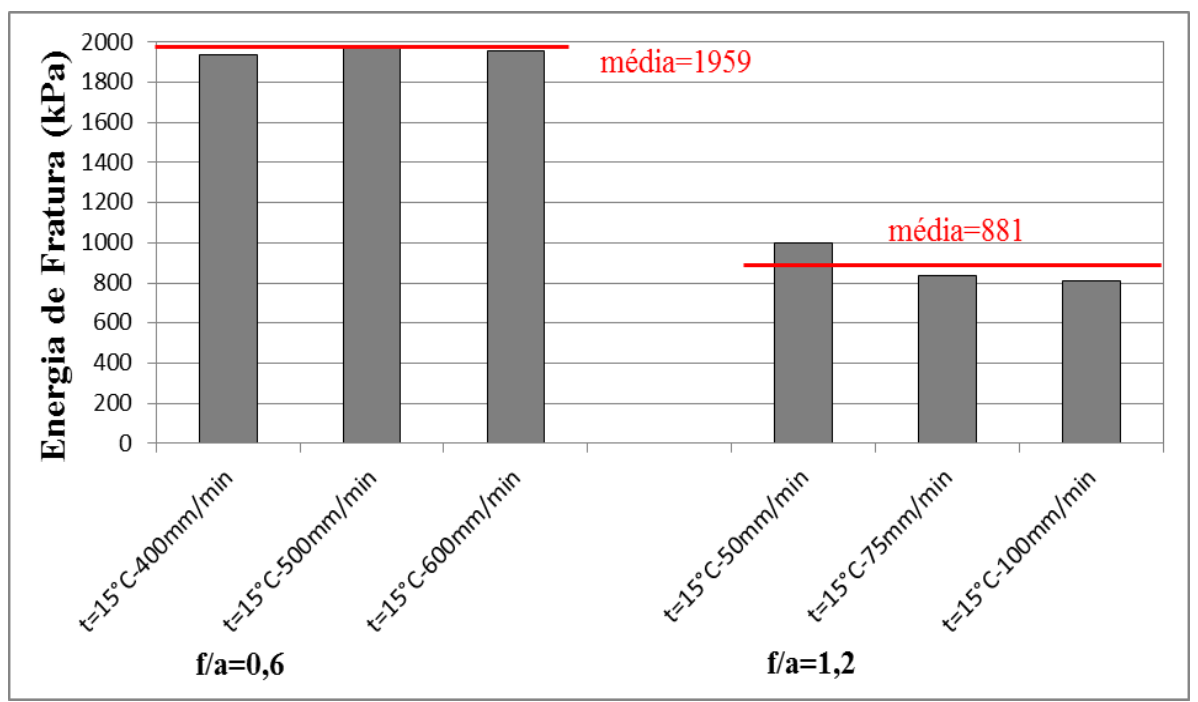

Figura 4.42 - Energia de Fratura para mástiques envelhecidos no PAV, compostos com fíler de pó calcário e CAP 85/100, para várias temperaturas de ensaio e taxas de carregamento.

Finalmente, foram realizados ensaios de energia de fratura em mástiques compostos pelo fíler de pó calcário, envelhecidos no PAV por 100 horas, na temperatura de $60{ }^{\circ} \mathrm{C}$. Para os mástiques compostos pelo CAP 50/70, os resultados estão apresentados na Figura 4.43, e para os mástiques com o CAP 85/100, na Figura 4.44. 


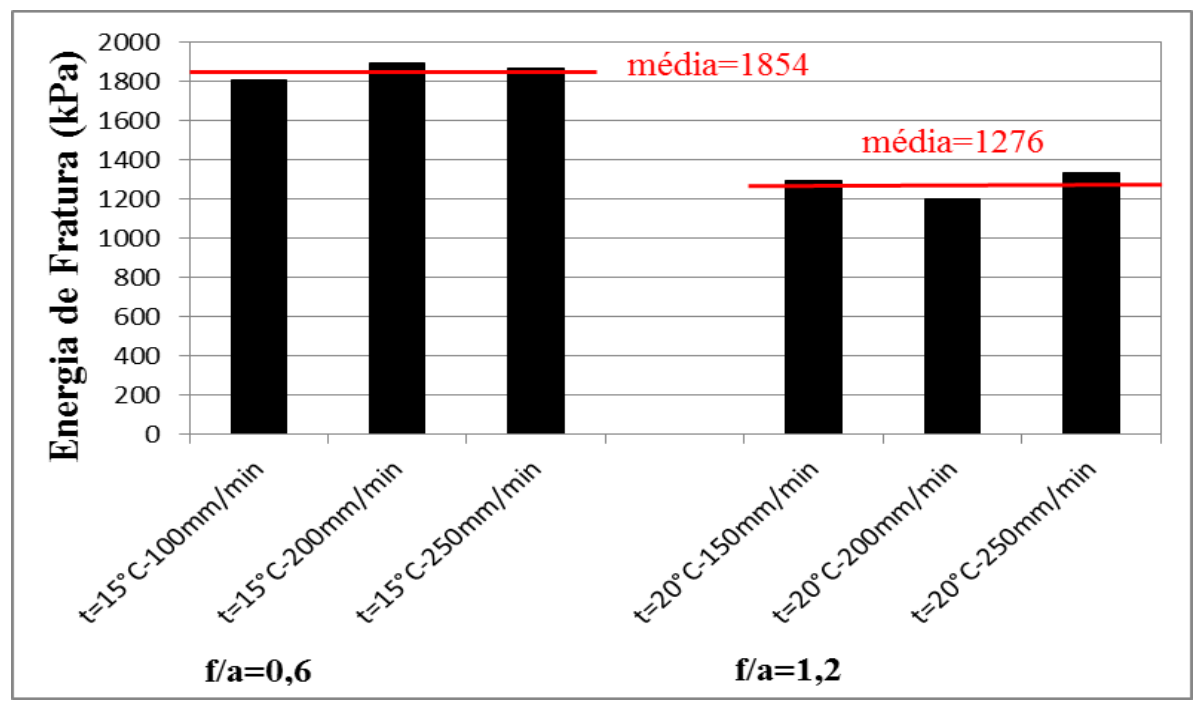

Figura 4.43 - Energia de Fratura para mástiques envelhecidos no PAV-100h- $60^{\circ} \mathrm{C}$, compostos com fíler de pó calcário e CAP 50/70, para várias temperaturas de ensaio e taxas de carregamento

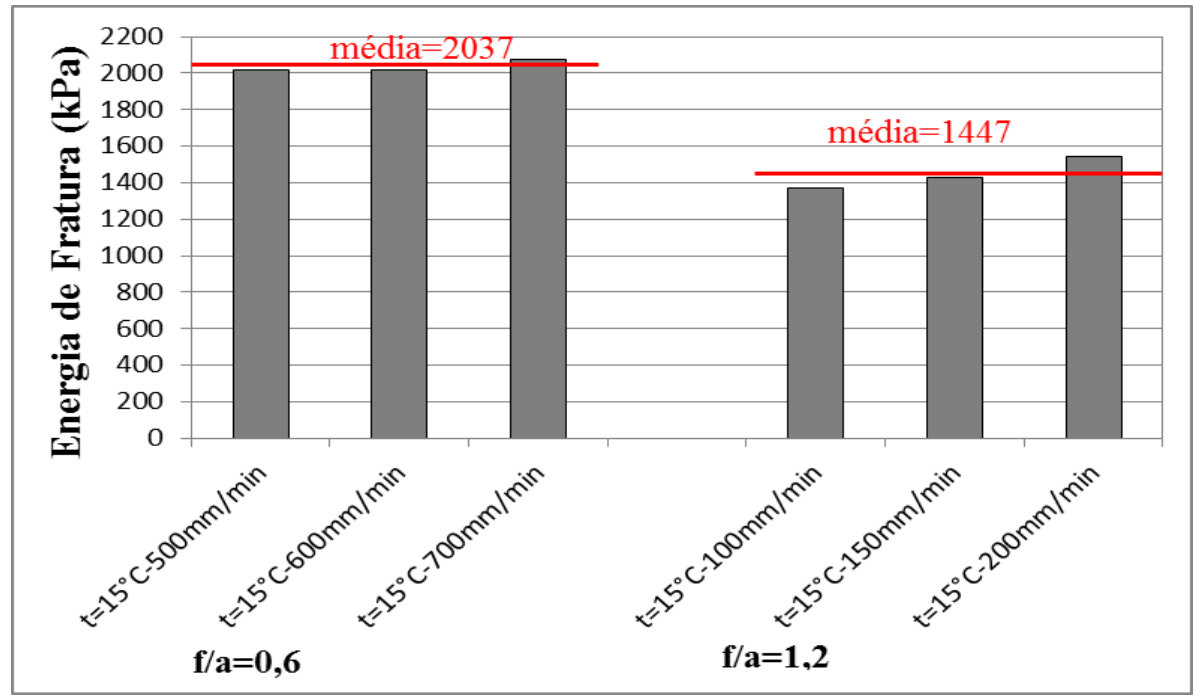

Figura 4.44 - Energia de Fratura para mástiques envelhecidos no PAV-100h- $60^{\circ} \mathrm{C}$ compostos com fíler de pó calcário e CAP 85/100, para várias temperaturas de ensaio e taxa de carregamento

As Figuras 4.45 e 4.46 mostram a curva tensão-deformação para os mástiques compostos pelo pó calcário e os ligantes asfálticos CAP 50/70 e CAP 85/100. Essas curvas tem o mesmo formato que as curvas de ligantes asfálticos puros não-modificados e sem envelhecimento, com apenas um pico de tensão seguido de um queda relativamente acentuada da curva tensão-deformação. 


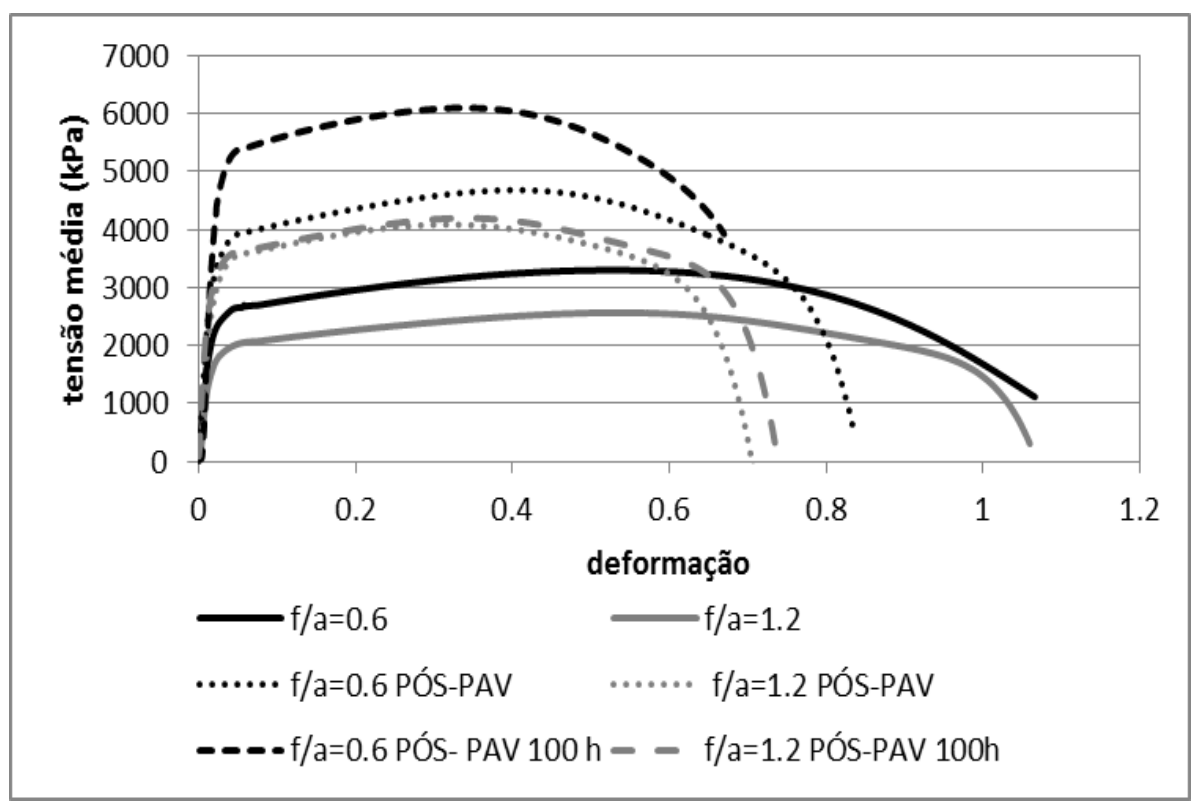

Figura 4.45 - Curva tensão-deformação para mástiques compostos pelo pó calcário e o ligante asfáltico CAP 50/70

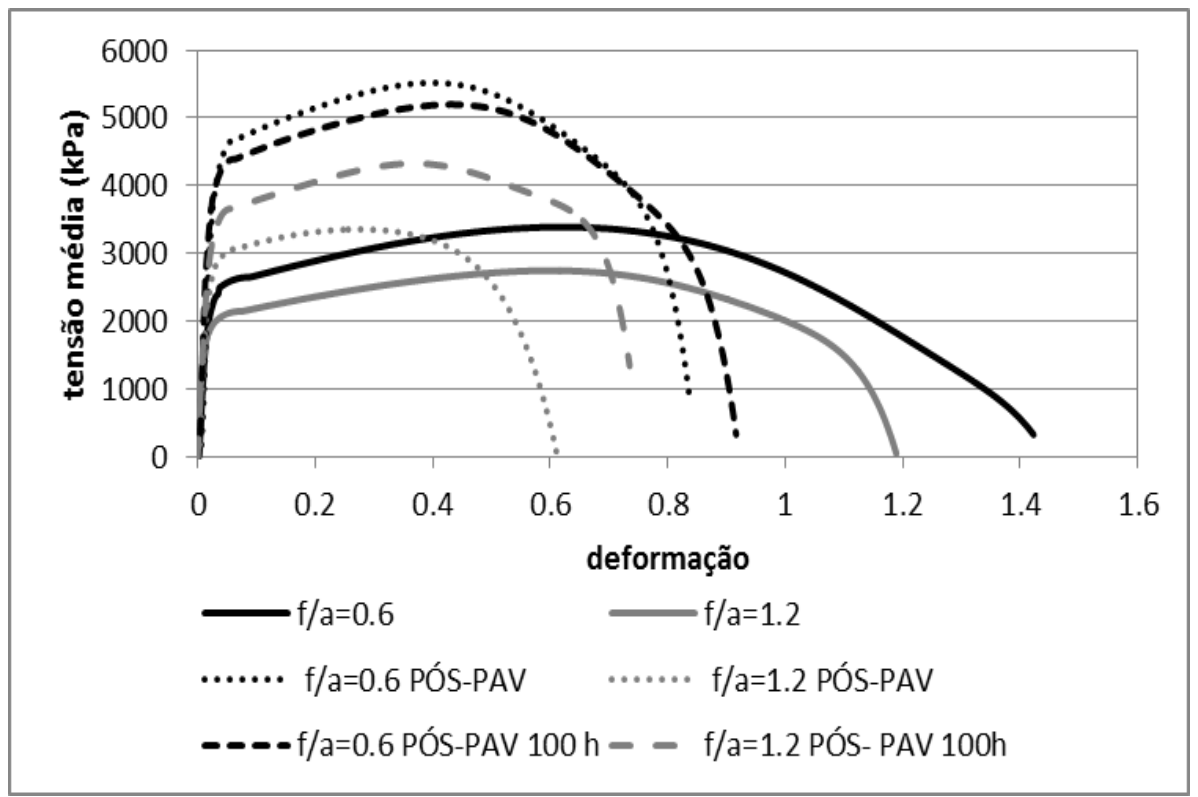

Figura 4.46 - Curva tensão- deformação para mástiques compostos pelo pó calcário e o ligante asfáltico CAP 85/100

\subsubsection{Resultados da Energia de Fratura para Mástiques Compostos com Cal Hidratada}

O ensaio de energia de fratura foi realizado para mástique compostos com cal hidratada (f/a=0,3 e 0,6). Foram utilizadas duas temperaturas $\left(15\right.$ e $\left.20{ }^{\circ} \mathrm{C}\right)$, e várias taxas de carregamento. Para os 
mástiques compostos pelo CAP 50/70, os resultados estão apresentados na Figura 4.47, e para os mástiques com o CAP 85/100, na Figura 4.48.

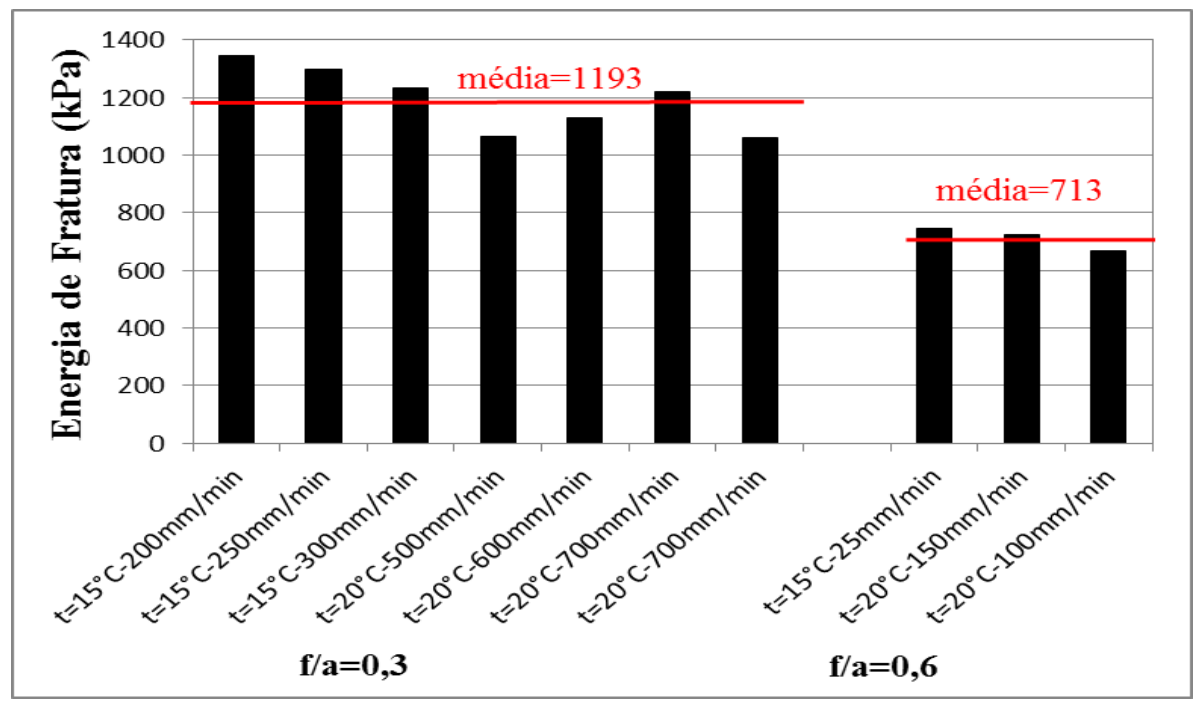

Figura 4.47 - Energia de Fratura para mástiques compostos com fíler de cal hidratada e CAP 50/70, para várias temperaturas de ensaio e taxas de carregamento

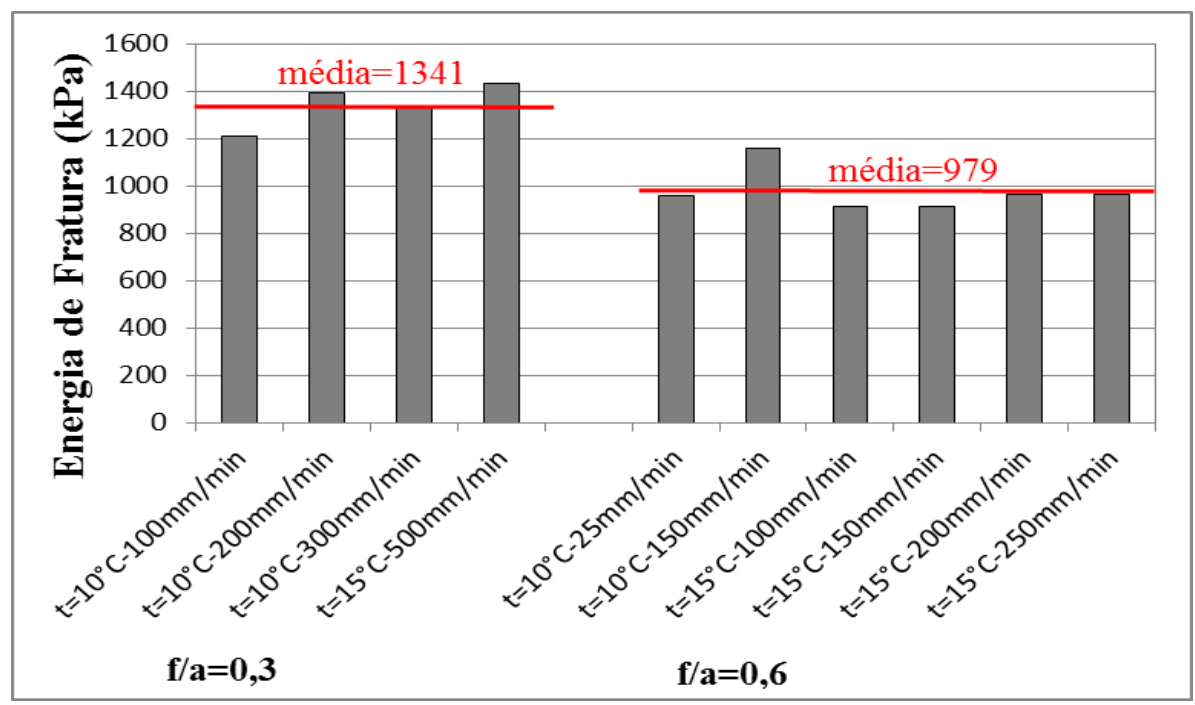

Figura 4.48 - Energia de Fratura para mástiques compostos com fíler de cal hidratada e CAP $85 / 100$, para várias temperaturas de ensaio e taxas de carregamento

As Figuras 4.49 e 4.50 apresentam os resultados do ensaio para os mástiques compostos pela cal hidratada, e pelo CAP 50/70 e CAP 85/100, respectivamente, envelhecidos no PAV $\left(100{ }^{\circ} \mathrm{C}\right.$ por 20 horas). 


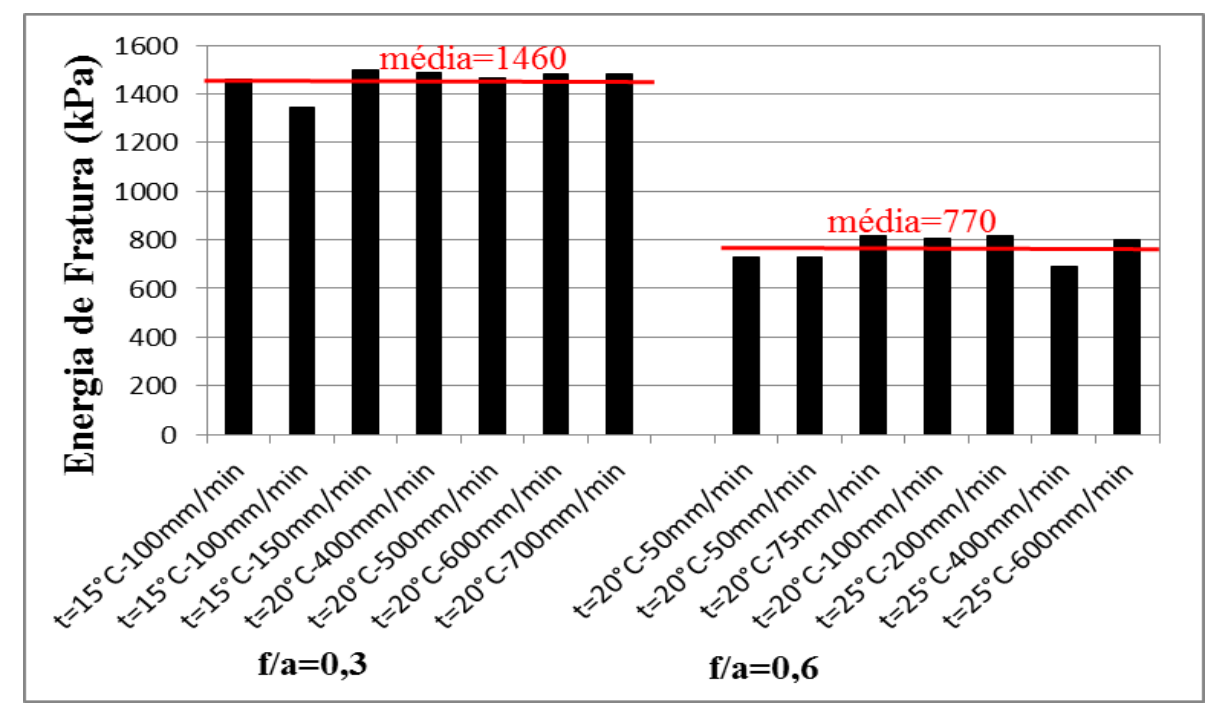

Figura 4.49 - Energia de Fratura para mástiques envelhecidos no PAV, compostos com fíler de cal hidratada e CAP 50/70, para várias temperaturas de ensaio e taxas de carregamento

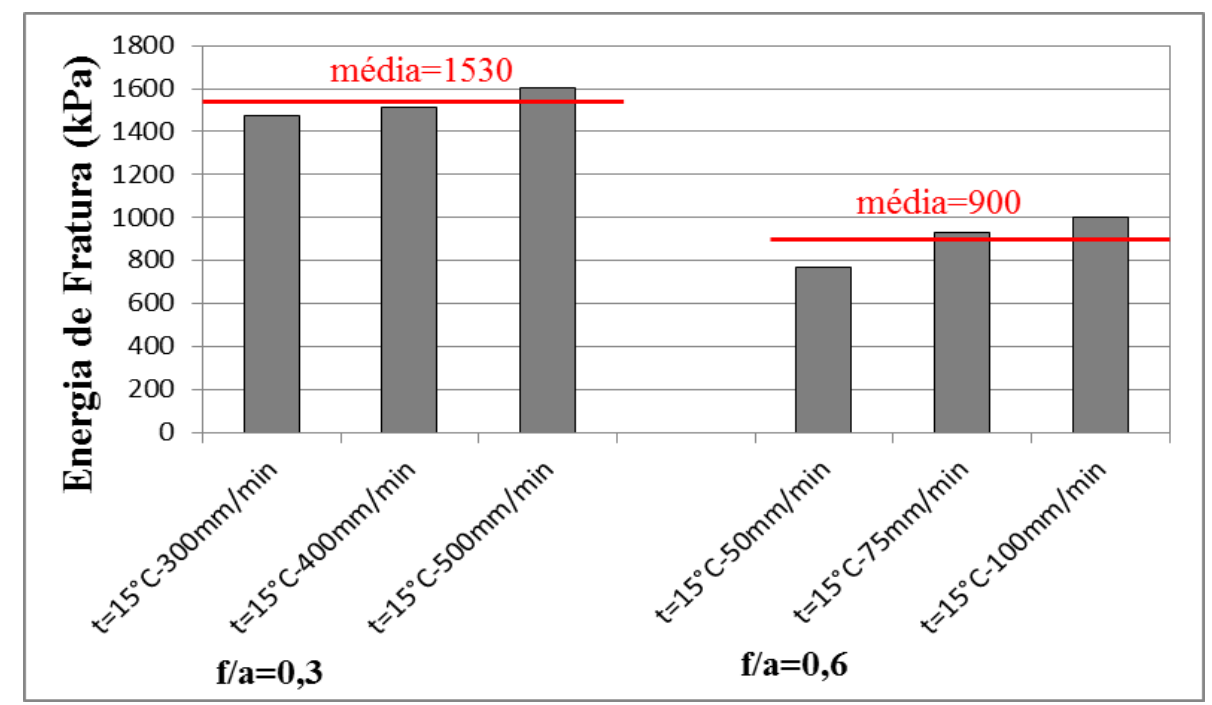

Figura 4.50 - Energia de Fratura para mástiques envelhecidos no PAV, compostos com fíler de cal hidratada e CAP 85/100, para várias temperaturas de ensaio e taxas de carregamento

Por último, foram realizados ensaios de energia de fratura em mástiques compostos pelo fíler de cal hidratada, envelhecidos no PAV por 100 horas, na temperatura de $60{ }^{\circ} \mathrm{C}$. Para os mástiques compostos pelo CAP 50/70, os resultados estão apresentados na Figura 4.51, e para os mástique com o CAP 85/100, na Figura 4.52. 


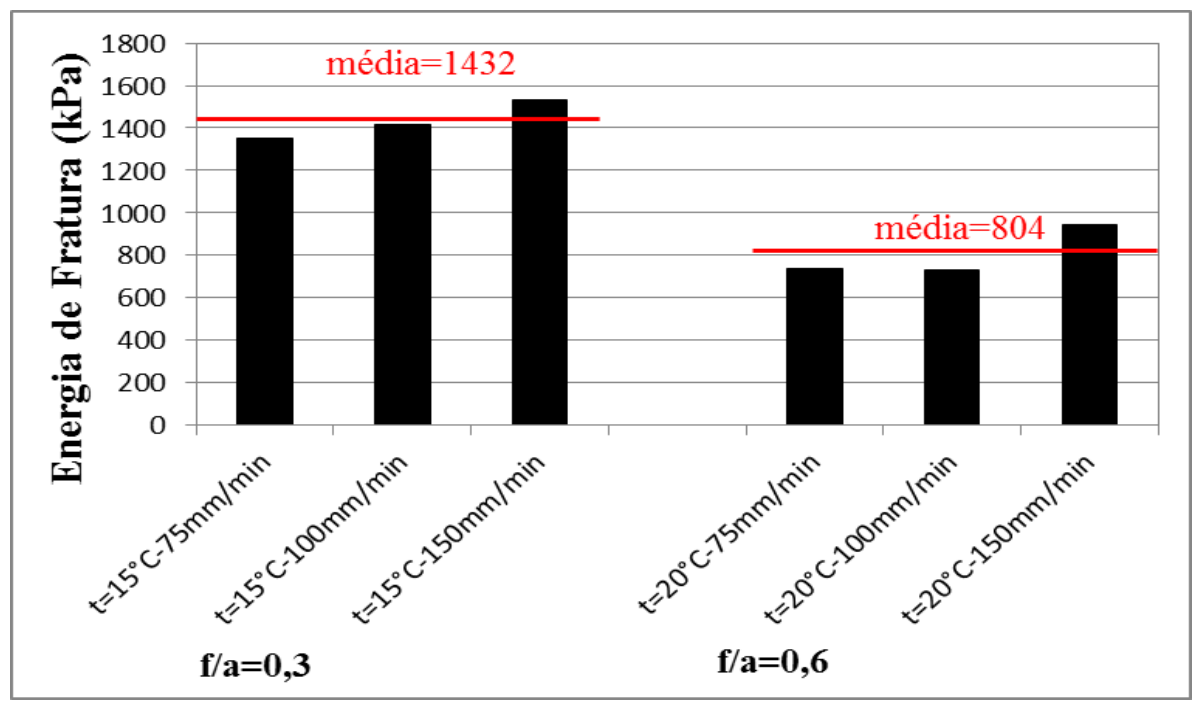

Figura 4.51 - Energia de Fratura para mástiques envelhecidos no PAV-100h-60 $\mathrm{C}$, compostos com fíler de cal hidratada e CAP 50/70, para várias temperaturas de ensaio e taxas de carregamento

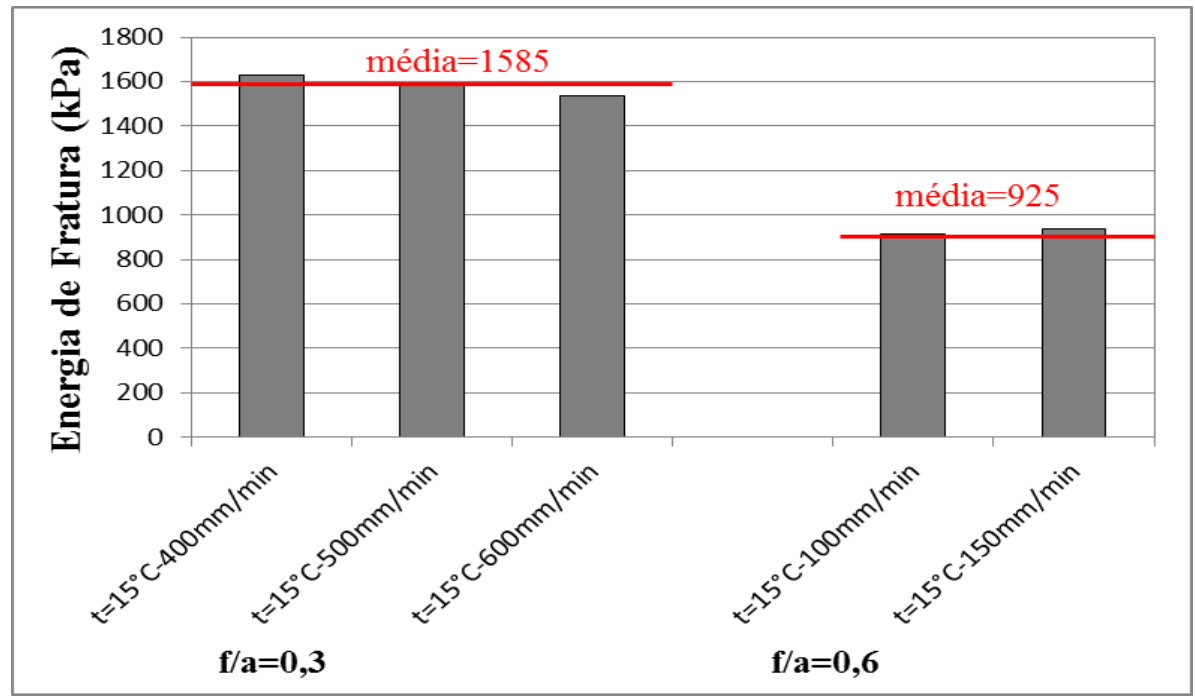

Figura 4.52 - Energia de Fratura para mástiques envelhecidos no PAV-100h- $60^{\circ} \mathrm{C}$, compostos com fíler de cal hidratada e CAP 85/100, para várias temperaturas de ensaio e taxas de carregamento

As Figuras 4.53 e 4.54 mostram a curva tensão-deformação para os mástiques compostos pela cal hidratada e os ligantes asfálticos CAP 50/70 e CAP 85/100. Essas curvas tem o mesmo formato que as curvas de ligantes asfálticos puros não-modificados e sem envelhecimento, com apenas um pico de tensão seguido de um queda relativamente acentuada da curva tensão-deformação. 


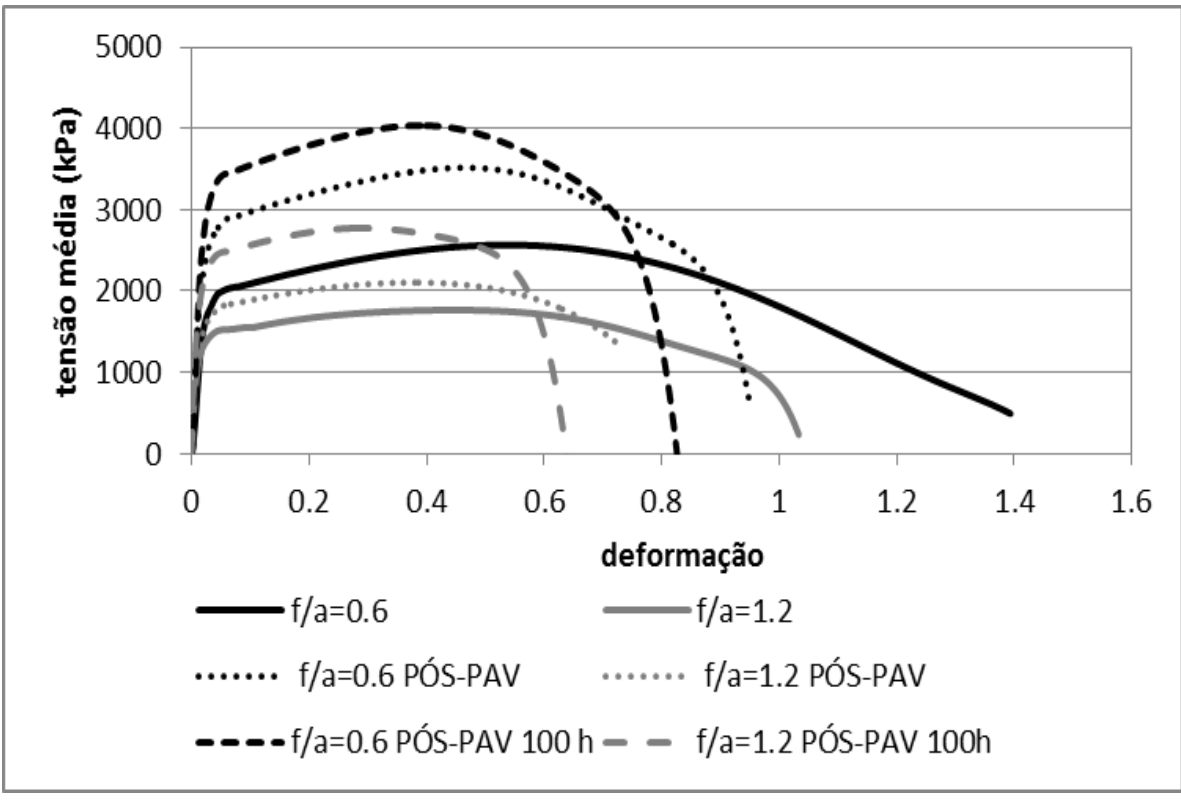

Figura 4.53 - Curva tensão-deformação para mástiques compostos pela cal hidratada e o ligante asfáltico CAP 50/70

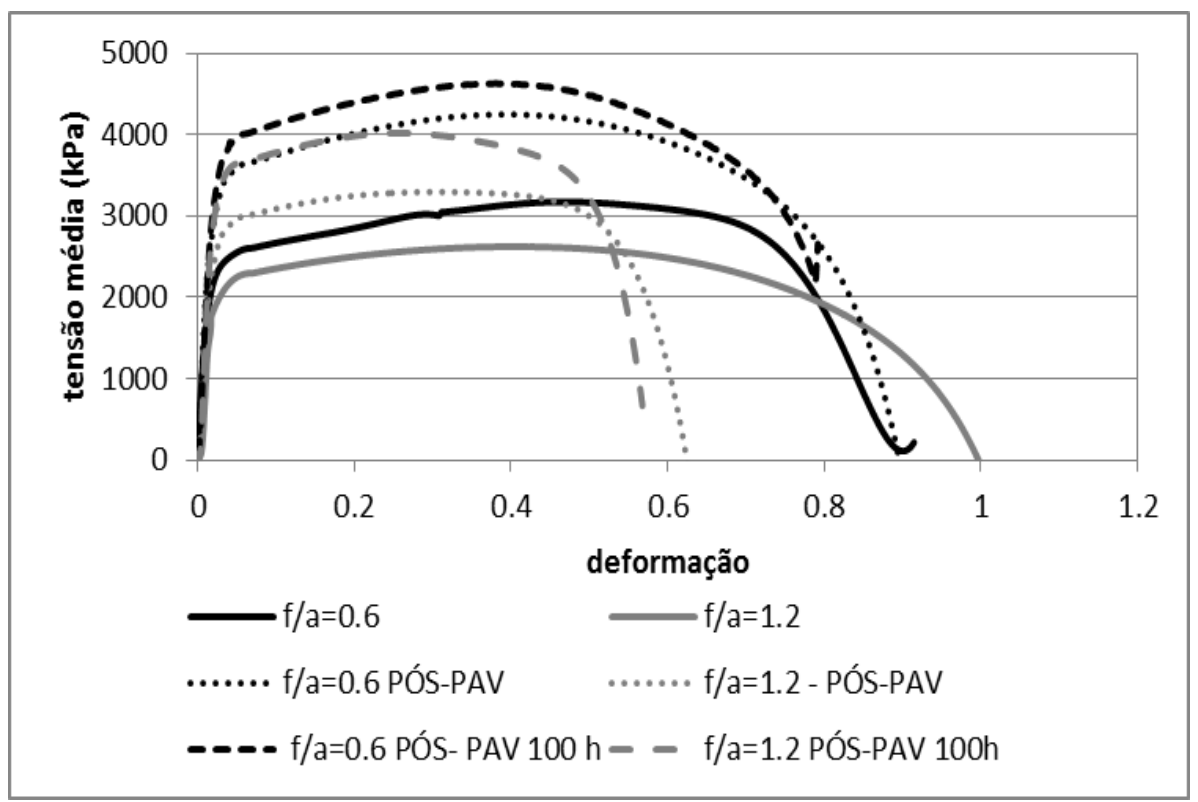

Figura 4.54 - Curva tensão- deformação para mástiques compostos pela cal hidratada e o ligante asfáltico CAP 85/100 


\subsubsection{Resumo e Análise de Variância dos Resultados}

\subsubsection{Resumo dos Valores da Energia de Fratura}

A Figura 4.55 apresenta o resumo das médias da energia de fratura para os mástiques compostos pelo CAP 50/70 e com os fileres de cimento Portland, pó calcário e cal hidratada. Pode-se perceber que a adição de fíler diminui o valor da energia de fratura quando comparado com o ligante asfáltico puro e que maiores concentrações de fíler diminuem ainda mais esse valor, exceto para o fíler de cimento Portland.

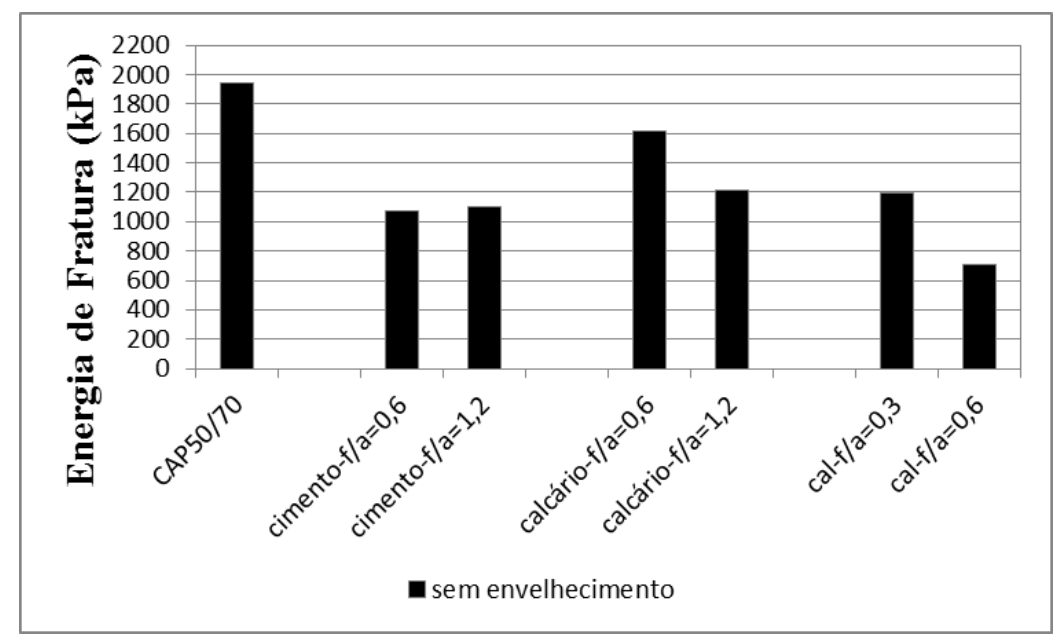

Figura 4.55 - Resumo das Médias da Energia de Fratura para mástiques compostos pelo CAP $50 / 70$

A Figura 4.56 apresenta o resumo das médias da energia de fratura para os mástiques sem envelhecimento e com envelhecimento no PAV convencional $\left(20 \mathrm{~h}\right.$ a $\left.100^{\circ} \mathrm{C}\right)$, compostos pelo CAP 50/70 e com os fileres de cimento Portland, pó calcário e cal hidratada. Pode-se perceber que o envelhecimento diminui o valor da energia de fratura para o ligante asfáltico puro, porém, aumenta os valores de energia de fratura para os mástiques, exceto para o fíler de pó calcário na relação f/a de 1,2. Pode-se perceber, também, que para os fileres de cimento Portland e cal hidratada o aumento da energia de fratura é maior em misturas com menor concentração de fíler. 


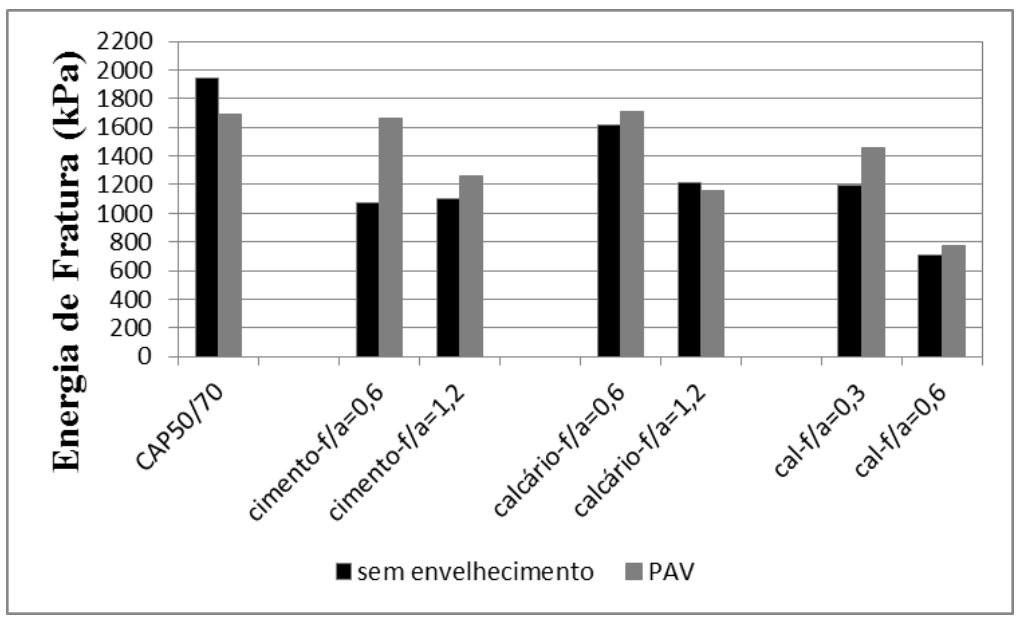

Figura 4.56 - Resumo das Médias da Energia de Fratura para mástiques compostos pelo CAP 50/70 sem envelhecimento e envelhecidos no PAV

A Figura 4.57 apresenta o resumo das médias da energia de fratura para os mástiques sem envelhecimento, com envelhecimento no PAV convencional $\left(20 \mathrm{~h}\right.$ a $\left.100^{\circ} \mathrm{C}\right)$ e com envelhecimento no PAV modificado $\left(100 \mathrm{~h}\right.$ a $\left.60^{\circ} \mathrm{C}\right)$, compostos pelo CAP 50/70 e com os fileres de cimento Portland, pó calcário e cal hidratada. Pode-se perceber que ambos os tipos de envelhecimento diminuem o valor da energia de fratura para o ligante asfáltico puro e que o PAV modificado apresenta uma menor diminuição da energia de fratura que o PAV convencional. Para os mástiques com menor concentração de fíler o envelhecimento aumenta consideravelmente o valor da energia de fratura, porém o tipo de envelhecimento parece não influenciar nos valores de energia de fratura. Para os mástiques com maior concentração de fíler, os diferentes tipos de envelhecimento apresentaram diferentes comportamentos, como por exemplo, para o fíler de cimento Portland, na relação f/a de 1,2, em que o PAV convencional aumenta o valor da energia de fratura, porém o PAV modificado não altera o valor da energia de fratura. 


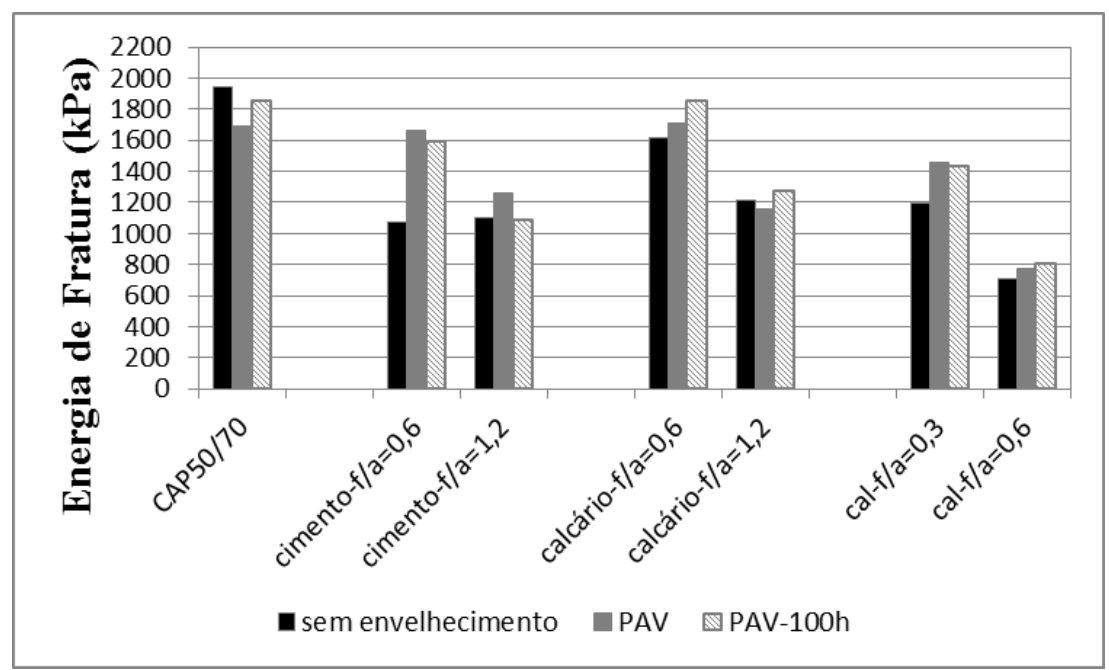

Figura 4.57 - Resumo das Médias da Energia de Fratura para mástiques compostos pelo CAP 50/70 sem envelhecimento, envelhecidos no PAV convencional e no PAV por 100 horas e a $60^{\circ} \mathrm{C}$

A Figura 4.58 apresenta o resumo das médias da energia de fratura para os mástiques compostos pelo CAP 85/100 e com os fileres de cimento Portland, pó calcário e cal hidratada. Da mesma maneira que para os mástiques compostos pelo CAP 50/70, a adição de fíler diminui o valor da energia de fratura quando comparado com o ligante asfáltico puro e que maiores concentrações de fíler diminuem ainda mais esse valor, inclusive para o fíler de cimento Portland.

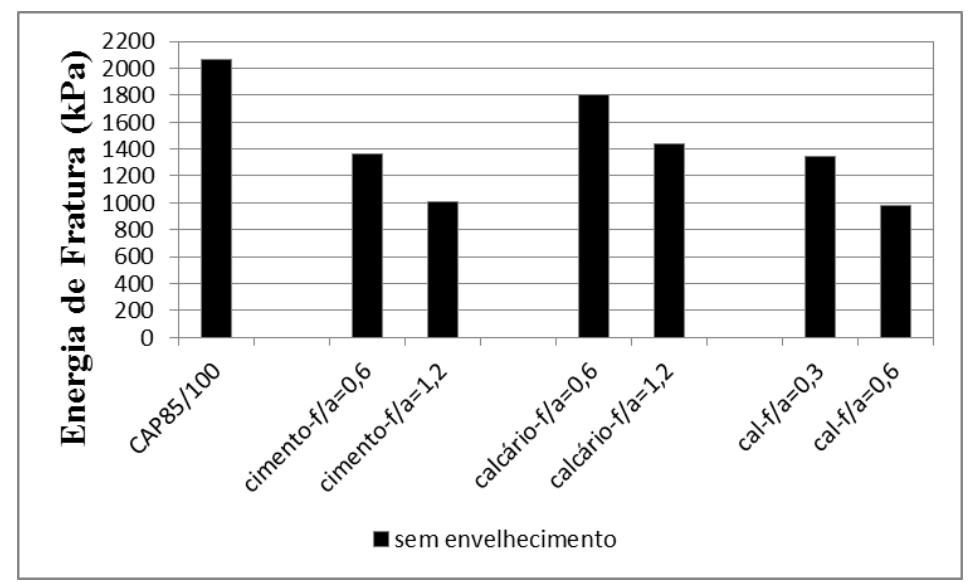

Figura 4.58 - Resumo das Médias da Energia de Fratura para mástiques compostos pelo CAP $85 / 100$

A Figura 4.59 apresenta o resumo das médias da energia de fratura para os mástiques sem envelhecimento e com envelhecimento no PAV convencional $\left(20 \mathrm{~h}\right.$ a $\left.100^{\circ} \mathrm{C}\right)$, compostos pelo 
CAP 85/100 e com os fileres de cimento Portland, pó calcário e cal hidratada. Pode-se perceber que o envelhecimento diminui o valor da energia de fratura para o ligante asfáltico puro. Para os mástiques com menor concentração de fíler o envelhecimento aumenta consideravelmente o valor da energia de fratura. Para os mástique com maior concentração de fíler, o envelhecimento apresentara diferentes comportamentos: para o fíler de cimento Portland, na relação f/a de 1,2, e para o fíler de cal hidratada, na relação f/a de 0,6, o envelhecimento praticamente não altera o valor da energia de fratura, porém, para o fíler de pó calcário, na relação f/a de 1,2, o envelhecimento diminui o valor da energia de fratura.

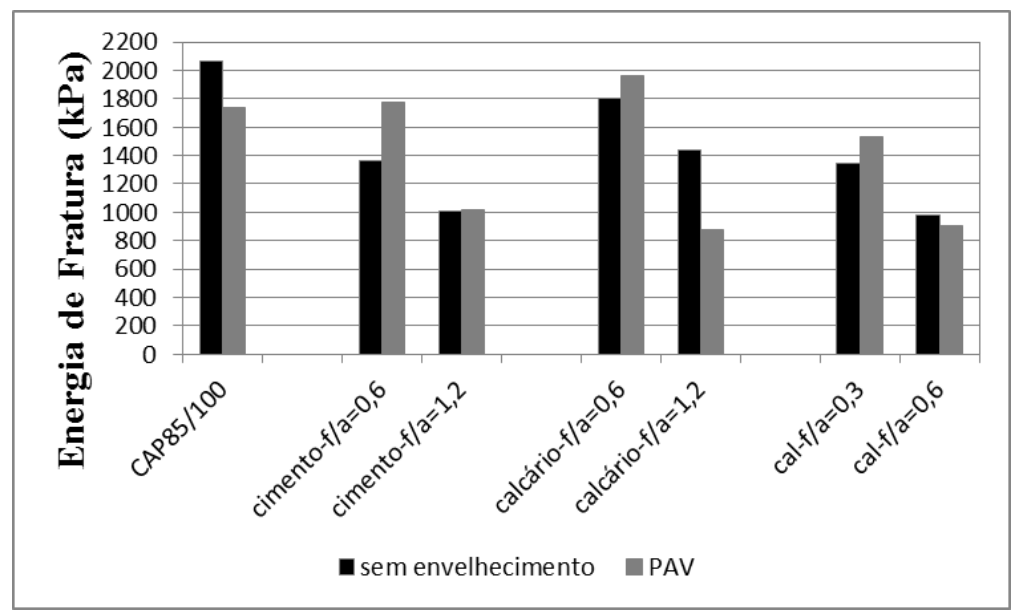

Figura 4.59 - Resumo das Médias da Energia de Fratura para mástiques compostos pelo CAP 85/100 sem envelhecimento e envelhecidos no PAV

A Figura 4.60 apresenta o resumo das médias da energia de fratura para os mástiques sem envelhecimento, com envelhecimento no PAV convencional $\left(20 \mathrm{~h}\right.$ a $\left.100^{\circ} \mathrm{C}\right)$ e com envelhecimento no PAV modificado $\left(100 \mathrm{~h} \mathrm{a} 60^{\circ} \mathrm{C}\right)$, compostos pelo CAP 85/100 e com os fileres de cimento Portland, pó calcário e cal hidratada. Pode-se perceber que ambos os tipos de envelhecimento diminuem o valor da energia de fratura para o ligante asfáltico puro e que o PAV modificado apresenta uma menor diminuição da energia de fratura que o PAV convencional, da mesma maneira que ocorreu para os mástiques compostos pelo CAP 50/70. O envelhecimento no PAV modificado aumenta os valores da energia de fratura dos mástiques, exceto para o composto pela cal hidratada na relação f/a de 0,6 . 


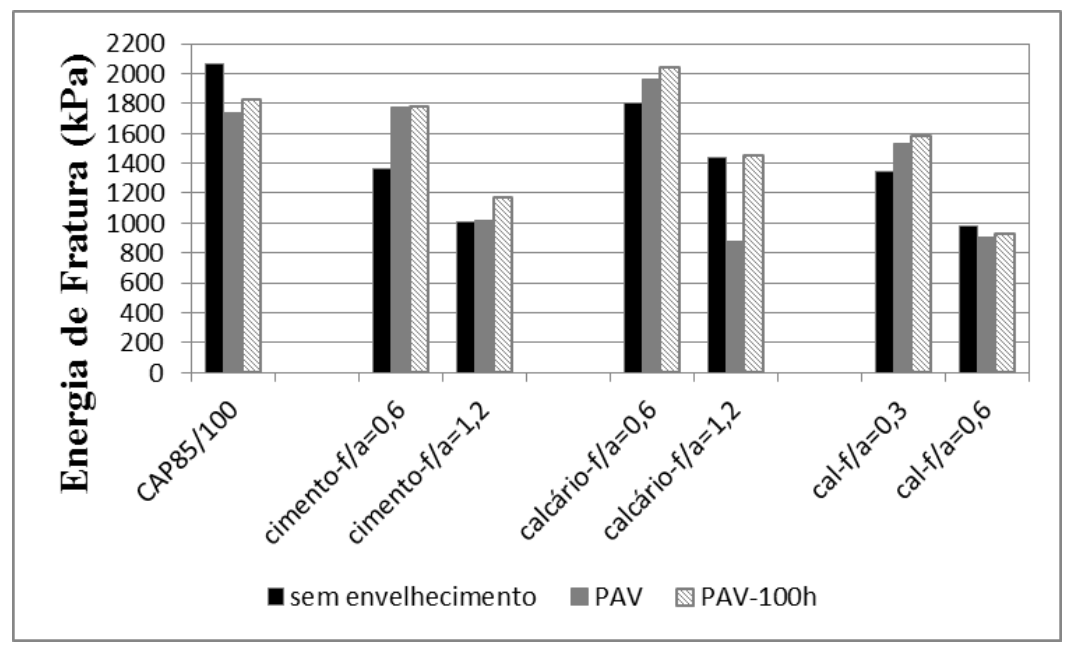

Figura 4.60 - Resumo das Médias da Energia de Fratura para mástique compostos pelo CAP 85/100 sem envelhecimento, envelhecidos no PAV convencional e no PAV por 100 horas e $60^{\circ} \mathrm{C}$

\subsubsection{Análise de Variância para a Energia de Fratura}

Os dados para a análise de variância da energia de fratura foram divididos, pois os mástiques compostos pelo fíler de cimento Portland e pó calcário foram ensaiados nas relações f/a de 0,6 e 1,2, enquanto os com fíler de cal hidratada foram ensaiados nas relações f/a de 0,3 e 0,6.

Foi avaliado se o envelhecimento tem influência na resposta da energia de fratura, comparandose os valores sem envelhecimento e com envelhecimento no PAV convencional (20 horas a 100 ${ }^{\circ} \mathrm{C}$ ), sem envelhecimento e com envelhecimento no PAV modificado (100 horas a $60{ }^{\circ} \mathrm{C}$ ) e, também, se os diferentes procedimentos de envelhecimento no PAV influenciam a energia de fratura.

A Tabela 4.1 mostra as combinações dos fatores de níveis das análises de variância e a Tabela 4.2 mostra os dados utilizados 
Tabela 4.1 - Combinações de fatores e níveis para a análise de variância da energia de fratura

\begin{tabular}{|c|c|c|c|c|}
\hline Fator & $\begin{array}{c}\text { A } \\
\text { Tipo de fíler } \\
\end{array}$ & $\begin{array}{c}\text { B } \\
\text { Relação f/a }\end{array}$ & $\begin{array}{c}\mathrm{C} \\
\text { Tipo de ligante } \\
\end{array}$ & $\begin{array}{c}\text { D } \\
\text { Tipo de envelhecimento }\end{array}$ \\
\hline \multicolumn{5}{|c|}{ Análise 1} \\
\hline \multirow{3}{*}{ Nível } & cimento & 0,0 & CAP 50/70 & sem envelhecimento \\
\hline & calcário & 0,6 & CAP 85/100 & PAV convencional \\
\hline & & 1,2 & & \\
\hline \multicolumn{5}{|c|}{ Análise 2} \\
\hline & cimento & 0,0 & CAP 50/70 & sem envelhecimento \\
\hline Nível & $\begin{array}{l}\text { calcário } \\
\text { cal }\end{array}$ & 0,3 & CAP 85/100 & PAV convencional \\
\hline \multicolumn{5}{|c|}{ Análise 3} \\
\hline \multirow{3}{*}{ Nível } & cimento & 0,0 & CAP 50/70 & PAV convencional \\
\hline & calcário & 0,6 & CAP 85/100 & PAV modificado \\
\hline & & 1,2 & & \\
\hline \multicolumn{5}{|c|}{ Análise 4} \\
\hline \multirow{3}{*}{ Nível } & cimento & 0,0 & CAP 50/70 & PAV convencional \\
\hline & calcário & 0,3 & CAP 85/100 & PAV modificado \\
\hline & cal & & & \\
\hline \multicolumn{5}{|c|}{ Análise 5} \\
\hline \multirow{3}{*}{ Nível } & cimento & 0,0 & CAP 50/70 & sem envelhecimento \\
\hline & calcário & 0,6 & CAP 85/100 & PAV modificado \\
\hline & & 1,2 & & \\
\hline \multicolumn{5}{|c|}{ Análise 6} \\
\hline \multirow{3}{*}{ Nível } & cimento & 0,0 & CAP 50/70 & sem envelhecimento \\
\hline & calcário & 0,3 & CAP 85/100 & PAV modificado \\
\hline & cal & & & \\
\hline
\end{tabular}


Tabela 4.2 - Dados para as análise de variância da energia de fratura

\begin{tabular}{cc|cc|cc|cc}
\hline \multirow{2}{*}{$\begin{array}{c}\text { Tipo } \\
\text { de } \\
\text { filer }\end{array}$} & $\begin{array}{c}\text { Relação } \\
\text { f/a }\end{array}$ & \multicolumn{2}{|c}{ sem envelhecimento } & \multicolumn{2}{c}{ PApo de envelhecimento convencional } & \multicolumn{2}{c}{ PAV modificado } \\
\cline { 3 - 8 } & & \multicolumn{2}{c}{ Tipo de ligante } & \multicolumn{2}{c}{ Tipo de ligante } & \multicolumn{2}{c}{ Tipo de ligante } \\
& & CAP 50/70 & CAP 85/100 & CAP 50/70 & CAP 85/100 & CAP 50/70 & CAP 85/100 \\
\hline \multirow{3}{*}{ cimento } & 0,0 & 1942,81 & 2068,27 & 1692,82 & 1742,28 & 1855,28 & 1826,95 \\
& 0,6 & 1076,18 & 1368,10 & 1666,92 & 1678,03 & 1593,21 & 1775,23 \\
& 1,2 & 1100,91 & 1012,01 & 1257,70 & 1020,53 & 1089,75 & 1173,22 \\
\hline \multirow{3}{*}{ calcario } & 0,0 & 1942,81 & 2068,27 & 1692,82 & 1742,28 & 1855,28 & 1826,95 \\
& 0,6 & 1618,21 & 1801,64 & 1713,55 & 1959,14 & 1853,63 & 2037,36 \\
& 1,2 & 1217,40 & 1436,24 & 1154,94 & 880,58 & 1276,18 & 1447,27 \\
\hline \multirow{3}{*}{ cal } & 0,0 & 1942,81 & 2068,27 & 1692,82 & 1742,28 & 1855,28 & 1826,95 \\
& 0,3 & 1193,10 & 1340,96 & 1459,89 & 1530,20 & 1431,55 & 1584,69 \\
& 0,6 & 712,65 & 978,94 & 770,03 & 900,83 & 803,60 & 924,91 \\
\hline
\end{tabular}

As Tabelas B.21, B.22 e B.23, do Apêndice B mostram o resumo da análise de variância das análises (1) e (2), que comparam os valores sem envelhecimento e com envelhecimento no PAV convencional (20 horas a $100{ }^{\circ} \mathrm{C}$ ); (3) e (4), que compara os valores dos diferentes procedimentos de envelhecimento no PAV e (5) e (6), que compara os valores sem envelhecimento e com envelhecimento no PAV modificado (100horas a $60^{\circ} \mathrm{C}$ ), respectivamente.

Nas Tabelas 4.3, 4.4 e 4.5 apresenta-se o resumo da análise de variância da energia de fratura, dos valores de $\mathrm{f}_{0}$ e da influência dos fatores e suas interações, para as análises (1) e (2), (3) e (4), e (5) e (6), respectivamente, considerando-se $\alpha=0,10$. Assim, a seguinte hipótese nula foi testada: $\mathrm{H}_{0}$ : os fatores não influenciam a energia de fratura; para valores de $\mathrm{F}_{0}$ maiores que $\mathrm{f}_{0}$, a hipótese nula $\mathrm{H}_{0}$ é rejeitada, ou seja, o fator influencia a energia de fratura. 
Tabela 4.3 - Resumo da Análise de Variância para as análises (1) e (2), valores de $f_{0}$ e influência dos fatores e suas interações

\begin{tabular}{ccccccc}
\hline Fator & \multicolumn{3}{c}{ análise (1) } & \multicolumn{3}{c}{ análise (2) } \\
& $\mathrm{F}_{0}$ & $\mathrm{f}_{0}$ & influência & $\mathrm{F}_{0}$ & $\mathrm{f}_{0}$ & influência \\
\hline A & 7,22 & 8,53 & não & 120,91 & 9,00 & sim \\
(tipo de fíler) & & & & & & \\
B & 73,64 & 9,00 & sim & 417,72 & 8,53 & sim \\
(teor de fíler) & & & & & & \\
C & 1,38 & 8,53 & não & 30,77 & 8,53 & sim \\
(tipo de ligante) & & & & & & \\
D & & & & & \\
(tipo de & 0,57 & 8,53 & não & 3,98 & 8,53 & não \\
envelhecimento) & & & & & & \\
AB & 3,94 & 9,00 & não & 120,91 & 9,00 & sim \\
AC & 0,44 & 8,53 & não & 0,14 & 9,00 & não \\
AD & 5,77 & 8,53 & não & 7,56 & 8,53 & não \\
BC & 2,71 & 9,00 & não & 4,11 & 8,53 & não \\
BD & 11,81 & 9,00 & sim & 92,04 & 8,53 & sim \\
CD & 2,89 & 8,53 & não & 3,81 & 8,53 & não \\
ABC & 0,15 & 9,00 & não & 0,14 & 9,00 & não \\
ABD & 1,48 & 9,00 & não & 7,56 & 9,00 & não \\
ACD & 0,00 & 8,53 & não & 1,00 & 9,00 & não \\
BCD & 0,60 & 9,00 & não & 0,18 & 8,53 & não \\
\hline
\end{tabular}


Tabela 4.4 - Resumo da Análise de Variância para as análises (3) e (4), valores de $\mathrm{f}_{0}$ e influência dos fatores e suas interações

\begin{tabular}{c|cccccc}
\hline Fator & \multicolumn{5}{|c}{ análise (3) } & \multicolumn{3}{c}{ análise (4) } \\
& $\mathrm{F}_{0}$ & $\mathrm{f}_{0}$ & influência & $\mathrm{F}_{0}$ & $\mathrm{f}_{0}$ & influência \\
\hline $\begin{array}{c}\text { A } \\
\text { (tipo de fíler) }\end{array}$ & 11,54 & 8,53 & sim & 324,64 & 9,00 & sim \\
B & & & & & & \\
(teor de fíler) & 248,55 & 9,00 & sim & 301,97 & 8,53 & sim \\
C & 1,68 & 8,53 & não & 19,66 & 8,53 & sim \\
(tipo de ligante) & & & & & & \\
D & 20,08 & 8,53 & sim & 24,21 & 8,53 & sim \\
(tipo de & & & & & & \\
envelhecimento) & 5,92 & 9,00 & não & 324,64 & 9,00 & sim \\
AB & 0,83 & 8,53 & não & 1,01 & 9,00 & não \\
AC & 8,16 & 8,53 & não & 0,73 & 8,53 & não \\
AD & 6,07 & 9,00 & não & 14,71 & 8,53 & sim \\
BC & 1,42 & 9,00 & não & 4,37 & 8,53 & não \\
BD & 5,24 & 8,53 & não & 0,40 & 8,53 & não \\
CD & 0,47 & 9,00 & não & 1,01 & 9,00 & não \\
ABC & 4,00 & 9,00 & não & 0,73 & 9,00 & não \\
ABD & 0,12 & 8,53 & não & 1,00 & 9,00 & não \\
ACD & 6,84 & 9,00 & não & 2,48 & 8,53 & não \\
BCD & & & & & & \\
\hline
\end{tabular}


Tabela 4.5 - Resumo da Análise de Variância para as análises (5) e (6), valores de $\mathrm{f}_{0}$ e influência dos fatores e suas interações

\begin{tabular}{|c|c|c|c|c|c|c|}
\hline \multirow{2}{*}{ Fator } & \multicolumn{3}{|c|}{ análise (5) } & \multicolumn{3}{|c|}{ análise (6) } \\
\hline & $\mathrm{F}_{0}$ & $\mathrm{f}_{0}$ & influência & $\mathrm{F}_{0}$ & $\mathrm{f}_{0}$ & influência \\
\hline $\begin{array}{c}\text { A } \\
\text { (tipo de fíler) }\end{array}$ & 73,61 & 8,53 & $\operatorname{sim}$ & 670,10 & 9,00 & $\operatorname{sim}$ \\
\hline $\begin{array}{c}\text { B } \\
\text { (teor de fíler) }\end{array}$ & 284,11 & 9,00 & $\operatorname{sim}$ & 2477,93 & 8,53 & $\operatorname{sim}$ \\
\hline $\begin{array}{c}\mathrm{C} \\
\text { (tipo de ligante) }\end{array}$ & 23,76 & 8,53 & $\operatorname{sim}$ & 134,02 & 8,53 & $\operatorname{sim}$ \\
\hline $\begin{array}{c}\text { D } \\
\text { (tipo de } \\
\text { envelhecimento) }\end{array}$ & 10,80 & 8,53 & $\operatorname{sim}$ & 11,52 & 8,53 & $\operatorname{sim}$ \\
\hline $\mathrm{AB}$ & 20,59 & 9,00 & $\operatorname{sim}$ & 670,10 & 9,00 & $\operatorname{sim}$ \\
\hline $\mathrm{AC}$ & 0,98 & 8,53 & não & 0,56 & 9,00 & não \\
\hline $\mathrm{AD}$ & 3,35 & 8,53 & não & 34,25 & 8,53 & $\operatorname{sim}$ \\
\hline $\mathrm{BC}$ & 3,91 & 9,00 & não & 50,96 & 8,53 & $\operatorname{sim}$ \\
\hline $\mathrm{BD}$ & 37,51 & 9,00 & $\operatorname{sim}$ & 339,33 & 8,53 & $\operatorname{sim}$ \\
\hline $\mathrm{CD}$ & 1,01 & 8,53 & não & 29,73 & 8,53 & $\operatorname{sim}$ \\
\hline $\mathrm{ABC}$ & 2,47 & 9,00 & não & 0,56 & 9,00 & não \\
\hline $\mathrm{ABD}$ & 2,07 & 9,00 & não & 34,25 & 9,00 & $\operatorname{sim}$ \\
\hline $\mathrm{ACD}$ & 0,14 & 8,53 & não & 1,00 & 9,00 & não \\
\hline BCD & 1,65 & 9,00 & não & 2,48 & 8,53 & não \\
\hline
\end{tabular}

Pode-se observar que:

- pelas análises (1) e (2), que comparam os valores sem envelhecimento e com envelhecimento no PAV convencional (20horas a $100{ }^{\circ} \mathrm{C}$ ), o fator que mais influencia a energia de fratura é o teor de fíler. O envelhecimento no PAV convencional não tem influência, enquanto o tipo de fíler é significativo apenas quando considera na análise o fíler de cal hidratada, o que já foi constatado nas análises do módulo complexo e do parâmetro de deformação permanente, em razão da grande atividade desse fíler mineral;

- pelas análises (3) e (4) que comparam os valores dos diferentes procedimentos de envelhecimento no PAV, os fatores que mais influenciam a energia de fratura são o teor e o tipo de fíler, embora os diferentes métodos de envelhecimento também influenciam a resposta dos mástiques; 
- pelas análises (5) e (6), que comparam os valores sem envelhecimento e com envelhecimento no PAV modificado $\left(100\right.$ horas a $\left.60{ }^{\circ} \mathrm{C}\right)$, os fatores que mais influenciam a energia de fratura são o teor e o tipo de fíler e o tipo de ligante asfáltico, embora o envelhecimento no PAV modificado também influencie a resposta do mástique. 


\section{CONCLUSÕES E SUGESTÕES PARA TRABALHOS FUTUROS}

Nesta pesquisa foi realizada uma investigação sobre a influência do fíler mineral no comportamento mecânico de misturas asfálticas densas. O estudo e a caracterização das misturas asfálticas densas foi realizado de três maneiras:

(i) Estudo das propriedades mecânicas da mistura asfáltica completa (agregados graúdos e miúdos, fíler mineral e ligante asfáltico);

(ii) Estudo das propriedades reológicas e empíricas do mástique (fíler e ligante asfáltico);

(iii) Estudo da energia de fratura do mástique.

Os fatores selecionados para o estudo foram o tipo de ligante asfáltico, o tipo de agregado e o tipo e o teor de fíler mineral. Cada um dos fatores foi considerado em vários níveis, para que pudesse ser avaliado o efeito provocado pela variação de cada fator nas propriedades mecânicas das misturas.

Para o estudo das misturas asfálticas completas foram testados dois tipos de ligantes asfálticos (CAP 50/70 e CAP 85/100), dois tipos de agregado (basalto e granito), quatro tipos de fíler mineral (pó calcário, sílica, cal hidratada e cimento Portland) e três níveis de fíler mineral (2,5; 5,0 e 7,5\%). Para que a execução dos ensaios de caracterização mecânica fosse viável durante o desenvolvimento da pesquisa, utilizou-se a técnica de fracionamento de experimentos, em que o experimento fatorial completo foi reduzido a um quarto, realizando-se, para isso, o acoplamento de alguns efeitos. Como descrito no Capítulo 2, o experimento reduziu-se a 12 condições experimentais realmente testadas em laboratório.

Para o estudo das propriedades reológicas e empíricas do mástique, nos ensaios de reômetro de cisalhamento dinâmico e ensaio de ponto de amolecimento, foram testados dois tipos de ligante asfáltico (CAP 50/70 e CAP 85/100), quatro tipos de fíler mineral (pó calcário, sílica, cal 
hidratada e cimento Portland) e três teores de fíler mineral (para os fileres de pó calcário, sílica e cimento Portland, nas relações f/a de 0,6; 0,9 e 1,2 e para o fíler de cal hidratada, nas relações f/a 0,6 e 0,3). No ensaio de fluência em viga, foram testados dois tipos de ligante asfáltico (CAP 50/70 e CAP 85/100), três tipos de fíler mineral (pó calcário, cal hidratada e cimento Portland) e dois níveis de fíler mineral (para os fileres de pó calcário e cimento Portland, nas relações f/a de 0,6 e 1,2 e para o fíler de cal hidratada, nas relações f/a 0,3 e 0,6), com procedimentos de envelhecimento na estufa de vaso pressurizado (PAV) com o método tradicional (20 horas a $100^{\circ} \mathrm{C}$ ) e um modificado (100 horas a $\left.60^{\circ} \mathrm{C}\right)$.

Para o estudo da energia de fratura de mástiques asfálticos, foi realizado o ensaio de tração direta "dog bone", desenvolvido na Universidade da Flórida, por Roque et. al. (2012). Neste ensaio foram testados dois tipos de ligante asfáltico (CAP 50/70 e CAP 85/100), três tipos de fíler mineral (pó calcário, cal hidratada e cimento Portland) e dois níveis de fíler mineral (para os fileres de pó calcário e cimento Portland, nas relações f/a de 0,6 e 1,2 e para o fíler de cal hidratada, nas relações f/a 0,3 e 0,6), com procedimentos de envelhecimento na estufa de vaso pressurizado (PAV) com o método tradicional $\left(20\right.$ horas a $\left.100^{\circ} \mathrm{C}\right)$ e um modificado $(100$ horas a $\left.60^{\circ} \mathrm{C}\right)$.

Através da análise de variância das propriedades mecânicas das misturas, das propriedades reológicas e de fratura dos mástiques asfálticos, medidas em ensaios de laboratório, identificaram-se os fatores que influenciam significativamente em cada resposta medida.

\subsection{PROPRIEDADES DA MISTURA ASFÁLTICA}

(a) Resistência à Tração

Analisando-se os resultados de resistência à tração, as misturas asfálticas compostas pelo ligante asfáltico CAP 50/70 apresentaram os maiores valores, sendo que as misturas compostas pelo agregado basáltico também apresentaram resistência à tração ligeiramente maior que as compostas com o agregado granítico. 
Em relação ao tipo de fíler, as misturas compostas pelo fíler de cimento Portland apresentaram os maiores valores de RT e a adição de maiores teores de fíler diminuíram os valores de resistência, ou seja, menores teores de fíler apresentam maiores valores de RT.

$\mathrm{Na}$ análise de variância, o tipo de agregado, o tipo de ligante asfáltico, o tipo e o teor de fíler apresentaram influência significativa na resposta da resistência à tração das misturas asfálticas, assim como a interação do tipo de agregado com o tipo de ligante asfáltico e com o tipo de fíler.

(b) Módulo de Resiliência

Analisando-se os resultados de módulo de resiliência, as misturas contendo o ligante asfáltico CAP 50/70 apresentaram os maiores valores. As misturas compostas pelo agregado granítico apresentaram módulo de resiliência ligeiramente maiores que as compostas com o agregado basáltico.

Em relação ao tipo de fíler, as misturas contendo fíler de cimento Portland apresentaram os maiores valores de MR com o agregado basáltico e CAP 50/70. As misturas com cal hidratada apresentaram os maiores valores de MR com o agregado granítico, independentemente do ligante asfáltico, mas, quando do uso de agregado basáltico, o maior MR foi obtido com o CAP 85/100. As misturas contendo o fíler de pó calcário apresentaram os menores valores de MR.

Em relação ao efeito do teor de fíler, para as misturas asfálticas contendo o agregado basáltico, quanto maior o teor de fíler, maior o valor de MR, enquanto que para as misturas contendo o agregado granítico, as misturas com teor de fíler de 2,5\% apresentam os menores valores de MR, e com os teores de 5,0 e 7,5\% não apresentaram diferença nos valores de MR.

$\mathrm{Na}$ análise de variância, o tipo de agregado, o tipo de ligante asfáltico e o tipo e o teor de fíler influenciaram o módulo de resiliência das misturas asfálticas, assim como a interação entre o tipo de agregado e o tipo de fíler.

(c) Vida de Fadiga 
Para a avaliação da vida de fadiga, para as diferentes condições experimentais, foi determinada, para cada mistura asfáltica, a deformação resiliente correspondente a $10^{7}$ solicitações do eixo padrão.

Analisando-se os resultados de vida de fadiga, as misturas compostas com o agregado basáltico e CAP 50/70 apresentaram os maiores valores de deformação resiliente, consequentemente, menores vidas de fadiga.

Em relação ao tipo de fíler, as misturas contendo o agregado basáltico, combinado com o fíler de pó calcário, apresentaram os maiores valores de deformação resiliente. As misturas contendo o fíler de cal hidratada apresentaram os menores valores de deformação resiliente, consequentemente, as maiores vidas de fadiga. Para as misturas compostas com o agregado granítico e CAP 85/100, a presença do fíler de cimento Portland resultou nos maiores valores de deformação resiliente, consequentemente, as menores vidas de fadiga.

Em relação ao teor de fíler, nas misturas contendo o CAP 50/70 o aumento do teor de fíler resultou em menores deformações resilientes. As misturas contendo o CAP 85/100 não foram afetadas pelo teor de fíler.

$\mathrm{Na}$ análise de variância, os fatores que influenciam os resultados da deformação resiliente e, consequentemente, a vida de fadiga, são o tipo de agregado, o tipo de ligante asfáltico e o tipo e teor de fíler na mistura asfáltica, bem como a interação do tipo de agregado com o tipo de fíler.

\section{(d) Deformação Permanente}

A avaliação da deformação permanente foi feita com base em sete parâmetros obtidos do ensaio de fluência por compressão uniaxial estática:

i. Deformação total: as misturas compostas pelo CAP 50/70 apresentaram os menores valores de deformação total, assim como as misturas contendo agregado basáltico. Em relação ao tipo de fíler, as misturas compostas pelo fíler de cimento Portland apresentaram os maiores valores de 
deformação total. As misturas contendo o fíler de cal hidratada apresentaram os menores valores de deformação total, quando combinadas com o agregado basáltico. Quanto ao teor de fíler, as misturas contendo os menores apresentaram menores valores de deformação total. Na Analise de Variância, o tipo de agregado, o tipo de ligante asfáltico, o tipo e o teor de fíler influenciam a deformação total das misturas asfálticas, assim como a interação do tipo de agregado com o tipo de ligante asfáltico;

ii. Deformação Recuperável: as misturas compostas pelo agregado basáltico apresentaram os menores valores de deformação recuperável e não há diferença significativa entre os valores para as misturas compostas pelo CAP 50/70 ou pelo CAP 85/100. Em relação ao tipo de fíler, para as misturas compostas pelo CAP 50/70 a deformação recuperável foi maior para as misturas com o cimento Portland. Para as misturas contendo o CAP 85/100 quase não há diferença em função do tipo de fíler ou do teor. Na análise de variância, apenas o tipo de agregado e o tipo de ligante asfáltico influenciaram a deformação recuperável das misturas asfálticas. O tipo de fíler influencia na resposta mecânica apenas quando o fíler de cal hidratada é considerado na análise, o que demostra a grande atividade desse material;

iii. Deformação não Recuperável: as misturas compostas pelo CAP 50/70 e agregado basáltico apresentaram os menores valores de deformação não recuperável. Em relação ao tipo de fíler, as misturas contendo o cimento Portland apresentaram os maiores valores de deformação não recuperável. Quanto ao teor de fíler, para todos os tipos, as misturas contendo o menor teor de fíler apresentaram os menores valores de deformação não recuperável, enquanto que as misturas contendo o valor intermediário de fíler apresentaram os maiores valores. Na análise de variância, o tipo de agregado, o tipo de ligante asfáltico e o tipo e o teor de fíler influenciaram a deformação não recuperável das misturas asfálticas, assim como a interação do tipo de agregado com o tipo de ligante asfáltico e com o tipo de fíler;

iv. Recuperação (\%): as misturas contendo o CAP 50/70 apresentaram os maiores valores de recuperação. Em relação ao tipo de fíler, as misturas compostas com o pó calcário apresentaram os maiores valores de recuperação, enquanto que as com o fíler de cimento Portland apresentaram os menores valores. Quanto ao teor de fíler, as misturas com os menores teores de fíler 
apresentaram os maiores valores de recuperação, enquanto que os teores intermediários $(5,0 \%)$ apresentaram os menores valores. $\mathrm{Na}$ análise de variância, o tipo de agregado, o tipo de ligante asfáltico e o teor de fíler influenciaram a recuperação das misturas asfálticas, assim como a interação do tipo de agregado com o tipo de ligante asfáltico e com o tipo de fíler. O tipo de fíler influencia a resposta mecânica apenas quando se considera na análise o fíler de cal hidratada;

v. Módulo de Fluência: as misturas compostas pelo agregado basáltico e o CAP 50/70 apresentaram os maiores valores de módulo de fluência. Em relação ao tipo de fíler, as misturas compostas pelo cimento Portland apresentaram os menores valores de módulo de fluência, enquanto que as compostas pelo pó calcário apresentaram os maiores valores. Quanto ao teor de fíler, as misturas contendo menores quantidades de fíler apresentam valores maiores de módulo de fluência, sendo que para os teores de 5,0 e 7,5\% apresentaram valores quase iguais. A análise de variância mostrou que o tipo de agregado, o tipo de ligante asfáltico e o tipo e o teor de fíler influenciam a recuperação das misturas asfálticas, assim como a interação entre o tipo de agregado e o tipo de ligante asfáltico;

vi. Módulo de Fluência após a Recuperação: as misturas compostas com o agregado basáltico e o CAP 50/70 apresentaram os maiores valores de módulo de fluência após a recuperação. Em relação ao tipo de fíler, as misturas contendo o pó calcário apresentaram os maiores, enquanto que as contendo o fíler de cimento Portland apresentam os menores valores. Quanto ao teor de fíler, as misturas contendo menores quantidades de fíler apresentaram os maiores valores, enquanto que as contendo teor intermediário $(5,0 \%)$ de fíler apresentam os menores. Na análise de variância, o tipo de agregado, o tipo de ligante asfáltico e o tipo e o teor de fíler influenciaram a recuperação das misturas asfálticas, assim como a interação entre o tipo de agregado com o tipo de ligante asfáltico e com o tipo de fíler;

vii. Inclinação: as misturas compostas com o CAP 50/70 apresentaram os maiores valores de inclinação. Quanto ao tipo de agregado, as misturas contendo granito com CAP 50/70 apresentaram os maiores valores de inclinação, já para o CAP 85/100, as misturas contendo os diferentes agregados não apresentaram diferenças significativas nos valores de inclinação. Em relação ao tipo de fíler, as misturas contendo o pó calcário com o CAP 50/70 apresentaram os 
menores valores de inclinação. As misturas contendo o CAP 85/100 e fíler de cimento Portland apresentaram os menores valores de inclinação. Quanto ao teor de fíler, as misturas contendo menores quantidades de fíler apresentam os menores valores de inclinação. $\mathrm{Na}$ análise de variância, o tipo de agregado, o tipo de ligante asfáltico e o tipo e o teor de fíler influenciaram a inclinação das misturas asfálticas, assim como a interação entre o tipo de agregado com o tipo de ligante asfáltico e a interação do tipo de ligante asfáltico com o teor de fíler.

\subsection{PROPRIEDADES REOLÓGICAS DOS MÁSTIQUES ASFÁLTICOS}

(a) Ensaio no Reômetro de Cisalhamento Dinâmico

Analisando-se os resultados do módulo complexo $\left(\mathrm{G}^{*}\right)$, a adição de fíler aumenta os valores de $\mathrm{G}^{*}$ para qualquer frequência de carregamento ou temperatura, o que torna o ligante asfáltico mais rígido. O comportamento do mástique asfáltico é similar ao do ligantes asfáltico, em que o módulo complexo aumenta linearmente com a frequência de carregamento e tende, assintóticamente, para o módulo de $10^{9} \mathrm{~Pa}$ (módulo vítreo).

A adição de fíler provocou um deslocamento vertical na escala de rigidez, praticamente uniforme ao longo da escala de frequência, e esse deslocamento (aumento do $\mathrm{G}^{*}$ ) aumenta quanto maior o teor de fíler adicionado ao mástique. A cal hidratada é o fíler que provoca o maior aumento do valor do módulo complexo, em todas as frequências de carregamento ( 0,$1 ; 1,0$ e 10,0 rad/s) e em ambos ligantes asfálticos, seguida pelo fíler de cimento Portland, sílica e pó calcário, nesta ordem.

Os mástiques compostos pelo CAP 50/70 apresentaram valores de $\mathrm{G}^{*}$ maiores, quando comparados aos com o CAP 85/100. O fíler de cal hidratada apresentou maior capacidade de enrijecimento quando combinado com o CAP 50/70, já o cimento Portland apresentou maiores valores de enrijecimento quando combinado ao CAP 85/100, o que leva à conclusão de que o comportamento do mástique depende da interação físico-química entre o fíler e o ligante asfáltico, pois o potencial físico-químico da cal hidratada é muito grande devido à forma das partículas e à textura superficial, que contribuem significativamente para o efeito enrijecedor. 
Analisando-se os resultados do ângulo de fase ( $\delta)$, a elasticidade aumenta com a adição dos fileres, o que se observa pela redução dos valores de ângulo de fase. O ângulo de fase dos mástiques asfálticos aumenta com a temperatura, uma tendência de variação semelhante à dos ligantes asfálticos.

O efeito do teor de fíler no mástique (relação f/a) é sutilmente diferente para cada frequência de carregamento: para a frequência de $0,1 \mathrm{rad} / \mathrm{s}$ pode-se perceber que o efeito da adição de fíler é mais expressivo, principalmente nas altas temperaturas; nas frequências de 1,0 e 10,0 rad/s a diminuição do ângulo de fase é maior nas temperaturas mais baixas, sendo mais expressiva para os mástiques compostos pelo fíler de cal hidratada e cimento Portland com o CAP 50/70, porém, esse efeito não é tão expressivo nos mástiques compostos com o CAP 85/100.

Em relação à dependência da temperatura, a incorporação do fíler mineral não interfere no comportamento, quando comparado ao do ligante asfáltico puro. Também não há mudança da dependência da temperatura com os diferentes tipos e teores de fíler utilizados, pondendo concluir que o potencial enrijecedor do fíler é o mesmo para diferentes temperaturas.

Analisando-se o parâmetro de deformação permanente da especificação Superpave, G*/sen $\delta(\geq$ $1 \mathrm{kPa}$ ), o efeito do teor de fíler no mástique (relação f/a) é semelhante ao efeito observado para a rigidez, com os valores do parâmetro $\mathrm{G}^{*} / \operatorname{sen} \delta$ diminuindo com a temperatura, de forma aproximadamente linear, quando a escala de $\mathrm{G}^{*} / \mathrm{sen} \delta$ é logarítmica, para ambos os tipos de CAP. Por apresentar consistência maior que a do CAP 85/100, o CAP 50/70 proporciona mástiques com valores de $\mathrm{G}^{*} / \mathrm{sen} \delta$ superiores, o que pode se refletir em misturas asfálticas com maior resistência à deformação permanente.

A utilização do fíler mineral aumenta a temperatura correspondente ao valor de $\mathrm{G}^{*} / \mathrm{sen} \delta \geq$ $1,00 \mathrm{kPa}$, da especificação Superpave, e, consequentemente, aumenta o valor do grau de desempenho (PG) do ligante asfáltico com fíler mineral. Como consequência, quanto maior o teor de fíler utilizado, maior a temperatura correspondente a $\mathrm{G}^{*} / \mathrm{sen} \delta \geq 1,00 \mathrm{kPa}$, o que pode se refletir em misturas asfálticas com maior resistência à deformação permanente. 
Nas análises de variâncias, os fatores que mais influenciam o módulo complexo, o ângulo de fase e o parâmetro de deformação permanente são a frequência de carregamento e o tipo de ligante asfáltico, como já observado pelas curvas mestre. Para o módulo complexo e o parâmetro de deformação permanente, o teor de fíler tem influência significativa nas respostas, já o tipo de fíler apresenta influencia apenas quando se considera na análise o fíler de cal hidratada, mostrando a grande atividade desse mineral. Já para o ângulo de fase, o teor de fíler tem influência maior que o tipo de fíler, sendo que os dois fatores influenciam significativamente a resposta do ângulo de fase do mástique.

\section{(b) Ensaio de Fluência em Viga}

Analisando-se os resultados da rigidez à fluência na flexão $(S(60))$, a presença de fíler mineral no mástique aumenta os valores de rigidez e esse aumento é maior com maiores teores de fíler, podendo-se afirmar que a utilização de maiores teores de fíler prejudica a resposta ao trincamento a baixas temperaturas.

Em relação ao tipo de fíler, o fíler de cal hidratada apresenta maior rigidez dentre os fileres estudados, para ambos os ligantes asfáltico (CAP 50/70 e CAP 85/100). Os mástiques compostos pelo cimento Portland apresentaram valores semelhantes ao da cal hidratada quando combinados com o CAP5070, já para o CAP 85/100, o mástique composto pelo fíler de pó calcário apresenta valor de rigidez maior que o com cimento Portland. Assim, observa-se que o comportamento de diferentes fileres depende não somente do tipo de fíler ou do tipo de ligantes asfáltico,mas da interação fíler-ligante asfáltico, da afinidade entre a superfície e composição do fíler e as propriedades do ligante asfáltico.

Analisando-se os resultados do módulo de relaxação (m(60)), o aumento do teor de fíler diminui os valores de m(60), ou seja, maiores teores de fíler diminuem a eficiência na dissipação das tensões formadas durante a contração do ligante asfáltico, quando a temperatura do pavimento cai abruptamente, aumentando a formação de trincas e fissuras. 
Em relação ao tipo de fíler, os mástiques compostos pela cal hidratada apresentaram os menores valores do módulo de relaxação, para ambos os ligantes asfálticos. O comportamento dos mástiques compostos pelo fíler de cimento Portland depende do tipo de ligante utilizado, pois para o CAP 50/70 ele apresentou valores de módulo de relaxação próximos ao da cal hidratada e para o CAP 85/100 os mástiques compostos pelo fíler de cimento Portland apresentaram os maiores valores de módulo de relaxação.

Também foram analisados os resultados de diferentes métodos de envelhecimento dos mástiques asfálticos nas respostas de rigidez à fluência na flexão e do módulo de relaxação. Observou-se que o comportamento da rigidez e do módulo de relaxação foi semelhante para os diferentes métodos, sendo que os valores de rigidez foram ligeiramente superiores, porém, a tendência foi a mesma para ambas as propriedades,

$\mathrm{Na}$ análise de variância, os fatores que mais influenciaram a rigidez na fluência na flexão e o módulo de relaxação são o teor de fíler e o tipo de ligante asfáltico. O tipo de fíler é significativo apenas quando se considera a cal hidratada na análise, o que confirma o caráter ativo desse fíler.

(c) Ensaio de Ponto de Amolecimento pelo Método Anel e Bola

Analisando-se as respostas da temperatura do ponto de amolecimento dos mástiques asfálticos, a adição de fíler aumentou os valores da temperatura e o aumento do teor de fíler no mástique também aumentou os valores da propriedade.

Em relação ao tipo de fíler, a cal hidratada proporcionou mástique com maiores valores de temperatura do ponto de amolecimento. Para o CAP 50/70, os mástique compostos pelo fíler de sílica apresentaram o segundo maior valor da propriedade (depois da cal hidratada), para teores maiores de fíler na mistura (relações f/a de 0,9 e 1,2). Para o CAP 85/100 os mástiques compostos pelo pó calcário apresentaram o segundo maior valor da propriedade, para todas as relações f/a. 
Em relação ao tipo de ligante, o CAP 50/70 produziu mástiques com maior temperatura de ponto de amolecimento, quando comparado ao CAP 85/100.

$\mathrm{Na}$ análise de variância, os fatores que mais influenciaram na temperatura do ponto de amolecimento são o tipo de ligante asfáltico e o teor de fíler. O tipo de fíler é muito significativo também, porém a influência é maior na análise que considera o fíler de cal hidratada.

\subsection{PROPRIEDADES DE ENERGIA DE FRATURA DOS MÁSTIQUES ASFÁLTICOS}

Analisando-se os resultados da energia de fratura dos ligantes (CAP 50/70 e CAP 85/100) e mástiques asfálticos não envelhecidos, a adição de fíler ao ligante puro diminuiu o valor da energia de fratura e, quanto maior o teor de fíler na mistura, menor o valor dessa propriedade. Como a energia de fratura é uma propriedade relacionada com a resistência á fadiga de ligantes asfálticos, com a previsão do desempenho do trincamento nas temperaturas intermediárias, quanto menor a energia de fratura, menor a habilidade da mistura em resistir ao trincamento por fadiga. Conclui-se que a adição de fíler no mástique diminui a resistência ao trincamento por fadiga nas temperaturas intermediárias, de forma análoga às observações realizadas no ensaio de fluência em viga, em que a utilização de maiores teores de fíler prejudica a resposta ao trincamento a baixas temperaturas.

Em relação aos resultados da energia de fratura após o envelhecimento no PAV convencional (20 horas a $100{ }^{\circ} \mathrm{C}$ ), quando comparados os valores do ligante asfáltico puro com os do mástique, a adição de fíler diminuiu o valor da energia de fratura, porém, essa diminuição é significativamente menor do que quando comparam-se o ligante puro e os mástiques sem envelhecimento. Assim, o envelhecimento aumenta a energia de fratura dos mástiques, o que aumenta a resistência ao trincamento por fadiga. Pode-se concluir que a presença de fíler na mistura durante o envelhecimento torna seus efeitos menos prejudiciais, porém, é necessário observar que isso ocorre apenas para teores baixos de fíler no mástique (relação f/a de 0,6 para o fíler de cimento Portland e pó calcário e 0,3 para o fíler de cal hidratada), pois para teores maiores de fíler a energia de fratura dos mástiques envelhecidos tem valores próximos aos sem envelhecimento. 
Quando analisamos os resultados da energia de fratura após o envelhecimento no PAV modificado (100 horas a $60{ }^{\circ} \mathrm{C}$ ), o efeito é o mesmo que o do PAV convencional, porém o aumento da energia de fratura dos mástiques envelhecidos no PAV modificado é maior, atingindo valores superiores, até mesmo ao do ligante asfáltico puro sem envelhecimento. Isso significa que o envelhecimento em temperatura menor e com a uniformização constante do mástique, visando simular da melhor forma a situação em campo, torna o mástique mais resistente aos efeitos do envelhecimento.

Em relação aos resultados de energia de fratura quanto ao tipo de fíler, os mástiques que apresentaram maiores valores de energia de fratura foram os compostos pelo fíler de pó calcário, enquanto o que apresentou o menor valor foram os compostos com cal hidratada. Porém, o efeito benéfico da presença do fíler mineral após o envelhecimento é muito mais notório para os mástiques compostos pelos fileres de cimento Portland e cal hidratada.

Nas análises de variâncias, os fatores que apresentaram maior influência na energia de fratura foram o teor de fíler e o tipo de fíler, porém esse último fator é mais significativo quando se considera o fíler de cal hidratada. O tipo de ligante é significativo apenas quando se considera o fíler de cal hidratada na resposta de energia de fratura. O envelhecimento convencional no PAV não influencia a resposta da energia de fratura, porém, o envelhecimento modificado tem efeito significativo.

\subsection{SUGESTÕES PARA TRABALHOS FUTUROS}

As sugestões para a continuidade da pesquisa são as seguintes:

- Realização dos ensaios mecânicos nas misturas asfálticas nas condições experimentais estimadas, tanto para verificação dos valores obtidos quanto para a validade do procedimento do cálculo estatístico;

- Realização de ensaios simulativos para avaliação da deformação permanente, já que o ensaio de compressão uniaxial estática fornece apenas parâmetros para avaliação desse defeito estrutural; 
- Realização de ensaios de caracterização do fíler mineral, como superfície específica, atividade superficial (energia de adsorção), distribuição granulométrica (análise granulométrica a laser), ensaios de microscopia ótica e de eletrônica para identificação da composição mineralógica, tamanho, forma e textura das partículas;

- Realização de ensaios na escala de matriz de agregado fino (mistura de ligante asfáltico, fíler e agregado fino) para avaliar a reologia e propriedades de fadiga, utilizando o “Dynamic Mechanical Analyses” (DMA);

- Realização de ensaios reológicos em mástiques asfálticos envelhecidos no Reômetro de Cisalhamento Dinâmico, comparando os diferentes procedimentos de envelhecimento. 
254 


\section{REFERÊNCIAS BIBLIOGRÁFICAS}

AASHTO (1991). Handbook of hot-mix asphalt paving. American Association of State Highway and Transportation Officials.

ABDALLA H.M.; KARIHALOO, B.L. (2003) "Determination of size-independent specific fracture energy of concrete from three-point bend and wedge splitting tests." Magazine of Concrete Research, Vol.55, pp. 133-141.

ABDULSHAFI, A.A.; MAJIDZADEH, K. (1985) “J-Integral and Cyclic Plasticity Approach to Fatigue and Fracture of Asphaltic Mixtures." Transportation Research Record. 1034, pp. 112-123.

ANDERSON, D.A. E DONGRE, R. (1995). "The SHRP Direct Tension Specification Test - Its Development and Use. Physical Properties of Asphalt Cement Binders", J.C. Hardin, Ed. ASTM Special Technical Publication 1241. American Society for Testing and Materials, Philadelphia, PA. pp. 51-66.

ANDERSON, D.A. (1987) Guidelines for Use of Dust in Hot Mix Asphalt Concrete Mixtures. Association of Asphalt Paving Technologists, v.56, p.492-516.

ANDERSON, D.A.; BAHIA, H.U; DONGRE, R. (1992) Rheological properties of mineral filerasphalt mixtures. Association of Asphalt Paving Technologists, v. 42, p 37-66.

ANDERSON, D A.; CHRISTENSEN, D. W. BAHIA, H. U.; DONGRÉ, R.; SHARMA, M. G.; ANTLE, C. E. e BUTTON, J. (1994) Binder Characterization and Evaluation: Volume 3 - Physical Characterization. Washington. Strategic Highway Research Program, National Research Council. Report SHRP-A-369.

ANDERSON, D.A.; GOETZ, W.H. (1973) “Mechanical Behavior and Reinforcement of Mineral Filler-Asphalt Mixtures" Proceedings of the Association of Asphalt Paving Technologists. Vol. 42, pp. 37-66.

ANDERSON, D. A.; LAPALU, L.; MARASTEANU, M.O.; HIR, Y. M. L; PLANCHE, J. P.; MARTIN, D. (2001) "Low-temperature thermal cracking of asphalt binders as ranked by strength and fracture properties" Journal of the Transportation Research Board, Volume 1766, page 1-6.

ANDRIESCU, A.; HESP, S.A.; YOUTCHEFF; J.S. (2004) "Essential and plastic works of ductile fracture in asphalt binders". Journal of the Transportation Research Board, Volume 1875, page 1-7.

ARMY CORPS OF ENGINEERS (1948) "Investigation of the Design and Control of Asphalt Paving Mixes", Waterways Experimental Station, Vicksburg, Miss., vol. 1, Technical Memo n 3-254. 
BAHIA, H. U. (1995) Critical Evaluation of Asphalt Modification Using Strategic Highway Research Program Concepts. Transportation Research Record, Washington, n. 1488, p. 82-88.

BAHIA, H.U.; ANDERSON, D.A.; CHRISTENSEN, D.W. (1992) "The Bending Beam Rheometer: a Simple Device for Measuring Low-Temperature Rheology of Asphalt Binders". Journal of the Association of Asphalt Paving Technologists, White Bear Lake, v. 61, pp. 117-153.

BARENBLATT, G.I. (1962) "The Mathematical Theory of Equilibrium Cracks in Brittle Fracture.” Advances in Applied Mechanics. Vol. VII, pp. 55-129.

BARKSDALE, R.D.; ALBA, J.; KHOSLA, N.P., KIM, R.; RAHMAN, M.S. (1997) Laboratory Determination of Resilient Modulus for Flexible Pavement Design. Project 1-28. Final Report. Georgia Tech Project E20-634, EUA.

BECHARA, M. F.; FAXINA, A. L.; FABBRI, G. T. P.; GIGANTE, A. C.; NASCIMENTO, D. R. (2008) Propriedades Reológicas de Mástiques Asfálticos a Altas Temperaturas. 39a Reunião Anual de Pavimentação. Recife/PE.

BIRGISSON, B., ROQUE, R.; VARADHAN, A.; THAI, T.; JAISWAL, L. (2006). "Evaluation of Thick Open Graded and Bonded Friction Course for Florida”. Final Report. Florida Department of Transportation, University of Florida, Gainesville, Março de 2006.

BOX, G.E.P.; HUNTER, W.G.; HUNTER, J.S. (1978). Statistics for Experimenters: an Introduction to Design, Data Analysis, and Model Building. Jonh Wiley \& Sons. New York.

BRAHAM, A. F.; BUTTLAR, W. G.; MARASTEANU, M. O. (2007) "Effect of Binder Type, Aggregate, and Mixture Composition on Fracture Energy of Hot-Mix Asphalt in Cold Climates". Transportation Research Record: Journal of the Transportation Research Board, No. 2001, Transportation Research Board of the National Academies, Washington, D.C., 2007, pp. 102-109. DOI: 10.3141/2001-12

BROWN E. R.; KHANDAL, P.S.; ZHANG, J. (2001) "Performance Testing for Hot Mix Asphalt." NCAT Report No 01-05.

BROWN, E.R.; COOLEY, Jr. L.A. (1999) Designing Stone Matriz Asphalt Mixtures for RutResistant Pavements. NCHRP Report 425. National Cooperative Highway Research Program. Transportation Research Board. National Research Council. Washington, D.C.

BUTTLAR, W.G.; YOU, Z. (2001) Discrete element Modeling of Aspahlt Concrete: a MicroFabric Approach. CD Room. TRB $80^{\text {th }}$ Annual Meeting. Transportation Research Board. Washington D.C.

CARPINTERI, A.; FERRO, G. (1994) "Size effects on tensile fracture properties: a unified explanation based on disorder and fractality of concrete microstructure." Materials and Structures. Vol. 28, pp. 563-571. 
CARPINTERI, A.; FERRO, G. (1998) "Scaling behavior and dual renormalization of experimental tensile softening responses." Materials and Structures. Vol. 31, pp. 303309.

CASTELO BRANCO, V.T.F. (2008) A Unified Method for the Analysis of Nonlinear Viscoelasticity and Fatigue Cracking of Asphalt Mixtures Using the Dynamic Mechanical Analyzer. Tese de Doutorado. Texas A\&M University. EUA.

CHEN, J.S.; PENG, C.H. (1998) Analyses of Tensile Failure Properties of Asphalt-mineral Filler Mastic. Journal of Materials in Civil Engineering, v.10, n.4, p. 256-262.

COELHO, V. (1996) Contribuição ao Estudo das Deformações Permanentes, nas Condições do Brasil, em Camadas de Concreto Asfálticos de Pavimentação. São Carlos, 281p. Tese de Doutorado. Escola de Engenharia de São Carlos - Universidade de São Paulo.

COLlOP, A.; CEBON, D. (1995) "A Theoretical Analysis of Fatigue Cracking in Flexible Pavements." Proceedings of the Institution of Mechanical Engineers. Vol. 209, pp. 345361.

COMINSKY, R.; LEAHY, R.B.; HARRIGAN, E.T. (1994) Level One Mix Design: Materials Selection, Compaction and Conditioning. Repot n. A-408, Strategic Highway Research Program. National Research Council. Washington, D.C.

COMINSKY, R.J; KILLINGSWORTH, B.M; ANDERSON， R.M; ANDERSON， D.A; CROCKFORD, W.W. (1998). Quality control and acceptance of SUPERPAVE - designed hot mix asphalt. National Cooperative Highway Research Program, report 409, p 1-26.

COOLEY JR., L.A.; STROUP-GARDINER, M.; BROWN, E.R.; HANSON , D.I.; FLETCHER, M.O. (1998) "Characterization Of Asphalt-Filler Mortars With Superpave Binder Tests". Proceedings of the Association of Asphalt Paving Technologists. vol 67, pp. 42-56.

CRAUS, J.; ISHAI, I. (1977) "A Method for the Determination of the Surface Area of Fine Aggregate in Bituminous Concrete," American Society for Testing and Materials Journal of Testing and Evaluation, JTEVA, Vol. 5, pp. 284-291.

CRAUS, J.; ISHIAI I.; SIDES A. (1978a). Guidelines for use of dust in hot-mix asphalt concrete mixtures. Proceedings of Asphalt Association of Paving Technologists. v. 56, pp. 492-516.

CRAUS, J.; ISHIAI I.; SIDES A. (1978b) "Some Physico-Chemical Aspects on the Effect of the Filler on the Properties and Behavior of Bituminous Paving Mixtures," Asphalt Paving Technology, Vol. 47, pp. 558-588.

CRAUS, J.; ISHIAI I.; POR, N. (1979) “Selective Sorption in Filler-Bitumen Systems," Journal of Material Science, Vol. 14, No. 9, pp. 21952204.

DNER-EM 367/97 (1997). Material de Enchimento para Misturas Betuminosas. Departamento Nacional de Estradas de Rodagem. Rio de Janeiro. 
DUGDALE, D.S. (1960) "Yielding of Steel Sheets Containing Slits." Journal of the Mechanics and Physics of Solids. Vol. 8, pp. 100-108.

DUKATZ, E. L.; D. A. ANDERSON, R. N. (1980) "The Effect of Various Fillers on the Mechanical Behavior of Asphalt and Asphaltic Concrete", Association of Asphalt Paving Technologists, v.49, p.530-557.

ELICES M.; GUINEA, G.V.; PLANAS, J. (1992) "Measurement of the fracture energy using the three point bend test: Part 3 - Influence of cutting the $P$ - $\delta$ tail." Materials and Structures. Vol. 25, pp. 327-334.

FAXINA, A.L. (2006) "Estudo da Viabilidade Técnica do Uso do Resíduo de Óleo de Xisto como Óleo Extensor em Ligantes Asfalto-Borracha". Tese (Doutorado) - Escola de Engenharia de São Carlos, Universidade de São Paulo, São Carlos.

FERNANDES JR., J.L. (1994). Investigação dos defeitos das solicitações do tráfego sobre o desempenho de pavimentos. Tese (Doutorado) - Escola de Engenharia de São Carlos, Universidade de São Paulo. São Carlos, 1994.

GUBLER, R.; LIU, Y.; ANDERSON, D.; PARTL, M. (1999) "Investigation of the System Filler and Asphalt Binders by Rheological Means". Proceedings of the Association of Asphalt Paving Technologists. vol 68, pp. 284-299

GONTIJO, P.R.A. (1980) A Fadiga de Misturas Betuminosas. Condições Essencial na Desenvolvimento Racional de Pavimentos Flexíveis. $15^{\circ}$ Reuniao Anual de Pavimentação. $55 \mathrm{p}$.

GRECO, J. A. S. (2004) Avaliação da Influência de Alguns Fatores nas Propriedades Mecânicas de Misturas Asfálticas Densas, à Luz da Técnica de Planejamento e Análise de Experimentos Fatoriais Fracionário Assimétricos. 340p. Tese de Doutorado Escola de Engenharia de São Carlos, Universidade de São Paulo, São Carlos.

HARM, E.; HUGHES, C. (1989) Paving Specifications and Inspection Related to Pavement Performance. Journal of the Association of Asphalt Paving Technologists. Vol. 58.

HARRIS, B.M., STUART, K.D. (1995). Analysis of Mineral Fillers and Mastic Used in Stone Matrix Asphalt. Journal of the Association of Asphalt Paving Technologists - AAPT, v. 64, p. 54-95, Portland, Oregon, EUA.

HIGHWAY RESEARCH BOARD (1962) The AASHTO Road Test. Washington, D.C. Highway Research Board, Special Report 73, 117p.

HILLERBORG, A.; MODEER, M.; PETERSSON, P.E.(1976) "Analysis of crack formation and crack growth in concrete by means of fracture mechanics and finite elements." Cement Concrete. Res 6, pp. 773-782. 
HILLERBORG A. (1985) "Results of Three Comparative Test Series for Determining the Fracture Energy GF of Concrete." Materials and Structures. Vol.18, No. 107, pp. 407413.

HOARE, T. R.; HESP, S.A. (2000) "Low-temperature fracture testing of asphalt binders" Journal of the Transportation Research Board, Volume 1728 /2000, page 36-42.

HOIBERG, A.J. (1964) "Bituminous Materials: Asphalts, Tars and Pitches". Jonh Wiley and Sons. New York.

HUANG, S.C.; ZENG, M. (2007) “Characterization Of Aging Effect On Rheological Properties Of Asphalt-Filler Systems". International Journal of Pavement Engineering, Vol. 8, No. 3, setembro de 2007, pp. 213-223

HUBER, G.A.; JONES, J.C.; MESSERSMITH, P.E.; JACKSON, M. (1998) Contribution of Fine Aggregate Angularity and Particle Shape to Superpave Mixture Performance. Transportation Research Record, n. 16099, pp. 28-35.

ILDEFONSO, J.S. (2007). Análise de Viabilidade Técnica da Utilização do copolímero Etileno Acetato de Vinila (EVA) Descartado pela Indústria Calçadista em Misturas Asfálticas (Processo Seco). Dissertação (Mestrado) - Escola de engenharia de São Carlos, Universidade de São Paulo. 330p. São Carlos.

ISHAI, I.; CRAUS, J. (1977) "Effects of the Filler on Aggregate-Bitumen Adhesion Properties in Bituminous Mixtures". Proceedings of the Association of Asphalt Paving Technologists. Vol. 46, pp. 228-258.

ISHAI, I.; CRAUS, J. (1978) “Effect of the Filler in Bituminous Paving Mixtures," Proceedings, RILEM International Symposium on Aggregates and Fillers, Budapest, Hungary, outubro de 1979.

ISHAI, I.; CRAUS, J.; SIDES, A. (1979) “Criteria for Evaluation of filler Properties and Their Influence on the Design and Behavior of Bituminous Mixtures". Research Report 79-19. Transportation research Institute, Technion, Haifa, Israel.

JACOBS, M.M.J. (1995) "Crack Growth in Asphaltic Mixes.” Tese (Doutorado). Delft Universiy of Technology, Road and Railroad Research Laboratory.

JACOBS, M.M.J.; HOPMAN , P.C.; MOLENAAR, A.A.A. (1996) "Application of Fracture Mechanics Principles to Analyze Cracking in Asphalt Concrete." Journal of the Association of Asphalt Paving Technologists. Vol.65, pp. 1-39.

JENQ, Y.S. ; PERNG, J.D. (1991) “Analysis of Crack Propagation in Asphalt Concrete Using a Cohesive Crack Model.” Transportation Research Record. No. 1317, pp. 90-99.

KALLAS, B.F.; PUZINAUSKAS, V.P. (1961). “A Study of Mineral Fillers in Asphalt Paving Mixtures". Proceedings of Asphalt Association of Paving Technologists. V. 30, pp. 493525 
KANDHAL, P.S.; FOO, K.Y.; MALLICK, R.B. (1998). Critical review of voids in mineral aggregate requirements in SUPERPAVE. Transportation Research Record, n. 1609, p21-27.

KHATTAR, M.J.; BALADI, G.Y. (2001) Fatigue and Permanent Deformation Models for Polymer-Modified Asphalt Mixtures. Transportation Research Record.

KAVUSSI, A.; HICKS, R.G. (1997) Properties of bituminous mixtures containing different fillers. Proceedings of Asphalt Association of Paving Technologists.

KIM, Y.R.; LITTLE, D.L.; BENSON, F. (1990) "Chemical and Mechanical Evaluation on Healing Mechanism of Asphalt Concrete." Journal of the Association of Asphalt Paving Technologists. Vol.59, pp. 240-276.

KIM, Y.R.; LEE, H.J.; LITTLE, D.N. (1997) "Fatigue Characterization of Asphalt Concrete using Viscoelasticity and Continuum Damage Theory." Journal of the Association of Asphalt Paving Technologists. Vol.66, pp. 520-569.

KIM, Y.R.; LITTLE, D.N.; SONG, I. (2003) Effect of mineral fillers on fatigue resistance and fundamental material characteristics - mechanic evaluation. Transportation Research Record, Washington, n.1832, p1-8.

KOH, C.; ROQUE, R. (2010) "Use of Nonuniform Stress-State Tests to Determine Fracture Energy of Asphalt Mixtures Accurately". Transportation Research Record: Journal of the Transportation Research Board, No. 2181, Transportation Research Board of the National Academies, Washington, D.C., 2010, pp. 55-66.

LEE, H.J.; KIM, Y.R. (1998a). "Viscoelastic Constitutive Model for Asphalt Concrete under Cyclic Loading." Journal of Engineering Mechanics. Vol. 124, No 1, pp. 32-40.

LEE, H.J; DANIEL, J.S.; KIM, R.Y. (2000) Continuum Damage Mechanics-Based Fatigue Model of Asphalt Concrete. Journal of Materials in Civil Engineering, Vol. 12, No. 2, 2000, pp. 105-112.

LIMA, C.S.; TOMÉ, L.G.A.; SANT'ANA, H.B.; SOARES, J.B.; SOARES, S. A. (2008) “Estudo do comportamento reológico por meio de curvas mestres dos ligantes asfalto-borracha". $19^{\circ}$ Encontro de Asfalto, IBP, 9 a 11 junho, RJ.

LITTLE, D.N.; BUTTON, J.W. ; WHITE, R.M. ; ENSLEY, E.K. ; KIM, Y.; AHMED, S.J. (1987) "Investigation of Asphalt Additives." Texas Transportation Institute, Report no FHWA/RD-87/001.

LITTLE, D.N.; BUTTON, J.W.; YOUSSEF, H. (1993) "Development of Criteria to Evaluate Uniaxial Creep Data and Asphalt Concrete Permanent Deformation Potential”. Transportation Research Record 1417, p.49-57.

MACK, C. (1957) "Physical Properties of Asphalts in Thin Films". Industrial and Engeneering Chemistry, Março de 1957. 
MARGOLIN, B.H. (1968). Orthogonal Main Effect 2n3n Designs and Two-factor Interaction Aliasing. Technometrics, v.10, n.3, p.559-73

MARQUES, G.L.O. (2004). Utilização do Módulo de Resiliência como Critério de Dosagem de Mistura Asfáltica; Efeito da Compactação por Impacto e Giratória.461p. Tese de Doutorado. Universidade Federal do Rio de Janeiro - COPPE-UFRJ.

MAJIDZADEH K.; KAUFMANN, E. M., RAMSAMOOJ, D.V. (1971) “Application of Fracture Mechanics in the Analysis of Pavement Fatigue." Journal of the Association of Asphalt Technologists. Vol.40, pp.227-246.

McGENNIS, R.B.; ANDERSON, T.M.; KENNEDY, T.W.; SOLAIMANIAN, M. (1994). Background of Superpave asphalt mixture design and analysis. Asphalt Institute Report FHWA-SA-95-003.

MEDINA, J. (1997) Mecânica dos Pavimentos. $1^{\circ}$ Edição, 380p. Rio de Janeiro. Editora UFRJ.

MEDINA, J.; MOTTTA, L.M.G. (2005). Mecânica dos pavimentos. $2^{\mathrm{a}}$ ed. 574p. Rio de Janeiro, UFRJ.

MIER, J.G.M; VAN VLIET, M.R.A. (1999) "Effect of strain gradients on the size effect of concrete in uniaxial tension." International Journal of Fracture. Vol.94, pp. 195-219.

MIHASHI H.; TAKHASHI, H.; WITTMANN, F.H. (1989) "Tension-Softening Curve Measurements for Fracture Toughness Determination in Granite." Proceedings of the International Workshop on Fracture Toughness and Fracture Energy-Test Methods for Concrete and Rock. Balkema, Rotterdam, pp.47-55.

MOHAMED, A.; NOFAL, M. (1998). Structural Design of Urban Roads. APWA International Publics Works Congress.

MOHAMED, H.H.; YUE, Z. (1994) Criteria for Evaluation of Rutting Potential Based on Repetitive Uniaxial Compression Test. Transportation Research Record 616, p. 38-40.

MOMM, L. (2001) Fadiga à Deformação Controlada em Modo Contínuo do concreto Asfáltico $33^{\circ}$ Reuniao Anual de Pavimentação. Florianópolis, SC.

MOLENAAR, A.A.A.; HAGOS, E.T.; VAN DE VEM, F.C.(2010) "Effects of Aging on the Mechanical Characteristics of Bituminous Binders in PAC'. Journal of Materials in Civil Engineering, Vol. 22, No. 8, agosto de 2010. DOI: 10.1061

MONTGOMERY, D. C. (2009) "Introduction to Statistical Quality Control”, 6th ed., John Wiley \& Sons, New York.

MOTTA, L.M.G., LEITE, L.F.M. (2000). Efeito do Fíler nas Características Mecânicas das Misturas Asfálticas. Anais do $11^{\circ}$ congresso Panamericano de Engenharia de Trânsito e Transporte, pp. 1007-1017, Gramado-RS, 19-23 Novembro. 
MOTTA, L.M.G., PINTO, S. (1994) “O Uso de Ensaios Estáticos na Definição de Parâmetros de Comportamento de Misturas Asfálticas" $12^{\circ}$ Encontro de Asfalto - Instituto Brasileiro de Petróleo e Gás. P. 152-178. Rio de Janeiro.

MOTTA, L.M.G.; TONIAL, I.; LEITE, L.M. (1996) Princípios do Projeto e Análise SUPERPAVE de Misturas Asfálticas. Tradução Comentada, Instituto Brasileiro do Petróleo - IBP.

MOURÃO, F.A.L. (2003) Misturas Asfálticas de Alto Desempenho Tipo SMA. Dissertação de Mestrado COPPE-UFRJ, Rio de Janeiro, RJ, Brasil.

MULL, M.A.; STUART, K.; YEHIA, A. (2002) "Fracture Resistance Characterization of Chemically Modified Crumb Rubber Asphalt Pavement." Journal of Material Science. Vol. 37, pp. 557-566.

MYERS, L. (2000) "Development and Propagation of Surface-Initiated Longitudinal Wheel Path Cracks in Flexible Highway Pavements.” Tese (Doutorado). University of Florida.

MYERS, L.; ROQUE, R.; BIRGISSON, B. (2001) “ Propagation Mechanisms for SurfaceInitiated Longitudinal Wheel Path Cracks." Transportation Research Record. No. 1778, pp. 113- 121.

PILAT, J.; RADZISZEWSKI, P.; KALABISKA, M. (2000) The Analysis of Visco-Elastic Properties of Mineral-Asphalt Mixes with Lime and Rubber Powder. $2^{\text {nd }}$ Eurasphalt and Eurobitume Congress. Barcelona.

PINILLA, A. (1965) O sistema fíler-betume, algumas considerações sobre sua importância nas misturas densas. Conselho Nacional de Pesquisa. Instituto de Pesquisas Rodoviárias.

PINTO, S. (1991) Estudos do comportamento à Fadiga de Misturas Betuminosas e Aplicações na Avaliação de Pavimentos. Tese de Doutorado. COPPE-UFRJ. Rio de Janeiro, RJ, Brasil.

PINTO, S.; PREUSSELER, E. (2002) Pavimentação Rodoviária - Conceitos Fundamentais sobre Pavimentos Flexíveis. Rio de Janeiro. Impressão COPIARTE.

PONNIAH, J.E.; CULLEN, R.A.; HESP, S.A.(1996), "Fracture energy specifications for modified asphalts" Preprints of Papers, Journal Volume 41, Journal Issue 4, Conference 212, National meeting of the American Chemical Society (ACS), Orlando, FL, USA, 2530 August 1996.

PUZINAUSKAS, V.P. (1969). “Filler in Asphalt Mixtures,” Asphalt Institute, RR69-2.

RAMSAMOO, J.D.V. (1980) "Fatigue Cracking of Asphalt Pavements." Journal of Transportation Research Record. No. 756, pp.43-48.

RAMSSAMOOJ, D.V. (1991) "Prediction of Fatigue Life of Asphalt Concrete Beams from Fracture Test." Journal of Testing and Evaluation. Vol.19, No. 3, pp. 231-239. 
RAMSSAMOOJ, D.V. (1993) "Fracture of Highway and Airport Pavements." Journal of Engineering Fracture Mechanics. Vol. 44, No. 4, pp. 609-626.

RICE, J.R. (1968) "A Path Independent Integral and the Approximate Analysis of Strain Contraction by Notches and Cracks." Journal of Applied Mechanics. June, pp. 379-386.

RICHARDSON, C. (1915) “Asphalt Construction for Pavements and Highways”. McGraw-Hill Book Co.

RIGDEN, P.J. (1947) "The Use of Fillers in Bituminous road Surfacing. A Study of Filler-Binder Systems in Relation to Filler Characteristics". Journal of the Society of Chemical Industry. Setembro de 1947.

ROBERTS, F.L.; KANDHAL, P.S.; BROWN, E.R.; LEE, D.Y.; KENNEDY, T.W. (1991) Hot Mix Asphalt Materials, Mixture Design and Construction. $1^{\circ} \mathrm{ed}$. NAPA Research and Education Foundation, National Center for Asphalt Technology - NCAT. Lanham, Maryland, EUA.

ROBERT, F.L., KANDHAL, P.S., BROWN, E.R. (1996). Hot Mix Asphalt Materials, Mixture Design and Construction, Second Edition, NAPA Educational Foundation Ingham, Maryland.

ROQUE, R.; ZHANG, Z.; SANKAR, B. (1999) "Determination of Crack Growth Rate Parameters of Asphalt Mixtures using the Superpave Indirect Tension Test (IDT)." Journal of the Association of Asphalt Paving Technologists. Vol. 68, pp. 404-433.

ROQUE R.; BIRGISSON, B.; SANGPTEGNAM , S.; ZHANG, Z. (2002). "Asphalt Fracture Mechanics: A Fundamental Crack Growth Law for Asphalt Mixtures." Journal of the Association of Asphalt Paving Technologists. Vol. 71, pp. 816-827.

ROQUE, R., LOPP, G., LI, W., NIU, T. (2009) “Evaluation Of Hybrid Binder Use In Surface Mixtures In Florida” Final report for FDOT BD-545 Contract, University of Florida, Gainesville, FL.

ROQUE, R.; NIU, T.; LOOP, G. (2012) Development Of A Binder Fracture Test To Determine Fracture Energy Final report for FDOT BDK-75-977-27 Contract, University of Florida, Gainesville, FL.

ROMEO, E. (2008) "Measurement and Prediction Of Fundamental Tensile Failure Limits Of Hot Mix Asphalt (HMA)”. Tese (Doutorado) Univesity of Florida, Gainesville, FL.

SADD, M.H.; DAI, Q. (2001) Effects of Microstructure on the Static and Dynamic Behavior of Recycled Asphalt Material. University of Rhode Island Transportation Center Report on Project $\mathrm{n}^{\circ}$ 536108. University of Rhode Island.

SADD, M.H.; DAI, Q.; PARAMESWARAN, V.; SHUKLA, A. (2002) Microstructural Simulation of Asphalt Materials: Modeling and Experimental Verification. $15^{\text {th }}$ ASCE Engineering Mechanics Conference. Columbia University. New York. 
SANTANA, H. (1995). Considerações sobre os Nebulosos Conceitos e definições de Fíler em Misturas Asfálticas. 29a Reunião Anual de Pavimentação, Cuiabá. Associação Brasileira de Pavimentação.

SANTOS, G.C.R. (2005) Avaliação das Influências do Tipo de Ligante e do Volume de Vazios na Vida de Fadiga de Algumas Misturas Asfálticas. Dissertação de Mestrado. Escola de Engenharia de Sáo Carlos - Universidade de São Paulo, São Carlos.

SCHAPERY R.A. (1973) "A Theory of Crack Growth in Visco-Elastic Media." Report MM 2764-73-1, Mechanics and Materials Research Center. Texas A\&M University, College Station, TX.

SCHAPERY R.A. (1975) "A Theory of Crack Initiation and Growth in Visco-Elastic Media, I: Theoretical Development, II: Approximate Methods of Analysis, III: Analysis of Continuous Growth." International Journal of Fracture. Vol. 11, No. 1, pp. 141-159. Vol. 11, No. 3, pp 369-388 and Vol. 11, No. 4, pp. 549-563.

SCHAPERY R.A. (1978) “A Method for predicting Crack Growth in Non-Homogeneous ViscoElastic Media.” International Journal of Fracture. Vol. 14, No. 3, pp. 293-309.

SCHAPERY, R.A. (1984) "Correspondence Principles and a Generalized J-Integral for Large Deformation and Fracture Analysis of Viscoelastic Media." International Journal of Fracture. Vol. 25, pp. 195-223.

SEDWICK, S. C. (1998) "Effect of Asphalt Mixture Properties and Characteristics on SurfaceInitiated Longitudinal Wheel Path Cracking”. Dissertação (Mestrado). Department of Civil and Coastal Engineering, University of Florida, Gainesville,

SEO, Y.; KIM, Y.R.; SCHAPERY, R.; WITCZAC, M.; BONAQUIST, R. (2004) "A Study of Crack-Tip Deformation and Crack Growth in Asphalt Concrete using Fracture Mechanics." Journal of the Association of Asphalt Paving Technologists. Vol. 73, pp. 697-730.

SMITH, B.J.; HESP, S.A.M. (2000) Crack Pinning in Asphalt Mastic and Concrete: Effect of Rest Periods and Polymer Modifiers on the Fatigue Life. $2^{\text {nd }}$ Eurasphalt and Eurobitume Congress. Barcelona.

SOARES, J.B.; CAVALCANTE, V.T.F. (2001) o Efeito do Tipo e do Teor de Fíler nas Propriedades Mecânicas das Misturas Asfálticas. Anais da $33^{\mathrm{a}}$ Reunião Anual de Pavimentação. Florianópolis-SC.

SOUSA, J.B.; CRAUS, J.; MONISMITH, C.L. (1991) "Summary Report on Permanent Deformation in Asphalt Concrete". SHRP-A/IR-91-103. Strategic Highway Research Program. National Research Council. Washington, DC, USA.

SOUZA, J.N.; RODRIGUES, J.K.G; SOUZA NETO, P.N. (1998). Utilização do Resíduo Proveniente da Serragem de Rochas Graníticas como Material de Enchimento em 
Concretos Asfálticos Usinados a Quente. Federação das Indústrias do Estado do Ceará IEL. (http://www.sfiec.org.br/).

STASTNA, J.; ZANZOTTO, L.; HO, K. (1994) "Fractional Complex Modulus Manifested in Asphalts". Rheologica Acta, vol. 33, p. 344-354, 1994.

SULAIMAN, S.J; STOCK, A.F. (1995) "The Use of Fracture Mechanics for the Evaluation of Asphalt Mixes." Journal of the Association of Asphalt Paving Technologists. Vol. 64, pp. 500-533.

SWARTZ S.E.; REFAI, T.M.E. (1987) "Influence of Size Effects on Opening Mode Fracture Parameters for Precracked Concrete Beams in Bending." Proceedings of the SEM/RILEM International Conference on Fracture of Concrete and Rock. Huston.

TANGELLA S.C.S.R.; CRAUS, J.; DEACON, J.A.; MONISMITH, C.L. (1990). Summary report on fatigue response on asphalt mixture. TM-UCB-A-003A-89-3, Strategic Highway Research Program (SHRP) - Project A-003-A. Institute of Transportation Studies. University of California. Berkley, California, 1990.

TAYBALI, A.A.; GOODRICH, J.L.; SOUSA, J.B.; MONISMITH, C.L. (1992) Influence of the Rheological Properties of Modified Asphalt Binders on the Load Deformation Characteristics of the Binder - aggregate Mixtures. American Society for Testing and Materials. ASTM STP 1108, p. 77-95.

TRAXLER, R.N. (1937) "The Evaluation of Mineral Powders as Filler for Asphalts". Proceedings of the Association of Asphalt Paving Technologists. Janeiro de 1937.

TUNNICLIFF, D. G. (1962). “A Review of Mineral Filler” Proceedings of Asphalt Association of Paving Technologists. v. 31, pp. $118-150$.

VALKRING, C. P.; LANCON, D.J.L.; HILSTER, STOKER, D.A. (1990) Rutting Resistance of Asphalt Mixes Containing Non-conventional and Polymer-modified Binders. Symposium - Improved Rut Resistance, Association of Asphalt Paving Technologists (AAPT). Proceedings, p. 590-609.

VON QUINTUS, H. L.; SCHEROCMAN, J.; HUGHES, C. (1989) “Asphalt-Aggregate Mixture Analysis System: Philosophy of the Concept. Asphalt Concrete Mix Design: Development of More Rational Approaches". ASTM STP 1041. American Society for Testing and Materials, Philadelphia, Pa., pp. 15-38.

WEGAN, V., BRULE, B. (1999), "The Structure of Polymer Modified Binders and Corresponding Asphalt Mixtures," Association of Asphalt Paving Technologists, Vol. 68.

WEN, H.; KIM, Y. R. (2002) "Simple Performance Test for Fatigue Cracking and Validation with WesTrack Mixtures". Transportation Research Record: Journal of the Transportation Research Board, No. 1789, Transportation Research Board of the National Academies, Washington, D.C., pp. 66-72. 
WITTMANN F.H. (1986) “Fracture Toughness and Fracture Energy of Concrete." Proceedings of the International Conference on Fracture Mechanics of Concrete. Lausanne, Switzerland.

WITTMANN, F.H.; MIHASHI, H.; NOMURA, N. (1990) "Size effect on fracture energy of concrete.” Engineering Fracture Mechanics. Vol. 35, pp. 107-115.

WITCZAK, 2004

WITCAZK e BARI, 2004

WHITEOAK, D. (1990) The Shell Bitumen Handbook.

WNUK, M.P. (1971) "Subcritical Growth of Fracture." International Journal of Fracture Mechanic. Vol. 7, pp. 383-486.

YILDIRIM, Y. (2000). “Mixing and Compaction Temperatures for Superpave Mixes". Journal of the Association of Asphalt Paving Technologists, White Bear Lake, v. 69, p.34-71.

YOU, Z.; BUTTLAR, W.G. (2005) Development of a Microfabric Discrete Element Modeling Techniques to Predict Complex Modulus of Asphalt-Aggregate Hollow Cylinders Subjected to Internal Pressure. CD Room. TRB $84^{\text {th }}$ Annual Meeting. Transportation Research Board. Washington D.C.

XU S.; ZHAO, G. (1991) "Fracture Energy of Concrete and its Variational Trend in Size Effect studied by using Three Point Bending Beams." Journal of Dalian University of Technology. Vol. 31, No. 1, pp. 79-86.

ZHANG, Z. (2000)Identification of Crack Growth Law for Asphalt Mixtures Using the Superpave Indirect Tensile Test (IDT). Tese (Doutorado). University of Florida, Gainesville.

ZHANG, Z; ROQUE, R.; BIRGISSON, B. (2001) "Evaluation of Laboratory-Measured Crack Growth Rate for Asphalt Mixtures". Transportation Research Record. No. 01-0272, pp. 67-75.

ZANZOTTO, L.; STASTNA, J.; HO, K. (1996) “Characterization of Regular and Modified Bitumens Via Their Complex Modulus”. Journal of Applied Polymer Science, vol. 59, p. 1897-1905, 1996. 


\section{APÊNDICES}


APÊNDICE A - PROPRIEDADES VOLUMÉTRICAS DOS CORPOS DE PROVA UTILIZADOS NOS ENSAIOS MECÂNICOS 


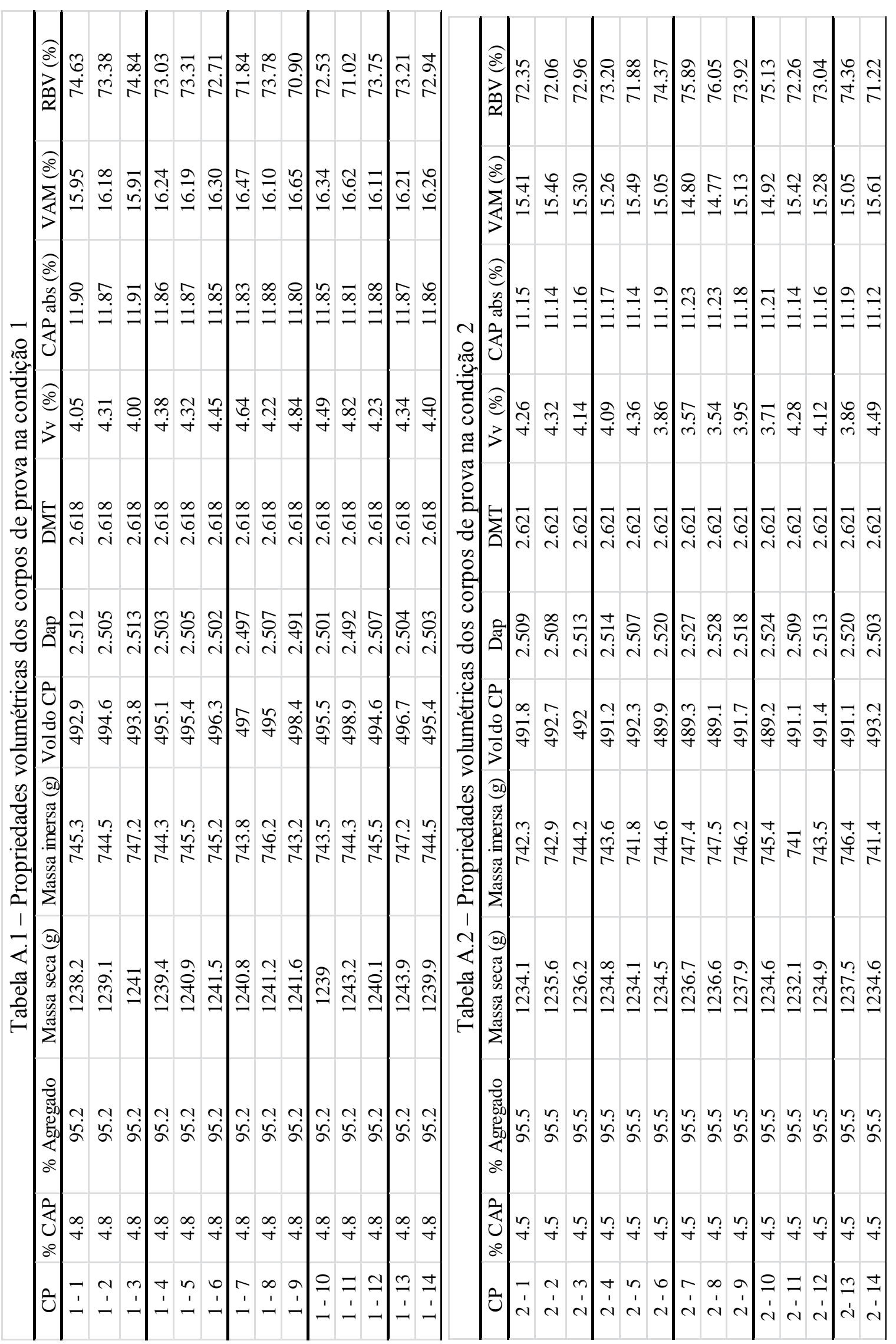




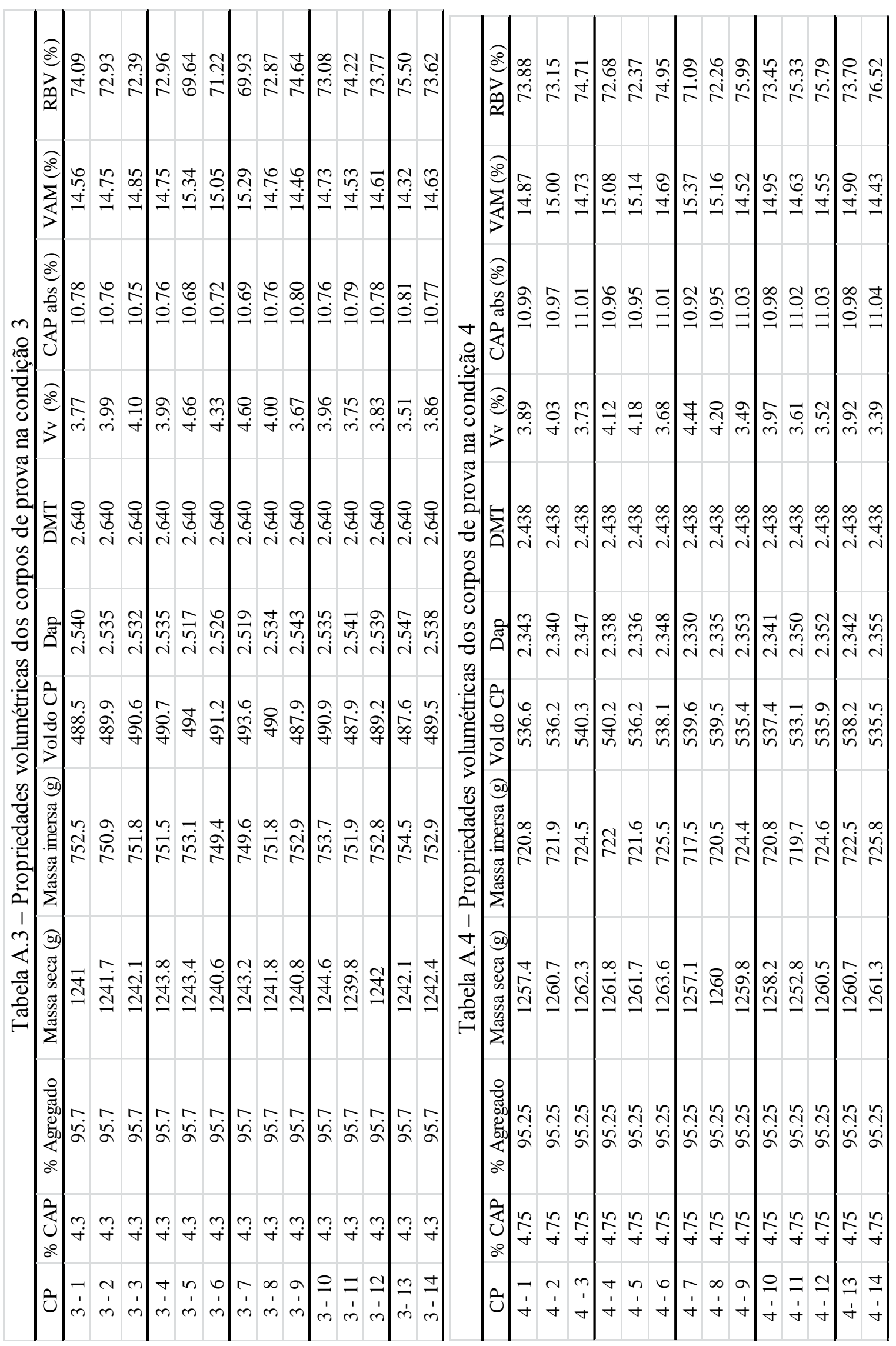




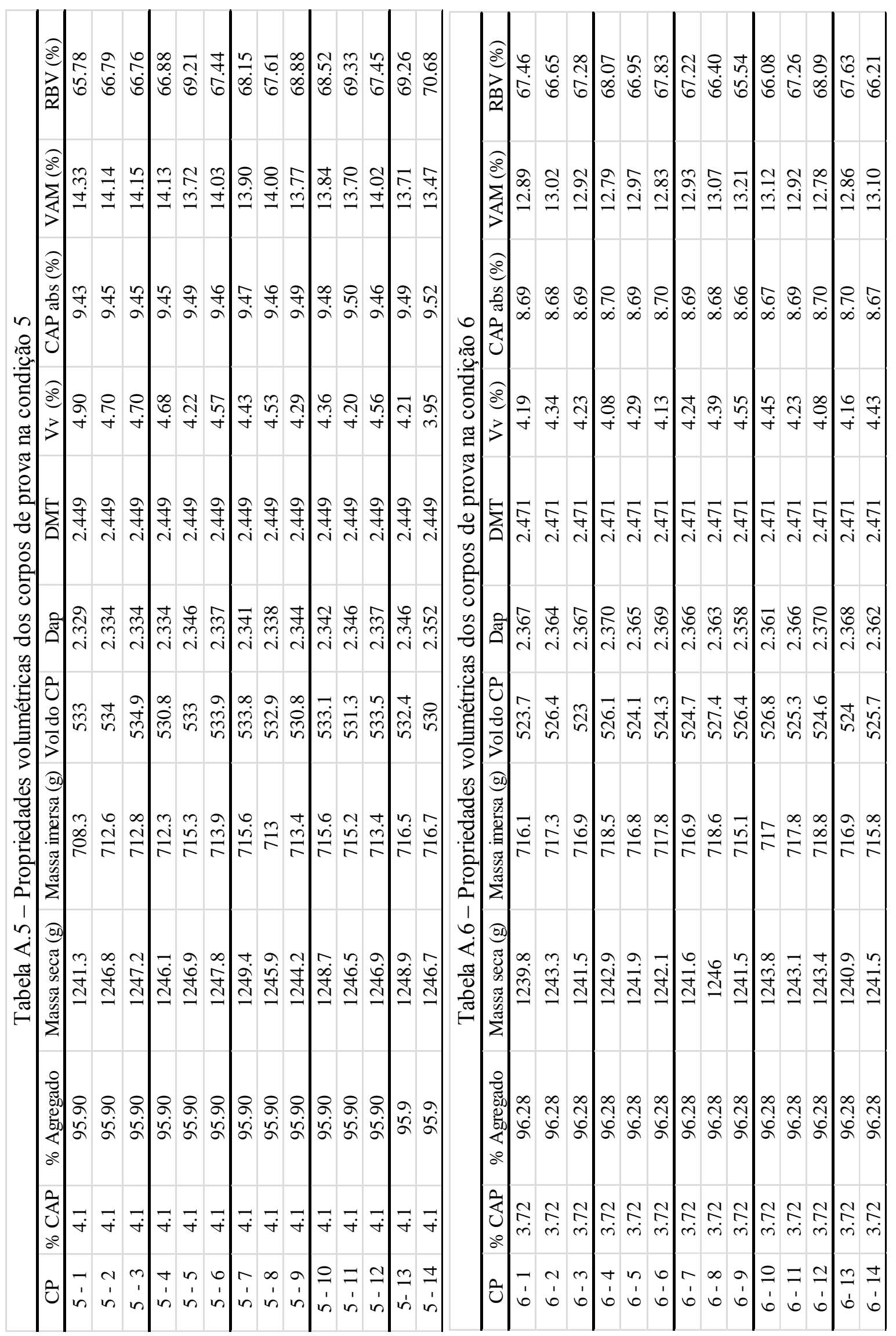




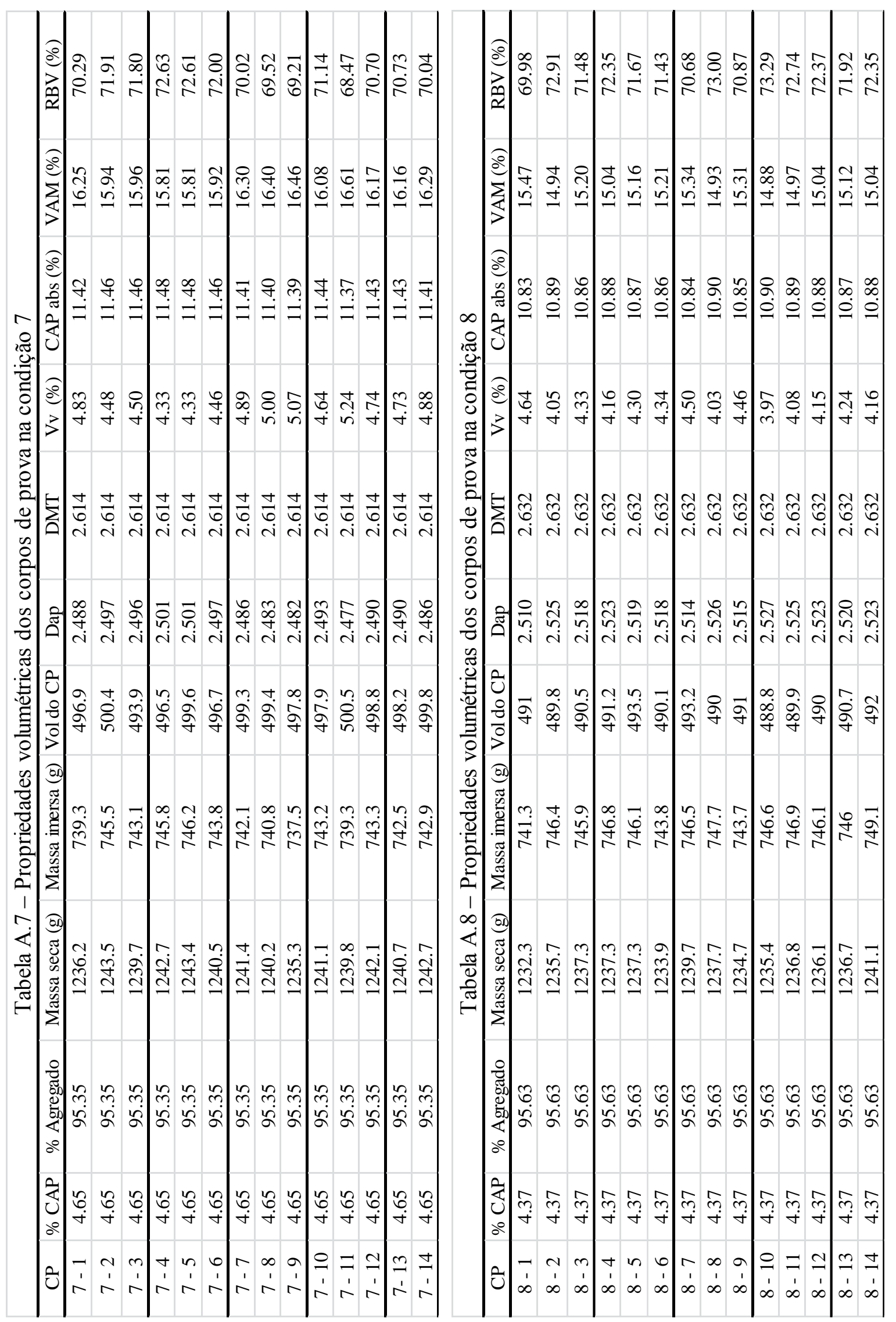




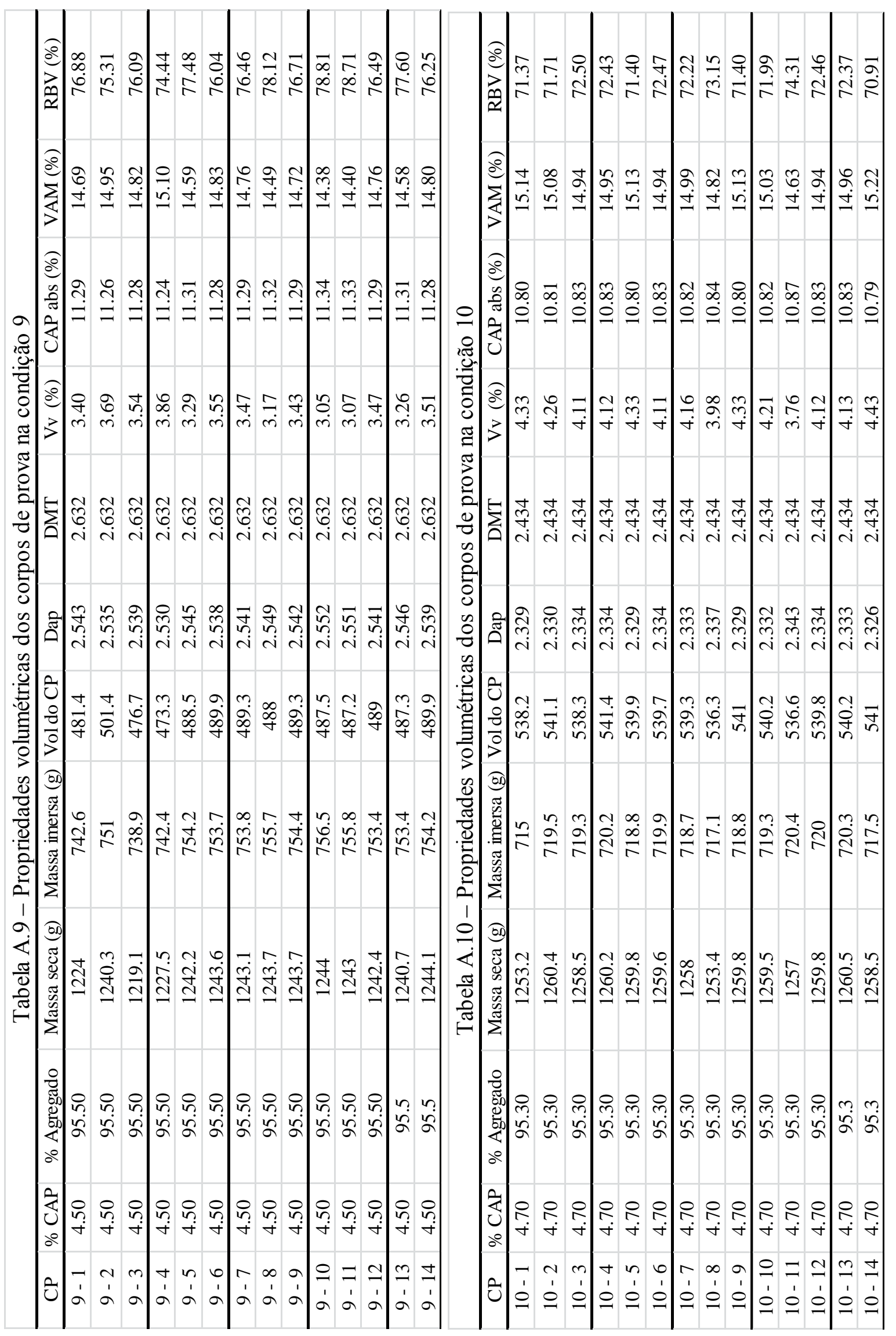




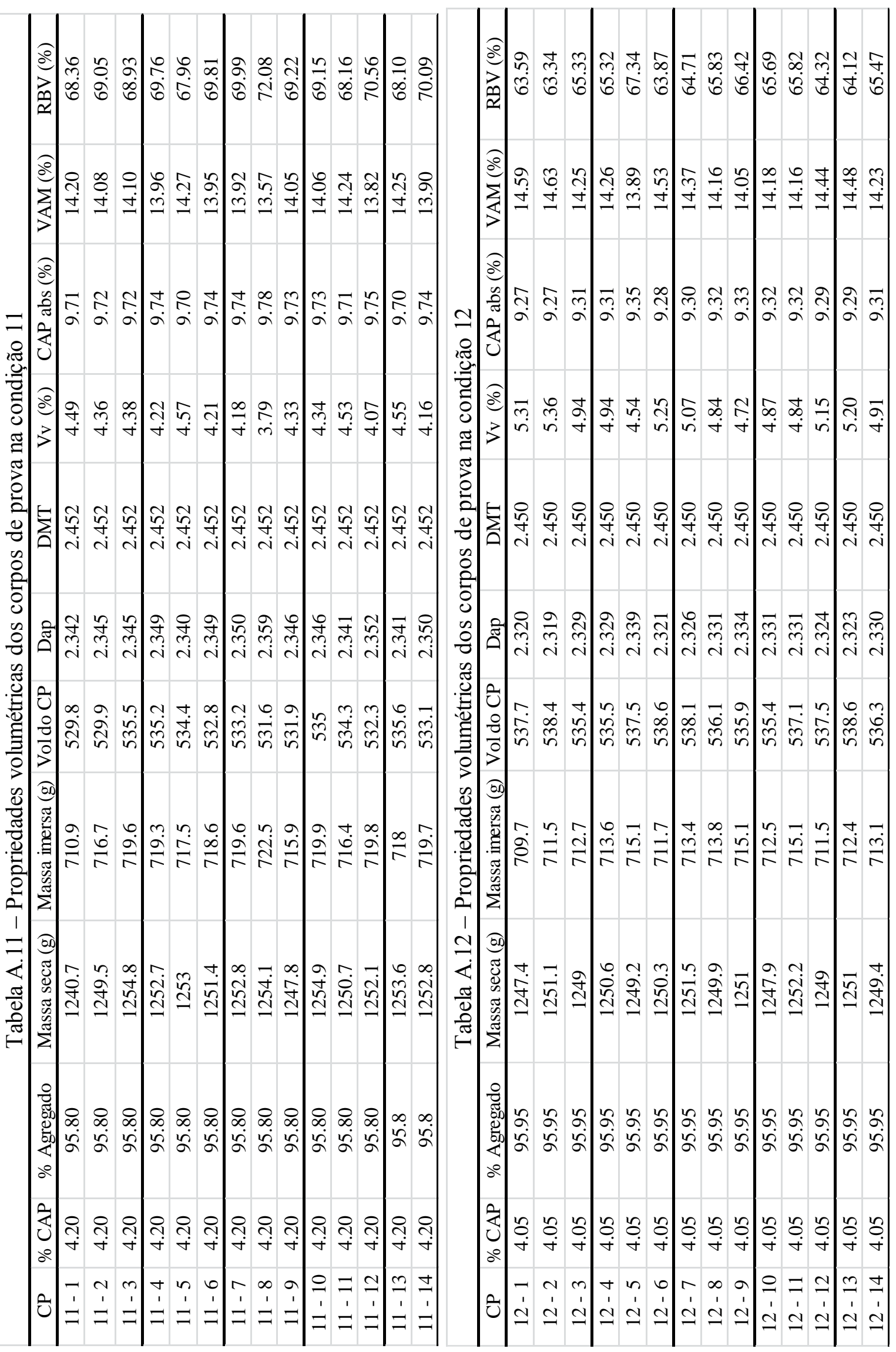




\section{APÊNDICE B - TABELAS DE ANÁLISE DE VARIÂNCIA}

Tabela B.1- Resumo dos valores da ANOVA o teor de ligante de projeto nas misturas asfálticas compostas pelo CAP 50/70

\begin{tabular}{ccccc}
\hline Fator & $\begin{array}{c}\text { Soma } \\
\text { Quadrática }\end{array}$ & $\begin{array}{c}\text { Graus de } \\
\text { Liberdade }\end{array}$ & $\begin{array}{c}\text { Média } \\
\text { Quadrática }\end{array}$ & $\mathrm{F}_{0}$ \\
\hline A & 0.98 & 1 & 0.98 & 227.12 \\
(tipo de agregado) & & & & \\
B & 0.29 & 3 & 0.010 & 22.58 \\
(tipo de fíler) & & & & \\
C & 3.64 & 2 & 1.82 & 424.39 \\
(teor de fíler) & 0.01 & 3 & 0.002 & 0.56 \\
AB & 0.04 & 2 & 0.02 & 4.07 \\
AC & 0.32 & 6 & 0.05 & 12.43 \\
BC & 0.52 & 6 & 0.09 & 20.07 \\
ABC & 0.10 & 24 & 0.004 & \\
Erro & 5.53 & 23 & & \\
Total & & &
\end{tabular}

Tabela B.2 - Resumo dos valores da ANOVA o teor de ligante de projeto nas misturas asfálticas compostas pelo agregado granítico

\begin{tabular}{ccccc}
\hline Fator & $\begin{array}{c}\text { Soma } \\
\text { Quadrática }\end{array}$ & $\begin{array}{c}\text { Graus de } \\
\text { Liberdade }\end{array}$ & $\begin{array}{c}\text { Média } \\
\text { Quadrática }\end{array}$ & $\mathrm{F}_{0}$ \\
\hline A & 0.02 & 1 & 0.02 & 2.89 \\
(tipo de ligante) & & & & \\
B & 0.36 & 3 & 0.12 & 14.56 \\
(tipo de fíler) & & & & \\
C & 3.77 & 2 & 1.88 & 227.91 \\
(teor de fíler) & 0.03 & 3 & 0.01 & 1.03 \\
AB & 0.02 & 2 & 0.01 & 1.46 \\
AC & 0.21 & 6 & 0.04 & 4.28 \\
BC & 0.15 & 6 & 0.03 & 2.97 \\
ABC & 0.20 & 24 & 0.01 & \\
Erro & 4.76 & 23 & & \\
Total & & &
\end{tabular}


Tabela B.3 - Resumo dos valores da ANOVA para a absorção nas misturas asfálticas compostas pelo CAP 50/70

\begin{tabular}{ccccc}
\hline Fator & $\begin{array}{c}\text { Soma } \\
\text { Quadrática }\end{array}$ & $\begin{array}{c}\text { Graus de } \\
\text { Liberdade }\end{array}$ & $\begin{array}{c}\text { Média } \\
\text { Quadrática }\end{array}$ & $\mathrm{F}_{0}$ \\
\hline A & 32.731 & 1 & 32.731 & 5045.08 \\
(tipo de agregado) & & & & \\
B & 0.166 & 3 & 0.055 & 8.54 \\
(tipo de fíler) & & & & \\
C & 0.033 & 2 & 0.016 & 2.57 \\
(teor de fíler) & 0.030 & 3 & 0.010 & 1.59 \\
AB & 0.051 & 2 & 0.025 & 3.95 \\
AC & 0.100 & 6 & 0.016 & 2.58 \\
BC & - & - & - & - \\
ABC & 0.155 & 24 & 0.0064 & \\
Erro & 33.269 & 23 & & \\
Total & & &
\end{tabular}

Tabela B.4 - Resumo dos valores da ANOVA para a absorção nas misturas asfálticas compostas pelo agregado granítico

\begin{tabular}{ccccc}
\hline Fator & $\begin{array}{c}\text { Soma } \\
\text { Quadrática }\end{array}$ & $\begin{array}{c}\text { Graus de } \\
\text { Liberdade }\end{array}$ & $\begin{array}{c}\text { Media } \\
\text { Quadrática }\end{array}$ & $\mathrm{F}_{0}$ \\
\hline $\begin{array}{c}\text { A } \\
\text { (tipo de ligante) }\end{array}$ & 0.008 & 1 & 0.0081 & 1.247 \\
B & 0.242 & 3 & 0.0808 & 12.449 \\
(tipo de fíler) & & & & \\
C & 0.004 & 2 & 0.0023 & 0.356 \\
(teor de filer) & 0.006 & 3 & 0.0021 & 0.321 \\
AB & 0.025 & 2 & 0.0128 & 1.968 \\
AC & 0.079 & 6 & 0.0133 & 2.054 \\
BC & - & - & - & - \\
ABC & 0.044 & 24 & 0.0019 & \\
Erro & 0.411 & 23 & & \\
Total & & & & \\
\hline
\end{tabular}


Tabela B.5 - Resumo dos valores da ANOVA para a resistência à tração, com o tipo de fíler em 3 níveis e o teor de fíler em 2 níveis (análise (1)) e com o tipo de fíler em 2 níveis e o teor de fíler em 3 níveis (análise (2)).

\begin{tabular}{|c|c|c|c|c|c|c|c|c|}
\hline \multirow{2}{*}{ Fator } & \multicolumn{4}{|c|}{ análise (1) } & \multicolumn{4}{|c|}{ análise (2) } \\
\hline & SQ & GL & MQ & $\mathrm{F}_{0}$ & SQ & GL & MQ & $\mathrm{F}_{0}$ \\
\hline $\begin{array}{c}\text { A } \\
\text { (tipo de agregado) }\end{array}$ & $1.14 \mathrm{E}-01$ & 1 & $1.14 \mathrm{E}-01$ & $8.05 E+12$ & $1.03 \mathrm{E}-01$ & 1 & $1.03 \mathrm{E}-01$ & $4.78 \mathrm{E}+08$ \\
\hline $\begin{array}{c}\text { B } \\
\text { (tipo de ligante } \\
\text { asfáltico) }\end{array}$ & $4.18 \mathrm{E}+00$ & 1 & $4.18 \mathrm{E}+00$ & $2.94 \mathrm{E}+14$ & $3.87 \mathrm{E}+00$ & 1 & $3.87 \mathrm{E}+00$ & $1.80 \mathrm{E}+10$ \\
\hline $\begin{array}{c}\text { C } \\
\text { (tipo de fíler) }\end{array}$ & $4.29 \mathrm{E}-02$ & 2 & $2.14 \mathrm{E}-02$ & $1.51 \mathrm{E}+12$ & $2.60 \mathrm{E}-03$ & 1 & $2.60 \mathrm{E}-03$ & $1.21 \mathrm{E}+07$ \\
\hline $\begin{array}{c}\mathrm{D} \\
\text { (teor de fíler) }\end{array}$ & $1.04 \mathrm{E}-02$ & 1 & $1.04 \mathrm{E}-02$ & $7.35 \mathrm{E}+11$ & $1.25 \mathrm{E}-02$ & 2 & $6.25 \mathrm{E}-03$ & $2.90 \mathrm{E}+07$ \\
\hline $\mathrm{AB}$ & $9.14 \mathrm{E}-04$ & 1 & $9.14 \mathrm{E}-04$ & $6.43 \mathrm{E}+10$ & $8.42 \mathrm{E}-04$ & 1 & $8.42 \mathrm{E}-04$ & $3.91 \mathrm{E}+06$ \\
\hline $\mathrm{AC}$ & $9.08 \mathrm{E}-06$ & 2 & $4.54 \mathrm{E}-06$ & $3.20 \mathrm{E}+08$ & $1.37 \mathrm{E}-05$ & 1 & $1.37 \mathrm{E}-05$ & $6.36 \mathrm{E}+04$ \\
\hline $\mathrm{AD}$ & $2.13 \mathrm{E}-14$ & 1 & $2.13 \mathrm{E}-14$ & 1.50 & $6.15 \mathrm{E}-04$ & 2 & $3.07 \mathrm{E}-04$ & $1.43 \mathrm{E}+06$ \\
\hline $\mathrm{BC}$ & $1.21 \mathrm{E}-02$ & 2 & $6.07 \mathrm{E}-03$ & $4.27 \mathrm{E}+11$ & $1.42 \mathrm{E}-14$ & 1 & $1.42 \mathrm{E}-14$ & $6.60 \mathrm{E}-05$ \\
\hline $\mathrm{BD}$ & $1.72 \mathrm{E}-09$ & 1 & $1.72 \mathrm{E}-09$ & 121228.00 & $6.46 \mathrm{E}-10$ & 2 & $3.23 \mathrm{E}-10$ & 1.50 \\
\hline $\mathrm{CD}$ & $6.46 \mathrm{E}-10$ & 2 & $3.23 \mathrm{E}-10$ & 22730.25 & $6.46 \mathrm{E}-10$ & 2 & $3.23 \mathrm{E}-10$ & 1.50 \\
\hline $\mathrm{ABC}$ & $3.03 \mathrm{E}-06$ & 2 & $1.51 \mathrm{E}-06$ & $1.07 \mathrm{E}+08$ & $1.42 \mathrm{E}-14$ & 1 & $1.42 \mathrm{E}-14$ & $6.60 \mathrm{E}-05$ \\
\hline $\mathrm{ABD}$ & $-2.13 \mathrm{E}-14$ & 1 & $-2.13 \mathrm{E}-14$ & -1.50 & $2.15 \mathrm{E}-10$ & 2 & $1.08 \mathrm{E}-10$ & 0.50 \\
\hline $\mathrm{ACD}$ & $-1.42 \mathrm{E}-14$ & 2 & $-7.11 \mathrm{E}-15$ & -0.50 & $2.15 \mathrm{E}-10$ & 2 & $1.08 \mathrm{E}-10$ & 0.50 \\
\hline $\mathrm{BCD}$ & $2.15 \mathrm{E}-10$ & 2 & $1.08 \mathrm{E}-10$ & 7576.50 & $-1.42 \mathrm{E}-14$ & 2 & $-7.11 \mathrm{E}-15$ & $-3.30 \mathrm{E}-05$ \\
\hline $\mathrm{ABCD}$ & - & - & - & - & $0.00 \mathrm{E}+00$ & & & \\
\hline Erro & $2.84 \mathrm{E}-14$ & 2 & $1.42 \mathrm{E}-14$ & & $4.31 \mathrm{E}-10$ & 2 & $2.15 \mathrm{E}-10$ & \\
\hline Total & $4.36 \mathrm{E}+00$ & 23 & & & 3.986683 & 23 & & \\
\hline
\end{tabular}


Tabela B.6 - Resumo dos valores da ANOVA para o módulo de resiliência, com o tipo de fíler em 3 níveis e o teor de fíler em 2 níveis (análise (1)) e com o tipo de fíler em 2 níveis e o teor de fíler em 3 níveis (análise (2)).

\begin{tabular}{c|cccc|cccc}
\hline \multirow{2}{*}{ Fator } & \multicolumn{5}{|c|}{ análise $(1)$} & \multicolumn{4}{c}{ análise (2) } \\
& $\mathrm{SQ}$ & $\mathrm{GL}$ & $\mathrm{MQ}$ & $\mathrm{F}_{0}$ & $\mathrm{SQ}$ & $\mathrm{GL}$ & $\mathrm{MQ}$ & $\mathrm{F}_{0}$ \\
\hline $\begin{array}{c}\text { A } \\
\text { (tipo de agregado) } \\
\text { B } \\
\text { (tipo de ligante } \\
\text { asfáltico) }\end{array}$ & $8.82 \mathrm{E}+05$ & 1 & $8.82 \mathrm{E}+05$ & 233.30 & $1.81 \mathrm{E}+06$ & 1 & $1.81 \mathrm{E}+06$ & 358.34 \\
$\begin{array}{c}\text { C } \\
\text { (tipo de fíler) }\end{array}$ & $4.41 \mathrm{E}+07$ & 1 & $4.41 \mathrm{E}+07$ & 11646.22 & $4.07 \mathrm{E}+07$ & 1 & $4.07 \mathrm{E}+07$ & 8071.32 \\
$\begin{array}{c}\text { D } \\
\text { (teor de fíler) }\end{array}$ & $7.15 \mathrm{E}+05$ & 2 & $3.58 \mathrm{E}+05$ & 94.52 & $1.06 \mathrm{E}+06$ & 1 & $1.06 \mathrm{E}+06$ & 209.96 \\
AB & $5.97 \mathrm{E}+06$ & 1 & $5.97 \mathrm{E}+06$ & 1579.05 & $4.29 \mathrm{E}+06$ & 2 & $2.15 \mathrm{E}+06$ & 425.34 \\
AC & $2.24 \mathrm{E}+04$ & 1 & $2.24 \mathrm{E}+04$ & 5.92 & $3.78 \mathrm{E}+05$ & 1 & $3.78 \mathrm{E}+05$ & 74.91 \\
AD & $7.40 \mathrm{E}+05$ & 2 & $3.70 \mathrm{E}+05$ & 97.88 & $8.79 \mathrm{E}+05$ & 1 & $8.79 \mathrm{E}+05$ & 174.38 \\
BC & $5.04 \mathrm{E}+03$ & 1 & $5.04 \mathrm{E}+03$ & 1.33 & $2.81 \mathrm{E}+05$ & 2 & $1.40 \mathrm{E}+05$ & 27.81 \\
BD & $1.40 \mathrm{E}+05$ & 2 & $6.98 \mathrm{E}+04$ & 18.46 & $5.04 \mathrm{E}+03$ & 1 & $5.04 \mathrm{E}+03$ & 1.00 \\
CD & $2.09 \mathrm{E}+05$ & 1 & $2.09 \mathrm{E}+05$ & 55.25 & $7.84 \mathrm{E}+04$ & 2 & $3.92 \mathrm{E}+04$ & 7.77 \\
ABC & $8.09 \mathrm{E}+04$ & 2 & $4.04 \mathrm{E}+04$ & 10.69 & $7.84 \mathrm{E}+04$ & 2 & $3.92 \mathrm{E}+04$ & 7.77 \\
ABD & $2.54 \mathrm{E}+05$ & 2 & $1.27 \mathrm{E}+05$ & 33.51 & $5.04 \mathrm{E}+03$ & 1 & $5.04 \mathrm{E}+03$ & 1.00 \\
ACD & $0.00 \mathrm{E}+00$ & 1 & $0.00 \mathrm{E}+00$ & 0.00 & $2.61 \mathrm{E}+04$ & 2 & $1.31 \mathrm{E}+04$ & 2.59 \\
BCD & $2.52 \mathrm{E}+03$ & 2 & $1.26 \mathrm{E}+03$ & 0.33 & $2.61 \mathrm{E}+04$ & 2 & $1.31 \mathrm{E}+04$ & 2.59 \\
ABCD & $3.37 \mathrm{E}+04$ & 2 & $1.68 \mathrm{E}+04$ & 4.45 & $1.01 \mathrm{E}+04$ & 2 & $5.04 \mathrm{E}+03$ & 1.00 \\
Erro & - & & & & & & & \\
Total & $7.56 \mathrm{E}+03$ & 2 & $3.78 \mathrm{E}+03$ & & $1.01 \mathrm{E}+04$ & 2 & $5.04 \mathrm{E}+03$ & \\
\hline & $5.31 \mathrm{E}+07$ & 23 & & & 49639008 & 23 & & \\
\hline
\end{tabular}


Tabela B.7 - Resumo dos valores da ANOVA para a deformação resiliente, com o tipo de fíler em 3 níveis e o teor de fíler em 2 níveis (análise (1)) e com o tipo de fíler em 2 níveis e o teor de fíler em 3 níveis (análise (2)).

\begin{tabular}{c|cccc|cccc}
\hline Fator & \multicolumn{5}{|c|}{ análise $(1)$} & \multicolumn{4}{c}{ análise (2) } \\
& $\mathrm{SQ}$ & $\mathrm{GL}$ & $\mathrm{MQ}$ & $\mathrm{F}_{0}$ & $\mathrm{SQ}$ & $\mathrm{GL}$ & $\mathrm{MQ}$ & $\mathrm{F}_{0}$ \\
\hline $\begin{array}{c}\text { A } \\
\text { (tipo de agregado) } \\
\text { B } \\
\text { (tipo de ligante } \\
\text { asfáltico) }\end{array}$ & $8.82 \mathrm{E}+05$ & 1 & $8.82 \mathrm{E}+05$ & 233.30 & $1.81 \mathrm{E}+06$ & 1 & $1.81 \mathrm{E}+06$ & 358.34 \\
$\begin{array}{c}\text { C } \\
\text { (tipo de fíler) } \\
\text { D }\end{array}$ & $4.41 \mathrm{E}+07$ & 1 & $4.41 \mathrm{E}+07$ & 11646.22 & $4.07 \mathrm{E}+07$ & 1 & $4.07 \mathrm{E}+07$ & 8071.32 \\
(teor de fíler) & $7.15 \mathrm{E}+05$ & 2 & $3.58 \mathrm{E}+05$ & 94.52 & $1.06 \mathrm{E}+06$ & 1 & $1.06 \mathrm{E}+06$ & 209.96 \\
AB & $5.97 \mathrm{E}+06$ & 1 & $5.97 \mathrm{E}+06$ & 1579.05 & $4.29 \mathrm{E}+06$ & 2 & $2.15 \mathrm{E}+06$ & 425.34 \\
AC & $2.24 \mathrm{E}+04$ & 1 & $2.24 \mathrm{E}+04$ & 5.92 & $3.78 \mathrm{E}+05$ & 1 & $3.78 \mathrm{E}+05$ & 74.91 \\
AD & $7.40 \mathrm{E}+05$ & 2 & $3.70 \mathrm{E}+05$ & 97.88 & $8.79 \mathrm{E}+05$ & 1 & $8.79 \mathrm{E}+05$ & 174.38 \\
BC & $5.04 \mathrm{E}+03$ & 1 & $5.04 \mathrm{E}+03$ & 1.33 & $2.81 \mathrm{E}+05$ & 2 & $1.40 \mathrm{E}+05$ & 27.81 \\
BD & $1.40 \mathrm{E}+05$ & 2 & $6.98 \mathrm{E}+04$ & 18.46 & $5.04 \mathrm{E}+03$ & 1 & $5.04 \mathrm{E}+03$ & 1.00 \\
CD & $2.09 \mathrm{E}+05$ & 1 & $2.09 \mathrm{E}+05$ & 55.25 & $7.84 \mathrm{E}+04$ & 2 & $3.92 \mathrm{E}+04$ & 7.77 \\
ABC & $8.09 \mathrm{E}+04$ & 2 & $4.04 \mathrm{E}+04$ & 10.69 & $7.84 \mathrm{E}+04$ & 2 & $3.92 \mathrm{E}+04$ & 7.77 \\
ABD & $2.54 \mathrm{E}+05$ & 2 & $1.27 \mathrm{E}+05$ & 33.51 & $5.04 \mathrm{E}+03$ & 1 & $5.04 \mathrm{E}+03$ & 1.00 \\
ACD & $0.00 \mathrm{E}+00$ & 1 & $0.00 \mathrm{E}+00$ & 0.00 & $2.61 \mathrm{E}+04$ & 2 & $1.31 \mathrm{E}+04$ & 2.59 \\
BCD & $2.52 \mathrm{E}+03$ & 2 & $1.26 \mathrm{E}+03$ & 0.33 & $2.61 \mathrm{E}+04$ & 2 & $1.31 \mathrm{E}+04$ & 2.59 \\
ABCD & $3.37 \mathrm{E}+04$ & 2 & $1.68 \mathrm{E}+04$ & 4.45 & $1.01 \mathrm{E}+04$ & 2 & $5.04 \mathrm{E}+03$ & 1.00 \\
Erro & - & & & & & & & \\
Total & $7.56 \mathrm{E}+03$ & 2 & $3.78 \mathrm{E}+03$ & & $1.01 \mathrm{E}+04$ & 2 & $5.04 \mathrm{E}+03$ & \\
\hline
\end{tabular}


Tabela B.8 - Resumo dos valores da ANOVA para a deformação total, com o tipo de fíler em 3 níveis e o teor de fíler em 2 níveis (análise (1)) e com o tipo de fíler em 2 níveis e o teor de fíler em 3 níveis (análise (2)).

\begin{tabular}{c|cccc|cccc}
\hline Fator & \multicolumn{5}{|c}{ análise $(1)$} & \multicolumn{4}{c}{ análise $(2)$} \\
\hline $\begin{array}{c}\text { A } \\
\text { (tipo deagregado) } \\
\text { B } \\
\text { (tipo de ligante } \\
\text { asfáltico) }\end{array}$ & SQ & GL & MQ & $\mathrm{F}_{0}$ & SQ & GL & MQ & $\mathrm{F}_{0}$ \\
$\begin{array}{c}\text { C } \\
\text { (tipo de fíler) } \\
\text { D } \\
\text { (teor de fíler) }\end{array}$ & $1.32 \mathrm{E}-07$ & 1 & $1.32 \mathrm{E}-07$ & 255.31 & $1.97 \mathrm{E}-07$ & 1 & $1.97 \mathrm{E}-07$ & 285.16 \\
AB & $2.23 \mathrm{E}-07$ & 2 & $1.12 \mathrm{E}-07$ & 215.35 & $1.84 \mathrm{E}-08$ & 1 & $1.84 \mathrm{E}-08$ & 26.61 \\
AC & $8.25 \mathrm{E}-08$ & 1 & $8.25 \mathrm{E}-08$ & 159.24 & $8.02 \mathrm{E}-08$ & 2 & $4.01 \mathrm{E}-08$ & 58.06 \\
AD & $3.34 \mathrm{E}-08$ & 1 & $3.34 \mathrm{E}-08$ & 64.43 & $1.47 \mathrm{E}-08$ & 1 & $1.47 \mathrm{E}-08$ & 21.30 \\
BC & $1.68 \mathrm{E}-08$ & 2 & $8.42 \mathrm{E}-09$ & 16.25 & $2.19 \mathrm{E}-08$ & 1 & $2.19 \mathrm{E}-08$ & 31.64 \\
BD & $7.27 \mathrm{E}-10$ & 1 & $7.27 \mathrm{E}-10$ & 1.40 & $1.51 \mathrm{E}-09$ & 2 & $7.53 \mathrm{E}-10$ & 1.09 \\
CD & $1.39 \mathrm{E}-08$ & 2 & $6.96 \mathrm{E}-09$ & 13.44 & $6.91 \mathrm{E}-10$ & 1 & $6.91 \mathrm{E}-10$ & 1.00 \\
ABC & $1.38 \mathrm{E}-09$ & 1 & $1.38 \mathrm{E}-09$ & 2.65 & $5.25 \mathrm{E}-10$ & 2 & $2.63 \mathrm{E}-10$ & 0.38 \\
ABD & $8.89 \mathrm{E}-10$ & 2 & $4.44 \mathrm{E}-10$ & 0.86 & $5.25 \mathrm{E}-10$ & 2 & $2.63 \mathrm{E}-10$ & 0.38 \\
ACD & $6.45 \mathrm{E}-09$ & 2 & $3.23 \mathrm{E}-09$ & 6.23 & $6.91 \mathrm{E}-10$ & 1 & $6.91 \mathrm{E}-10$ & 1.00 \\
BCD & $1.16 \mathrm{E}-13$ & 1 & $1.16 \mathrm{E}-13$ & 0.00 & $1.75 \mathrm{E}-10$ & 2 & $8.76 \mathrm{E}-11$ & 0.13 \\
ABCD & $3.64 \mathrm{E}-10$ & 2 & $1.82 \mathrm{E}-10$ & 0.35 & $1.75 \mathrm{E}-10$ & 2 & $8.76 \mathrm{E}-11$ & 0.13 \\
Erro & $1.20 \mathrm{E}-09$ & 2 & $5.99 \mathrm{E}-10$ & 1.16 & $1.38 \mathrm{E}-09$ & 2 & $6.91 \mathrm{E}-10$ & 1.00 \\
Total & - & & & & & & & \\
\hline
\end{tabular}


Tabela B.9 - Resumo dos valores da ANOVA para a deformação recuperável, com o tipo de fíler em 3 níveis e o teor de fíler em 2 níveis (análise (1)) e com o tipo de fíler em 2 níveis e o teor de fíler em 3 níveis (análise (2)).

\begin{tabular}{c|cccc|cccc}
\hline \multirow{2}{*}{ Fator } & \multicolumn{5}{|c}{ análise (1) } & \multicolumn{5}{c}{ análise (2) } \\
& SQ & GL & MQ & $\mathrm{F}_{0}$ & SQ & GL & MQ & $\mathrm{F}_{0}$ \\
\hline A & $2.69 \mathrm{E}-07$ & 1 & $2.69 \mathrm{E}-07$ & 3811.11 & $2.79 \mathrm{E}-07$ & 1 & $2.79 \mathrm{E}-07$ & 3776.77 \\
B & $1.11 \mathrm{E}-08$ & 1 & $1.11 \mathrm{E}-08$ & 157.43 & $1.69 \mathrm{E}-08$ & 1 & $1.69 \mathrm{E}-08$ & 228.88 \\
C & $3.34 \mathrm{E}-09$ & 2 & $1.67 \mathrm{E}-09$ & 23.62 & $1.34 \mathrm{E}-10$ & 1 & $1.34 \mathrm{E}-10$ & 1.81 \\
D & $9.12 \mathrm{E}-10$ & 1 & $9.12 \mathrm{E}-10$ & 12.90 & $3.16 \mathrm{E}-09$ & 2 & $1.58 \mathrm{E}-09$ & 21.38 \\
AB & $4.17 \mathrm{E}-12$ & 1 & $4.17 \mathrm{E}-12$ & 0.06 & $2.40 \mathrm{E}-10$ & 1 & $2.40 \mathrm{E}-10$ & 3.25 \\
AC & $3.75 \mathrm{E}-11$ & 2 & $1.87 \mathrm{E}-11$ & 0.27 & $1.30 \mathrm{E}-10$ & 1 & $1.30 \mathrm{E}-10$ & 1.76 \\
AD & $4.98 \mathrm{E}-11$ & 1 & $4.98 \mathrm{E}-11$ & 0.71 & $1.35 \mathrm{E}-10$ & 2 & $6.75 \mathrm{E}-11$ & 0.91 \\
BC & $9.58 \mathrm{E}-10$ & 2 & $4.79 \mathrm{E}-10$ & 6.78 & $7.38 \mathrm{E}-11$ & 1 & $7.38 \mathrm{E}-11$ & 1.00 \\
BD & $1.30 \mathrm{E}-09$ & 1 & $1.30 \mathrm{E}-09$ & 18.41 & $3.30 \mathrm{E}-10$ & 2 & $1.65 \mathrm{E}-10$ & 2.23 \\
CD & $3.24 \mathrm{E}-10$ & 2 & $1.62 \mathrm{E}-10$ & 2.29 & $3.30 \mathrm{E}-10$ & 2 & $1.65 \mathrm{E}-10$ & 2.23 \\
ABC & $1.92 \mathrm{E}-10$ & 2 & $9.60 \mathrm{E}-11$ & 1.36 & $7.38 \mathrm{E}-11$ & 1 & $7.38 \mathrm{E}-11$ & 1.00 \\
ABD & $6.12 \mathrm{E}-11$ & 1 & $6.12 \mathrm{E}-11$ & 0.87 & $1.92 \mathrm{E}-10$ & 2 & $9.58 \mathrm{E}-11$ & 1.30 \\
ACD & $1.17 \mathrm{E}-10$ & 2 & $5.84 \mathrm{E}-11$ & 0.83 & $1.92 \mathrm{E}-10$ & 2 & $9.58 \mathrm{E}-11$ & 1.30 \\
BCD & $5.54 \mathrm{E}-10$ & 2 & $2.77 \mathrm{E}-10$ & 3.92 & $1.48 \mathrm{E}-10$ & 2 & $7.38 \mathrm{E}-11$ & 1.00 \\
ABCD & - & & & & & & & \\
Erro & $1.41 \mathrm{E}-10$ & 2 & $7.07 \mathrm{E}-11$ & & $1.48 \mathrm{E}-10$ & 2 & $7.38 \mathrm{E}-11$ & \\
Total & $2.88 \mathrm{E}-07$ & 23 & & & $3.01 \mathrm{E}-07$ & 23 & & \\
\hline
\end{tabular}


Tabela B.10 - Resumo dos valores da ANOVA para a deformação não recuperável, com o tipo de fíler em 3 níveis e o teor de fíler em 2 níveis (análise (1)) e com o tipo de fíler em 2 níveis e o teor de fíler em 3 níveis (análise (2)).

\begin{tabular}{c|cccc|cccc}
\hline \multirow{2}{*}{ Fator } & \multicolumn{5}{|c|}{ análise $(1)$} & \multicolumn{4}{c}{ análise $(2)$} \\
& SQ & GL & MQ & $\mathrm{F}_{0}$ & SQ & GL & MQ & $\mathrm{F}_{0}$ \\
\hline A & $1.87 \mathrm{E}-08$ & 1 & $1.87 \mathrm{E}-08$ & 77.95 & $9.82 \mathrm{E}-09$ & 1 & $9.82 \mathrm{E}-09$ & 32.94 \\
B & $6.90 \mathrm{E}-08$ & 1 & $6.90 \mathrm{E}-08$ & 287.13 & $1.02 \mathrm{E}-07$ & 1 & $1.02 \mathrm{E}-07$ & 341.25 \\
C & $1.71 \mathrm{E}-07$ & 2 & $8.56 \mathrm{E}-08$ & 356.26 & $1.61 \mathrm{E}-08$ & 1 & $1.61 \mathrm{E}-08$ & 54.16 \\
D & $6.35 \mathrm{E}-08$ & 1 & $6.35 \mathrm{E}-08$ & 264.35 & $8.59 \mathrm{E}-08$ & 2 & $4.29 \mathrm{E}-08$ & 144.05 \\
AB & $3.33 \mathrm{E}-08$ & 1 & $3.33 \mathrm{E}-08$ & 138.41 & $1.84 \mathrm{E}-08$ & 1 & $1.84 \mathrm{E}-08$ & 61.66 \\
AC & $1.72 \mathrm{E}-08$ & 2 & $8.62 \mathrm{E}-09$ & 35.90 & $2.43 \mathrm{E}-08$ & 1 & $2.43 \mathrm{E}-08$ & 81.62 \\
AD & $1.13 \mathrm{E}-09$ & 1 & $1.13 \mathrm{E}-09$ & 4.70 & $2.57 \mathrm{E}-09$ & 2 & $1.29 \mathrm{E}-09$ & 4.31 \\
BC & $7.74 \mathrm{E}-09$ & 2 & $3.87 \mathrm{E}-09$ & 16.11 & $2.98 \mathrm{E}-10$ & 1 & $2.98 \mathrm{E}-10$ & 1.00 \\
BD & $4.63 \mathrm{E}-13$ & 1 & $4.63 \mathrm{E}-13$ & 0.00 & $6.27 \mathrm{E}-11$ & 2 & $3.13 \mathrm{E}-11$ & 0.11 \\
CD & $5.94 \mathrm{E}-10$ & 2 & $2.97 \mathrm{E}-10$ & 1.24 & $6.27 \mathrm{E}-11$ & 2 & $3.13 \mathrm{E}-11$ & 0.11 \\
ABC & $4.42 \mathrm{E}-09$ & 2 & $2.21 \mathrm{E}-09$ & 9.20 & $2.98 \mathrm{E}-10$ & 1 & $2.98 \mathrm{E}-10$ & 1.00 \\
ABD & $6.67 \mathrm{E}-11$ & 1 & $6.67 \mathrm{E}-11$ & 0.28 & $1.10 \mathrm{E}-10$ & 2 & $5.49 \mathrm{E}-11$ & 0.18 \\
ACD & $6.64 \mathrm{E}-10$ & 2 & $3.32 \mathrm{E}-10$ & 1.38 & $1.10 \mathrm{E}-10$ & 2 & $5.49 \mathrm{E}-11$ & 0.18 \\
BCD & $5.18 \mathrm{E}-10$ & 2 & $2.59 \mathrm{E}-10$ & 1.08 & $5.96 \mathrm{E}-10$ & 2 & $2.98 \mathrm{E}-10$ & 1.00 \\
ABCD & - & & & & & & & \\
Erro & $4.80 \mathrm{E}-10$ & 2 & $2.40 \mathrm{E}-10$ & & $5.96 \mathrm{E}-10$ & 2 & $2.98 \mathrm{E}-10$ & \\
Total & $3.89 \mathrm{E}-07$ & 23 & & & $2.61 \mathrm{E}-07$ & 23 & & \\
\hline
\end{tabular}


Tabela B.11 - Resumo dos valores da ANOVA para a recuperação, com o tipo de fíler em 3 níveis e o teor de fíler em 2 níveis (análise (1)) e com o tipo de fíler em 2 níveis e o teor de fíler em 3 níveis (análise (2)).

\begin{tabular}{c|cccc|cccc}
\hline \multirow{2}{*}{ Fator } & \multicolumn{5}{|c}{ análise (1) } & \multicolumn{5}{c}{ análise (2) } \\
& SQ & GL & MQ & F0 & SQ & GL & MQ & F0 \\
\hline A & 6.18 & 1 & 6.18 & 62.21 & 15.75 & 1 & 15.75 & 187.62 \\
B & 30.42 & 1 & 30.42 & 306.07 & 45.28 & 1 & 45.28 & 539.24 \\
C & 114.84 & 2 & 57.42 & 577.68 & 14.75 & 1 & 14.75 & 175.67 \\
D & 39.79 & 1 & 39.79 & 400.29 & 74.96 & 2 & 37.48 & 446.34 \\
AB & 22.57 & 1 & 22.57 & 227.08 & 14.14 & 1 & 14.14 & 168.41 \\
AC & 13.65 & 2 & 6.83 & 68.68 & 20.60 & 1 & 20.60 & 245.28 \\
AD & 1.11 & 1 & 1.11 & 11.16 & 3.49 & 2 & 1.75 & 20.79 \\
BC & 4.07 & 2 & 2.03 & 20.47 & 0.08 & 1 & 0.08 & 1.00 \\
BD & 0.65 & 1 & 0.65 & 6.49 & 0.14 & 2 & 0.07 & 0.83 \\
CD & 0.62 & 2 & 0.31 & 3.12 & 0.14 & 2 & 0.07 & 0.83 \\
ABC & 2.53 & 2 & 1.26 & 12.72 & 0.08 & 1 & 0.08 & 1.00 \\
ABD & 0.15 & 1 & 0.15 & 1.47 & 0.24 & 2 & 0.12 & 1.43 \\
ACD & 0.77 & 2 & 0.39 & 3.89 & 0.24 & 2 & 0.12 & 1.43 \\
BCD & 0.60 & 2 & 0.30 & 3.02 & 0.17 & 2 & 0.08 & 1.00 \\
ABCD & - & & & & - & & & \\
Erro & 0.20 & 2 & 0.10 & & 0.17 & 2 & 0.08 & \\
Total & 238.16 & 23 & & & 190.23 & 23 & & \\
\hline
\end{tabular}


Tabela B.12 - Resumo dos valores da ANOVA para o módulo de fluência, com o tipo de fíler em 3 níveis e o teor de fíler em 2 níveis (análise (1)) e com o tipo de fíler em 2 níveis e o teor de fíler em 3 níveis (análise (2)).

\begin{tabular}{c|cccc|cccc}
\hline \multirow{2}{*}{ Fator } & \multicolumn{5}{|c}{ análise (1) } & \multicolumn{4}{c}{ análise (2) } \\
& SQ & GL & MQ & F0 & SQ & GL & MQ & F0 \\
\hline A & 1228.27 & 1 & 1228.27 & 1989.81 & 1044.43 & 1 & 1044.43 & 1581.44 \\
B & 292.51 & 1 & 292.51 & 473.87 & 446.10 & 1 & 446.10 & 675.47 \\
C & 607.27 & 2 & 303.63 & 491.89 & 43.21 & 1 & 43.21 & 65.42 \\
D & 199.63 & 1 & 199.63 & 323.40 & 261.76 & 2 & 130.88 & 198.17 \\
AB & 76.42 & 1 & 76.42 & 123.80 & 57.54 & 1 & 57.54 & 87.13 \\
AC & 23.35 & 2 & 11.67 & 18.91 & 31.49 & 1 & 31.49 & 47.69 \\
AD & 4.88 & 1 & 4.88 & 7.91 & 12.60 & 2 & 6.30 & 9.54 \\
BC & 39.14 & 2 & 19.57 & 31.70 & 0.66 & 1 & 0.66 & 1.00 \\
BD & 0.56 & 1 & 0.56 & 0.90 & 0.24 & 2 & 0.12 & 0.19 \\
CD & 2.44 & 2 & 1.22 & 1.98 & 0.24 & 2 & 0.12 & 0.19 \\
ABC & 3.72 & 2 & 1.86 & 3.01 & 0.66 & 1 & 0.66 & 1.00 \\
ABD & 0.49 & 1 & 0.49 & 0.79 & 0.73 & 2 & 0.37 & 0.55 \\
ACD & 3.17 & 2 & 1.59 & 2.57 & 0.73 & 2 & 0.37 & 0.55 \\
BCD & 2.00 & 2 & 1.00 & 1.62 & 1.32 & 2 & 0.66 & 1.00 \\
ABCD & - & & & & - & & & \\
Erro & 1.23 & 2 & 0.62 & & 1.32 & 2 & 0.66 & \\
Total & 2485.07 & 23 & & & 1903.05 & 23 & & \\
\hline
\end{tabular}


Tabela B.13 - Resumo dos valores da ANOVA para o módulo de fluência após a recuperação, com o tipo de fíler em 3 níveis e o teor de fíler em 2 níveis (análise (1)) e com o tipo de fíler em 2 níveis e o teor de fíler em 3 níveis (análise (2)).

\begin{tabular}{c|cccc|cccc}
\hline \multirow{2}{*}{ Fator } & \multicolumn{5}{|c|}{ análise (1) } & \multicolumn{5}{c}{ análise (2) } \\
& SQ & GL & MQ & F0 & SQ & GL & MQ & F0 \\
\hline A & 14204.60 & 1 & 14204.60 & 285.88 & 6043.63 & 1 & 6043.63 & 167.02 \\
B & 20017.59 & 1 & 20017.59 & 402.87 & 31722.46 & 1 & 31722.46 & 876.66 \\
C & 68839.19 & 2 & 34419.59 & 692.73 & 8894.56 & 1 & 8894.56 & 245.80 \\
D & 25400.05 & 1 & 25400.05 & 511.20 & 41963.89 & 2 & 20981.95 & 579.84 \\
AB & 9567.96 & 1 & 9567.96 & 192.56 & 6017.59 & 1 & 6017.59 & 166.30 \\
AC & 7812.36 & 2 & 3906.18 & 78.62 & 12472.02 & 1 & 12472.02 & 344.67 \\
AD & 625.46 & 1 & 625.46 & 12.59 & 2612.97 & 2 & 1306.49 & 36.11 \\
BC & 3477.71 & 2 & 1738.86 & 35.00 & 36.19 & 1 & 36.19 & 1.00 \\
BD & 1021.18 & 1 & 1021.18 & 20.55 & 234.25 & 2 & 117.12 & 3.24 \\
CD & 501.88 & 2 & 250.94 & 5.05 & 234.25 & 2 & 117.12 & 3.24 \\
ABC & 1391.51 & 2 & 695.75 & 14.00 & 36.19 & 1 & 36.19 & 1.00 \\
ABD & 90.19 & 1 & 90.19 & 1.82 & 198.34 & 2 & 99.17 & 2.74 \\
ACD & 448.02 & 2 & 224.01 & 4.51 & 198.34 & 2 & 99.17 & 2.74 \\
BCD & 511.00 & 2 & 255.50 & 5.14 & 72.37 & 2 & 36.19 & 1.00 \\
ABCD & - & & & & & & & \\
Erro & 99.37 & 2 & 49.69 & & 72.37 & 2 & 36.19 & \\
Total & 154008.09 & 23 & & & 110809.41 & 23 & & \\
\hline
\end{tabular}


Tabela B.14 - Resumo dos valores da ANOVA para a inclinação, com o tipo de fíler em 3 níveis e o teor de fíler em 2 níveis (análise (1)) e com o tipo de fíler em 2 níveis e o teor de fíler em 3 níveis (análise (2)).

\begin{tabular}{c|cccc|cccc}
\hline \multirow{2}{*}{ Fator } & \multicolumn{5}{|c}{ análise (1) } & \multicolumn{5}{c}{ análise (2) } \\
& SQ & GL & MQ & F0 & SQ & GL & MQ & F0 \\
\hline A & $4.25 \mathrm{E}-04$ & 1 & $4.25 \mathrm{E}-04$ & 500.24 & $2.53 \mathrm{E}-04$ & 1 & $2.53 \mathrm{E}-04$ & 1501.23 \\
B & $2.40 \mathrm{E}-03$ & 1 & $2.40 \mathrm{E}-03$ & 2832.76 & $1.95 \mathrm{E}-03$ & 1 & $1.95 \mathrm{E}-03$ & 11543.16 \\
C & $4.63 \mathrm{E}-05$ & 2 & $2.31 \mathrm{E}-05$ & 27.26 & $8.40 \mathrm{E}-05$ & 1 & $8.40 \mathrm{E}-05$ & 497.89 \\
D & $5.95 \mathrm{E}-05$ & 1 & $5.95 \mathrm{E}-05$ & 70.07 & $4.09 \mathrm{E}-05$ & 2 & $2.04 \mathrm{E}-05$ & 121.10 \\
AB & $9.22 \mathrm{E}-05$ & 1 & $9.22 \mathrm{E}-05$ & 108.66 & $1.10 \mathrm{E}-04$ & 1 & $1.10 \mathrm{E}-04$ & 652.00 \\
AC & $8.05 \mathrm{E}-06$ & 2 & $4.02 \mathrm{E}-06$ & 4.74 & $2.56 \mathrm{E}-07$ & 1 & $2.56 \mathrm{E}-07$ & 1.52 \\
AD & $8.93 \mathrm{E}-06$ & 1 & $8.93 \mathrm{E}-06$ & 10.52 & $8.99 \mathrm{E}-05$ & 2 & $4.50 \mathrm{E}-05$ & 266.43 \\
BC & $3.31 \mathrm{E}-05$ & 2 & $1.66 \mathrm{E}-05$ & 19.51 & $1.69 \mathrm{E}-07$ & 1 & $1.69 \mathrm{E}-07$ & 1.00 \\
BD & $3.08 \mathrm{E}-05$ & 1 & $3.08 \mathrm{E}-05$ & 36.26 & $2.11 \mathrm{E}-05$ & 2 & $1.06 \mathrm{E}-05$ & 62.65 \\
CD & $2.42 \mathrm{E}-05$ & 2 & $1.21 \mathrm{E}-05$ & 14.23 & $2.11 \mathrm{E}-05$ & 2 & $1.06 \mathrm{E}-05$ & 62.65 \\
ABC & $1.97 \mathrm{E}-06$ & 2 & $9.86 \mathrm{E}-07$ & 1.16 & $1.69 \mathrm{E}-07$ & 1 & $1.69 \mathrm{E}-07$ & 1.00 \\
ABD & $2.89 \mathrm{E}-06$ & 1 & $2.89 \mathrm{E}-06$ & 3.40 & $1.09 \mathrm{E}-05$ & 2 & $5.45 \mathrm{E}-06$ & 32.30 \\
ACD & $8.80 \mathrm{E}-06$ & 2 & $4.40 \mathrm{E}-06$ & 5.18 & $1.09 \mathrm{E}-05$ & 2 & $5.45 \mathrm{E}-06$ & 32.30 \\
BCD & $2.78 \mathrm{E}-07$ & 2 & $1.39 \mathrm{E}-07$ & 0.16 & $3.37 \mathrm{E}-07$ & 2 & $1.69 \mathrm{E}-07$ & 1.00 \\
ABCD & - & & & & & & & \\
Erro & $1.70 \mathrm{E}-06$ & 2 & $8.49 \mathrm{E}-07$ & & $3.37 \mathrm{E}-07$ & 2 & $1.69 \mathrm{E}-07$ & \\
Total & $3.15 \mathrm{E}-03$ & 23 & & & $2.59 \mathrm{E}-03$ & 23 & & \\
\hline
\end{tabular}


Tabela B.15 - Resumo dos valores da ANOVA para o módulo complexo, considerando o tipo de fíler em 4 níveis e o teor de fíler em 3 níveis (análise 1) e o tipo de fíler em 3 níveis e o teor de fíler em 4 níveis (análise 2).

\begin{tabular}{|c|c|c|c|c|c|c|c|c|}
\hline \multirow{2}{*}{ Fator } & \multicolumn{4}{|c|}{ análise (1) } & \multicolumn{4}{|c|}{ análise (2) } \\
\hline & SQ & GL & MQ & $\mathrm{F}_{0}$ & SQ & GL & MQ & $\mathrm{F}_{0}$ \\
\hline $\begin{array}{c}\text { A } \\
\text { (tipo de fíler) }\end{array}$ & $4.14 \mathrm{E}+12$ & 3 & $1.38 \mathrm{E}+12$ & 24.92 & $3.06 \mathrm{E}+11$ & 2 & $1.53 \mathrm{E}+11$ & 1.04 \\
\hline $\begin{array}{c}\text { B } \\
\text { (teor de fíler) }\end{array}$ & $2.51 \mathrm{E}+13$ & 2 & $1.25 \mathrm{E}+13$ & 226.05 & $3.05 \mathrm{E}+13$ & 3 & $1.02 \mathrm{E}+13$ & 68.94 \\
\hline $\begin{array}{c}\mathrm{C} \\
\text { (tipo de ligante ) }\end{array}$ & $1.29 \mathrm{E}+13$ & 1 & $1.29 \mathrm{E}+13$ & 233.43 & $1.92 \mathrm{E}+13$ & 1 & $1.92 \mathrm{E}+13$ & 130.10 \\
\hline $\begin{array}{c}\text { D } \\
\text { (frequência de } \\
\text { carregamento) }\end{array}$ & $1.11 \mathrm{E}+14$ & 2 & $5.53 \mathrm{E}+13$ & 997.97 & $1.47 \mathrm{E}+14$ & 2 & $7.35 \mathrm{E}+13$ & 498.37 \\
\hline $\mathrm{AB}$ & $2.65 E+12$ & 6 & $4.41 \mathrm{E}+11$ & 7.97 & $1.37 \mathrm{E}+12$ & 6 & $2.28 \mathrm{E}+11$ & 1.54 \\
\hline $\mathrm{AC}$ & $4.19 \mathrm{E}+11$ & 3 & $1.4 \mathrm{E}+11$ & 2.52 & $4.81 \mathrm{E}+11$ & 2 & $2.4 \mathrm{E}+11$ & 1.63 \\
\hline $\mathrm{AD}$ & $3.45 \mathrm{E}+12$ & 2 & $1.73 \mathrm{E}+12$ & 31.13 & $2.49 \mathrm{E}+11$ & 4 & $6.21 \mathrm{E}+10$ & 0.42 \\
\hline $\mathrm{BC}$ & $2.93 \mathrm{E}+12$ & 2 & $1.46 \mathrm{E}+12$ & 26.41 & $5.27 \mathrm{E}+12$ & 3 & $1.76 \mathrm{E}+12$ & 11.91 \\
\hline $\mathrm{BD}$ & $2.58 \mathrm{E}+13$ & 4 & $6.45 \mathrm{E}+12$ & 116.42 & $3.58 \mathrm{E}+13$ & 6 & $5.96 \mathrm{E}+12$ & 40.41 \\
\hline $\mathrm{CD}$ & $1.27 \mathrm{E}+13$ & 2 & $6.36 \mathrm{E}+12$ & 114.77 & $2.12 \mathrm{E}+13$ & 2 & $1.06 \mathrm{E}+13$ & 71.88 \\
\hline $\mathrm{ABC}$ & $6.75 \mathrm{E}+11$ & 6 & $1.13 \mathrm{E}+11$ & 2.03 & $1.76 \mathrm{E}+12$ & 6 & $2.93 \mathrm{E}+11$ & 1.99 \\
\hline $\mathrm{ABD}$ & $2.34 \mathrm{E}+12$ & 12 & $1.95 \mathrm{E}+11$ & 3.52 & $1.5 \mathrm{E}+12$ & 12 & $1.25 \mathrm{E}+11$ & 0.85 \\
\hline $\mathrm{ACD}$ & $3.4 \mathrm{E}+11$ & 6 & $5.67 \mathrm{E}+10$ & 1.02 & $5.88 \mathrm{E}+11$ & 4 & $1.47 \mathrm{E}+11$ & 1.00 \\
\hline $\mathrm{BCD}$ & $2.69 \mathrm{E}+12$ & 4 & $6.73 \mathrm{E}+11$ & 12.13 & $6.31 \mathrm{E}+12$ & 6 & $1.05 \mathrm{E}+12$ & 7.13 \\
\hline $\mathrm{ABCD}$ & - & - & - & - & - & - & - & \\
\hline Erro & $6.65 \mathrm{E}+11$ & 12 & $5.54 \mathrm{E}+10$ & & $1.77 \mathrm{E}+12$ & 12 & $1.47 \mathrm{E}+11$ & \\
\hline Total & $2.07 \mathrm{E}+14$ & 71 & & & $2.73 \mathrm{E}+14$ & 71 & & \\
\hline
\end{tabular}


Tabela B.16 - Resumo dos valores da ANOVA para o ângulo de fase, considerando o tipo de fíler em 4 níveis e o teor de fíler em 3 níveis (análise 1) e o tipo de fíler em 3 níveis e o teor de fíler em 4 níveis (análise 2).

\begin{tabular}{|c|c|c|c|c|c|c|c|c|}
\hline \multirow{2}{*}{ Fator } & \multicolumn{4}{|c|}{ análise (1) } & \multicolumn{4}{|c|}{ análise (2) } \\
\hline & SQ & GL & MQ & $\mathrm{F}_{0}$ & SQ & GL & MQ & $\mathrm{F}_{0}$ \\
\hline $\begin{array}{c}\text { A } \\
\text { (tipo de fíler) }\end{array}$ & 26.66 & 3 & 8.89 & 14.70 & 14.64 & 2 & 7.32 & 10.78 \\
\hline $\begin{array}{c}\text { B } \\
\text { (teor de fíler) }\end{array}$ & 72.75 & 2 & 36.37 & 60.15 & 46.20 & 3 & 15.40 & 22.68 \\
\hline $\begin{array}{c}\mathrm{C} \\
\text { (tipo de ligante ) }\end{array}$ & 403.10 & 1 & 403.10 & 666.60 & 446.63 & 1 & 446.63 & 657.89 \\
\hline $\begin{array}{c}\text { D } \\
\text { (frequência de } \\
\text { carregamento) }\end{array}$ & 1895.63 & 2 & 947.81 & 1567.40 & 1864.55 & 2 & 932.27 & 1373.24 \\
\hline $\mathrm{AB}$ & 14.68 & 6 & 2.45 & 4.05 & 6.21 & 6 & 1.03 & 1.52 \\
\hline $\mathrm{AC}$ & 4.54 & 3 & 1.51 & 2.50 & 3.09 & 2 & 1.54 & 2.27 \\
\hline $\mathrm{AD}$ & 11.66 & 2 & 5.83 & 9.64 & 7.63 & 4 & 1.91 & 2.81 \\
\hline $\mathrm{BC}$ & 11.50 & 2 & 5.75 & 9.51 & 11.48 & 3 & 3.83 & 5.63 \\
\hline $\mathrm{BD}$ & 18.45 & 4 & 4.61 & 7.63 & 14.28 & 6 & 2.38 & 3.50 \\
\hline $\mathrm{CD}$ & 32.13 & 2 & 16.07 & 26.57 & 35.78 & 2 & 17.89 & 26.36 \\
\hline $\mathrm{ABC}$ & 3.62 & 6 & 0.60 & 1.00 & 7.40 & 6 & 1.23 & 1.82 \\
\hline $\mathrm{ABD}$ & 6.26 & 12 & 0.52 & 0.86 & 7.94 & 12 & 0.66 & 0.97 \\
\hline $\mathrm{ACD}$ & 11.15 & 6 & 1.86 & 3.07 & 7.34 & 4 & 1.83 & 2.70 \\
\hline $\mathrm{BCD}$ & 4.13 & 4 & 1.03 & 1.71 & 5.35 & 6 & 0.89 & 1.31 \\
\hline $\mathrm{ABCD}$ & - & - & - & - & - & - & - & \\
\hline Erro & 7.26 & 12 & 0.60 & & 8.15 & 12 & 0.68 & \\
\hline Total & 2523.51 & 71 & & & 2486.65 & 71 & & \\
\hline
\end{tabular}


Tabela B.17 - Resumo dos valores da ANOVA para o parâmetro G*/sen $\delta$, considerando o tipo de fíler em 4 níveis e o teor de fíler em 3 níveis (análise 1) e o tipo de fíler em 3 níveis e o teor de fíler em 4 níveis (análise 2).

\begin{tabular}{c|cccc|cccc}
\hline \multirow{2}{*}{ Fator } & \multicolumn{5}{|c|}{ análise (1) } & \multicolumn{5}{c}{ análise (2) } \\
& SQ & GL & MQ & $\mathrm{F}_{0}$ & SQ & GL & MQ & $\mathrm{F}_{0}$ \\
\hline $\begin{array}{c}\text { A } \\
\text { (tipo de fíler) } \\
\begin{array}{c}\text { B } \\
\text { (teor de fíler) }\end{array}\end{array}$ & 47.08 & 3 & 15.69 & 5.51 & 9.81 & 2 & 4.91 & 0.86 \\
$\begin{array}{c}\text { C } \\
\text { (tipo de ligante } \\
\text { asfáltico) }\end{array}$ & 567.06 & 2 & 283.53 & 99.46 & 728.36 & 3 & 242.79 & 42.61 \\
AB & 352.67 & 1 & 352.67 & 123.71 & 455.01 & 1 & 455.01 & 79.86 \\
AC & 26.10 & 6 & 4.35 & 1.53 & 33.60 & 6 & 5.60 & 0.98 \\
BC & 12.58 & 3 & 4.19 & 1.47 & 49.40 & 2 & 24.70 & 4.33 \\
Erro & 22.90 & 2 & 11.45 & 4.02 & 42.28 & 3 & 14.09 & 2.47 \\
Total & 17.10 & 6 & 2.85 & & 34.19 & 6 & 5.70 & \\
\hline
\end{tabular}


Tabela B.18 - Resumo dos valores da ANOVA para a rigidez a fluência na flexão, considerando o tipo de fíler em 3 níveis e o teor de fíler em 2 níveis (análise (1) e considerando o tipo de fíler em 2 níveis e o teor de fíler em 3 níveis (análise (2)).

\begin{tabular}{|c|c|c|c|c|c|c|c|c|}
\hline \multirow{2}{*}{ Fator } & \multicolumn{4}{|c|}{ análise (1) } & \multicolumn{4}{|c|}{ análise (2) } \\
\hline & SQ & GL & MQ & $\mathrm{F}_{0}$ & SQ & GL & MQ & $\mathrm{F}_{0}$ \\
\hline $\begin{array}{c}\text { A } \\
\text { (tipo de fíler) }\end{array}$ & 25042.52 & 2 & 12521.26 & 10.85 & 222.42 & 1 & 222.42 & 0.50 \\
\hline $\begin{array}{c}\text { B } \\
\text { (teor de fíler) }\end{array}$ & 402573.29 & 1 & 402573.29 & 348.72 & 1207454.84 & 2 & 603727.42 & 1344.76 \\
\hline $\begin{array}{l}\text { (tipo de ligante } \\
\text { asfáltico) }\end{array}$ & 109004.37 & 1 & 109004.37 & 94.42 & 193388.09 & 1 & 193388.09 & 430.76 \\
\hline $\begin{array}{c}\text { D } \\
\text { (tipo de } \\
\text { envelhecimento) }\end{array}$ & 3521.94 & 1 & 3521.94 & 3.05 & 2028.22 & 1 & 2028.22 & 4.52 \\
\hline $\mathrm{AB}$ & 25042.52 & 2 & 12521.26 & 10.85 & 2788.62 & 2 & 1394.31 & 3.11 \\
\hline $\mathrm{AC}$ & 3809.39 & 2 & 1904.69 & 1.65 & 2942.33 & 1 & 2942.33 & 6.55 \\
\hline $\mathrm{AD}$ & 7721.74 & 2 & 3860.87 & 3.34 & 9.63 & 1 & 9.63 & 0.02 \\
\hline $\mathrm{BC}$ & 9297.36 & 1 & 9297.36 & 8.05 & 40462.71 & 2 & 20231.35 & 45.06 \\
\hline $\mathrm{BD}$ & 84.79 & 1 & 84.79 & 0.07 & 5647.59 & 2 & 2823.80 & 6.29 \\
\hline $\mathrm{CD}$ & 1506.27 & 1 & 1506.27 & 1.30 & 12.36 & 1 & 12.36 & 0.03 \\
\hline $\mathrm{ABC}$ & 3809.39 & 2 & 1904.69 & 1.65 & 2425.37 & 2 & 1212.69 & 2.70 \\
\hline $\mathrm{ABD}$ & 7721.74 & 2 & 3860.87 & 3.34 & 2637.80 & 2 & 1318.90 & 2.94 \\
\hline $\mathrm{ACD}$ & 3201.28 & 2 & 1600.64 & 1.39 & 5219.69 & 1 & 5219.69 & 11.63 \\
\hline $\mathrm{BCD}$ & 1928.55 & 1 & 1928.55 & 1.67 & 3674.15 & 2 & 1837.08 & 4.09 \\
\hline $\mathrm{ABCD}$ & 3201.28 & 2 & 1600.64 & 1.39 & 3218.23 & 2 & 1609.12 & 3.58 \\
\hline Erro & 27706.67 & 24 & 1154.44 & & 10774.78 & 24 & 448.95 & \\
\hline Total & 623929.41 & 23 & & & 1480868.99 & 23 & & \\
\hline
\end{tabular}


Tabela B.19 - Resumo dos valores da ANOVA para o módulo de relaxação, considerando o tipo de fíler em 3 níveis e o teor de fíler em 2 níveis (análise (1)), e considerando o tipo de fíler em 2 níveis e o teor de fíler em 3 níveis (análise (2)).

\begin{tabular}{c|cccc|cccc}
\hline Fator & \multicolumn{5}{|c}{ análise (1) } & \multicolumn{5}{c}{ análise (2) } \\
& SQ & GL & MQ & $\mathrm{F}_{0}$ & SQ & GL & MQ & $\mathrm{F}_{0}$ \\
\hline $\begin{array}{c}\text { A } \\
\text { (tipo de fíler) } \\
\text { B } \\
\text { (teor de fíler) }\end{array}$ & $1.07 \mathrm{E}-04$ & 2 & $5.34 \mathrm{E}-05$ & 5.86 & $8.83 \mathrm{E}-07$ & 1 & $8.83 \mathrm{E}-07$ & 0.23 \\
$\begin{array}{c}\text { C } \\
\text { (tipo de ligante) }\end{array}$ & $4.72 \mathrm{E}-03$ & 1 & $4.72 \mathrm{E}-03$ & 518.50 & $7.98 \mathrm{E}-03$ & 2 & $3.99 \mathrm{E}-03$ & 1027.54 \\
$\begin{array}{c}\text { D } \\
\text { (tipo de } \\
\text { envelhecimento) }\end{array}$ & $1.28 \mathrm{E}-03$ & 1 & $1.28 \mathrm{E}-03$ & 140.93 & $1.14 \mathrm{E}-03$ & 1 & $1.14 \mathrm{E}-03$ & 294.07 \\
AB & $5.36 \mathrm{E}-05$ & 1 & $5.36 \mathrm{E}-05$ & 5.89 & $1.69 \mathrm{E}-05$ & 1 & $1.69 \mathrm{E}-05$ & 4.35 \\
AC & $1.07 \mathrm{E}-04$ & 2 & $5.34 \mathrm{E}-05$ & 5.86 & $8.27 \mathrm{E}-06$ & 2 & $4.14 \mathrm{E}-06$ & 1.06 \\
AD & $1.23 \mathrm{E}-05$ & 2 & $6.14 \mathrm{E}-06$ & 0.67 & $1.35 \mathrm{E}-05$ & 1 & $1.35 \mathrm{E}-05$ & 3.47 \\
BC & $3.48 \mathrm{E}-05$ & 2 & $1.74 \mathrm{E}-05$ & 1.91 & $4.05 \mathrm{E}-08$ & 1 & $4.05 \mathrm{E}-08$ & 0.01 \\
BD & $1.86 \mathrm{E}-05$ & 1 & $1.86 \mathrm{E}-05$ & 2.05 & $2.05 \mathrm{E}-05$ & 2 & $1.02 \mathrm{E}-05$ & 2.64 \\
CD & $2.67 \mathrm{E}-06$ & 1 & $2.67 \mathrm{E}-06$ & 0.29 & $2.32 \mathrm{E}-05$ & 2 & $1.16 \mathrm{E}-05$ & 2.99 \\
ABC & $2.22 \mathrm{E}-05$ & 1 & $2.22 \mathrm{E}-05$ & 2.44 & $3.75 \mathrm{E}-06$ & 1 & $3.75 \mathrm{E}-06$ & 0.97 \\
ABD & $1.23 \mathrm{E}-05$ & 2 & $6.14 \mathrm{E}-06$ & 0.67 & $1.12 \mathrm{E}-05$ & 2 & $5.62 \mathrm{E}-06$ & 1.45 \\
ACD & $3.48 \mathrm{E}-05$ & 2 & $1.74 \mathrm{E}-05$ & 1.91 & $7.82 \mathrm{E}-06$ & 2 & $3.91 \mathrm{E}-06$ & 1.01 \\
BCD & $1.95 \mathrm{E}-05$ & 2 & $9.77 \mathrm{E}-06$ & 1.07 & $2.22 \mathrm{E}-05$ & 1 & $2.22 \mathrm{E}-05$ & 5.73 \\
ABCD & $7.21 \mathrm{E}-06$ & 1 & $7.21 \mathrm{E}-06$ & 0.79 & $1.01 \mathrm{E}-05$ & 2 & $5.05 \mathrm{E}-06$ & 1.30 \\
Erro & $1.95 \mathrm{E}-05$ & 2 & $9.77 \mathrm{E}-06$ & 1.07 & $1.88 \mathrm{E}-05$ & 2 & $9.38 \mathrm{E}-06$ & 2.41 \\
Total & $2.18 \mathrm{E}-04$ & 24 & $9.10 \mathrm{E}-06$ & & $9.32 \mathrm{E}-05$ & 24 & $3.88 \mathrm{E}-06$ & \\
\hline & $6.58 \mathrm{E}-03$ & 23 & & & $9.36 \mathrm{E}-03$ & 23 & & \\
\hline
\end{tabular}


Tabela B.20- Resumo da Análise de Variância realizado com das temperaturas do ponto de amolecimento, dos valores de $\mathrm{f}_{0}$ e da influência dos fatores e sua interação, considerando o fator tipo de fíler em 4 níveis e o teor de fíler em 3 níveis (análise (1)) e o fator tipo de fíler em 3 níveis e o teor de fíler em 2 níveis (análise (2)).

\begin{tabular}{c|cccc|cccc}
\hline \multirow{2}{*}{ Fator } & \multicolumn{5}{|c|}{ análise (1) } & \multicolumn{4}{c}{ análise (2) } \\
& SQ & GL & MQ & $\mathrm{F}_{0}$ & SQ & GL & MQ & $\mathrm{F}_{0}$ \\
\hline A & 596.66 & 3 & 198.89 & 1131.11 & 4.87 & 2 & 2.43 & 16.78 \\
B & 937.79 & 2 & 468.90 & 2666.71 & 564.35 & 3 & 188.12 & 1297.36 \\
C & 376.32 & 1 & 376.32 & 2140.21 & 366.31 & 1 & 366.31 & 2526.26 \\
AB & 483.27 & 6 & 80.54 & 458.07 & 5.39 & 6 & 0.90 & 6.19 \\
AC & 1.98 & 3 & 0.66 & 3.76 & 2.28 & 2 & 1.14 & 7.88 \\
BC & 1.53 & 2 & 0.77 & 4.35 & 0.94 & 3 & 0.31 & 2.16 \\
ABC & 1.04 & 6 & 0.17 & 0.99 & 1.41 & 6 & 0.24 & 1.63 \\
Erro & 4.22 & 24 & 0.18 & & 3.48 & 24 & 0.15 & \\
Total & 2402.82 & 23 & & & 949.03 & 23 & & \\
\hline
\end{tabular}


Tabela B.21 - Resumo da análise de variância, realizado para a energia de fratura, da análise (1)

\begin{tabular}{|c|c|c|c|c|c|c|c|c|}
\hline \multicolumn{9}{|c|}{ e (2) } \\
\hline \multirow{2}{*}{ Fator } & \multicolumn{4}{|c|}{ análise (1) } & \multicolumn{4}{|c|}{ análise (2) } \\
\hline & SQ & GL & MQ & $\mathrm{F}_{0}$ & SQ & GL & MQ & $\mathrm{F}_{0}$ \\
\hline $\begin{array}{c}\mathrm{A} \\
\text { (tipo de fíler) }\end{array}$ & 106840.3 & 1 & 106840.3 & 7.22 & 895888.8 & 2 & 447944.4 & 120.91 \\
\hline $\begin{array}{c}\text { B } \\
\text { (teor de fíler) }\end{array}$ & 2178069.6 & 2 & 1089034.8 & 73.64 & 1547531.6 & 1 & 1547531.6 & 417.72 \\
\hline $\begin{array}{c}\mathrm{C} \\
\text { (tipo de ligante) }\end{array}$ & 20434.4 & 1 & 20434.4 & 1.38 & 113976.5 & 1 & 113976.5 & 30.77 \\
\hline $\begin{array}{c}\text { D } \\
\text { (tipo de } \\
\text { envelhecimento) }\end{array}$ & 8484.8 & 1 & 8484.8 & 0.57 & 14758.7 & 1 & 14758.7 & 3.98 \\
\hline $\mathrm{AB}$ & 116584.2 & 2 & 58292.1 & 3.94 & 895888.8 & 2 & 447944.4 & 120.91 \\
\hline $\mathrm{AC}$ & 6551.8 & 1 & 6551.8 & 0.44 & 1072.4 & 2 & 536.2 & 0.14 \\
\hline $\mathrm{AD}$ & 85358.2 & 1 & 85358.2 & 5.77 & 55980.5 & 2 & 27990.3 & 7.56 \\
\hline $\mathrm{BC}$ & 80054.1 & 2 & 40027.1 & 2.71 & 15218.9 & 1 & 15218.9 & 4.11 \\
\hline $\mathrm{BD}$ & 349346.8 & 2 & 174673.4 & 11.81 & 340990.1 & 1 & 340990.1 & 92.04 \\
\hline $\mathrm{CD}$ & 42682.5 & 1 & 42682.5 & 2.89 & 14120.0 & 1 & 14120.0 & 3.81 \\
\hline $\mathrm{ABC}$ & 4582.3 & 2 & 2291.1 & 0.15 & 1072.4 & 2 & 536.2 & 0.14 \\
\hline $\mathrm{ABD}$ & 43828.4 & 2 & 21914.2 & 1.48 & 55980.5 & 2 & 27990.3 & 7.56 \\
\hline $\mathrm{ACD}$ & 0.2 & 1 & 0.2 & 0.00 & 7409.4 & 2 & 3704.7 & 1.00 \\
\hline $\mathrm{BCD}$ & 17616.4 & 2 & 8808.2 & 0.60 & 663.0 & 1 & 663.0 & 0.18 \\
\hline $\mathrm{ABCD}$ & - & - & - & - & - & - & - & - \\
\hline Erro & 29577.2 & 2 & 14788.6 & & 7409.4 & 2 & 3704.7 & \\
\hline Total & 3090011.3 & 23 & & & 3967961.1 & 23 & & \\
\hline
\end{tabular}


Tabela B.22 - Resumo da análise de variância, realizado para a energia de fratura, da análise (3) e (4)

\begin{tabular}{c|cccc|cccc}
\hline \multirow{2}{*}{ Fator } & \multicolumn{5}{|c|}{ análise (3) } & \multicolumn{4}{c}{ análise (4) } \\
& $\mathrm{SQ}$ & $\mathrm{GL}$ & $\mathrm{MQ}$ & $\mathrm{F}_{0}$ & $\mathrm{SQ}$ & $\mathrm{GL}$ & $\mathrm{MQ}$ & $\mathrm{F}_{0}$ \\
\hline $\begin{array}{c}\text { A } \\
\text { (tipo de fíler) } \\
\text { B } \\
\text { (teor de fíler) }\end{array}$ & 47530.3 & 1 & 47530.3 & 11.54 & 1210304.9 & 2 & 605152.5 & 324.64 \\
$\begin{array}{c}\text { C } \\
\text { (tipo de ligante) }\end{array}$ & 2046696.6 & 2 & 1023348.3 & 248.55 & 562902.5 & 1 & 562902.5 & 301.97 \\
D & 6926.8 & 1 & 6926.8 & 1.68 & 36656.7 & 1 & 36656.7 & 19.66 \\
(tipo de & & & & & & & & \\
envelhecimento) & 82686.6 & 1 & 82686.6 & 20.08 & 45136.9 & 1 & 45136.9 & 24.21 \\
AB & 48771.5 & 2 & 24385.8 & 5.92 & 1210304.9 & 2 & 605152.5 & 324.64 \\
AC & 3422.9 & 1 & 3422.9 & 0.83 & 3777.7 & 2 & 1888.9 & 1.01 \\
AD & 33603.1 & 1 & 33603.1 & 8.16 & 2706.0 & 2 & 1353.0 & 0.73 \\
BC & 49982.2 & 2 & 24991.1 & 6.07 & 27416.5 & 1 & 27416.5 & 14.71 \\
BD & 11717.9 & 2 & 5858.9 & 1.42 & 8138.5 & 1 & 8138.5 & 4.37 \\
CD & 21572.6 & 1 & 21572.6 & 5.24 & 746.2 & 1 & 746.2 & 0.40 \\
ABC & 3868.1 & 2 & 1934.0 & 0.47 & 3777.7 & 2 & 1888.9 & 1.01 \\
ABD & 32954.0 & 2 & 16477.0 & 4.00 & 2706.0 & 2 & 1353.0 & 0.73 \\
ACD & 485.7 & 1 & 485.7 & 0.12 & 3728.2 & 2 & 1864.1 & 1.00 \\
BCD & 56299.8 & 2 & 28149.9 & 6.84 & 4618.9 & 1 & 4618.9 & 2.48 \\
ABCD & - & - & - & - & - & - & - & - \\
Erro & 8234.6 & 2 & 4117.3 & & 3728.2 & 2 & 1864.1 & \\
Total & 2454752.7 & 23 & & & 3126649.8 & 23 & & \\
\hline
\end{tabular}


Tabela B.23 - Resumo da análise de variância, realizado para a energia de fratura, da análise (5) e (6)

\begin{tabular}{|c|c|c|c|c|c|c|c|c|}
\hline \multirow{2}{*}{ Fator } & \multicolumn{4}{|c|}{ análise (5) } & \multicolumn{4}{|c|}{ análise (6) } \\
\hline & SQ & GL & MQ & $\mathrm{F}_{0}$ & SQ & GL & MQ & $\mathrm{F}_{0}$ \\
\hline $\begin{array}{c}\text { A } \\
\text { (tipo de fíler) }\end{array}$ & 260279.3 & 1 & 260279.3 & 73.61 & 962791.1 & 2 & 481395.6 & 670.10 \\
\hline $\begin{array}{c}\text { B } \\
\text { (teor de fíler) }\end{array}$ & 2009176.2 & 2 & 1004588.1 & 284.11 & 1780121.4 & 1 & 1780121.4 & 2477.93 \\
\hline $\begin{array}{c}\mathrm{C} \\
\text { (tipo de ligante) }\end{array}$ & 83998.5 & 1 & 83998.5 & 23.76 & 96278.0 & 1 & 96278.0 & 134.02 \\
\hline $\begin{array}{c}\text { D } \\
\text { (tipo de } \\
\text { envelhecimento) }\end{array}$ & 38196.8 & 1 & 38196.8 & 10.80 & 8275.3 & 1 & 8275.3 & 11.52 \\
\hline $\mathrm{AB}$ & 145573.4 & 2 & 72786.7 & 20.59 & 962791.1 & 2 & 481395.6 & 670.10 \\
\hline $\mathrm{AC}$ & 3469.7 & 1 & 3469.7 & 0.98 & 803.4 & 2 & 401.7 & 0.56 \\
\hline $\mathrm{AD}$ & 11848.3 & 1 & 11848.3 & 3.35 & 49207.9 & 2 & 24603.9 & 34.25 \\
\hline $\mathrm{BC}$ & 27628.8 & 2 & 13814.4 & 3.91 & 36606.1 & 1 & 36606.1 & 50.96 \\
\hline $\mathrm{BD}$ & 265277.1 & 2 & 132638.5 & 37.51 & 243769.2 & 1 & 243769.2 & 339.33 \\
\hline $\mathrm{CD}$ & 3566.6 & 1 & 3566.6 & 1.01 & 21358.3 & 1 & 21358.3 & 29.73 \\
\hline $\mathrm{ABC}$ & 17495.3 & 2 & 8747.6 & 2.47 & 803.4 & 2 & 401.7 & 0.56 \\
\hline $\mathrm{ABD}$ & 14608.6 & 2 & 7304.3 & 2.07 & 49207.9 & 2 & 24603.9 & 34.25 \\
\hline ACD & 503.5 & 1 & 503.5 & 0.14 & 1436.8 & 2 & 718.4 & 1.00 \\
\hline $\mathrm{BCD}$ & 11702.3 & 2 & 5851.1 & 1.65 & 1782.0 & 1 & 1782.0 & 2.48 \\
\hline $\mathrm{ABCD}$ & - & - & - & - & - & - & - & - \\
\hline Erro & 7071.8 & 2 & 3535.9 & & 1436.8 & 2 & 718.4 & \\
\hline Total & 2900396.0 & 23 & & & 4216668.7 & 23 & & \\
\hline
\end{tabular}




\section{APÊNDICE C - PROPRIEDADES MECÂNICAS DOS CORPOS DE PROVA}

(a) Resistência à Tração

Tabela C.1 - Valores de resistência à tração para as misturas asfálticas na condição 1

\begin{tabular}{cccccc}
\hline CP & $\begin{array}{c}\text { Diâmetro } \\
(\mathbf{c m})\end{array}$ & $\begin{array}{c}\text { Altura } \\
(\mathbf{c m})\end{array}$ & $\begin{array}{c}\text { Força } \\
(\mathbf{k g})\end{array}$ & $\begin{array}{c}\text { RT } \\
(\mathbf{k g f} / \mathbf{c m} 2)\end{array}$ & $\begin{array}{c}\text { RT } \\
\text { Mpa }\end{array}$ \\
\hline $1-1$ & 9.991 & 6.465 & 2040 & 20.117 & 2.012 \\
$1-7$ & 9.994 & 6.537 & 2112 & 20.591 & 2.059 \\
$1-14$ & 9.984 & 6.557 & 1957 & 19.041 & 1.904 \\
média & 10.0 & 6.5 & $\mathbf{2 0 3 6 . 3}$ & $\mathbf{1 9 . 9 1 6}$ & $\mathbf{1 . 9 9 2}$ \\
\hline
\end{tabular}

Tabela C.2 - Valores de resistência à tração para as misturas asfálticas na condição 2

\begin{tabular}{cccccc}
\hline CP & $\begin{array}{c}\text { Diâmetro } \\
(\mathbf{c m})\end{array}$ & $\begin{array}{c}\text { Altura } \\
(\mathbf{c m})\end{array}$ & $\begin{array}{c}\text { Força } \\
(\mathbf{k g})\end{array}$ & $\begin{array}{c}\text { RT } \\
(\mathbf{k g f} / \mathbf{c m} 2)\end{array}$ & $\begin{array}{c}\text { RT } \\
\text { Mpa }\end{array}$ \\
\hline $2-1$ & 9.982 & 6.491 & 1791 & 17.606 & 1.761 \\
$2-6$ & 9.989 & 6.514 & 2168 & 21.222 & 2.122 \\
$2-14$ & 9.982 & 6.543 & 1880 & 18.334 & 1.833 \\
média & 10.0 & 6.5 & $\mathbf{1 9 4 6 . 3}$ & $\mathbf{1 9 . 0 5 4}$ & $\mathbf{1 . 9 0 5}$ \\
\hline
\end{tabular}

Tabela C. 3 - Valores de resistência à tração para as misturas asfálticas na condição 3

\begin{tabular}{cccccc}
\hline CP & $\begin{array}{c}\text { Diâmetro } \\
(\mathbf{c m})\end{array}$ & $\begin{array}{c}\text { Altura } \\
(\mathbf{c m})\end{array}$ & $\begin{array}{c}\text { Força } \\
(\mathbf{k g})\end{array}$ & $\begin{array}{c}\text { RT } \\
(\mathbf{k g f} / \mathbf{c m} 2)\end{array}$ & $\begin{array}{c}\text { RT } \\
\text { Mpa }\end{array}$ \\
\hline $3-1$ & 9.994 & 6.421 & 2208 & 21.916 & 2.192 \\
$3-7$ & 9.981 & 6.545 & 1921 & 18.730 & 1.873 \\
$3-14$ & 9.993 & 6.429 & 2179 & 21.603 & 2.160 \\
média & 10.0 & 6.5 & $\mathbf{2 1 0 2 . 7}$ & $\mathbf{2 0 . 7 5 0}$ & $\mathbf{2 . 0 7 5}$ \\
\hline
\end{tabular}

Tabela C.4 - Valores de resistência à tração para as misturas asfálticas na condição 4

\begin{tabular}{cccccc}
\hline CP & $\begin{array}{c}\text { Diâmetro } \\
(\mathbf{c m})\end{array}$ & $\begin{array}{c}\text { Altura } \\
(\mathbf{c m})\end{array}$ & $\begin{array}{c}\text { Força } \\
(\mathbf{k g})\end{array}$ & $\begin{array}{c}\text { RT } \\
(\mathbf{k g f} / \mathbf{c m} 2)\end{array}$ & $\begin{array}{c}\text { RT } \\
\text { Mpa }\end{array}$ \\
\hline $4-5$ & 9.99 & 7.08 & 2436 & 21.939 & 2.194 \\
$4-7$ & 10.00 & 7.09 & 1960 & 17.613 & 1.761 \\
$4-8$ & 10.00 & 7.01 & 2136 & 19.406 & 1.941 \\
\hline média & 10.0 & 7.1 & $\mathbf{2 1 7 7 . 3}$ & $\mathbf{1 9 . 6 5 3}$ & $\mathbf{1 . 9 6 5}$ \\
\hline
\end{tabular}


Tabela C.5 - Valores de resistência à tração para as misturas asfálticas na condição 5

\begin{tabular}{cccccc}
\hline CP & $\begin{array}{c}\text { Diâmetro } \\
(\mathbf{c m})\end{array}$ & $\begin{array}{c}\text { Altura } \\
(\mathbf{c m})\end{array}$ & $\begin{array}{c}\text { Força } \\
(\mathbf{k g})\end{array}$ & $\begin{array}{c}\text { RT } \\
(\mathbf{k g f} / \mathbf{c m} 2)\end{array}$ & $\begin{array}{c}\text { RT } \\
\mathbf{M p a}\end{array}$ \\
\hline $5-1$ & 10.00 & 6.94 & 1797 & 16.486 & 1.649 \\
$5-7$ & 9.99 & 6.99 & 2037 & 18.595 & 1.860 \\
$5-13$ & 10.00 & 7.00 & 2009 & 18.272 & 1.827 \\
média & 10.0 & 7.0 & $\mathbf{1 9 4 7 . 7}$ & $\mathbf{1 7 . 7 8 5}$ & $\mathbf{1 . 7 7 8}$ \\
\hline
\end{tabular}

Tabela C.6 - Valores de resistência à tração para as misturas asfálticas na condição 6

\begin{tabular}{cccccc}
\hline CP & $\begin{array}{c}\text { Diâmetro } \\
(\mathbf{c m})\end{array}$ & $\begin{array}{c}\text { Altura } \\
(\mathbf{c m})\end{array}$ & $\begin{array}{c}\text { Força } \\
(\mathbf{k g})\end{array}$ & $\begin{array}{c}\text { RT } \\
(\mathbf{k g f} / \mathbf{c m} 2)\end{array}$ & $\begin{array}{c}\text { RT } \\
\text { Mpa }\end{array}$ \\
\hline $6-1$ & 9.99 & 6.94 & 1996 & 18.323 & 1.832 \\
$6-9$ & 9.99 & 6.88 & 1904 & 17.645 & 1.765 \\
$6-14$ & 9.98 & 6.90 & 1568 & 14.506 & 1.451 \\
média & 10.0 & 6.9 & $\mathbf{1 8 2 2 . 7}$ & $\mathbf{1 6 . 8 2 5}$ & $\mathbf{1 . 7 9 8}$ \\
\hline
\end{tabular}

Tabela C.7 - Valores de resistência à tração para as misturas asfálticas na condição 7

\begin{tabular}{cccccc}
\hline CP & $\begin{array}{c}\text { Diâmetro } \\
(\mathbf{c m})\end{array}$ & $\begin{array}{c}\text { Altura } \\
(\mathbf{c m})\end{array}$ & $\begin{array}{c}\text { Força } \\
(\mathbf{k g})\end{array}$ & $\begin{array}{c}\text { RT } \\
(\mathbf{k g f} / \mathbf{c m} 2)\end{array}$ & $\begin{array}{c}\text { RT } \\
\text { Mpa }\end{array}$ \\
\hline $7-1$ & 9.99 & 6.48 & 1135 & 11.158 & 1.116 \\
$7-10$ & 9.99 & 6.50 & 1185 & 11.614 & 1.161 \\
$7-14$ & 10.00 & 6.55 & 1220 & 11.865 & 1.187 \\
\hline média & 10.0 & 6.5 & $\mathbf{1 1 8 0 . 0}$ & $\mathbf{1 1 . 5 4 6}$ & $\mathbf{1 . 1 5 5}$ \\
\hline
\end{tabular}

Tabela C.8 - Valores de resistência à tração para as misturas asfálticas na condição 8

\begin{tabular}{cccccc}
\hline CP & $\begin{array}{c}\text { Diâmetro } \\
(\mathbf{c m})\end{array}$ & $\begin{array}{c}\text { Altura } \\
(\mathbf{c m})\end{array}$ & $\begin{array}{c}\text { Força } \\
(\mathbf{k g})\end{array}$ & $\begin{array}{c}\text { RT } \\
(\mathbf{k g f} / \mathbf{c m} 2)\end{array}$ & $\begin{array}{c}\text { RT } \\
\mathbf{M p a}\end{array}$ \\
\hline $8-1$ & 9.99 & 6.53 & 1051 & 10.259 & 1.026 \\
$8-6$ & 9.99 & 6.46 & 1208 & 11.929 & 1.193 \\
$8-12$ & 9.98 & 6.50 & 1142 & 11.205 & 1.120 \\
\hline média & 10.0 & 6.5 & $\mathbf{1 1 3 3 . 7}$ & $\mathbf{1 1 . 1 3 1}$ & $\mathbf{1 . 1 1 3}$ \\
\hline
\end{tabular}

Tabela C.9 - Valores de resistência à tração para as misturas asfálticas na condição 9

\begin{tabular}{cccccc}
\hline CP & $\begin{array}{c}\text { Diâmetro } \\
(\mathbf{c m})\end{array}$ & $\begin{array}{c}\text { Altura } \\
(\mathbf{c m})\end{array}$ & $\begin{array}{c}\text { Força } \\
(\mathbf{k g})\end{array}$ & $\begin{array}{c}\text { RT } \\
(\mathbf{k g f} / \mathbf{c m} 2)\end{array}$ & $\begin{array}{c}\text { RT } \\
\text { Mpa }\end{array}$ \\
\hline $9-1$ & 9.99 & 6.35 & 1100 & 11.057 & 1.106 \\
$9-9$ & 9.99 & 6.46 & 1235 & 12.192 & 1.219 \\
$9-14$ & 9.99 & 6.44 & 1176 & 11.651 & 1.165 \\
\hline média & 10.0 & 6.4 & $\mathbf{1 1 7 0 . 3}$ & $\mathbf{1 1 . 6 3 4}$ & $\mathbf{1 . 1 6 3}$ \\
\hline
\end{tabular}


Tabela C.10 - Valores de resistência à tração para as misturas asfálticas na condição 10

\begin{tabular}{cccccc}
\hline CP & $\begin{array}{c}\text { Diâmetro } \\
(\mathbf{c m})\end{array}$ & $\begin{array}{c}\text { Altura } \\
(\mathbf{c m})\end{array}$ & $\begin{array}{c}\text { Força } \\
(\mathbf{k g})\end{array}$ & $\begin{array}{c}\text { RT } \\
(\mathbf{k g f} / \mathbf{c m} 2)\end{array}$ & $\begin{array}{c}\text { RT } \\
\text { Mpa }\end{array}$ \\
\hline $10-1$ & 9.99 & 7.00 & 1142 & 10.399 & 1.040 \\
$10-7$ & 10.00 & 7.00 & 1263 & 11.487 & 1.149 \\
$10-11$ & 10.00 & 6.98 & 1153 & 10.523 & 1.052 \\
\hline média & 10.0 & 7.0 & $\mathbf{1 1 8 6 . 0}$ & $\mathbf{1 0 . 8 0 3}$ & $\mathbf{1 . 0 8 0}$ \\
\hline
\end{tabular}

Tabela C.11 - Valores de resistência à tração para as misturas asfálticas na condição 11

\begin{tabular}{cccccc}
\hline CP & $\begin{array}{c}\text { Diâmetro } \\
(\mathbf{c m})\end{array}$ & $\begin{array}{c}\text { Altura } \\
(\mathbf{c m})\end{array}$ & $\begin{array}{c}\text { Força } \\
(\mathbf{k g})\end{array}$ & $\begin{array}{c}\text { RT } \\
(\mathbf{k g f} / \mathbf{c m} 2)\end{array}$ & $\begin{array}{c}\text { RT } \\
\text { Mpa }\end{array}$ \\
\hline $11-1$ & 10.01 & 6.93 & 1166 & 10.716 & 1.072 \\
$11-4$ & 9.99 & 6.96 & 1042 & 9.540 & 0.954 \\
$11-14$ & 10.00 & 6.96 & 1087 & 9.948 & 0.995 \\
\hline média & 10.0 & 7.0 & $\mathbf{1 0 9 8 . 3}$ & $\mathbf{1 0 . 0 6 8}$ & $\mathbf{1 . 0 0 7}$ \\
\hline
\end{tabular}

Tabela C.12 - Valores de resistência à tração para as misturas asfálticas na condição 12

\begin{tabular}{cccccc}
\hline CP & $\begin{array}{c}\text { Diâmetro } \\
(\mathbf{c m})\end{array}$ & $\begin{array}{c}\text { Altura } \\
(\mathbf{c m})\end{array}$ & $\begin{array}{c}\text { Força } \\
(\mathbf{k g})\end{array}$ & $\begin{array}{c}\text { RT } \\
(\mathbf{k g f} / \mathbf{c m} 2)\end{array}$ & $\begin{array}{c}\text { RT } \\
\text { Mpa }\end{array}$ \\
\hline $12-3$ & 10.00 & 7.00 & 1099 & 9.995 & 0.999 \\
$12-4$ & 9.99 & 7.02 & 1131 & 10.279 & 1.028 \\
$12-8$ & 10.00 & 7.03 & 1034 & 9.369 & 0.937 \\
média & 10.0 & 7.0 & $\mathbf{1 0 8 8 . 0}$ & $\mathbf{9 . 8 8 1}$ & $\mathbf{0 . 9 8 8}$ \\
\hline
\end{tabular}


(b) Módulo de Resiliência

Tabela C.13 - Valores de módulo de resiliência para as misturas asfálticas na condição 1

\begin{tabular}{ccccc}
\hline CP & $\begin{array}{c}\text { Modulo Total } \\
\text { DNER }\end{array}$ & $\begin{array}{c}\text { Desvio } \\
\text { Padrão }\end{array}$ & $\begin{array}{c}\text { Modulo Total } \\
\text { NCHRP }\end{array}$ & $\begin{array}{c}\text { Desvio } \\
\text { Padrão }\end{array}$ \\
\hline $1-1$ & 6725.1 & 168.12 & 6731.9 & 189.8 \\
$1-2$ & 5756.3 & 135.25 & 5760.9 & 133.76 \\
$1-3$ & 6460.6 & 155.89 & 6487.9 & 166.79 \\
$1-4$ & 5211.9 & 108.98 & 5208.5 & 120.32 \\
$1-5$ & 7836.4 & 221.83 & 7816.4 & 211.09 \\
$1-6$ & 6943.6 & 175.79 & 6972.6 & 196.34 \\
$1-7$ & 6970.8 & 161.27 & 6947.2 & 147.1 \\
$1-8$ & 6376.9 & 214.22 & 6369 & 220.2 \\
$1-9$ & 5783.3 & 150.03 & 5810.4 & 129.29 \\
$1-10$ & 5368.5 & 127.3 & 5385 & 123.63 \\
$1-11$ & 5833 & 152.43 & 5812.2 & 137.3 \\
$1-12$ & 6012.5 & 137.16 & 6031.8 & 138.47 \\
$1-13$ & 7551.8 & 207.92 & 7558.9 & 203.37 \\
$1-14$ & 5727.4 & 146.88 & 5716 & 133.94 \\
\hline média & 6325.58 & 161.65 & 6329.19 & 160.8143 \\
\hline Desvio padrão & 796.04 & & 793.25 & \\
\hline
\end{tabular}

Tabela C.14 - Valores de módulo de resiliência para as misturas asfálticas na condição 2

\begin{tabular}{ccccc}
\hline CP & $\begin{array}{c}\text { Modulo Total } \\
\text { DNER }\end{array}$ & $\begin{array}{c}\text { Desvio } \\
\text { Padrão }\end{array}$ & $\begin{array}{c}\text { Modulo Total } \\
\text { NCHRP }\end{array}$ & $\begin{array}{c}\text { Desvio } \\
\text { Padrão }\end{array}$ \\
\hline $2-1$ & 7169.5 & 198.03 & 7160.5 & 202.92 \\
$2-2$ & 7451.5 & 204.53 & 7446 & 193.47 \\
$2-3$ & 6403.1 & 153.74 & 6411.9 & 152.17 \\
$2-4$ & 6240.5 & 178.17 & 6230 & 148.77 \\
$2-5$ & 5662.4 & 121.79 & 5660.9 & 126.31 \\
$2-6$ & 6483.7 & 204.26 & 6494.4 & 196.65 \\
$2-7$ & 6142.9 & 205.74 & 6157.9 & 216.96 \\
$2-8$ & 6760.2 & 211.88 & 6810.2 & 212.23 \\
$2-9$ & 7960 & 222.13 & 7988.8 & 229.45 \\
$2-10$ & 9666.1 & 271.52 & 9649.3 & 327.59 \\
$2-11$ & 6566.8 & 176.48 & 6587.9 & 191.47 \\
$2-12$ & 7065.9 & 198.13 & 7073.6 & 212.01 \\
$2-13$ & 6893 & 218.41 & 6919.8 & 214.83 \\
$2-14$ & 7200.4 & 199.83 & 7200.7 & 204.76 \\
\hline média & 6976.14 & 197.47 & 6985.14 & 202.11 \\
\hline Desvio padrão & 971.87 & & 967.66 & \\
\hline
\end{tabular}


Tabela C.15 - Valores de módulo de resiliência para as misturas asfálticas na condição 3

\begin{tabular}{ccccc}
\hline $\mathrm{CP}$ & $\begin{array}{c}\text { Modulo Total } \\
\text { DNER }\end{array}$ & $\begin{array}{c}\text { Desvio } \\
\text { Padrão }\end{array}$ & $\begin{array}{c}\text { Modulo Total } \\
\text { NCHRP }\end{array}$ & $\begin{array}{c}\text { Desvio } \\
\text { Padrão }\end{array}$ \\
\hline $3-1$ & 7994.7 & 264.03 & 8015.4 & 280.98 \\
$3-2$ & 8355.9 & 276.45 & 8342 & 239.4 \\
$3-3$ & 7302 & 224.91 & 7318.3 & 211.49 \\
$3-4$ & 7197.4 & 201.47 & 7227.6 & 224.7 \\
$3-5$ & 6691.9 & 176.19 & 6703.5 & 187.18 \\
$3-6$ & 7680.2 & 236.52 & 7689.1 & 257.3 \\
$3-7$ & 6494.8 & 175.31 & 6525.1 & 209.53 \\
$3-8$ & 9985.5 & 323.63 & 10039.8 & 328.76 \\
$3-9$ & 8133.1 & 218.15 & 8168.9 & 243.87 \\
$3-10$ & 9407.1 & 331.64 & 9423.9 & 343.73 \\
$3-11$ & 9612.9 & 277.32 & 9581 & 283.57 \\
$3-12$ & 8031.6 & 273.15 & 8042.8 & 304.16 \\
$3-14$ & 7242 & 255.04 & 7219.1 & 230.4 \\
\hline média & 8009.93 & 248.75 & 8022.81 & 257.31 \\
\hline Desvio padrão & 1097.45 & & 1097.45 & \\
\hline
\end{tabular}

Tabela C.16 - Valores de módulo de resiliência para as misturas asfálticas na condição 4

\begin{tabular}{ccccc}
\hline CP & $\begin{array}{c}\text { Modulo Total } \\
\text { DNER }\end{array}$ & $\begin{array}{c}\text { Desvio } \\
\text { Padrão }\end{array}$ & $\begin{array}{c}\text { Modulo Total } \\
\text { NCHRP }\end{array}$ & $\begin{array}{c}\text { Desvio } \\
\text { Padrão }\end{array}$ \\
\hline $4-1$ & 5780.3 & 177.45 & 5759.5 & 198.35 \\
$4-2$ & 6499.4 & 219.74 & 6514 & 221.46 \\
$4-3$ & 9137 & 369.15 & 9158.8 & 327.33 \\
$4-4$ & 6354.1 & 253.74 & 6433.3 & 269.81 \\
$4-5$ & 7311.3 & 281.14 & 7350.7 & 325.26 \\
$4-6$ & 5959.3 & 211.52 & 5918.7 & 193.99 \\
$4-8$ & 7782.6 & 346.6 & 7775.5 & 360.93 \\
$4-9$ & 6118.4 & 223.72 & 6135.5 & 202.23 \\
$4-10$ & 6170.7 & 219.46 & 6170.6 & 214.5 \\
$4-11$ & 6932.1 & 258.57 & 6968.2 & 251.28 \\
$4-12$ & 7180.1 & 277.51 & 7219.1 & 288.15 \\
$4-13$ & 7574.2 & 240.46 & 7607.8 & 263.73 \\
$4-14$ & 5988.6 & 172.07 & 5978.7 & 160.04 \\
média & 6829.85 & 250.09 & 6845.42 & 252.08 \\
\hline Desvio padrão & 957.12 & & 967.66 & \\
\hline
\end{tabular}


Tabela C.17 - Valores de módulo de resiliência para as misturas asfálticas na condição 5

\begin{tabular}{ccccc}
\hline CP & $\begin{array}{c}\text { Modulo Total } \\
\text { DNER }\end{array}$ & $\begin{array}{c}\text { Desvio } \\
\text { Padrão }\end{array}$ & $\begin{array}{c}\text { Modulo Total } \\
\text { NCHRP }\end{array}$ & $\begin{array}{c}\text { Desvio } \\
\text { Padrão }\end{array}$ \\
\hline $5-1$ & 7418.9 & 286.35 & 7419.9 & 209.09 \\
$5-2$ & 9408.7 & 381.96 & 9439 & 494.44 \\
$5-3$ & 7981.8 & 335.41 & 7929.1 & 320.8 \\
$5-4$ & 6494.3 & 236.47 & 6516.1 & 220.68 \\
$5-5$ & 11439 & 517.72 & 11424.4 & 593.17 \\
$5-6$ & 8686.9 & 340.55 & 8657 & 354.46 \\
$5-7$ & 7894.6 & 325.67 & 7906.7 & 340.49 \\
$5-8$ & 10615.9 & 450.63 & 10623.6 & 390.46 \\
$5-9$ & 7145.4 & 246.39 & 7160.6 & 246.41 \\
$5-10$ & 7799.1 & 288.29 & 7777.9 & 302.69 \\
$5-11$ & 7405.3 & 202.05 & 7392.5 & 226.46 \\
$5-12$ & 8028.6 & 264.22 & 8074.3 & 285.32 \\
$5-13$ & 10161.5 & 468.8 & 10125.7 & 511.44 \\
$5-14$ & 7095.8 & 254.5 & 7074.7 & 274.39 \\
\hline média & 8398.27 & 328.50 & 8394.39 & 340.74 \\
\hline Desvio padrão & 1471.17 & & 1467.34 & \\
\hline
\end{tabular}

Tabela C.18 - Valores de módulo de resiliência para as misturas asfálticas na condição 6

\begin{tabular}{ccccc}
\hline CP & $\begin{array}{c}\text { Modulo Total } \\
\text { DNER }\end{array}$ & $\begin{array}{c}\text { Desvio } \\
\text { Padrão }\end{array}$ & $\begin{array}{c}\text { Modulo Total } \\
\text { NCHRP }\end{array}$ & $\begin{array}{c}\text { Desvio } \\
\text { Padrão }\end{array}$ \\
\hline $6-1$ & 8134.5 & 312.65 & 8094.4 & 327.37 \\
$6-2$ & 7162.1 & 280.22 & 7170.7 & 269.9 \\
$6-3$ & 7925.7 & 285.15 & 7928.9 & 307.32 \\
$6-4$ & 7782 & 273.65 & 7842.7 & 323.61 \\
$6-5$ & 7336.3 & 265.64 & 7354.1 & 265.6 \\
$6-6$ & 9905 & 414.63 & 9900.1 & 407.72 \\
$6-7$ & 6959.3 & 260.69 & 6945.8 & 270.38 \\
$6-8$ & 8957.1 & 326.46 & 8912.1 & 338.68 \\
$6-9$ & 6125.1 & 227.35 & 6130.1 & 197.58 \\
$6-10$ & 8839.9 & 401.8 & 8841.7 & 380.65 \\
$6-11$ & 6999.2 & 214.02 & 7021.3 & 228.95 \\
$6-12$ & 8105.9 & 293.75 & 8130.2 & 330.69 \\
$6-13$ & 8111.3 & 243.22 & 8135.9 & 299.76 \\
$6-14$ & 6636.9 & 199.51 & 6633.1 & 180.48 \\
\hline média & 7784.31 & 285.62 & 7788.65 & 294.91 \\
\hline Desvio padrão & 1011.26 & & 1005.32 & \\
\hline
\end{tabular}


Tabela C.19 - Valores de módulo de resiliência para as misturas asfálticas na condição 7

\begin{tabular}{ccccc}
\hline CP & $\begin{array}{c}\text { Modulo Total } \\
\text { DNER }\end{array}$ & $\begin{array}{c}\text { Desvio } \\
\text { Padrão }\end{array}$ & $\begin{array}{c}\text { Modulo Total } \\
\text { NCHRP }\end{array}$ & $\begin{array}{c}\text { Desvio } \\
\text { Padrão }\end{array}$ \\
\hline $7-1$ & 3936.5 & 96.45 & 3933.2 & 109.12 \\
$7-2$ & 3921.5 & 90.89 & 3951.1 & 98.69 \\
$7-3$ & 4091.1 & 99.38 & 4092.4 & 92.04 \\
$7-4$ & 4235.3 & 116.86 & 4220.4 & 117.28 \\
$7-5$ & 4911.7 & 115.89 & 4903.8 & 130.24 \\
$7-6$ & 4863.9 & 88.63 & 4868.3 & 101.08 \\
$7-7$ & 5043.9 & 144.84 & 5031.2 & 150.29 \\
$7-8$ & 3481.4 & 75.39 & 3470.8 & 91.31 \\
$7-9$ & 4511.3 & 154.06 & 4497.7 & 150.92 \\
$7-10$ & 4789.8 & 109.04 & 4796 & 104.5 \\
$7-11$ & 2918.4 & 81.13 & 2908.4 & 80.7 \\
$7-12$ & 3889.7 & 93.66 & 3863.7 & 98.78 \\
$7-13$ & 3625.9 & 83.4 & 3614.2 & 72.49 \\
$7-14$ & 4380.5 & 110.76 & 4373.4 & 113.87 \\
\hline média & 4185.78 & 104.31 & 4180.33 & 107.95 \\
\hline Desvio padrão & 612.61 & & 614.11 & \\
\hline
\end{tabular}

Tabela C.20 - Valores de módulo de resiliência para as misturas asfálticas na condição 8

\begin{tabular}{ccccc}
\hline CP & $\begin{array}{c}\text { Modulo Total } \\
\text { DNER }\end{array}$ & $\begin{array}{c}\text { Desvio } \\
\text { Padrão }\end{array}$ & $\begin{array}{c}\text { Modulo Total } \\
\text { NCHRP }\end{array}$ & $\begin{array}{c}\text { Desvio } \\
\text { Padrão }\end{array}$ \\
\hline $8-1$ & 5841.6 & 152.44 & 5761.6 & 148.63 \\
$8-2$ & 3200.5 & 76.64 & 3195.4 & 73.39 \\
$8-3$ & 4873.9 & 97.7 & 4888.3 & 79.96 \\
$8-4$ & 4168.3 & 101.4 & 4163.1 & 110.74 \\
$8-5$ & 6094.5 & 196.94 & 6111.9 & 200.05 \\
$8-6$ & 4695.1 & 157.39 & 4751.6 & 234.18 \\
$8-7$ & 4385 & 175.75 & 4339.3 & 193.29 \\
$8-8$ & 4894.9 & 162.79 & 4853.2 & 170.26 \\
$8-9$ & 4867 & 152.98 & 4840.8 & 166.49 \\
$8-10$ & 4198 & 81.84 & 4220.2 & 83.76 \\
$8-11$ & 4713.9 & 153.95 & 4697.8 & 156.78 \\
$8-12$ & 5432.1 & 137.08 & 5418.3 & 146.6 \\
$8-13$ & 3817.9 & 90.29 & 3827.9 & 90.75 \\
$8-14$ & 4414.4 & 108.42 & 4416 & 105.9 \\
\hline média & 4685.51 & 131.83 & 4677.53 & 140.06 \\
\hline Desvio padrão & 765.57 & & 757.75 & \\
\hline
\end{tabular}


Tabela C.21 - Valores de módulo de resiliência para as misturas asfálticas na condição 9

\begin{tabular}{ccccc}
\hline CP & $\begin{array}{c}\text { Modulo Total } \\
\text { DNER }\end{array}$ & $\begin{array}{c}\text { Desvio } \\
\text { Padrão }\end{array}$ & $\begin{array}{c}\text { Modulo Total } \\
\text { NCHRP }\end{array}$ & $\begin{array}{c}\text { Desvio } \\
\text { Padrão }\end{array}$ \\
\hline $9-1$ & 4063 & 80.47 & 4074 & 85.6 \\
$9-2$ & 3910.7 & 83.02 & 3925.8 & 79.96 \\
$9-3$ & 4361.7 & 81.01 & 4381.6 & 93.31 \\
$9-4$ & 4009.6 & 77.05 & 4013.2 & 84.66 \\
$9-5$ & 5831.3 & 136.58 & 5852.4 & 137.92 \\
$9-6$ & 5806.8 & 143.03 & 5835.8 & 140.22 \\
$9-7$ & 5577.3 & 149.06 & 5600.2 & 152.69 \\
$9-8$ & 4006.4 & 116.74 & 4005 & 116.5 \\
$9-9$ & 5176.4 & 135.68 & 5171.6 & 134.81 \\
$9-10$ & 4141 & 96.58 & 4158.1 & 105.29 \\
$9-11$ & 3720.1 & 71.42 & 3735.4 & 85.78 \\
$9-12$ & 3831.5 & 101.84 & 3836.6 & 88.66 \\
$9-13$ & 4207.5 & 110.75 & 4214.8 & 109.67 \\
$9-14$ & 5069.3 & 143.37 & 5046 & 145.73 \\
\hline média & 4550.90 & 109.04 & 4560.75 & 111.49 \\
\hline Desvio padrão & 769.47 & & 772.18 & \\
\hline
\end{tabular}

Tabela C.22 - Valores de módulo de resiliência para as misturas asfálticas na condição 10

\begin{tabular}{ccccc}
\hline CP & $\begin{array}{c}\text { Modulo Total } \\
\text { DNER }\end{array}$ & $\begin{array}{c}\text { Desvio } \\
\text { Padrão }\end{array}$ & $\begin{array}{c}\text { Modulo Total } \\
\text { NCHRP }\end{array}$ & $\begin{array}{c}\text { Desvio } \\
\text { Padrão }\end{array}$ \\
\hline $10-1$ & 4128.8 & 81.63 & 4129.2 & 85.77 \\
$10-2$ & 3906.9 & 105.1 & 3896.6 & 90.3 \\
$10-3$ & 4810.7 & 135.86 & 4828.8 & 146.26 \\
$10-4$ & 3517.9 & 84.43 & 3511 & 97.76 \\
$10-5$ & 6255.2 & 192.84 & 6193.6 & 216.56 \\
$10-6$ & 4258.5 & 109.29 & 4259.4 & 95.74 \\
$10-7$ & 4247.8 & 103.82 & 4234.4 & 121 \\
$10-8$ & 3733.5 & 82.29 & 3728.3 & 92.09 \\
$10-9$ & 4828.2 & 123.93 & 4831.2 & 138.85 \\
$10-10$ & 4659.2 & 111.13 & 4653.1 & 112.03 \\
$10-11$ & 3494.5 & 83.93 & 3496.9 & 81.75 \\
$10-12$ & 5070.1 & 145.3 & 5037 & 131.53 \\
$10-13$ & 5084.1 & 170.24 & 5073.1 & 168 \\
$10-14$ & 4174.3 & 100.26 & 4164 & 106.46 \\
\hline média & 4440.69 & 116.43 & 4431.19 & 120.29 \\
\hline Desvio padrão & 744.62 & & 732.90 & \\
\hline
\end{tabular}


Tabela C.23 - Valores de módulo de resiliência para as misturas asfálticas na condição 11

\begin{tabular}{ccccc}
\hline CP & $\begin{array}{c}\text { Modulo Total } \\
\text { DNER }\end{array}$ & $\begin{array}{c}\text { Desvio } \\
\text { Padrão }\end{array}$ & $\begin{array}{c}\text { Modulo Total } \\
\text { NCHRP }\end{array}$ & $\begin{array}{c}\text { Desvio } \\
\text { Padrão }\end{array}$ \\
\hline $11-1$ & 4895.5 & 104.53 & 4898.6 & 116.01 \\
$11-2$ & 5470.2 & 133.58 & 5445.6 & 131.35 \\
$11-3$ & 5192.5 & 139.84 & 5195.8 & 136.39 \\
$11-4$ & 5940.2 & 167.18 & 5967.7 & 143.65 \\
$11-5$ & 4881.7 & 134.91 & 4904.3 & 128.9 \\
$11-6$ & 3946.6 & 105.52 & 3918.6 & 94.15 \\
$11-7$ & 4771 & 155.53 & 4782.2 & 149.22 \\
$11-8$ & 4291.4 & 98.58 & 4308.8 & 87.93 \\
$11-9$ & 3985.6 & 92.99 & 3981.1 & 89.89 \\
$11-10$ & 4446.3 & 134.11 & 4459 & 137.24 \\
$11-11$ & 4613.1 & 101.57 & 4619.5 & 103.05 \\
$11-12$ & 6308.8 & 196.86 & 6331.5 & 216.84 \\
$11-13$ & 4355.2 & 117.62 & 4354.8 & 112.79 \\
$11-14$ & 4182.4 & 113.29 & 4184 & 121.71 \\
\hline média & 4805.75 & 128.29 & 4810.82 & 126.37 \\
\hline Desvio padrão & 711.74 & & 718.81 & \\
\hline
\end{tabular}

Tabela C.24 - Valores de módulo de resiliência para as misturas asfálticas na condição 12

\begin{tabular}{ccccc}
\hline CP & $\begin{array}{c}\text { Modulo Total } \\
\text { DNER }\end{array}$ & $\begin{array}{c}\text { Desvio } \\
\text { Padrão }\end{array}$ & $\begin{array}{c}\text { Modulo Total } \\
\text { NCHRP }\end{array}$ & $\begin{array}{c}\text { Desvio } \\
\text { Padrão }\end{array}$ \\
\hline $12-1$ & 5276.5 & 118.9 & 5275.4 & 113.71 \\
$12-2$ & 4469.6 & 103.63 & 4492 & 106.2 \\
$12-3$ & 5779.9 & 104.99 & 5765.8 & 107.93 \\
$12-4$ & 5492.4 & 122.39 & 5503 & 133.34 \\
$12-5$ & 5892.4 & 155.66 & 5910.8 & 156.75 \\
$12-6$ & 5850 & 128.68 & 5857.7 & 148.78 \\
$12-7$ & 6144.8 & 144.3 & 6191.1 & 144.62 \\
$12-8$ & 6091.1 & 187.95 & 6096.6 & 175.21 \\
$12-9$ & 6290.5 & 169.01 & 6295.3 & 155.83 \\
$12-10$ & 3402.1 & 73.64 & 3407.1 & 72.66 \\
$12-11$ & 6954.2 & 185.98 & 6974.7 & 161.49 \\
$12-12$ & 4541.3 & 115.5 & 4540.7 & 115.64 \\
\hline média & 5515.40 & 134.22 & 5525.85 & 132.68 \\
\hline Desvio & 967.13 & & 970.81 & \\
padrão & & & & \\
\hline
\end{tabular}

(c) Vida de Fadiga 
Tabela C.24 - Dados do ensaio de fadiga para as condições 1, 2, 3, 4, 5 e 6

\begin{tabular}{|c|c|c|c|c|c|c|c|c|c|c|}
\hline \multirow{2}{*}{$\mathrm{CP}$} & Diâmetro & Altura & RT & MR & $\sigma$ & \multirow{2}{*}{$\% \mathrm{RT}$} & $\mathrm{F}$ & $\Delta \sigma$ & \multirow{2}{*}{$\mathrm{N}$} & \multirow{2}{*}{$\varepsilon r$} \\
\hline & $(\mathrm{mm})$ & $(\mathrm{mm})$ & (MPa) & (MPa) & (MPa) & & $\mathrm{N}$ & (MPa) & & \\
\hline $1-2$ & 99.88 & 65.05 & 1.99 & 5760.9 & 0.199 & 10 & 1992 & 0.78112 & 47788 & $3.5 \mathrm{E}-05$ \\
\hline $1-9$ & 99.86 & 65.93 & 1.99 & 5810.4 & 0.199 & 10 & 1992 & 0.77079 & 15890 & $3.4 \mathrm{E}-05$ \\
\hline $1-4$ & 99.99 & 64.85 & 1.99 & 5208.5 & 0.398 & 20 & 3984 & 1.5653 & 3984 & 7.6E-05 \\
\hline $1-11$ & 99.99 & 65.17 & 1.99 & 5812.2 & 0.398 & 20 & 3984 & 1.55754 & 3490 & $6.9 \mathrm{E}-05$ \\
\hline $1-5$ & 99.84 & 65.16 & 1.99 & 7816.4 & 0.598 & 30 & 5976 & 2.3403 & 2279 & 7.6E-05 \\
\hline $1-13$ & 99.87 & 65.21 & 1.99 & 7558.9 & 0.598 & 30 & 5976 & 2.33792 & 1323 & 7.9E-05 \\
\hline $1-6$ & 99.80 & 65.63 & 1.99 & 6972.6 & 0.797 & 40 & 7968 & 3.0995 & 785 & 0.00011 \\
\hline $1-10$ & 99.82 & 65.11 & 1.99 & 5385 & 0.797 & 40 & 7968 & 3.12342 & 296 & 0.00015 \\
\hline $2-2$ & 99.86 & 65.53 & 1.91 & 7446 & 0.191 & 10 & 1905 & 0.74163 & 34111 & $2.6 \mathrm{E}-05$ \\
\hline $2-8$ & 99.97 & 64.95 & 1.91 & 6810.2 & 0.191 & 10 & 1905 & 0.74753 & 25454 & $2.8 \mathrm{E}-05$ \\
\hline $2-4$ & 99.98 & 64.55 & 1.91 & 6230 & 0.381 & 20 & 3810 & 1.50417 & 5316 & 6.1E-05 \\
\hline $2-10$ & 99.87 & 64.99 & 1.91 & 9649.3 & 0.381 & 20 & 3810 & 1.49559 & 2277 & $3.9 \mathrm{E}-05$ \\
\hline $2-5$ & 99.85 & 65.34 & 1.91 & 5660.9 & 0.572 & 30 & 5715 & 2.2317 & 2222 & 0.0001 \\
\hline 2- 13 & 99.82 & 64.77 & 1.91 & 6919.8 & 0.572 & 30 & 5715 & 2.2 & 959 & \\
\hline $2-7$ & 99.97 & 65.36 & 1.91 & 6157.9 & 0.762 & 40 & 7620 & 2.9 & & \\
\hline $2-11$ & 100.00 & 64.75 & 1.91 & 6587.9 & 0.762 & 40 & 7620 & 2.9 & & \\
\hline $3-3$ & $\begin{array}{l}99.88 \\
\end{array}$ & 64.69 & 2.08 & 7318.3 & 0.208 & 1 & 2075 & 0.8 & 22719 & \\
\hline $3-9$ & 99.93 & 64.38 & 2.08 & 8168.9 & 0.208 & 10 & 2075 & 0.8 & & \\
\hline $3-4$ & 99.87 & 65.18 & 2.08 & 7227.6 & 0. & 2 & 4150 & 1.6 & & \\
\hline $3-11$ & 99.81 & 64.40 & 2. & 9581 & 15 & 2 & 4150 & 1.6 & & \\
\hline $3-5$ & 99.95 & 64.50 & 2. & 670 & & & 6225 & & & \\
\hline $3-12$ & 99.87 & 64.89 & 2.08 & 8042.8 & 0.623 & 3 & 6225 & 2.44 & & \\
\hline $3-6$ & 99.94 & 64.76 & 2.08 & 7689.1 & 0.830 & 40 & 8300 & 3.2676 & 406 & 0.0001 \\
\hline 3- 13 & 99.96 & 63.74 & 2.08 & 8022.81 & 0.830 & 40 & 8300 & 3.3 & & 0.0001 \\
\hline $4-1$ & 99.86 & 69.85 & 1. & 5759.5 & 0. & 10 & 1965 & & 7 & \\
\hline $4-2$ & 99.86 & 70.70 & 1. & & & & 1965 & & & \\
\hline $4-6$ & 99.89 & 70.36 & 1. & 5918.7 & & & 3931 & & & \\
\hline $4-12$ & 99.95 & 69.59 & 1. & 72 & & & 3931 & & & \\
\hline $4-9$ & 99.90 & 69.92 & 1.97 & 6135.5 & 0. & 3 & 5896 & & 1006 & \\
\hline 4- 13 & 99.90 & 70.30 & 1.97 & 7607.8 & 0.590 & 3 & 5896 & 2.1 & 81 & -05 \\
\hline $4-11$ & 99.96 & 69.34 & 1.97 & 6968.2 & 0.7 & 4 & 7861 & 2.8 & 4 & \\
\hline $4-14$ & 99.91 & 69.85 & 1.97 & 5978.7 & 0 & 40 & 7861 & 2.8 & P & \\
\hline $5-2$ & 99.99 & 69.86 & 1.78 & 9439 & 0.178 & 1 & 1778 & 0.6 & 14078 & $1.9 \mathrm{E}-05$ \\
\hline $5-8$ & 99.88 & 70.03 & 1.78 & 10623.6 & 0.178 & 10 & 1778 & 0.64781 & 28421 & $1.7 \mathrm{E}-05$ \\
\hline $5-3$ & 99.9 & 70.29 & 1. & 7929.1 & 0.3 & 2 & 3557 & 1.2 & 8 & $4.5 \mathrm{E}-05$ \\
\hline $5-9$ & 100.01 & 69.12 & 1.78 & 7160.6 & & 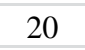 & 3557 & & & \\
\hline $5-4$ & 99.85 & 70.18 & 1.78 & 6516.1 & 0.534 & 3 & 5335 & 1.9 & 1263 & 8.2E-05 \\
\hline $5-10$ & 99.98 & 69.76 & 1.78 & 7777.9 & 0.534 & 30 & 5335 & 1.94897 & 1304 & $6.9 \mathrm{E}-05$ \\
\hline $5-6$ & 99.94 & 69.68 & 1.78 & 8657 & 0.711 & 40 & 7114 & 2.60277 & 975 & $8.2 \mathrm{E}-05$ \\
\hline $5-12$ & 99.91 & 69.45 & 1.78 & 8074.3 & 0.711 & 40 & 7114 & 2.61214 & 462 & $8.8 \mathrm{E}-05$ \\
\hline $6-2$ & 99.90 & 68.83 & 1.6825 & 7170.7 & 0.168 & 10 & 1682 & 0.6234 & 19287 & $2.3 \mathrm{E}-05$ \\
\hline $6-8$ & 99.96 & 69.10 & 1.6825 & 8912.1 & 0.168 & 10 & 1682 & 0.62058 & 16449 & $1.9 \mathrm{E}-05$ \\
\hline $6-3$ & 99.99 & 68.94 & 1.6825 & 7928.9 & 0.336 & 20 & 3365 & 1.24373 & 6458 & 4.2E- 05 \\
\hline $6-10$ & 99.89 & 69.43 & 1.6825 & 8841.7 & 0.336 & 20 & 3365 & 1.23613 & 4920 & $3.8 \mathrm{E}-05$ \\
\hline $6-5$ & 99.89 & 68.89 & 1.6825 & 7354.1 & 0.505 & 30 & 5047 & 1.86857 & 2342 & $6.9 \mathrm{E}-05$ \\
\hline $6-11$ & 99.99 & 68.94 & 1.6825 & 7021.3 & 0.505 & 30 & 5047 & 1.86548 & 1169 & 7.2E-05 \\
\hline $6-7$ & 100.05 & 68.74 & 1.6825 & 6945.8 & 0.673 & 40 & 6730 & 2.49328 & 738 & 9.7E-05 \\
\hline 6- 13 & 99.86 & 68.95 & 1.6825 & 8135.9 & 0.673 & 40 & 6730 & 2.49001 & 688 & 8.3E-05 \\
\hline
\end{tabular}


Tabela C.25 - Dados do ensaio de fadiga para as condições 7, 8, 9, 10, 11 e 12

\begin{tabular}{|c|c|c|c|c|c|c|c|c|c|c|}
\hline \multirow{2}{*}{$\mathrm{CP}$} & Diâmetro & Altura & RT & MR & $\sigma$ & \multirow{2}{*}{$\% \mathrm{RT}$} & $\mathrm{F}$ & $\Delta \sigma$ & \multirow[t]{2}{*}{$\mathrm{N}$} & \multirow[t]{2}{*}{$\varepsilon r$} \\
\hline & $(\mathrm{mm})$ & $(\mathrm{mm})$ & $(\mathrm{MPa})$ & $(\mathrm{MPa})$ & $(\mathrm{MPa})$ & & $\mathrm{N}$ & $(\mathrm{MPa})$ & & \\
\hline $7-2$ & 99.94 & 65.48 & 1.15 & 3951.10 & 0.115 & 10 & 1154.58 & 0.4495 & 2210 & 2.9E-05 \\
\hline $7-9$ & 99.96 & 65.38 & 1.15 & 4497.70 & 0.115 & 10 & 1154.58 & 0.4501 & 2739 & 2.6E-05 \\
\hline $7-3$ & 99.85 & 65.23 & 1.15 & 4092.40 & 0.231 & 20 & 2309.16 & 0.9033 & 914 & 5.6E-05 \\
\hline $7-11$ & 99.86 & 65.94 & 1.15 & 2908.40 & 0.231 & 20 & 2309.16 & 0.8934 & 476 & 7.9E-05 \\
\hline $7-7$ & 99.84 & 65.46 & 1.15 & 5031.20 & 0.346 & 30 & 3463.74 & 1.3503 & 301 & $6.9 \mathrm{E}-05$ \\
\hline $7-12$ & 99.88 & 65.63 & 1.15 & 3863.70 & 0.346 & 30 & 3463.74 & 1.3462 & 235 & $9 \mathrm{E}-05$ \\
\hline $7-8$ & 99.88 & 65.71 & 1.15 & 3470.80 & 0.462 & 40 & 4618.31 & 1.7929 & 140 & 0.00013 \\
\hline 7- 13 & 99.89 & 65.01 & 1.15 & 3614.20 & 0.462 & 40 & 4618.31 & 1.8120 & 145 & 0.00013 \\
\hline $8-2$ & 99.98 & 64.63 & 1.11 & 3195.40 & 0.111 & 10 & 1113.08 & 0.4389 & 4156 & $3.5 \mathrm{E}-05$ \\
\hline $8-7$ & 99.82 & 64.92 & 1.11 & 4339.30 & 0.111 & 10 & 1113.08 & 0.4376 & 6214 & 2.6E-05 \\
\hline $8-3$ & 99.82 & 64.62 & 1.11 & 4888.30 & 0.223 & 20 & 2226.16 & 0.8793 & 1184 & 4.6E-05 \\
\hline $8-13$ & 99.92 & 64.88 & 1.11 & 3827.90 & 0.223 & 20 & 2226.16 & 0.8749 & 631 & 5.8E-05 \\
\hline $8-4$ & 99.80 & 64.89 & 1.11 & 4163.10 & 0.334 & 30 & 3339.23 & 1.3137 & 505 & $8 \mathrm{E}-05$ \\
\hline $8-9$ & 99.94 & 64.54 & 1.11 & 4840.80 & 0.334 & 30 & 3339.23 & 1.3191 & 286 & $6.9 \mathrm{E}-05$ \\
\hline $8-5$ & 99.88 & 64.40 & 1.11 & 6111.90 & 0.445 & 40 & 4452.31 & 1.7635 & 286 & 7.3E-05 \\
\hline $8-14$ & 99.93 & 64.96 & 1.11 & 4416.00 & 0.445 & 40 & 4452.31 & 1.7476 & 173 & 0.0001 \\
\hline $9-3$ & 99.87 & 63.42 & 1.16 & 4381.60 & 0.116 & 10 & 1163.36 & 0.4680 & 6941 & 2.7E-05 \\
\hline $9-10$ & 99.92 & 63.87 & 1.16 & 4158.10 & 0.116 & 10 & 1163.36 & 0.4645 & 9263 & $2.8 \mathrm{E}-05$ \\
\hline $9-5$ & 99.88 & 63.87 & 1.16 & 5852.40 & 0.233 & 20 & 2326.73 & 0.9293 & 1766 & $4 \mathrm{E}-05$ \\
\hline $9-11$ & 99.88 & 64.30 & 1.16 & 3735.40 & 0.233 & 20 & 2326.73 & 0.9231 & 1073 & $6.2 \mathrm{E}-05$ \\
\hline $9-7$ & 99.79 & 64.38 & 1.16 & 5600.20 & 0.349 & 30 & 3490.09 & 1.3840 & 519 & $6.2 \mathrm{E}-05$ \\
\hline $9-12$ & 99.89 & 64.51 & 1.16 & 3836.60 & 0.349 & 30 & 3490.09 & 1.3798 & 274 & 9.1E-05 \\
\hline $9-8$ & 99.84 & 64.04 & 1.16 & 4005.00 & 0.465 & 40 & 4653.46 & 1.8544 & 163 & 0.00012 \\
\hline $9-13$ & 99.87 & 63.72 & 1.16 & 4214.80 & 0.465 & 40 & 4653.46 & 1.8632 & 154 & 0.00011 \\
\hline $10-2$ & 99.89 & 70.94 & 1.08 & 3896.60 & 0.108 & 10 & 1080.32 & 0.3884 & 3944 & $2.8 \mathrm{E}-05$ \\
\hline $10-12$ & 100.00 & 70.09 & 1.08 & 5037.00 & 0.108 & 10 & 1080.32 & 0.3927 & 5414 & 2.1E-05 \\
\hline $10-4$ & 100.01 & 70.38 & 1.08 & 3511.00 & 0.216 & 20 & 2160.63 & 0.7820 & 1348 & $6.2 \mathrm{E}-05$ \\
\hline $10-9$ & 99.92 & 70.35 & 1.08 & 4831.20 & 0.216 & 20 & 2160.63 & 0.7831 & 1048 & 4.5E-05 \\
\hline $10-5$ & 99.89 & 70.60 & 1.08 & 6193.60 & 0.324 & 30 & 3240.95 & 1.1710 & 542 & 5.2E-05 \\
\hline $10-10$ & 99.86 & 70.25 & 1.08 & 4653.10 & 0.324 & 30 & 3240.95 & 1.1770 & 478 & $7 \mathrm{E}-05$ \\
\hline $10-6$ & 99.85 & 70.43 & 1.08 & 4259.40 & 0.432 & 40 & 4321.27 & 1.5656 & 52 & 0.0001 \\
\hline $10-14$ & 99.87 & 70.44 & 1.08 & 4164.00 & 0.432 & 40 & 4321.27 & 1.5651 & 246 & 0.0001 \\
\hline $11-2$ & 100.02 & 69.38 & 1.01 & 5445.60 & 0.101 & 10 & 1006.78 & 0.3696 & 7569 & $1.8 \mathrm{E}-05$ \\
\hline $11-9$ & 100.01 & 69.33 & 1.01 & 3981.10 & 0.101 & 10 & 1006.78 & 0.3699 & 4896 & 2.5E-05 \\
\hline $11-3$ & 100.04 & 69.50 & 1.01 & 5195.80 & 0.201 & 20 & 2013.56 & 0.7378 & 1812 & 3.9E-05 \\
\hline $11-10$ & 99.90 & 70.38 & 1.01 & 4459.00 & 0.201 & 20 & 2013.56 & 0.7296 & 1172 & 4.5E-05 \\
\hline $11-5$ & 99.93 & 69.76 & 1.01 & 4904.30 & 0.302 & 30 & 3020.34 & 1.1039 & 615 & $6.2 \mathrm{E}-05$ \\
\hline $11-11$ & 99.91 & 69.67 & 1.01 & 4619.50 & 0.302 & 30 & 3020.34 & 1.1056 & 421 & $6.5 \mathrm{E}-05$ \\
\hline $11-7$ & 100.02 & 69.35 & 1.01 & 4782.20 & 0.403 & 40 & 4027.12 & 1.4792 & 273 & 8.4E-05 \\
\hline $11-13$ & 100.00 & 69.69 & 1.01 & 4354.80 & 0.403 & 40 & 4027.12 & 1.4722 & 187 & 9.2E-05 \\
\hline $12-1$ & 100.03 & 70.71 & 0.99 & 5275.40 & 0.099 & 10 & 988.117 & 0.3559 & 11230 & 1.9E-05 \\
\hline $12-10$ & 99.89 & 70.56 & 0.99 & 3407.10 & 0.099 & 10 & 988.117 & 0.3572 & 10524 & 2.9E-05 \\
\hline $12-2$ & 100.04 & 70.62 & 0.99 & 4492.00 & 0.198 & 20 & 1976.23 & 0.7127 & 2592 & 4.4E-05 \\
\hline $12-11$ & 99.90 & 70.29 & 0.99 & 6974.70 & 0.198 & 20 & 1976.23 & 0.7170 & 6063 & 2.8E-05 \\
\hline $12-6$ & 99.91 & 70.86 & 0.99 & 5857.70 & 0.296 & 30 & 2964.35 & 1.0668 & 1332 & 5.1E-05 \\
\hline $12-12$ & 99.89 & 70.50 & 0.99 & 4540.70 & 0.296 & 30 & 2964.35 & 1.0725 & 823 & $6.5 \mathrm{E}-05$ \\
\hline $12-7$ & 99.98 & 70.14 & 0.99 & 6191.10 & 0.395 & 40 & 3952.47 & 1.4359 & 391 & 6.4E-05 \\
\hline $12-13$ & 100.02 & 70.55 & 0.99 & 6096.60 & 0.395 & 40 & 3952.47 & 1.4270 & 360 & $6.5 \mathrm{E}-05$ \\
\hline
\end{tabular}


(d) Compressão Uniaxial Estática 


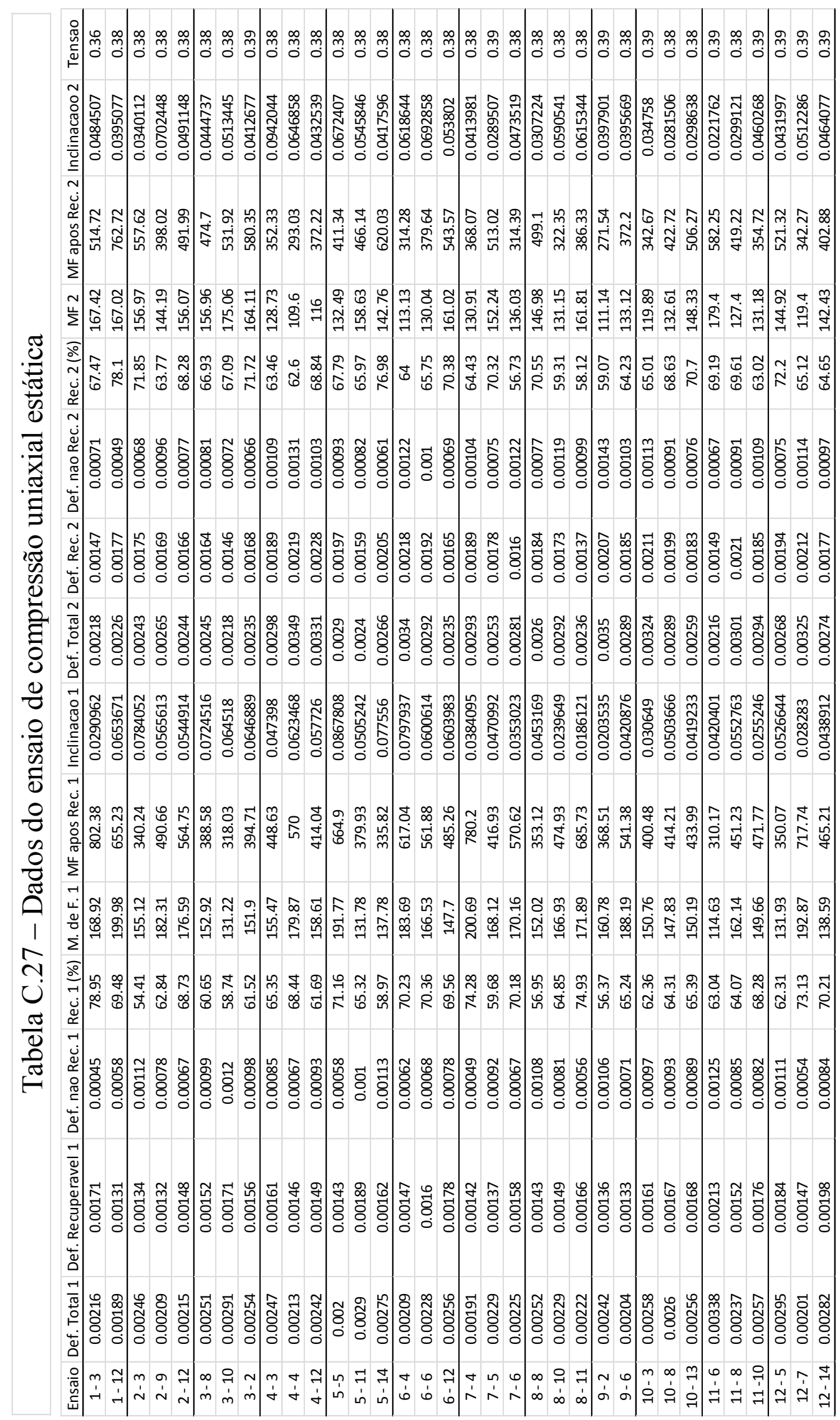


